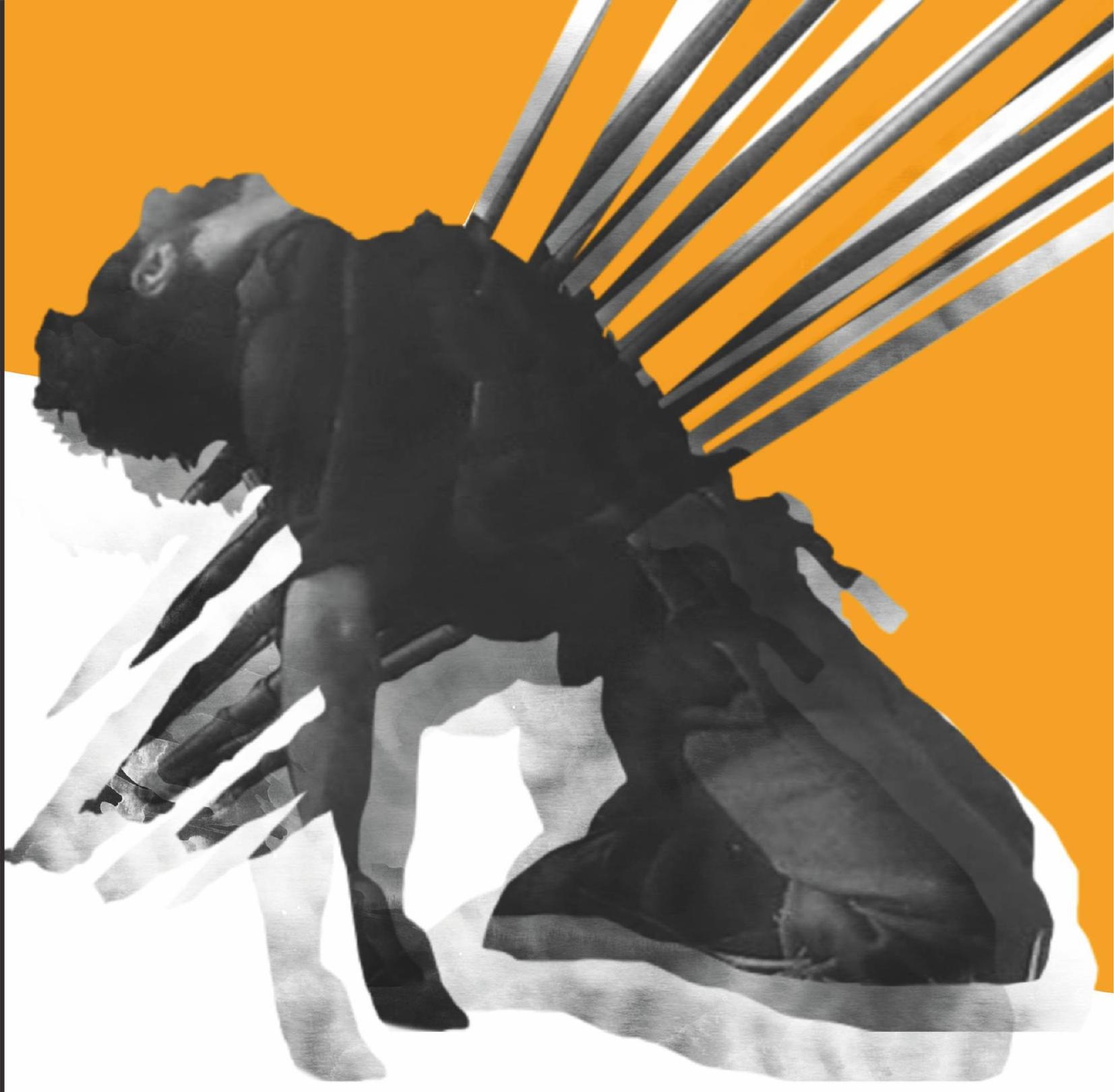

Anna Miller-KLejsa

\title{
RESISTENZA \\ WE WŁOSKIM \\ FILMIE FABULARNYM
}

FILMO!ZNAWCY 
Anna Miller-KLejSA

RESISTENZA

WE WŁOSKIM

FILMIE FABULARNYM

FILMO!ZNAWCY 


\title{
REDAKCJA SERII WYDAWNICZEJ \\ „FILMO!ZNAWCY”
}

\author{
PWSFTviT \\ prof. dr hab. Jolanta Dylewska (współprzewodnicząca Komitetu Redakcyjnego) \\ dr Piotr Mikucki, dr Anna Zarychta
}

UNIWERSYTET ŁÓDZKI

prof. zw. dr hab. Ryszard W. Kluszczyński (współprzewodniczący Komitetu Redakcyjnego) prof. dr hab. Tomasz Kłys, prof. dr hab. Piotr Sitarski 
Anna Miller-KLejSA

\section{RESISTENZA}

WE WLOSKIM

FILMIE FABULARNYM

FILMO!ZNAWCY

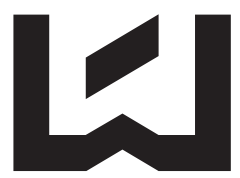

WYDAWNICTWO

UNIWERSYTETU

ŁÓDZKIEGO

Łódź 2013 
Anna Miller-Klejsa - Uniwersytet Łódzki, Wydział Filologiczny, Zakład Italianistyki 90-114 Łódź, ul. H. Sienkiewicza 21

ania.miller@gmail.com

RECENZENT

Piotr Zwierzchowski

REDAKTOR WYDAWNICTWA UŁ

Dorota Stępień

SKŁAD I ŁAMANIE

Oficyna Wydawnicza Edytor.org

PROJEKT OKŁADKI

Adrian Dutkowski

Na okładce wykorzystano zdjęcie z filmu Noc świętego Wawrzyńca P. i V. Tavianich

UARODOWY PROGRAM

Książka została opublikowana w ramach programu Ministra Nauki i Szkolnictwa Wyższego pod nazwą Narodowy Program Rozwoju Humanistyki (projekt Italianistyka dla filmoznawstwa, filmoznawstwo dla italianistyki. Paradygmat audiowizualny w badaniach polsko-włoskiego transferu kulturowego realizowany na Wydziale Filologicznym Uniwersytetu Łódzkiego w latach 2012-2014)

(c) Copyright by Uniwersytet Łódzki, Łódź 2013

Wydane przez Wydawnictwo Uniwersytetu Łódzkiego

Wydanie I. W.06355.13.0.M

ISBN (ebook) 978-83-7969-275-0

https://doi.org/10.18778/7969-033-6

Wydawnictwo Uniwersytetu Łódzkiego

90-131 Łódź, ul. Lindleya 8

www.wydawnictwo.uni.lodz.pl

e-mail: ksiegarnia@uni.lodz.pl

tel. (42) 6655863 , faks (42) 6655862 


\section{Spis treści}

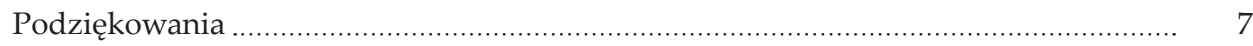

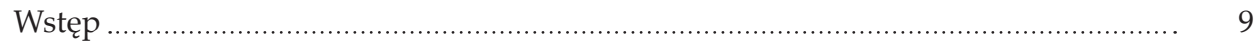

Rozdział I. Resistenza w kulturze politycznej Włoch ....................................................... 15

Rozdział II. Film fabularny jako medium opowieści historycznej ............................. 31

Wokół filmu historycznego jako gatunku i jego społeczno-kulturowej funkcji .... 33

Historiofotia - historia w obrazach ................................................................ 46

Film historyczny jako zwierciadło dyskursów teraźniejszych .......................... 58

Fabularyzacja faktów historycznych versus film z tłem epoki ............................. 63

Rozdział III. Lata 1945-1959: krzepnięcie włoskiej republiki ....................................... 77

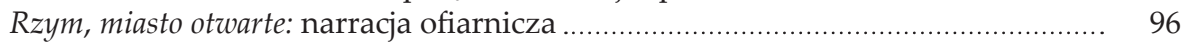

Rozdział IV. Lata 1960-1968: pół żartem, pół serio ............................................................. 113

Generat Della Rovere: scherzo all'italiana, czyli symfonia nie całkiem bohaterska .... 136

Rozdział V. Lata 1969-1978: kontestacja i rozliczenia ................................................... 153

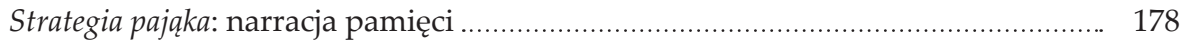

Rozdział VI. Lata 1979-1994: baśniowe formuły …........................................................ 195

Noc świętego Wawrzyńca: cienie (zapomnianych) przodków ............................... 201

Rozdział VII. Lata 1995-2012: historyczne rewizje ........................................................... 217

Człowiek, który nadejdzie: historia, która powraca .............................................. 233

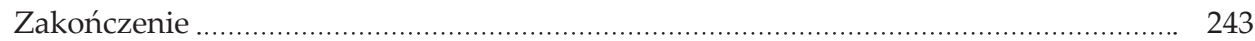

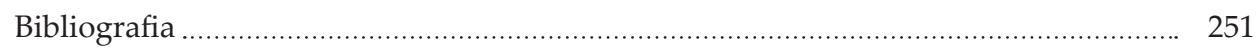

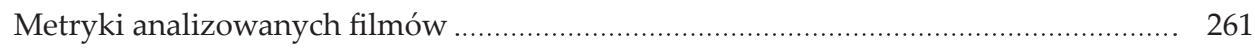

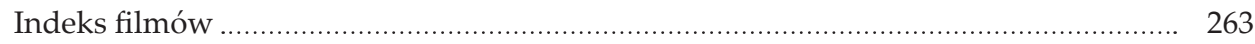

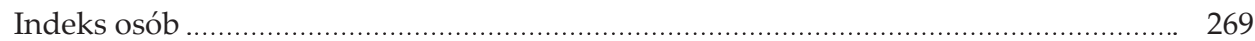

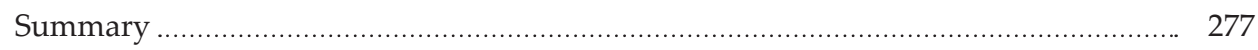

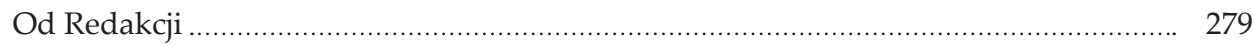





\section{Podziękowania}

Chciałabym podziękować za pomoc i życzliwość, jakich doświadczyłam od wielu osób w trakcie pracy nad tą książką.

Przede wszystkim pragnę podziękować prof. Piotrowi Zwierzchowskiemu oraz prof. Arturowi Gałkowskiemu za wnikliwą lekturę mojej pracy, poczynione uwagi i sugestie, które pozwoliły mi dokonać jej korekty i uniknąć najpoważniejszych błędów.

Dziękuję także prof. Tomaszowi Kłysowi (promotorowi mojej pracy doktorskiej) za wszelkie spostrzeżenia i komentarze w toku prac nad ostatecznym kształtem publikacji, prof. Ewelinie Nurczyńskiej-Fidelskiej oraz koleżankom i kolegom z Zakładu Historii i Teorii Filmu za gesty życzliwości oraz rady - stanowiły one dla mnie wielką pomoc. Za wytrwałe poszukiwanie potrzebnych mi filmów dziękuję Bartoszowi Zającowi i Michałowi Dondzikowi oraz moim najbliższym, którzy również zaangażowali się $w$ zdobycie rozmaitych, niekiedy naprawdę trudno dostępnych materiałów.

Z całego serca dziękuję mojej Rodzinie (w szczególności Agacie i moim Rodzicom) oraz Przyjaciołom (przede wszystkim Ewie i Maćkowi) za wsparcie, słowa otuchy i wyrozumiałość, które pozwoliły mi sprostać sfinalizowaniu mojej pracy. Poza wszelką kolejnością pragnę podziękować - choć mam wrażenie, że sens tego, co chciałabym wyrazić, umknie gdzieś „między słowami” - mojemu mężowi Konradowi, który wspierał mnie przez cały ten niełatwy dla mnie czas przygotowywania niniejszej publikacji i był przy mnie w najtrudniejszych chwilach. Bez tego nieocenionego wsparcia książka ta zapewne by nie powstała.

Książkę dedykuję moim Rodzicom. Żałuję, że mojemu Tacie nie dane było wraz ze mną zobaczyć ostatecznego efektu pracy, której ukończenia tak wyczekiwał. 



\section{Wstęp}

Ironiczna uwaga Susan Sontag o bliskim końcu czasu „ludzi oczytanych" i rychłym nadejściu świata "ludzi opatrzonych" pochodzi z początku lat 70. XX wieku' ${ }^{1}$. Mimo że była ona pomyślana raczej jako prowokacyjny bon mot niż jako prognoza, okazała się uderzająco trafna. Patrząc z dzisiejszej perspektywy, nie ulega wątpliwości, że tworzywem (i jednocześnie "opakowaniem”) wiedzy potocznej, także tej o czasach minionych, są w coraz większej mierze obrazy.

Popularność tematyki historycznej w kinie współczesnym rodzi potrzebę badań naukowych, które z wielu perspektyw ukazywałyby rozmaite aspekty związków historii i filmu. Potrzeba ta jest motywowana także względami społecznymi: film to swoisty wehikuł pamięci kulturowej oraz narodowej mitologii. Celem niniejszej pracy jest ukazanie obecnych w kinie włoskim strategii opowiadania o antyfaszystowskim ruchu oporu we Włoszech (1943-1945). Fenomen ten zajmuje ważne miejsce w pamięci kulturowej Italii - o czym świadczą liczne praktyki komemoracyjne resistenzy (uroczyste rocznice, pomniki i muzea, okolicznościowe przemówienia itd.). Stanowi także punkt odniesienia konieczny dla powstania i stabilizacji kolektywnej tożsamości społeczeństwa Półwyspu Apenińskiego.

Mając świadomość, jak rozległy jest wybrany przeze mnie temat, uznałam za stosowne zawęzić pole poszukiwań do kinowych, pełnometrażowych filmów fabularnych z zakresu interesującej mnie problematyki. Przyjmuję kryterium tematyczne, nie stylistyczne - co oznacza, iż poddane analizie zostaną zarówno filmy zaliczane do nurtu kina autorskiego, jak i produkcje kina popularnego (ważne fenomeny z kręgu filmu dokumentalnego zasługują na odrębne omówienie - w niniejszej rozprawie siłą rzeczy pozostaną na marginesie podejmowanych rozważań).

Jak już zostało powiedziane, centrum mojego zainteresowania stanowią filmowe reprezentacje włoskiego ruchu oporu. Oznacza to, że pominięte są filmy podejmujące inne wątki dotyczące II wojny światowej (m.in. Holocaustu lub udziału Włochów na innych frontach - w Grecji, na Bałkanach czy w Afryce). Choć większość umieszczonych w niniejszej pracy

${ }^{1}$ Książka On Photography, w której znalazło się przywołane sformułowanie, ukazała się w 1973 roku. Polski przekład: Susan Sontag, O fotografii, tłum. Sławomir Magala, Kraków 2009, s. 35. 
filmów o resistenzy prezentuje działania zbrojne partyzantów, do swojego wywodu włączam także filmy traktujące o "resistenzy biernej” - a zatem produkcje koncentrujące się raczej na obserwacji przeżyć i zachowań cywilów, którzy niejednokrotnie decydują się dołączyć do zorganizowanych oddziałów włoskiego ruchu oporu. Skupienie uwagi wyłącznie na "oporze zbrojnym” w moim przekonaniu znacznie zubożyłoby obecny we włoskim filmie fabularnym obraz resistenzy.

Książkę otwiera rozdział o charakterze przeglądowym. Jego funkcja polega na zaprezentowaniu kluczowych wydarzeń politycznych związanych z tematem oraz współgrających z nimi fenomenów artystycznych. Ponieważ tematyka ta została szczegółowo omówiona przez innych autorów, nie dokonuję tu ustaleń nowych - bibliografia poświęcona resistenzy jako fenomenowi historycznemu obejmuje wiele pozycji. Przedstawiam tu raczej autorską rekonstrukcję dynamiki zjawiska, którego obszerność utrudnia próby zwięzłej eksplikacji. $Z$ tego samego powodu rezygnuję z przytaczania obszernej faktografii dotyczącej włoskiego ruchu oporu (zawierającej na przykład nazwy wielu partii politycznych czy ugrupowań partyzanckich). Nie było bowiem moim zamiarem przygotowanie monografii resistenzy jako takiej, a jedynie nakreślenie kontekstu, wzbogacającego ogląd fenomenów filmowych. Ograniczam się zatem do krótkiego przedstawiania tych zjawisk, które w istotny sposób wpłynęły na kształt kultury filmowej.

Rozdział drugi dotyczy konceptualizacji relacji historii i filmu akcentujących tematykę reprezentacji wydarzeń autentycznych $\mathrm{w}$ filmach fabularnych. Oczywiście, zagadnienie to jest niezwykle obszerne i stanowi splot wielu problemów; pragnę je zasygnalizować celem wypracowania własnego narzędzia klasyfikacji. W rozdziale drugim, prócz prezentacji i porównania wybranych koncepcji (m.in. Roberta Rosenstone'a i Haydena White'a), podejmuję zatem próbę zbudowania własnego modelu pojęciowego, który byłby adekwatny do systematyzacji materiału poddawanego analizie $e^{2}$ W niniejszej pracy stanowią go filmy podejmujące temat resistenzy, jakim poświęcone są rozdziały analityczne. Mając świadomość,

${ }^{2}$ Należy przy tym wspomnieć, że w polskim piśmiennictwie można znaleźć kilka prac poświęconych wzajemnym relacjom filmu i historii - Marka Hendrykowskiego (Film jako źródło historyczne, Poznań 2000), Piotra Witka (Kultura - film - historia. Metodologiczne problemy doświadczenia audiowizualnego, Lublin 2005) i Doroty Skotarczak (Media audiowizualne w warsztacie historyka, Poznań 2008). W rozdziale teoretycznym stają się one dla mnie istotnymi punktami odniesienia; nie wyczerpują jednak poszukiwań konceptualizacji teoretycznych dla analizy interesujących mnie fenomenów. Ważną publikacją dla dyskusji nad metodologią badań „historii w obrazach” jest także antologia przekładów pod redakcją Iwony Kurz (Film i historia, Warszawa 2008). Istotną lekturą jest również niedawno przełożona na język polski praca Marca Ferro (Kino i historia, Warszawa 2011). 
że zaproponowany przeze mnie schemat jest podatny na korekty i uzupełnienia, akcentuję przede wszystkim jego wartość operacyjną (łzn. służy mi on głównie do uporządkowania materiału).

Wyodrębnione przeze mnie kryteria omawiam szczegółowo w rozdziale teoretycznym. W przypadku filmów traktujących o fenomenach należących do przeszłości w momencie realizacji tych filmów (w mojej pracy są to wszystkie produkcje o resistenzy) kryteria te obejmują: charakter fabuły (rozróżniam zatem, czy film jest fabularyzacją faktów historycznych czy raczej filmem ewokującym „wrażenie epoki”), horyzont narracji (czy akcja filmu rozgrywa się wyłącznie w przeszłości w odniesieniu do czasu jego powstania czy też zawiera on współczesną ramę narracyjną względnie „współczesny” prolog bądź epilog „po latach”) oraz obecność w narracji materiałów archiwalnych.

Zasadnicza część książki poświęcona jest sposobom ujmowania interesującej mnie problematyki - tematu włoskiego ruchu oporu - we włoskim filmie fabularnym. Aby lepiej unaocznić trajektorię ewoluowania interesującego mnie zagadnienia w kinematografii Włoch, ta część pracy została podzielona na rozdziały. Ich wyróżnienie nastręczało pewnych trudności. Chciałam bowiem, aby przyjęte ramy czasowe $\mathrm{z}$ jednej strony były wyznaczone rzeczywiście przez wydarzenia polityczne we włoskiej historiografii powszechnie przyjmowane jako cezury w dziejach powojennej republiki, z drugiej - by korespondowały możliwie najpełniej z faktycznymi zmianami, jakie dostrzec można w filmowych reprezentacjach analizowanego fenomenu. I tak, rozważając rozmaite możliwości i szukając "złotego środka" zdecydowałam, by datami granicznymi wyróżnionych segmentów uczynić we wszystkich przypadkach wydarzenia polityczne, które w widoczny sposób zaważyły na obecności włoskiego ruchu oporu w dyskursie publicznym. Przyjęta w książce periodyzacja wyznaczana jest zatem przez: rok 1960 (datę wyboru Fernando Tambroniego na premiera Włoch, która to decyzja wywołała społeczne zamieszki, o czym będzie jeszcze mowa), "gorącą jesień" 1969 roku (będącą apogeum młodzieżowej kontestacji w Italii), zabójstwo Alda Moro przez Czerwone Brygady w 1978 roku (taki układ wynika nie tylko z odrębności reprezentacji tego fenomenu w kinie włoskim w latach 1969-1978, ale także podkreśla związek istniejący między włoskim ruchem oporu a "dekadą ołowiu” ${ }^{3}$ ) oraz wybór Silvio Berlusconiego na premiera Włoch w 1994 roku.

${ }^{3} \mathrm{O}$ dekadzie lat 70. - tzw. latach ołowiu (anni di piombo) - piszę więcej w artykule Fabularyzacje zabójstwa Aldo Moro w filmie włoskim, [w:] Przeszłość we wspótczesnej narracji kulturowej, red. Andrzej Plichta, Kraków 2012 oraz „Przypadkowa śmierć anarchisty”. Tzw. sprawa Pinellego i jej fabularyzacja w włoskich tekstach kultury, [w:] Historia w kulturze współczesnej, red. Piotr Witek, Mariusz Mazur, Ewa Solska, Lublin 2011. 
Próba doprecyzowania narzędzi badawczych pomocnych $\mathrm{w}$ interpretacji filmów historycznych wynika z przekonania, iż medium filmowe dokumentuje napięcia w społeczno-politycznym dyskursie, stając się źródłem wiedzy na temat kształtowania, upowszechniania bądź zanikania rozmaitych strategii mówienia o przeszłości. Uznając zatem komunikaty filmowe za ważne świadectwa społecznych przemian, pragnę uwypuklić wielopoziomowe relacje pomiędzy analizowanymi filmami a szeroko pojętym dyskursem politycznym (tym samym w książce mimowolnie pojawi się wątek refleksji nad rolą filmu w opisie i interpretacji dziejów najnowszych). Choć zatem analiza tekstualna będzie podstawowym modus operandi mojego postępowania badawczego, to w niniejszej rozprawie społeczno-polityczne oraz kulturowe konteksty nie będą pominięte. Przedmiotem uwagi są bowiem "filmy o historii”, które zarazem są w historię uwikłane - tzn. uzależnione od ideologicznych, politycznych i społecznych mechanizmów.

Kierunek postępowania przy omawianiu interesujących mnie zagadnień każdorazowo jest zatem następujący: rozpoczynam od przypomnienia tych faktów z życia społeczno-politycznego, które w istotny sposób profilowały $\mathrm{w}$ danym okresie filmowe reprezentacje resistenzy. Następnie prezentuję filmy, które podejmując ten temat, realizują wyróżnione w części teoretycznej strategie. Są to zarówno tytuły powszechnie znane, często zaliczane do kanonu, jak i niemal całkowicie - czasem niesłusznie - zapomniane.

W obrębie poszczególnych rozdziałów pracy wyróżnionych wedle kryterium chronologicznego znajdują się podrozdziały analityczne. Każdy z rozdziałów przeglądowych „opatrzony” więc został analizą filmu reprezentatywnego dla danego przedziału czasowego. Starałam się, aby wybrane przeze mnie do osobnej analizy filmy lokalizowały problemy istotne dla tematu ruchu oporu w danym okresie. I tak, w rozdziale odnoszącym się do lat 1960-1968 zrealizowany przez Rosselliniego Generat Della Rovere $\left(1959^{4}\right)$ stanowi głos polemiczny wobec wcześniejszego dzieła tego samego reżysera - Rzymu, miasta otwartego (1945), który analizowany jest w rozdziale dotyczącym lat 1945-1959. W rozdziale obejmującym filmy z okresu 1969-1978 Strategia pająka (reż. B. Bertolucci, 1970), w formule eksponowanego wtedy konfliktu pokoleń, wyraziście unaocznia gorący

${ }^{4}$ Choć film ten został zrealizowany w 1959 roku, pozwoliłam sobie przesunać jego analizę do kolejnego rozdziału, bowiem faktycznie recepcja tego filmu rozpoczyna się w 1960 roku. Zob. także: Gli atti delle rassegne e seminari "Il sole sorge ancora" ed "Europa ritrovata", red. Paola Olivetti, Torino 1995. 
wówczas temat rozliczeń z dziedzictwem faszyzmu i wojny. Wreszcie Noc świętego Wawrzyńca (reż. P. i V. Taviani, 1982) oraz Człowiek, który nadejdzie (reż. G. Diritti, 2009) - filmy analizowane w rozdziałach dotyczących kolejno lat 1979-1994 oraz 1995-2012 - łączy subiektywny ogląd wydarzeń z perspektywy dziecka, chętnie wykorzystywany współcześnie w narracjach o resistenzy.

$\mathrm{W}$ piśmiennictwie polskim uwagi w zakresie interesującej mnie problematyki pojawiają się w monografiach poświęconych kinu włoskiemu (pióra Tadeusza Miczki) oraz kinu kontestacji (autorstwa Konrada Klejsy) ${ }^{5}$, ale stanowią one raczej punkt wyjścia do rozważań na inne tematy. Wśród włoskich publikacji na zajmujący mnie temat warto wspomnieć prace Gianfranco Goriego, Sary Pesce i Giuseppe Ghigiego ${ }^{6}$.

Spośród anglojęzycznych opracowań nieco refleksji nad reprezentacją włoskiego ruchu oporu w kinie oraz telewizji znajduje się w publikacjach Roberta Boswortha, Pierre'a Sorlina oraz Philipa Cooke'a'. Żadna z wymienionych publikacji nie wyczerpuje jednak interesującego mnie tematu i nie profiluje go w taki sposób, jaki zaproponowałam w mojej pracy.

Opisując przemiany dyskursu dotyczącego resistenzy, próbowałam zdystansować się wobec silnie zideologizowanego trybu argumentacji, właściwemu przede wszystkim rozpolitykowanej dekadzie lat 70 . W rozdziałach analitycznych $\mathrm{w}$ większym stopniu ujawniałam własne opinie i uwzględniałam bardziej subiektywne komentarze i oceny. Jeżeli mój styl wypowiedzi wyda się czytelnikowi nie dość wyważony, pozostaje przyjąć mi tę uwagę z pokorą.

Jeśli nie zaznaczono inaczej, tłumaczenia tekstów (zarówno anglojęzycznych, jak i włoskich) podaję w przekładzie własnym. Przy pierwszym wzmiankowaniu danego filmu zamieszczam jego tytuł polski, tytuł oryginalny, nazwisko reżysera oraz datę produkcji. Tytuł polski jest niekiedy moim tłumaczeniem, co każdorazowo zaznaczam. Podrozdział o filmie

5 Tadeusz Miczka, 10000 km od Hollywood. Historia kina włoskiego od 1896 roku do potowy lat 50. XX wieku, Kraków 1992; idem, W Cinecittà i okolicach. Historia kina włoskiego od połowy lat pięćdziesiatych do końca lat osiemdziesiątych XX wieku, Kraków 1993; idem, Kino włoskie, Gdańsk 2009 (to w zasadzie przedruk obu wyżej wymienionych tomów, uzupełnionych o część 1990-1999); Konrad Klejsa, Filmowe oblicza kontestacji, Warszawa 2008.

${ }_{6}$ Storia al cinema. Ricostruzione del passato/interpretazione del presente, red. Gianfranco Gori, Roma 1994; Sara Pesce, Memoria e immaginario. La seconda guerra mondiale nel cinema italiano, Genova 2008; Giuseppe Ghigi, La memoria inquieta. Cinema e resistenza, Venezia 2009.

7 Philip Cooke, The Legacy of the Italian Resistance, New York 2011; Italian Fascism. History, Memory and Representations, red. Robert Bosworth, Patrizia Dogliani, London 1999; Pierre Sorlin, The Film in History. Restaging the Past, Oxford 1980. 
Noc świętego Wawrzyńca ukazał się wcześniej - w nieco skróconej formie $-\mathrm{w}$, „Kwartalniku Filmowym” ${ }^{8}$.

Z pewnością fenomen resistenzy i jego obecność we włoskim filmie fabularnym mógł zostać omówiony w sposób inny niż ten zaproponowany przeze mnie; wierzę jednak, że najważniejsze problemy i zagadnienia udało mi się przedstawić. Mam jednocześnie nadzieję, że książka ta będzie stanowić przyczynek do dalszych badań z zakresu historii filmu oraz włoskiej kultury filmowej.

8 Anna Miller-Klejsa, Noc Świętego Wawrzyńca. Cienie (zapomnianych) przodków, „Kwartalnik Filmowy" 2013, nr 81. 


\section{Rozdział I}

\section{Resistenza w kulturze politycznej Włoch}

W Italii ruch oporu (tzw. resistenza: 1943-1945) stał się mitem założycielskim Republiki Włoskiej. Stosunek Włochów do wojny określiło po jej zakończeniu wszechobecne w środkach przekazu, dychotomiczne oddzielenie faszystowskich zbrodni popełnianych przez "odszczepieńców”, od działań i aspiracji ",dobrego" narodu włoskiego. Historyczna narracja, ukazująca Italię jako kraj bohatersko walczący po stronie aliantów, spełniała rolę terapeutyczną: pozwalała zapomnieć o wstydliwej, faszystowskiej przeszłości, a zarazem utrwalić w zbiorowej pamięci obraz wspólnego wroga - Niemców. Ale przecież Włochy od czerwca 1940 roku uczestniczyły w wojnie po stronie III Rzeszy; dopiero we wrześniu 1943 roku, po serii porażek militarnych, rząd włoski zerwał koalicję z państwami osi. 25 lipca 1943 roku, kiedy na Sycylii wylądowali już Amerykanie, Wielka Rada Faszystowska wystąpiła z wotum nieufności wobec Benito Mussoliniego; jego miejsce zajął powołany przez króla marszałek Pietro Badoglio, zaś 3 września 1943 roku podpisano tajny rozejm między aliantami a Włochami, który de facto dotarł do opinii publicznej - za pośrednictwem radia -8 września i spowodował ogólny zamęt w całym kraju. Badoglio wezwał bowiem siły zbrojne Włoch do zaprzestania działań wojennych przeciw aliantom, natomiast nie wydał jednoczesnego rozkazu, aby wojsko przystąpiło do obrony macierzystego terytorium. Sam Badoglio wraz z królem Wiktorem Emanuelem I uciekł na południe kraju, do Brindisi, pod „opiekę" wojsk alianckich.

W 1943 roku alianci po opanowaniu Sycylii dopiero zaczynali inwazję na południową część kraju. Tymczasem 12 września niemieccy komandosi pod wodzą Ottona Skorzennego uwolnili więzionego w Apeninach Mussoliniego i ten już trzy dni później proklamował Republikę Socjalną Salò - marionetkowe państwo, faktycznie całkowicie podporządkowane Niemcom, którzy zaczęli okupować terytorium północnej Italii ${ }^{1}$. Włoskie

${ }^{1}$ Określenie państwa jako republikańskiego miało znaczyć nie tyle podkreślenie społecznych treści i aspiracji Republiki Salò, ile symbolizować dystans do monarchii Sabaudii, uznanej przez faszystów za zdradziecką. 
społeczeństwo było zatem podzielone między zwolenników Mussoliniego (urzędującego nad jeziorem Garda) a partyzantów, wspieranych przez utworzony w 1943 roku Komitet Wyzwolenia Narodowego, wewnątrz którego także istniały światopoglądowe różnice ${ }^{2}$. Najwyrazistsze konflikty przebiegały na linii dwóch najliczniejszych jego stronnictw - chadecji i włoskiej partii komunistycznej, które stały się zresztą głównymi aktorami politycznej areny Włoch po wojnie. Obie partie wykorzystywały mit resistenzy, podkreślając własny udział w ruchu oporu. Pierwsze dwa lata po zakończeniu zbrojnego konfliktu (święto wyzwolenia obchodzone jest do dziś 25 kwietnia $^{3}$ ) to jednak przede wszystkim okres „współpracy ponad podziałami”" ${ }^{4}$. W Paryżu, w sierpniu 1946 roku, odbyła się wystawa poświęcona resistenzy (pod kuratelą włoskiego rządu), by także za granicą przekonać o wielkim wysiłku włoskiego społeczeństwa włożonym w wyzwoleńczą walkę.

Luigi Salvatorelli, naczelny redaktor gazety "La Stampa”, określił już w czasie wojny faszyzm jako antirisorgimento ${ }^{5}$. Takie sprofilowanie ustroju wprowadzonego przez państwo Mussoliniego pomogło po wojnie traktować faszyzm jako obce ciało, które nie mogło przyjąć się „w zdrowym organizmie włoskim" ${ }^{\prime 6}$. Ruch oporu 1943-1945 nazywano zaś secondo risor-

${ }^{2}$ Komitet Wyzwolenia Narodowego zrzeszał wszystkie antyfaszystowskie siły partyzanckie: chadecję, komunistów, socjalistów oraz zwolenników Partii Czynu (Partito d'Azione) - zradykalizowanego ruchu liberalnego.

${ }^{3} 25$ kwietnia - rocznica Wyzwolenia Włoch (L'anniversario della Liberazione d'Italia), zwana także Świętem Wyzwolenia (Festa della Liberazione) lub rocznicą ruchu oporu (L'anniversario della resistenza) to data umowna. 25 kwietnia 1945 roku miało miejsce wyzwolenie Mediolanu i Turynu (ostatnich przyczółków faszystowskiej władzy).

${ }^{4}$ "Celem walki jest narodowe wyzwolenie i zniszczenie faszyzmu. Wszystkie inne problemy będą rozwiązywane przez wolne, obywatelskie konsultacje i wybór Zgromadzenia Konstytucyjnego, gdy całe Włochy zostaną wyzwolone" - mówił Palmiro Togliatti w Salerno już w 1944 roku, po powrocie z ZSRR do Włoch. Zob. Donald Sassoon, The Strategy of the Italian Communist Party: From the Resistance to the Historic Compromise, London 1981, s. 18. O podkreślaniu narodowego charakteru resistenzy świadczy także zorganizowany w 1947 roku I narodowy kongres ANPI (Associazione Nazionale Partigiani d'Italia - największego partyzanckiego stowarzyszenia we Włoszech, powstałego w czerwcu 1944 roku). Kongres odbył się bowiem w stolicy - w rzymskim Teatro Italia. Z tej okazji ANPI wydał także jedyny numer gazety, zatytułowanej „Il Tricolore” (nawiązując w ten sposób do włoskiej flagi). Związek szybko jednak się podzielił (zwyciężyły polityczne różnice) - w 1948 roku chadecy, liberałowie i „niezależni” utworzyli FIVL (Federazione italiana volontari della libertà), a zwolennicy partii czynu i demokraci w 1949 roku utworzyli FIAP (Federazione italiana delle associazioni partigiane).

${ }^{5}$ Risorgimento to okres ruchów wyzwoleńczych XIX wieku, dążących do zjednoczenia Włoch. Zob. Luigi Salvatorelli, Pensiero e azione nel Risorgimento, Turin 1943, s. 189.

${ }^{6}$ Do takiego postrzegania faszyzmu przyczynił się z pewnością Benedetto Croce, który w cyklu swoich esejów pisał o faszyzmie jako o „intelektualnej i moralnej chorobie”, która zainfekowała Włochów po I wojnie światowej i zablokowała postęp kraju. 
gimento, co dodatkowo akcentowało narodowy charakter wyzwoleńczej walki przeciw obcemu wrogowi. Używanie tego określenia w odniesieniu do resistenzy było na tyle żywotne, że po wojnie w Mediolanie zorganizowano wystawę Pierwsze $i$ drugie "risorgimento" łączącą te dwa fenomeny. Innym ciekawym przejawem ich połączenia jest pierwsza wersja obrazu Renato Guttuso La battaglia di Ponte dell'Ammiraglio (1952). Obraz przedstawia kluczową bitwę risorgimenta - na koniu widać Garibaldiego. Gdy przyjrzymy się twarzom jego współtowarzyszy, okaże się, że to komunistyczni bohaterowie resistenzy (drugiego risorgimento): Pajetta, Trombadori, Longo, Vittorini ${ }^{7}$.

O tym, że ruch oporu traktowano jako swoistą cezurę - moment narodzin nowej republiki - świadczy najlepiej nieco poetycka wypowiedź jednego z partyzantów, Teresio Olivellego:

Resistenza to rewolta przeciw systemowi i epoce, przeciw sposobowi myślenia i życia. Nigdy nie czuliśmy się tak wolni jak wtedy, gdy odkryliśmy w głębi naszej świadomości zdolność do buntu przeciw biernej akceptacji brutalnych faktów [...]. Wielki ból i wojenne cierpienie oczyściły nas z grzechu [...]. Zaczynamy od nowa! Spieszmy się, by tworzyć ${ }^{8}$.

Epoka faszyzmu stała się natomiast odległym wspomnieniem, co dobrze unaocznia fragment artykułu, który ukazał się w listopadzie 1945 roku w periodyku „Società":

[...] wojna niedawno się skończyła, ale nikt z nas nie może sobie przypomnieć życia przed wojną. Nikt nie może odnaleźć swojej przeszłości. Wydaje nam się ona niezrozumiała. Nawet Renesans lub wiek XIX wydają się bliższe niż smutne lata dnia wczorajszego... Nasze życie teraz zdominowane jest przez instynktowne poszukiwanie kierunku9 .

\section{Jak słusznie zauważa Robert Bosworth,}

przez 20 lat miliony Włochów poddawały się obietnicom Mussoliniego, który mamił Włochów narodową jednością i międzynarodowym prestiżem. [...] Dyktatura

7 Obraz dostępny pod adresem: www.arte.it/opera/la-battaglia-di-ponte-dell-ammiraglio-4920 (dostęp: 10.07.2013).

${ }^{8}$ Cyt. za: Ugoberto Grimaldi, Marina Saba, Cultura a passo romano, Milano 1983, s. 76-77. Bojownicy ruchu oporu byli często dezerterami z armii faszystowskiej. Cytowany Teresio Olivelli w 1940 roku zdobył np. pierwszą nagrodę w konkursie Littoriali za esej o tematyce faszystowskiej.

9 Przedruk w: Italian Fascism. History, Memory and Representations, red. Robert Bosworth, Patrizia Dogliani, London 1999, s. 83. 
przyniosła jednak nie tylko okupację innych krajów, ale i wojnę domowa, przez co wzmocniła u Włochów poczucie własnej krzywdy; w konsekwencji rzadko widzieli się oni jako agresorzy ${ }^{10}$.

Choć więc po wojnie istniało pragnienie sprawiedliwości (czego dowodem była powojenna komisja ds. zbrodni faszyzmu) i zemsty (liczne samosądy), trauma klęski oraz konieczność odbudowy ostatecznie utemperowała zamiary defaszyzacji. W konsekwencji, jak podaje Bosworth, niewielu zwolenników Mussoliniego po wojnie straciło pracę lub zapłaciło kary; tym bardziej, że w czerwcu 1946 roku Togliatti, ówczesny minister sprawiedliwości - dążąc do narodowego pojednania - ogłosił amnestię dla "faszystowskich kryminalistów”. Niektórzy z nich, jak Giuseppe Bottai czy Dino Alfieri, nie tylko nie odbyli kary pozbawienia wolności, ale także pobierali emerytury za służbę narodowi sprawowaną w czasie faszystowskiego reżimu ${ }^{11}$.

Zawiązana w ostatnich latach zbrojnego konfliktu unia włoskich partii nie przetrwała zimnej wojny. Korzystające z amerykańskiej pomocy Włochy pozostawały pod silnym wpływem Stanów Zjednoczonych. W kwietniu 1948 roku w wyborach do parlamentu zwyciężyła popierana przez nie Chrześcijańska Demokracja, zaś komuniści zostali wykluczeni z rządu. $\mathrm{W}$ konsekwencji włoski ruch oporu, kojarzony w dużej mierze z partią komunistyczna, stał się tematem niewygodnym, by nie powiedzieć - cenzurowanym (okres od 1948 do początku lat 50. nazywany jest niekiedy okresem rozprawy z włoską partyzantką - tzw. processo alla resistenza).

Faktem jest, że w roku 1948 nastąpiły liczne aresztowania byłych (związanych z partią komunistyczną) partyzantów, którzy zostali uznani za przestępców. Rzeczywiście, niektórzy z nich, szczególnie na północy kraju, wymierzali „sprawiedliwość" na własną rękę. Wielu aresztowanym postawiono jednak zarzuty niesłusznie ${ }^{12}$. W 1948 roku ówczesny minister spraw wewnętrznych, Mario Scelba, ograniczył także możliwość publicz-

\footnotetext{
10 Ibidem, s. 87.
}

11 Amnestię tłumaczono tradycją - akt ułaskawienia ogłaszany był zazwyczaj przy wyborze nowego króla. Pomimo że Włochy stały się po wojnie republika, uzus został zachowany. O tym, że proces defaszyzacji nie był radykalny, świadczy także fakt wydania w końcu lat 40. wszystkich prac Mussoliniego oraz tych napisanych przez członków rodziny Duce. I tak na przykład w 1948 roku Rachele Mussolini opublikowała książkę zatytułowaną Moje życie z Benito, zaś 10 lat później Vittorio Mussolini wydał wspomnienia Życie z moim ojcem.

12 Dowodem takiej „pomyłki” jest m.in. los Antonia Meluschi (włoskiego partyzanta i męża pisarki Renaty Viganò), który został zatrzymany w 1949 roku i był przetrzymywany w więzieniu przez kilka miesięcy. Antonio Meluschi po wojnie napisał La morte non costa niente (1946) - powieść o swoich wojennych doświadczeniach. 
nych demonstracji (również tych podczas Święta Wyzwolenia). Artykuł opublikowany w chadeckim "Il Popolo Nuovo" dobrze oddaje atmosferę uroczystości narodowego święta resistenzy w Turynie:

Prócz kilku niegodnych epizodów, zainicjowanych przez włoską partię komunistyczna, prawdziwe obchody święta 25 kwietnia miały miejsce wczesnym rankiem na cmentarzu, gdzie położono kwiaty na grobach poległych i odbyła się msza. Tu również nie obyło się bez zakłóceń: delegacja chadeckich partyzantów została obrzucona wyzwiskami przez kilka komunistek ${ }^{13}$.

Lata 50. to dekada usuwania narracji o ruchu oporu z dyskursu publicznego. Jak podaje Giuseppe Ghigi, w 1955 roku (w dziesiątą rocznicę wyzwolenia) do szkół wysłano cyrkularz, w którym „radzono”, by 25 kwietnia zaprezentować uczniom przede wszystkim jako (faktyczną) datę urodzenia Guglielmo Marconiego i to na tej postaci (a nie na włoskim ruchu oporu) skoncentrować ich uwagę. Sytuację tę żartobliwie ujmuje Philip Cooke pisząc, że w latach 50. zamiast o resistenzy można mówić o „desistenzy" ${ }^{14}$. Jakiekolwiek próby „oddolnego" zorganizowania alternatywnych - wobec oficjalnych uroczystości - obchodów upamiętniających resistenzę napotykały ogromne trudności. Dopiero w 1958 roku odbyła się większa demonstracja poparta przez grupę włoskich intelektualistów (m.in. Carla Leviego i Alberta Moravię). Wystosowali oni wtedy deklarację przypominająca, że „,̇adna forma kultury, która nie miałaby

${ }^{13}$ Fragment artykułu z „Il Popolo Nuovo”, 26.04.1948. Przedruk w: Culture, Censorship and the State in Twentieth-Century Italy, red. Guido Bonsaver, Robert S. C. Gordon, Oxford 2005 , s. 121. Walka o pamięć udziału w resistenzy trwała. Włoska partia komunistyczna podkreślała swą rolę w ruchu oporu poprzez poświęcone temu zagadnieniu książki. Należy tu wymienić choćby wydane w tej samej serii - Biblioteka Ruchu Robotniczego - publikacje autorstwa członków PCI: Pietro Secchia, I comunisti e l'insurrezione: 1943-1945, Roma 1954; Luigi Longo, Sulla via dell'insurezione nazionale, Roma 1954. O zdolnościach propagandowych członków partii komunistycznej opowiada z przymrużeniem oka Gustaw Herling-Grudziński, wspominając wizytę Palmiro Togliattiego w domu Benedetto Crocego (ojca swojej żony Lidii): „Przywódca komunistyczny okazał żywe zainteresowanie tym, że Lidię ciekawi literatura rosyjska. Przysłał jej potem książkę wydaną w ZSRR w półmilionowym nakładzie, co podkreślił w widoczny sposób. Zwróciłem na to uwagę, bo to w oczywisty sposób ujawniało zdolności propagandowe Togliattiego, który tę młodą dziewczynę, uczącą się rosyjskiego uznał za ewentualnego partnera do rozmowy". Gustaw Herling-Grudziński, Pod światło, Kraków 1998, s. 52. Jest to przekład wywiadu rzeki przeprowadzonego przez Titti Marrone z Herlingiem-Grudzińskim, który ukazał się we Włoszech w 1995 roku.

${ }_{14}$ Philip Cooke, The Italian State and the Resistance Legacy in the 1950s and 1960s, [w:] Culture, Censorship and the State in Twentieth-Century Italy, red. Guido Bonsaver, Robert S. C. Gordon, Oxford 2005, s. 120. „Desistenza” to gra słów - esistenza to bowiem po włosku „istnienie"/"bycie” zaś przedrostek „de" wskazuje na negację, brak. Określenie to jest tym bardziej udane, że fonetycznie przypomina resistenzę. 
swoich źródeł pośrednio lub bezpośrednio w wielkim ruchu resistenzy, nie mogłaby dziś we Włoszech istnieć' ${ }^{\prime \prime 15}$.

Pewnym przełomem dla obecności tematu włoskiego ruchu oporu w dyskursie publicznym był dopiero rok 1960. Na czele włoskiego rządu tworzonego przez chadecję stanął wtedy Fernando Tambroni, który otrzymał w wyborach poparcie od Włoskiego Ruchu Socjalnego (MSI), wywodzącego się z partii faszystowskiej. W dowód wdzięczności Tambroni wyraził zgodę na organizację krajowego kongresu MSI w Genui - mieście z tradycjami antyfaszystowskimi, odznaczonym złotym orderem resistenzy. Decyzja ta doprowadziła do protestów (byłych partyzantów, robotników i studentów), które rozszerzyły się na inne miasta. O tym, że w czasie strajków temat resistenzy był eksponowany, świadczą m.in. słowa Sandro Pertiniego (byłego partyzanta i późniejszego prezydenta Włoch) skierowane do zebranego tłumu:

Partyzanci i pracownicy, genueńczycy wszystkich klas. Władze w Rzymie ciężko wysilają się, by znaleźć osoby, które uważają za prowokatorów i podżegaczy tych antyfaszystowskich demonstracji. Nie muszą się jednak tak wysilać. Mogę wam powiedzieć panowie, kim są nasi podżegacze - polegli w Turchino, Benedicta i Corvasco ${ }^{16}$.

I choć zamieszki zostały brutalnie spacyfikowane przez policję Celere (podległą ministrowi spraw wewnętrznych), w następstwie tych faktów Tambroni podał się do dymisji, zaś chadecja zerwała stosunki z postfaszystowskim Włoskim Ruchem Socjalnym i zwróciła się do sojuszu z Partią Socjalistyczną - w ten sposób powstał pierwszy w powojennych Włoszech centrolewicowy rząd ${ }^{17}$.

O tym, że w latach 60. mit ruchu oporu powrócił do sfery publicznej, świadczy także transformacja miejskich przestrzeni. Jak podaje Cooke, w latach 1963-1968 wzniesiono 49 nowych monumentów upamiętniających wojenny dramat. Większość z nich powstała jednak z "oddolnej”, lokalnej inicjatywy. Jedynym oficjalnym „pomnikiem pamięci” sponsorowanym przez administrację centralną było wówczas mauzoleum wybu-

${ }^{15}$ Cyt. za: Lucio Cecchini, Per la libertà d'Italia, per L'Italia delle Libertà. Profilo storico dell'Associazione Nazionale Partigiani d'Italia, Roma 1996, s. 179.

16 Turchino, Benedicta i Corvasco to miejsca w Ligurii, gdzie miały miejsce nazistowskie represje.

17 Sprawa Tamborniego była klęską Włoskiego Ruchu Socjalnego (MSI), ale partia cały czas prężnie działała. O ile w latach 50 . na rynku wydawniczym pojawiły się indywidualne wspomnienia weteranów Republiki Socjalnej Salò, o tyle w 1960 roku ukazały się te, które były swego rodzaju odpowiedzią na Lettere di condannati a morte della Resistenza italiana, red. Piero Malvezzi, Giovanni Pirelli, Torino 1952. 
dowane w końcu lat 40. na miejscu masakry w Jaskiniach Ardeatyńskich (wł. Fosse Ardeatine), w której zginęło 330 Włochów ${ }^{18}$.

Dopiero w 1965 roku obchody upamiętniające włoski ruch oporu zostały zorganizowane przez narodowy komitet (na czele z ówczesnym premierem Aldo Moro), w którym znaleźli się także przedstawiciele opozycyjnej partii komunistycznej ${ }^{19}$. Podczas uroczystości śpiewano Bella ciao - najpopularniejszą piosenkę resistenzy. Lata 60. to zresztą złoty wiek partyzanckiej piosenki (wydano wtedy cały dziesięciopłytowy cykl I canti della resistenza italiana oraz trzypłytową kolekcję: I canti della resistenza europea zawierającą 46 piosenek z 16 krajów (w oryginalnych językach). W latach 60. pojawiają się także książki o resistenzy dla młodzieży - na przykład w Mediolanie wydano na ten temat 10 książek w serii Racconto per ragazzi.

Ruch oporu stał się gorącym tematem pod koniec dekady, w okresie społecznego wrzenia, gdy kontestująca młodzież domaga się od pokolenia rodziców wyznania zbiorowej winy i przyjęcia jednostkowej odpowiedzialności za popełnione w przeszłości zbrodnie. Pacyfistyczne formy protestu ulegają radykalizacji. Jak celnie podsumowuje Sara Pesce:

Od długich włosów szybko przechodzi się do zaciśniętej pięści. [...] I tak po byciu hipisem [...] młodzi przeistaczają się szybko w maoistów-ekstremistów. Zmiana wisi w powietrzu [...] Włochy wchodzą w spiralę przemocy: terroryzm puka do drzwi swoim ciężarem ofiar i strachu ${ }^{20}$.

W latach 70. resistenzy nadane zostaje nowe znaczenie - wedle środowisk skrajnie lewicowych powojenna włoska republika przywróciła porządek społeczny i ekonomiczny faszystowskiego reżimu. Zdaniem

18 Philip Cooke, The Legacy of the Italian Resistance, New York 2011, s. 105. Zespó budowli z ogrodem uzupełnionym o bramę zaprojektowaną przez Mirko Basaldella w 1951 roku upamiętnia poległych w nazistowskiej masakrze, będącej odpowiedzią Niemców na partyzancki zamach na Via Rasella w Rzymie, w wyniku którego zginęło 33 Niemców; w mauzoleum nie ma jednak słowa o zamachu na Via Rasella i rzymskim ruchu oporu oraz faszyzmie. Na temat pomników poświęconych włoskiemu ruchowi oporu zob. też: Luciano Galmozzi, Monumenti alla libertà. Antifascismo Resistenza e pace nei monumenti italiani dal 1945 al 1985, Milan 1986.

19 Więcej o tym zob. Philip Cooke, op. cit., s. 103.

20 Sara Pesce, Memoria e immaginario. La seconda guerra mondiale nel cinema italiano, Genova 2008, s. 185. Ciekawostką jest fakt, że do opisania politycznych sympatii lat 60. i 70. radykałowie używali metafory arbuza, wskazując, że owoc zielono-biało-czerwony ma takie barwy, jak flaga Włoch. Biała część - niemająca wartości odżywczych - to chadecja; pyszny czerwony miąższ miał symbolizować komunizm, a czarne niestrawne pestki miały symbolizować ugrupowania neofaszystowskie. 
radykałów potrzebna była zatem kontynuacja ruchu oporu rozumianego jako walka ze współczesnym „faszyzmem”.

W "dekadzie ołowiu” owa walka rozgrywała się nie tylko w sensie dosłownym - działania wymierzone w politycznych przeciwników nazywano „walką partyzancką” (lotta partigiana) lub „partyzanckim ruchem oporu" (resistenza partigiana) - ale również na polu symbolicznym. Świadectwem czerpania z tradycji ruchu oporu przez ugrupowania lewackie były slogany skandowane podczas manifestacji: "resistenza nas nauczyła, że zabicie faszysty nie jest przestępstwem”; "faszyści, panowie, dla was nie ma jutra, właśnie organizują się nowi partyzanci”, ,"towarzysze partyzanci, jesteśmy u waszego boku" ${ }^{21}$. Nietrudno więc zauważyć, że dla młodych aktywistów faszyzm nie odnosił się do historii (reżimu Mussoliniego), ale także dotyczył rzeczywistości współczesnej. Przynależność do tradycji resistenzy oznaczała swoiste usprawiedliwienie dla używania tych samych, co partyzanci "siłowych środków dywersji”. Jak słusznie zauważa Paul Ginsborg, „terroryści uważali, iż podobnie jak antyfaszystowski ruch oporu stanowią przykład mniejszości ludzi młodych, którzy używają przemocy dla słusznych celów"22.

Świadectwem wykorzystywania ruchu oporu przez środowiska politycznych radykałów były nie tylko ulotki i komunikaty politycznych ugrupowań, ale także agitacyjne plakaty. Wiele z nich, choć mówiło o czasach współczesnych, odwoływało się do czasów II wojny światowej. Przykładowo, plakat ultraprawicowego MSI (Włoskiego Ruchu Społecznego) prezentował żołnierza, trzymanego na muszce pistoletu; wizerunek mężczyzny - hełm, karminowe usta i kwadratowa szczęka - przypominał ikoniczne reprezentacje Duce. Z jednej strony plakat umownie ukazywał więc egzekucję Mussoliniego jako akt terroryzmu; z drugiej zaś przedstawiał lewackich terrorystów jako spadkobierców resistenzy.

Odwołania do tradycji włoskiego ruchu oporu w latach 70. zostały utrwalone także we wzniesionych pomnikach. Dobrym przykładem jest ten stojący w centrum Mediolanu, poświęcony Claudio Varalli i Giannino Zibecchiemu - „poległym” w demonstracjach z kwietnia 1975 roku. Na monumencie pod wykutymi twarzami ofiar widoczny jest napis: „caduti partigiani della nuova resistenza" („, polegli partyzanci nowej resistenzy”).

${ }^{21} \mathrm{~W}$ oryginale slogany te niejednokrotnie rymują się: la resistenza ce l'ha insegnato uccidere un fascista non è reato; fascisti, padroni, per voi non c'è domani, si stanno organizzando i nuovi partigiani.

22 Por. Paul Ginsborg, Storia d'Italia dal dopoguerra a oggi, Torino 1990, s. 128. 
Resistenza funkcjonowała także jako oficjalna pamięć lewackiego terroryzmu (szczególnie Czerwonych Brygad). W książce Mara, Renato e io, Alberto Franceschini, jeden z założycieli grupy opisuje spotkanie z partyzantem, który ponoć przekazał mu broń użytą przeciw Niemcom. Franceschini wyznaje, iż gest ten był zarazem powierzeniem mu przez sędziwego „żołnierza" partyzanckich ideałów oraz utraconej młodości i siły ${ }^{23}$. W innym miejscu wspomina:

słuchaliśmy opowieści bojowników ruchu oporu. Podążając za ich wskazówkami szukaliśmy składów broni ukrytych w górach. Wejście na partyzancką ścieżkę było jednym z naszych inicjacyjnych rytów ${ }^{24}$.

Wedle Marie-Anne Matard-Bonucci, spotkanie z partyzantem staje się swoistym toposem wspomnień brygadierów. Wielu z nich podkreśla rodzinne więzi z bojownikami oporu, uwypuklając tym samym pokoleniową ciągłość „,wojennych doświadczen" ${ }^{25}$. Owszem, zdarzały się przypadki rzeczywistego zaangażowania byłych partyzantów w działalność lewackich ekstremistów ${ }^{26}$, jednak to głównie media przyczyniły się do wykreowania wspólnej historii „brygadierów” i partyzantów (znamienny pod tym względem jest na przykład tytuł artykułu zamieszczonego w "La Repubblica” z 1990 roku: Franceschini: Czerwone Brygady używaja broni partyzantów $\left.{ }^{27}\right)$.

Fenomen resistenzy został więc w "dekadzie ołowiu" w skrajny sposób upolityczniony. Odczytywany przez skrajną lewicę w kluczu marksistowsko-leninowskim stał się także orężem krytyki wobec włoskiej partii komunistycznej, próbującej dążyć do dialogu i historycznego kompromisu z chrześcijańską demokracją. Towarzysze, którzy nie chcieli przekształcić

${ }^{23}$ Alberto Franceschini, Mara, Renato e io. Storia dei fondatori delle BR, Milano 1988, s. 3-4.

${ }^{24}$ Wypowiedź cytowana w: Mario Moretti, Brigate Rosse. Una storia italiano, Milano 2007, s. 157.

${ }^{25}$ Morucci i Franceschini opowiadają o swoich ojcach - partyzantach i więźniach Auschwitz; Franceschini wspomina dziadka antyfaszystę, deklarując, iż jego opowieści o resistenzy były dla niego bajkami na dobranoc, zaś Renato Curcio przywołuje pamięć o wujku, który został zabity przez nazistów podczas wyzwalania Turynu. Zob. rozdział: Usi dell'antifascismo e della resistenza nelle Brigate rosse, [w:] Il libro degli anni di piombo. Storia e memoria del terrorismo italiano, red. Marc Lazar, Marie-Anne Matard-Bonucci, Milano 2010.

${ }^{26}$ Jednym z takich partyzantów był Cino Moscatelli - z którym ukrywający się Franceschini jadał obiady. Tak to wspomina: „nasi towarzysze wyglądali na zadowolonych, że mogą zjeść z wielkim Cino. I także my byliśmy, czuliśmy się prawie jak szefowie partyzanckich grup". Więcej o tym zob. Alberto Franceschini, op. cit., s. 50-51.

${ }^{27}$ Cyt. za: Il libro degli anni di piombo..., s. 27. 
„wiatru z północy” (jak określano ruch oporu) w „wiatr ze wschodu” (w rewolucję społeczną), zasługiwali w oczach radykałów na potępienie. Owo upolitycznienie reisistenzy, a zarazem nieustanne odwoływanie się przez środowisko lewicowe do jej tradycji, dobrze unaocznia tekst piosenki Dziewiaty maja (Nove maggio) autorstwa Ivana Della Mei, która, jak odnotowuje Ghigi, stała się pieśnią młodych buntowników („Wczoraj walczyłem/przeciw faszyście i okupantowi/dziś walczę przeciw padrone/o tę samą wolność" - głosi jedna ze zwrotek ${ }^{28}$. Mimmo Franzinelli celnie podsumowuje: „we Włoszech dekady buntu resistenza stanowiła idealny model walki, partyzanci postrzegani zaś byli przez młodych jako «starsi bracia», którzy w perspektywie psychoanalitycznej zastępowali ojca wyrzuconego z pola widzenia przez pokoleniową kontestację ${ }^{29}$.

Po rozpolitykowanych, naznaczonych terroryzmem latach 70. (ich symboliczną, graniczną datą jest 1978 - rok zabójstwa Aldo Moro przez Czerwone Brygady), kolejna dekada stanowi okres politycznej stabilizacji w okresie rządów Bettino Craxiego (reprezentanta Włoskiej Partii Socjalistycznej). To zarazem, jak podsumowuje Ghigi, czas zmierzchu mitu resistenzy (choć prezydentem Włoch jest wtedy były partyzant, Sandro Pertini, wybrany na głowę państwa w 1978 roku) ${ }^{30}$.

Za symptom zmian $\mathrm{w}$ postrzeganiu włoskiego ruchu oporu może zostać uznana sprawa losów Waltera Redera odpowiedzialnego za masakrę w Marzabotto ${ }^{31}$. Wedle Cooke'a stała się ona w latach 80. politycznym i ideologicznym polem bitewnym ${ }^{32}$. Po wyjściu Herberta Kapplera

${ }^{28}$ „W czasach walki/czerwony był moim kolorem/ale dziś w godzinie pamięci/noszę trzy kolory./W barwach Włoch jest plac/W barwach Włoch są partyzanci/Wszyscy jesteśmy Włochami/Niech żyje, niech żyje nowa jedność./Jakie obchody i pieśni,/jakie krzyki i huk/jest Longo i Parri/i jest także Andreotti./Jest także mój przełożony,/ten, który mnie zwolnił,/także on w barwach Włoch./Zerwałem więc chustkę/tę biało-zielono-czerwona/i na szyję założyłem tę,/która jest tylko czerwona./Wczoraj walczyłem/przeciw faszyście i okupantowi./Dziś walczę przeciw padrone/o tę samą wolność".

${ }^{29}$ Por. Mimmo Franzinelli, La resistenza e le provocazioni del sessantotto, „L'impegno” 2001, nr 2. Artykuł dostępny na stronie: www.storia900bivc.it/pagine/editoria/franzinelli201.html (dostęp: 25.07.2013).

${ }^{30}$ Cały proces neoresistenzy miał swój punkt kulminacyjny w 1978 roku wraz z wyborem na prezydenta republiki Sandro Pertiniego, bohatera włoskiego ruchu oporu - stwierdza nie bez racji Philip Cooke. Zob. Philip Cooke, op. cit., s. 118. To jeden z argumentów za przyjętym przeze mnie podziałem badanego materiału i wyodrębnieniem rozdziału 1970-1978.

${ }^{31} \mathrm{O}$ tej największej zbrodni wojennej na terenie Włoch piszę obszerniej w dalszej części pracy.

${ }^{32}$ Ibidem, s. 133. Pertini - weteran wojenny i jeden z sygnatariuszy wyroku śmierci na Mussoliniego - udał się z jedną z pierwszych oficjalnych wizyt w 1979 roku właśnie do Marzabotto. 
(pułkownika gestapo; biorącego udział w masakrze w Fosse Ardeatine) na wolność, Reder pozostawał jedynym zbrodniarzem wojennym „dużego formatu" odbywającym karę we Włoszech. Mimo to, w 1983 roku wojskowy sąd w Bari wydał decyzję, że więzień może wyjść na wolność po pięciu latach od daty orzeczenia. Po fali społecznych protestów, które przetoczyły się przez kraj, sprawa trafiła do parlamentu. Nie wszyscy włoscy politycy okazali się przeciwni uwolnieniu Redera: Ugoberto Grimaldi - na łamach periodyka swojej partii "Avanti” stwierdził na przykład, że jako socjalista nie może pogodzić się z karą dożywocia.

W obliczu narastającego sporu Craxi postanowił przeprowadzić referendum na terenach Marzabotto i okolic w sprawie uwolnienia Redera. Większość mieszkańców, jak można było przypuszczać, opowiedziała się za tym, by Niemiec pozostał w więzieniu. Równocześnie w innych rejonach kraju coraz głośniej wybrzmiewały głosy zachęcające do uwolnienia wojennego zbrodniarza. Wśród tej grupy był m.in. poważany we Włoszech Giorgio Bocca - eseista i dziennikarz, który w czasie wojny należał do włoskiej partyzantki. Opublikował on na łamach „La Repubblica” artykuł Jestem za uwolnieniem Redera, w którym stwierdzał, że są „inni, ważniejsi od tej sprawy - «wrogowie», z którymi powinno się teraz walczyć" ${ }^{\prime 33}$. Craxi ostatecznie obłaskawił Redera ${ }^{34}$. Przedstawiciele pentapartito ${ }^{35}$ na łamach prasy niedwuznacznie wyrażali aprobatę dla decyzji polityka. Politycy lewicy byli natomiast zbulwersowani. Ugo Pecchioli, ówczesny senator partii komunistycznej, nazwał gest Craxiego „niepokojącym sygnałem”, a w artykule opublikowanym w "Rinascita” w marcu 1985 roku wyraził swoje obawy, dotyczące faktu, że resistenze uznaje się za zjawisko historyczne należące do odległej przeszłości, a zatem mało istotne. Sygnałem tego sposobu myślenia było - wedle polityka - właśnie uwolnienie Redera ${ }^{36}$.

Lata 90. to we Włoszech okres głębokich przemian. W pierwszej połowie dekady dochodzi do zasadniczych zmian na arenie politycznej, spowodowanych ujawnieniem - w ramach akcji "czyste ręce” (mani pulite) - skorumpowania niemal całego włoskiego systemu politycznego i gospodarczego (przed sądem stanął nawet Craxi, który w wyniku afery musiał

${ }^{33}$ Giorgio Bocca, Io sono a favore di Reder libero, „La Repubblica”, 29.12.1984.

${ }^{34}$ Reder wrócił do Austrii, gdzie na lotnisku z honorami przyjęty został przez Friedhelma Frischenschlagera, ówczesnego ministra obrony.

35 Pentapartito to termin używany na określenie pięciopartyjnej koalicji rządowej, która sprawowała władzę we Włoszech w latach 1980-1992.

36 Pecchioli wymieniał też inne symptomy tego kierunku: poparcie neofaszystowskiego Włoskiego Ruchu Społecznego (MSI) dla rządu oraz słowa nowego premiera o konieczności zakończenia "gettoizacji” tego ugrupowania. Ugo Pecchioli, Perché si è riaperto il dibattito su fascismo e antifascismo, „Rinascita” 1985, nr 8-9. 
opuścić Włochy i schronił się w Tunezji). Mediolan, będący ekonomiczno-finansowym centrum kraju, zyskał wtedy niechlubne miano Tangentopoli - miasta łapówek, którym zaczęto wkrótce określać całe Włochy. W konwencji system partyjny Włoch uległ całkowitej transformacji: rozpadły się zarówno chadecja, jak i partia komunistyczna, zaś na arenie politycznej pojawiły się całkowicie nowe ugrupowania; wśród nich Forza Italia, kierowana przez Berlusconiego, który w 1994 roku objął władzę i zawarł koalicję m.in. z faszyzującym Włoskim Ruchem Społecznym.

Jak zauważa Ghigi, nowa władza, by legitymizować sojusz z partią postfaszystowska, próbowała przezwyciężyć opozycję faszyzm/antyfaszyzm w imię historycznego pojednania ${ }^{37}$. Celem stało się więc społeczne zaakceptowanie postawy wielu Włochów, którzy po 8 września 1943 roku poparli Republikę Salò i Mussoliniego. Wydarzenia z lat 19431945 nie były już określane jako „walka z faszyzmem”; częściej używa się terminu „wojna domowa”38, w której strony konfliktu - „chłopcy z Salò" i partyzanci (wywodzący się w dużej mierze z włoskiej partii komunistycznej) są niejako dwiema stronami medalu. Gianfranco Fini mówił wręcz o Italia parificata, postulując równe traktowanie walczących po obu stronach konfliktu w latach 1943-1945 (chciał, by mieli oni takie same prawa, na przykład otrzymywali pensje w tej samej wysokości). Nieprzypadkowo na forum publicznym powrócił wtedy ponownie temat działających po wojnie „poza prawem” byłych partyzantów (o czym była już mowa).

Sygnały dążenia do zrównania ze sobą statusu włoskich partyzantów oraz chłopców z Salò dały się odczuć w 50. rocznicę wyzwolenia. W trakcie jubileuszowych obchodów upamiętniających włoski ruch oporu, które były - jak dowodzi Cooke - największą polityczno-kulturalną inicjatywą w historii narodu (większą niż wszystkie obchody risorgimento razem wzięte) ${ }^{39}$, z ust polityków padały bowiem rozmaite postulaty. I tak, ówczesny minister edukacji, Lombardi apelował w mediach do szkół, by uroczystości poświęcone resistenzy umożliwiły dzieciom „przyswojenie sobie pozytywnych wartości” i by uwrażliwiły najmłodszych na „przemoc

37 Giuseppe Ghigi, La memoria inquieta. Cinema e resistenza, Venezia 2009, s. 215.

${ }^{38}$ Pod tym tytułem w 1995 roku, a zatem w 50. rocznicę zakończenia wojny, ukazało się opracowanie historyczne analizujące ten okres autorstwa Claudio Pavone. Zob. Claudio Pavone, Guerra civile. Saggio storico sulla moralità nella Resistenza, Roma 1995.

39 Jeśli wierzyć 800-stronicowemu raportowi wydanemu we Włoszech z okazji okrągłej rocznicy resistenzy, w jubileuszowym roku miało miejsce ok. 500 rozmaitych uroczystości jej poświęconych, nie licząc inicjatyw szkolnych, które zaangażowało około 2 miliony studentów i uczniów oraz blisko 500 wystaw. 
w jakiejkolwiek postaci". Gianfranco Fini w przededniu głównych, kwietniowych obchodów jubileuszu udzielił zaś wywiadu dla "Corriere della Sera", wyrażając nadzieję, że 50. rocznica wyzwolenia i włoskiego ruchu oporu będzie pierwszym dniem roku pojednania „włoskiego narodu jako takiego" ${ }^{\prime 0}$. Co więcej, w dzień poprzedzający 25 kwietnia Fini uczestniczył w uroczystości nad grobem nieznanego żołnierza, gdzie zwolennicy partii neofaszystowskiej złożyli wieniec opatrzony napisem: „Naszym poległym braciom, bracia pojednani". Silvio Berlusconi w ogóle nie pojawił się na oficjalnych obchodach w 1994 roku i od tego momentu jego obecność na rocznicowych uroczystościach była tematem rozmaitych spekulacji.

Proces stopniowego postponowania resistenzy odbywał się także poprzez podkreślanie sprzeczności wewnątrz włoskiego ruchu oporu oraz sugestię, że jego komunistycznym oddziałom chodziło nie tyle o wyzwolenie kraju i stworzenie demokracji, ile rozpowszechnianie innego totalitaryzmu. Trudno nie zgodzić się więc z Giovannim De Luną, który stwierdza, że resistenza przypomina swoisty „supermarket pamięci”, w którym każda opcja polityczna znajduje elementy legitymizujące swoje wizje i projekty ${ }^{41}$.

Zmiany tonu wypowiedzi o nie tak odległej przecież historii kraju można doszukać się również $\mathrm{w}$ przemówieniach prezydenta Włoch Oscara Scalfaro. Dnia 8 września (w dzień ogłoszenia publicznie przez Italię zmiany frontu) Scalfaro powiedział, że „Lojalne respektowanie prawdy może być pewną bazą prawdziwego pojednania". Trudno temu przekonaniu cokolwiek zarzucić. Kontrowersje mogą budzić jednak słowa wypowiedziane przez prezydenta $\mathrm{w}$ kwietniu tego samego roku (w trakcie głównych obchodów). Scalfaro w swym przemówieniu podkreślił wtedy, że „szczególnie młodzi z Republiki Socjalnej Salò byli przekonani, że służyli narodowi" ${ }^{42}$. Wypowiedź ta przeszła bez echa. Jak dowodzi Cooke, „nie skomentowano faktu, że prezydent Włoch zrobił z ragazzi di Salò narodowych patriotów" ${ }^{\prime \prime 3}$.

${ }^{40}$ Przedruk wypowiedzi w: Philip Cooke, op. cit., s. 156.

${ }^{41}$ Giovanni De Luna, Fascismo/Antifascismo: le idee, le identità, Firenze 1995, s. 82. Lata 90. to także okres, w którym pojawia się sporo książek o resistenzy: dla dzieci m.in. ta Guido Pettera Nazywano nas bandytami (Ci chiamavano banditi, Firenze 1995); dla starszych popularne gialli m.in. Eduardo Angelino, L'inverno dei Mongoli, Turin 1995 i Giampaolo Pansa, Ma l'amore no, Milan 1994 (w obu przypadkach detektywem jest mieszkaniec Republiki Salò).

42 Philip Cooke, op. cit., s. 159.

${ }^{43}$ Ibidem, s. 160. Tego dnia na Rai Due pokazano odnowioną wersję Rzymu, miasta otwartego (reż. R. Rossellini, 1945) ukazującego resistenzę jako narodowy zryw. Film analizuję w dalszej części pracy. 
Przemówieniem, jakie wywołało społeczny oddźwięk, było natomiast to autorstwa Luciano Violante - prawnika i polityka, działacza włoskiej partii komunistycznej, który po jej rozpadzie wstąpił do Demokratycznej Partii Lewicy. Violante, gdy objął w 1996 roku urząd przewodniczącego Izby Deputowanych, wygłosił mowę, w której nawoływał do pojednania partyzantów i zwolenników Mussoliniego. „Powinniśmy spróbować pojąć, dlaczego tak wielu młodych mężczyzn i kobiet zdecydowało się walczyć dla Republiki Salò. Ten wysiłek pomoże nam zrozumieć złożoność historii naszego kraju i uczynić wolność wartością wszystkich ludzi" - mówił Violante ${ }^{44}$. Niezależnie od intencji polityka, jego wypowiedź została uznana za usprawiedliwienie faszystów ${ }^{45}$. Politycy Sojuszu Narodowego triumfowali - Violante był wszak człowiekiem lewicy. Niedługo potem w programie o bieżących sprawach politycznych Porta a porta w telewizji RAI, Mirko Tremaglia - były faszysta, ówcześnie członek Sojuszu Narodowego - wyjaśniał z zaangażowaniem dziennikarzowi, że przyłączył się do Republiki Socjalnej Salò z przekonania ${ }^{46}$.

Pierwsza dekada XXI wieku przyniosła publikacje rewizjonistyczne - dowodzące, że włoska partia komunistyczna zawłaszczyła, a przynajmniej próbowała zawłaszczyć - i to dość skutecznie - pamięć o włoskim ruchu oporu. Już same tytuły mówią za siebie: Wielkie kłamstwo (La grande menzogna, 2001) Sandro Fontany oraz Wymazana resistenza (La Resistenza cancellata, 2004) Ugo Finettiego. Ta ostatnia publikacja ma interesującą okładkę, oddającą niejako główną tezę książki - na zdjęciu widnieje słynne zdjęcie przywódców włoskiego ruchu oporu, paradujących po ulicach Mediolanu: komunisty Luigi Longo, niezależnego Alfredo Pizzoni i chadeka Enrico Mattei. Te dwie ostatnie postacie są jednak przekreślone czerwonym krzyżykiem - w ten sposób, że najbardziej widoczny jest komunista Longo ${ }^{47}$.

${ }^{44}$ Cały tekst przemowy jest dostępny na stronie polityka: www.lucianoviolante.it (dostęp: 6.07.2013).

${ }^{45}$ W tym samym 1996 roku, co głośno komentowane wystąpienie Violante, włoski sąd orzekł, że sprawa Ericha Priebke (jednego z odpowiedzialnych za masakrę w Fosse Ardeatine), który w 1994 roku został wytropiony przez Amerykanów w Argentynie (de facto Priebke sam udzielił wywiadu dla amerykańskiej telewizji i przyznał się do uczestnictwa w egzekucji) była zbrodnią wojenna, a nie przeciw ludzkości, ponadto uległa przedawnieniu. Prokuratura odwołała się od wyroku i w 1998 roku uzyskała korzystny dla siebie wyrok: sąd apelacyjny skazał Priebkego na karę dożywotniego pozbawienia wolności. W czerwcu 2007 roku sąd przyznał mu prawo wychodzenia do pracy, co wywołało protesty organizacji żydowskich, więc decyzja sądu została uchylona.

${ }^{46}$ O tym wydarzeniu zob. Salo, capire e superare, „La Repubblica”, 16.05.1996.

${ }^{47}$ Innymi ciekawymi publikacjami, świadczącymi o tym, że resistenza w nowym milenium istnieje w dyskursie publicznym, są: wydany w dwóch tomach słownik włoskiego 
Umberto Eco w swoim (napisanym w połowie lat 90.) eseju Wieczny faszyzm - celnie zauważył:

Dziś we Włoszech niektórzy twierdza, że mit ruchu oporu był komunistycznym kłamstwem. To prawda, że komuniści z chwilą gdy zaczęli w ruchu oporu odgrywać główną rolę, eksploatowali go jak swoją własność. Ale ja pamiętam partyzantów noszących różnokolorowe, nie tylko czerwone chustki ${ }^{48}$.

O tym, że cały czas włoski ruch oporu kryje w sobie zagadki i domaga się kolejnych badań, świadczy najlepiej raport parlamentarnej komisji o wojennych masakrach popełnionych na terenie Włoch - przedstawiony w 2006 roku pod wpływem odkrycia kolejnych, pochodzących z czasów wojny, dokumentów ${ }^{49}$.

Silvio Berlusconi, którego partia przez wiele lat pozostawała w sojuszu z ugrupowaniem o tradycjach faszystowskich, w swoich wypowiedziach wielokrotnie umniejszał wagę reżimu Mussoliniego, przypisując winę Hitlerowi ${ }^{50}$, a w 2006 roku wdzięcznie zareagował na tłum skandujący Duce, Duce po jego przemówieniu ${ }^{51}$. W 2009 roku, w czasie obchodów upamiętniających resistenzę, Berlusconi z dumą wspominał natomiast partyzantów wszystkich politycznych ugrupowan ${ }^{52}$. Można zatem powiedzieć, że resistenza staje się od czasu do czasu języczkiem u wagi włoskiej areny politycznej, a jej wytrawni aktorzy umieją odwołać się do chlubnej karty historii kraju w dogodnym dla siebie momencie.

ruchu oporu (Dizionario della Resistenza, red. Enzo Colotti et al., vol. 1-2, Turin 2000-2001) i historyczny atlas resistenzy (Atlante storico della Resistenza italiana, red. Luca Baldissara, Milan 2000).

48 Umberto Eco, Wieczny faszyzm, [w:] Pięć pism moralnych, tłum. Ireneusz Kania, Kraków 2007, s. 32.

${ }^{49}$ W 1994 roku w Rzymie w Palazzo Cesi-Gaddi, który był ówcześnie kancelarią sądu wojskowego, odkryto drewnianą skrzynię, tzw. szafę wstydu (armadio della vergogna) z dokumentami z czasów wojny, które zawierały m.in. informacje na temat zbrodni popełnionych na terenie Włoch. Więcej o tym wydarzeniu zob. Mimmo Franzinelli, Le stragi nascoste. L'armadio della vergogna: impunità e rimozione dei crimini di guerra nazifascisti 1943-2001, Milano 2003; Franco Giustolisi, L'Armadio della vergogna, Roma 2004.

${ }^{50}$ Do licznych wpadek Berlusconiego zaliczyć można nazwanie niemieckiego socjalisty Martina Schulza w 2003 roku „doskonałym aktorem do roli kapo w filmie o Holocauście”. Na ten temat zob. Berlusconi al tedesco Schulz: «Kapò», „C Corriere della Sera”, 2.07.2003.

${ }^{51} \mathrm{Na}$ ten temat zob. Giacomo Lichtner, Fascism in Italian Cinema since 1945, New York 2013, s. 22.

52 Silvio Berlusconi, 25 aprile: un sonore e un impegno, "Corriere della Sera", 25.04.2009 (przedruk przemówienia). 
Włoski ruch oporu jest nadal tematem politycznie użytecznym, o czym świadczy najlepiej wypowiedź następcy Berlusconiego - Mario Montiego, który w czasie obchodów Święta Wyzwolenia 25 kwietnia 2012 roku umieścił fenomen resistenzy w kontekście współczesnym, wykorzystując go jako wzmocnienie apelu o społeczną wytrwałość w zwalczaniu kryzysu.

Resistenza jest [...] jednym z fundamentów naszej demokracji i wolności - przypominał Monti. Dziś chodzi o wskrzeszenie tego doświadczenia oczywiście w formule mniej dramatycznej. Celem jest bowiem znowu wyzwolenie - tym razem jednak od niektórych sposobów myślenia i życia, do których się przyzwyczailiśmy. Ruch oporu stanowi świadectwo dramatycznego poświęcenia wielu młodych, którzy dołożyli wszelkich starań, by wyzwolić nasz kraj. Dziś to, o co prosi się każdego obywatela, jest mniej dramatyczne, ale wymaga tego samego, społecznego zaangażowania ${ }^{53}$.

53 Artykuł, w którym zawarte są fragmenty wypowiedzi Montiego, jest dostępny na stronie: http://politicaesocieta.blogosfere.it/2012/04/25-aprile-2012-monti-tutti-insieme-contro-la-crisi.html (dostęp: 15.08.2013). 


\section{Rozdział II}

\section{Film fabularny jako medium opowieści historycznej}

Wzajemne relacje między filmem a historiografią mają charakter wielowymiarowy i zróżnicowany. Zależy on m.in. od instytucji kinematograficznej (polityki historycznej, cenzury, systemów wsparcia produkcji i dystrybucji) oraz właściwości samych komunikatów audiowizualnych. Kryterium różnicujące dotyczy tu najczęściej tzw. rodzaju filmowego, tj. umownego podziału na film fabularny i film dokumentalny. Pomijając liczne, wielokrotnie opisywane trudności ze sprecyzowaniem tych terminów należy pamiętać, że „film fabularny" jest pojęciem potocznym, rozumianym wedle społecznego uzusu (teoretyczna poprawność nakazywałaby mówić raczej o filmie fikcjonalnym, bowiem dokument także posługuje się fabułą). We współczesnej kulturze audiowizualnej coraz trudniej zresztą określić rodzajową specyfikę komunikatu filmowego - istnieją przecież filmy fikcjonalne udające dokumenty (mockumentaries) oraz produkcje, które w swej strukturze zawierają zarówno partie fikcjonalne, jak i dokumentalne. Hybrydyczności filmowej formy towarzyszy przy tym niejednokrotnie trudność w precyzyjnym określeniu tematyki ekranowych obrazów, będącej innym „wymiarem” historyczno-filmowych związków. Stosowany potocznie termin „film historyczny” jest bowiem, o czym będzie jeszcze mowa, niezwykle wieloznaczny. W wielu burzliwych dyskusjach wypowiadali się na ten temat i historycy, i filmoznawcy, i literaturoznawcy.

Wieloaspektowość zagadnienia relacji film-historia polega także na tym, iż film jest jednocześnie świadectwem oraz narzędziem kreacji historii. Trudno bowiem zaprzeczyć, że film, pełniąc „funkcję reprezentacji historii", stanowi zarazem symptom społecznych przemian, a jednocześnie wehikuł pamięci kulturowej (np. narodowej mitologii). Temat niniejszej pracy każe przyjrzeć się bliżej teoretycznej konceptualizacji tych relacji historii i filmu, które akcentują tematykę historyczną w filmach fabularnych. Oczywiście, zagadnienie to jest niezwykle obszerne; stanowi splot 
wielu problemów, których nie zamierzam w tej pracy rozstrzygać. Pragnę jedynie zasygnalizować podstawowe konteksty i dylematy teoretyczne celem wypracowania własnego narzędzia metodologicznego.

Problem związków między filmem a historią pojawił się u zarania kina. Już wówczas Bolesław Matuszewski dostrzegł możliwość wykorzystania nowego wynalazku w charakterze źródła historycznego. W marcu 1898 roku w paryskim dzienniku „Le Figaro” opublikowano jego artykuł o znamiennym tytule: Nowe źródło historii, a w sierpniu tegoż roku w Paryżu złożył do druku książkę - Ożywiona fotografia, czym jest, czym być powinna. Oczywiście, Matuszewski pisze w swoich tekstach o filmie dokumentalnym (choć nie używa tego pojęcia), o filmie fabularnym pisać nie mógł, gdyż ten dopiero się rodził. Matuszewskiego ujmowała autentyczność, dokładność i precyzja przedstawienia filmowego (tu głównie w funkcji reprodukcyjnej), która miała zagwarantować przyszłym pokoleniom dostęp do bogactwa szczegółów nieprzekazywalnych za pomocą innych mediów ${ }^{1}$.

Na obszarze filmu fikcjonalnego w naturalny sposób w centrum uwagi badaczy - zarówno historyków, jak i filmoznawców - znalazły się tzw. filmy historyczne. Zanim przejdę do omówienia rozmaitych argumentów, jakie wysuwano wobec nowego źródła historii (podkreślających jego walory, częściej jednak zwracających uwagę na jego mankamenty), kilka słów na temat samego pojęcia "film historyczny", które dalekie jest od jednoznaczności. Poniższy przegląd nie aspiruje do przedstawienia w sposób wyczerpujący „dziejów pojęcia”, wydaje się jednak nieodzowny dla klarowności dalszego wywodu.

${ }^{1}$ Podobną myśl do Matuszewskiego wyraził Władysław Umiński, w artykule Z krainy czarów na łamach warszawskiego „Tygodnika Ilustrowanego". Pisząc o „cynematografie”, pisarz stwierdzał: „Przyrząd ten stanie się nie tylko przyjemną rozrywką, nauczycielem, ale i zbieraczem cennych dokumentów życiowych, z których będą korzystali nasi synowie i wnukowie. W połączeniu z fonografem nabierze on jeszcze większej wartości, gdy równocześnie pozwoli nam słyszeć i widzieć ubiegłe rzeczy i wypadki. [...] Jednym słowem, możemy dziś przenosić się w każdej chwili do przeszłości". Władysław Umiński, Z krainy czarów, „Tygodnik Ilustrowany” 1896, nr 1. W kontekście przywołanej opinii warto wspomnieć, iż w 1902 roku Georges Méliès zrealizował jedyny w swoim rodzaju film, będący antycypacją zdarzenia, które miało dopiero nastąpić (sic!). Mowa o słynnej filmowej replice, jaką była Koronacja Edwarda VII. Mając gotowy film, Méliès odczekał z premierą i pokazał go po raz pierwszy dzień po koronacji; wiedział bowiem doskonale, jak wielką atrakcję stanowi dla widza aktualność tematu. Zob. Marek Hendrykowski, Film jako źródło historyczne, Poznań 2000, s. 24. 


\section{Wokól filmu historycznego jako gatunku i jego społeczno-kulturowej funkcji}

Kategoryzacja filmów potocznie zwanych historycznymi nie jest sprawą prostą i łatwą. Termin "film historyczny" jest jedną z kilku nazw (inne, to m.in. "film kostiumowy" i "film z epoki") stosowanych w odniesieniu do filmów, których narracja w części bądź w całości jest osadzona $\mathrm{w}$ przeszłości ${ }^{2}$. Pojęcie to podsuwa z reguły wyobraźni barwne widowisko kostiumowe lub batalistyczne, w jakim można oglądać piękne wnętrza, starodawne stroje i uzbrojenie, stąd przeszłość rozumiana bywa zazwyczaj jako miniony (najczęściej dawny) okres historii, w odniesieniu do czasu powstania filmu. Niektórzy badacze, jak np. Natalie Davies, twierdzą jednak, że osadzenie akcji filmu w przeszłości nie jest wystarczającym warunkiem, by zaklasyfikować dane dzieło jako historyczne. Na miano to w sensie właściwym zasługiwać by miały wyłącznie filmy odwołujące się do rzeczywistych „,historycznych” zdarzeń lub postaci ${ }^{3}$. Taka definicja wyklucza więc z zakresu tego terminu osadzone w przeszłości opowieści czysto fikcjonalne (np. adaptacje dzieł literackich z epoki). Te ostatnie, gdzie liczy się przede wszystkim design, nazywane są najczęściej filmami kostiumowymi (choć zdarzają się i inne określenia, np. Pierre Sorlin nazywa je filmami quasi-historycznymi ${ }^{4}$ ).

2 James Chapman wyróżnia jeszcze „kino dziedzictwa”, zwracając uwagę, iż jest to raczej kategoria krytyczna niż formuła, która miałaby szersze zastosowanie w samym filmoznawstwie. Określenie „kino dziedzictwa” pojawiło się w dyskursie krytycznym w latach 80., kiedy służyło za etykietkę mody na takie adaptacje dzieł literackich, jak Podróż do Indii (A Passage to India, reż. D. Lean, 1984) czy Pokój z widokiem (A Room with a View, reż. J. Ivory, 1986); z tym, że następnie termin ten stosowano retrospektywnie do dzieł sprzed 1980 roku, aby objąć nim nawet niektóre filmy z czasów kina niemego. Zob. James Chapman, Film historyczny - kino narodowe, „Kwartalnik Filmowy” 2005, nr 52, s. 17. Chapman wspomina także kostiumowe baśnie filmowe, gdzie sytuuje m.in. film Rycerze Okragłego Stołu (Knights of the Round Table, reż. R. Thorpe, 1953). Na temat dyskusji nad „kinem dziedzictwa" zob. m.in. Andrew Higson, The Heritage Film and British Cinema, [w:] Dissolving Views: Key Writings of British Cinema, red. Andrew Higson, London 1996, s. 232-248.

${ }^{3}$ Wedle Natalie Zemon Davies filmami historycznymi są takie realizacje, w których sjużet opiera się na rzeczywistych, historycznych faktach, a intryga rozwija się w taki sposób, że historyczne fakty są centralne i niezbędne dla fabuły. Zob. Natalie Zemon Davies, Slaves on Screen: Film and Historical Vision, Cambridge 2000. Definicja Davies nie wyklucza więc obecności fikcjonalnych wątków pobocznych, ale wskazuje na problem skali, proporcji pomiędzy tym, co "prawdziwe” a „wymyślone”.

${ }^{4}$ Inna stosowana przez Pierre'a Sorlin nazwa to dzieła z tzw. pretekstem historycznym, ewentualnie filmy o zabarwieniu historycznym; autor wymienia tu tzw. dramaty kostiumowe spod znaku "płaszcza i szpady”. Pierre Sorlin, Klio na ekranie albo historyk w mroku, „Film na Świecie” 1980, nr 4, s. 48-49. 
Z logicznego punktu widzenia podział ten wydaje się sensowny; uzus jest jednak inny, o czym zaświadcza m.in. definicja filmu historycznego zamieszczona w Encyklopedii kina pod redakcją Tadeusza Lubelskiego. Czytamy w niej, iż film historyczny to ,jeden z najstarszych gatunków filmowych odwołujący się zazwyczaj [podkr. A. M.-K.] do wydarzeń i postaci historycznych" („zazwyczaj” - więc nie "zawsze”). Wieloznaczność samego pojęcia oraz zasygnalizowaną $\mathrm{w}$ przywołanym fragmencie definicji dość migotliwą - zważywszy na trudności z jej kodyfikacją - gatunkowość filmu historycznego, potwierdza dalsza część hasła: prócz „reinscenizacji wydarzeń [...] modną odmianą filmu historycznego stał się supergigant historyczny, którego gatunkowymi wyznacznikami były (obok wystawnego budżetu): gwiazdorska obsada, rozbudowane sekwencje batalistyczne, swobodne traktowanie faktów, oraz długi (trwający nawet kilka lat) okres produkcyjny”. Wspomniane zostają także „rekonstrukcje wydarzeń sprzed lat uzupełniające fabułę o elementy poetyki dokumentu oraz filmy wykorzystujące bogatą dokumentację historyczną z epoki". W ten sposób obok siebie, niejako jednym tchem wymienione zostają m.in. następujące dzieła: Napoleon (reż. A. Gance, 1927), Quo vadis (reż. E. Guazzoni, 1913), Spartakus (reż. S. Kubrick, 1960), Potop (reż. J. Hoffman, 1974), Bitwa o Algier (Battaglia di Algeri, reż. G. Pontecorvo, 1965), Akcja pod Arsenałem (reż. J. Łomnicki, 1978) oraz Rzemiosto wojenne (Mestiere delle armi, reż. E. Olmi, 2001) ${ }^{5}$.

Prób opisu konwencji filmu historycznego było oczywiście wiele; nie sposób omówić tu rozmaitych opracowań tego zagadnienia. Najczęściej ich autorzy usiłowali wprowadzać kategorie "gatunkowe" - odwoływali się, jak George Custen, do filmu biograficznego ${ }^{6}$ lub wprowadzali bardziej szczegółową typologię. Dobrym przykładem takiej systematyzacji jest propozycja Roberta Burgoyne. W obrębie filmu historycznego wyróżnia on właśnie film: biograficzny, wojenny, epicki (w którym akcentuje się inscenizacyjny rozmach), "tematyczny" (skoncentrowany na jednym temacie, wątku) oraz metahistoryczny (prezentujący alternatywną wersję historii) ${ }^{7}$. Niektóre ze sformułowanych definicji są uargumentowane lepiej, niektóre zaś zupełnie chybione. Dość kontrowersyjna wydaje się np. ta za-

${ }^{5}$ Hasło "film historyczny" opracowane przez Piotra Litkę w: Encyklopedia kina, red. Tadeusz Lubelski, Kraków 2010, s. 415.

${ }^{6}$ George Custen, Bio/pics: How Hollywood Constructed Public History, New Jersey 1992.

7 Robert Burgoyne, The Hollywood Historical Film, Malden 2008. Do filmów "tematycznych" (zdaję sobie sprawę z niezręczności tłumaczenia „topical”) Burgoyne zalicza m.in. film World Trade Center (reż. O. Stone, 2006) oraz Titanic (reż. J. Cameron, 1997), zaś do metahistorycznych - JFK (reż. O. Stone, 1991) i Podróż do Nowej Ziemi (The New World, reż. T. Malick, 2005). 
mieszczona w książce Films by Genre. Daniel Lopez wyróżnia w niej dwa nurty filmu historycznego - mniej liczny, reprezentowany przez dzieła, w których „filmowiec reprodukuje historyczny materiał tak dokładnie i tak dobrze, jak tylko potrafi", oraz ten silniejszy, tworzony przez filmy, w których „historyczny element jest tylko pretekstem dla spektaklu, romansu i rozrywki" ${ }^{8}$. Słabość tej formuły wynika nie tylko z braku precyzji - autor nie wyjaśnia np. ile musi być w dziele "historycznej reprodukcji” (50\%? 70\%?), aby zakwalifikować dany film do pierwszej kategorii, ale przede wszystkim z osobliwego kryterium "rozrywki”. Z podanej definicji wynika bowiem, że nawet $100 \%$ rekonstrukcji nie gwarantuje statusu „historyczności”, jeśli była ona użyta „dla spektaklu, przygody, rozrywki” (można by więc zapytać, czy "prawdziwe historyczne filmy” muszą być śmiertelnie nudne).

Relacjonuję te propozycje, aby unaocznić złożoność całego zagadnienia. Chciałabym zarazem zaakcentować, że wyłączenie z interesującego mnie semantycznego pola tzw. "filmów kostiumowych" (nieodwołujących się do historycznych wydarzeń) wydaje mi się zabiegiem sztucznym, trudno bowiem zaprzeczyć, że ewokują one historię - jak słusznie zauważa Bolesław Michałek, bez względu na to, czy opowieści takie mają ton bardzo poważny, melodramatyczny, ckliwy czy też żartobliwy, historia jest ich materia, choć nie jest ich bohaterem? ${ }^{9}$ Sam podział na filmy fabularne oparte na faktach (z domyślnym dopowiedzeniem: „o istotnym znaczeniu historycznym”; nie każdy film "inspirowany wydarzeniami autentycznymi" musi być bowiem "historyczny") oraz filmy czysto fikcjonalne $z$ tzw. "tłem epoki” jest natomiast w moim przekonaniu sensowny. Pozwala wstępnie uporządkować obszerny zbiór dzieł opatrzony etykietką "film historyczny".

Naszkicowawszy zaledwie kontur problematyki związanej z kryterium odwoływania się przez film historyczny do świata pozafilmowego, a dokładniej do rzeczywistych postaci i wydarzeń historycznych (na uściślenia przyjdzie jeszcze czas), wypada omówić pokrótce pierwszy

${ }^{8}$ Daniel Lopez, Films by Genre: 777 Categories, Styles, Trends and Movements Defined, with a Filmography for each, North Carolina 1993, s. 142.

9 Bolesław Michałek, Jednostka i mechanizmy historii, „Kino” 1973, nr 10, s. 58. Filmy kostiumowe do „filmów historycznych" zalicza także m.in. Leger Grindon. Zob. idem, Shadows on the Past: Studies in the Historical Fiction Film, Philadelphia 1994. Warta przypomnienia jest również uwaga historyka Ryszarda Wagnera: „Przyjęło się rozumienie, że film historyczny to film kostiumowy bez względu na to, czy dotyczy on zdarzeń historycznych, czy jest ekranizacją powieści opartej na faktach historycznych, czy po prostu filmem przygodowym typu na przykład płaszcza i szpady, którego akcja przebiega w mniej lub bardziej odległej przeszłości". Ryszard Wagner, Film fabularny jako źródło historyczne, „Kultura i Społeczeństwo” 1974, t. XVIII, nr 2, s. 185. 
z podanych wyróżników filmu historycznego - osadzenie jego akcji w przeszłości. Dyskusyjność tego wyznacznika wynika nie tylko z faktu, iż wiele filmów określanych jako historyczne zawiera w swej strukturze wątek współczesny lub ramę narracyjną (wprowadzającą retrospekcje lub closure „po latach”), zaś część filmów z przewagą tematu współczesnego wykorzystuje fragmenty materiałów archiwalnych. Dla teoretyków filmu, ale i historyków wypowiadających się na temat „ekranowych obrazów historii", problemem stało się ustalenie granicy, gdzie kończy się okres miniony, a zaczyna współczesność. Symptomatyczne pod tym względem są pochodzące z lat 70. wypowiedzi polskich historyków na temat "historycznych filmów”, publikowane głównie na łamach miesięcznika „Kino”. I tak np. Bronisław Geremek stwierdza: "Jestem przeciwny spieraniu się o definicję, co jest filmem historycznym, a co nim nie jest. W jakimś sensie poza filmami science fiction wszystkie filmy są historyczne, ponieważ pokazują jakieś wydarzenia, które się odbyły"10, zaś Ryszard Koniczek pozostawia sprawę otwartą: „,nie wiemy jak można dzielić filmy na historyczne i współczesne; historia to współczesność, tylko dziejąca się trochę wcześniej" $^{\prime 11}$. Znamienny jest wreszcie komentarz zawarty w nocie redakcyjnej do numeru „Filmu na Świecie” poświęconego wzajemnym relacjom filmu i historii: „Filmem historycznym jest w pewnym sensie każdy film. Wystarczy tylko trochę poczekać"12.

Kwestią cezur czasowych, a więc próbą odpowiedzi na pytanie, w jakim przedziale czasowym można nazwać konkretny obraz filmowy współczesnym, a kiedy mówi on o okresie minionym i staje się „historycznym", zajął się m.in. Ryszard Wagner w nieco zapomnianym, lecz już cytowanym tu artykule Film fabularny jako źródło historyczne. Autor wskazuje w nim, iż tradycyjne kryterium jednego pokolenia (25 lat) nie sprawdza się w przypadku kina (z uwagi na jego dynamiczny rozwój), podobnie jak narzucenie jakiejkolwiek apriorycznej cezury biorącej pod uwagę czas filmowej akcji i premiery samego dzieła. Wagner słusznie zauważa, iż na to, do której grupy film jest zaliczany, wpływ mają „pewne wydarzenia historyczne i dziejowe procesy" ${ }^{13}$. W związku z tym proponuje, aby nie

10 Zob. dyskusja Rozumieć czy ilustrować historię, „Kino” 1975, nr 6, s. 9. To ciekawe i nieprecyzyjne sformułowanie - można bowiem powiedzieć, że wydarzenia w filmie science-fiction też się odbyły (w świecie przedstawionym).

${ }_{11}$ Ryszard Koniczek, Nasz film historyczny, „Kino" 1975, nr 6, s. 4.

12 „Film na Świecie” 1980, nr 4, s. 3.

${ }^{13}$ Problematyka artykułu jest oczywiście znacznie szersza. Wagner analizuje w nim także poszczególne dziedziny kinematografii jako źródło historyczne m.in. scenografię, muzykę, ale i aktorstwo, reżyserię oraz ,język filmu". 
przyjmować mechanicznego kryterium liczby lat dzielących produkcję od zdarzeń rozgrywających się $\mathrm{w}$ danym filmie, a jako kryterium współczesności przyjąć to, czy film był realizowany w tym samym okresie historycznym, o którym mówi akcja fabuły („filmem współczesnym nazywamy więc film, którego akcja fabularna przypada na ten sam okres, co i jego realizacja"14). Na przykład Zakazane piosenki z 1947 roku opowiadające o latach 1939-1945 - a więc o okresie „nieodległym”, który zakończył się dwa lata wcześniej - byłyby filmem historycznym. Mówi on bowiem o czasach charakteryzujących się odmiennymi realiami od tych panujących w momencie filmowej produkcji, a zatem należących do przeszłości. Jak stwierdza Wagner, jeśli

akcja filmu rozgrywa się w 1944 roku w czasie Powstania Warszawskiego, a film realizowany jest po roku 1945, po zakończeniu wojny, czyli w innym okresie historycznym, zaliczamy go do filmów okresu minionego, czyli filmów historycznych, mimo krótkiego czasu dzielącego akcję od realizacji [...]. Gdyby natomiast akcja filmu dotyczyła np. wypadków majowych w roku 1926, a film został zrealizowany przed rokiem 1939 to - mimo trzynastu lat dzielących od momentu akcji do chwili realizacji filmu - film ten nazwiemy współczesnym ${ }^{15}$.

Relacjonuję tę koncepcję tak szczegółowo, gdyż ustalenia poczynione przez Wagnera wydają się użyteczne dla moich własnych działań analitycznych. Pisząc w dalszej części pracy o filmach opowiadających o włoskim ruchu oporu (resistenzy), niejako za Wagnerem nazwę je wszystkie „filmami historycznymi”, pomimo iż np. Rzym, miasto otwarte (Roma, città aperta) Roberta Rosselliniego został zrealizowany w 1945 roku.

Ciekawą uwagą Wagnera jest również ta zamieszczona przy okazji wprowadzanej przez autora typologii filmu jako źródła historycznego. Wyróżnia on bowiem także „realistyczno-naturalistyczne (werystyczne) filmy współczesne". Pod tym dość osobliwym pojęciem rozumie dzieło

[...] którego akcja toczy się w tym samym okresie historycznym, w którym film był realizowany; nakręcony w konwencji takiej, aby widz odniósł wrażenie, iż rozgrywające się w czasie akcji filmu zdarzenia, inspirowane historią bieżąca, miały miejsce naprawdę $[\ldots]^{16}$.

\footnotetext{
14 Ryszard Wagner, op. cit., s. 184.

${ }^{15}$ Ibidem.

${ }^{16}$ Ibidem.
} 
Badacz nie odmawia zatem filmom określanym jako współczesne zdolności do „przekształcania się” w źródło historyczne ${ }^{17}$, podobnie zresztą jak Marek Hendrykowski. W swojej książce Film jako źródło historyczne Hendrykowski zauważa bowiem:

ilekroć traktujemy film jako źródło historyczne, w grę mogą wchodzić dwa typy narracji. Jeden to narracja historyczna, $\mathrm{w}$ ramach której przedstawione zdarzenia zostają ukazane z odległej perspektywy czasowej (za przykład posłuży nam introdukcja z udziałem narratora zza kadru w Kanale Andrzeja Wajdy [...]. Drugim jest narracja kronikarska, której charakterystyczną cechę stanowi ukazywanie aktualnych zdarzeń, zapisywanych na taśmie z myślą o ich rychłym wykorzystaniu jako źródła informacji i współczesnej historii (przykład klasyczny stanowi tu Triumf woli [Triumph des Willens, 1934] Leni Riefenstahl) ${ }^{18}$.

Wspominam o tych koncepcjach dla porządku - z filmami o włoskim ruchu oporu nie miałam takiego dylematu, gdyż moje rozważania dotyczą włoskiego kina powojennego, a zatem kina, w którym fenomen resistenzy należał już wyłącznie do przeszłości.

Filmy o tematyce historycznej uruchamiają specyficzny tryb analizy, którą można by nazwać ",analizą faktograficzną". Polega ona na weryfikacji danych zawartych w tekście filmu w celu sprawdzenia wiarygodności komunikatu. Dzieła te podlegają zatem podobnej procedurze interpretacyjnej, co filmy będące adaptacjami literatury, tzn. porównaniu z materiałem prymarnym. Przy czym o ile w przypadku filmów "historycznych” punktem odniesienia pozostaje rzeczywistość świata pozafilmowego, o tyle dla filmowych adaptacji jest nim literacki orygina ${ }^{19}$.

Na sposób oświetlania danego fragmentu historycznej przeszłości wpływ ma oczywiście inwencja twórcza, ale także świadomość hi-

17 Przykładowo, zrealizowane w PRL-u filmy współczesne są dziś traktowane jako źródło historyczne właśnie, np. do badania historii obyczaju. Zob. Rafał Marszałek, Kino rzeczy znalezionych, Gdańsk 2006.

${ }_{18}$ Marek Hendrykowski, op. cit., s. 49. Choć intuicja Hendrykowskiego jest słuszna, podany przykład jest nieco niefortunny - dlatego że Triumf woli potocznie uznawany jest za dokumentalny.

${ }^{19}$ Ciekawym opracowaniem porównania faktów i filmów o tematyce historycznej jest książka Past Imperfect: History According to the Movies, red. Mark Carnes et al., New York 1996. 
storyczna i ideologiczna, jaką dysponuje nadawca komunikatu; faktograficzny tryb jego analizy jest zaś możliwy dzięki i zależny od wiedzy pozafilmowej widza oraz paratekstów (a więc zewnętrznych informacji okalających filmowy tekst). To na tej podstawie identyfikujemy czysto fikcyjne elementy fabuły oraz te odsyłające do świata rzeczywistego ${ }^{20}$. Konieczność odniesienia filmu - reprezentującego wybrany fragment dziejów i postrzeganego jako potencjalne źródło historii - do historycznej wiedzy (widza, ale i twórcy dzieła) podkreślają zarówno historycy zajmujący się filmem (m.in. Ryszard Wagner oraz Andrzej Garlicki, który stwierdza: „Film historyczny z natury rzeczy musi odwoływać się do jakiejś wiedzy społecznej, musi w jakiś sposób odwoływać się do tego kapitału, który w społeczeństwie funkcjonuje ${ }^{21}$ ), jak i filmoznawcy: Marek Hendrykowski (procesowi „filmowej weryfikacji” poświęcony jest cały kilkustronicowy rozdział książki Film jako źródło historyczne) oraz Dorota Skotarczak. Autorka ta zwraca przy tym uwagę, iż kwestia adresata filmowego jest szczególnie ważna w kinematografiach państw rządzonych niedemokratycznie, gdzie duży wpływ na ostateczny kształt dzieła mają nie tyle preferencje publiczności kinowej, ile władza ${ }^{22}$.

Zabieg możliwie najbardziej starannej weryfikacji materiału filmowego niesie jednak ze sobą niebezpieczeństwo poszukiwania bezpośredniej odpowiedniości obrazu filmowego do sfery realności historycznej, w wyniku czego film postrzegany jako artystyczna rejestracja wydarzeń historycznych będzie "rozliczany” wyłącznie z wierności wobec

${ }^{20}$ O tym, jak ważne są prateksty, świadczy m.in. słynna audycja Orsona Wellesa z 1940 roku, w której informował on o inwazji Marsjan. Nieporozumienie, a nawet panika, jaką wiadomość ta wywołała, wyniknęły z faktu, że słuchacze nie odczytali fikcyjnego charakteru nadawanego programu. Sprawę wiedzy pozafilmowej widza ciekawie ujmuje zaś Umberto Eco, pisząc, iż konstruujemy różne światy odniesienia dla rozmaitych gatunków wypowiedzi. Na przykład powieść historyczna (i film historyczny) wymaga, aby odnosić ją do świata encyklopedii historycznej, podczas gdy bajka wymaga co najwyżej odniesienia do encyklopedii doświadczenia potocznego, aby można było doznawać przyjemności z różnych nieprawdopodobieństw, jakie ona przedstawia. Por. Umberto Eco, Sześć przechadzek po świecie fikcji, Kraków 1995, s. 162.

${ }^{21}$ Andrzej Garlicki, Film wobec świadomości historycznej, „Kino” 1975, nr 10, s. 25.

22 Zob. Marek Hendrykowski, op. cit., s. 30-33 i Dorota Skotarczak, Obraz społeczeństwa PRL w komedii filmowej, Poznań 2004, s. 26. Autorka wyróżnia trzy grupy odbiorców: publiczność kinowa środowisko artystyczne oraz władzę. Na różne aspekty relacji filmu i historii Skotarczak wskazuje także w artykule Historia wizualna. Założenia teoretyczne $i$ zakres badawczy, [w:] Historia w kulturze wspótczesnej, red. Piotr Witek, Mariusz Mazur, Ewa Solska, Lublin 2011. Ciekawą lekturę porównawczą dla tego tekstu stanowi artykuł Vanessy R. Schwarz, Film and History, [w:] The Sage Handbook of Film Studies, red. James Donald, Michael Renov, Los Angeles 2008, s. 199-215. 
historycznych faktów. W polskim piśmiennictwie na to zagrożenie zwraca uwagę Rafał Marszałek:

W skrajnych wypadkach badacz kierujący się taką orientacją będzie komentatorem faktów historycznych przez film odzwierciedlonych; nie będzie natomiast komentatorem samego filmu i jego różnorodnych, kulturowych, społecznych, politycznych impulsów ${ }^{23}$.

W innym miejscu dodaje zaś, że „subiektywizacja świata przedstawionego wcale nie oznacza niewierności historycznej” ${ }^{24}$. Marszałek jest więc zwolennikiem ujęcia problemowego, które domaga się wykroczenia poza czysto „ilustracyjny" schemat (reżyser, podobnie jak historyk, konstruuje bowiem, a nie odtwarza, rzeczywistość $)^{25}$. Polscy badacze są w tym miejscu zgodni - historyk Antoni Mączak deklaruje: „I naprawdę nie to jest najbardziej ważne, czy wszystkie guziki w tych filmach się zgadzają, tylko czy trafnie oddano stosunki społeczne, motywacje postępowania i sposób myślenia" ${ }^{26}$, zaś Jerzy Płażewski określa filmy historyczne jako dzieła, które „nie rezygnują z fabuły, bohaterów fikcyjnych, z elementu sentymentalnego i sensacyjnego, ale przy tym respektują prawdę dziejową"27.

Generalnie jednak wśród historyków dominuje sceptycyzm wobec filmowego medium - Tadeusz Łepkowski zastrzega: „Przekładalność historycznej prawdy rozumianej w kategoriach intuicji i wizji artystycznej oraz prawdy naukowej, typu dyskursywnego, jest nader wątpliwa" 28 . „Tradycyjni historycy" niejednokrotnie wydają się więc zapominać, że film nie może „reprezentować” przeszłości, zastępując ją jakąś imitacją. Tworzy on bowiem zawsze (podobnie jak tradycyjna historiografia) zredukowane i częściowe przedstawienie zastępujące spektrum zdarzeń, do których się odnosi. Ta reguła eksponowana jest natomiast przez filmoznawców

${ }^{23}$ Rafał Marszałek, Polska wojna w obcym filmie, Wrocław 1976, s. 11.

${ }^{24}$ Rafał Marszałek, Krajobraz przed bitwa. Aktualności historii, „Kino” 2006, nr 2, s. 11.

${ }^{25}$ Marszałek w swojej książce Filmowa pop-historia zastanawia się, na ile filmy historyczne mogą zastąpić powstałe już wcześniej popularne pisarstwo historyczne. Według Marszałka, „film historyczny” jest spokrewniony z beletrystyką historyczną i może z nią współwystępować. Tok jego wykładu prowadzi czytelnika od rozrywkowych popularyzacji ",historii naiwnej”, przez filmy płaszcza i szpady, biogramy oraz wielkie hollywoodzkie widowiska o starożytności. Film historyczny Marszałek rozumie więc szeroko. Rafał Marszałek, Filmowa pop-historia, Kraków 1984.

${ }_{26}$ Zob. dyskusja Rozumieć czy ilustrować historie, s. 9.

27 Jerzy Płażewski, Na ekranie-historia, „Kino” 1978, nr 4, s. 43.

${ }_{28}$ Tadeusz Łepkowski, Kilka uwag o filmowej historii. Wokół prawdy, fatszów i przemilczeń, „Kino” 1981, nr 9, s. 18. 
- „Film reprezentuje rzeczywistość tylko jako tekst, a nie jako jej oczywisty i naturalny analogon" ${ }^{29}$. Zawsze mamy zatem do czynienia z subiektywizacją ekranowych przedstawień; dociera do nas jeden z możliwych kątów widzenia "historii”, jedna z wielu potencjalnych perspektyw; zdarzenie w swoim filmowym kształcie, nawet to odwołujące się do faktów, pozostaje w naszej świadomości niczym innym, jak hipotezą zdarzenia, któremu przypisujemy status faktualności. Prawdą jest, rzecz jasna, iż w licznych filmach charakteryzujących się jakoby kronikarską dokładnością formułuje się, a raczej deformuje się przebiegi zdarzeń, ich kolejne fazy, ich uwarunkowania tak, by nabrały kształtu tradycyjnego dramatu, z ekspozycją, rozwinięciem, kulminacją i epilogiem. Nie jest to jednak specyfika wyłącznie filmowego medium, lecz także tradycyjnej historiografii, np. narracji w podręcznikach szkolnych.

Stosunek filmów fabularnych do prawdy historycznej jest oczywiście bardzo złożony i określa się na kilku płaszczyznach. Na jedną z nich zwraca uwagę Bolesław Michałek, gdy stwierdza, banalny w swej prostocie fakt, iż np. oglądając film fabularny o Mussolinim zdajemy sobie doskonale sprawę, że Duce nie jest tam „prawdziwym wodzem”, lecz jedynie aktorem. Ta ciągła dwuznaczność, fałsz wyraźny i stale uświadamiany nie jest $\mathrm{w}$ istocie - jak dowodzi krytyk - „niczym kompromitującym prawdę, jak chcą tego bezkompromisowi krytycy gatunku. Gdyby tak było, musielibyśmy odrzucić całą prozę historyczną, także i teatr z historycznymi sztukami Szekspira itd. Taka dwuznaczność towarzyszy $\mathrm{w}$ istocie całej sztuce" ${ }^{\prime 30}$.

Za szczególnie wpływowego teoretyka refleksji nad historią i kinem uznaje się francuskiego historyka Marca Ferro, współwydawcę przeglądu „Annales" i czasopisma "Historia Współczesna”, badacza zaangażowanego także w pracę nad telewizyjną serią filmową cyklu Obrazy historii. W optyce Ferro historiografia jest kontrolowana przez interesy klasy rządzącej (,od początku historycy pracowali na rzecz państwa, które ich zatrudniało" ${ }^{31}$ ), dlatego oczekuje on od mass mediów dekonstrukcji tego, co pokolenia ludzi u władzy zbudowały w takiej harmonii. Kino ma więc

\footnotetext{
29 Marek Hendrykowski, op. cit., s. 42.

30 Bolesław Michałek, op. cit., s. 58.

31 Marc Ferro, Historycy i kino, „Kino” 1989, nr 10, s. 26.
} 
wedle Ferro stanowić swoistą przeciwwładzę i przyczyniać się do rozwoju świadomości społecznej ${ }^{32}$. W jaki sposób, skoro jak sam stwierdza - „filmowcy - świadomie lub nie - są jak każdy na usługach jakiejś sprawy, jakiejś ideologii”, a „,wybór sytuacji i protagonistów oraz praca artysty nigdy nie są niewinne i przypadkowe" ${ }^{\prime 33}$ ?

Ferro nie ma złudzeń, że praca filmowca oraz historyka polega w istocie na tym samym - ma charakter konstrukcyjny („nikt nie doszedł do tego, że dobór historycznych dokumentów, ich zestawy, przedstawienie argumentów jest również jakimś montażem, czymś sztucznym i fałszywym" ${ }^{34}$ ); „,czyż mając możliwość korzystania z tych samych źródeł wszyscy historycy napisaliby taką samą historię Rewolucji" ${ }^{35}$ ? - pyta retorycznie badacz. Odnosząc powyższe spostrzeżenie do kina, można by w tym miejscu przywołać rozmaite filmy, podejmujące ten sam „historyczny temat", np. takie, w których pojawia się epizod rzezi w Noc Św. Bartłomieja. Wątek ten obecny jest zarówno w Nietolerancji (Intolerance, 1916) D. W. Griffitha, Królowej Margot (La Reine Margot, 1953) Jeana Dreville'a, jak i w filmie o tym samym tytule Partice Chereau (Królowa Margot [La Reine Margot], 1993). Każda z realizacji wydobywa jednak w ekranowej wizji tego wydarzenia co innego. Wszystkie pozostają też "wiarygodne” jako wyobrażenia historii należące do macierzystej dla nich epoki, a więc takie, którym ówczesna świadomość historyczna byłaby skłonna przypisać status wiarygodności. Zdaniem Ferro, obecna niekiedy w filmach o tematyce historycznej „drobiazgowa troska o adekwatność szczegółów odgrywa rolę wstydliwego okrycia, mającego zapewnić nieprzeniknioność sekretnej ideologii filmu, poddającej perwersyjnemu przekształceniu przeszłość, którą można by przedstawić inaczej"36.

32 O skuteczności faktu filmowego świadczy wedle Ferro epizod z 1975 roku, kiedy nieistniejące już ORTF pokazało film łotewski na temat obozów w ZSRR, co wzbudziło natychmiastową reakcję Francuskiej Partii Komunistycznej, która do tej pory się przed interwencją wzbraniała. Marc Ferro, Kino i historia, tłum. Tomasz Falkowski, Warszawa 2011, s. 20.

${ }^{33}$ Ibidem, s. 238.

${ }_{34}$ Marc Ferro, Historycy i kino, s. 27. O konwencjach historii pisanej, m.in. o przypisach zob. Anthony Grafton, The Footnote: A Curious History, Cambridge 1999. Podobieństwo filmu i historii dostrzega też Michèle Lagny, używając metafory filmowych obrazów, by pozbyć się ideału „faktycznej prawdy” na rzecz wielorakich punktów widzenia. Stwierdza bowiem: „Historia przypomina obraz, ponieważ wymaga - jak fotografia lub film - selekcji kadrowania i oświetlenia. Tak samo jak film podlega także procesowi montażu”. Michèle Lagny, Film History: or History Expropriated, "Film History” 1994, nr 6, s. 31.

${ }_{35}$ Marc Ferro, Historycy i kino, s. 27.

${ }^{36}$ Marc Ferro, Kino i historia, s. 238. 
Na czym więc polega demistyfikatorska rola kina - „fabryki marzeń" i jednostkowego filmu, który „pod przykrywką funkcji przedstawieniowej - indoktrynuje i gloryfikuje", pozostając zawsze "anegdota, fikcja ocenzurowanymi informacjami" ${ }^{37}$. W swojej książce Kino $i$ historia Ferro wielokrotnie zwraca uwagę na propagandowy wymiar filmowej historii, zauważając nie bez racji, że

kiedy tylko rządzący zdali sobie sprawę z funkcji, jaką może pełnić kino, próbowali nim zawładnąć i wykorzystać do własnych celów. Różnice w tym przypadku sytuują się na poziomie świadomości, nie zaś ideologii, albowiem zarówno na Zachodzie, jak i na Wschodzie rządzący przyjmowali identyczną postawę $e^{38}$.

Otóż wedle Ferro rzeczywistość, którą oferuje nam kino, „niekoniecznie odpowiada twierdzeniom rządzących oraz schematom teoretyków [...]. Zdarza się, że zamiast odzwierciedlać ich dyskurs, objawia jego śmieszność" ${ }^{\prime 39}$. Każda filmowa reprezentacja historii zawiera bowiem rozmaite potknięcia realizatorskie, ujawniające to, co ukryte zostało „pod powierzchnią" filmowej narracji. Pęknięcia te pozwalają niejako wniknąć w sferę rzeczywistości niewidocznej - mimowolnie odsłaniają motywacje twórców i dostarczają dowodów na to, jak na tekst wpływała współczesna im polityczna rzeczywistość. I tak, trywialny „ciąg obrazów: ci przechodnie, ta ulica, ten płacz [...] wszystko to stanowi materię historii innej niż Historia: prawdziwej kontranalizy społeczeństwa" ${ }^{40}$. To owe „realizatorskie lapsusy" czynią zatem z filmów pełnoprawny obiekt namysłu historyka - stanowią materiał dla innej nieinstytucjonalnej historii, a tym samym umożliwiają skorygowanie lub dekonstrukcję uporządkowanej, oficjalnej Historii (przez duże „H”). Wedle Ferro, historyk ma bowiem za zadanie

pozbawić różnego rodzaju aparaty monopolu, który sobie one przyznały - monopolu na bycie jedynym źródłem historii. Aparatom tym - rządom, partiom politycznym,

Kościołom bądź syndykatom - nie wystarcza dominacja nad społeczeństwem; chcą

37 Ibidem, s. 37.

${ }^{38}$ Ibidem. Ferro zaznacza jednak, że podrzędny status obrazu, jego podporządkowanie tekstowi i pismu, przez długi czas wykluczało go z rzędu pełnoprawnych obiektów namysłu. „Obraz - pozostawiony sam sobie, budzący nieufność i znajdujący się poza prawem - przypominał dzikusa, był ideowo i politycznie neutralny. [...] Jeszcze w 1940 roku rząd szwedzki tłumaczył, że pokazując równolegle niemieckie i angielskie kroniki filmowe bez głosu, zachowuje neutralność" - ibidem, s. 63.

39 Ibidem, s. 37.

${ }^{40}$ Marc Ferro, Film. Kontranaliza społeczeństwa?, [w:] Film i historia. Antologia, red. Iwona Kurz, Warszawa 2008, s. 67-89. 
być też jego świadomością. Historyk musi pomóc społeczeństwu w uświadomieniu sobie tej mistyfikacji ${ }^{41}$.

Ferro popiera swą koncepcję licznymi filmowymi przykładami (analizy case studies są chyba najciekawszym aspektem jego rozważań) zaczerpniętymi głównie z kinematografii rosyjskiej. Badacz unaocznia m.in. podskórną ideologię filmu Czapajew (Чanaeb, reż. S. i G. Wasiljew, 1934) oraz Wedtug prawa (По законy, reż. L. Kuleszow, 1926), za każdym razem konfrontując ją $\mathrm{z}$,jawną treścią" dzieła. Stwierdza m.in., że o ile jawne przesłanie filmu Wasiljewów można by zawrzeć w stwierdzeniu „bohaterowie umierają ale nie umiera partia komunistyczna, która zapewnia zwycięstwo rewolucjonistów", o tyle niewidoczna (a ujawniona w analizie Ferro) konstrukcja Czapajewa mówi, że „nowa władza zaszczepia się w ramach starej władzy" ${ }^{\prime 2}$. Film Według prawa Kuleszowa również potwierdza, że dzięki kadrowaniu, reżyserii i oświetleniu jawna treść scenariusza może zostać całkowicie przekroczona. Jak stwierdza Ferro:

w filmie chodzi o adaptację powieści Jacka Londona na temat zbrodni popełnionej przez poszukiwacza złota w Kanadzie, jednak ukryty sens tej adaptacji kinematograficznej przekształca ją w refleksję nad trybunałami ludowymi, które funkcjonowały wówczas w kraju radzieckim ${ }^{43}$.

Próbę systematyzacji swojej koncepcji podejmuje Ferro, prezentując własną klasyfikację filmów w ich odniesieniu do historii, obierając za kryterium źródła dyskursów na temat społeczeństwa oraz sposób, w jaki filmy podchodzą do problemów społecznych i historycznych. Wyróżnia cztery źródła dyskursów na temat społeczeństwa. Są to:

- instytucje i panujące ideologie, które wyrażają zarówno punkt widzenia państwa, jak i każdej innej organizacji mającej daną wizję świata,

- przeciwnicy tego rodzaju wizji, tworzący przeciw-historię albo kontranalizę, o ile są do tego zdolni i mają po temu odpowiednie środki,

- pamięć społeczna bądź historyczna, która przetrwała w pamięci ustnej albo w uznanych dziełach sztuki,

- interpretacje niezależne, naukowe.

O ile dwie pierwsze kategorie wydają się zrozumiałe, choć aby mówić o przeciw-historii (albo „kontranalizie”), trzeba określić ów dominujący punkt widzenia państwa, czego Ferro nie robi (nie mówiąc także, w jaki

\footnotetext{
${ }^{41}$ Marc Ferro, Kino i historia, s. 69.

${ }^{42}$ Ibidem, s. 79-98.

${ }^{43}$ Ibidem, s. 190.
} 
sposób można by to uczynić), o tyle dwie kolejne są niejasne i kontrowersyjne. Czym różnią się „interpretacje niezależne” od „kontranalizy”? Dlaczego Ferro umieszcza w swojej klasyfikacji pamięć, która stanowi całkowicie osobny problemat? To wątpliwości, które pozostają bez odpowiedzi. Drugi podział filmów - ze względu na sposób, w jaki podchodzą do problemów społecznych i historycznych, jest jeszcze bardziej niejasny, by nie powiedzieć - bełkotliwy. Ferro wyróżnia bowiem:

- sposób odgórny (from above), a więc spojrzenie na władzę i instytucję,

- sposób oddolny (from below), a więc taki, który analizuje te problemy z punktu widzenia chłopów bądź robotników,

- trzecie podejście ujmuje zjawiska "od wewnątrz” (from within): np. narrator-twórca wyjaśnia swoje postępowanie, komentując je spoza kadru bądź rozmawia z własną kamera,

- czwarty sposób podejścia do wspomnianych problemów polega na budowaniu modeli „z zewnątrz” (from without), rekonstruując twórczo dane zjawisko społeczne lub polityczne bez zamiaru jego odtworzenia.

W efekcie stworzony przez Ferro ogólny schemat, choć na pierwszy rzut oka wygląda interesująco, okazuje się - delikatnie mówiąc - mało operacyjny ${ }^{44}$.

Pomimo teoretycznej słabości przywołanego schematu, koncepcja Ferro pozostaje ważnym głosem w dyskusji na temat relacji historia-film. Zwraca bowiem uwage na ideologiczny wymiar filmowego medium i podkreśla zarazem, że relacje między filmem a historią dotyczą $\mathrm{w}$ istocie także dzieł, które w czasie produkcji określane są jako współczesne. Ferro unaocznia ponadto, że horyzont semantyczny filmu poszerza się wraz z upływem czasu; udowadnia nawet, że w dwóch różnych momentach historycznych dane dzieło można odczytywać w odmienny, a nawet przeciwny sposób. Jako przykład podaje tu Towarzyszy broni (Grande Illusion, reż. J. Renoir, 1937),

film, który miał być w zamierzeniu pacyfistyczny, lewicowy, internacjonalistyczny - i tak też go odczytano w 1938 roku - obejrzany po roku 1946 jawił się jako dzieło głęboko dwuznaczne, w pewien sposób vichystowskie avant la lettre i pod każdym względem nieprzystające do trwałych wartości lewicy ${ }^{45}$.

Koncepcja Ferro uzmysławia zatem, że film o tematyce historycznej jest zawsze silnie związany z dyskursami politycznymi teraźniejszości.

\footnotetext{
${ }^{44}$ Ibidem, s. 221.

${ }^{45}$ Ibidem, s. 23.
} 


\section{Historiofotia - historia w obrazach}

Trudno zaprzeczyć, że we współczesnej kulturze audiowizualnej filmy historyczne zyskują coraz większe znaczenie - coraz liczniej reprezentowane są one w repertuarze kin, dystrybucji telewizyjnej oraz obiegu DVD. Pytanie o źródła takiego stanu rzeczy znacznie wykracza poza ambicje niniejszej pracy. Odpowiedzi na nie można doszukać się w monumentalnym dziele Czas i opowieść Paula Ricoeura. Badacz, podejmując zagadnienie permanentności fabulacji, wskazuje, że pozwala ona uchwycić ludzkie doświadczenie czasu - doświadczenie bolesne, zawierające dramatyczne sprzeczności zwane przez Ricoeura aporiami. Pośród tych aporii najważniejsze miejsce zajmuje konflikt między jednostkowym a kosmologicznym poczuciem czasu (któremu daje wyraz historia czy fizyka). Wedle Ricoeura to właśnie w fabulacji ( $p l o t$, emplotment, récit) znajdują wyraz te dwa bieguny doświadczenia czasu: „,czas obiektywny”, w którym jest się „,zanurzonym” i czas aktywnego działania: życia, które na bieżąco się staje; dlatego dwa wielkie regiony fabulacji to dziedziny fikcji artystycznej i historiografii. To właśnie ze sprzężenia i wymiany pomiędzy uhistorycznianiem fabuły fikcyjnej i fikcjonalizacją fabuły historycznej rodzi się coś, co można nazwać czasem opowiedzianym (nie przypadkiem słowo „historia” w większości języków oznacza zarówno przebieg zdarzeń rzeczywistych, "opowieść" o tych zdarzeniach, jak i fikcyjną fabułę ${ }^{46}$. W świetle powyższych rozważań film o tematyce historycznej byłby zatem najpełniejszą realizacją tej wymiany; relacji, dzięki której bolesne doświadczenie ludzkiego czasu, możliwe jest do uchwycenia i zaakceptowania.

Choć od zarania kino zajmowało się „ożywianiem przeszłości”, to w ujęciu "tradycyjnym”, dominującym do - mniej więcej - końca lat 70., odmawiano filmom historycznym statusu porównywalnego do narracji pisanych (twierdzono, iż te ostatnie miałyby być rzekomo bardziej wiarygodne i zobiektywizowane). Zwolennikiem odmiennej - współcześnie coraz częściej akceptowanej w środowisku historyków - optyki, wedle której medium filmowe jest pełnoprawnym sposobem narracji historycznej i może być traktowane na równi z opracowaniami pisanymi, był m.in. Hayden White; do jego koncepcji odwoływał się zaś Robert Rosenstone. Oczywiście, nie sposób omówić tu osobno wszystkich, dość licznych publikacji poświęconych temu zagadnieniu. Dość wspomnieć, iż w samych latach 90. relacjom filmu i historii poświęcony został amerykański periodyk „Film and History” (powstały z inicjatywy Historians Film Commit-

\footnotetext{
${ }^{46}$ Por. Tomasz Kłys, Film fikcji i jego dominanty, Warszawa 1999, s. 69.
} 
tee, założonego przez Johna E. O'Connora i Martina A. Jacksona), a na łamach „American Historical Review" miała miejsce debata poświęcona wizualizacji historii $\mathrm{w}$ filmie, w której udział wzięli znani historycy ${ }^{47}$. Z inicjatyw współczesnych, prócz cyklicznych publikacji na ten temat, należy zaś wymienić portal internetowy założony przez historyków młodego pokolenia - www.historiaimedia.org. Ograniczę się więc do przywołania wybranych koncepcji oraz tych wątków refleksji, które uznałam za najistotniejsze.

$$
* \quad * \quad *
$$

Koncepcja White'a odsłania narracyjny i konstrukcyjny wymiar historii. W wydanej w 1973 r. Metahistory, która stała się centralnym tekstem dla dyskusji na temat pisarstwa historycznego, Hayden White dowodzi, iż poznaniem historycznym rządzą również tropy i figury literackie, a badana przez nauki historyczne przeszłość jest niedostępna inaczej niż za pomocą narracji. Wątki te pojawiły się już we wcześniejszym artykule badacza - Brzemie historii z 1966 roku, jednak dopiero w Metahistory White jednoznacznie proponuje, aby spojrzeć na historiografię jak na pisarstwo („Traktuje dzieło historyczne jako coś, czym ono w sposób oczywisty jest: jako werbalną strukturę wyrażaną w formie narracyjnej prozy dyskursu" ${ }^{\prime \prime 8}$ ). Zarazem usiłuje White ukazać sposoby, dzięki którym każdy, kto próbuje nadać sens przeszłości, zanim ową przeszłość odkryje (discover), musi ją najpierw „wynaleźć” (invent). Nie znaczy to oczywiście, że wedle White'a rzeczywiste wydarzenia nie miały miejsca w przeszłości („nigdy nie twierdziłem, że przeszłość sama w sobie nie istnieje, że wydarzenia historyczne nigdy nie miały miejsca, że nie ma prawdy o przeszłości, czy że nie istnieją różnice między historią a fikcją" $)^{49}$. Znaczy to jedynie, że zanim historyczne wydarzenia staną się przedmiotem badań i analiz muszą zostać najpierw „wyobrażone” (imagined). Narracja historyczna stanowi bowiem "zapośredniczenie między wydarzeniami, o których opowiada, a strukturami fabularnymi konwencjonalnie wykorzystywanymi w obrębie naszej kultury do nadawania sensu zdarzeniom i sytuacjom nierozpoznanym" ${ }^{\prime 50}$.

47 Zob. „American Historical Review” 1992, t. 97, nr 2.

${ }^{48}$ Hayden White, Metahistory. The Historical Imagination in Nineteenth-Century Europe, Baltimore-London 1973, s. IX (wstęp).

${ }^{49}$ Hayden White, Poetyka pisarstwa historycznego, red. Ewa Domańska, Marek Wilczyński, Kraków 2000, s. 33.

${ }^{50}$ Ibidem, s. 91. Podobną myśl w polskim piśmiennictwie wyraził Witold Kula stwierdzając, że szczególna trudność poznania historycznego tkwi właśnie w braku dostępu 
Historia byłaby więc dla White’a bardziej sztuką interpretacji niż nauką nastawioną na wyjaśnienia - przede wszystkim dlatego, iż w swoich badaniach historyk opiera się na relacjach i dokumentach będących już czyimiś opowieściami i autonarracjami; korzysta więc z okruchów interpretacji, selekcjonuje je i umieszcza we własnej narracji, w pewnym stopniu reinterpretując zebrane informacje. Przekształcanie chronologicznie uporządkowanej, niezakończonej kroniki wydarzeń w opowiadanie z określonym początkiem, częścią środkową i końcem, a zatem transpozycję amorficznego chaosu danych - „prozy przeszłości”, na uporządkowaną „poezję historiografii" - nazywa White fabularyzacją (emplotment). „Przez fabularyzację - pisze - rozumiem po prostu kodowanie faktów zawartych w kronice, jako składników specyficznego rodzaju struktur fabularnych" ${ }^{\prime \prime 1}$. Historia w koncepcji White'a przypomina więc raczej partię językowych szachów, której zwycięzcy wyznaczają aktualnie obowiązującą „politykę eksplanacji”. Wybór fabularnej struktury zależy rzecz jasna od samego historyka/interpretatora, który jednak - o czym zapomnieć nie wolno - uwarunkowany jest teraźniejszymi dla niego kulturowymi i estetycznymi kategoriami, tworzącymi przestrzeń dla jego narracji. Konstatacja ta sygnalizuje problem „wolności piszącego”. White nie rozwiązuje jednak tego dylematu, ograniczając się do istotnego skądinąd spostrzeżenia, iż wszelki język funkcjonuje zawsze w sposób nieświadomy dla tych, którzy go używają; poza ich kontrolą i wolą tworzy nieprzewidziane oraz niestałe znaczenia („,dyskurs historyczny [...] znaczy zawsze więcej niż to, co mówi dosłownie, mówi coś innego niż to, co zdaje się znaczyć i ujawnia coś o świecie jedynie za cenę ukrycia czegoś innego" ${ }^{25}$ ).

Pozwoliłam sobie na tak obszerne zreferowanie poglądów White'a na temat historiografii, ponieważ stanowią one podstawę do jego refleksji nad reprezentacjami historii $\mathrm{w}$ filmie - tzw. historiofotia, czyli „historią w obrazach". Prezentowane przez niego podejście narratywistyczne umożliwia niejako obronę „historiofotycznego potencjału” zawartego w filmowym medium. White stwierdza bowiem, iż „każda historia pisana powstaje $\mathrm{w}$ efekcie kondensacji, przeniesienia, symbolizacji oraz selekcji: są to dokładnie te same procesy, które decydują o kształcie reprezentacji

do przeszłości - poznajemy bowiem rzeczywistość nieistniejąca, niepodległą temu samemu poznaniu bezpośredniemu, poznawalną jedynie pośrednio, za pośrednictwem źródeł. Por. Witold Kula, Rozważania o historii, Warszawa 1958, s. 42.

${ }^{51}$ Hayden White, Poetyka pisarstwa historycznego, s. 82.

${ }^{52}$ Hayden White, Figuring the Nature of the Times Deceased: Literary Theory and Historical Writing, [w:] The Future of Literary Theory, red. Ralph Cohen, New York-London 1989, s. 25. 
filmowej. Medium jest inne, ale sposób kreowania przekazu pozostaje ten sam”53. I choć stwierdza: „współcześni historycy powinni być świadomi, że analiza obrazów wizualnych wymaga sposobu czytania odmiennego niż wypracowany do lektury dokumentów pisanych" - to jednocześnie zauważa: „mamy skłonność do takiego traktowania świadectw wizualnych, jakby w najlepszym razie stanowiły uzupełnienie zapisów werbalnych, a nie samodzielną wypowiedźn ${ }^{\prime \prime 4}$.

Opór akademickich historyków wobec prób sfilmowania historii skupia się wedle White'a przede wszystkim na wyliczeniu potencjalnych strat wynikających z procesu przekładu. Wymienia się wśród nich m.in. precyzję szczegółu oraz złożoność wyjaśnienia. A przecież, jak dowodzi White, „zapisy wizualne (zwłaszcza fotograficzne i filmowe) stanowią dużo wierniejszą podstawę do odtworzenia scenerii i atmosfery przeszłości niż wszystko, co można by wyczytać z samych tylko świadectw pisanych" ${ }^{\prime \prime}$. Przy czym nie chodzi tu wyłącznie o większe podobieństwo do rzeczywistości czy silniejsze oddziaływanie emocjonalne, ale także przedstawienie mniej dwuznaczne - filmową konkretyzację. Na zastrzeżenia, które budzą filmowe uogólnienia wymuszone na przykład brakiem lub niedostępnością świadectw dokumentalnych, White odpowiada zaś, iż prawdziwość filmowej sekwencji „powinna zostać ulokowana nie na poziomie konkretu, lecz na innym poziomie właściwym typizacji. Sekwencję tę należy uważać za reprezentację jakiegoś typu wydarzenia. Tym, do czego odsyła, jest typ wydarzenia ukazanego na ekranie ${ }^{256}$.

Aby lepiej zobrazować swój koncept, White powołuje się na scenę z filmu Richarda Attenborough Gandhi (1982), twierdząc, że przedstawienie anonimowego południowoafrykańskiego konduktora, który wypchnął młodego Gandhiego z pociągu, nie jest przedstawieniem fałszywym, pomimo że aktor grający tę rolę nie mógł być fizycznie podobny do rzeczywistego sprawcy tego czynu. Prawdziwość tej sceny polega bowiem „na przedstawieniu pewnej postaci, której historyczne znaczenie wynika z rodzaju działania podjętego w określonym miejscu i czasie". White dodaje przy tym, iż „żądanie od filmu prawdy niemożliwej do osiągnięcia $\mathrm{w}$ żadnym innym medium reprezentacji, nie wyłączając historii pisanej, wynika z mylenia historycznych postaci z ich «charakterystykami» tworzonymi dla celów dyskursywnych tak w mediach werbalnych,

\footnotetext{
${ }^{53}$ Hayden White, Historiografia i historiofotia, [w:] Film i historia, s. 119.

${ }^{54}$ Ibidem, s. 118.

${ }^{55}$ Ibidem.

${ }^{56}$ Ibidem, s. 124.
} 
jak i wizualnych"57. W ujęciu White'a filmowa reprezentacja historyczna, podobnie jak ta pisana, jest więc niejako działaniem poetyckim, opartym na analogii: narracja w historycznym splataniu wątków pozostaje w relacji $\mathrm{z}$ analogią do zdarzeń, które faktycznie miały miejsce. Filmując czy pisząc historię, reżyser lub historyk konstruuje model, który jest zdolny zastąpić minioną rzeczywistość - co nie sugeruje ani identyfikacji z przeszłościa, ani oderwania od niej, ale coś pomiędzy. Zarówno reżyser, jak i historyk ustanawiają zatem relację podobieństwa między rzeczywistością przeszłości a swoim dyskursem o niej, nie narażając na szwank autonomii żadnego z tych czynników (relacja między dyskursem a realnością opiera się na podobieństwie, które zarówno oddziela dyskurs od realności, jak i łączy go z nią). Koncepcja White'a sytuowałaby się zatem w opozycji do tego stanowiska w filozofii historii, które usuwa dystans między działaniem historyka a przeszłością i identyfikuje narrację historyczną z tym, co było ongiś, ale pozostaje także w kontrze wobec historiografii różnicy (zwolennicy tej opcji dowodzą iż o przeszłości nie można mówić głosem teraźniejszości $\left.{ }^{58}\right)$.

Rozważaniami nad możliwością przedstawienia historii w filmie zajął się także Robert A. Rosenstone. W jego tekstach odnajdziemy swego rodzaju fascynację filmowym medium, która wyraża się m.in. w domniemaniach, iż obecnie, „w świecie postpiśmiennym”, czyli przesyconym obrazami, „być może kultura wizualna po raz kolejny zmieni istotę naszego związku z przeszłością". Trudno zaprzeczyć, że współcześnie, jak zauważa Rosenstone, „ludzie coraz częściej czerpią swoje wyobrażenia na temat przeszłości z kina i z telewizji, z filmów pełnometrażowych, fabularyzowanych dokumentów, miniseriali i produkcji dokumentalnych". Wydaje się, że Rosenstone ma również rację, gdy stwierdza, iż dla więk-

57 Ibidem, s. 126.

58 Trzy stanowiska rozumienia historycznej mimesis - to, co tożsame, różne i analogiczne omawia dokładnie w swoim dziele Paul Ricoeur. Zob. Paul Ricoeur, Czas i opowieść, t. 3: Czas opowiadany, tłum. Urszula Zbrzeźniak, Kraków 2008, s. 203-215. Ricoeur podkreśla, że historyk może wyłącznie dążyć do zrównoważenia ciężaru chwili teraźniejszej, która zniekształca lub przemieszcza jego punkt widzenia. Przekonanie o iluzoryczności obiektywizmu w badaniu historii i neutralności dyskursu ją opisującego zbliża White'a do przedstawicieli Nowego Historyzmu, podkreślającego tekstualny aspekt historii i kontekstowe uwikłanie narracji historycznej. 
szej części społeczeństwa podstawowym źródłem wiedzy historycznej - poza "znienawidzonymi podręcznikami” - są dziś z pewnością media wizualne $^{59}$. Badacz ogniskuje więc swoje refleksje przede wszystkim na względnej przystawalności tego, co moglibyśmy nazwać historiofotia, do kryteriów prawdy i ścisłości, które rzekomo - jak zakładają niektórzy - rządzą praktyką historiografii. Innymi słowy, Rosenstone zastanawia się, czy możliwe jest dokonanie przekładu tekstu pisanego z dziedziny historii na jego wizualno-dźwiękowy odpowiednik bez znaczącej utraty treści.

Rosenstone, podobnie jak Hayden White, zwraca uwagę na narracyjny i konstrukcyjny charakter każdej historii (także filmowej), który stanowi swego rodzaju wspólny mianownik dla rozmaitych „historycznych opowieści”. Konstatuje bowiem: „Fakt, że film fabularny ze swej istoty opiera się na konfliktach między bohaterami i przedstawia materię filmową w zgodzie z konwencjami narracyjnymi nie odróżnia go znacząco od większości dzieł historii pisanej" ${ }^{\prime 60}$. W innym miejscu deklaruje zaś:

Po pierwsze, ani życie ludzi, ani narodów nie ma kształtu „opowieści” historycznej. Narracje, czyli spójne opowieści posiadające początek, środek i zakończenia, są konstruowane przez historyków, którzy próbują nadać sens przeszłości. Po drugie, narracje pisane przez historyków to w rzeczywistości "fikcje werbalne". Historia stanowi przedstawienie przeszłości, nie samą przeszłość. Po trzecie, natura świata historycznego w narracji zależy po części od gatunku lub stylu (podobnie jak w literaturze pięknej), w jakim historyk prowadzi opowieść. Wreszcie po czwarte, język nie jest przezroczysty i nie oddaje przeszłości takiej, jaką była ona naprawdę. Język nie tyle odzwierciedla przeszłość, co raczej ją stwarza, nadaje jej strukturę i nasyca znaczeniem $^{61}$.

Uświadomienie sobie tych uwarunkowań powinno wedle Rosenstone'a prowadzić do zaakceptowania faktu, iż może istnieć więcej niż jeden rodzaj prawdy historycznej oraz że prawdy przekazywane za pomocą obrazów mogą się różnić od tych, które są komunikowane słowami (choć niekoniecznie muszą być z nimi sprzeczne $)^{62}$.

Rosenstone sugeruje kilka "fabularnych technik” historycznej reprezentacji (stosowanych zarówno w pisanej, jak i filmowej historii): kompresję, kondensację, alternację i metaforę. Kompresja jest wedle badacza techniką przedstawiania relatywnie obszernego zdarzenia historycznego

${ }^{59}$ Robert A. Rosenstone, Historia w obrazach/historia w stowach: rozważania nad możliwościa przedstawienia historii na taśmie filmowej, [w:] Film i historia, s. 96.

${ }^{60}$ Ibidem, s. 103.

${ }^{61}$ Ibidem, s. 106.

${ }^{62}$ Por. ibidem, s. 113. 
za pomocą stosunkowo krótkich scen, które ścieśniają i streszczają je. Kondensacja stanowi figurę podobną do poprzedniej - to selekcja szczególnych faktów z całości archiwizowanych świadectw po to, by przedstawić zbiorowe doświadczenie szerokich grup społecznych. Zarówno kompresja, jak i kondensacja działają więc na zasadzie synekdochy - część zastępuje całość. Alternacja odnosi się do zmian, jakie reżyser/historyk wprowadza w udokumentowane rzeczywiste zdarzenia historyczne, by dokonać ogólniejszej konstatacji historycznej: brak wierności na poziomie dosłownym prowadzi do prawdy dyskursywnej. Koncept metafory zaproponowany przez Rosenstone'a jest mniej przejrzysty; wydaje się, że odnosi się do technik symbolizowania, w których określony obraz lub seria obrazów ma za zadanie zastępować bardziej abstrakcyjne wypowiedzenia.

Opisując "retoryczne chwyty" prezentowania historii, Rosenstone - podobnie jak White - zaznacza jednak, że w żadnym razie nie twierdzi, iż „historia i fikcja są tym samym”. Badacz podkreśla, że „tak jak książka, film historyczny nie może ignorować wyników badań i tez o tym, co wiemy do tej pory z innych źródeł. Tak jak każda praca o historii, film musi być osądzany w ramach wiedzy o przeszłości, którą obecnie posiadamy" ${ }^{\prime 6}$. Innymi słowy, konstrukcja materiału fabularnego powinna być podporządkowana „prawdzie dyskursu o przeszłości” (opartego na naszej dotychczasowej wiedzy), a osąd musi pojawić się ze skumulowanej wiedzy pochodzącej z historycznych tekstów kultury, do których należy także film.

Ponownie podkreślone zostają także - tak samo jak przez White'a - możliwości medium. Na czym one polegają? Rosenstone odpowiada na to pytanie niekiedy przez negację - prezentując listę żywionych przez historyków uprzedzeń do filmowych historii. I tak ci ostatni, jak stwierdza Rosenstone, zarzucają filmom podejmującym temat historyczny bardzo małą wartość informacyjną („mały ładunek informacji”) ${ }^{64}$. Jednak „niedosyt profesjonalnego historyka” wywołany "ekranową liczbą danych” (jego zdaniem bez porównania skromniejszą w porównaniu z jej wersją pisaną) jest wedle Rosenstone'a nieuzasadniony, ponieważ zawsze stopień szczegółowości przyjęty przez historyka stanowi po części jego arbitralny wybór. „Można zatem wskazać wiele krótkich i dłuższych prac dotyczących różnych zagadnień historycznych" ${ }^{65}$. Ponadto, jak słusznie zauważa Rosenstone (zgadzając się tym samym z Whitem), różnica mię-

${ }^{63}$ Robert Rosenstone, The Historical Film: Looking at the Past in a Postliterate Age, [w:] The Historical Film: History and Memory in Media, red. Marcia Landy, New Brunswick, New Jersey 2001, s. 66.

${ }^{64}$ Ibidem, s. 99.

${ }^{65}$ Ibidem, s. 103. 
dzy pisanymi i filmowymi narracjami historycznymi polega także na stopniu konkretyzacji pisanej oraz audiowizualnej historii. Jedna krótka sekwencja filmowa konstruuje bowiem i streszcza w obrazach ogromne ilości danych, których zakomunikowanie za pomocą pisanej narracji wymagałoby użycia ogromnej liczby słów.

Co więcej, film zawsze ukazuje integralny obraz danej osoby lub wydarzenia. Rosenstone słusznie zauważa, że pewne zjawiska - np. krajobrazy, dźwięki - można przedstawić w filmie „łatwiej” niż w jakiejkolwiek jedynie werbalnej formie, która zamyka je w gorsecie języka, redukując do sekwencji kilkuset, może więcej słów. Nie są one rozbite na rozdziały, tematy i kategorie, jak w narracji pisanej, która najczęściej traktuje oddzielnie różne aspekty omawianego fenomenu (życie rodzinne postaci, politykę państwa etc.). W świetle powyższych argumentów trudno powiedzieć, iż historia prezentowana za pośrednictwem filmu jest uboższa niż ta przekazywana w tradycyjnej historiografii. Należy jednak zaznaczyć, że Rosenstone ma na myśli obowiązującą formę widowiska określaną jako film fabularny w stylu zerowym; popełnia zatem błąd, pisząc o „filmie w ogóle".

Skoro film jest medium bogatym w znaki przedstawiające nasze doświadczenie przestrzennej i czasowej realności świata, istnieje zatem pokusa domagania się dzieła naśladowczego: replikacji przeszłości historycznej w całej jej szczegółowości. Jednak, jak słusznie dowodzi Rosenstone, nawet przy pomocy historyków i dzięki dostępowi do wszelkich pisanych, wizualnych i audialnych archiwów, film może jedynie starać się zmniejszyć rozziew między przedstawieniami a literalnymi realiami historycznego doświadczenia. Rosenstone konstatuje: „Tak film może nam pokazywać świat lub powierzchnię jakiegoś fragmentu świata, ale nigdy nie może odtworzyć literalnie zdarzenia, które miało miejsce w przeszłości. Nie może być nigdy dokładną repliką tego, co się zdarzyło" ${ }^{66}$. Przekonanie to wyraża on także w prowokacyjnym paradoksie: „Na ekranie historia musi być fikcyjna po to, by była prawdziwa" ${ }^{\prime 67}$. W innym zaś miejscu dodaje:

Musimy sobie uświadomić, że film zawsze będzie zawierać obrazy zarazem wymyślone i prawdziwe. Prawdziwe w tym sensie, że symbolizują kondensują lub sumują większą ilość danych; prawdziwe w tym, że przekazują ogólne znaczenie przeszłości, która może być zweryfikowana, udokumentowana lub uargumentowana ${ }^{68}$.

${ }^{66}$ Robert A. Rosenstone, Visions of the Past: The Challenge of Film to Our Idea of History, Cambridge 1995, s. 70.

${ }^{67}$ Ibidem.

${ }^{68}$ Robert A. Rosenstone, The Historical Film..., s. 60. 
Rosenstone zaznacza zatem, że fikcjonalizacja - kreacja postaci czy zdarzeń, które nigdy nie istniały - niekoniecznie nadwyręża historyczne intencje reżysera i może być ważnym instrumentem docierania do prawdy historycznej:

Czasami film musi ukazać twarz osoby bez twarzy [...]. W takich wypadkach pewne fakty dotyczące postaci muszą zostać wykreowane. Oczywiście jest to tworzenie fikcji, ale z pewnością takie uzupełnienie pisemnej relacji nie czyni historii żadnej krzywdy, przynajmniej dopóty, dopóki znaczenie generowane przez „odtwórców ról” w jakiś sposób uwydatnia ważniejsze znaczenie historycznej postaci, którą przedstawiają ${ }^{69}$.

W wypowiedzi tej bez trudu można dopatrzeć się echa przywołanych wcześniej poglądów White’a. Rosenstone jest także bliski White'owi, gdy stwierdza, że „audiowizualna opowieść historyczna konstruuje historyczne światy możliwe będące $\mathrm{w}$ relacjach nie tyle przyległości, co równoległości i sąsiedztwa z alternatywnymi historycznymi światami możliwymi, powstałymi $\mathrm{w}$ oparciu o strategie pisanej i oralnej tradycji historycznej"70. Rosenstone wydaje się tu bowiem zwolennikiem "tego, co analogiczne", proponując - podobnie jak White - pozytywną relację między dyskursem a rzeczywistością przeszłości.

Ciekawym aspektem rozważań Rosenstone'a nad relacjami historii i filmu jest stosowana przez badacza typologia. W swoim artykule Looking at the Past in Postliterate Age wyróżnia bowiem umownie trzy szerokie kategorie ewokowania historii w filmie:

1) historię „udramatyzowaną", ujętą w formule filmu fikcjonalnego (history as drama),

2) historię $\mathrm{w}$ formule filmu dokumentalnego (history as document),

3) historię $\mathrm{w}$ dziełach eksperymentalnych (history as experiment), czyli filmach twórców awangardowych ${ }^{71}$.

Rosenstone najwięcej miejsca poświęca trzeciemu wariantowi; zwraca jednak uwagę, iż to zbiór pierwszego typu jest najobszerniejszy, zaś film dokumentalny budzi największe zaufanie tradycyjnych historyków ze względu na jego pozorną nieodległość od ukazywanej rzeczywistości. Wedle Rosenstone'a tradycyjni historycy są zdania, iż film dokumentalny to swoiste okno na świat, przez które można „zobaczyć (i najprawdopodobniej poczuć) to co ludzie w przeszłości widzieli i czuli"72. Przekonanie

\footnotetext{
${ }^{69}$ Robert A. Rosenstone, Historia w obrazach/historia w słowach, s. 107.

${ }^{70}$ Robert A. Rosenstone, Visions of the Past..., s. 78.

${ }^{71}$ Robert A. Rosenstone, The Historical Film..., s. 52-53.

${ }^{72}$ Ibidem, s. 53.
} 
o swoistej „prawdziwości” materiałów archiwalnych pojawia się niekiedy również w refleksji filmoznawczej. Symptomatyczna pod tym względem jest opinia Lino Micciché, który w artykule Film i historia stwierdza:

Jedynym kinem zdolnym do pełnienia funkcji historiograficznej [...] jest kino „oparte na" [...] dokumentach kroniki filmowej. Obrazy z danego czasu są prawdziwymi, a właściwie jedynymi wstępnymi tekstami historycznymi, mogącymi doprowadzić do historycznie ugruntowanego "tekstu filmowego", którego starcie z organiczną tendencją istniejącej struktury filmowej i jej ideologii do przekształcania wszystkiego w „przygodę wyobraźni” może okazać się zwycięskie. Prawdziwym jedynym filmem historycznym w pełnym znaczeniu tego słowa może być film, który odtwarza epokę, zdarzenie, postać w oparciu o obrazy kroniki filmowej zarejestrowane w danej epoce, $\mathrm{z}$ okazji danego zdarzenia, w obecności danej postaci. Ich zestawienie, selekcja i swobodny montaż będą z pewnością sugestywnym dziełem autora, wyrażającym nieuchronnie, wręcz koniecznie, dzisiejszy punkt widzenia, ale „przeżycie” w tych obrazach, na których opiera się dyskurs, jest przeżyciem Historii, to jest świata i ludzi, a nie tylko przeżyciem realizacji filmowej, która jednakowo odczuwa fikcję i rzeczywistość i je ze sobą miesza, zrównuje, wymienia. „Film historyczny” przynajmniej tu i teraz robi się z prawdziwych obrazów historii ${ }^{73}$.

Jak już wspomniałam, najbardziej interesujące są dla Rosenstone’a filmy eksperymentalne (o chwiejnej strukturze), które według badacza zwracają się do nas w sposób bardzo odmienny od tak zwanych filmów realistycznych (filmy eksperymentalne „w swej formalnej niezwykłości dążą do podważenia podstawowej konwencji przedstawiania historii w filmie - jej «realizmu»" ${ }^{14}$ ) i konstruują odmienny świat historyczny: „Nie otwierają okna wprost na przeszłość, a raczej na różne sposoby myślenia o przeszłości"75. Podczas gdy produkcje głównego nurtu wysuwają na plan pierwszy moralnie bezproblemowa, krzepiącą narrację i indywidualnego bohatera kosztem grupy społecznej; nasycają zdarzenia emocjami i dramatyzują je oraz ukazują idee przeszłości przez przywiązanie do stylu epoki, filmy eksperymentalne są inne. Kontestują one konwencje klasycznej narracji filmowej oferując „,dzieła analityczne [...] zdystansowane, wieloprzyczynowe; [...] historie, które nie pokazują nam zwyczajnie przeszłości"76.

${ }^{73}$ Lino Micciché, Film i historia, „Kino” 1981, nr 7, s. 26.

${ }^{74}$ Robert Rosenstone, Historia w obrazach/historia w słowach, s. 111.

75 Robert A. Rosenstone, Visions of the Past..., s. 63.

${ }^{76}$ Ibidem, s. 61. Koncepcję Rosenstone'a „przedstawiania historii przez film” omawia pokrótce Dorota Skotarczak. Dorota Skotarczak, Obraz społeczeństwa PRL w komedii filmowej, s. 17. 
Zgodnie ze swoją argumentacją Rosenstone odrzuca więc nie tylko tradycyjną historiografię głównego nurtu, ale także kino głównego nurtu. Choć przyznaje, że pomiędzy tymi dwoma mediami istnieje istotna różnica, dostrzega uderzającą zbieżność, jeśli chodzi o sposób reprezentacji historii. Tradycyjna historiografia, podobnie jak historyczne filmy hollywoodzkie, ukazuje historię, tak jakby prezentowane wydarzenia zdarzyły się w rzeczywistości. Filmy głównego nurtu chcą „byśmy myśleli, że są one realnością", chcą zasugerować nam, że „możemy patrzeć przez okno ekranu bezpośrednio na rzeczywisty świat" ${ }^{\prime 77}$, zaś wszystkie filmy zachęcające do krytycznego namysłu odmawiają takiej perspektywy - analityczna funkcja dyskursu często dominuje tu nad wymogami opowiadania. Wedle Rosenstone'a, największy wkład historycznego filmu leży więc w sposobie prezentowania dziejów. Film o tematyce historycznej ma kontestować, wyobrażać i reinterpretować (rewidować) historię. Dlatego badacz ceni m.in. film Alaina Resnais Hiroszima, moja miłość (Hiroshima, mon amour, 1959), w którym miast statystyk ofiar nuklearnej katastrofy oglądamy parę kochanków z Hiroszimy opętanych wspomnieniami z wojny (wedle Rosenstone'a, „w tej luce między abstrakcyjną ideą i konkretnym przypadkiem, historyczny film znajduje przestrzeń, by kwestionować historię. By podawać w wątpliwość konwencjonalne obrazy, prawdy"78) oraz dzieło Hansa Syberberga Hitler: film z Niemiec (Hitler - ein Film aus Deutschland, 1977), który stanowi niekonwencjonalna, „marionetkową" reprezentację nazizmu.

Choć jasne jest, że Rosenstone występuje przeciwko czysto ilustracyjnej, muzealnej reprezentacji historii i postuluje nowe krytyczne oświetlenie przeszłości, to część wywodów dotycząca kategoryzacji filmów (tych, w których badacz rozpoznaje historiograficzny głos) na eksperymentalne i „typowe” wydaje się dość kontrowersyjna. W świetle tej koncepcji badacz niejako z zasady neguje bowiem możliwość istnienia wartościowego filmu o tematyce historycznej, posługującego się narracją klasyczna; waloryzuje ujemnie „naiwne” kino komercyjne, stawiając je

77 Wedle Rosenstone'a, filmy fabularne próbują uśpić nasze krytyczne myślenie o tym, co oglądamy, niejako z zasady konstruując historyczne światy możliwe w wizualnym czasie teraźniejszym, skracając tym samym dystans pomiędzy "teraz” a „wtedy”. "Gigantyczne obrazy na ekranie i dobiegające ze wszystkich stron dźwięki ogarniają nas, zalewają zmysły i udaremniają jakiekolwiek próby zachowania dystansu, krytycyzmu i niezaangażowania. W kinie stajemy się na chwilę więźniami historii". Robert Rosenstone, Historia w obrazach/historia w stowach, s. 100.

${ }^{78}$ Revisioning History: Film and the Construction of a New Past, red. Robert A. Rosenstone, Princetone 1995, s. 8. 
W opozycji do „samoświadomego" kina artystycznego. A przecież jest to zbytnie uproszczenie - można podać liczne przykłady stosowania strategii zwrotnych w kinie hollywoodzkim od burleski przez kreskówki aż do musicalu czy komedii ${ }^{79}$. Jak słusznie zauważa Patrick Vonderau, krytyczno-ideologiczny impuls, za którym Rosenstone podąża, prowadzi go także "do uromantycznienia filmowej produkcji; pomija on fakt, że film jest generalnie zorientowaną na zyski kolektywną pracą". Co więcej, jeśli „oszukańcza strategia filmów hollywoodzkich jest tak nieskazitelna, w jaki sposób jest ona dostrzegalna dla Rosenstone'a" ${ }^{\prime 80}$ ? Z Rosenstonem polemizuje także White, twierdząc, iż choć przywołane przez badacza filmy eksperymentalne rzeczywiście podważają typ realizmu, jaki przypisujemy zarówno konwencjonalnym filmom, jak i historiografii, to ,jednak dzieje się tak nie dlatego, że w filmach tych precyzję szczegółu można poświęcić na rzecz skupienia uwagi na problemie wyboru formy przedstawiania przeszłości. Inaczej - pokazują nam one, że kryteria określające «precyzję szczegółu» zależą od formy wybranej do przedstawiania «przeszłości» i naszego wyobrażenia o jej historycznym znaczeniu" ${ }^{\prime 1}$.

Pomimo tych zastrzeżeń, koncepcja Rosenstone'a pozostaje kluczowa dla niniejszej pracy. Badacz zwraca bowiem uwagę, że film jako tekst kultury, pełniący rolę „dokumentu” epoki, może być traktowany na równi ze źródłami pisanymi. Co istotne, wedle badacza, twórca filmowy ma prawo do własnej wizji historii, do negacji uznanych naukowo prawd; winien jednak pamiętać o tym, by subiektywny charakter jego dzieła był łatwo identyfikowalny, by odbiorca traktował go jako propozycję ujętą w formie hipotezy, nie zaś jako na poły dokumentalną relację o tym, jak rzeczywiście było. Dlatego Rosenstone deklaruje: „Jako historyk wierzę w rzeczywistość desygnatów - czyli świata. Wierzę, że empiryczne fakty istnieją i twierdzę, że jeśli z tego przekonania zrezygnujemy - nie będziemy więcej historykami" ${ }^{82}$.

${ }^{79}$ W opozycji do Rosenstone'a sytuuje się też praca Vivian Sobchack, która udowadnia, że filmy historyczne głównego nurtu nie proponują naiwnej, transparentnej wersji historii. Zob. Vivian Sobchack, "Surge and Splendor" A Phenomenology of the Hollywood Historical Epic, "Representations” 1990, nr 29, s. 24-49.

${ }^{80}$ Patrick Vonderau, Historiography and Film: A Dangerous Liasion?, [w:] Film as History/History as Film, red. Patrick Vonderau, Florence-Berlin 1999, s. 19-20.

${ }^{81}$ Hayden White, Historiografia i historiofotia, s. 127.

${ }^{82}$ Robert A. Rosenstone, Visions of the Past..., s. 246. 


\section{Film historyczny jako zwierciadło dyskursów teraźniejszych}

Uzasadniona wydaje się opinia, iż film historyczny mówi więcej o czasie swego powstania niż o wydarzeniach, o których traktuje. Filmy poświęcone tematyce historycznej (bez względu na to, czy mamy do czynienia z fabularyzacją autentycznych wydarzeń, czy z „czystą fikcją" osadzoną w realiach przeszłości) w szczególny bowiem sposób ujawniają napięcia w dyskursie społecznym właściwym dla czasu ich realizacji.

Zarówno produkcja, jak i interpretacja tekstu, są uwarunkowane społecznie i przez wartości oraz wizje świata obowiązujące $\mathrm{w}$ danym momencie historycznym. Film jest więc za każdym razem, jak słusznie zauważa Lino Micciché, „dokumentem danego momentu historycznego [...] do niego także, właśnie z tego powodu będzie się musiał odwołać historyk-interpretator dnia jutrzejszego ${ }^{\prime 83}$. Opinia ta nie jest rzecz jasna odosobniona, pojawia się zarówno w polskiej, jak i obcojęzycznej refleksji. Odnajdziemy ją m.in. u Rafała Marszałka (,,w istocie ekranowa pop-historia mniej zajmuje się narodem historycznym, tj. wpisanym w odtwarzaną epokę, niż pozostającym wokół filmu współczesnym sobie narodem" ${ }^{84}$ ), u Marka Hendrykowskiego („proces filmowania, on także staje się faktem, które zakotwiczone w pewnym tu i teraz dostarcza za każdym razem historykowi, ale i interpretatorowi niezwykle cennych informacji" ${ }^{\prime \prime 5}$ ), ale i np. u Gian Piero Brunety (film fabularny jest źródłem historycznym czasu, w którym powstał ${ }^{86}$ ).

Fakt, iż każdy film historyczny jest bardziej obrazem epoki, w której powstał, niż tej, o której traktuje, podkreślają także Pierre Sorlin oraz Martin A. Jackson. Wedle Sorlina, „film historyczny [...] byłby poświęcony przede wszystkim problemom współczesnym; w sposób przewrotny opierający się na tematach aktualnych, zajmujący stanowisko wobec teraźniejszych konfliktów" ${ }^{87}$. Martin A. Jackson ujmuje zaś tę dwoistość filmu o tematyce historycznej, odwołując się do dzieła Tony'ego Richardsona Szarża lekkiej brygady (The Charge of the Light Brigade, 1968). Otóż - zdaniem badacza - film ten opowiada wprawdzie o epoce panowania królowej Wiktorii i wojnie krymskiej, ale - co jest bardziej istotne - ukazuje on przede wszystkim Anglię lat 60. i ówczesne postawy Anglików ${ }^{88}$.

${ }^{83}$ Lino Micciché, Film i historia, s. 26.

${ }^{84}$ Rafał Marszałek, Film i historia (II), „Kino” 1981, nr 2, s. 29.

${ }_{85}$ Marek Hendrykowski, op. cit., s. 26.

${ }^{86}$ Gian Piero Brunetta, Il cinema come storia, [w:] La storia al Cinema. Ricostruzione del passato/interpretazione del presente, red. Gianfranco Gori, Roma 1994, s. 468.

87 Pierre Sorlin, op. cit., s. 49.

${ }^{88}$ "Szarża lekkiej brygady została nakręcona w momencie, kiedy Anglia była w trakcie szybkiego tracenia swojej pozycji wielkiej potęgi i kiedy uświęcone idee minionej chwały 
Podkreślam ten „współczesny” aspekt filmów historycznych - zdiagnozowany również przez wspominanych wcześniej Marca Ferro, Rosenstone'a i White'a - z kilku powodów ${ }^{89}$. Po pierwsze, uzasadnia on obecną $\mathrm{w}$ strukturze niniejszej pracy perspektywę diachroniczną (uzupełnioną jednak przez ogląd komparatystyczny; myślę tu o podrozdziałach ukierunkowanych problemowo). Pozwala ona bowiem na prześledzenie dokonującej się w czasie ewolucji filmowych reprezentacji resistenzy, a zatem i swoistej świadomości historycznej włoskiego społeczeństwa na temat interesujących mnie fenomenów. Współczesny wymiar filmów o tematyce historycznej wiąże się także $\mathrm{z}$ przyjętą $\mathrm{w}$ pracy opcją metodologiczną. Choć bowiem szczególną uwagę zwracam na tekstualne umocowanie stawianych hipotez, nie pomijam także społeczno-politycznych czy kulturowych kontekstów.

Niekiedy kontekst zewnętrznych okoliczności zmienia zasadniczo wymowę przedstawienia, nadając mu zupełnie nowe znaczenie, a rzeczywistość poza kadrem dopisuje dodatkowy sens. Dobrym przykładem jest tu choćby film Andrzeja Wajdy - Danton (1982; na podstawie dramatu Stanisławy Przybyszewskiej Sprawa Dantona). Dla interpretacji tego nakręconego we Francji dzieła pierwszoplanowe znaczenie ma kontekst trwającego wówczas w Polsce stanu wojennego. Narzucające się polskiemu widzowi analogie - zręcznie rozrzucone po całym filmie (m.in. słynne koksowniki stojące na ulicach) - skłaniały do tego, by czytać film o XVIII-wiecznej Francji przez pryzmat współczesności. Innym biegunowo różnym przykładem związku filmowej historii $\mathrm{z}$ „pozafilmową teraźniejszością" jest Aleksander Newski (Александp Невский, 1938) Siergieja Eisensteina, opowiadający o pewnym epizodzie z historii XIII-wiecznej Rusi. Wybór tego właśnie tematu wiąże się bowiem ściśle z ekspansją

imperium brytyjskiego zostały zakwestionowane, jeśli nie szczerze ośmieszone przez młodych [...]. Sławna szarża lekkiej brygady nie wygląda już tu jak akt heroizmu czy nawet źle pojętej lojalności, ale jak monstrualny absurd wywołany kryminalnym niedbalstwem, który obszedł się okrutnie z najlepszymi oddziałami. Nie jest to na pewno spojrzenie, które zastosowałby angielski filmowiec lat 30.". Martin A. Jackson, Historyk i kino, „Film na Świecie” 1980, nr 4, s. 69. Zależność filmu od kontekstu dobrze unaocznia także praca Marii Wyke, która analizuje różne realizacje o Spartakusie - m.in. tę z roku 1914 i tę Kubricka z lat 60. Maria Wyke, Projecting the Past: Ancient Rome, Cinema and History, London 1997, s. 34-72.

${ }^{89}$ Jak słusznie zauważa Jacques Le Goff, „,każda historia rzeczywiście jest zawsze historią współczesną w tej mierze, w jakiej przeszłość uchwytna jest w teraźniejszości, a więc znajduje się w kręgu jej zainteresowań. Jest to nie tylko nieuniknione, ale wręcz uprawnione. [...] Zadaniem historyka/interpretatora jest dokonanie analizy przeszłości w dwojakim kształcie. Oczywiście, samemu będąc wplątanym w historię, nie osiągnie on prawdziwego obiektywizmu, ale żadna inna historia nie jest możliwa". Jacques Le Goff, Historia i pamięć, tłum. Anna Gronowska, Joanna Stryjczyk, Warszawa 2007, s. 195. 
stalinizmu i sytuacją polityczną, w jakiej znalazł się Związek Sowiecki w drugiej połowie lat 30. Przywołuję te tytuły niejako na marginesie rozważań, aby jedynie zasygnalizować fakt, iż film historyczny, zajmujący uprzywilejowaną pozycję $\mathrm{w}$ dyskursach dotyczących tożsamości narodowej $^{90}$, staje się niejednokrotnie pretekstem i areną sporów o wartości współczesne. Kostium historyczny służył (i służy nadal) twórcom do wyrażenia krytycznej opinii na temat władzy czy obowiązującego porządku społecznego, ale i jest wykorzystywany do celów propagandowych.

Instrumentalne traktowanie historii na potrzeby bieżącej polityki wyjątkowo wyraźnie rysuje się rzecz jasna w kontekście systemów totalitarnych (tam wizje ekranowe przypominały najczęściej doraźnie fabrykowaną wersję wydarzeń w myśl Orwellowskiego hasła: „kto kontroluje przeszłość, kontroluje przyszłość"). Klasycznym przykładem propagandowego użytku filmu historycznego jest Żyd Süss (Jud Süß, reż. V. Harlan, 1940). Opowieść o XVIII-wiecznym bankierze żydowskim, zdobywającym dzięki swym intrygom wpływy na dworze księcia Wirtembergii, miała przygotować społeczeństwo niemieckie do „ostatecznego rozwiązania kwestii żydowskiej". Stąd główny bohater (postać autentyczna) przedstawiony został jako lubieżny i okrutny przedstawiciel narodu, który pragnie zdobyć władzę nad światem ${ }^{91}$. Innym dziełem, w którym zrealizowany został zamysł wprzęgnięcia przeszłości w służbę propagandy, jest Henryk V (Henry V, reż. L. Olivier, 1944). Bitwę pod Agincourt, w której znacznie mniej liczna armia angielska pokonała siły książąt Francji, pojęto bowiem jako odpowiednik sytuacji Wielkiej Brytanii jesienią 1940 roku, gdy tak niewielu wzlatywało w niebo i zdołało powstrzymać inwazję potężnego najeźdźcy (współczesny wymiar "ekranowej historii” podkreślała dodatkowo dedykacja zamieszczona na początku filmu: „Żołnierzom i lotnikom Wielkiej Brytanii - w imię męstwa przodków, które twórcy próbowali z pokorą ukazać w tym dziele" ${ }^{\prime 92}$ ).

${ }_{90} \mathrm{Na}$ ten temat zob. Cinema and Nation, red. Mette Hjort, Scott Mackenzie, London 2000. O wysokiej temperaturze debat na temat filmowej narodowej historii świadczą liczne anegdoty, np. fakt, iż film Prywatne życie Henryka VIII (The Private Life of Henry VIII, reż. A. Korda) sprowokował w 1933 roku reakcję cenzury z uwagi na sposób przedstawienia zachowania się króla przy stole.

$91 \dot{Z} y d$ Süss jest dla Marca Ferro przykładem na to, że „istnieje ideologia na poziomie stylu, na poziomie czysto technicznego użytku zrobionego z kamery". Ferro zwraca mianowicie uwagę na obecne w filmie przenikanie obrazów, które według badacza "razem tworzą swoistą strukturę, przedstawiając doktrynę nazistowską w pigułce". Marc Ferro, Kino i historia, s. 157.

92 Ciekawy w tym kontekście jest tytuł jednej z książek historyka Roberta Toplina: History by Hollywood: The Use and Abuse of the American Past, Urbana 1996. 
W kinematografii włoskiej wśród filmów o tematyce historycznej, które były nośnikiem oficjalnej propagandy władzy, należałoby wymienić te zrealizowane w okresie faszystowskiego reżimu: choćby film 1860 (reż. A. Blasetti, 1934) oraz Scypiona Afrykańskiego (Scipione l'Africano, reż. C. Gallone, 1937). Zarówno bohaterstwo walk o zjednoczenie w okresie risorgimenta, jak i odwołanie do mitu starożytnego Rzymu stanowiły istotne punkty polityki historycznej faszystowskich Włoch; budowały one narodową tożsamość Włochów, którzy czuli się prawowitymi spadkobiercami Imperium Romanum. Jak słusznie zauważa Rafał Marszałek:

podobne Scypionowi Afrykańskiemu próby zmitologizowania faszystowskich Włoch przez nawiązanie do historii Rzymu odpowiadają nie tylko idei reżimu przez propagandę cnót paramilitarnych, ale też budują tradycję. Dwudziestowieczny rytuał odwołuje się do starożytnej obrządkowości, tak jakby stanowił jej rzeczywistą kontynuację; historia nobilituje dzień dzisiejszy ${ }^{93}$.

Kostium historyczny bywał oczywiście wykorzystywany nie tylko w pseudoromańskich, filmowych kolosach, realizowanych w epoce faszyzmu, ale i później w funkcji artystycznego komentarza do włoskiej areny politycznej. Przykładem takiego „alegorycznego kina” są m.in. realizacje braci Tavianich: Święty Michał miał koguta (San Michele aveva un gallo, 1972) oraz Allonsanfan (1974). Fabuły te, osnute na wydarzeniach historycznych, nie odnosiły się bowiem wprost do dekady lat 70., ale były odczytywane przez pryzmat dekady „ołowiu” (,te filmy czynią wyraźną aluzję do fundamentalnych dyskusji lewicy począwszy od roku 1968"- pisał Guido Fink ${ }^{94}$ ). Podobnie Zabójstwo Matteotiego (Delitto Matteotti, reż. F. Vancini, 1973) - film mówiący o wspólnej walce opozycji lewicowej i centrowej $\mathrm{z}$ faszyzmem w latach 20., który powstał w momencie, kiedy idea centrolewicy włoskiej umacniała się w świadomości całego społeczeństwa,

${ }^{93}$ Rafał Marszałek, Film i historia (II), s. 30. Na rolę narracji o przeszłości w konstytuowaniu poczucia zbiorowej tożsamości wskazywali już w latach 90. m.in. David Morley w pracy Space of Identity a także Tim Edensor w pracy Tożsamość narodowa, kultura popularna $i$ życie codzienne. Obaj przekonuja że współcześnie to kultura popularna ma największe znaczenie dla tworzenia poczucia "tożsamości narodowej”; to film i telewizja miałyby konstytuować „,wspólnoty wyobrażone”, jak nazywa je Benedict Anderson. Wyczerpujące omówienie tej kwestii (wpływu kina historycznego na tożsamość narodową) znacznie wykracza poza temat niniejszej pracy. Zob. David Morley, Kevin Robins, Spaces od Identity: Global Media, Electronic Landscapes and Cultural Boundaries, London 1995; Tim Edensor, Tożsamość narodowa, kultura popularna i życie codzienne, tłum. Agata Sadza, Kraków 2004.

${ }_{94}$ Guido Fink, Być czy istnieć; film włoski-czas i historia, "Cultures” 1974, nr 1 (przedruk w „Film na Świecie” 1980, nr 4, s. 60). 
odczytywać można w kategoriach politycznych i społecznych potrzeb chwili. Co nie znaczy, że film ten (podobnie jak inne tego typu) ma tylko sens doraźny, a jego znaczenie jest ograniczone do określonego momentu politycznego.

Przykłady można by mnożyć w nieskończoność; nie o wyliczankę jednak chodzi, ale o zasygnalizowanie jeszcze jednego, niekiedy „niebezpiecznego", związku filmu i historii - a mianowicie, o zwrócenie uwagi na pamięciotwórczą (a więc i historiotwórczą) rolę kina. W filmowych obrazach historii toczy się bowiem gra, której stawką jest pamięć zbiorowa. W procesie tym, wciąż ponawianym, nie tylko teraźniejszość wchodzi w dialog z przeszłościa, ale także zapisana na taśmie przeszłość dialoguje ze współczesnością. Filmowe obrazy dotyczące historii są nie tylko świadectwem tego, jak wyglądała przeszłość i jak widzi się ją w teraźniejszości; są zatem nie tylko wyrazem pamięci kulturowej w określonym momencie historycznym, ale także - w równej mierze - czynnikiem wpływającym na jej $\operatorname{stan}^{95}$.

Nie zamierzam tu dokładniej omawiać związku pamięci i kina - temat ten, niezwykle obszerny, znacznie wykracza poza problematykę niniejszej pracy $^{96}$. Nie sposób jednak o pamięciotwórczej roli kina nie wspomnieć; bez niej relacje filmu i historii zostałyby istotnie zubożone. W naszych czasach bowiem - jak słusznie zauważa Jacques Le Goff - „historia niemal utożsamiła się z pamięcią i wydaje się rozwijać według modelu przypominania, anamnezy i zapamiętywania $[\ldots]^{\prime \prime 97}$, zaś potencjał kina jako nośnika pamięci (leżący z jednej strony w obrazowości filmów, z drugiej

95 Jak zauważa Andrzej Garlicki: „Mamy tu oczywiście do czynienia ze sprzężeniem zwrotnym, bo zarówno film kreuje świadomość historyczną społeczeństwa, jak i świadomość historyczna oddziałuje na film". Andrzej Garlicki, Film wobec świadomości historycznej, s. 25. Pamięć kulturową rozumiem jako pamięć utrwaloną w instytucjach i tekstach kultury. Jej wyróżnikiem jest uwolnienie się od bezpośrednich relacji świadków i trwałość przekazów. Zasięg pamięci kulturowej wydaje się bowiem sięgać tak daleko wstecz, jak długo możemy odnaleźć jej materialne nośniki, które świadczą o przeszłości.

${ }^{96}$ Moim zamiarem jest wyłącznie zasygnalizowanie wielowymiarowych relacji między historią i pamięcia, istotnych $\mathrm{w}$ kontekście podjętego przeze mnie tematu; nie chcę czynić z owych związków problemu pierwszorzędnego. Ograniczę się więc do przywołania koncepcji „miejsc pamięci” Pierre'a Nory oraz prac poświęconych temu zagadnieniu w języku polskim. Myślę tu choćby o książce Krzysztofa Pomiana Historia. Nauka wobec pamięci (2006), publikacji Barbary Szackiej Czas przeszły, pamięć, mit (2006-2007), oraz nieco wcześniejszej antologii przekładów z anglo-amerykańskiej historiografii lat 90 . XX wieku Pamięć, etyka, historia pod redakcją Ewy Domańskiej (2002).

${ }_{97}$ Ten pamięciowy zwrot jest także widoczny w tradycyjnej historiografii - choćby w coraz liczniej reprezentowanej biografistyce, w której króluje żywioł osobistego doświadczenia. 
zaś w ich narracyjności) jest ogromny i niepodważalny ${ }^{98}$. „Zwrot pamięciowy" - czyli przesunięcie punktu ciężkości z problemu reprezentacji historycznej na kwestię pamięci, jest tu o tyle wart zaakcentowania, o ile ekspansja pamięci zbiorowej (do której ów zwrot prowadzi) w przestrzeni publicznej, niesie ze sobą określone zagrożenia: możliwość manipulacji pamięcią zbiorowa, jej polityzacji czy ideologizacji oraz możliwość nadawania historii znamion emocjonalnych i irracjonalnych. Na oba niebezpieczeństwa należy być wyczulonym nie tylko przy interpretacji i analizie filmowych produkcji o historycznej tematyce. Jak zauważa Le Goff: „Nazbyt faworyzować pamięć to zanurzyć się w nieujarzmionym nurcie czasu" ${ }^{\prime \prime 9}$. Kino, będące wehikułem narracji o wydarzeniach minionych - a zarazem świadectwem krystalizacji, upowszechniania bądź zaniku dyskursów myślenia o przeszłości - stanowi dynamiczny impuls do przemodelowania sposobów jej interpretacji. Filmowe medium, czułe niczym barometr na społeczno-polityczne przemiany, przyczynia się bądź do utrwalania danego porządku, bądź do burzenia stereotypowych wyobrażeń o przeszłości. Filmy o włoskim ruchu oporu w większym stopniu nawiązuja, legitymizują bądź krytykują pamięć zbiorową niż przywołują historię jako klasycznie rozumiany zapis dziejów. Są zatem zawsze interpretacjami przeszłości uzależnionymi od kontekstu, w jakim powstały.

\section{Fabularyzacja faktów historycznych versus film z tłem epoki}

Na potrzeby niniejszej pracy konieczne jest wypracowanie kryteriów, którymi mogłabym się kierować przy wyróżnianiu strategii i analizowaniu filmów o tematyce historycznej. Poniżej postaram się więc zarysować schemat wyznaczający możliwości modelowych ukształtowań interesującego mnie zagadnienia. Dążąc do ich wyodrębnienia, będę się kierowała wyznacznikami wynikającymi przede wszystkim z właściwości formalnych (immanentnych jakości) samych filmów. Moim celem jest, by wypracowane wzorce interpretacyjne z jednej strony opisywały jak najszczegółowiej specyfikę analizowanych dzieł, a zarazem by zachowały swą ważność ogólną.

O kłopotach z pojęciem „film historyczny” była już mowa. Wszelkie definicje opierają się na intuicjach, których trafność zazwyczaj załamuje

98 Poetycko tę właściwość kina ujmuje Andrzej Garlicki, pisząc: „Oto twórcy filmów historycznych na podobieństwo ucznia czarnoksiężnika dysponują świadomie czy nie, orężem z punktu widzenia świadomości historycznej szalenie silnym i szalenie niebezpiecznym". Andrzej Garlicki, Film wobec świadomości historycznej, s. 26.

${ }_{99}$ Jacques Le Goff, Historia i pamięć, s. 26. 
się po kilku chwilach krytycznej dyskusji. Nie chodzi przy tym o to, aby potoczne rozpoznanie tej materii było w jakiś zasadniczy sposób błędne. Kłopot zaczyna się wtedy, kiedy próbuje się ową specyfikę opisać. Ze względu na niedającą się wtłoczyć w żaden jednolity paradygmat olbrzymią różnorodność filmów, próba opisania tego, co w odbiorze intuicyjnym odróżnia się dość łatwo, napotyka na olbrzymie przeszkody. Pierwszym rozróżnieniem, które można dokonać, aby zaprowadzić nieco porządku wśród obszernego zbioru filmów o tematyce historycznej, jest określenie, czy filmy odwołują się do rzeczywistych, "historycznych"100 zdarzeń lub postaci, czy też pozostają one "czysto fikcjonalne", ewokują jedynie tło epoki poprzez rozmaite walory wizualne lub dźwiękowe (m.in. scenografię, kostiumy, muzykę). Dystynkcja ta (była już o niej mowa wcześniej), niewątpliwie sensowna i pojawiająca się dość często w refleksji badaczy przy okazji prób zdefiniowania „filmu historycznego”, domaga się jednak doprecyzowania.

Wyraźną niezręcznością $\mathrm{w}$ podanym rozróżnieniu jest zwrot filmy "czysto fikcjonalne". Chodzi tu rzecz jasna o brak wątków, które odnosiłyby się do konkretnych wydarzeń historycznych. Takie dopowiedzenie wydaje się konieczne, ale chyba niewystarczające. O ile bowiem w tak zarysowanej kategorii "filmu z tłem epoki” z powodzeniem można by ulokować np. Niebezpieczne zwiazki (Liaisons dangereuses, reż. S. Frears, 1988; XVIII-wieczna Francja jest tu rzeczywiście wyłącznie scenerią dla pierwszoplanowych, salonowych intryg głównych, fikcyjnych bohaterów), o tyle np. filmy Przeminęło z wiatrem (Gone With the Wind, reż. V. Fleming, 1939) czy Trzej muszkieterowie (Three Musketeers, reż. S. Herek, 1993) mogłyby już budzić pewne obiekcje. W epopei Fleminga mamy bowiem wyraźne odwołanie do wojny secesyjnej, zaś w adaptacji powieści Dumasa kilkakrotnie pojawia się Ludwik XIII. Wypadałoby zatem w roboczej definicji dookreślić, iż przy „brak wątku” motywy historyczne (epizodycznie przywołane $\mathrm{w}$ filmie autentyczne postacie lub faktyczne wydarzenia) występować mogą.

Ktoś mógłby zapytać, dlaczego nie posługuję się przy opisie tej kategorii funkcjonującym przecież terminem (o czym była już mowa) „film kostiumowy"; przywołane filmowe przykłady doskonale doń pasują. Otóż preferuję określenie „film ewokujący wrażenie epoki” czy "film z tłem

100 „Historycznych” - w domyśle o istotnym znaczeniu. Jak słusznie zauważa Katarzyna Rosner: „Aby były badane jako historia, przeszłe ludzkie działania muszą być traktowane przez członków jakiejś ludzkiej grupy jako należące do jej przeszłości i muszą być ważne i warte rozumienia z punktu widzenia jej aktualnych interesów". Katarzyna Rosner, Narracja, tożsamość i czas, Kraków 2006, s. 66. 
epoki", gdyż wydaje mi się ona zręczniejsza, biorąc pod uwagę temat mojej pracy. Interesują mnie bowiem filmy podejmujące temat nie zamierzchłej przeszłości, ale te dotyczące historii najnowszej: włoskiego ruchu oporu w czasie II wojny światowej. Niezręcznie byłoby zatem mówić tu o ",filmie kostiumowym", podobnie jak np. w przypadku filmu Przestuchanie (reż. R. Bugajski, 1982) czy Matki Królów (reż. J. Zaorski, 1982). Mimo że akta sprawy Toni Dziwisz, podobnie jak rodziny Królów z filmu Janusza Zaorskiego, nie spoczywają w żadnej teczce archiwalnej, losy tych bohaterów są prawdziwe $\mathrm{w}$ tym sensie, że stanowią uogólnioną biografię „wielu takich jak oni".

Sformułowanie „odwoływanie się przez filmy o tematyce historycznej do rzeczywistych, «historycznych» zdarzeń lub postaci" - które wyznacza opozycyjną kategorię wobec filmów "ewokujących wrażenie epoki” - także należałoby opatrzyć dodatkowym komentarzem. Ideałem, do którego dąży kino fikcji, nie jest bynajmniej protokół historii. W filmie fabularnym historyczne fakty stają się tematem, materiałem artystycznej wyobraźni, ulegając pod jej wpływem niejednokrotnie daleko idącemu przekształceniu. Niezwykle rzadko mamy do czynienia z dokładną rekonstrukcją wydarzeń historycznych właściwą formule Sensacji XX wieku Bogusława Wołoszańskiego; z reguły kino operuje fabularyzacją historycznych faktów, której towarzyszą rozbudowane wątki fikcjonalne. I tak na przykład w filmie Kopia mistrza (Copying Beethoven, reż. A. Holland, 2006) relacja łącząca kompozytora z Anną Holtz (postacią fikcyjna, wyrosłą z inspiracji losami dwóch rzeczywistych kobiet) jest wiodącą linią opowieści. Z kolei w Katyniu (reż. A. Wajda, 2007), jak słusznie zauważa Piotr Zwierzchowski, „Wajda odwoływał się do aktualnego stanu wiedzy historycznej, ale nacisk kładł nie na fakty, które były w tym momencie znane od kilkunastu lat, ale na problem pamięci zbiorowej"101. Niekiedy więź z rzeczywistym wydarzeniem jest silniejsza, wydaje się jakby reżyser wziął na warsztat fakt i jedynie trochę go „przykroił” do wymogów filmowej dramaturgii, innym razem odniesienie do historycznych zdarzeń jest słabiej zarysowane. Inaczej związek ten funkcjonuje np. w filmie Śmierć prezydenta (reż. J. Kawalerowicz, 1977), podejmującym temat okoliczności zamachu na Gabriela Narutowicza, gdzie dominuje raczej protokolarny styl narracji i montaż akcji równoległych w postaci paralelnie prowadzonych wątków: prezydenta i jego zabójcy, Eligiusza Niewiadomskiego, a inaczej w filmie Zwycięzca (Vincere, 2009) Marco Bellocchia, traktującym o mało znanym rozdziale biografii Benito Mussoliniego - jego romansie

${ }^{101}$ Piotr Zwierzchowski, Pisanie historii, konstruowanie pamięci, [w:] Historia w kulturze wspótczesnej, s. 165. 
i nigdy niepotwierdzonym ślubie z Idą Dalser (w tym drugim przypadku właściwsze byłoby chyba mówienie o inspiracji losami Duce niż o filmie "opartym na faktach").

Akcentuję te różnice po to, by unaocznić fakt, iż każdy z wyodrębnionych przeze mnie wyznaczników ma postać skali, płynnego continuum. Na użytek tej pracy, aby nie mnożyć bytów ponad miarę, w konstruowanym przeze mnie modelu uwzględniam następujące rozróżnienie:

Tabela 1

\begin{tabular}{|l|l|}
\hline \multicolumn{2}{|c|}{ Charakter fabuły } \\
\hline $\begin{array}{l}\text { Fabularyzacji faktów historycznych towa- } \\
\text { rzyszą rozbudowane wątki fikcjonalne }\end{array}$ & $\begin{array}{l}\text { Film ewokuje „wrażenie epoki” przez wa- } \\
\text { lory wizualne lub/i dźwiękowe bez wątków } \\
\text { odnoszących się do konkretnych wydarzeń } \\
\text { historycznych; motywy historyczne mogą } \\
\text { być obecne (przywołane postacie, wydarze- } \\
\text { nia); (film kostiumowy) }\end{array}$ \\
\hline
\end{tabular}

Źródło: opracowanie własne.

Czynię to jednak ze świadomością że tak zarysowane kategorie lokalizują wyłącznie kluczowe dla tematu napięcia, a nie całą gamę możliwych do pomyślenia wariantów i odcieni tego problemu. Sprawa komplikuje się jeszcze bardziej, jeśli weźmiemy pod uwagę fakt, iż niekiedy bezpośrednie odwołanie do historycznych faktów lub postaci ustępuje miejsca odniesieniom mniej oczywistym, choć identyfikowalnym - dyskurs podtrzymuje bowiem zasadę ekwiwalencji z realiami, do których się odnosi. Opis takiego przypadku (którego nie omawiają niestety dokładniej przywołani przeze mnie wcześniej badacze) zyska być może na klarowności, jeśli zilustrujemy go przykładem filmu Jana Kidawy-Błońskiego Różyczka (2010). Nawiązanie do burzliwego życiorysu uznanego polskiego pisarza i eseisty Pawła Jasienicy, który w latach 60. nieświadomie poślubił tajną współpracownicę SB, Zofię Darowska, okazało się na tyle wyraźne, że rodzina Jasienicy publicznie apelowała o niekojarzenie losów fikcyjnego artysty z życiorysem postaci autentycznej. Oczywiście jasne jest, że Kidawa przemodelował całą historię na potrzeby własnego spektaklu - przetasowana talia filmowych zdarzeń odnosi się do faktów na tyle swobodnie, by wykluczyć jakikolwiek sądowy proces (dystans twórczy podkreślają dodatkowo „zmienione" nazwiska postaci: filmowy pisarz nosi nazwisko Warczewski, zaś jego żona, współpracownica SB, to Kamila Sakowicz). Pomimo tego film otwiera napis: „historia oparta na faktach”. Czy w ta- 
kich kategoriach mógłby być zatem interpretowany? W przypadku Różyczki można by odpowiedzieć twierdząco, ale np. w przypadku Obywatela Kane'a (Citizen Kane, reż. O. Welles, 1941), gdzie o zgoła inną różyczkę chodzi, podjęcie takiego tropu interpretacyjnego wydaje się wątpliwe; film Wellesa był jednak odczytywany także jako kryptoportret magnata prasowego Williama Randolpha Hearsta, który zresztą zainicjował kampanię przeciw dystrybucji filmu.

Oczywiście, nie zamierzam tu podawać uniwersalnej recepty, wedle której można by jednoznacznie pogrupować filmy o historycznej tematyce. Niekiedy trudno stwierdzić z aptekarską precyzja, czy więcej jest w danym filmie „wrażenia epoki” czy wątków „opartych na faktach”. Czy Ziemia obiecana (1974) Andrzeja Wajdy, będąca panoramicznym obrazem przeszłości, w której z niebywałą sugestywnością została wykorzystana jedna z największych, zachowanych do czasów realizacji filmu w niemal niezmienionym kształcie, naturalnych scenografii przemysłowego miasta, bliższa jest pierwszej czy drugiej kategorii?

Choć niektóre spośród filmowych przykładów są skazane na wielość interpretacji, ich kwalifikacja powinna zostać poprzedzona kontekstualizacją filmu pojawiającego się zawsze w określonym czasie i miejscu. To właśnie uhistorycznienie danego dzieła oraz poszanowanie autorskiej intencjonalności powinno pomóc zadecydować, z którą z zaproponowanych w modelu opcji mamy do czynienia. Samo zagadnienie „intencjonalności nadawczej" wykracza poza tematykę niniejszej pracy i zostało już drobiazgowo omówione w innym miejscu ${ }^{102}$. Ograniczę się zatem do przypomnienia sedna zjawiska, które lapidarnie, a zarazem przenikliwie ujął Tomasz Kłys, pisząc:

oczywiście nie chodzi tu o jakiś psychologizm, „odgadywanie” świadomych zamiarów autora realnego ( $w$ filmie byłby zresztą problem $\mathrm{z}$ jednoznacznym przypisaniem tego autorstwa), lecz o uwzględnienie historycznego kontekstu filmów. Ów kontekst może być rozmaity - polityka, ekonomia, socjologia, ideologia danego momentu historycznego; technologia dostępna ekipie realizatorskiej; wreszcie - paradygmat estetyczny, obejmujący zespoły konwencji, norm, możliwych rozwiązań i opcji w czasie i w miejscu powstania dzieła ${ }^{103}$.

102 Tomasz Kłys słusznie zauważa, że ,jedne filmy są intencjonalnie «ujednoznacznione» (filmy socrealistyczne czy kino gatunków w okresie klasycznym), inne - zwłaszcza zaś z tzw. «kina artystycznego» - programowo wieloznaczne, pozbawione klarownego czy niesprzecznego systemu znaczeń abstrakcyjnych, niejako nastawione na odbiorców «maksymalnych», którzy będą drążyć diegesis «W głąb»" - Tomasz Kłys, op. cit., s. 45-46.

${ }^{103}$ Ibidem, s. 47. 
Za każdym razem to nasza wiedza determinuje sposób widzenia przedstawianej "filmowej rzeczywistości”. Tekstualne wskazówki są danymi, których odbiorca nie jest w stanie zmienić. Wskutek swej niekompetencji, chwilowego stanu (zmęczenie) czy jeszcze z jakichś innych powodów może je tylko źle odczytać. Odbiorca taki nie zrozumie jednak filmu o tematyce historycznej (i każdej innej), jeśli nie odczyta zawartych w nim znaczeń referencyjnych i eksplicytnych ${ }^{104}$ (widz nieznający np. wyglądu Koloseum nie rozpozna, że akcja toczy się w Rzymie). Zrozumie go zaś nie w pełni, jeśli odniesienie do realnego świata pozatekstowego ( $w$ interesującym mnie przypadku - do historycznych wydarzeń lub postaci) umieszczone zostanie na poziomie bardziej abstrakcyjnych znaczeń implikowanych, które należy uznać za wypełnione nie całkowicie (stąd $\mathrm{w}$ procesie ich wypełniania $\mathrm{w}$ odbiorze możliwa jest pewna, nawet znaczna dowolność). Jak słusznie zauważa Kłys, „,diegesis jest w pewnym tylko stopniu unaocznionym dzięki percepcji obrazu i dźwięku, w znacznej zaś mierze domniemanym przez widza, w aspekcie zarówno fikcyjnej przestrzeni i czasu, jak i zdarzeń implikowanych przez logikę opowieści"105. W przypadku filmu o tematyce historycznej konieczne jest także odwołanie do wiedzy historycznej widza.

Można by zatem zaryzykować twierdzenie, że pewnym constans filmów „historycznych” jest swoiste otwarcie na świat zewnętrzny (pozatekstowy). Materiał dany „naocznie” (to, z czym styka się widz w momen-

${ }^{104}$ Wedle Kłysa diegetyczne referenty i znaczenia eksplicytne powinny zostać uznane za intersubiektywnie weryfikowalny zakres diegesis. Oczywiście, pisząc o znaczeniach, które pozwalają „usensownić film”, autor powołuje się na neoformalistyczną koncepcję Bordwella i Thompson. Zob. np. David Bordwell, Kristin Thompson, Film Art: an Introduction, New York 1990.

105 Tomasz Kłys, op. cit., s. 21. Autor zwraca przy tym uwagę, że nie zawsze mamy do czynienia ze zgodnością znaczenia percepcyjnego i fikcyjnej roli poszczególnych obiektów. Pojedynczy "fabularny element”, jakim jest bohaterka Mrocznego przedmiotu pożądania (Cet obscur objet du désir, reż. L. Buñuel, 1977), a dwa znaczenia denotowane (percepcyjne): dwie całkiem odmienne dziewczyny. Por. ibidem, s. 17. Podobnie dzieje się np. w filmowej wariacji na temat możliwych biografii Boba Dylana (Gdzie indziej jestem [I'm not there, reż. T. Haynes, 2007). Ciekawym przykładem niezrozumienia filmowego dzieła jest przypadek Strajku (Cmaчka, 1924) Eisensteina. Jak dowodzi Marc Ferro, końcowa scena filmu, owacyjnie przyjęta w Petersburgu - gdzie społeczeństwo było najbardziej wykształcone - na wsi wywołała reakcje odmienne. W filmie są naprzemienne ujęcia żołnierzy rozstrzeliwujących uczestników strajku i rzeźnika uśmiercającego zwierzęta - ich krew miesza się w ścieku... Otóż ta alegoria cara-rzeźnika była niezrozumiała dla chłopów, ponieważ nie uważali oni zabijania zwierząt za zbrodnię. Po pojawieniu się na ekranie tych samych ujęć, widząc po raz drugi rzeźnika, zaczęli wychodzić z sali, gdyż byli przekonani, że rozpoczął się drugi seans. Por. Marc Ferro, Kino i historia, s. 196. 
cie oglądu filmu) odsyła bądź do konkretnego wydarzenia historycznego lub postaci, bądź do pasma zdarzeń zapisanych tak czy inaczej w historii (w przypadku filmów $\mathrm{z}$,tłem epoki" przybierają one, jak wspominałam, formułę motywów, a nie wątków). Jak słusznie zauważa Marek Hendrykowski, pełnią one funkcję przęseł, niezwykle ważną z konstrukcyjnego punktu widzenia. Opuszczając brzeg teraźniejszości i przeprawiając się na drugą stronę, nie przeprawiamy się po przęsłach, lecz po moście przemyślnie zbudowanej filmowej fikcji; ale przeprawa ku przeszłości jest możliwa tylko dzięki owej koniecznej podbudowie faktograficznej ${ }^{106}$.

Choć filmy historyczne „naginają” świat przeszłości do wymogów opowiadania, to jednak właściwości tego świata nie giną bez reszty. Kino o tematyce historycznej przezwycięża niejako sprzeczność między faktycznym a wyobrażonym, tworząc oryginalną syntezę. Podczas gdy fabularyzacje faktów historycznych mniej lub bardziej sugestywnie wypełniają luki w "materiale dowodowym”, w filmach ewokujących wrażenie epoki materiał faktyczny pełni funkcję „niezobowiązującego tła”. Tego typu realizacje posługują się raczej logiką autentyczności wobec faktycznego przebiegu wydarzeń; ukazują epizody, które - choć czysto fikcjonalne - mogłyby się zdarzyć jako typowe dla prezentowanego okresu dziejów. Innymi słowy, w przypadku filmów z tłem epoki „wystarczy”, by przesłanki rzeczywistych wydarzeń spowinowacone z fikcją dały w sumie obraz o dużej sugestii autentyzmu podejmowanego tematu, tak by rzeczywistość wymyślona mówiła w istocie o rzeczywistości materialnej. Kwestię autentyzmu filmu o tematyce historycznej ciekawie komentuje Peter Brook, czyniąc uwagę z dziedziny psychologii odbioru:

Jeśli chce się kazać uwierzyć w obraz epoki, trzeba żeby publiczność zarejestrowała 90\% tego, co jest „,na powierzchni” jako rzecz najzupełniej naturalna, nie przyciagającą uwagi. Odkąd nieznany przedmiot został wprowadzony w waszą sferę obserwacji, zgarnia on największą część uwagi. [...] Kiedy pragnie się, by epoka historyczna - powiedzmy wiek $X$ - wydawała się absolutnie wiarygodna dla dzisiejszego widza, trzeba zrozumieć, że jest on niezdolny do tolerowania więcej niż setnej części wizualnych detali epoki ${ }^{107}$.

106 Por. Marek Hendrykowski, op. cit., s. 59. Oczywiście, niekiedy informacje o faktach historycznych podawane są także w formie elementów niediegetycznych (przeznaczonych wyłącznie dla widza, a niewidocznych dla bohaterów) - to z nich w przywoływanym już filmie Zwycięzca dowiadujemy się na przykład o śmierci Mussoliniego, który 28 kwietnia 1945 roku zostat rozstrzelany przez partyzantów.

107 Peter Brook, „Politique Hebdo” 1970. Cyt. za: Rafał Marszałek, Film i historia (I), „Kino” 1981, nr 1, s. 23. 
W świetle powyższego nie dziwi fakt, iż pojawienie się zegarków na rękach niektórych rycerzy $\mathrm{w}$ trakcie sceny bitwy pod Grunwaldem w ekranizacji Krzyżaków (reż. A. Ford, 1960) czy ujęte w kadrze druty telefoniczne w filmowej wersji Pana Wołodyjowskiego (reż. J. Hoffman, 1968) zostały uznane jako rażąca historyczna nieścisłość i „realizatorski błąd”.

Kolejnym bezspornym (i chyba najczęściej przywoływanym) wyróżnikiem filmu historycznego, który należy uwzględnić w budowanym modelu, jest „osadzenie akcji filmu w przeszłości”. To lapidarne stwierdzenie, okazuje się jednak wysoce nieprecyzyjne, a przez to mało „operacyjne" - w zasadzie nic nie wyjaśnia bez dodatkowego komentarza. Trzeba bowiem określić moment, z jakiego roztacza się przyjęta perspektywa oglądu; tylko względem jakiegoś punktu odniesienia możemy „wyznaczyć przeszłość”. Innymi słowy, podając jako wyróżnik filmu historycznego „osadzenie jego akcji w przeszłości”, należy doprecyzować, czy punktem odniesienia jest np. horyzont czasowy widza czy - jak czyni się zazwyczaj - data produkcji filmu. W mojej pracy biorę pod uwagę moment zrealizowania filmu. Należałoby przy tym od razu zastrzec, że we wspomnianej formule nie chodzi o rzeczywisty, "ekranowy" czas filmu, ale o „wewnątrztekstowy" czas świata przedstawionego ${ }^{108}$. Gwoli ścisłości wypadałoby też zaznaczyć, że większość fabularnych filmów historycznych (z wyjątkiem tych posiadających narracyjną ramę) opowiada o przeszłości tak, jakby była ona teraźniejszością. Coś, co działo się dawniej, zostaje oto przedstawione na ekranie jako rozgrywająca się tu i teraz rzeczywistość. Obraz filmowy jest „uobecnioną teraźniejszością”, naturalnie złudna, jeśli weźmiemy pod uwagę upływ czasu, jaki istnieje między rzeczywistością profilmowa, utrwaleniem jej na taśmie światłoczułej czy innym nośniku i ostatecznie oglądem ze strony widza ${ }^{109}$. Po tej rozszerza-

108 Trudno nie zgodzić się z opinią, iż pod pewnym względem (jeśli idzie o samo „opowiadanie”) podany wymóg spełnia właściwie każda realizacja. W istocie rzeczy każdy film, o ile nie jest transmisją bezpośrednia, pokazuje coś, co już było. W tym sensie każdy film jest oglądaniem się za siebie i świadectwem czasu minionego.

${ }^{109} \mathrm{O}$ złudności kinowego czasu teraźniejszego pisze poetycko Andrzej Zalewski: „dziwna to teraźniejszość, pozbawiona blasku i skażona nieobecnością przedmiotu odniesienia. Żadna, choćby najbardziej namiętna osmoza między nami a obrazem nie jest w stanie zniweczyć świadomości, że ów fascynujący obraz został nam na krótko tylko 
jącej pole widzenia dygresji należy powrócić do podjętych przeze mnie kategoryzacji.

Pozostaje pytanie, w jakim przedziale czasowym można nazwać konkretny obraz filmowy „współczesnym”, a kiedy mówi on o okresie minionym i staje się „historycznym”. Innymi słowy, ile lat, miesięcy, a może dni musi minąć, abyśmy mogli z przekonaniem powiedzieć, iż akcja filmu rozgrywa się w przeszłości (w odniesieniu do czasu jego powstania). O kontrowersjach wobec tego zagadnienia była już mowa. Tak jak już sygnalizowałam, ciekawa i pomocna wydaje mi się omówiona wcześniej koncepcja cezur czasowych zaproponowana przez Wagnera. Podobnie jak on, uważam za bezcelowe wyznaczanie sztywnych, apriorycznych ram. Kryterium kwalifikującym dany film jako współczesny bądź historyczny winno być rozpoznanie, czy dany film był realizowany w tym samym okresie historycznym, o którym mówi akcja fabuły. Jeśli opowiada ona o czasach charakteryzujących się odmiennymi realiami od tych panujących w momencie filmowej produkcji, a zatem należących do przeszłości, uznaję film - podobnie jak Wagner - za historyczny (do tego zbioru kwalifikuję więc wszystkie filmy o włoskim ruchu oporu, mimo iż np. Rzym, miasto otwarte Roberto Rosselliniego zrealizowany został w 1945 roku; czas dzielący akcję filmu od jego realizacji jest więc bardzo niewielki).

Doprecyzowanie kolejnego wyznacznika filmu historycznego, którym jest osadzenie jego akcji w przeszłości (w odniesieniu do czasu powstania filmu), konieczne jest dla klarowności budowanego modelu - nie wyczerpuje jednak złożoności zagadnienia. Akcja wielu filmów określanych jako historyczne nie rozgrywa się bowiem wyłącznie w okresie minionym. Realizacje te, jak już wspominałam, często mieszają „"czasowe porządki”, tak jak zaproponował Andrzej Wajda w Człowieku z marmuru (1976), lub zawierają w swej strukturze „współczesną” ramę narracyjną (wprowadzającą retrospekcje lub closure „po latach”). W konstruowanym schemacie należałoby zatem wyróżnić przynajmniej dwie możliwości w obrębie kategorii, którą umownie nazwałam horyzontem narracji. Zarys proponowanego schematu wyglądałby wtedy następująco:

wypożyczony z archiwów czasowej oddali. Percepcja kadrów filmowych z wierzchu nakłada na siebie girlandy radości, podczas gdy u spodu przyobleka się w czerń żałoby". Andrzej Zalewski, Meandry czasu teraźniejszego, „Kwartalnik Filmowy” 2001, nr 34, s. 26-27. 
Tabela 2

\begin{tabular}{|c|c|c|c|}
\hline \multicolumn{2}{|c|}{ Charakter fabuły } & \multicolumn{2}{|c|}{ Horyzont narracji } \\
\hline $\begin{array}{l}\text { Fabularyzacji } \\
\text { faktów historycz- } \\
\text { nych towarzyszą } \\
\text { rozbudowane } \\
\text { wątki fikcjonalne }\end{array}$ & $\begin{array}{l}\text { Film ewokuje „wra- } \\
\text { żenie epoki” przez } \\
\text { walory wizualne } \\
\text { lub/i dźwiękowe bez } \\
\text { wątków odnoszących } \\
\text { się do konkretnych } \\
\text { wydarzeń historycz- } \\
\text { nych; motywy hi- } \\
\text { storyczne mogą być } \\
\text { obecne (przywołane } \\
\text { postacie, wydarzenia); } \\
\text { (film kostiumowy) }\end{array}$ & $\begin{array}{l}\text { Akcja filmu roz- } \\
\text { grywa się wyłącz- } \\
\text { nie w przeszłości } \\
\text { (w odniesieniu do } \\
\text { czasu powstania } \\
\text { filmu) }\end{array}$ & $\begin{array}{l}\text { Istnieje współczesna } \\
\text { rama narracyjna (pro- } \\
\text { log bádź epilog); prze- } \\
\text { szłość ewokowana } \\
\text { w opowiadaniu, a akt } \\
\text { narracji ulokowany } \\
\text { jest w teraźniejszości }\end{array}$ \\
\hline
\end{tabular}

Źródło: opracowanie własne.

W trzeciej kolumnie mieściłyby się takie filmy, jak Spartakus (reż. S. Kubrick, 1960) czy Joanna D'Arc (reż. L. Besson, 1999), ale także realizacja, w której np. średniowieczny mnich wspomina okres starożytności. Przykładem dzieła sytuującego się w czwartej kolumnie byłby zaś m.in. film Noc świętego Wawrzyńca (reż. P. i V. Taviani, 1982). Oczywiście użyte do opisu tego wariantu określenia („współczesna”, „teraźniejszość”) odnoszę konsekwentnie do czasu powstania filmu. Dość niejasne może się tu wydać także sformułowanie: "przeszłość ewokowana w opowiadaniu”. Nasuwa się bowiem pytanie, w jaki sposób może być ona przywoływana. Czy np. wystarczy napomknięcie o niej w dialogach? Na potrzeby niniejszej pracy przyjmuję, iż film, spełniający wymogi zarysowanej kategorii, ewokuje „przeszłość”, czyli „historię”, przez walory wizualne; widz musi niejako stać się jej naocznym świadkiem w toku fabuły ${ }^{110}$. Tak skonstruowany model nie uwzględnia rzecz jasna wszystkich wariantów omawianego zagadnienia. Nie obejmuje np. przypadku, gdy akcja filmu rozgrywa się w przeszłości i doprowadzona zostaje do teraźniejszości. Mój wybór jest jednak świadomy - takie poszerzenie zakresu zaowocowałoby bodaj zbytecznym nadmiarem; jak wspomniałam, zależy mi na zasygnalizowaniu najistotniejszych, tj. najczęściej spotykanych możliwości, których kombinatoryka doprowadzi do najliczniej występujących empirycznie strategii ewokowania historii $\mathrm{w}$ filmie.

110 Pojęcie „akt narracyjny” rozumiem za Przylipiakiem. Zob. Mirosław Przylipiak, hasło „narracja”, [w:] Stownik pojęć filmowych, t. 5, red. Alicja Helman, Kraków 1993, s. 34. 
Fakt, że zaproponowane opracowanie kryterium, nazwane „horyzontem narracji", nie ma charakteru definitywnego (tzn. typologiczne rozstrzygnięcia funkcjonują tu raczej jako punkty orientacyjne), dobrze unaoczniają filmy zawierające $\mathrm{w}$ swej strukturze kompozycyjnej kunsztowną architekturę kilku powiązanych ze sobą znaczeniowo momentów historycznych. Przykładem takiego dzieła jest choćby Człowiek z marmuru (1976). Naturalnie, filmów wymykających się takiej prostej klasyfikacji jest wiele - szczególnie trudne do przyporządkowania są te, które traktują chronologię z dezynwoltura, łamiąc właściwy "stylowi zerowemu" łańcuch przyczynowo-skutkowy. Wszędzie tam, gdzie film o tematyce historycznej jest „zaprojektowany" na nieprzezroczystość tekstualnych środków wyrazu, widz może mieć problem ze skonstruowaniem nie tylko spójnej „mapy” diegetycznej, ale i „kognitywnego zegara” fikcyjnego czasu; w konsekwencji wszelka typologia będzie utrudniona.

* * *

Spotkanie inwencji reżyserskiej i pozafilmowych faktów powoduje, iż wiele filmów o tematyce historycznej zawiera w swej strukturze dokumentalne sekwencje. Obecność footage stanowi zatem kolejne kryterium budowanego modelu. Materiały dokumentalne wprowadzane są przy tym w różnym trybie. Służą jako znacznik informacyjny o czasie akcji - przykładowo, zamiast planszy „1978” można pokazać znane ujęcie prezentujące nowego papieża, kardynała Karola Wojtyłę, na watykańskim balkonie. Czasem zaś zastępują wydarzenia, które nie zostały odegrane przed kamera (sceny zbiorowe, np. strajki, zamieszki itp.). Realizacjami, w których często wykorzystuje się fragmenty dokumentalnych nagrań, są filmowe biografie - np. film Żelazna Dama (The Iron Lady, reż. P. Lloyd, 2011), traktujący o politycznej karierze Margaret Thatcher, zawiera fragmenty „rzeczywistych” przemów premier Wielkiej Brytanii, zaś w Jak zostać królem (King's Speech, reż. T. Hopper, 2010), który prezentuje losy brytyjskiego monarchy Jerzego VI i jego terapeuty, oglądamy archiwalne zdjęcia z uroczystości z udziałem rodziny królewskiej.

Oczywiście, może zdarzyć się tak, że jakieś fragmenty identyfikowane przez widza jako footage, wyglądające nawet bardzo wiarygodnie zostały zainscenizowane; ukazujące się na ekranie wydarzenia w swym nieuporządkowanym przebiegu okazują się w istocie sfabrykowane. Dobrą ilustracją tego problemu - trudności w rozpoznaniu materiałów archiwalnych - jest JFK (reż. O. Stone, 1991). Przykładowo, scena zamachu na 
Kennedy'ego, zainscenizowana i sfilmowana w sposób przypominający dokument, została następnie zmontowana $\mathrm{z}$ oryginalnymi nagraniami tak, że nie jesteśmy do końca pewni, co pochodzi z rzeczywistego, „,spontanicznie" sfilmowanego nagrania, a co zostało zainscenizowane ${ }^{111}$. Przy tym kryterium nie pytam więc o autentyczność materiałów (czasem bowiem trudno jednoznacznie orzec o ich statusie ontycznym), ale o samą obecność ujęć, które bądź mają charakter dokumentalny, bądź takowy imitują za pomocą określonych środków stylistycznych (m.in. identyfikowanej z dokumentem kamery z ręki, czarno-białej barwy obrazu oraz jego "gruboziarnistej" faktury).

Po uwzględnieniu ostatnich ustaleń schemat wyglądałby więc tak:

Tabela 3

\begin{tabular}{|c|c|c|c|c|c|c|}
\hline & \multicolumn{2}{|c|}{ Charakter fabuły } & \multicolumn{2}{|c|}{ Horyzont narracji } & \multicolumn{2}{|c|}{$\begin{array}{c}\text { Materiały } \\
\text { archiwalne }\end{array}$} \\
\hline & $\begin{array}{l}\text { Fabularyza- } \\
\text { cji faktów } \\
\text { histo- } \\
\text { rycznych } \\
\text { towarzyszą } \\
\text { rozbudo- } \\
\text { wane wątki } \\
\text { fikcjonalne }\end{array}$ & $\begin{array}{l}\text { Film ewokuje „wra- } \\
\text { żenie epoki” przez } \\
\text { walory wizualne } \\
\text { lub/i dźwiękowe bez } \\
\text { wątków odnoszą- } \\
\text { cych się do kon- } \\
\text { kretnych wydarzeń } \\
\text { historycznych; } \\
\text { motywy historyczne } \\
\text { mogą być obecne } \\
\text { (przywołane posta- } \\
\text { cie, wydarzenia); } \\
\text { [film kostiumowy] }\end{array}$ & $\begin{array}{l}\text { Akcja filmu } \\
\text { rozgrywa } \\
\text { się wy- } \\
\text { łącznie } \\
\text { w przeszło- } \\
\text { ści (w od- } \\
\text { niesieniu } \\
\text { do czasu } \\
\text { powstania } \\
\text { filmu) }\end{array}$ & $\begin{array}{l}\text { Istnieje współczesna } \\
\text { rama narracyjna } \\
\text { (prolog bądź epilog); } \\
\text { przeszłość ewoko- } \\
\text { wana w opowia- } \\
\text { daniu, a akt narra- } \\
\text { cji ulokowany jest } \\
\text { w teraźniejszości }\end{array}$ & tak & nie \\
\hline 1 & $\bullet$ & & $\bullet$ & & $\bullet$ & \\
\hline 2 & - & & $\bullet$ & & & $\bullet$ \\
\hline 3 & - & & & - & $\bullet$ & \\
\hline 4 & $\bullet$ & & & $\bullet$ & & $\bullet$ \\
\hline 5 & & $\bullet$ & $\bullet$ & & $\bullet$ & \\
\hline 6 & & - & $\bullet$ & & & $\bullet$ \\
\hline 7 & & $\bullet$ & & $\bullet$ & $\bullet$ & \\
\hline 8 & & $\bullet$ & & $\bullet$ & & $\bullet$ \\
\hline
\end{tabular}

Źródło: opracowanie własne.

111 Jaskrawym przykładem „mieszania” fikcji z dokumentem jest film Forrest Gump (reż. R. Zemeckis, 1994), w którym za pomocą efektów specjalnych uzyskano sceny przedstawiające głównego bohatera m.in. z Johnem F. Kennedym i Richardem Nixonem. Często przywoływanym przykładem takiego związku jest także Zelig (reż. W. Allen, 1983). 
Zaprezentowany model jest zapewne podatny na korekty i uzupełnienia, gdyż przy całej aprioryczności przedsięwzięcia przedłożona kombinatoryka nie uwzględnia wszelkich kryteriów ewokowania interesującego mnie tematu w filmie fabularnym. Takie poszerzenie macierzy zaowocowałoby jednak zbytecznym nadmiarem, podczas gdy nałożone ograniczenie w postaci wyobrażalnych najczęściej spotykanych empirycznie ośmiu strategii (ich liczba uwarunkowana jest zestawieniem trzech wyodrębnionych kategorii) nadaje wyliczeniu rozsądne rozmiary. Ponadto, jak w przypadku wszelkich modelowych i typologicznych rozstrzygnięć, niektóre spośród filmowych przykładów są skazane na wielość interpretacji, tzn. dają się wpasować $\mathrm{w}$ więcej niż jedną z wyszczególnionych rubryk. Sam przedmiot badań jest na tyle rozległy, iż obserwacje, które tu poczyniłam, są prowizoryczne i otwarte na dalsze uściślenia. Choć daleko jeszcze do całościowego opracowania zagadnienia reprezentacji historii w filmie, mam nadzieję, że jakiś krok na drodze ku rzeczywiście miarodajnemu opisowi tych relacji został zrobiony. Jeśli ten model (i cała praca) okaże się przydatny dla badaczy lub miłośników - jako pomoc lub kontrastowe tło dla ich własnych spekulacji - wówczas będzie on usprawiedliwiony przynajmniej w sensie użytkowym.

$$
* \quad * \quad *
$$

Nikt spośród badaczy nie dezawuuje filmu jako historycznego źródła. Podkreśla się tylko jego „nietypowość” czy „nietradycyjność”. To podejście celnie ilustruje opinia Marka Hendrykowskiego: „mimowolny lub raczej mimowiedny dokument historii, jakim jest filmowa fikcja [...], okazuje się równorzędnym, alternatywnym wobec zapisu dokumentalnego komunikatem, wnoszącym niekiedy ogromną wartość do naszej wiedzy historycznej o danym aspekcie przeszłości"112. Przy czym istotne jest, aby zawarta w filmach perspektywa historyczna nie służyła jako kryterium wartościowania. Zamiast czynić zarzuty z niewierności historycznej należy raczej starać się wniknąć w wewnętrzną logikę dyskursu i próbować odpowiedzieć na pytanie, jak i dlaczego historyczna rzetelność zostaje użyta lub nadużyta. Niekiedy, jak zauważa Tadeusz Sobolewski, „dopiero pewne nieprawdopodobieństwo wnosi do filmu oddech prawdy"113.

112 Marek Hendrykowski, op. cit., s. 47. Podkreślić trzeba, że w przypadku potraktowania filmu jako historycznego śladu nie będą ważne jego walory artystyczne.

${ }^{113}$ Krytyk odwołuje się tu do filmu Życie na podstuchu (reż. F. Donnersmarck, 2006), które jak stwierdza: „niewiele by nas obchodziło gdyby film był relacją o zacnych opozycjonistach i wrednym esbeku (mającym swój historyczny pierwowzór)". Zob. Tadeusz Sobolewski, Obsesja historii. Prawda i pojednanie, „Kino” 2007, nr 6, s. 36-37. 
Na koniec jeszcze uwaga natury ogólnej - choć w centrum mojego zainteresowania znajdują się filmy o tematyce historycznej, zgadzam się m.in. z Patrickiem Vonderau, który twierdzi, iż „każdy film może być interpretowany jako historyczny dokument, nawet gdy to nie jest jego funkcja główna. Filmowi może być bowiem w określonym kontekście przypisana funkcja oświetlania ówczesnych mu idei o teraźniejszości lub przeszłości"114. Podobnie jak Vonderau, uważam zatem, że utwór filmowy o charakterze fikcjonalnym może stać się dla badacza źródłem studiowania i poznawania historii w zasadzie zawsze, jeżeli interpretacja nastawiona niejako na funkcję referencyjną obejmie kontekst historyczny, w jakim pojedynczy przekaz powstał. Niezależnie od tego, czy w centrum naszej uwagi znajdują się takie filmy, czy też dzieła o tematyce historycznej, należy jednak pamiętać, że „ograniczenia tradycyjnej historii nie mogą być przezwyciężone przez zwykłą zmianę medium, jeśli historiograficzna analiza filmu jest $\mathrm{w}$ istocie przedmiotem jej własnych, metodologicznych ograniczeń"115.

114 Patrick Vonderau, Historiography and Film: A Dangerous Liasion?, s. 21.

115 Ibidem. 


\section{Rozdział III}

\section{Lata 1945-1959: krzepnięcie włoskiej republiki}

Po drugiej wojnie światowej o włoskiej kinematografii staje się głośno za sprawą neorealizmu. Zwyczajowo definicja tego nurtu konstruowana jest za pomocą katalogu wyróżników (głównie stylistycznych), które w uproszczeniu można by sprowadzić do następującej listy: zdjęcia kręcone w plenerze, długie ujęcia, zachowanie montażowych zasad stylu klasycznego, naturalne oświetlenie, podejmowanie ówczesnych (współczesnych) tematów wziętych z życia, fabuła z elementami improwizacji, otwarte zakończenia, naturszczycy obsadzani w rolach głównych i pobocznych, dialogi w języku potocznym. Aspiracje neorealistycznego projektu polegały jednak nie tylko na innowacjach estetycznych, ale wiązały się przede wszystkim, o czym niekiedy się zapomina, z dyskursem politycznym charakterystycznym dla powojennych Włoch. Jak słusznie zauważa Robert Bosworth, zarówno krytycy, jak i reżyserzy filmowi postrzegali bowiem neorealizm jako „powrót do uczciwości” po latach faszystowskiej retoryki, a także jako odkrycie ",prawdziwej Italii" ${ }^{1}$. Nie bez powodu w wielu filmach tego nurtu eksponowane były „środowiska stanu naturalnego" (dzieci, wieś), zaś włoski naród przedstawiany był jako brava gente: nieskażony dwiema dekadami faszyzmu. Na Półwyspie Apenińskim debaty wokół neorealizmu toczyły się w mniejszym stopniu wokół wpływu, jaki neorealistyczne filmy wywarły na ewolucję języka filmowego, w większej zaś mierze koncentrowały się na społecznej roli, jaką twórcy filmowi odegrali po drugiej wojnie światowej. Pisma włoskich teoretyków neorealizmu - m.in. Guido Aristarco i Umberto Barbaro - poświadczają iż w ich oglądzie neorealizmu chodziło przede wszystkim o stworzenie historycznej narracji zdolnej „wyzerować” lub zastąpić dotychczasowy stan rzeczy (oczywiście nie pozostawało to bez związku z komunistycznymi sympatiami niektórych twórców i krytyków związanych z neorealizmem).

${ }^{1}$ Italian Fascism: History, Memory and Representations, red. Robert Bosworth, Patrizia Dogiliani, London 1999, s. 84. 
Wojna oraz ruch oporu stały się kluczowymi tematami neorealistycznego nurtu. Wedle Giuseppe De Santisa, „resistenza jest matką neorealizmu [...], resistenza wyznacza rok zerowy - rok, w którym Italia zmienia twarz $^{\prime 2}$. Powojenne filmowe reprezentacje ruchu oporu, które współtworzyły narodowy mit „walki z okupantem”, wyciszając zarazem wspomnienia o faszystowskim dziedzictwie kraju, doskonale wpisywały się w proces ",społecznej odnowy”. Pół żartem, pół serio pisał o nim Massimo Mida (właśc. Puccini; scenarzysta i reżyser):

Można by w istocie wyprodukować całą serię filmów o partyzantach, taką jak ta o kowbojach w Ameryce. W ten sposób partyzant mógłby stać się narodową tradycja tak jak w Stanach Zjednoczonych należy do niej Buffalo Bill. Dla Italii i włoskiego kina byłby to prawdziwy akt narodzin ${ }^{3}$.

Proces mitologizacji włoskiego ruchu oporu w powojennym kinie Włoch podsumował po latach, nieco w innym tonie, Gian Piero Brunetta:

hasło "zacząć od zera" oznaczało wymazywanie - przy społecznej aprobacie - świadomości o faktycznej przeszłości Italii [...]. Polegało więc na przypisywaniu maksimum win i zła sojusznikowi nazistowskiemu, i zredukowaniu do minimum odpowiedzialności Włochów w czarnych koszulach ${ }^{4}$.

Resistenza była rzecz jasna eksponowana także w powojennej włoskiej literaturze. Fakt, że nadawano jej cechy „początku”, swoistego „odkupienia win" przeszłości, dobrze ilustruje fragment ze Ścieżki pajęczych gniazd - literackiego debiutu przyszłego noblisty, Italo Calvino. W tej partyzanckiej epopei wydarzenia prezentowane są z punktu widzenia Pina, 10-letniego chłopca, dla którego resistenza to przede wszystkim niezwykła przygoda. W powieści padają znamienne słowa:

my, włoscy partyzanci, w historii jesteśmy po stronie odkupienia, oni [Niemcy] po stronie przeciwnej. U nas nic nie jest stracone, żaden czyn, żaden wystrzał [...]. Wszystko będzie służyć, jeśli nie do uwolnienia nas samych, to do uwolnienia naszych dzieci, do stworzenia ludzkości już bez gniewu, pogodnej, w której wreszcie będzie można nie być złym ${ }^{5}$.

${ }^{2}$ Wypowiedź umieszczona w Mario Serandrei. Giorni di gloria, red. Laura Gaiardoni, Roma 1998, s. 23-24.

${ }^{3}$ Massimo Mida, Per un film sui partigiani, "Charlie Chaplin” 1944. Przedruk w: Giuseppe Ghigi, La memoria inquieta. Cinema e resistenza, Venezia 2009, s. 85.

${ }^{4}$ Gian Piero Brunetta, Cent'Anni di cinema italiano, Roma-Bari 1995, s. 26.

${ }^{5}$ Italo Calvino, Ścieżka pajęczych gniazd, tłum. Władysław Minkiewicz, Warszawa 1957, s. 129. W 1964 roku, we wstępie do kolejnego wydania książki, Calvino uznał swój 
Błędem byłoby jednak twierdzić, że kino włoskie pierwszych lat po wojnie było zdominowane przez poetykę neorealizmu. Dzieła neorealistyczne z małymi wyjątkami zostały odrzucone przez publiczność zafascynowaną kinem amerykańskim. Gdy wygasło wojenne embargo, nastąpiła inwazja filmów amerykańskich na włoskie ekrany, która nasiliła się jeszcze bardziej w okresie zimnej wojny. Również plan Marshalla i udział Włoch w strukturach wojskowych NATO (od 1949 roku) wpłynęły na stanowisko rządu wobec rodzimej kinematografii. Dominację proamerykańskiej polityki dobrze unaocznia David Ellwood, który zauważa, że prócz hollywoodzkich filmów rozrywkowych i tych propagandowych, dotyczących planu Marshalla, organizowano także koncerty i audycje radiowe na ten temat. Istniały nawet objazdowe spektakle kukiełkowe, by dotrzeć $\mathrm{z}$ „nowiną" planu Marshalla do dzieci, ale tak naprawdę chodziło o to, by dotrzeć przez nich do dorosłych, półanalfabetów ${ }^{6}$. Zresztą Amerykanie niemal od pierwszych dni swojego pobytu w stolicy kraju wywierali wpływ na politykę wewnętrzną rządu włoskiego i rozwój włoskiego kina, o czym świadczą często przywoływane słowa admirała Stone’a, który na zebraniu Komisji Wojsk Sprzymierzonych miał oświadczyć:

Tak zwane włoskie kino stworzyli faszyści. A więc musi ono być zlikwidowane. Muszą również być zniszczone narzędzia, które służą do tego celu i to wszystkie, również Cinecittà. We Włoszech nigdy nie istniał przemysł filmowy, nie było tu nigdy przemysłowców produkujących filmy. Kim są ci przemysłowcy? Spekulantami i oszustami, oto kim są! Zresztą Włochy są krajem rolniczym, czy potrzebny jest im przemysł filmowy??

Prawdziwą dominację proamerykańskiej polityki zapewniły jednak wybory z 1948 roku, w których zwyciężyła popierana przez USA chadecja. Jej polityka kulturalna wywołała sprzeciw wielu twórców. W 1955 roku członkowie klubu Circolo Romano, zrzeszającego włoskich reżyserów (należeli tu m.in. Luigi Zampa, Cesare Zavattini, Alberto Lattauda, Michelangelo Antonioni, Vittorio De Sica), wystosowali nawet manifest, w którym ostro zaatakowali wielkich potentatów z Hollywood.

debiut za książkę będącą głosem nowego pokolenia, które miało wrażenie, że oto historia rozpoczyna się raz jeszcze, inaczej i lepiej. Ujawnienie rozmaitości doświadczeń i różnorodności regionalnej Włoch złożyło się zdaniem pisarza na poetykę neorealizmu, który nie był szkoła, lecz raczej wspólnym pokoleniowym doświadczeniem. Por. Italo Calvino, Il sentiero dei nidi di ragno, Milano 1993, s. XII (wstęp).

${ }^{6}$ Por. David Ellwood, Il cinema e la proiezione del modello Americano, [w:] Hollywood in Europa, red. Gian Piero Brunetta, Dawid Ellwood, Firenze 1991, s. 23.

7 Cyt. za: Tadeusz Miczka, 10000 km od Hollywood, Kraków 1992, s. 168. 
W rezultacie przez kilka lat członkowie tego stowarzyszenia nie mogli wyjechać do USA, np. Federico Fellini miał kłopot z odbiorem Oscara za La stradę w 1956 roku.

Jak słusznie zauważa Tadeusz Miczka, „neorealizm jako poetyka biedy, jako ruch rozrachunkowy i sympatyzujący z włoską lewicą powstał i rozwijał się w opozycji do oficjalnej władzy" ${ }^{8}$. Słynnym tego świadectwem pozostaje list Giulio Andreottiego do twórców Umberto D. (reż. V. De Sica, 1952), oskarżający ich o działanie na szkodę Włoch. Do ograniczenia swobody twórczej przyczyniło się tzw. prawo Andreottiego (wprowadzone w 1949 roku), premiujące włoskie filmy „o wysokiej jakości artystycznej". De facto oznaczało to, że producenci, aby otrzymać kredyty, musieli wcześniej poddać scenariusz kontroli prewencyjnej. Komisje cenzorskie miały zaś prawo występować o sądowe skonfiskowanie kopii. Wszelkie niewygodne tematy mogły być zatem eliminowane. Ową sytuację „ekonomicznej cenzury" dobrze opisuje Carlo Ponti, który w latach 50. stwierdził:

Dziś każdy, kto chce wyprodukować film, musi wejść na pola minowe kompromisu i ryzyka. Jeśli producent jest wystarczająco odważny, może podjąć ryzyko, ale tylko raz. Drugi raz będzie wolał zainwestować swoje pieniądze w filmy czysto rozrywkowe, których jest pewny, że przyniosą zysk, a także subwencje za „wyjątkową jakość” 9 .

I komedii nie omijało jednak cenzuralne sito - np. w filmie Totò $i \mathrm{Ka}$ rolina (Totò e Carolina, reż. M. Monicelli, 1955), okrzyk anarchisty - „precz z właścicielami!" zmieniono w trakcie dubbingu na „niech żyje wolność!”

Ciekawym przejawem cenzury był także los Ulicy ubogich kochanków (Cronache di poveri amanti, reż. C. Lizzani, 1954) - adaptacji powieści Vasco Pratoliniego o tym samym tytule, co film. Choć bowiem akcja filmu dotyczyła wydarzeń z lat 20., zawarty w nim obraz lewicującego ruchu oporu został odczytany przez pryzmat współczesności. Lizzani zdawał się su-

${ }^{8}$ Ibidem, s. 162. Podobnie było w kinematografii RFN - po 1949 roku temat wojenny na kilka lat niemal zniknął z ekranów kin.

9 Pierre Leprohon, Le cinéma italien, Paris 1967, s. 127. Ponti odnosi się tutaj do wspominanego wcześniej tzw. prawa Andreottiego. Więcej o prawie Andreottiego zob. Antonio Medici, Gli anni della censura, [w:] Carlo Lizzani, Cinema, storia e storia del cinema, red. Gualtiero De Santi, Bernardo Valli, Napoli 2007, s. 58. Warto w tym miejscu przypomnieć, że choć w 1945 roku zniesiono wiele aktów prawnych wprowadzonych w okresie faszyzmu, nie uchylono innego rozwiązania legislacyjnego - nadal obowiązywał regulamin kontroli rządowej produkcji filmowych (Regolamento per la vigilanza governativa sulle pellicole cinematografiche) funkcjonujący od 1923 roku. W myśl tego dokumentu dystrybucja filmów w kraju i za granicą musiała być poprzedzona uzyskaniem pozytywnej opinii specjalnej komisji. 
gerować, że historia lubi się powtarzać, a zimnowojenne restrykcje rządu chadeckiego nie pozwalają wesoło myśleć o przyszłości... Film - powstały jako niezależna produkcja składkowa ${ }^{10}$ - nie otrzymał zgody na dystrybucję poza granicami Włoch, mimo że chodziło o realizację opartą na bestsellerze przetłumaczonym uprzednio na wiele języków.

Ulica ubogich kochanków pokazana na festiwalu filmowym w Cannes została uhonorowana nagrodą (Prix International), choć jeśli wierzyć relacjom ówczesnego przewodniczącego jury - Jeana Cocteau - miała pierwotnie otrzymać Złotą Palmę. Na ostatecznym werdykcie zaważyła ponoć osobliwa interwencja jednego z przedstawicieli włoskiego rządu: Nicoli De Pirro, który zapukał nocą do pokoju Cocteau i na kolanach błagał go o ponowne rozpatrzenie werdyktu. W przeciwnym razie po sukcesie filmu, kręgi zwolenników włoskiej lewicy mogłyby się powiększyć, przez co zwycięstwo wyborcze komunistów w kolejnych wyborach byłoby - wedle De Pirro - trudne do uniknięcia ${ }^{11}$.

Szczególnie drastyczne środki zastosowano natomiast wobec Guida Aristarco, autora scenariusza Armii Sagapo, oraz Renza Renziego, który w 1953 roku na łamach "Cinema Nuovo" opublikował artykuł na temat trudności związanych z przygotowaniami do realizacji tego filmu. Fabuła, która postawiła Aristarco oraz Renziego przed trybunałem wojskowym, dotyczyła zdarzeń z czasów okupacji włoskiej w Grecji, prezentując włoskie wojsko w niekorzystnym świetle. W wyniku procesu obaj twórcy zostali skazani na kilkumiesięczną karę więzienia (ostatecznie kary nie odbyli), film zaś nie został zrealizowany.

Przywołany casus Armii Sagapo dobrze unaocznia, jak zapalnym punktem był we Włoszech lat 50. temat przeszłości. Ruch oporu (o czym

${ }_{10}$ Film został wyprodukowany przez Spółdzielnię Widzów i Producentów Filmowych (tą sama, która wyprodukowała, analizowany w dalszej części pracy, film Achtung! Banditi!). Pieniądze zostały wyłożone głównie przez robotników i studentów, do których Spółdzielnia zwróciła się o pomoc. Decyzja uniemożliwiająca rozpowszechnianie filmu w szerszych kręgach przyczyniła się do upadku spółdzielni. Zob. Assunta Petricelli, Da „Achtung! Banditi!" a "Maria José": La Resistenza nei film di Lizzani, [w:] La storia sullo schermo, il Novecento, red. Pasquale Iaccio, Coscenza 2004, s. 39. Więcej o samym filmie oraz jego podobieństwach i różnicach wobec literackiego pierwowzoru zob. Joanna Ozimska, Ulica ubogich kochanków: literacki świat via del Corno na cenzurowanym, [w:] Od Manzoniego do Maraini. Ekranizacje literatury włoskiej, red. Artur Gałkowski, Anna Miller-Klejsa, Łódź 2012.

11 Wspomina o tym Antonio Medici, op. cit., s. 65. Nicola De Pirro to były faszysta. W 1948 roku pełnił rolę głównego sekretarza ds. widowisk (Segretario Generale dello Spettacolo) w rządzie De Gasperiego. Posadę utrzymał także Gianni De Tommasi - w okresie reżimu faszystowskiego pracował on w Ministerstwie Kultury (Ministero della Cultura Popolare), a po wojnie został szefem oddziału biura cenzury. Więcej o cenzurze we włoskim kinie zob. Lorenzo Quaglietti, Storia economico politica del cinema italiano 1945-1980, Roma 1980. 
była już mowa we wstępie) stał się w tej dekadzie niemal tabu. Jak zauważa Pierre Sorlin, „,w czasie zimnej wojny rządzący Włochami - z uwagi na znaczący udział komunistów we włoskiej partyzantce, ale także ze względu na własną przeszłość związaną z faszystowskim reżimem (wielu polityków i urzędników zachowała bowiem faktyczną ciągłość sprawowania władzy) - zniechęcali, by nie powiedzieć: zabraniali wspominania o resistenzy"12. Sytuację tę dobrze opisał Luigi Zampa, który w swej powieści Sukces ustami bohatera Giulia stwierdza:

\begin{abstract}
Zaraz po wojnie [...] istniała swoboda wypowiedzi, bez której żadna sztuka nie może się rozwijać. [...] Od pewnego czasu obręcz cenzury zaciska się każdego dnia coraz bardziej. [...] Wszystko to spowodowane jest stopniowym wzrostem wpływów partii rządzącej, która swoimi działaniami, wymierzonymi przeciw twórczej swobodzie bynajmniej nie dowiodła, że chce stworzyć rząd liberalny i demokratyczny [...]. Tak się nieszczęśliwie składa, że cenzura wytwarza jeszcze gorszą autocenzurę, w rezultacie dzisiaj nikt nie jest pewien, co mu wolno powiedzieć: z pewnością wie tylko, czego powiedzieć nie może. Kino włoskie zaczęło tracić odwagę, oddaliło się od ostrych sporów ${ }^{13}$.
\end{abstract}

W Italii w latach 50. możliwości prezentowania historii na ekranie były więc dość ograniczone. Owszem, produkowane były (wzorowane na amerykańskich) filmy wojenne; rozgrywały się one jednak poza Włochami, a ich głównym przesłaniem była pochwała heroizmu i poświęcenia włoskich żołnierzy. Giuseppe Ghigi odnotowuje: „resistenza schodzi ze sceny i zostaje zastąpiona przez «bajki bez historii» - o obrońcach Amba Alagi, El Alamein i o pilotach włoskich w Libii. W istocie nie chodzi bo-

12 Pierre Sorlin, Di qua e di là delle Alpi: come è stata rappresentata la Resistenza, [w:] Cinema, storia, resistenza, 1944-1985, red. Gian Piero Brunetta et al., Milano 1987, s. 58. Jak podsumowuje Sorlin - powrót do urzędu sprawowanego w okresie faszystowskiego reżimu był masowy. Amnestia Togliattiego nie dotyczyła jedynie tych, którzy zostali splamieni bardzo okrutnymi zbrodniami. Wśród tych zrehabilitowanych byli oczywiście ludzie kina, jak np. Luigi Chiarini, który był szefem festiwalu w Wenecji w latach 60. Ze środowiska filmowego usunięty został w zasadzie tylko Luigi Freddi (stracił stanowisko w Narodowej Dyrekcji Kinematografii). W innym miejscu Sorlin zauważa, że o ile we Włoszech w latach 50. (podobnie jak we Francji) w zasadzie brak filmów o resistenzy, w tym samym czasie w Niemczech realizacje o ruchu oporu powstają jak grzyby po deszczu. Zob. interesujące zestawienie w: Pierre Sorlin, Cinema e identità europea. Percorsi nel secondo novecento, Firenze 2001, s. 75-77. W ten sposób, jak słusznie zauważa Sorlin, poprzez filmy ukazujące sprzeciw indywidualnych jednostek wobec reżimu Hitlera, pokonane Niemcy przyspieszyły proces stopniowej reintegracji w Europie Zachodniej (wstępując najpierw do Europejskiej Wspólnoty Węgla i Stali, później zaś zostając członkiem NATO).

${ }^{13}$ Luigi Zampa, Il sucesso, Roma 1957. Fragment cytowany w Il cinema italiano degli anni 50., red. Giorgio Tinazzi, Venezia 1979, s. 99. 
wiem o fakty, lecz o ukazanie siły i odwagi Włochów"14. Sytuację tę w następujący sposób podsumował reżyser (filmowy i teatralny) Gianfranco De Bosio: „defaszyzacja została zahamowana, zaś wielkie reformy zostały zapisane tylko na papierze (w konstytucji). Bezpośrednią tego konsekwencją było wygaszenie dyskursu politycznego prowadzonego przez powojenne kino antyfaszystowskie ${ }^{\prime 15}$.

Większość filmów zrealizowanych w okresie 1945-1959 prezentuje zagadnienie włoskiego ruchu oporu $w$ trybie fikcjonalnym: $\mathrm{tzn}$. ich fabuły nie dążą do rekonstrukcji faktów, lecz raczej ewokują „wrażenie epoki”; nie zawierają przy tym w swej strukturze materiałów archiwalnych. Wczesnym przykładem takiej realizacji jest wyprodukowany przez Narodowy Związek Włoskich Partyzantów (Associazione Nazionale Partigiani d'Italia) film Słońce wschodzi (Sole sorge ancora, 1946), sygnowany przez Aldo Vergano, a przez krytykę sytuowany w kręgu neorealizmu ${ }^{16}$. Historia Cesare - młodego żołnierza, który po zawieszeniu broni, 8 września 1943 roku ${ }^{17}$ postanawia wrócić do rodzinnego miasteczka i przyłącza się do włoskich partyzantów - pozostaje w pierwszej kolejności wypowiedzią reprezen-

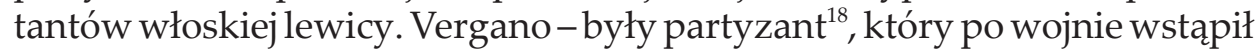

${ }^{14}$ Giuseppe Ghigi, op. cit., s. 108. W tej grupie filmów można by wymienić m.in. Bohaterski atak (Carica Eroica, reż. F. De Robertis, 1952), Żywe torpedy (Siluri umani, reż. A. Leonviola, 1954) i Palące niebo (Il cielo brucia, reż. G. Masini, 1957). Jak podaje Lichtner, film Bohaterski atak doczekał się nawet parlamentarnej interpelacji komunistów: Pietro Grifone i Giorgio Amendoli. Wzywali oni, by zakazać projekcji filmu, który uznali za faszystowską apologię. Więcej na ten temat zob. Giacomo Lichtner, Fascism in Italian Cinema since 1945, New York 2013, s. 198.

15 Gianfranco De Bosio, Il cinema della resistenza come dialettica aperta, "Filmcritica" 1966, nr 163, s. 36. W latach 50. w rodzimej produkcji filmowej obok filmów wygasającego już neorealizmu pojawiła się pierwsza formacja kina autorskiego - realizacje Antonioniego, Viscontiego i Felliniego z połowy lat 50. znamionuje już bowiem ich autorski idiom. W pejzażu włoskiego kina dominowały zaś komedie "różowego neorealizmu” markujące swoje powinowactwa z neorealizmem przysłowiową „ideologią i poetyką biedy”.

16 Zob. m.in. Roy Armes, Patterns of Realism. A Study of Italian Neo-Realist Cinema, New Jersey 1971, s. 94-95; Paolo Noto i Francesco Pitassio, Il cinema neorealista, Firenze 2010, s. 38 .

17 Wiadomość ta zastaje bohatera w domu publicznym, który szybko zostaje oblężony przez Niemców (prostytutki pomagają Włochom uciec).

18 Vergano walczył w regionie Lazio; aresztowany po zamachu uciekłz więzienia. Warto przypomnieć w tym miejscu „polski akcent” w karierze reżysera: Aldo Vergano w 1949 roku 
do włoskiej partii komunistycznej - do współpracy nad scenariuszem zaprosił bowiem m.in. ówczesnych krytyków związanych z periodykiem "Cinema": Giuseppe De Santisa (który był także reżyserem głośnego Gorzkiego ryżu [Riso amaro, 1949]), Guido Aristarco oraz Carlo Lizzaniego (dwaj ostatni wystąpili w filmie wraz z młodziutkim Gillo Pontecorvo - późniejszym twórcą m.in. Kapò [1960] i Bitwy o Algier [1966]).

Film okazał się hołdem dla patriotyzmu ludu, a zarazem oskarżeniem klasy posiadającej o zdradę. Zastosowany w filmie schemat dramaturgiczny jest bliski poetyce socrealistycznej - zamożne mieszczaństwo, reprezentowane przez hrabiankę Matyldę i jej najbliższych, kolaboruje z Niemcami i dba o własne interesy. Bunt, który przeradza się w powstanie przeciwko okupantowi, wybucha w cegielni, zaś partyzanci rekrutują się z chłopów oraz robotników. Cesare początkowo ulega wdziękom pięknej hrabianki, ale ostatecznie jego „świadomość dojrzewa” - wraz z partyzantami walczy przeciw Niemcom, a swą przyszłość wiąże z Laurą (córką dowódcy oddziału).

Dychotomiczny podział na „dobry lud" i „zepsute mieszczaństwo" budowany jest konsekwentnie przez cały film za pomocą postaci, które - jak słusznie zauważa Gianni Rondolino - są nośnikami postaw, a nie bohaterami z „krwi i kości”, o pogłębionym portrecie psychologicznym ${ }^{19}$. I tak, światem mającej wielu kochanków, a zatem „zdradliwej” Matyldy, jest willa (bohaterkę dosięga śmiertelny pocisk, gdy wygląda przez okno, co podkreśla niejako jej postawę biernego obserwatora politycznych wydarzeń). Laura zaś, córka przywódcy partyzantów-cegielnika, to przeciwieństwo arystokratki: dziewczyna aktywnie działa w ruchu oporu, a przy tym troszczy się o najbliższych (opiekuje się np. dziećmi zmarłej siostry $)^{20}$. Opozycja ta uwypuklona jest także poprzez montaż. W filmie wielokrotnie bowiem, na zasadzie kontrastu, zestawiane są ujęcia eleganckich wnętrz pałacu i nędzne izdebki dworskich czworaków.

Film Vergano ustanawia swoisty, wielokrotnie później powtarzany, model prezentowania Niemców. Demoniczny charakter nadaje im eks-

\footnotetext{
przyjechał do Warszawy, aby wraz z Tadeuszem Kańskim nakręcić socrealistyczny film o młodym góralu z Zakopanego, który jako żołnierz udaremnił akcję szajki przemytniczej, próbującej wywieźć z kraju kolekcję kamei. Tak powstał film Czarci Żleb (1949).

${ }_{19}$ Gianni Rondolino przyrównuje filmowe postaci do marionetek. Zob. Atti del Convegno di studi sulla resistenza nel cinema italiano del dopoguerra, 24-27.04.1970, red. Camillo Bassotto, Venezia 1970, s. 102.

${ }^{20}$ Wedle Giuseppe Ghigiego Laurę można nazwać pierwszą świadomą politycznie kobietą we włoskim kinie o resistenzy. Później dołączą do niej Agnieszka (Agnieszka idzie na śmierć, reż. G. Montaldo) oraz Libera (Libera, moja miłość, reż. M. Bolognini). Zob. Giuseppe Ghigi, op. cit., s. 68.
} 
presjonistyczne światło zastosowane choćby w sekwencji osobliwej „zabawy" sylwestrowej gestapowca, który jeżdżąc bryczką bierze na cel ludzi. Obcość między Włochami a okupantem wzmacniana jest dodatkowo przez powziętą przez reżysera decyzję, by Niemcy mówili po niemiecku (w filmie ich słowa nie są tłumaczone), a Włosi - po włosku. Skojarzenie nazistów z "aniołami śmierci" chyba najpełniej wytwarza sekwencja rozstrzelania w obecności ludu księdza Don Camillo oraz partyzanta-komunisty. Egzekucja odbywa się bowiem w akompaniamencie litanii, rozpoczętej przez kapłana. Powtarzane przez tłum ora pro nobis wraz z coraz szybszym montażem (w kolejnych ujęciach widzimy rozmodlone, pełne wzruszenia twarze starców, kobiet i dzieci) buduje emocjonalne natężenie sceny i nadaje jej charakter bez mała ewangeliczny - niezawinionego męczeństwa; ofiary za sprawę ${ }^{21}$. Hipotezę, że ruchowi oporu w narracji Vergano został nadany "odkupicielski" charakter potwierdza także napis ją otwierający: „Ten film jest dedykowany poległym za rezurekcję [podkr. - A. M.-K.] ojczyzny”. Słowo „rezurekcja” uwypukla niejako „religijną" ambicję dyskursu - losy Włoch zostają tu ujęte (podobnie jak w Rzymie, mieście otwartym, o czym będzie jeszcze mowa) przez pryzmat cierpienia, pokuty i zbawienia. Warto także zaznaczyć, że Vergano (jak Rossellini) podkreśla konsensus komunistów i katolików - scena „wspólnej śmierci" kapłana i partyzanta jest tu emblematyczną ilustracją „,jedności" Włochów (podczas pogrzebu Matyldy pada zdanie: właściciele ziemscy także ucierpieli w wojnie). Choć Vergano piętnuje zatem inercję włoskiego mieszczaństwa (obarczając je odpowiedzialnością za tragedię wojny), linia wojennego frontu zdaje się jednak przebiegać $\mathrm{w}$ filmie podług tożsamości narodowej (Włosi/Niemcy). Finał filmu - zwycięstwo ruchu oporu - wydaje się zwiastunem "lepszego jutra” (dosłownie zapowiadanego przez tytuł filmu: Słońce wschodzi $i^{22}$ ).

Inny przykład tej kategorii reprezentacji (a zatem: realizacja fikcjonalna, niezawierająca w swej strukturze materiałów archiwalnych) stanowi film Przed nim drżat cały Rzym (Avanti a lui tremava tutta Roma, reż. C. Gallone, 1946), jeden z popularnych po wojnie filmów muzycznych

${ }^{21}$ Carlo Lizzani - jeden ze scenarzystów filmu oraz odtwórca roli Don Camilla - wspomina, że podczas kręcenia sekwencji egzekucji (zimą 1945 i 1946 roku) wielu ze zgromadzonych naturszczyków przeżywało całą scenę tak, jakby rozgrywała się ona naprawdę, stąd jej efekt był zaskakujący dla samego Vergano. Wypowiedź zamieszczona w: Franca Faldini, Goffredo Foffi, L' avventurosa storia del cinema italiano 1939-1959, Milano 1959, s. 119.

${ }_{22}$ Także $\mathrm{z}$ uwagi na wyrażoną $\mathrm{w}$ finale wiarę $\mathrm{w}$ ufundowanie nowego porządku film ten określano jako neorealistyczny. 
(tzw. film-opera ${ }^{23}$ ). Na tle późniejszych fabuł o resistenzy film Gallone wyróżnia się miejscem akcji: rozgrywa się ona głównie w bogatym wnętrzu willi sławnego tenora (Marco ukrywa tu rannego Anglika pozostającego $\mathrm{w}$ kontakcie $\mathrm{z}$ aliantami i włoską partyzantką) oraz teatrze ${ }^{24}$. Protagoniści zaś to zaangażowana w rzymski ruch oporu para operowych śpiewaków.

Wystawiana w teatrze opera Pucciniego - Tosca, w której gra Marco i jego wybranka - staje się drugą równoważną do współczesnej (wojennej) linią fabularną. W ten sposób, jak zauważa Alberto Farassino, w filmie Gallone ukochana przez Włochów Tosca staje się operą „partyzancką" ${ }^{25}$. Reżyser buduje bowiem analogię między losami zaangażowanych w resistenze śpiewaków zagrożonych niemieckim aresztowaniem a postaciami z libretta - Caravadossim i tytułową Tośką. Pomysł ten nie przekonał ówczesnej krytyki: „Od początku widać, że ta historia jest szyta grubymi nićmi. [...] Analogia między Rzymem Scarpii a Rzymem Kesserlinga jest wydumana, a paralela między dwoma sytuacjami - tej z libretta i tej współczesnej - wydaje się sztuczna" ${ }^{26}$ - pisał na łamach „Filmu” Carlo Felice (trudno się z jego opinią nie zgodzić). Niemniej, zestawienie opery Pucciniego z współczesnym losem śpiewaków jest o tyle ciekawe, że ilustruje wręcz dosłownie powojenne łączenie włoskiego ruchu oporu z tradycją risorgimento (jak już wspominałam, ruch oporu nazywany był secondo risorgimento). Odwoływanie się do tradycji ruchów wyzwoleńczych dodatkowo akcentowało bowiem narodowy charakter walki oraz jedność społeczeństwa (maskując tym samym fakt, iż resistenza była niejednokrotnie walką bratobójczą). Przed nim drżat caty Rzym jest zatem etapem tworzenia swoistej konwencji, która będzie wykorzystywana w innych powojennych włoskich filmach: Niemcy są tu bez wyjątku źli i okrutni (choć niektórzy z oficerów zachowują dżentelmeńskie maniery), Włosi zaś to bądź ofiary (mowa jest m.in. o wielu sierotach, które w wyniku bombardowań straciły nie tylko dom, ale i najbliższych), bądź bojownicy ruchu oporu (w filmie nie znajdziemy choćby wzmianki o włoskim faszyzmie!).

„Dla kogoś, kto przeżył dziewięć miesięcy niemieckiej okupacji w Rzymie jest nieco śmieszne, że teatr - który był miejscem stacjonowania hitlerowskiego wojska - został w realizacji Gallone przekształcony w rodzaj fabryki ruchu oporu i miejsce partyzanckich akcji" - pisano po pro-

23 Zob. Guglielmo Pescatore, La voce e il corpo. L'opera lirica al cinema, Udine 2001, s. 46.

${ }^{24}$ Można by powiedzieć, że przenosząc działania ruchu oporu do teatru, Gallone nieintencjonalnie wskazuje na "teatralny" charakter włoskiej resistenzy, która w istocie miała mniej spektakularny wymiar niż wynika z filmów.

25 Opinia cytowana w: Non solo Scipione: il Cinema di Carmine Gallone, red. Pasquale Iaccio, Roberto Calabretto, Napoli 2003, s. 29.

${ }^{26}$ Carlo Felice, Avanti a lui tremava tutta Roma, "Film” 1946, nr 32 (przedruk w Giuseppe Ghigi, op. cit., s. 99). 
jekcji filmu w „Rivista del Cinematografo" ${ }^{27}$. Rzeczywiście, w Przed nim drżat cały Rzym wojna pozostaje za drzwiami teatru i willi; bohaterowie zaś pławią się w luksusie i wydają się żyć w innym świecie (gdy słychać huk bombardowań, popijają kawę, wylegując się na sofie). Grozę zbrojnego konfliktu mają chyba oddać w filmie właśnie odgłosy niemieckich nalotów oraz postać polskiego pianisty żydowskiego pochodzenia, któremu Niemcy wymordowali całą rodzinę, a który wzięty na przesłuchanie połyka zaszyty w klapie marynarki cyjanek potasu i przed śmiercią wznosi okrzyk - „Jeszcze Polska nie zginęła!"”28.

Przed nim drżał cały Rzym przypomina swą konwencją tzw. kino białych telefonów z epoki faszystowskiej (zresztą bohaterowie kilkakrotnie używają telefonu, który przecież w czasie wojny był raczej nieosiągalnym luksusem). Ten zdawałoby się niemożliwy, czy w najlepszym razie sztuczny mariaż tematu ruchu oporu z estetyką eskapistycznego kina rodem z epoki Mussoliniego, wynika także stąd, iż reżyserem omawianego filmu jest Carmine Gallone (twórca m.in. propagandowego giganta historycznego Scypion Afrykański [1937]), który, jak pisze Ghigi, chciał realizacją o włoskim ruchu oporu „zatrzeć niewygodną przeszłość" ${ }^{29}$. Nie on jeden zresztą - wielu twórców kina reżimu faszystowskiego realizowało po wojnie filmy, w których wątek resistenzy wydaje się niejako "doklejony" i funkcjonuje raczej jako swoiste usprawiedliwienie reżyserów pragnących odnaleźć się w nowej sytuacji politycznej. I tak na przykład Giorgio Ferroni (asystent Carmine Gallone przy Scypionie Afrykańskim), który w czasie wojny przeniósł się do Wenecji (siedziby kinematografii Włoskiej Republiki Socjalnej), w 1946 roku realizuje film Plan gziazd (Pian delle stelle), w którym pojawia się wątek ruchu oporu ${ }^{30}$, zaś Alessandro Blasetti (autor m.in. propagandowego filmu Stara gwardia [Vecchia guardia, 1934]) kręci Jeden dzień z życia (Un giorno nella vita, 1946). W obsadzie tego filmu, w którym partyzantom udzielają azylu zakonnice, pojawiły się gwiazdy kina faszystowskiego (występuje tu m.in. Amedeo Nazzari oraz diwy: Elisa Cegani, Marcella Lotti, Dina Sossoli); nic więc dziwnego, że Jeden dzień z życia został oceniony jako „triumf światopoglądowej transformacji" ${ }^{31}$.

${ }^{27}$ Luigi Ferro, „Rivista del Cinematografo”, styczeń 1947, s. 15 (materiały z płyty DVD).

${ }^{28}$ Film zawiera ciekawą scenę wspólnej gry na pianinie Niemca i Żyda (Niemiec nie orientuje się, z kim koncertuje na cztery ręce).

${ }_{29}$ Giuseppe Ghigi, op. cit., s. 99.

30 Ghigi zwraca uwagę na kuriozalny dobór kostiumów w tych partiach filmów, w których pojawiają się domniemani członkowie resistenzy (chłopka z kolczykami ze złota, uciekinier z niemieckiego więzienia w fularze i marynarce). Zob. ibidem, s. 88.

31 Eugenio Palmieri, Un giorno nella vita, „Film” z 1.06.1946, przedruk w: ibidem, s. 97. Film ten (jego polski tytuł podaję w tłumaczeniu własnym) zdobył Srebrną Wstążkę 
Istotnym przykładem filmu, który pod względem ewokowania historii sytuuje się w tej samej co realizacja Gallone i Vergano strategii, jest debiut reżyserski Carlo Lizzaniego Achtung! Banditi! (1951), także niekiedy wymieniany wśród dzieł neorealistycznych ${ }^{32}$. Podobnie jak w Słońce wschodzi, wyraźnie podkreślona została tu rola robotników wspierających ruch oporu (film zrealizowany ze składek genueńskich robotników zawiera m.in. sceny strajku tramwajarzy oraz sabotażu $\mathrm{w}$ fabryce ${ }^{33}$ ). Wątek ten również profiluje „ideologicznie” działalność włoskiej resistenzy (partyzanci współpracują z pracownikami zakładu). Celem okazuje się bowiem nie tylko wolność kraju, ale także po marksistowsku pojmowane przekształcenie struktury własności środków produkcji (przedstawione w filmie jako „ochrona włoskiego przemysłu”). Fabryka jest w naszych rękach, fabryka jest naszym życiem. To, co pozostało, będziemy bronić paznokciami i zębami. Dziś jest coś ważniejszego do ratowania niż nasza skóra - mówi inżynier, który nie godzi się na współpracę z Niemcami i zostaje rozstrzelany.

W centrum fabuły pozostaje grupa partyzantów dzielnie znosząca wojenne trudy (scena otwierająca film ukazuje Włochów, którzy ranni i skrajnie wycieńczeni brną przez górskie śniegi) i z poświęceniem walcząca „za ojczyznę" (film zawiera kilka rozbudowanych sekwencji batalistycznych, $\mathrm{w}$ tym finałowe, decydujące starcie z Niemcami). Co istotne, oddział włoskiego ruchu oporu złożony jest z przedstawicieli różnych regionów Italii (m.in. Liguryjczyków, Sardyńczyków, Rzymian, Piemontczyków) oraz

(nagrodę włoskiej krytyki) za najlepszą reżyserię (ex quo z Dziećmi ulicy Vittorio De Siki) i, jeśli wierzyć relacjom z premiery, otrzymał owacje publiczności (zob. Carlo Trabucco, „Il Popolo" z 7.04.1946. Przedruk w: Atti del Convegno di studi sulla resistenza nel cinema italiano del dopoguerra...). Innym reżyserem, którego światopogląd uległ podobnie nagłej transformacji, jest Fernando Cerchio. W 1944 roku zrealizował on dla Republiki Salò film Szczéślizwy los (La buona fortuna, polski tytuł podaję w tłumaczeniu własnym), a rok później nakręcił dokument Aldo mówi $26 \times 1$ (Aldo dice 26x1) o partyzantach i wyzwoleniu Turynu. Polski tytuł filmu podaję $\mathrm{w}$ tłumaczeniu własnym.

${ }^{32}$ Lizzani, o czym rzadko się pamięta, współpracował z Rossellinim przy Rzymie mieście otwartym i słynnym Gorzkim ryżu De Santisa. Ciekawostką jest fakt, że w obsadzie prócz młodej Lollobrigidy występuje także Lamberto Maggiorani („gwiazda" Złodziei rowerów [Ladri di biciclette, reż. V. De Sica, 1948]). Tytułowymi bandytami nazywani są przez Niemców działacze ruchu oporu. W tym filmie jako operator debiutuje Gianni di Venanzo (późniejszy operator m.in. Felliniego, Antonioniego i Viscontiego).

${ }^{33}$ Film został wyprodukowany przez Spółdzielnię Widzów i Producentów Filmowych założoną w Genui przez grupę niezależnych entuzjastów X muzy; sfinansowany zaś głównie przez robotników. „Pierwszą grupa, która odpowiedziała na apel o finansową pomoc, była grupa genueńskich tramwajarzy. Dlatego też zdecydowaliśmy się umieścić w filmie epizod upamiętniający strajk tramwajów w czasie nazistowskiej okupacji" - wspomina Lizzani. Wypowiedź umieszczona w: Genova in celuloide. Luoghi, protagonisti, storie, Genova 1983, s. 192-193. 
rozmaitych grup społecznych (chłop, inżynier, student). Taka struktura partyzanckiej grupy przypomina swoisty "mikrokosmos Włoch” i sprawia wrażenie, że oto wszyscy Włosi aktywnie uczestniczą w resistenzy, zjednoczeni przeciw wspólnemu wrogowi.

Faszyści w realizacji Lizzaniego są fizycznie nieobecni (wspominani wyłącznie w dialogach), zaś jedyni Włosi kolaborujący z Niemcami (oddział Alpini ${ }^{34}$ ) w finale filmu walczą już po stronie partyzantó $w^{35}$. W filmie Lizzaniego mamy zatem ponownie manichejski świat: dobrych Włochów i złych Niemców, ukazanych stereotypowo jako żołnierzy okrutnych i bezlitosnych, którzy wykrzykują po niemiecku niezrozumiałe dla Włochów rozkazy. Należy przy tym zaznaczyć, że współpraca Alpini z okupantem nie jest pokazana, a wyłącznie zasugerowana w dialogach: Ludzie zaczynaja źle mówić o Alpini. Twierdza, że walcza przeciw partyzantom - informuje swego brata, żołnierza zatroskana bohaterka. Plotki. Wygląa na to, że z partyzantami będzie rozejm - odpowiada mężczyzna. Światopoglądowy rozłam we włoskich szeregach jest zatem w filmie Lizzaniego wyłącznie sygnalizowany, a następnie zniwelowany przez finałowe pojednanie Włochów. Ponoć w pierwotnej wersji filmu problem ten był bardziej wyeksponowany, ale został wyciszony przez cenzurę (usunęła ona np. scenę, w której kobiety z rodzin robotniczych opluwają i wyzywają Alpini od kolaborantów $\left.{ }^{36}\right)$. Jak możemy przeczytać w archiwalnych zapisach cenzuralnych: „spektakl ukazujący bratobójczą wojnę w momencie formowania włoskiej świadomości jedności jest społecznie szkodliwy; przynosi także szkodę wizerunkowi kraju za granicą" ${ }^{37}$. Z tego samego powodu wśród filmowych postaci nie mieli pojawić się „zindywidualizowani” komuniści. Sugestie cenzury wynikały oczywiście z wewnętrznych napięć politycznych, o których była już mowa - będąca u władzy chadecja nie chciała akcentować udziału komunistów w ruchu oporu, a jedność narodu była szczególnie ważna dla tych, którzy pomimo swej faszystowskiej przeszłości odnaleźli się w nowym porządku na wysokich stanowiskach. Pomimo

${ }^{34}$ Alpini - włoskie oddziały strzelców alpejskich, utworzone w 1872 roku, które w czasie II wojny początkowo wspierały faszystów, a następnie dołączyły do aliantów. Do dziś w regionie Lombardii obchodzone jest coroczne święto Alpini.

35 W filmie mamy także ambiwalentną figurę doświadczonego dyplomaty (od 15 lat). Na pytanie partyzanta, w jakim rządzie pracował, mężczyzna odpowiada wymijająco, że ,jest w stanie spoczynku”. Sugestia, że aktywnie uczestniczył w życiu politycznym reżimu faszystowskiego zostaje jednak „unieważniona” przez fakt, że dyplomata pomaga partyzantom. Ostatecznie ginie z rąk „zaprzyjaźnionego” Niemca. Czyżby była to ilustracja kruchości włosko-niemieckiego sojuszu?

${ }^{36}$ Informację podaję za: Giuseppe Ghigi, op. cit., s. 61.

37 Przedruk dokumentów w: ibidem, s. 106. 
uwzględnienia przez Lizzaniego uwag cenzury, na film nałożono zakaz eksportu.

Film był niewygodny dla władzy jeszcze z innego powodu. Ukazywał on bowiem osamotnienie włoskich partyzantów, pozbawionych wsparcia władz oraz aliantów. Rozgoryczenie członków ruchu oporu jest w Achtung! Banditi! wyrażone wprost: Dotąd nikt nam nie pomógł - stwierdza jeden z mężczyzn. Co więcej, w filmie wspomniany jest komunikat radiowy Harolda Alexandra (brytyjskiego polityka, głównodowodzącego wojsk we Włoszech), który w listopadzie 1944 roku radził, aby partyzanci zawiesili walkę zbrojną i poczekali na bardziej korzystny układ polityczny. Jesteś zaniepokojony wiadomościami? - pyta w filmie swego dowódcę kolega z oddziału. - Nie... [...] ale chętnie zrzekłbym się dowództwa. To trudne brać odpowiedzialność za życie innych - odpowiada kompan, po czym dodaje: uczestniczymy w bardzo trudnej wojnie. Zawsze bez kontaktu $z$ dowództwem. $Z$ tysiacem pytań do rozwiazania... W filmie, na przekór oficjalnemu rozkazowi, partyzanci decydują się walczyć dalej ${ }^{38}$.

Podobnym w wymowie filmem są Opuszczeni (Sbandati, reż. F. Maselli, 1955). Tytułowymi „opuszczonymi” można nazwać zarówno grupę włoskich żołnierzy, uciekinierów z transportu wojskowego po politycznej wolcie Italii z 8 września 1943 roku (ich zamiarem jest jak najszybsze dołączenie do formujących się w górach oddziałów partyzanckich), jak i arystokratyczną młodzież, która spędza czas w wiejskiej posiadłości - na dolce far niente $\mathrm{z}$ dala od nękanego nalotami Mediolanu. Synowie bogatych rodzin $\mathrm{z}$ tradycjami oraz willa, $\mathrm{w}$ jakiej przebywaja, wydają się zapomniane przez historię. Dopiero pojawienie się partyzantów burzy spokój mężczyzn. W filmie można doszukać się negatywnej oceny mieszczaństwa, obarczonego w dużej mierze odpowiedzialnością za wojenną tragedię (to jeden z zamożnych młodzieńców, Ferruccio, denuncjuje przyjaciół opiekujących się partyzantami) ${ }^{39}$. Ostrze tej krytyki jest jednak wyraźnie stępione: po pierwsze dlatego, że posażni przyjaciele „denuncjatora" stają po

${ }^{38}$ Zaznaczony w Achtung! Banditi! brak wsparcia władz i sugestia samowystarczalności partyzanckich oddziałów wobec wroga mogły być również odczytane jako komentarz do współczesności. W latach 50., a zatem w momencie realizacji filmu, dziedzictwo resistenzy zostało bowiem niejako (o czym była już mowa) zapomniane przez oficjalne organy państwa.

39 Na łamach „Il Contemporaneo” (1955, nr 37) Chiarini pisał, że film Masellego ukazuje umiejętnie kryzys mieszczańskiej młodzieży w czasie resistenzy. To sformułowanie jest ciekawe, ponieważ sugeruje, że włoski ruch oporu był zjawiskiem powszechnym, narodowym. Chiarini w swej recenzji wskazuje także na pewne nieprawdopodobieństwa fabularne filmu - stąd jej tytuł: Cinema senza realtà (Kino pozbawione odniesienia do rzeczywistości). 
stronie ruchu oporu (Ferruccio jest więc wyjątkiem), a po drugie z uwagi na to, że działanie chłopaka nie wynika z jego politycznych przekonań, lecz powodowane jest strachem przed represjami ze strony Niemców (ich obcość ponownie podkreśla nietłumaczony język niemiecki). W Opuszczonych wprowadzony zostaje także dyskurs ofiar cywilnych (słyszymy na przykład historię kobiety, której mąż zginął w bombardowaniach). Włosi w filmie Masellego pozostają zatem wyłącznie ofiarami wojny - bohaterowie mówią o jej skutkach, ale nikt nie wspomina o przyczynach.

\section{Z perspektywy współczesnej}

Filmem, który traktuje o włoskim ruchu oporu w trybie fikcjonalnym, jest także Żyć w pokoju (Vivere in pace, reż. L. Zampa, 1947). Dzieło to należy jednak do innej kategorii - biorąc pod uwagę sposób ewokowania tematu resistenzy - niż filmy omówione wcześniej. W odróżnieniu od dotychczas analizowanych produkcji film ten przynależy do realizacji, które mają poszerzony horyzont narracji: zawierają w swej strukturze współczesną ramę narracyjną (wprowadzającą retrospekcje lub closure „po latach").

Wspomniany film Zampy jest o tyle istotnym przykładem tej strategii, że nie znajdziemy w nim figury partyzanta. Owszem, o ruchu oporu się mówi - wiadomo nawet, że jeden $z$ drugoplanowych bohaterów (doktor) jest w kontakcie z lokalna resistenza, ale pozostaje ona w tle; tak jakby Zampa sugerował, inaczej niż jego koledzy po fachu, że fenomen ten dotyczył $\mathrm{w}$ istocie niewielkiej grupy Włochów. Większość przyjmowała bowiem postawę politycznej obojętności, reprezentowaną przez Tignę - głównego bohatera, którego mottem jest tytułowe życie w (s)pokoju - oraz innych mieszkańców odległej od uczęszczanych szlaków (a zatem i geograficznie położonej na peryferiach) wioski w Apeninach, gdzie rozgrywa się akcja ${ }^{40}$.

Ustalony, leniwy rytm życia rodziny Tigny ulega zakłóceniu, gdy dobroduszny wieśniak odkrywa w swej stodole dwóch Amerykanów: jeden

${ }^{40}$ Jest to w zasadzie jedyny film Zampy, którego akcja rozgrywa się w czasie wojny. Jego słynna trylogia na podstawie scenariuszy Vitaliano Brancatiego: Trudne lata (Anni difficili, 1948), Łatwe lata (Anni facili, 1953) i Sztuka kombinowania (L'arte d'arrangairsi, 1954) traktuje głównie bądź o czasach przedwojennych (ukazując w krzywym zwierciadle czas reżimu faszystowskiego [Trudne lata]), bądź opowiada o latach przed- i powojennych, wskazując na podobieństwa obu rzeczywistości (Eatwe lata, Sztuka kombinowania). O czasach przedwojennych traktuje także film Zampy Ryczace lata (Anni Ruggenti, 1963). Ciekawie omawia te filmy Lichtner - zob. Giacomo Lichtner, Luigi Zampa: Fascism and italianità, [w:] idem, op. cit., s. 63-83. 
z nich, czarnoskóry, jest ranny. Znaleźli się tutaj, ponieważ pierwszej pomocy, w sekrecie przed dorosłymi, udzieliła im kilkunastoletnia siostrzenica Tigny. Jej wuj wolałby nie mieć tego strapienia, zna treść obwieszczeń SS, ale wzdraga się przed wyrzuceniem żołnierza na pewną śmierć. Wszystko rozwija się pomyślnie (bohater cieszy się nawet, że pomaga związanym z ruchem oporu aliantom), do czasu gdy z wizytą przychodzi nieoczekiwanie Hans, miejscowy reprezentant władzy okupacyjnej, a pośpiesznie ukryty w spiżarni, zdrowy już Joe nie może oprzeć się pokusie skosztowania zapasów wina. Na nic wysiłki rodziny, która usiłuje zagłuszyć hałasy zza ściany i wlewa bez ograniczeń trunek w Niemca: podchmielony Joe wkracza w końcu do izby. Sekwencja ukazująca frenetyczny taniec pijanego Niemca i przerażonych zajściem Włochów stanowi rozbudowany, autonomiczny gag. Ale przecież można ją interpretować metaforycznie jako swoistą ilustrację sytuacji Italii - tańczącej, jak jej każą, by nie ucierpieć $\mathrm{w}$ aliancko-niemieckim konflikcie.

Wydarzenia przedstawione $\mathrm{w}$ tej zabawnej scence maja jednak poważne konsekwencje. Hans reaguje nieoczekiwanie: kiedy mija obopólne osłupienie, brata się z wrogiem i wychodzi na ulicę. Wystrzelone na wiwat salwy budzą mieszkańców, wybucha euforia, bo skoro ci dwaj są razem - musi to oznaczać zawieszenie broni. Sekwencja przekazywania sobie informacji o zakończeniu wojny należy do jednej z bardziej komicznych w filmie. Zampa piętnuje w niej z humorem konformizm rodaków. Przykładowo, jeden z Włochów, usłyszawszy omyłkowo, że wygrali Niemcy, wkłada przygotowany w szafie niemiecki mundur, który wisi obok... ubrania aliantów. Gdy nieporozumienie zostaje wyjaśnione, pojawia się lęk (co stanie się, gdy Niemiec wytrzeźwieje?) przemieszany z nadzieją (a może nie będzie pamiętał zajścia?). Hans co prawda pamięta, ale - ku zadowoleniu pacyfistycznie nastawionych Włochów (w filmie nie ma ani jednego, który cieszyłby się ze zbrojnego konfliktu!) - ma dość wojny. Wtedy nadchodzą informacje o zbliżających się Amerykanach. Hans chce przebrać się w ubrania cywilne i prosi o nie Tignę. Niestety, właśnie wtedy nadjeżdża patrol SS. Niemcy (na ryczących maszynach, krzycząc niezrozumiałe dla Włochów rozkazy) uciekają przed atakiem amerykańskim. Ewakuują się, ale sieją jeszcze zniszczenie - od ich kul giną Tigna i Hans (w przebraniu cywila). Wesołość i kpina nadające ton filmowi Zampy, w finale ustępują zatem miejsca tragedii. Konkluzja jest gorzka - reżyser zdaje się sugerować, że nie można liczyć na przeczekanie kataklizmu dziejowego, nie można ufać, że w czasie wojny dobre chęci i lokalna neutralność zagwarantują bezpieczeństwo.

Komentarz na początku filmu - podczas gdy w obrazie prezentowane jest miejsce akcji i jej mieszkańcy - podkreśla, że przedstawione 
przypadki wydarzyły się naprawdę ${ }^{41}$. Współczesna rama narracyjna, głównie filmowy epilog, który dopowiada losy bohaterów wojennych wydarzeń, jest natomiast przewrotny. Kiedy ponadkadrowy głos informuje m.in. o karierze dziennikarskiej Amerykanina oraz życiu dorosłej już siostrzenicy Tigny, która planuje ślub, obraz powtarza bowiem jedno z ujęć z prologu - to ukazujące główną uliczkę wioski z okolicznymi sklepikami, kościołem i biegającymi po niej dziećmi. W ten sposób Zampa sugeruje, że pomimo wojennej zawieruchy nic tak naprawdę się nie zmieniło. Można by zatem powiedzieć, że film kończy się happy endem: życie toczy się jak dawniej (mówi ponadkadrowy głos). W finale można jednak usłyszeć i nutkę goryczy. Czyż bowiem Zampa nie sugeruje w ten sposób, że i włoska obojętność na sprawy kraju oraz postawa konformistyczna przetrwały bez szwanku?

\section{Materiały archiwalne}

Odmienną grupą fikcjonalnych filmów o resistenzy są te, których akcja pozbawiona jest współczesnej ramy narracyjnej, ale które zawierają w swej strukturze materiały archiwalne. Do tej kategorii zalicza się m.in. Paisà (1946) ${ }^{42}$, okrzyknięta arcydziełem włoskiego neorealizmu. Film Rosselliniego, będący panoramą Italii w przełomowym okresie wojny (to sześć nowel uporządkowanych wedle chronologii i geografii stopniowego wyzwalania Włoch przez aliantów, uzupełnionych komentarzem o działaniach na froncie w latach 1943-1945), doczekał się tak wielu opracowań i recenzji, że trudno zaproponować doń oryginalny klucz interpretacyjny.

${ }^{41}$ Informacja ta pojawia się także na końcu filmu. Inspiracją do jego powstania była ponoć autentyczna historia przyjaciółki jednego ze scenarzystów filmu. Zampa tak wspomina pracę nad scenariuszem: „Suso Cecchi d'Amico, Tellini i ja próbowaliśmy stworzyć scenariusz o kobietach w Specjalnych Służbach amerykańskiej armii. Nic nam jednak nie szło. Podczas chyba czwartego spotkania Suso powiedziała: dziś spotkałam moją znajoma, która mi opowiedziała... I zaczęła nam opowiadać o swojej znajomej, mającej posiadłość na przedmieściach Florencji, do której przychodzili Niemcy na herbatę, ale goszczącej także amerykańskich żołnierzy zbiegłych z obozów koncentracyjnych. Znajoma przebierała ich za wieśniaków i wysyłała w pole, gdy przychodzili Niemcy. Jedynym problemem był fakt, że jeden z Amerykanów był czarnoskóry - jego więc ukrywała w piwniczce, bojąc się zawsze, że może on spróbować i upić się zgromadzonym tam winem. Pamiętam, że gdy Suso skończyła opowiadać, wziąłem papiery, nad którymi siedzieliśmy, wyrzuciłem je i powiedziałem: przestańmy tracić czas - to jest pomysł na film, który powinniśmy zrobić. Ponti i Lux zgodzili się". Cyt. za: Franca Faldini, Goffredo Foffi, op. cit., s. 123.

42 „Paisà” to zawołanie, jakim zwracali się do Włochów żołnierze amerykańscy (od zniekształconego paesani - rodacy). 
„Paisà to album, w którym wszyscy się odnajdujemy; za kilka lat może okazać się dokumentem naszej kinematografii o czasach wojny" - pisano na łamach "Corriere della Sera" ${ }^{\text {43 }}$. Podkreślające aurę autentyzmu zabiegi „dokumentalizacyjne" - inkrustowanie narracji materiałami archiwalnymi (rozpoczynający film footage z lądowania Amerykanów na Sycylii płynnie przechodzi $\mathrm{w}$ inscenizację) oraz ponadkadrowy komentarz, który stanowi swoistą ramę dla poszczególnych nowel - bywają najczęściej przywoływane w kontekście estetyki neorealistycznej. Dla mnie najważniejsze będą rzecz jasna te epizody, w których pojawia się temat włoskiego ruchu oporu, a zatem czwarty (florencki) i ostatni (rozgrywający się w dolinie Padu).

W noweli czwartej, partyzanci wyzwalają Florencję, podczas gdy Anglicy na wzgórzach otaczających miasto czekają na rozwój sytuacji. Harriet, jedna $z$ alianckich sanitariuszek, przedostaje się (w towarzystwie Massimo, włoskiego przyjaciela) do miasta w poszukiwaniu dawnego ukochanego. Okazuje się, że stał się on teraz przywódcą partyzantów, zwanym „Lupo". W finale noweli dziewczyna dowiaduje się o śmierci ukochanego.

Epizod rozpoczyna się rozbudowaną sekwencją w szpitalu, ukazującą opatrywanie ran partyzantów, a kończy śmiercią jednego z nich na rękach Harriet. Ostatnie ujęcie stylizowane jest przy tym na Pietę Michała Anioła, przez co śmierci młodzieńca przydany zostaje sens ewangeliczny. Cierpienie i ogólnonarodowa tragedia zostają także podkreślone poprzez przestrzeń. Miasto jest zniszczone (dowiadujemy się, że jedyny most, który ocalał od niemieckiej destrukcji to Ponte Vecchio); eksponowane są ruiny i fizyczne "rany" włoskiej sztuki (bohaterowie przebiegają w pewnym momencie przez słynną Galerię Uffizi, ale jest ona niemal pusta)!

W noweli pojawia się tylko jeden Włoch obojętny na wojenną tragedię - jest nim osobliwy weteran I wojny światowej, który rozpoznaje broń po odgłosie strzału i prosi o hełm, ponieważ razi go słońce. Niemniej, oglądając czwarty epizod Paisy, możemy odnieść wrażenie, że niemal wszyscy Włosi solidarnie współdziałają w ruchu oporu; choć - jak deklaruje jeden z bohaterów - bez pomocy długo nie pociagna. Anglicy napotkani przez Harriet i Massimo obserwują przez lornetkę walkę, ale bardziej zainteresowani są rozpoznawaniem włoskich zabytków Florencji. W dziele Rosselliniego zostaje zatem podkreślone włoskie osamotnienie w walce $\mathrm{z}$ wrogiem. Angielscy sojusznicy, którzy zatrzymali się po drugiej stronie Arno, przypominają raczej turystów, całkowicie zobojętnianych i głuchych na rozgrywający się wokół dramat.

43 Autor recenzji o inicjałach G.V., „Corriere della Sera” z 19.09.1946. Przedruk w: La resistenza nel cinema italiano 1945-1995, red. Mauro Manciotti, Aldo Viganò, Genova 1995, s. 5. 
Podobną sytuację odnajdziemy w ostatniej noweli Paisy. W epizodzie szóstym samotną walkę z Niemcami prowadzą bowiem wspólnie - wśród rozlewisk Padu - włoscy partyzanci i amerykańscy żołnierze. Wkrótce Niemcy osaczają pozbawiony amunicji oddział. Alianci jako jeńcy wojenni mają być odesłani do obozu, partyzanci zaś są traktowani jako „zdrajcy i buntownicy" (ich dowódca zostaje powieszony, pozostali - strąceni w nurt rzeki z kamieniami u nóg). Jeden z amerykańskich jeńców, który - nie mogąc znieść widoku egzekucji - rzuca się na Niemców, zostaje zastrzelony.

Tragiczny finał w dolinie Padu pokazuje zatem solidarne współdziałanie oddziału aliantów i włoskich partyzantów ${ }^{44}$, choć - jak sugeruje Rossellini - prawdziwymi ofiarami wojny pozostają Włosi. Nie tylko są oni bestialsko potraktowani $\mathrm{w}$ zakończeniu noweli (i filmu); również $\mathrm{w}$ pierwszym ujęciu widzimy pływające w rzece zwłoki włoskiego partyzanta. Co więcej, Niemcy mordują garstkę mieszkających w okolicy rybackich rodzin, które pomagały bojownikom ruchu oporu. Od początku epizodu Rossellini buduje zatem manichejski świat dobra (dzielnych, bohatersko walczących o wolność Włochów, wspomaganych przez Amerykanów) i zła (bezwzględnych Niemców). Naziści w ostatniej noweli Paisy przypominają bowiem nie tyle "zwykłych" zbrodniarzy, co diabelskie moce, pragnące zawładnąć światem. W jednej z ostatnich sekwencji filmu Niemiec stwierdza: mamy wielkie plany; jesteśmy zwycięzcami; nowa cywilizacja [...], ale przedtem trzeba zniszczyć wszystko. Niemcy zapanuja nad światem, to nasza misja.

Podobnie jak $\mathrm{w}$ epizodzie florenckim, w noweli rozgrywającej się wśród rozlewisk Padu włoscy partyzanci wydają się opuszczeni. Pozbawieni pomocy desperacko walczą i tragicznie giną. Jak informuje ponadkadrowy głos w finale noweli (i filmu), To stało się zima 1944. Na poczatku wiosny wojna się skończyła. Wedle Paula Sitneya komentarz ten sugeruje „bezsensowność ukazanej ofiary" ${ }^{45}$. Można jednak również powiedzieć, że taki finał uwypukla przede wszystkim poświęcenie i cierpienie

${ }^{44}$ Można zatem zaryzykować twierdzenie, że stosunki między aliantami a Włochami, w miarę geograficznego postępu wojsk z południa na północ, ulegają z noweli na nowelę transformacji. Perspektywa amerykańska pojawia się w zasadzie w każdym epizodzie. Jak podaje Sitney, film miał początkowo nosić tytuł Siedmiu z USA, a siódmy epizod, który ostatecznie nie powstał, miał rozgrywać się w dolinie Aosty. Inicjatywa powstania Paisy była zresztą przynajmniej w części amerykańska: Foreign Film Production - dostarczycielka sprzętu i funduszy na realizację filmu to bowiem spółka założona przez Roda E. Geigera, zdemobilizowanego żołnierza armii USA. Zob. Paul Adams Sitney, Vital Crises in Italian Cinema, Austin 1995, s. 52.

${ }^{45}$ Ibidem, s. 54. 
Włochów w walce o wolność. Poprzez dramatyczne zakończenie Rossellini buduje włoskiemu społeczeństwu swoisty pomnik pamięci. Wedle logiki narracji, która ilustruje drogę wojsk angielskich i amerykańskich od wylądowania na Sycylii przez Neapol, Rzym, Florencję i dolinę Padu, Paisà powinna zakończyć się zwycięstwem i całkowitym wyzwoleniem kraju. Rossellini domyka jednak opowieść epizodem rozgrywającym się w zimie 1944, a zatem jednym z najbardziej dramatycznych momentów dla włoskiego ruchu oporu, kiedy to partyzanci są zdezorientowani komunikatem Harolda Alexandra (o którym była już mowa), nawołującego do zaprzestania walk. Decyzja o wprowadzeniu licznych obrazów męczeństwa włoskiego narodu (nieprzypadkowo akcja rozgrywa się w różnych regionach kraju) oraz wątku włoskiego ruchu oporu okazała się ważna dla politycznej wymowy filmowego dyskursu. Jak słusznie zauważa Sara Pesce, pozwoliła ona bowiem zatrzeć winę związanych z faszyzmem Włochów, eksponując heroizm tych, którzy polegli za wolność Italii ${ }^{46}$.

\section{Rzym, miasto otwarte: narracja ofiarnicza}

Dzieło Rosselliniego jest powszechnie znane i uważane za arcydzieło włoskiego kina. Można by powiedzieć, pół żartem pół serio, że wszystkie drogi rozmaitych; pisanych z różnych perspektyw, historiografii kina (nie tylko włoskiego) prowadzą do... Rzymu (miasta otwartego). Obszerna literatura poświęcona temu filmowi (jak i twórczości samego Rosselliniego) sprawia, iż wyjście z zaklętego kręgu gotowych szablonów interpretacyjnych wydaje się trudne, a znalezienie nowego, oryginalnego klucza do lektury filmu stanowi nie lada wyzwanie. Świadoma trudności w uniknięciu powtórzeń, chciałabym na wstępie zastrzec, iż niniejsza analiza filmu stoi niejako w opozycji wobec dominującego, interpretacyjnego nurtu. Rzym, miasto otwarte uznawany jest bowiem powszechnie za pierwsze dzieło włoskiego neorealizmu sensu stricto i to właśnie z tej „,neorealistycznej" perspektywy jest zazwyczaj rozpatrywane ${ }^{47}$.

46 Sara Pesce, Memoria e immaginario. La seconda guerra mondiale nel cinema italiano, Genova 2008, s. 75. Podobny sąd wyraża Alicja Helman: „w swym procesie o uniewinnienie i rehabilitację Włoch - bo takim właśnie procesem jest Paisà - Rossellini powołał na świadka samą rzeczywistość". Zob. Alicja Helman, Roberto Rossellini: neorealizm bez granic, [w:] Autorzy kina europejskiego IV, Kraków 2008, s. 155.

${ }^{47}$ Zob. m.in. Alicja Helman, Roberto Rossellini: neorealizm bez granic, [w:] Autorzy kina europejskiego IV, Kraków 2008; Milicent Marcus, Italian Film in the Light on Neorealism, Princeton 1986; Gian Piero Brunetta, Il cinema neorealista italiano da «Roma città aperta» 
Przeważająca większość analiz filmu Rosselliniego skoncentrowana jest na konfrontowaniu samego dzieła z katalogiem wyróżników (głównie estetycznych) zwyczajowo definiujących neorealizm. Pytanie, do jakiego stopnia Rzym, miasto otwarte odznacza się tymi właściwościami, jest dla niniejszego wywodu drugorzędne. Moją intencją jest bowiem takie sprofilowanie analizy, by wydobyć wątki kluczowe dla tematu resistenzy, co oczywiście nie oznacza, że neorealistyczne motywy zostaną z niniejszej interpretacji całkowicie wyłączone. Jest to niemożliwe choćby z uwagi na fakt, iż neorealizm jest integralnie związany z tzw. momentem historycznym; wedle manifestu sformułowanego przez Cesare Zavattiniego w 1953 roku:

\begin{abstract}
Wojna jest kluczowym elementem neorealizmu. [...] Nam Włochom wojna wydała się tym bardziej potworna, że nie znajdowaliśmy żadnej przyczyny, by w niej uczestniczyć, a wręcz przeciwnie mieliśmy wiele powodów, by w niej nie brać udziału. Nie chodziło jednak o protest tylko wobec tej wojny; [...] było to odkrycie absolutne, [...] że wojna zawsze uderza w podstawowe potrzeby i bardzo nam drogie wartości humanistyczne ${ }^{48}$.
\end{abstract}

Neorealizm miał być więc swoistą "szkołą wyzwolenia”, jak chciał André Bazin, ale też sposobem na rozliczenie z przeszłością. Pierre Sorlin zauważa: „Filmując zniszczone wioski i miasta, głodne dzieci i kobiety, Włosi chcieli przekonać aliantów, że byli traktowani jako wrogowie przez Niemców i że zapłacili cierpieniem za błędy epoki faszystowskiej"49.

\title{
Historia „na gorąco"
}

Włoski rząd ogłosił Rzym „miastem otwartym” po raz pierwszy 14 sierpnia 1943 roku - w niecałe trzy tygodnie po upadku Mussoliniego. Decyzję tę, mającą zapobiec wojennym zniszczeniom oraz ofiarom wśród

$a$ «I soliti ignoti», Roma-Bari 2009; Christopher Wagstaff, Italian neorealist cinema: an aestethic approach, Toronto 2007. W polskim piśmiennictwie nie znalazłam oddzielnej analizy poświęconej Rzymowi, miastu otwartemu. Wypada tu nadmienić, że dzieło Rosselliniego było jednym z nielicznych neorealistycznych sukcesów kasowych (innym przebojem był Gorzki ryż De Santisa) - nagrodzone na festiwalu w Cannes w 1946 roku, było także nominowane do Oscara.

${ }^{48}$ Zob. Cesare Zavattini, Neorealizm wedtug mnie, tłum. Krystyna Wojtynek-Musik, [w:] Europejskie manifesty kina, red. Andrzej Gwóźdź, Warszawa 2002.

49 Pierre Sorlin, The Film in History: Restaging the Past, Oxford 1980, s. 190. Na temat neorealizmu jako "szkoły wyzwolenia” zob. André Bazin, An Aesthetic of Realism: Neorealism. Cinematic Realism and the Italian School of Liberation, [w:] idem, What is cinema: Volume II, Berkeley 2004. 
ludności cywilnej (zgodnie z prawem wojennym agresor powinien zaprzestać atakowania danego miasta otwartego) powtórzono raz jeszcze we wrześniu tego samego roku. Została ona jednak zignorowana zarówno przez aliantów, jak i Niemców, i nie miała żadnego wpływu na przebieg wojennych działań. W ulotkach partii komunistycznej, rozprowadzanych w marcu 1944 roku, hasło „Rzym, miasto otwarte” było wykorzystywane w celach propagandowych - wzywało do mobilizacji włoskiego społeczeństwa: („Żądamy poszanowania Rzymu, miasta otwartego. Musimy zjednoczyć się przeciwko przemocy na Rzymie mieście otwartym i na jej tragicznych konsekwencjach" ${ }^{\prime 50}$ ). Tytuł filmu Rosselliniego, odwołujący się do hasła, które dla włoskiego widza w momencie premiery (we wrześniu 1945 roku) było z pewnością znajome, sugeruje zatem, że oto wieczne miasto i jego mieszkańcy są ofiarą obcego najeźdźcy. Wróg zostaje określony w komunikacie otwierającym dzieło: wydarzenia przedstawione w filmie są oparte na dramatycznej i heroicznej historii okupacji nazistowskiej (nie ma mowy o faszystach!).

Akcja filmu obejmuje de facto trzy dni 1944 roku (czasowym znacznikiem jest tu wzmianka o „piekle” pod Monte Cassino). Fabuła składa się z czterech głównych, splecionych ze sobą wątków: 1) inżyniera Manfrediego (właśc. Luigiego Ferrisa) - przywódcy Frontu Wyzwolenia Narodowego, ukrywanego przez zaprzyjaźnionego drukarza, lecz zdradzonego przez sprzedajną kochankę i narkomankę Marinę; 2) komunisty Francesco (drukarza) oraz jego narzeczonej Piny; 3) księdza Don Pietro sprzyjającego partyzantom oraz 4) dzieci, które także są zaangażowane w działalność dywersyjną.

Każda $z$ wymienionych linii fabularnych inspirowana jest $w$ mniejszym lub większym stopniu faktycznymi wydarzeniami. I tak, wedle Roya Armesa, postać Manfrediego była wzorowana na Celeste Negarville’u, komuniście z Turynu, działającym w Komitecie Wyzwolenia Narodowego i późniejszym wydawcy "L'Unità", który - inaczej niż „ekranowy” bohater - przeżył wojnę, a w momencie premiery filmu był jednym z polityków w rządzie Feruccio Parriego ${ }^{51}$. Epizod śmierci Piny nawiązywał natomiast do tragicznej historii Marii Teresy Gullace, ciężarnej kobiety zastrzelonej przez Niemców, gdy biegła za ciężarówką z wywożonym na roboty mężem. W historii Don Pietro nie bez słuszności dopatrywano

${ }^{50}$ Cyt. za: David Forgacs, Space, Rethoric and divided city in "Roma, città aperta", [w:] Roberto Rossellini's ",Rome, Open City”, ed. Sidney Gottlieb, Cambridge 2004, s. 107.

${ }^{51}$ Roy Armes, Patterns of Realism. A Study of Italian Neo-Realist Cinema, New Yersey 1971, s. 90. W dwóch starszych kobietach, które pojawiają się w pierwszej sekwencji (właścicielkach mieszkania, gdzie ukrywa się Manfredi) dopatrywano się zaś pani Riccieri oraz jej pokojówki Nanniny z Piazza Spagna 51, gdzie komunistyczni liderzy Alicata i Ingrao sprawdzali druki „L’Unità” i gdzie przebywał Togliatti, gdy wrócił do Rzymu. 
się losów Don Giuseppe Morosiniego - proboszcza z Santa Melania, rozstrzelanego 4 kwietnia 1944 roku przez gestapo za pomoc udzielaną dezerterom $^{52}$. Rossellini w wywiadach przyznawał zresztą, że początkowo zamierzał zrealizować o duchownym film dokumentalny (podobne plany miał wobec tematu dziecięcej działalności partyzanckiej) ${ }^{53}$.

Inspiracji postaciami rzeczywistymi doszukiwano się także w figurach Niemców. Umberto Barbaro rozpoznał w Hartmannie - Eugena Dolmana (SS Standartenführer), zaś w bezimiennym szefie policji - Pietra Caruso

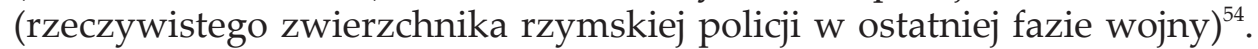
Wedle Milicent Marcus, Eugen Dolman oraz Herbert Kappler (szef Gestapo w Rzymie) byli zaś „prototypami” postaci gestapowca - Bergmanna ${ }^{55}$. Te historyczne afiliacje są istotne o tyle, że tłumaczą po części żywe przyjęcie filmu przez włoską krytykę, która tropiła historyczne aluzje i podkreślała „kronikarski” (!) wymiar filmu. Carlo Lizzani pisał:

wreszcie zobaczyliśmy włoski film! Rozumiemy przez włoski film, realizację, która opowiada o naszych sprawach, i doświadczeniach naszego kraju. Rossellini z Rzymem, miastem otwartym przeniósł na ekran, z kronikarską dokładnością dni opresji i śmierci, które stolica przeżyła pod niemiecką okupacją ${ }^{56}$.

Nadawanie filmowi "quasi-dokumentalnego" wymiaru, z dzisiejszej perspektywy wydaje się oczywistą przesadą: odniesienia do ówczesnych bohaterów włoskiego ruchu oporu, wyraziste w momencie powstania filmu (ponoć w pierwotnej wersji miał on nosić tytuł Storie di yeri-Historie dnia wczorajszego) zblakły. Film otwiera zresztą napis informujący, że wydarzenia przedstawione w filmie [...] sa fikcyjne, a wszelkie podobieństwo do osób i faktów jest czysto przypadkowe - trudno zatem mówić o „fabularyzacji faktów". Prawdą jest jednak, że Rossellini wplótł w swój dyskurs footage uwieczniający obraz wojennych zniszczeń oraz pokazał Włochom miejsca istotne dla kulturowej pamięci, które niosły ze sobą wtedy spory ładunek emocjonalny. Chyba najbardziej znana, wykorzystaną w filmie „autentyczną" lokacją jest pole Forte Bravetta - miejsce egzekucji Don Pietra,

${ }^{52}$ David Bruni wymienia prócz Don Morosiniego także innego księdza - Pietro Papagallo, który miałby być pierwowzorem Don Pietra, a który w czasie wojny także pomagał partyzantom. David Bruni, Roberto Rossellini, "Roma, città aperta", Torino 2006, s. 29.

${ }^{53}$ Wspomina o tym także Alicja Helman, zob. Alicja Helman, op. cit., s. 161.

${ }_{54}$ Zob. przedruk recenzji w: Convegno di studi: La Resistenza nel cinema italiano del dopoguerra (La Biennale di Venezia, XXXI Mostra Internazionale d'Arte Cinematografica), ed. Nedo Ivaldi, Venezia 1970, s. 10.

${ }^{55}$ Milicent Marcus, op. cit., s. 37-38.

${ }^{56}$ Gian Piero Brunetta, op. cit., s. 33. 
gdzie faktycznie rozstrzelano Don Giuseppe Morosiniego. Po wyzwoleniu Rzymu, 10 czerwca 1944 roku, na tym samym polu odbywały się zaś egzekucje wielu faszystów - m.in. Pietro Caruso (23 wrzesień 1944), Federico Scarpato (27 kwietnia 1945) i Pietro Kocha (5 czerwca 1945) ${ }^{57}$.

Rzym, miasto otwarte jest więc ciekawym przypadkiem filmu historycznego (traktującego o zamkniętym okresie włoskiej przeszłości), który został jednak zrealizowany "na gorąco" ${ }^{58}$. W jednym z wywiadów Sergio Amidei, jeden ze scenarzystów filmu przyznawał: „Zrobiliśmy Rzym, miasto otwarte pod wrażeniem i pod wpływem tego, co przeżyliśmy. Więcej, byliśmy wyrazicielami woli podziemnej armii, która chciała zapisać swoją kartę w księdze historii" ${ }^{\prime 59}$.

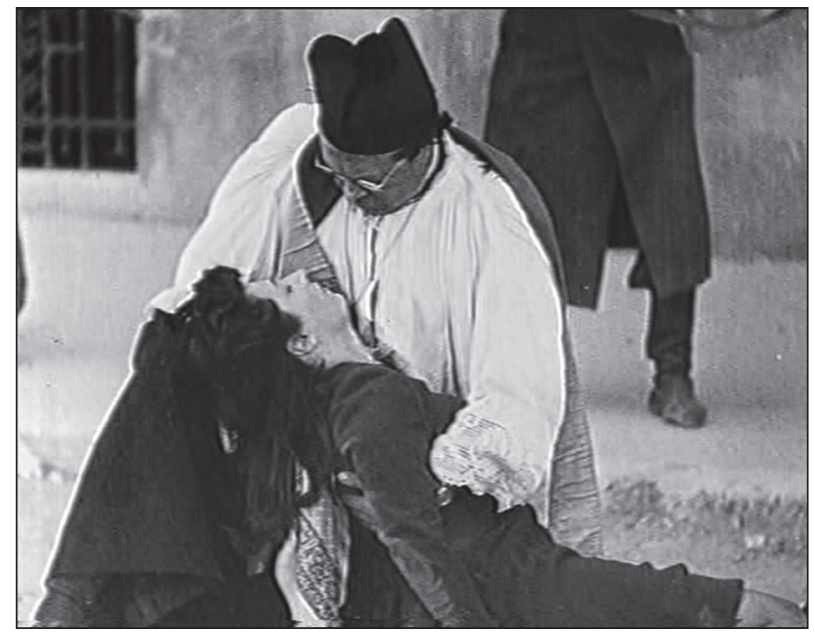

Fot. 1. Rzym, miasto otwarte (reż. Roberto Rossellini, 1945) Tragiczna śmierć Piny - Pieta według Rosselliniego

${ }^{57}$ Federico Scarpato to znany z okrucieństwa funkcjonariusz pracujący w siedzibie gestapo na Via Tasso, zaś Pietro Koch to włoski żołnierz (jego ojciec był Niemcem), lider Łzw. grupy Kocha, która znana była z bestialskiej walki z włoskimi partyzantami. Część tych egzekucji uwieczniono w dokumentalnym filmie Dni chwały (Giorni di gloria; współprodukowanym z Amerykanami), pierwszy raz pokazywanym we wrześniu 1945 roku na tym samym festiwalu, co Rzym, miasto otwarte.

${ }^{58}$ Jak twierdzi Guido Fink, u Rosselliniego nie ma różnicy między prezentowaniem „historii dawnej” a tej „z wczoraj”. Autor Rzymu, miasta otwartego zdaje się różnicować pomiędzy „historia, która jest rzeczywistością zamrożona, umarłą (np. relikwie czy kości w filmie Podróż do Włoch [Viaggio in Italia, 1954]), a historia, która jest życiem i drogą pełną cierpienia między ludźmi". Zob. Guido Fink, Essere o essere stati: il film italiano, il tempo, la storia, [w:] La storia al cinema. Ricostruzione del passato/interpretazione del presente, red. Gianfranco Gori, Roma 1994, s. 33.

${ }^{59}$ Milicent Marcus, op. cit. s. 36. 


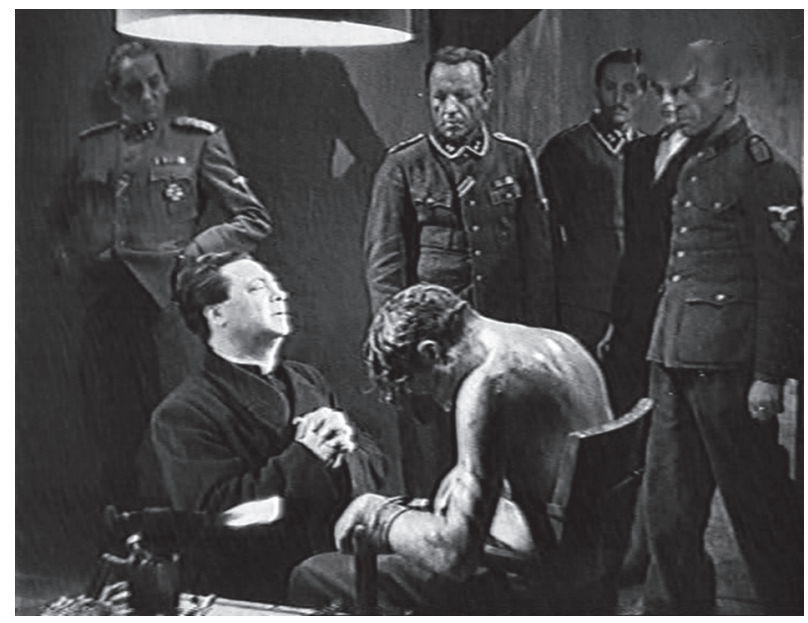

Fot. 2. Rzym, miasto otwarte (reż. Roberto Rossellini, 1945)

Don Pietro i skatowany Manfredi w otoczeniu nazistowskich demonów

\section{Wszyscy Włosi to jedna rodzina}

Nietrudno zauważyć, że niemal wszyscy pierwszoplanowi bohaterowie filmu włoskiego pochodzenia są zaangażowani w ruch oporu. Resistenza animuje niejako działania postaci, pozostając centralnym tematem spajającym wszystkie narracyjne wątki. $\mathrm{O}$ ile zdeklarowany komunista, inżynier Manfredi, jest poszukiwanym przez Gestapo przywódcą Frontu Wyzwolenia Narodowego (nie uczestniczy więc czynnie w dywersji), o tyle ksiądz Don Pietro osobiście wspomaga partyzantów: m.in. przekazuje pieniądze dla jednego z oddziałów ruchu oporu, wystawia fałszywe dokumenty poszukiwanym Włochom oraz ocala broń Romoletta - przywódcy dziecięcej grupy partyzantów, która w toku opowieści detonuje ładunek wybuchowy. Jedynie Pina wydaje się bohaterką wrzuconą w wojenny wir wydarzeń bez politycznej świadomości: wszyscy łudzili się, że wojna szybko się skończy $i \dot{z} e$ będziemy ją oglądać tylko w kinie - mówi Francesco, podkreślając tym samym swój dystans do wojennych działań, które zyskują w jego wypowiedzi charakter „plagi”, którą należy przetrwać (Pina przyrównuje wojnę do uporczywej zimy). Obydwoje jednak pomagają Manfrediemu, postrzegają Niemców jako zło (nienawidzę tych drani, kiedy człowiek widzi te świnie, ma ochotę napluć im w twarz - wyznaje kobieta) i utożsamiają się z ruchem resistenzy. Jesteśmy dobrymi ludźmi, walczacymi o dobra sprawe - stwierdza Francesco, który jako drukarz komunistycznej „L'Unità" rozpowszechnia partyzanckie komunikaty. 
Wśród bohaterów filmu można więc znaleźć zarówno robotnika, jak i księdza; zarówno mężczyzn, jak i kobiety; osoby starsze, ale także najmłodsze pokolenie Włochów, świadome, że - jak mówi synek Piny $-w$ walce $z$ wrogiem trzeba się zjednoczyć. Takie zdywersyfikowanie postaci pod względem płci, wieku, światopoglądu, ale też społecznego statusu, przy jednoczesnym podkreśleniu solidarnego oporu bohaterów przeciw wspólnemu wrogowi, potęguje wrażenie wszechobecności resistenzy. Jest ono zresztą budowane konsekwentnie przez cały film za pomocą epizodów (widzimy np. „przypadkową” - nieznaną z wcześniejszych scen - praczkę pomagającą partyzantom w ucieczce) oraz dialogów, których znaczenie poszerza niejako „szeregi bojowników o wolność": wiem, że inni zapłacili tu życiem za swa lojalność wobec ojczyzny - mówi Manfredi podczas przesłuchania na Gestapo, sugerując tym samym masowy charakter włoskiego ruchu oporu; skatowany komunista zostaje zresztą pochowany pod fałszywym nazwiskiem, aby - deklaruje Bergmann - nie mnożyć męczenników; mają ich już dosyćco.

W Rzymie, mieście otwartym jest scena, gdy nazistowski oficer przegląda gazety, które były wydawane przez partie zaangażowane we włoski ruch oporu. Na ekranie widać wyraźnie strony tytułowe: „Il Popolo”, „L'Unità", „L'Avanti”, ,Voce Operaia”, „L'Italia Libera”, „Risorgimento Liberale" i raz jeszcze "Il Popolo”. Oczywiście, dla ówczesnych widzów było jasne, która partia wydawała jakie gazety. Dla polskich czytelników wypada jednak przypomnieć, że "Il Popolo" to periodyk chadecji, „L'Unità" - komunistów, „L'Avanti” - socjalistów; „L'Italia Libera” wydawana była przez Partię Czynu (Partito d'Azione), zaś „Risorgimento Liberale" - przez Włoską Partię Liberalną (Partito Liberale Italiano). Wszystkie wymienione stronnictwa były członkami wspomnianego wcześniej Komitetu Wyzwolenia Narodowego (CLN), który koordynował działania resistenzy na poziomie narodowym. Przywołana sekwencja przeglądu prasy jest istotna, gdyż ponownie sugeruje, że to całe Włochy - bez względu na poglądy polityczne i wyznanie - brały udział w resistenzy, która tym samym w filmie Rosselliniego ma charakter ruchu ogólnonarodowego.

Taka wizja niedawnej historii spotkała się z entuzjastycznym przyjęciem ze strony włoskiej krytyki. Film był chwalony zarówno na łamach komunistycznej „L'Unità", jak i sympatyzującej z chadecją „Il Popolo”.

${ }^{60} \mathrm{~W}$ Rzymie, mieście otwartym, z uwagi na zdywersyfikowanie postaci oraz ich klarowne portrety psychologiczne, doszukiwano się elementów commedii dell'arte. Na podstawie wyjściowego pomysłu - ukazania Rzymu okupowanego przez nazistów - Rossellini tworzy swoją commedię dell'arte. Por. wypowiedź Adriano Apry zamieszczona w: Dibattito su Rossellini, ed. Gianni Menon, Roma 1972, s. 37-38. 
Carlo Trabucco pisał, że polifoniczna struktura filmu jest reprezentatywna dla całego włoskiego narodu, a prawdziwym bohaterem uczynił Rossellini de facto tytułowy Rzym (a nawet cały kraj), który „cierpi i stawia opór" ${ }^{\prime \prime 1}$.

W Rzymie, mieście otwartym jedynymi „negatywnymi” Włochami (prócz faszystów, o których za chwilę) są kobiety utrzymujące bliskie kontakty z Niemcami: Lauretta (siostra Piny) i Marina (dawna kochanka Manfrediego, która donosi na niego na Gestapo ${ }^{62}$ ). Ta ostatnia jest dodatkowo uzależniona od kokainy; film zawiera także sugestię, że kobieta ma skłonności lesbijskie (jej partnerką i „dilerką” jest Ingrid, Niemka pracująca dla Bergmanna). Pierre Sorlin twierdzi, że postacie, które „zdradzają włoski ruch oporu", traktowane są w Rzymie „jak choroba rodzinna, wstydliwa i niezasługująca na karę"; są zdyskredytowane i umieszczone na społecznym marginesie przez sam nałóg (narkotyki - Marina; alkohol - Lauretta) ${ }^{63}$. Wydaje mi się jednak, że uzależnienie Mariny (nadużywanie alkoholu przez Laurettę nie jest w filmie wyraźnie zasugerowane) nie tyle piętnuje ją i wyklucza z grona "prawych dobrych Włochów”, co niejako usprawiedliwia jej postawę. Marina donosi na Francesco właśnie z uwagi na swój nałóg - jest osobą słabą i chora, której uzależnienie od kokainy jest bezwzględnie wykorzystywane przez Ingrid. Współpracuje więc z Niemcami w stanie odurzenia (Co ja zrobiłam - rozpacza odzyskawszy świadomość i dopytuje się, czy Manfrediemu nic się nie stanie). Co istotne, Marina - podobnie jak Lauretta - pochodzi z proletariatu, jest córką dozorczyni (bawity się w jednej katuży - wspomina Pina). Film zawiera zatem sugestie, że to trudne warunki ekonomiczne pchnęły Marinę "na złą drogę" - do zdrady i kolaboracji z Niemcami, którzy „odurzali” także obietnicą luksusu (za donos Marina dostaje futro) ${ }^{64}$. Tak, miałam wielu kochanków; wszystkie tak robia; inaczej przymieratybyśmy głodem - tłumaczy Manfrediemu ${ }^{65}$.

${ }^{61}$ Zob. Carlo Trabucco (przedruk recenzji) w: Convegno di studi: La Resistenza nel cinema italiano del dopoguerra..., s. 9. Koncept chóralności (pierwszy raz użyty przez Trabucco) został szybko podchwycony przez krytykę i stał się swoistą interpretacyjną kliszą.

${ }^{62}$ Poniekąd analogiczną postacią jest Frau "Kędziorek” z Zakazanych piosenek (reż. L. Buczkowski, 1947). Także w pierwszym polskim filmie o czasach okupacji nośnikiem postawy kolaboranckiej jest kobieta.

${ }^{63}$ Pierre Sorlin, op. cit., s. 199.

${ }^{64}$ Zwraca na to uwagę Milicent Marcus. Zob. Milicent Marcus, op. cit., s. 37-38. Wyjątkiem potwierdzającym regułę byłaby tu Pina, która choć wychowała się w takich samych „trudnych" warunkach jak Lauretta i Marina, nie zeszła na „złą drogę”.

${ }^{65}$ Postać Mariny - jej fryzura, makijaż, ale i związany z kobietą romansowy wątek (zdrady kochanka) nasuwa skojarzenia z włoskim kinem faszystowskim. Marinę pierwszy raz widzimy $\mathrm{w}$ filmie $\mathrm{w}$ sypialni $\mathrm{w}$ atłasowym szlafroku, wśród poduszek $\mathrm{z}$ telefonem 
Wątek kolaboracji z wrogiem rozegrany zostaje zatem $\mathrm{w}$ filmie $\mathrm{w}$ taki sposób, że obie "zdrajczynie" zostają usprawiedliwione (Lauretta także ma przebłysk świadomości - Manfredi ma rację, jesteśmy głupie).

\section{Oblicza wroga}

Faszyści w filmie Rosselliniego mają niewiele wspólnego ze znienawidzonym wrogiem. Pojawiają się na marginesie opowiadania, zaledwie w kilku scenach, ale nigdy nie używają przemocy wobec swoich rodaków. Wręcz przeciwnie, okazują raczej zrozumienie dla innych rzymian (gdy kobiety walczą o chleb przed piekarnia, policjant mówi, że wolałby nie być w mundurze i przyłączyć się do tłumu), a nawet mimowolnie pomagają partyzantom. Faszystowski żandarm wbrew Niemcom pozwala Don Pietro na udzielenie ostatniego namaszczenia choremu, dzięki czemu ocalona zostaje broń schowana w łóżku staruszka, należąca do dziecięcej grupy dywersyjnej; Manfrediemu zaś udaje się uciec, ponieważ włoskie oddziały bardziej niż polityczną akcją zainteresowane są spódniczkami stojących nad nimi kobiet. Jak słusznie twierdzi Bondanella, faszyści w filmie Rosselliniego to zatem raczej sympatyczni, ale nieudolni i nieszkodliwi klowni, wrażliwi na kobiece wdzięki ${ }^{66}$. Żandarm wyjaśnia swoim kolegom z patrolu: przyszła do mnie, żebym pomógł wydostać jej narzeczonego. Przekonała mnie, miała uda, jak bochny chleba.

W scenie łapanki słychać okrzyki: Niemcy i faszyści okrażaja nasz dom, które podkreślają niejako wykluczenie zwolenników Mussoliniego z włoskiego społeczeństwa. Można jednak odnieść wrażenie, że linia wojennego „frontu” przebiega raczej podług tożsamości narodowej (Włosi/Niemcy), a nie afiliacji politycznych (partyzanci/naziści i faszyści). Hipotezę tę potwierdzają epizody (Pina daje np. głodnemu faszyście bułkę, gdy ten odprowadza ją do domu), ale przede wszystkim finałowa sekwencja filmu - egzekucji Don Pietra. Włoski oddział, który ma rozstrzelać księdza-partyzanta, odmawia bowiem wykonania zadania. To Niemiec zabija kapłana, przez co wina przypisana zostaje wyłącznie Niemcom; faszystowskie wojsko „umywa ręce”. Obcość między Włochami a Niemcami wzmacniana

$\mathrm{w}$ dłoni (w filmie kilkakrotnie zresztą dzwoni). Te kadry są jakby wyjęte $\mathrm{z}$ kina białych telefonów (sic!) - eskapistycznego nurtu, który nie miał wiele wspólnego z codziennością widzów (telefon był przed wojna, jak i w jej czasie niemal nieobecnym we włoskich domach, towarem luksusowym, podobnie jak radio, którym dysponuje Marina). Można zaryzykować twierdzenie, że kreując Marinę na kolaborującą femme fatale, Rossellini pośrednio krytykuje właśnie kino reżimu faszystowskiego.

${ }^{66}$ Peter Bondanella, The Films of Roberto Rossellini, Cambridge 1993, s. 54. 
jest dodatkowo przez powziętą przez Rosselliniego decyzję, by Niemcy mówili po niemiecku, a Włosi po włosku (podczas gdy na przykład w filmach amerykańskich "obcy” posługują się albo Oxford English, albo angielskim z innym akcentem, by odróżnić ich od Amerykanów ${ }^{67}$ ).

W Rzymie, mieście otwartym Niemcy - zauważa Alicja Helman - mają w sobie groteskowe rysy demonów zła: zarówno Bergmann, skazujący partyzantów włoskich na tortury i śmierć, jak i jego agentka Ingrid - złowrogi wampir-lesbijka ${ }^{68}$. Okrucieństwo gestapowców podkreślane jest $\mathrm{w}$ filmie za pomocą stosowanej przez nich nagminnie przemocy - zadawane włoskim partyzantom katusze zdają się sprawiać Niemcom sadystyczną przyjemność (Ingrid z uwagą przygląda się katowanemu Manfrediemu $)^{69}$. Diaboliczny charakter nadaje również nazistom ekspresjonistyczne światło w sekwencji tortur lidera resistenzy. Zresztą generalnie Niemcy przynależą w Rzymie... do sfery cienia; kadrowani są niemal wyłącznie w zamkniętych pomieszczeniach, podczas gdy "dobrzy Włosi” identyfikowani są ze światłem. Dobrą ilustracją tego chwytu jest scena prezentująca postać Piny (kobieta po raz pierwszy zostaje ukazana w tłumie Włoszek na zalanej słońcem ulicy) oraz finałowa egzekucja Don Pietra.

${ }^{67}$ Zwraca na to uwagę Paul Sitney. Zob. Paul Adams Sitney, Vital Crises in Italian Cinema, Austin 1995, s. 36.

68 Alicja Helman, op. cit., s. 161. Rzadko podkreśla się natomiast, że aktor grający Bergmanna to austriacki baletmistrz Harry Feist - sławny ówcześnie tancerz będący homoseksualistą. W Rzymie, mieście otwartym mamy zatem skojarzenie "zła” z inną niż heteroseksualna orientacją seksualną.

${ }^{69}$ Scenę tortur Manfrediego skomentował w swej teorii filmu Siegfried Kracauer. Wypowiadając się na temat kinowych reprezentacji przemocy, Kracauer odróżnił postawę drżącego i zachwyconego możliwością bezkarnego uczestnictwa w akcie przemocy widza od postawy świadomego obserwatora. W przypadku sceny tortur Manfrediego, sugeruje Kracauer, Rossellini skłania widza do tego drugiego zachowania (w świecie przedstawionym reprezentuje je Don Pietro; przez pewien czas oglądamy wyłącznie przerażoną twarz księdza). Wedle Kracauera trudno o postępowanie bardziej usprawiedliwione niż przedstawienie widowisk burzących spokój umysłu. W ten sposób film uniemożliwia nam bowiem zamykanie oczu na ślepy napór rzeczy. Te zapatrywania Kracauera, które błyskotliwie komentuje Tomasz Majewski, znajdują się w podrozdziale Głowa Meduzy, umieszczonym pod koniec Teorii filmu (pominiętym w polskim tłumaczeniu). Kino zostaje w opisie mitu o Gorgonie i Perseuszu przyrównane do tarczy, która pozwoliła Perseuszowi zobaczyć to, co w swej bezpośredniości jest niemożliwe do zobaczenia. Bezpośrednio „nie widzimy i nie możemy widzieć rzeczywistych okropności”. Rzecz jednak nie w tym, by zobaczyć obrazy śmierci „na tarczy-ekranie”, ale aby nakłonić widza, „by ściął głowę okropnościom”, które obrazy te ukazują. Zob. Siegfried Kracauer, Theory of Film. The Redemptions of Physical Reality, Princeton 1997, s. 323 oraz Tomasz Majewski, Zobaczyć Gorgonę: Siegfried Kracauer i teoria filmu po Zagładzie, „Kwartalnik Filmowy" 2009, nr 67-68. 
Odbywa się ona bowiem przy bezchmurnym niebie, w ostrym słonecznym świetle. Diabelska konotacja Niemców staje się wyraźniejsza w jednej z wcześniejszych scen, gdy Don Pietro wobec bestialstwa i śmierci przyjaciela przeklina ich słowami z Ewangelii, a gestapowcy bezwiednie cofają się pod wpływem słów kapłana (zbił mnie z tropu ten klecha - powie później Bergmann).

Niemcy niczym demony kuszą do grzechu i zdrady obietnicą bogactwa (Marina), sieją niezgodę (próbują poróżnić księdza z lewicowym patriotą), jawią się w filmie jako aniołowie śmierci i cierpienia - zabijają ciężarną Pinę (osieroca Marcella), Manfrediego oraz Don Pietra. Swoistym komentarzem do okrucieństwa nazistów jest epizod z owieczką. Niemcy przychodzą do restauratora Flavio (który także współpracuje z ruchem oporu) z żywym jagniątkiem, aby ten je przyrządził. Jestem kucharzem, nie rzeźnikiem - deklaruje Włoch. A gdy Niemcy oferują że sami zabiją owieczkę, Flavio z ironią komentuje: zapomniatem, w zabijaniu, jesteście specjalistami.

Jedynym „dobrym” Niemcem wydaje się początkowo Hartmann. Wygłasza on tyradę, w której potępia przemoc oraz krytykuje nazistowską ideologię: Niemcy nie moga zrozumieć, że ludzie pragna wolności. [...] Potrafimy tylko zabijać; cała Europę zasłaliśmy grobami, na których wyrasta nienawiść; nienawiść, która nas osacza i zabije bez litości. Oficer przemawia jednak $\mathrm{w}$ alkoholowym upojeniu (jak wyznaje - upija się co wieczór, żeby zapomnieć o nazistowskich zbrodniach). Na trzeźwo, to właśnie Hartmann zabija Don Pietro, wyręczając w tym faszystowski oddział. Manichejska opozycja dobra i zła pozostaje zatem w filmie nienaruszona - wszyscy Niemcy są źli, a wszyscy Włosi (z natury) dobrzy.

\section{Wątki chrześcijańskie}

W Rzymie, mieście otwartym Rossellini nieustannie podkreśla konsensus komunistów i katolików. Chyba najbardziej wyrazistą tego ilustracją jest współpraca między Manfredim a Don Pietrem (to na prośbę lidera Frontu Wyzwolenia ksiądz włącza się w akcję przekazania pieniędzy partyzantom oraz wystawia mężczyźnie nowe dokumenty), która w toku narracji, za sprawą wspólnych cierpień - więzienia i tortur - przekształca się w silniejszą więź. Bergmannowi nie udaje się poróżnić kapłana z Manfredim; obaj zginą ze świadomością sensu swojego poświęcenia. Gdy Niemiec przypomina księdzu, że komuniści to przeklęci wrogowie kościoła, Don Pietro ripostuje, że wszyscy ludzie, którzy walczą za sprawiedliwość i wolność, chodza ścieżkami Pana. Jak słusznie zauważa Pierre Sorlin, podczas 
gdy Don Pietro co rusz odwołuje się do chrześcijańskiego miłosierdzia, Manfredi nie wspomina o swoich politycznych przekonaniach, przez co poglądy chadecji stają się w filmie bardziej słyszalne ${ }^{70}$. Przekonania komunisty pozostają zatem $\mathrm{w}$ zasadzie niezwerbalizowane; interesujący jest natomiast sposób zwizualizowania ich niezłomności. Torturowany partyzant przypomina ukrzyżowanego Chrystusa, a gdy umiera (jako zadeklarowany ateista) jest przez księdza błogosławiony (Chcieliście zabić jego duszę, ale zabiliście tylko ciało - mówi kapłan Niemcom). Mamy tu zatem do czynienia jeśli nie ze swoistą „,chrystyfikacją” politycznego adwersarza, to z pewnością z podkreśleniem ducha społecznej jedności i swego rodzaju ekumenicznego dialogu. Podobny wydźwięk ma - ostatecznie niesfinalizowany - ślub Piny i komunisty Francesco ${ }^{71}$.

Perypetie Don Pietra i Manfrediego były nawet przyrównywane do losów chrześcijańskich apostołów - Piotra (Don Pietro) i Pawła (Manfredi). Wedle Meyera Schapiro, Manfredi, podobnie jak Paweł - jest początkowo przeciwnikiem Kościoła i jak Paweł umiera pod innym imieniem, bardziej chrześcijańskim od swojego poprzedniego. Rzeczywiście, Don Pietro przygotowuje dla poszukiwanego partyzanta fałszywe dokumenty i to pod nowym nazwiskiem - Giovanniego Episcopo ${ }^{72}$ - śmierć „męczennika ojczyzny" jest zarejestrowana przez Gestapo. Gdyby wyciągnąć z tej analogii dalej idące konsekwencje, okazałoby się, że skoro wcześniejszym wcieleniem Manfrediego byłby Szaweł (który w Listach Apostolskich jest fanatycznym mordercą chrześcijan), wówczas komuniści „przed nawróceniem" zostaliby w tej interpretacji utożsamieni ze zbrodniarzami. Rozpoznanie tych chrześcijańskich konotacji skłania Schapiro do wniosków bardziej już ryzykownych, ocierających się o nadinterpretację. O ile można się zgodzić, że Don Pietro, niczym św. Piotr, stanowi w filmie opokę chrześcijańskiej wiary, o tyle już pewną przesadą wydaje mi się

70 Por. Pierre Sorlin, op. cit., s. 201. Można by jednak argumentować, że pod względem liczby postaci „zdeklarowanych politycznie” przeważają komuniści (Manfredi i Francesco). Być może także postawa komunistów nie wymagała w 1945 roku dodatkowych wyjaśnień, wydawała się widzom „bardziej naturalna”. To jednak wyłącznie domniemanie.

${ }^{71}$ Niezawarte małżeństwo między katoliczką Piną a komunistą Francesco wytwarza skojarzenia z ostatecznie niezrealizowanym kompromisem między chadecją a komunistami - postulatem, który powtórzy się w latach 70. XX wieku. Bliskość obu stronnictw w filmie Rosselliniego podkreślana jest także przestrzennie - w sklepie z dewocjonaliami, w podziemiu mieści się drukarnia "L'Unità" - oraz poprzez dialogi. Drukarz zwraca się do Don Pietra: Księdza pomoc jest nieoceniona, na co ten odpowiada - Mam obowiazek pomagać innym.

72 Episcopo to po włosku „biskup”. Jest to zarazem nawiązanie do opowiadania Gabriele D'Annunzia - Giovanni Episcopo. 
upatrywanie przez Schapiro podobieństwa śmierci obu postaci - Don Pietro zostaje rozstrzelany inaczej niż zwykli więźniowie (ustawiony jest tyłem do wojska) podobnie jak św. Piotr, który także skonał w nietypowej pozycji - został ukrzyżowany do góry nogami ${ }^{73}$.

Wedle Sorlina obecne w filmie wątki chrześcijańskie spełniają funkcje swoistego fundamentu, na którym budowany jest mit powszechnego ruchu oporu; jak pisze, „w kraju podzielonym między Niemców a aliantów, między faszystów a zwolenników króla, wiara katolicka stanowi wspólny mianownik dla Włochów" ${ }^{\prime 74}$. Rzeczywiście, film odwołuje się do niej na różne sposoby: korzysta z chrześcijańskiej ikonografii (skatowany Manfredi, o czym była już mowa, nasuwa asocjacje z ukrzyżowanym Chrystusem), ale jest też przesycony odwołaniami do chrześcijańskich wartości za sprawą jednej z pierwszoplanowych postaci filmu - Don Pietra. Postępowanie księdza oraz jego zaangażowanie w resistenzę wynika z ludzkiego miłosierdzia oraz postrzegania kapłańskiej misji jako niesienia nadziei i pomocy bliźnim. Don Pietro reprezentuje więc w Rzymie, mieście otwartym Kościół tolerancyjny (jest zdecydowany udzielić ślubu ateiście Francesco i ciężarnej Pinie), pełen ludzkiego ciepła, ponad dogmatami. Kapłan słucha więc np. spowiedzi Piny na ulicy, a także udziela ostatniego namaszczenia choremu staruszkowi - po to tylko jednak, aby oszukać Gestapo i ocalić niepełnosprawnego Romoletta oraz zgromadzoną broń.

Zaryzykuję twierdzenie, że w Rzymie, mieście otwartym Rossellini buduje ścisły związek między resistenzq a chrześcijańską (katolicką) wiarą także za pomocą bardzo bliskiego powiązania sakramentów świętych z działaniami włoskiego ruchu oporu. O namaszczeniu chorych (w celach „politycznych”) oraz pokucie była już mowa (Don Pietro wysłuchuje spowiedzi Piny w trakcie akcji przekazywania partyzantom pieniędzy). Można pokusić się jednak o odnalezienie i pozostałych sakramentów oraz nadanych im politycznych afiliacji, które zostały $\mathrm{w}$ filmie rozproszone. Wspominałam już o małżeństwie Piny i drukarza Francesco, które można

${ }^{73}$ Meyer Schapiro, A Note on The open city, "New International” 1946 - przedruk w: James T. Farell, Literature and Morality, New York 1946, s. 312-313. Niekiedy badacze nieco nadgorliwie tropią wątki chrześcijańskie w omawianym filmie i można mieć wrażenie, że nie tyle je odnajduja, ile wytwarzają przez wolną "grę skojarzeń". I tak, wedle Marcus - Bazylika św. Piotra to nawiązanie do postaci Don Pietra oraz sugestia, że jego chrześcijańskie miłosierdzie będzie panować w wyzwolonym Rzymie. Por. Milicent Marcus, op. cit., s. 52. Virgilio Fantuzzi doszukuje się zaś w śmierci Don Pietra nawiązań do cierpienia ukrzyżowanego Chrystusa, a w dzieciach obserwujących egzekucję - płaczących kobiet na Golgocie. Zob. Virgilio Fantuzzi, Riflessi sull'iconografia religiosa nel film "Roma, città aperta” di Roberto Rossellini, „La Civiltà Cattolica” 1995, nr 3489.

${ }^{74}$ Pierre Sorlin, op. cit., s. 201. 
interpretować jako „unię" komunistów i katolików identyfikujących się z partyzantami. Pozostaje: chrzest, bierzmowanie, eucharystia i kapłaństwo (dla jasności: idzie tu o specyficzną transpozycję znaczeń związanych z sakramentami, nie zaś o ich bezpośrednie „zekranizowanie”). I tak, Pina ma nieślubne dziecko, które umiera nieochrzczone, ale fabuła zawiera sekwencję innego „chrztu": narodzin gazety - „L'Unità", rozpowszechniającej istotne dla okupowanych Włoch informacje. Marcello mówi Don Pietro, że nie uczęszcza na katechezę, gdyż w obecnej sytuacji byłoby to stratą czasu. Przygotowuje się do bierzmowania w inny sposób, naśladując walczących w grupie Romoletta starszych kolegów. Sakramentu komunii możemy dopatrzeć się nie tylko w scenie rozdawania chleba, ale także w "ofiarowaniu” baranka (w restauracji, gdzie ukrywają się partyzanci). Nawet kapłaństwo ma swoje odniesienie polityczne - przy czym nie chodzi tu o Don Pietra, angażującego się w ruch oporu, ale o postać Manfrediego. Bergmann nie chce uczynić z lidera partyzantów kolejnego męczennika, więc każe pochować go, o czym była już mowa, pod jego pseudonimem - Giovanni Episcopo (episcopo to po włosku biskup). W finale filmu bohater - ateista - zostaje więc niejako "wyświęcony".

Rzym, miasto otwarte rozpada się na trzy części. Każdą z nich wyznacza śmierć jednej z głównych postaci - Piny (zabitej w pogoni za ukochanym), Manfrediego (skatowanego przez gestapo) oraz Don Pietra (rozstrzelanego w finale filmu). O ile skatowany Manfredi jest stylizowany na Chrystusa, a w egzekucji Don Pietra dopatrywano się odniesienia do losu św. Piotra Apostoła (o czym była już mowa), scenę zgonu Piny pamięta się również przez pryzmat zastosowania chrześcijańskiej ikonografii, konkretnie przez słynne ujęcie ukazujące Don Pietra obejmującego martwe ciało Piny w pozie przypominającej pietę. Pojawia się więc ewangeliczny motyw męczeńskiego ofiarowania życia za sprawę (Don Pietro, Manfredi), ale i cierpienia oraz śmierci niezawinionej; z miłości (Pina).

Bezbronność kobiety podkreślona zostaje dodatkowo przez montaż, który zarazem buduje kolejne konotacje chrześcijańskie. Scena pogrzebu Piny jest bowiem umieszczona $\mathrm{w}$ filmie $\mathrm{w}$ bezpośrednim sąsiedztwie zabicia przez Niemców owieczki przytarganej przez nich do restauracji; powstaje zatem skojarzenie kobiety z niewinną owieczką. Jeśli weźmiemy pod uwagę funkcjonujące we Włoszech utożsamianie figury kobiecej z losami kraju, niewinną ofiarą okaże się Italia ${ }^{75}$. Znaczenie to jest jednak możliwe do uchwycenia i bez znajomości funkcjonujących we Włoszech porównań.

75 Rzeczywiście, w 1944 roku pisarz Corrado Alvaro przyrównał Włochy do „biednej owieczki złożonej w ofierze holocaustu". Zob. Corrado Alvaro, L'Italia rinunzia?, Palermo 1986 (pierwszy raz opublikowane w 1944). 
Sekwencja zarzynania owieczki nasuwa na myśl kolokację „Baranek Boży”, która ponownie kieruje interpretację $\mathrm{w}$ stronę chrześcijańskiej ofiary, niewinności Rzymu i jego mieszkańców, pozostawionych samym sobie (w filmie ani razu nie pojawiają się alianci).

To paraboliczne znaczenie filmowej historii podkreśla także profilmowa przestrzeń. Rzym, w którym rozgrywa się akcja filmu, nie przypomina bowiem znanej na całym świecie stolicy Italii z turystycznych folderów. Prócz finałowego ujęcia prezentującego Bazylikę św. Piotra, w Rzymie, mieście otwartym nie odnajdziemy sławnych architektonicznych zabytków. Forgacs dowodzi przy tym, że w filmie miasto jest „wertykalnie podzielone: przez Niemców widziane z góry, od dołu zaś doświadczane przez mieszkańców oraz ruch oporu" ${ }^{\prime 76}$. Forgacs utrzymuje - biorąc pod uwagę zwłaszcza sposób sprawowania władzy przez Bergmanna, który dowiaduje się o działaniach partyzanckich, nie wychodząc ze swego biura - że film przydziela okupantowi spojrzenie z góry, kontrolujące miasto ${ }^{77}$. Podziemny ruch oporu pozostaje natomiast $\mathrm{w}$ posiadaniu miasta na poziomie ulicy. Jeśli odwołamy się do wytwarzanego przez film skojarzenia Niemców z „wcielonym złem”, okaże się, że Włosi przyjmują tu rolę krzewiących dobro chrześcijan. Nie bez powodu miejsca, gdzie się gromadza, porównywano do katakumb.

Mit ujmujący losy Włoch przez pryzmat cierpienia Chrystusa (tortury Manfrediego byłyby tutaj dosłowną ilustracją męczeńskiej pasji), pokuty i zbawienia (jedna $\mathrm{z}$ wersji scenariusza nosiła tytuł La disfatta di Satana - Klęska Szatana ${ }^{78}$ ) budowany jest także poprzez dialogi. Kiedy skończa się te cierpienia i obawy? Czy Bóg o nas zapomniał? - pyta Pina Don Pietra; w odpowiedzi słyszy: wszyscy zadaja mi to pytanie, gdyż uważaja, że nie zasługuja na te plagę ${ }^{79}$. Ale czy naprawdę żyliśmy zgodnie z przykazaniami Bożymi? Bóg okaże nam miłosierdzie, ale musimy okazać skruchę. Pojawia się zatem motyw wojny jako zarazy (zesłanej deus ex machina), ale i konieczność odkupienia „winy". Choć można upatrywać w tej wypowiedzi odniesienia do epoki faszystowskiej, w filmie Rosselliniego w szeregach Włochów nie ma odpowiedzialnych za przeszłość (wszyscy Włosi - o czym była już mowa

${ }^{76}$ David Forgacs, op. cit.

${ }^{77}$ Kiedy szef włoskiej policji ogląda zdjęcie, na którym uwieczniony jest Manfredi i pyta - Jak go znalazłeś?, Bergmann odpowiada: Spotkałem go tu, na tym biurku. Każdego wieczora robię długi spacer ulicami Rzymu, nie wychodzac z biura. Lubię ten rodzaj fotografii, która tapie ludzi znienacka.

78 Podaję za: David Bruni, op. cit., s. 90.

${ }^{79} \mathrm{~W}$ oryginalnej ścieżce dźwiękowej pada słowo "flagello" oznaczające plagę, nieszczęście (zesłane przez Boga). W języku włoskim funkcjonuje także określenie "flagello di Dio" - bicz boży. „Flagello" to dosłownie bat, bicz. 
- tworzą w Rzymie, mieście otwartym jedną rodzinę, która zmaga się z okupantem). Nie wolno nam się bać przyszłości, gdyż jesteśmy dobrymi ludźmi, walczacymi o dobra sprawe [...]. Może droga będzie długa i ciernista, ale dojdziemy do celu - zapewnia Pinę Francesco, eksponując raz jeszcze wątek pasyjny narracji Rosselliniego.

Jak słusznie stwierdza Sara Pesce:

Poprzez zawarte w filmie wątki chrześcijańskie - Rzym, miasto otwarte zadość czyni kolektywnej opowieści, której potrzebuje kraj pokonany i upokorzony, a która usensowniałaby śmierć, poczucie desperacji i pustki. Rossellini tworzy narrację, która umożliwia przepracowanie narodowej traumy ${ }^{80}$.

Transpozycja chrześcijańskich wyobrażeń poprzez nadanie im sensów politycznych może wydać się ryzykowna i dyskusyjna (a dla osób wierzących - bliska bluźnierstwu). W ten sposób w Rzymie, mieście otwartym, resistenzy zostaje jednak nadana waga ewangeliczna, a przez to - historiozoficzna. Sens Ewangelii w swej istocie nakierowany jest bowiem na przyszłość - film Rosselliniego to zatem nie tylko doraźne "rozliczenie z przeszłością”, ale także zapowiedź „lepszego jutra”, o którym na ekranie mówi wprost Francesco, dodając: nie wolno nam tracić nadziei.

Ostatnia sekwencja filmu to panorama Rzymu, w której centrum znajduje się Bazylika św. Piotra. W środku dolnej części ekranu, na pierwszym planie widzimy zaś grupę Romoletta. Chłopcy schodzą ścieżką w dół, zajmując większość kadru. Zwykło się argumentować, że koniec filmu sugeruje majaczące już na horyzoncie pokój i solidarność. Dzieci wydają się symbolem niewinności, nowego pokolenia oraz nadziei na lepsze jutro $^{81}$. Ten „odkupicielski charakter" narracji Rosselliniego podkreślony zostaje przez imię jednego z chłopców. Nieprzypadkowo nazywa się on przecież Romoletto, czyli Romulus - tak samo jak założyciel Rzymu. Również z tego powodu - ze względu na wyrażone w zakończeniu dążenie do ufundowania "nowego początku” - film Rosselliniego określano jako neorealistyczny. Waga filmu Rosselliniego, zawiera się więc nie tyle w kształcie dzieła (pod względem stylistycznym jest on raczej klasyczny, co wielokrotnie podkreślano ${ }^{82}$ ), lecz w planie treści. Forgacs słusznie

${ }^{80}$ Sara Pesce, Memoria e immaginario. La seconda guerra mondiale nel cinema italiano, Genova 2008, s. 55.

${ }^{81}$ Peter Bondanella, op. cit., s. 60.

82 O klasycznym stylu dzieła Rosselliniego wspomina m.in. Christopher Wagstaff (op. cit.), Adriano Aprà (zob. idem, Il dopoguerra di Rossellini, Roma 1995, s. 12) oraz David Bruni (op. cit.). 
zauważa, że „surowy materiał dokumentu” Rossellini przykrawa tu wedle określonej miary; zamrażając miasto w stanie idealnej wspólnoty tworzy mityczną pamięć wojny zdolną wyprzeć bolesne, traumatyczne wspomnienia - tchórzostwa lub współpracy z wrogiem $^{83}$. Niezależnie od tego, finałowy obraz Romoletta, który wraz z kolegami oddala się od miejsca egzekucji, wydaje się mieć dodatkowy semantyczny potencjał. Mały Romulus - przyszły fundator „nowego porządku” - jest bowiem kaleki. Czyżby film niejako „mimowolnie” zawierał sugestię, że postfaszystowski Rzym (Italia) będzie upośledzony (nierozliczoną) przeszłością?

${ }^{83}$ David Forgacs, op. cit., s. 109. Popularność i sława tego filmu bywa z perspektywy czasu odczytywana jako symptom zbiorowej amnezji, który redukuje do minimum odpowiedzialność Włochów związanych z faszyzmem i zrzuca winę na nazistów. Zob. Sara Pesce, op. cit., s. 57. 


\section{Rozdział IV}

\section{Lata 1960-1968: pół żartem, pół serio}

Lata 60. przez wielu krytyków oraz historyków nazywane są często, nie bez racji, „złotą epoką” włoskiej kinematografii. W tym okresie Półwysep Apeniński stał się bowiem swoistym filmowym imperium (pod koniec dekady w całym kraju istniało prawie 12 tys. kin - najwięcej w skali europejskiej; powstało około 400 nowych wytwórni, m.in. ta należąca do Dino De Laurentiisa oraz przedsiębiorstwo Italnoleggio, mające na celu gromadzenie kapitału umożliwiającego interwencje w zakresie rozpowszechniania filmów; prężnie działała także Cinecittà; dość powiedzieć, że Włochy produkowały wtedy ok. 200 pełnometrażowych filmów kinowych rocznie). Międzynarodowe uznanie kino włoskie zyskało za sprawą trzech autorów - Felliniego, Viscontiego i Antonioniego ${ }^{1}$. Kino popularne zdominowane było zaś w tej dekadzie przez gialli (kryminały), filmy neomitologiczne, spaghetti westerny, które rozsławiły Sergia Leone ${ }^{2}$ oraz sexy films. Ogromną popularnością cieszy się także commedia all'italiana. Wysoka była również artystyczna klasa filmów realizowanych przez mniej znanych reżyserów, o czym świadczą przyznawane włoskim filmowcom nagrody na najważniejszych przeglądach i festiwalach. Te ostatnie, przynajmniej w Italii, przeżywały zmienną koniunkturę: autorytet festiwalu w Wenecji podważyły w 1960 roku kontrowersje związane z przyznaniem

1 Stodkie życie (Dolce vita) Felliniego i Rocco i jego bracia Viscontiego były najpopularniejszymi filmami 1960 roku w Italii. Informację podaję za: Carlo Celli, Marga Cottino-Jones, A New Guide to Italian Cinema, Palgrave 2007, s. 175.

${ }^{2}$ W tej konwencji realizują także swoje filmy m.in. Duccio Tessari (np. Pistolet dla Ringa [Pistola per Ringo], 1965), Sergio Corbucci (Django, 1966) czy Damiano Damiani (El Chuncho, quien sabe?, 1966). Nie mniejszą popularnością cieszyły się filmy neomitologiczne (tzw. peplum) z Maciste (popularnym olbrzymem z Cabirii [1914]), Ursusem, Herkulesem czy Samsonem. Widowni nie przeszkadzało, iż mieszały one swobodnie czasy historyczne, doprowadzając przykładowo do spotkania Maciste z Zorro czy Samsona z Inkami. Por. Peter Bondanella, Italian Cinema from Neorealism to the Present, New York 1997, s. 156. 
nagrody filmowi André Cayatte'a (Przejście nad Renem [Passage du Rhin]) i pominięciem dzieła Viscontiego (Rocco $i$ jego bracia [Rocco e $i$ suoi fratelli]). Werdykt, przyjęty ze wzburzeniem przez jurorów (m.in. Jerzego Toeplitza), stał się impulsem do zorganizowania konkurencyjnej imprezy: jeszcze $\mathrm{w}$ tym samym roku odbył się festiwal w Poretta Terme, mający na celu promowanie dzieł twórców niezależnych, przekształcony w 1965 roku w Festiwal Nowego Kina w Pesaro.

Lata 60. to także stopniowy powrót do pytań o niedawną historię kraju: przede wszystkim o postawę Włochów w czasie reżimu faszystowskiego i wojny. Zainteresowanie filmowców tym tematem korespondowało z atmosfera, która w lipcu 1960 roku doprowadzi do (wspominanych wcześniej) demonstracji przeciw - wspieranemu przez neofaszystowską partię - rządowi Tambroniego. Wtedy właśnie pojawiły się pierwsze, przełamujące milczenie lat 50., filmy o wojennej przeszłości i resistenzy, m.in. Noc nad Rzymem (Era Notte a Roma, reż. R. Rossellini, 1960), Matka i córka (Ciociara, reż. V. De Sica, 1960), Kapò (reż. G. Pontecorvo, 1960), Długa noc 1943 (Lunga notte del 1943, reż. F. Vancini, 1960). Część z nich utrzymana była w tonie humorystycznym; opowiadając o wojnie, włoscy twórcy nie stronili od parodii i autoironii.

W latach 60. za sprawą centrolewicowego rządu (o czym była już mowa) temat włoskiego ruchu oporu powrócił do oficjalnego dyskursu - stanowił bowiem swoistą legitymizację obecnej demokracji. Informacje o antyfaszyzmie i resistenzy pojawiały się coraz częściej w podręcznikach szkolnych i zaczęły istnieć w życiu kulturalnym Italii. W 1966 roku, z inicjatywy Ferruccio Parriego i ówczesnego burmistrza Turynu - Giuseppe Grosso, powstało Narodowe Archiwum Kinematograficzne Ruchu Oporu (L'Archivio Nazionale Cinematografico della Resistenza), organizowano także związane z tym tematem retrospektywy i przeglądy, m.in. cykliczny festiwal filmów o resistenzy w Cuneo. Zmianę, jaka nastąpiła w dyskursie politycznym, dobrze ilustruje strona tytułowa programu tego festiwalu z 1965 roku:

Dlaczego ten festiwal? 1) Żeby ten, kto nie mógł przeżyć resistenzy, mógł ją poznać i zrozumieć jej wagę historyczną. 2) Żeby ten, kto jej doświadczył, mógł przemyśleć motywy ją ożywiające. 3) Żeby ten, kto wie, jak opowiadać, w kinie i w książce zweryfikował efektywność swoich środków wyrazu. 4) Żeby i inni opowiadali oraz pomagali podtrzymywać refleksję o włoskim ruchu oporu ${ }^{3}$.

${ }^{3}$ Cyt. za: Sara Pesce, Memoria e immaginario. La seconda guerra mondiale nel cinema italiano, Genova 2008, s. 162. O tym, że podobne, edukacyjne festiwale były potrzebne zobojętniałemu na historię włoskiemu społeczeństwu przekonuje jedna z opowieści nowelowego filmu Potwory (I mostri, reż. D. Risi, 1963) pod tytułem Zapada niepamięć (Scende 
Istotnym przykładem pure fiction, niezawierającej w swej strukturze materiałów archiwalnych, a rozgrywającej się wyłącznie w przeszłości w stosunku do momentu realizacji, jest film Wszyscy do domu (Tutti a casa, reż. L. Comencini, 1960). Jest on zaliczany do nurtu commedia all'italiana i wpisuje się w szerszą tendencję włoskiego kina lat 60., które na początku dekady powraca do tematu resistenzy, traktując go jednak w formule „pół żartem, pół serio"; w tej konwencji utrzymane są m.in. także Federale ${ }^{4}$ (reż. L. Salce, 1961) oraz Dzień lwów (Un giorno da leoni, reż. N. Loy, 1961), o których będzie jeszcze mowa. Humorystyczne momenty, obecne w zrealizowanych od razu po wojnie włoskich filmach o ruchu oporu (wystarczy przypomnieć słynną scenę ogłuszenia staruszka patelnią przez Don Pietro w Rzymie, mieście otwartym), w latach 60. niejako rozrastają się do autonomicznych fabuł, utrzymanych w komicznym tonie.

I tak, historia żołnierza Alberto Innocenziego (Alberto Sordi), który wraz z kompanami z wojska próbuje wrócić do domu po zawieszeniu broni, pełna jest sytuacyjnych gagów (przykładowo, napotkany przez włoskich żołnierzy Niemiec chce koniecznie zostać więźniem wojennym zgodnie z obowiązującymi konwencjami, a Innocenzi odgania go niczym natrętną muchę). Zresztą już sama reakcja bohatera i jego towarzyszy na rozpoczynającą film wiadomość o rozejmie, zdradza humorystyczny ton filmu, a zarazem oddaje chaos zdezorientowanych informacją Włochów. Innocenzi telefonicznie informuje swojego przełożonego: dzieje się coś nieprawdopodobnego: Niemcy sa sojusznikami Amerykanów, a gdy rozlegają się wybuchy, jest przekonany, że to działanie Jankesów. Ku zaskoczeniu Włochów atakującą stroną okazują się Niemcy (do najzabawniejszych scen filmu można zaliczyć tę, w której Innocenzi wraz z towarzyszami macha powitalnie do nazistów, a ci w odpowiedzi posyłają im serię z karabinu).

l'oblio). Akcja nowelki rozgrywa się w kinie. Para nuworyszy (Ugo Tognazzi i Luisa Rispoli) oglądają film o włoskim ruchu oporu. Ona - ufryzowana, wymalowana, w futrze - bawi się dużym pierścionkiem na palcu; on, w eleganckim garniturze z pomadą na włosach i złotym zegarkiem, wyjmuje złotą papierośnicę i częstuje nią kobietę. W oglądanym przez parę filmie Niemcy ustawiają Włochów pod murem i zabijają jednego, który próbuje uciec. Scena ta nie wywołuje na widzach wrażenia: ona jest wyraźnie znudzona; on spokojnie pali papierosa. Także w filmie młody oficer niemiecki pali, gdy wreszcie znudzony, wypowiada rozkaz Ognia!, żołnierze strzelają a następnie odchodza, zostawiając stos trupów i płaczące dziecko. Para widzów pozostaje dalej obojętna. Nagle on nachyla się nad kobietą i szepcze: O zobacz - mur naszej willi, chciałbym właśnie taki, prosty. Gdy z offu słyszymy kobiece potakiwanie, w obrazie kinowym widać zwłoki rozstrzelanych.

${ }^{4}$ Federale oznacza po włosku wysokiego urzędnika faszystowskiego. Z uwagi na brak adekwatnego polskiego odpowiednika, w pracy postanowiłam pozostawić tytuł oryginalny. 
Włoscy żołnierze w filmie Comenciniego opuszczają front, manifestując w ten sposób swą przynależność do społeczności „ludzi prostych", w gruncie rzeczy niewinnych (nazwisko głównego bohatera - Innocenzi - to po włosku „niewinny”), wplątanych w wojnę przez zewnętrzny przymus. Komunikat o rozejmie wywołuje euforię - wszyscy myśla, że konflikt zbrojny został zażegnany i wrócą wreszcie do swoich domów i rodzin. Po co te lata wojny? - pyta retorycznie spotkany przez Alberto oficer, który radzi protagoniście, by ten przestał paradować w faszystowskim mundurze (rozbudowana scena przebierania się bohatera zdaje się podkreślać włoską łatwość zmiany frontu i adaptacji do nowych okoliczności). Wyłącznie ojciec mężczyzny (bohater odwiedza go, by później kontynuować marszrutę $\mathrm{w}$ towarzystwie swego kompana - neapolitańczyka) pragnie, by zaciągnął się on do nowo tworzonego wojska Republiki Salò. W filmie zawarta jest jednak sugestia, że ojciec protagonisty czyni to wyłącznie z biedy (upatruje w tym możliwość łatwego zarobku). To ona każe solidaryzować się postaci ze starym porządkiem.

Włosi w filmie Comenciniego wydają się zatem pacyfistami, dotkniętymi niezrozumiała, wojenną plagą. Na logiczne pytanie Amerykanina: Dlaczego uczestniczysz w wojnie, skoro ci się nie podoba? Alberto odpowiada z rezygnacją: Cóż może zrobić jeden, wobec wielu? No, ale kilku mogłoby się sprzeciwić?... Wiesz, wszyscy razem - nalega Amerykanin. Jego pytanie trafia już jednak w pustkę - Alberto jest bardziej zainteresowany amerykańskim papierosem niż politycznymi dysputami ${ }^{5}$. W tym sensie między

${ }^{5}$ Amerykanin i Włoch rozmawiają później o kobietach i hollywoodzkim kinie - Innocenzi okazuje się m.in. miłośnikiem Ginger Rogers i Freda Astaire'a. Osobliwa konwersacja inspirowana była ponoć autentycznym wydarzeniem. Jeden ze scenarzystów filmu, Age, przyznaje, że zawarł tu swoje wspomnienia: „Opowiadaliśmy sobie, co pamięta się z 8 września i doszliśmy do wniosku, że 8 września to data niesamowita w historii Włoch, ponieważ trudno uwierzyć, by w jakimś innym kraju lud usłyszał w radiowej audycji, że sojusznik wojenny staje się wrogiem [...] i to bez żadnych wyjaśnień. [...] W zasadzie tak powstała idea, by zrobić film, który byłby zatytułowany Tutti a casa, ponieważ było to zawołanie tamtego czasu; żołnierze po wiadomości o rozejmie mówili: wszyscy do domu, wojna się skończyła". Cyt. za: L' avventurosa storia del cinema italiano raccontata dai suoi protagonisti. 1960-1969, red. Franca Faldini, Goffredo Fofi, Milano 1981, s. 89. Ponoć w pierwotnej wersji filmu Innocenzi w czasie swej podróży po 8 września komentował: Jeśli król ucieka do Brindisi, pozwolisz, że ja ucieknę do swojego domu? Jak wspomina reżyser, po pierwszych pokazach zdanie to zostało usunięte przez "tajemniczego życzliwego". Zob. Memoria, mito, storia. La parola ai registi, 37 interviste, red. Alessandro Amaducci et al., Torino 1994, s. 65. O 8 września i podziałach włoskiego społeczeństwa nieco w innym tonie opowiada Lizzani: „Kilka dni po 8 września, w Rzymie, spotkałem Enrico Fulchignoni, reżysera i krytyka, który wiedział, że podobnie jak on pisuję o kinie. Fulchignoni położył mi rękę na ramieniu i westchnął: «Wreszcie»! Było to bardzo dwuznaczne, ponieważ ja byłem przekonany, 
wierszami (obrazami?) w filmie ujawniona zostaje kolektywna odpowiedzialność Włochów za faszystowski reżim oraz tragedię wojny. Sugestia ta wyrażona jest jednak przez Amerykanina, który w filmie sam staje się źródłem kłopotów dla ukrywającej go rodziny - to przez niego przyjaciel Alberta zostaje aresztowany.

Innocenzi uosabia zatem przywary przeciętnego Włocha, który dba przede wszystkim o własną skórę i biernie poddaje się historycznym "nawałnicom" (w czym można dopatrzeć się podobieństwa do Munkowskiego Piszczyka). Jego uległość oraz zagubienie wytwarza jednak wrażenie, że to on, Alberto, jest ofiarą. Efekt ten jest potęgowany przez filmowy wizerunek Niemców (włoskich wrogów), którzy ukazani są jako okrutnicy i sadyści, strzelający do bezbronnych cywilów. Fakt, że naziści nie są w żaden sposób zindywidualizowani (jawią się jako "bezosobowe” postaci w mundurach), dodatkowo czyni ich "ciałem obcym”, uosabiającym abstrakcyjne zło. Polityczny indyferentyzm Alberta (tzw. qualunquismo) dobrze ilustruje sekwencja, w której Innocenzi spotyka podczas swej wędrówki grupę partyzantów. Co ciekawe, są oni u Comenciniego pokazani jako grupa dość przypadkowa, powstała spontanicznie (nie ma w niej dowódcy; partyzanci są ubrani po cywilnemu, nie mają żadnych oznaczeń, które mogłyby wskazywać na ich działalność). Rozmowa mężczyzn kolejny raz ujawnia społeczną dezinformację. Jak mówia, że wojna się skończyła, to trwa, a jak trwa, to się skończyła - ze stoickim spokojem dochodzi do paradoksalnego wniosku jeden z partyzantów. Pomimo zaproszenia, Innocenzi nie przyłącza się do nich (jest wręcz przerażony, że na wozie z sianem, którym podróżują mężczyźni, znajduje się arsenał broni) ${ }^{6}$.

że to «Wreszcie» odnosiło się do zmiany frontu przez Włochy po 8 września. Nie zorientowałem się, że Fulchignoni wyszedł z teatru Adriano, gdzie słuchał wystąpienia faszysty - marszałka Rodolfo Graziani. «Wreszcie» - kontynuował Fulchignoni - «Republika Salò, prawdziwy faszyzm». Wszystko stało się jasne". Cyt. za: Carlo Lizzani, Cinema, storia e storia del cinema, red. Gualtiero De Santi, Bernardo Valli, Napoli 2007, s. 36.

${ }^{6}$ Innym filmem, w którym Sordi odgrywa „partyzanta z przypadku”, który ceni sobie przede wszystkim własną prywatność, jest Trudne życie (Una vita difficile, reż. D. Risi, 1961). Sam film jest w zasadzie panoramą Włoch od czasów wojny do lat 60. i ekonomicznego cudu. Jak pisał na łamach „Cinema Nuovo” Vittorio Spinazzola, film Risiego jest „parabolą włoskiej demokracji - od powojennego entuzjazmu do politycznego oportunizmu i stagnacji intelektualnej" - Vittorio Spinazzola, Il mestiere del critico, "Cinema Nuovo" 1962, nr 156. Przedruk w: Gianfranco Casadio, La Guerra al cinema. I film di Guerra nel cinema italiano, t. I, Ravenna 1998, s. 219. Partyzanckie losy Silvio Magnozziego funkcjonują tu zatem jako otwierający fabułę epizod. Silvio - ucieka przed Niemcami (jednego przypadkowo zabija) i trafia do młyna, w którym spotyka piękną Włoszkę. Sprawy polityczne w mig odchodzą na dalszy plan. Można odnieść wrażenie, że wojna w ogóle nie istnieje. Głównym problemem bohatera jest bowiem ból zębów... Już po wojnie Magnozzi (z „partyzancką” 
W finale filmu, gdy podczas walk w Neapolu (bohaterowie uczestniczą w słynnym powstaniu) przyjaciel Alberta umiera na jego rękach, Innocenzi chwyta jednak za broń po stronie partyzantów. Film kończy napis informujący o wyzwoleniu Neapolu. Innocenzi z antybohatera przeistacza się więc (dosłownie $\mathrm{w}$ ostatnich minutach) w bohatera (czyżby to znowu Piszczykowy rys?). Można zatem powiedzieć, że jego podróż przez Włochy posiada także sens metaforyczny - z biernego świadka historii, staje się aktywnym jej aktorem (podobnie jak protagoniści filmów Generał Della Rovere [Generale Della Rovere, 1959], Dzień lwów czy Federale, o których za chwilę).

Wymowa filmu Comenciniego jest zastanawiająca (szczególnie w świetle wypowiedzi reżysera deklarującego, że chciał zrobić film dydaktyczny $^{7}$ ): wynika z niego bowiem, że w czasie wojny we Włoszech istnieli albo bohaterscy partyzanci, albo niezainteresowani polityka, a więc w zasadzie niewinni, ",zwykli śmiertelnicy”, którzy choć popełniali błędy, ostatecznie dokonali słusznego wyboru. Ponoć Alberto Sordi proponował inne zakończenie. W wersji aktora, w finale filmu „Innocenzi widzi przechodzących Amerykanów - bogatych zwycięzców - i wyciąga do nich rękę po papierosa. Amerykanin z jeepa rzuca mu paczkę. Upokorzony i pokonany Innocenzi bierze i zapala jednego" ${ }^{8}$. Miast tej gorzkiej puenty, Comencini zaproponował widzom „społeczną katharsis”, dzięki której najgorsi okazują się najlepsi.

W podobnym, satyrycznym tonie utrzymany jest film Federale (reż. L. Salce, 1961). Primo Arcovazzi (Ugo Tognazzi), oddany, lecz nieco ciamajdowaty żołnierz faszystowskiego wojska otrzymuje do wykonania zadanie - ma wziąć w niewolę filozofa Bonafé, antyfaszystę, który w opinii swych zwolenników może zostać prezydentem Republiki. Jeśli misja się powiedzie, Arcovazzi awansuje - zostanie mianowany tytułowym federale (sekretarzem policji faszystowskiej). Lwią część narracji stanowi zatem - podobnie jak w filmie Wszyscy do domu - podróż bohaterów przez Włochy. Tym razem jest to pełna rozmaitych przygód wędrówka Prima i jego więźnia do Rzymu.

przeszłością) pisze wspomnienia z wojny, ale żaden wydawca nie chce ich opublikować. Bohater idzie więc z nimi do kina. Ten epizod można interpretować jako sugestię, że kino to najmniej wymagające medium, ale też medium, które jest blisko życia i historii (wątek kina jest $\mathrm{w}$ filmie podejmowany wielokrotnie - pojawiają się w nim zreszta, pod swoimi realnymi nazwiskami, Blasetti, Mangano i Gassman).

7 „Musiał to być film, który wyjaśniłby historię w sposób prosty, tak by zrozumieli ją także młodzi, którzy nie wiedzieli nic o tym okresie, bo w szkole też o nim nie słyszeli" - deklarował reżyser. Cyt. za: Sara Pesce, op. cit., s. 142.

${ }^{8}$ Wypowiedź Sordiego umieszczona w: Memoria, mito, storia. La parola ai registi, 37 interviste, s. 66. 
Arcovazzi, niezbyt lotny umysłowo, ale sypiący jak z rękawa wyuczonymi na pamięć faszystowskimi formułkami, jest oddany sprawie całym sercem (Primo daje się nawet wtrącić Niemcom do więzienia razem z profesorem, by nie stracić go z oczu). Dobroduszna naiwność żołnierza oraz determinacja, z jaką pragnie on spełnić swoją misję (i marzenie o awansie), każe spojrzeć na bohatera przychylnym okiem? ${ }^{9}$. W istocie Primo, jak słusznie zauważono w ówczesnych recenzjach filmu, wydaje się z natury dobry i kompletnie nieświadomy, że stoi po „niewłaściwej stronie ${ }^{\prime 10}$. Skoro nieświadomy, to także niewinny - chciałoby się dopowiedzieć.

Ciamajdowatość protagonisty z pewnością ośmiesza zwolenników Mussoliniego i jego reżim. Nieudolność wojska sugeruje np. komiczna scena ćwiczeń wojskowych, kiedy z karabinu trzymanego przez Prima odpada lufa. Ćwiczenia odbywają się zresztą przy (ilustracyjnej) muzyce cyrkowej. Skojarzenie faszyzmu z cyrkiem wzmocnione jest dodatkowo przez zachowanie bohatera - w pewnym momencie przeskakuje on bowiem niczym prawdziwy akrobata przez rozżarzoną obręcz. Taka kreacja Arcovazziego-faszysty sugeruje zarazem, że inni Włosi - zdeklarowani zwolennicy Mussoliniego - byli tacy jak Primo; tzn. nie byli faszystami z przekonania (nie rozumieli celów i założeń doktryny), ale raczej dostosowali się w ten sposób do okoliczności, w nadziei na społeczną akceptację.

Primo w swoich działaniach kieruje się "zdrowym rozsądkiem” - tj. dba przede wszystkim o własną skórę (gdy zostaje aresztowany przez Niemców ${ }^{11}$, na pytanie o obowiązek więźnia odpowiada: uciekać). Powodowany własnym bezpieczeństwem zaczyna nawet współpracować ze swoim zakładnikiem - na tyle skutecznie (Włosi konstruują chałupniczo bombę), że udaje im się (w przebraniu wroga) uciec. Zawiązuje się zatem „włoska koalicja” znosząca polityczne podziały. Niemcy to nasi naturalni wrogowie od czasów Attyli - stwierdza profesor, a Primo skwapliwie przytakuje. Protagonista nieintencjonalnie zatem staje się bohaterem - ratuje i chroni szykowanego na prezydenta Bonafé. I choć niekiedy drogi postaci się rozchodzą (profesor próbuje bowiem umknąć swemu nadzorcy), przedziwny zbieg okoliczności powoduje, że odnajdują się na nowo i razem, w trudach dnia codziennego, przychodzi im współpracować. Czyżby

${ }^{9}$ Wędrowcy mają rozmaite przygody (zostają m.in. dwukrotnie okradzeni, ostrzelani przez partyzantów oraz uwięzieni przez Niemców) i są zmuszeni wielokrotnie zmieniać środki transportu (podróżują m.in. motorem, „niezniszczalnym” niemieckim samochodem-amfibia, który niespodziewanie tonie; płyną nawet na pustym baku z samolotu).

10 Zob. np. recenzję Leo Pestelli, Federale, „La Stampa”, 17.09.1961 - dostępna na stronie internetowej: www.ugotognazzi.com/home.htm.

${ }^{11}$ Bohater zostaje aresztowany, gdy okłamuje Niemców, że czytał książkę autorstwa Bonafé broniącą Żydów i bardzo mu się podobała. 
Salce wskazywał w ten sposób, że „postępowa”, wykształcona, antyfaszystowska część Włoch (uosabia ją profesor) musi współpracować z tą druga, reprezentowaną przez Prima - Italią „starego porządku”?

Co istotne, dużą część czasu ekranowego zajmują sceny ukazujące materialne problemy bohaterów (np. zdobycie pożywienia). Brak jest natomiast światopoglądowych dysput, jakie można by sobie wyobrazić w obranym przez reżysera schemacie fabularnym (wspólnej podróży dwóch „politycznych” przeciwników). Można by zatem zaryzykować twierdzenie, że film Salcego wpisuje się w ogólną tendencję włoskiego kina, którego wyróżnikiem jest traktowanie dramatycznego tematu w sposób prozaiczny i koncentrowanie się na codziennych troskach bohaterów ${ }^{12}$.

Taka perspektywa oglądu koresponduje niejako z indyferentyzmem politycznym bohaterów. Choć deklarują oni przynależność do określonych opcji, są tak naprawdę „odklejeni” od wielkiej polityki i zajęci ratowaniem własnej skóry; pozostają zatem w pierwszej kolejności mistrzami włoskiej l'arte d'arrangiarsi (sztuki kombinowania). Swoisty konformizm jest w filmie cechą niemal wszystkich Włochów. Jak pisał na łamach „Cinema Nuovo" Adelio Ferrero, „film Salcego po mistrzowsku uwydatnia qualunquismo nazionale wiecznie żywe w Italii" ${ }^{13}$. I tak, gdy na początku ekranowej historii profesor zostaje przez Prima wzięty do niewoli, na drodze bohaterów pojawiają się uzbrojeni w widły chłopi. Można by zatem przypuszczać, że będą oni chcieli uwolnić - rozpoznawalnego w okolicy - profesora. Wieśniacy jednak ze stoickim spokojem mijają postaci, komentując dość obojętnie, że nawet Bonafé przyłaczył się do faszystów. W chacie, do której trafia profesor po ucieczce z niemieckiego więzienia, czeka kolejne rozczarowanie - gdy bohater opowiada wieśniakom swoje perypetie i ujawnia prawdziwą tożsamość, mając nadzieję, że otrzyma ciepły posiłek, zostaje bez pardonu wygnany za drzwi. Nic nie mamy, jesteśmy biednymi chłopami - krzyczą paesani ${ }^{14}$.

Najwyrazistszym przykładem włoskiego oportunizmu pozostaje jednak w Federale postać pisarza - „obrotowego ideologa”. Bohaterowie trafiają bowiem do domu faszystowskiego poety (Primo obeznany z twórczością wieszcza chce zobaczyć go na żywo). Niestety, rodzina informuje podróżników, że „oddany Mussoliniemu artysta” zginął na polu bitwy w Albanii. Mit bohaterskiego faszysty szybko się jednak kruszy - okazuje się, że poeta ukrywa się na strychu; co więcej, przeszedł obecnie na stronę (rosnących w siłę) partyzantów i to im ma zamiar poświęcić swoje kolejne wiersze.

12 Zwraca na to uwage Sara Pesce, op. cit., s. 137.

13 Adelio Ferrero, Federale, „Cinema Nuovo" 1962, nr 155.

${ }^{14}$ Scena ta jest jedną z bardziej zabawnych, z uwagi na wykorzystanie w niej specyficznego dialektu z regionu Abruzzo. 
W zbrojnej akcji resistenza ukazana jest w Federale tylko raz (partyzanci ostrzeliwują samochód Primo i Bonafé, ale nie rozpoznają uwięzionego profesora). Prócz scen z filozofem, który pozostaje niejako duchowym przywódcą partyzantów, ruch oporu pojawia się tylko na początku i w finale filmu. W otwierającej go scenie widzimy zakonników, którzy z niekłamaną radością witają swoje rodziny, namiętnie całując stęsknione kobiety. Okazuje się, że to bracia-partyzanci ukrywający się w klasztorze przed okupantem. Salce już w pierwszej sekwencji filmu uwydatnia przy tym różnice ich poglądów: bracia nieustannie ze sobą dyskutują o strategii walki i przyszłości Włoch, zażegnując polityczne spory przy... wspólnym posiłku. W finale partyzanci ratują zaś Primo od publicznego linczu (bohaterowie docierają do wyzwolonego niejako deus ex machina Rzymu, gdzie panoszą się zawsze uśmiechnięci Amerykanie $\left.{ }^{15}\right)$. Ruch oporu wydaje jednak na Primo (który wcześniej zakupił i przebrał się w mundur wymarzonego federale) wyrok śmierci. Od kłopotów bohatera wybawia „dawny więzień" - profesor Bonafé, zadeklarowawszy, że to on wymierzy Primo karę; puszcza go jednak wolno. Czyżby to sugestia powojennej zgody i „odpuszczenia win"? Arcovazzi odchodzi, by ponownie odnaleźć się $\mathrm{w}$ nowej rzeczywistości... ${ }^{16}$

$\mathrm{O}$ „bohaterach z przypadku” opowiada także Dzień lwów (Un giorno da leoni, reż. N. Loy, 1961). Historia trzech przyjaciół (Michele, Danillo i Gino), którzy po zawieszeniu broni w 1943 roku $^{17}$ próbują przedrzeć się na „bezpieczne” tereny zajęte przez aliantów, pełna jest sytuacyjnych gagów (wystarczy wspomnieć choćby humorystyczną scenę, gdy Michele ukrywa się przed Niemcem w toalecie). Traf sprawia jednak, że na swej drodze spotykają grupę partyzantów, którzy pod dowództwem Orlando mają za zadanie wysadzić most - strategiczny punkt tranzytowy.

Przebywając $\mathrm{w}$ towarzystwie partyzantów, którzy dalecy są od spiżowych herosów (nieobcy im jest strach; nawet łącznik Eduardo, który ostatecznie umiera w więzieniu, nie zdradziwszy towarzyszy, ma swoją achillesową piętę - narzeka na prawą stopę [!]), mężczyźni decydują się przyłączyć do „dywersyjnej akcji”. Przy czym nie jest do końca jasne, czy

15 Amerykanie pytają Primo - jesteś faszysta? A gdy bohater przytakuje, robią mu zdjęcie, tak jak byłby on muzealnym eksponatem.

16 „Finał filmu to fraternizacja między Italiani brava gente, niezależnie od tego czy noszą czarne koszule czy mieszczański garnitur i krawat" - podsumowywał Lino Miccichè. Zob. Lino Miccichè, Il cinema italiano degli anni '60, Venezia 1975, s. 49.

${ }^{17}$ Komunikat radiowy o zawieszeniu broni rozpoczyna film. Wśród ludności wybucha wtedy euforia radości, co od początku sugeruje, że wojna, w której uczestniczą Włosi, jest przez nich niechciana. 
czynią to z przekonania (przeistoczywszy się, pod wpływem widoku powieszonych na miejskim placu partyzantów, z obojętnych italiano medio w świadomych powagi historycznej chwili bohaterów) czy też z lenistwa (tzn. nie są w stanie zmienić nowej sytuacji i towarzystwa, w jakich się znaleźli). Za tą drugą hipotezą przemawia reakcja Michele, który w jednym z nielicznych poważnych momentów filmu - na widok wystawionych na pokaz trupów - zdejmuje okulary (by nie widzieć zbrodni); tymczasem Orlando (chyba jedyny w całym filmie „partyzant z wyboru”) deklaruje: Nie możecie tego nigdy zapomnieć, nigdy!

Choć motywacja postępowania trójki przyjaciół nie jest klarowna, w finale filmu uczestniczą oni w akcji wysadzenia mostu (Michele traci w niej życie). Akcja przeprowadzona została tak perfekcyjnie, że Niemcy w komunikacie radiowym podaja iż była ona... sabotażem amerykańskich spadochroniarzy. Partyzanci i bohaterowie z przypadku przeżywają więc w cichości swój „dzień lwów”, choć tytuł ten wydaje się nieco ironiczny. Swoistym refrenem filmu jest bowiem faszystowska pieśń Bataliony Duce (Battaglioni del Duce), wysławiająca „lwy” Mussoliniego, mające zapewnić mu zwycięstwo. Przyjaciele, którzy przy padkiem zmieniają front (początkowo Michele chce pracować w Republice Salò, a Danilo nie zaciąga się do faszystowskiego wojska tylko dlatego, że boi się śmierci), przeistaczają się z tchórzy w herosów włoskiej partyzantki. Fakt, że zastępy biernych i niezdolnych do podjęcia działania na własną rękę "lwów Mussoliniego" są cały czas spore, sugeruje ostatnia scena filmu - w czasie komunikatu o sabotażu oglądamy gimnastykę młodych faszystów. Raz, dwa, trzy, cztery, od poczatku - powtarza beznamiętnie raz po raz nauczyciel. Kamera ukazuje jego twarz w zbliżeniu - puste oczy i monotonny głos sprawiają wrażenie, jakby Włoch działał "automatycznie”, bez przekonania. W pewnym momencie milknie (wydaje się, przez moment, że coś zmieni), ale... po chwili od nowa powtarza komendy.

Filmem wpisującym się w omawianą strategię reprezentacji resistenzy jest także Zamachowiec (Terrorista, reż. G. De Bosio, 1963). Debiut filmowy związanego z teatrem i operą De Bosio, który sam był partyzantem, przełamuje mit ruchu oporu jako fenomenu jednolitego i spójnego ideologicznie. Akcja filmu rozgrywa się w ciągu kilku dni grudnia 1943 roku w Wenecji (należącej wówczas do Republiki Salò). Po kolejnej partyzanckiej akcji przeciwko okupantom (wybuch w komendanturze) Niemcy grożą rozstrzelaniem zakładników, jeśli nie ujawnią się sprawcy zamachu. Miejscowy Komitet Wyzwolenia Narodowego, grupujący przywódców wszystkich stronnictw podziemia, postanawia, ze względu na sytuację ludności cywilnej, zaniechać czynów zbrojnych i wystąpić, poprzez autorytety duchowne, o zwolnienie zatrzymanych w zamian za deklarację 
spokoju; chrześcijańskim demokratom po dyskusjach z komunistami udaje się osiągnąć porozumienie. Nim jednak wiadomość dociera do grupy sabotażowej "inżyniera” Braschiego, ta podejmuje następne zamachy. „Inżynier" zgadza się na odstąpienie swojej działalności, jednak nie bezwarunkowo: zabija komendanta SS odpowiedzialnego za represje, a $\mathrm{w}$ finale filmu sam ginie.

Reżyser, traktując o wydarzeniach znanych z autopsji, akcentuje polityczne różnice wewnątrz włoskiego ruchu oporu (każdą decyzję poprzedzają długie dysputy). Jak przyznawał w jednym z wywiadów: „Obraz mitycznej, wyidealizowanej resistenzy, w której wszyscy się zgadzają i w której wszyscy sięgają po broń, [...] wydaje mi się sztuczny. Ruch oporu był $\mathrm{w}$ istocie fenomenem bardzo złożonym, $[\ldots]$ niewolnym od dyskusji i różnicy zdań. Przy czym nie dotyczyły one wyłącznie podziałów ideologicznych, ale także formy walki. Te kontrasty powodowały polityczne napięcia i moralne dylematy dużego kalibru"18.

W filmie mamy zatem „inżyniera” Braschiego (Gian Maria Volonté) - tytułowego zamachowca i reprezentanta weneckiego GAP - który zdeterminowany do walki, wbrew oficjalnym rozkazom głównego "sztabu resistenzy", organizuje na własną rękę dywersyjne akcje, nie dbając przy tym o ich ewentualne konsekwencje. Z drugiej zaś strony, koordynować działania partyzantów chce Komitet Wyzwolenia Narodowego, skłaniający się ku „polityce umiaru”. Reprezentanci wszystkich partii podziemia (w dyskusji uczestniczą: chadek, komunista, socjalista, przedstawiciel partii liberalnej oraz Partii Czynu) powątpiewają w sensowność akcji ,,inżyniera" (represje wobec włoskich cywilów są bowiem coraz dotkliwsze). W trakcie kluczowej, kilkunastominutowej sekwencji debaty - w której chyba najsilniej ujawnia się predylekcja sceniczna reżysera do obfitego dialogu - działania Braschiego zostają nawet nazwane terrorystycznymi. To mocne określenie jest jednak od razu zniwelowane przez wypowiedź profesora De Cevi prowadzącego zebranie. Mówi on bowiem: Nie chce słowa terroryzm w naszym protokole. Teroryzmem sa akcje Niemców i trupy, które rozłożyli oni wzdłuż ulicy. Odpowiedzialnym za terroryzm jest Platzkommandant ${ }^{19}$. Oglądając film, trudno orzec, która z zaprezentowanych postaw jest faworyzowana. O intencjach autora scenariusza zaświadcza natomiast określający go wstęp:

18 Wypowiedź umieszczona w: Marco Bongioanni, I film della resistenza, Torino 1965, s. $61-62$.

${ }^{19}$ W filmie, w czasie dyskusji pojawia się też wątek Kościoła kolaborującego z faszyzmem, ale zostaje on niejako zniwelowany przez postać księdza, który pomaga partyzantom, choć nie chce wiedzieć o szczegółach akcji. 
By obudzić kraj uśpiony przez dwadzieścia lat faszyzmu, należało zrobić trzęsienie ziemi. Cena krwi się nie liczyła. Problem moralny jest nie do rozwiązania. Problem polityczny, który w ten sposób został rozwikłany przez historię, przyznaje rację zamachowcowi/terroryście ${ }^{20}$.

Zamachowiec zawiera informację, że „wydarzenia przedstawione w filmie [...] są fikcyjne”, a „wszelkie podobieństwo do osób i faktów jest przypadkowe”. Choć trudno tu więc mówić o "fabularyzacji faktów”, realizacja De Bosio odwołuje się przynajmniej do dwóch istotnych wydarzeń dla weneckiej resistenzy (choć nie przestrzega ich faktycznych dat): nawiązuje do zamachu na siedzibę faszystowskiego sztabu oraz rozstrzelania przez Niemców (w odwecie za śmierć jednego nazisty) siedmiu partyzantów. Sylwetki niektórych bohaterów filmu są zaś inspirowane postaciami rzeczywistymi. $\mathrm{W}$ jednym $\mathrm{z}$ wywiadów reżyser deklarował: „prawie wszyscy bohaterowie w Zamachowcu mają dla mnie swoje imię i nazwisko. Wiem doskonale, kim są"21. I tak, inspirację dla „inżyniera” Braschiego stanowi postać Otello Pighina (pseudonim Renato) - komendanta brygady weneckiego GAP, odznaczonego złotym medalem ruchu oporu, który zginął w walce w 1945 roku. Uczestniczący w debacie komunista Piero wzorowany jest zaś na partyzancie Idelmo Mercandino (alias Piero), weteranie hiszpańskiej wojny domowej, w którego oddziale - już we Włoszech - walczył De Bosio ${ }^{22}$; w filmie Piero antycypuje niejako wspominany już koncept Togliattiego (wyrażony przez tego polityka w 1944 roku w Salerno) o unii wszystkich sił antyfaszystowskich. Wreszcie profesor De Ceva zainspirowany został postacią Egidia Meneghetti - prorektora uniwersytetu w Padwie, związanego z Partią Czynu, który był ponoć w bliskim kontakcie $\mathrm{z}$ „inżynierem” Pighinem (w filmie „inżynierem" Braschi). Analogie między postaciami na tym się nie kończą.

${ }^{20}$ Gianfranco De Bosio, Luigi Squarzina, Il terrorista, Vicenza 1963, s. XI. Inżynier Braschi w swoim nieposłuszeństwie wobec rozkazów sztabu partyzantów i działaniu na własną rękę przypomina nieco bohatera filmu Garbus (Il Gobbo, reż. C. Lizzani, 1960; polski tytuł podaję w tłumaczeniu własnym). Tytułowy bohater Alvaro Coscenza (wzorowany na autentycznej postaci Giuseppe Albano) jest, jak pisał Adelio Ferrero: „trochę jak Robin Hood, trochę jak pospolity przestępca. Nie jest to postać negatywna, ale indywidualista; rebeliant z powołania, okrutny dla faszystów i nazistów, czuły dla prostytutek i dzieci" (Adelio Ferrero, Il Gobbo, "Cinema Nuovo” 1961, nr 149. Przedruk w: Gianfranco Casadio, op. cit., t. I, s. 298). Wbrew rozkazom, „garbus” nie składa broni po wyzwoleniu Rzymu, ale walczy dalej, stając się w oczach wielu zwykłym rzezimieszkiem. Ostatecznie ginie wraz ze swoją ukochaną z rąk „przyjaciół” - przy udziale Amerykanów.

${ }^{21}$ Marco Bongioanni, op. cit., s. 62.

${ }^{22}$ Giuseppe Ghigi, La memoria inquieta. Cinema e resistenza, Venezia 2009, s. 142. 
Aby uniknąć aresztowania, Meneghetti - podobnie jak De Ceva w filmie - schronił się w 1944 roku w klinice w Padwie, ale ostatecznie został zadenuncjowany i aresztowany.

Traktujący o przeszłości Zamachowiec był jednak także odczytywany przez pryzmat współczesności ${ }^{23}$. Wymowy politycznej dopatrywano się szczególnie w scenie, w której Braschi zwierza się swojej ukochanej żonie:

Czasem myślę o tych, którzy zginęli w latach 20., by zatrzymać faszystów przed ich dojściem do władzy [...]. A następnie myślę o tym, co zdarzyło się później, kiedy wszyscy wydawali się usatysfakcjonowani... Panowała atmosfera nudy i sytości. [...] Czasem myślę, czy w przyszłości znowu będzie okres, w którym ludzie zostana uśpieni... zasna syci, otoczeni spokojem i nadmiarem. I dla dóbr materialnych będa gotowi ponownie wszystko zaprzepaścić... Wolność... Więc pozostaje walka, ale jest nas niewielu.

W wywiadach De Bosio udowadniał, że taki -,,sceptyczny" wobec przyszłości - dialog mógł mieć w czasie wojny miejsce. Trudno jednak nie oprzeć się wrażeniu, że nawiązuje on bardziej do czasu realizacji filmu, do lat 60 . Braschi byłby w tej optyce porte-parole młodych, wedle których duch resistenzy i związanej z nią nadziei na zmianę został zaprzepaszczony; dobrobyt spowodował zaś bezkrytyczną akceptację konserwatywnych rządów chadecji. Co ciekawe, dekadę później - w rozpolitykowanych anni di piombo - „inżynier" Braschi został okrzyknięty lewackim compagno avant la lettre (nie bez znaczenia była tu obsada aktorska - Gian Maria Volonté stał się bowiem w latach 70. ikoną włoskiego kina politycznego). Jak zauważa Alan O'Leary, odseparowany od społeczeństwa zamachowiec miał antycypować figurę terrorysty „na wygnaniu” - poza prawem, która pojawi się we włoskim kinie „dekady ołowiu" ${ }^{24}$.

\section{Z perspektywy współczesnej}

Nagrodzona w Wenecji w kategorii filmowego debiutu Długa noc 1943 (reż. F. Vancini, 1960), która pod względem strategii ewokowania tematu resistenzy sytuuje się $\mathrm{w}$ grupie realizacji, które mają poszerzony horyzont

${ }^{23}$ Zob. Christian Uva, Schermi di piombo. Il terrorismo nel cinema italiano, Rubbettino 2007, s. 14. Jak wspomina De Bosio, we Francji film został o wiele lepiej przyjęty niż we Włoszech. Był on bowiem prezentowany i polecany przez samego Sartréa. Krytyka francuska została w ten sposób od razu nastawiona pozytywnie. Wypowiedź w Memoria, mito, storia. La parola ai registi, 37 interviste, s. 72.

${ }^{24}$ A. O’Leary, Tragedia all'italiana. Cinema e terrorismo tra Moro e Memoria, Tissi 2007, s. 39. 
narracji - zawierają w swej strukturze współczesną ramę narracyjną (wprowadzająca retrospekcje lub closure „po latach”) - zainspirowana została opowiadaniem Giorgio Bassaniego o niemal identycznym co film tytule: Noc $1943^{25}$. Akcja filmu rozgrywa się jesienią 1943 roku. Do rodzinnej Ferrary powraca zdemobilizowany Franco Vilani. Jego dawna narzeczona Anna jest obecnie żoną aptekarza - sparaliżowanego i przykutego do inwalidzkiego wózka. Stłumione rozłąką uczucie między dawnymi kochankami odżywa. Anna decyduje się wreszcie umówić z Franco na nocną schadzkę. Tej samej nocy miejscowi faszyści, korzystając z poparcia burmistrza-faszysty, szykują krwawą rozprawę ze swymi politycznymi przeciwnikami. Kilkunastu z oponentów reżimu zostaje uprowadzonych i zabitych (wśród nich ojciec Franca).

Przez pryzmat perypetii miłosnego trójkąta Vancini podejmuje zatem trudny temat bratobójczej rozgrywki. Inaczej niż w większości włoskich filmów tamtych lat, faszyści (jeśli w ogóle pojawiają się na ekranie) nie są tu sympatycznymi, zagubionymi ciamajdami, ale ludźmi okrutnymi, nieznającymi litości. Co istotne, epizod zabójstwa zwolenników ruchu oporu, stanowiący punkt kulminacyjny, pozostaje jedyną sekwencją ukazująca w filmie działania wojenne (w tym wypadku nie jest to walka, lecz egzekucja bezbronnych antyfaszystów). Choć zatem o zbrojnym konflikcie dyskutuje się na ulicach i w kawiarniach, front wojenny przebiega daleko, poza granicami Ferrary. Wojna i resistenza obecne są wyłącznie „w słowach" - tak jak w domu Franco, gdzie mówi się o akcjach wyzwoleńczych i konieczności działania, ale nie wciela się tych poglądów w życie. Wszyscy pozostają bierni; ideały stanowią swego rodzaju wygodne alibi.

Społeczna inercja podkreślona zostaje przez postać sparaliżowanego Pino, który jest niemym świadkiem tragicznych wydarzeń. Mężczyzna obserwuje świat z okna swojego salonu. Jego bierna - wymuszona chorobą - postawa wobec oglądanych zdarzeń jest w filmie wielokrotnie podkreślana. Pino, podobnie jak Jeff z Okna na podwórze (Rear Window, reż. A. Hitchcock, 1954) unieruchomiony w swym mieszkaniu na wózku inwalidzkim, jest niczym widz, który obserwuje świat, wiedząc zarazem, że od oglądanych wydarzeń dzieli go „bezpieczny” dystans. Skojarzenie

${ }^{25}$ Opowiadanie to znajduje się w zbiorze Pięć historii ferraryjskich (1956). O różnicach między literackim pierwowzorem a filmem traktuje artykuł Federiki Villa - zob. Federika Villa, A writer cannot believe two stories at once: Modes of adaptation in "La lunga notte del '43" (Florestano Vancini, 1960), [w:] Watching Pages, Reading Pictures, red. Daniela De Pau, Georgina Torcello, Cambridge 2008, s. 279-294. Bassani jest znany głównie jako autor, przeniesionej zresztą na ekran, powieści Ogród rodziny Finzi-Continich (1962). 
z seansem filmowym nie jest tutaj przypadkowe. W Długiej nocy 1943 wątek kina został bowiem wyeksponowany - bohaterowie oglądają filmy (m.in. hit tamtych lat Fiołki we włosach [Violette nei capelli, reż. C. Bragaglia, 1941]) oraz je komentują (filmy włoskie opowiadaja głupstwa, podczas gdy lepsze sa filmy amerykańskie). Przypatrywanie się z dystansu i nieangażowanie się w obserwowaną rzeczywistość stanowi komentarz do postawy wielu Włochów w czasie wojny. Można zaryzykować twierdzenie, że ich bierność wobec politycznych zdarzeń i skupienie na problemach prywatnych sugerowane są także poprzez strukturę narracyjną filmu. Zabicie zwolenników ruchu oporu przez faszystów zbiega się bowiem z wydarzeniem miłosnym - momentem zdrady przez Annę jej męża. Decyzja o porzuceniu Pina następuje zaś zaraz po rozbudowanej sekwencji oglądania ciał poległych. Za każdym razem wielka historia wojenna niwelowana jest zatem przez tę prywatna, miłosną.

Co istotne, Franco - spadkobierca poglądów ojca i nieprzejednany przeciwnik reżimu Mussoliniego - ucieka do Szwajcarii; odcina się zatem od polityki i kultywowanej $\mathrm{w}$ domu tradycji resistenzy. W finale, piętnaście lat po wojnie (film zawiera współczesne "domknięcie” po latach), mężczyzna wraca do Ferrary wraz ze szwajcarską żoną i dzieckiem, by pokazać synowi grób dziadka - pamiątkową tablicę uwieczniającą mord sprzed lat. Niespodziewanie pojawia się dawny burmistrz, dziś nobliwy staruszek (uczestnik i sprawca okrutnej egzekucji), z którym Franco, znając prawdę, wita się jakby nigdy nic. Na pytanie żony, kim był „serdeczny znajomy”, mężczyzna odpowiada: w przeszłości byt kimś w rodzaju faszystowskiego dostojnika, ale nie wierzę, że kiedykolwiek zrobił coś złego.

Jak wynika z filmu, faszyści nie zostali zatem rozliczeni i ukarani za wojenne zbrodnie. Cały czas żyją i mają się dobrze w powojennej rzeczywistości Włoch. Riposta Franco sugeruje także swoiste wypaczenie pamięci - wymazanie niewygodnej przeszłości kraju. Na pamiątkowej tablicy nie ma słowa o sprawcach egzekucji. Widnieją tam wyłącznie nazwiska ofiar, data i napis „poległym za wolność”. Jak słusznie zauważa Ghigi, ukazana w filmie tablica pamięci to tak naprawdę pomnik klęski: faszyści żyją w Ferrarze, stopniowo zacierając faktyczny przebieg wydarzeń, w którym mieli swój udział ${ }^{26}$. Czyżby więc Vancini sugerował, że tytułowa „długa noc" skrywająca mroczną przeszłość trwa nadal, w piętnaście lat po zakończeniu wojny?

${ }^{26}$ Por. Giuseppe Ghigi, op. cit., s. 119. 


\section{Materiały archiwalne}

Rossellini, po sukcesie Generała Della Rovere (analizowanego w dalszej części pracy), ponownie powraca do tematu II wojny światowej i włoskiego ruchu oporu w Nocy nad Rzymem (Era notte a Roma, reż. R. Rossellini, 1960), tym razem czyniąc fabularną osią fikcyjne losy trzech aliantów: angielskiego majora Michaela Pembertona, amerykańskiego porucznika Petera Bradley i... sowieckiego sierżanta Fiodora Nazukowa. Akcja rozgrywa się po zawieszeniu broni (po 8 września 1943). Trójka uciekinierów z rzymskiego więzienia początkowo jest ukrywana przez odważną Włoszkę - Esperię ${ }^{27}$. Po nawiązaniu kontaktów z włoskimi partyzantami i dekonspiracyjnej wpadce Amerykanin i Anglik (Rosjanin zostaje zabity) znajdują azyl u włoskiej arystokracji, by następnie przenieść się do klasztoru. Film kończy się wyzwoleniem Rzymu.

Trzeba przyznać, że fabuła Nocy nad Rzymem jest miejscami nieprawdopodobna (pomijając już dość zaskakującą obecność Rosjanina wśród anglojęzycznych sojuszników Włoch, razi nieco kryjówka aliantów, przypominająca przestronny apartament, jak również fakt, że bohaterowie swobodnie wychodzą na ulicę, pomimo deklarowanej „,ścisłej konspiracji”) i mało spójna (pierwszoplanowa postać Esperii w pierwszej części filmu później kompletnie znika, by powrócić w finale niejako na zasadzie deus ex machina). Film pozostaje jednak ciekawą wypowiedzią o włoskiej resistenzy - ukazuje bowiem nie tylko ruch oporu, który walczy z okupantem poprzez działania militarne (Noc nad Rzymem zawiera dość rozbudowaną sekwencję przygotowywania przez partyzantów środków wybuchowych), ale także podkreśla rolę spontanicznej resistenzy "nie-politycznej” ${ }^{28}$, która aktywnie przeciwstawia się wrogowi, pomagając "mundurowym”. W sukurs aliantom przychodzą zarówno pochodząca „z ludu” Esperia oraz jej narzeczony Renato, jak i opływająca w luksusy włoska arystokracja. Ogólnonarodowa odwaga i heroizm Włochów eksponowane są już na początku

${ }^{27}$ W filmie Rosselliniego ponownie pojawia się (obecny w twórczości reżysera) wątek zderzenia kultur i związanych z tym nieporozumień. W jednej ze scen wykorzystano grę słowną: ",voglio te" $i$,tè" („,chcę ciebie" i „,chcę herbaty"). Różnica w wymowie między obydwoma wyrażeniami jest niewielka (tzw. „e" otwarte i „e" zamknięte), ale znaczenie diametralnie inne. Podczas gdy Esperia jest przerażona, że stanie się ofiarą gwałtu, Anglikowi chodzi o herbatę... Noc nad Rzymem operuje przy tym stereotypami - Anglik pali fajkę i pije herbatę, Amerykanin „rwie się do walki”, zaś Rosjanin o rzewnej słowiańskiej duszy - łatwo się wzrusza i pięknie śpiewa.

${ }^{28}$ Określenia tego używa Pierre Sorlin. Zob. Pierre Sorlin, The Night of the Shooting Stars. Fascism, Resistance and the Liberation of Italy, [w:] Revisioning History. Film and the Construction of a New Past, red. Robert A. Rosenstone, Princeton 1995, s. 78. 
filmu. Podczas gdy archiwalne zdjęcia ukazują wojenne samoloty i bombardowanie, ponadkadrowy głos informuje o wrześniowym rozejmie oraz jego konsekwencjach: Po 8 września wielu z żotnierzy, głównie brytyjskich ucieka z obozów koncentracyjnych i łączy się z uciekinierami włoskimi, proszac o gościnę na wsi i w miastach. Co najważniejsze, w dalszej części komentarza dowiadujemy się, że: Nikt nie odmówit tej gościny. Choć na zewnątrz niemieckie ogłoszenia mówity, że kto udziela schronienia aliantom będzie ukarany śmiercia [...], nikt nigdy nie odmówił bezinteresownej gościnności.

Oglądając Noc nad Rzymem, można więc odnieść wrażenie, że niemal wszyscy Włosi walczą o wolność kraju; resistenza stanowi zatem ruch ogólnonarodowy. Efekt ten jest w filmie potęgowany przez nieobecność faszystów (wyłącznie kulawy dozorca-szpicel wydaje się związany z reżimem Mussoliniego, ale postawa mężczyzny wynika bardziej z biedy niż z politycznych przekonań - milczenie dozorcy można bowiem kupić paczką kawy lub innym niedostępnym w czasie wojny smakołykiem) oraz wprowadzoną do narracji za pośrednictwem prasy wiadomość o partyzanckim zamachu na Via Rasella i o związanej z nim masakrze w Fosse Ardeatine.

W Nocy nad Rzymem nieustannie podkreślana jest solidarność między aliantami. Rosjanin, wygłaszający przy stole wigilijnym płomienną przemowę o dalekiej ojczyźnie i swoim cierpieniu z powodu oddalenia od rodziny, wypowiada także słowa, które można by uznać za „ekumeniczne” przesłanie filmu - mówimy różnymi językami, ale się rozumiemy. Wokół nas jest śmierć, zniszczenie i wojna, której nigdy nie chcieliśmy [...]. Tyle cierpienia, smutku, krwi. Ale przez wojne staliśmy się również przyjaciótmi. Nigdy tego nie zapomnę. W wypowiedzi Fiodora kolejny raz wyraźnie zostaje podkreślony niezawiniony udział w konflikcie zbrojnym; pojawia się także motyw wojny jako swoistej lekcji, doświadczenia, które może zaowocować dobrem - przyjaźnią ponad podziałami. Nieprzypadkowo wyzwoleniu towarzyszą kościelne dzwony.

Do słodkiej i kojącej wizji wojennych losów Italii w zrealizowanym na początku lat 60 . filmie, Rossellini dokłada jednak przysłowiową łyżkę dziegciu. Noc nad Rzymem zawiera bowiem dialog, który ujmuje w dystansujący cudzysłów zaprezentowany w filmie heroizm włoskiego narodu.

Spotkałem wielu Włochów w Italii: farmerów, pasterzy, pracujących w mieście i tych mieszkajacych w górach. Nigdy nie styszatem, by któryś z nich powiedziat: "jestem faszysta" - stwierdza Amerykanin. - Tak, ja też spotkałem wielu Włochów ostatnimi laty [...], ale nigdy nie trafitem na faszystę! - przytakuje Anglik. Więc jak wyttumaczysz fakt, że faszyzm tak długo panował we Włoszech, bez faszystów? - zastanawia się Amerykanin. Stojący obok Włoch ripostuje: Myśle, że już odpowiedzieliście na to pytanie sami. Włosi sa jak choragiewki na 
wietrze... Kiedy wszystko szło dobrze, każdy był faszysta. Teraz, kiedy sprawy maja się źle, nie pozostat żaden faszysta.

Istotnym dla tematu niniejszej pracy przykładem pure fiction, który zawiera materiały archiwalne, jest Strzał do gołębia (Tiro al piccione, reż. G. Montaldo, 1961). Filmowy debiut Montaldo jest bowiem jednym z nielicznych utworów ukazujących wydarzenia wojenne (po zawieszeniu broni w 1943 roku) z perspektywy młodego, przekonanego o słuszności własnych wyborów faszysty. To z punktu widzenia Marco, odznaczonego orderem za zaangażowanie $w$ walce, oglądamy większość prezentowanych wydarzeń: jesteśmy świadkami bombardowania, w wyniku którego na oczach bohatera ginie wielu jego kolegów-faszystów; uczestniczymy wraz z nim w opatrywaniu odniesionych w bitwie ran oraz w "polowaniach na partyzantów". Nawet w tych bratobójczych potyczkach kamera ukazuje głównie śmierć zwolenników Mussoliniego, eksponując w finale filmu obraz ich zwłok. Można zatem odnieść wrażenie, że to stronnictwu faszystów nadawany jest w Strzale do gołębia status ofiar (wiktymizacyjną rolę posiada także rozbudowana sekwencja ukazująca przemarsz wycieńczonego oddziału przez górskie śniegi).

Dla równowagi Montaldo umieszcza w filmie sekwencję rozstrzelania partyzantów (oprawcami są jednak Niemcy, a nie rodzimi faszyści!) oraz rozbudowuje - konsekwentnie pojawiający się przez cały film - wątek dokumentalnego footage opatrzonego komentarzem. Głos ponadkadrowy informuje zatem, że Mussolini to człowiek, który doprowadził Włochy do klęski, że $\mathrm{w}$ górach i miastach formuje się $i$ działa resistenza (w obrazie widać wtedy uśmiechniętych młodzieńców z plecakami), która na przemoc odpowiada ogniem i walczy jak prawdziwe wojsko. Film zawiera wreszcie migawkę z wyzwolenia Rzymu, ukazującą rozradowanych Włochów - roześmiane kobiety i dzieci rzucające Amerykanom kwiaty.

Postać uczciwego, nieco naiwnego Marco, który z młodzieńczym zapałem stoi z uporem po stronie faszystów (choć nie wiemy, co go do takiej decyzji skłoniło) i z którym, można założyć, w intencji twórców miał identyfikować się widz, powoduje jednak, że Strzał do gołębia może być odczytany - co zauważyli już współcześni premierze filmu krytycy - jako usprawiedliwienie zwolenników Mussoliniego (w finale dowódca faszystowskiego oddziału popełnia honorowo samobójstwo, a Marco ni stąd, ni zowąd zmienia front; ta cudowna konwersja jest kompletnie nieuzasadniona). Jak pisał na łamach „Cinema Nuovo” Adelio Ferrero,

Giuliano Montaldo zaprasza nas do uczestnictwa w wędrówce moralnej „bohatera na opak" - faszysty. [...] Nie tłumaczy jednak jego wyborów. Może się więc zdarzyć, 
że reżyser, o politycznych poglądach poza wszelkim podejrzeniem, na podstawie swojego debiutu zostanie oskarżony o zrobienie filmu pro-faszystowskiego ${ }^{29}$.

Wymowę usprawiedliwiającą bohatera ma także prolog filmu. Strzat do gołębia rozpoczyna się obrazem wojennych zniszczeń. Głos ponadkadrowy informuje o rozejmie 8 września oraz o opuszczeniu Włochów przez władzę (ucieczce króla i Badoglia do Brindisi - na bezpieczne tereny kontrolowane przez aliantów). Kiedy na ekranie pojawiają się obrazy przerażonych kobiet i dzieci (uwydatniające niewinność włoskiego społeczeństwa), komentarz zaznacza: nie było wtedy łatwo znaleźć właściwa drogę. Na zbliżeniach widać następnie propagandowe komunikaty: kara śmierci; będzie rozstrzelany (prolog kończy się zresztą „ślepym”, bo słyszanym na ściemnieniu, strzałem). I choć w finale filmu, gdy Marco doznaje „cudownej", światopoglądowej konwersji, padają słowa (voice over): Twoja iluzja się skończyła. W rzeczywistości teraz powracasz na łono ojczyzny, ponieważ ojczyzna była gdzie indziej - po ich stronie, to komentarz wskazujący „właściwą drogę" brzmi jednak bardzo sztucznie w zestawieniu ze zdezorientowanym i smutnym obliczem rozczarowanego młodzieńca. Pozostaje wrażenie, że tytułowymi gołąbkami, które uczestniczą w okrutnej zabawie strzeleckiej, są przede wszystkim koledzy Marco z batalionów Mussoliniego ${ }^{30}$.

\section{Rekonstrukcje}

Przykładem filmu traktującego o włoskim ruchu oporu, którego akcja rozgrywa się w czasie wojny i który zawiera w swej strukturze dokumentalny footage, są Cztery dni Neapolu (Quattro giornate di Napoli, reż. N. Loy, 1962). Film, nagrodzony w kraju i nominowany do Oscara, fabularyzuje tragiczne wydarzenia z końca września 1943 roku, kiedy to ludność Neapolu, nie czekając na nadejście aliantów, w trwającym tytułowe cztery dni powstaniu, wyzwoliła swoje miasto od hitlerowskiego terroru ${ }^{31}$.

${ }_{29}$ Adelio Ferrero, Tiro al piccione, „Cinema Nuovo” 1962, nr 155, s. 57. Przedruk w: Gianfranco Casadio, op. cit., t. II, s. 56. W ostrzejszym tonie utrzymana jest recenzja Umberto Tani: „Ton dyskursu, który proponuje nam Montaldo jest $\mathrm{w}$ istocie podobny do tego wielu niemieckich filmów o nazizmie, gdzie próbuje się usprawiedliwić swoją przeszłość i swoje winy bez odwagi by zrobić szczery rachunek sumienia" (Umberto Tani, Tiro al piccione, "Nuovo Spettatore Cinematografico” 1961, nr 25. Przedruk w: La resistenza nel cinema italiano 1945-1995, red. Mauro Manciotti, Aldo Viganò, Genova 1995).

30 Oryginalny tytuł - Tiro al piccione to nie tyle "strzał do gołębia", co nazwa zawodów strzeleckich (dziś zakazanych), polegających na strzelaniu do gołębi wypuszczanych kolejno z klatek.

31 O tym, jak ważny to epizod w historii Włoch, świadczą przyznane mieszkańcom Neapolu wojskowe odznaczenia. Prócz placu, ulicy i stacji metra upamiętniających 
Zamysł skrupulatnej rekonstrukcji faktów ujawniony zostaje już na początku realizacji. Cztery dni Neapolu otwiera bowiem napis: epizody prezentowane w tym filmie oparte sa na wydarzeniach rzeczywistych. Całość dedykowana jest zaś poległemu w starciu Gennaro Capuozzo, 12-letniemu partyzantowi, odznaczonemu złotym medalem wojskowym, a także $l u d$ ności neapolitańskiej i wszystkim Włochom, którzy walczyli za wolność. Owa wierność faktom, poparta umiejętnym łączeniem inscenizacji z materiałami archiwalnymi (ukazującymi głównie wojenne zniszczenia miasta), „kronikalną" fakturą zdjęć oraz udziałem wielu naturszczyków - występujących obok gwiazd włoskiego kina (m.in. Gian Maria Volonté) - została dostrzeżona przez ówczesną krytykę. Gianni Grazzini na łamach „Corriere della Sera” pisał o „doskonałej rekonstrukcji” i polifonicznej strukturze filmu, przypominającego „historyczny fresk”, zaś Leo Pestelli w „La Stampie” chwalił: „zaskakuje kronikarska wierność wydarzeń oraz dokumentalna dbałość, z jaką został w filmie odtworzony wizerunek ówczesnego Neapolu" ${ }^{\prime 32}$.

Prawdziwym bohaterem filmu jest właśnie Neapol, a w zasadzie jego uciemiężeni mieszkańcy (mamy tu mało zindywidualizowanych postaci, za to wiele scen zbiorowych) ${ }^{33}$. Szczególnie rozbudowana jest sekwencja opłakiwania przez matkę i jej bliskich zabitego w walce syna (piękny młodzieniec, wśród lamentujących głosów kobiet, ostatecznie wyniesiony zostaje w ramionach ojca - kadr ten stylizowany jest na Pietę) oraz scena obwożenia przez grupę mężczyzn zwłok chłopaka na dachu samochodu, w akompaniamencie buńczucznych okrzyków w neapolitańskim dialekcie ${ }^{34}$.

powstanie, w Neapolu stoi także pomnik małego powstańca - scugnizzo (w neapolitańskim dialekcie dosł. „ulicznika”) - powstały w 1963 roku. Dla porządku należy wspomnieć o innym filmie przypominającym bohaterskie cztery dni Neapolu - O sole mio (reż. G. Gentilomo, 1946). Zaczerpnięty $\mathrm{z}$ arii tytuł realizacji jest tu tropem istotnym. $\mathrm{W}$ roli protagonisty wystąpił bowiem śpiewak operowy, Tito Gobbi, który w filmie jest włosko-amerykańskim solista, pracującym w Służbach Specjalnych, a jego spadochron ląduje w Neapolu we wrześniu 1943 roku. Bohater przybywa z misją śpiewania za pośrednictwem radia... zakodowanych rozkazów. Niestety, nie udało mi się obejrzeć tego filmu, stąd wspominam go jedynie na marginesie głównych rozważań.

${ }^{32}$ Gianni Grazzini, Quattro giornate di Napoli, "Corriere della Sera”, 24.11.1962; Leo Pestelli, Quattro giornate di Napoli, „La Stampa”, 17.11.1962. Przedruk w: La resistenza nel cinema italiano 1945-1995, s. 195-196.

${ }^{33}$ Film zawiera także następujący napis: „Producent dziękuje wszystkim aktorom, którzy w hołdzie Ludowi Neapolitańskiemu - prawdziwemu bohaterowi czterech dni - zgodzili się w nim zagrać".

${ }^{34}$ Ikonograficznie scena ta nasuwa skojarzenie ze zdarzeniem z polskiego Grudnia 1970 - z pochodem ulicami Gdyni ze zwłokami Zbyszka Godlewskiego (zastrzelonego podczas strajków 1970 roku i zmitologizowanemu w znanej pieśni jako „Janek Wiśniewski”). 
Okrucieństwo Niemców - utożsamianych w filmie Loya z maszynami (zazwyczaj są oni kadrowani w samochodach, czołgach lub na motorach) - podkreślają także długie sekwencje egzekucji. Bezpośrednim impulsem, który wyzwolił w neapolitańczykach narastający odruch buntu, było rozstrzelanie zdemobilizowanego włoskiego marynarza. W filmie sekwencji jego publicznej egzekucji zostaje nadany charakter niewinnej ofiary; młodzieniec ubrany na biało przypomina owieczkę, która jest zgładzona na oczach tłumu (długa panorama twarzy prezentuje głównie płaczące kobiety). Wrażenie niewinności włoskiego społeczeństwa zostaje wzmocnione także przez sceny ukazujące walczące desperacko dzieci (Gennaro $\mathrm{z}$ granatem w dziecięcej rączce rzuca się na niemiecką kolubrynę) oraz obrazy przerażonych twarzy mieszkańców (głównie kobiet), eksmitowanych $\mathrm{z}$ nadmorskiego pasa Neapolu w celu przygotowania oporu przed aliantami.

W Czterech dniach Neapolu niemal wszyscy neapolitańczycy zaangażowani są w ruch oporu. Mozaika epizodów ukazuje grupy źle uzbrojonej ludności, która pod kierunkiem nielicznych kombatantów buduje barykady, oblega stadion oraz blokuje Niemców w ciasnych uliczkach miasta (sekwencja wyrzucania domowych sprzętów przez okna na głowy Niemców należy do wyjątkowo humorystycznych). Nanni Loy zdecydował się na pokazanie możliwie rozległej panoramy wydarzeń, aby wydobyć zespołowość i spontaniczność powstańczej akcji, w której biorą udział wszyscy mieszkańcy bez względu na wiek i płeć. Prócz działających mężczyzn oglądamy zatem również m.in. walczącą z poświęceniem grupę młodzieży z poprawczaka oraz kobiety transportujące granaty w wiklinowych koszykach. Jedynym Włochem na usługach Niemców jest rozlepiacz plakatów informujących o przymusowych robotach. Na uwagę rodaka: gdybyś byt człowiekiem, nie rozwieszałbyś tego plakatu. Oni [Niemcy] to sami powinni robić, własnymi rękami, zastraszony neapolitańczyk nie zaprzecza, lecz konfidencjonalnie ostrzega: Salvatore, nie podnoś głosu, oni rozumieją włoski.

Sam Loy tak tłumaczył swoje artystyczne wybory i podjęcie tematu ruchu oporu:

Jeśli idzie o moje zainteresowanie resistenzą i antyfaszyzmem, będące podstawą tego filmu [...] muszę przyznać, że stoi za nim moje zamiłowanie do filmów, za pomocą których demaskuje się niedostatek określonych wartości we współczesnym włoskim społeczeństwie [...] przymiotów takich jak solidarność, współczucie, duch poświęcenia, altruizm, które moglibyśmy nazwać obywatelskimi. [...] Jestem przekonany, że resistenza we Włoszech nie polegała wyłącznie na wyzwoleniu kraju z niemieckiej okupacji i nie oznaczała jedynie zaangażowania w walkę polityczna, ale niosła ze sobą także inne wartości: właśnie solidarności i braterstwa między Włochami ${ }^{35}$.

${ }^{35}$ Nanni Loy un regista fattapposta, red. Antioco Floris, Paola Ugo, Cagliari 1996, s. 95. 
Ze słów Loya wynika więc jasno, że resistenza to dla niego nie tylko walka o wolność narodową. Ruchowi oporu zostaje tu nadany pewien horyzont etyczny; resistenza jawi się jako proces regeneracji i odnowienia włoskiego społeczeństwa po traumie wojny oraz faszyzmu.

Inną autentyczną historię z czasów wojny opowiedział Gianni Puccini w filmie Siedmiu braci Cervi (Sette fratelli Cervi, 1968). Fabularyzacja tragicznego losu tytułowych braci, zaangażowanych w partyzancką walkę w rodzinnej Emilii Romanii, którzy za swoją dywersyjną działalność zostali rozstrzelani 28 grudnia 1943 roku, jest warta odnotowania przynajmniej z dwóch powodów. Nie tylko podtrzymuje bowiem pamięć o ważnym epizodzie dla włoskiego ruchu oporu (wspomnienie to przechowywane jest także poprzez szkoły i ulice imienia „braci Cervi” oraz w poświęconych rodzeństwu pieśniach i włoskiej poezji), ale również niejako zapowiada rozpolitykowane lata $70 .{ }^{36}$ Można zatem powiedzieć, że film zapowiada niejako kolejną dekadę - kiedy to młode pokolenie Włochów zapytało otwarcie o przeszłość ojców, żądając rozliczenia z niewygodnym, historycznym dziedzictwem.

W centrum narracji pozostaje Aldo Cervi (jeden z braci; w tej roli Gian Maria Volonté). To z jego perspektywy poznajemy losy chłopskiej rodziny i to on staje się głównym rzecznikiem aktywnego zaangażowania w wyzwolenie Włoch. Podczas gdy jego bracia mają wątpliwości, czy postępują słusznie, dołączając do partyzantów i zostawiając swoje żony i dzieci wraz z gospodarstwem, Aldo bez wahania opowiada się za walką. W jego politycznych dysputach z Lucia, teatralną aktorką należącą do komunistycznego odłamu Komitetu Narodowego Wyzwolenia, dopatrywano się komentarza do ówczesnych napięć politycznych Italii i wzbierającej fali włoskiej kontestacji, która $\mathrm{w}$ rok po premierze filmu zaprezentuje swe „walczące” oblicze podczas gorącej jesieni 1969 roku. Aldo uosabiałby w tej optyce głos młodego pokolenia, które chce zmienić świat „rewolucją czynu", zaś Lucia $^{37}$ byłaby reprezentantką włoskiej partii komunistycznej. Podczas gdy Aldo wykrzykuje ze złością: myślę, że potrzeba byłoby wieków, żeby przekonać [do walki] wszystkich za pomoca ulotek i plakatów. Włosi

36 Warto w tym miejscu przypomnieć, że w języku polskim ukazała się w 1963 roku książka Moich siedmiu synów autorstwa Alcide Cerviego (ojca): Alcide Cervi, Moich siedmiu synów, tłum. Maria Baranowicz, Warszawa 1963.

${ }^{37}$ W roli Lucii wystąpiła Lisa Gastoni, ówczesna muza Salvatore Samperiego uważanego za jednego z prekursorów włoskiego kina kontestacji. W tym samym roku co Siedmiu braci Cervi, Samperi realizuje film Dziękuję, ciociu (Grazie zia, 1968), w którym Lisa Gastoni gra główną rolę. Analiza tego filmu znajduje się w pracy Konrada Klejsy. Zob. Konrad Klejsa, Filmowe oblicza kontestacji, Warszawa 2008, s. 264-272. 
od osiemnastu lat śpia, Lucia - kobieta silna i odważnie wyrażająca swe poglądy - powtarza, że trzeba mieć cierpliwość i nie można tracić głowy ${ }^{38}$.

Wojna rozgrywa się w tle - początkowo przyćmiewa ją rozbudowany wątek ciężkiej pracy chłopów (bracia Cervi są wielokrotnie ukazywani podczas wspólnej pracy przy uprawie pola) oraz industrializacji wsi. Nacisk na ten aspekt świata przedstawionego pozwala sądzić, że autorom filmu bliskie były tezy popularnego w latach 60. Antonio Gramsciego. W Braciach Cervi dominują jednak polityczne dysputy (teatralne dyskusje wydają się niekiedy bardzo sztuczne i przeładowane ideologią). Pojawia się także wątek komunisty. Uświadamia on Aldo co do wielu światopoglądowych spraw, choć Cervi (w kinie podczas propagandowego filmu z Mussolinim) przyznaje, że nie zgadza się z komunistycznym manifestem, gdyż jest katolikiem. Nie zmienia to faktu, że - jak słusznie zauważa Sara Pesce - Aldo Cervi przypomina bardziej proletariusza o poglądach intelektualisty z roku 1968 niż chłopa z lat $40 .^{39}$

Przez pryzmat współczesności odczytywano także sekwencję strajku w fabryce i bratobójczej walki (robotnicy zostają ostrzelani przez faszystów). W filmie Pucciniego wrogami nie są bowiem Niemcy, ale "bracia” faszyści. To oni w finałowej scenie zabijają siedmiu braci (egzekucja odbywa się szybko, bez zbędnych słów; po serii strzałów na ekranie pojawia się napis: wszystkim, którzy pracowali przy tym filmie dziękujemy - Reggio Emilia). Akcentowanie przez Pucciniego wewnętrznych sporów Włoch można zarazem interpretować jako zwiastun dekady lat 70 . w tym sensie, iż w dekadzie tej (o czym będzie jeszcze mowa) środowiska lewackie mówiły otwarcie o powrocie faszyzmu, przypisując takie poglądy ugrupowaniom skrajnie prawicowym.

Siedmiu braci Cervi pozostaje więc filmem o ruchu oporu, który był odczytywany w kluczu współczesnym. Jak słusznie zauważa Paul

38 Byłoby świetnie gdyby wszystkie kobiety nauczyły się mówić «nie», gdyby nauczyły się protestować - mówi w pewnym momencie Lucia, co można interpretować ponownie przez pryzmat współczesności - emancypacji kobiet, która pod koniec lat 60. i w kolejnej dekadzie stała się istotnym postulatem organizacji politycznych wywodzących się z ruchów kontestacyjnych.

39 Sara Pesce, op. cit., s. 189. Jak wynika z jednej z recenzji, film miał ograniczoną widownię. „Finałowa scena rozstrzelania braci na poligonie w Reggio Emilia [...] wraz z innymi dwoma scenami wojny kazała cenzurze, która jest tak pobłażliwa w stosunku do okrucieństwa westernów all'italiana zakazać wyświetlania filmu dla osób poniżej 14 lat, a więc dla tej grupy, która mogłaby się z filmu coś nauczyć" pisał na łamach "La Stampy" Alberto Blanchi. Zob. Alberto Blanchi, Vita e morte dei sette fratelli Cervi rievocate in un film nobile e commovente, „La Stampa”, 18.02.1968. Przedruk recenzji w: Bruno Bonino, Il cinema racconta la Resistenza, Torino 1979. 
Ginsborg, realizacja Pucciniego nie tylko podtrzymuje narodową legendę, ale przede wszystkim podejmuje współczesne problemy, pytając o przyczyny frustracji dnia dzisiejszego ${ }^{40}$.

\section{Generat Della Rovere: scherzo all'italiana, czyli symfonia nie całkiem bohaterska}

Nagrodzony w Wenecji Złotym Lwem film Generał Della Rovere (reż. Roberto Rossellini, 1959) został zrealizowany w zawrotnym tempie (zdjęcia trwały niespełna miesiąc $)^{41}$. Borykający się z problemami finansowymi Rossellini, ukończywszy film o Indiach, gdzie schronił się po obyczajowym skandalu wywołanym przez ślub reżysera z Ingrid Bergman, przyjął propozycję Ergasa Morisa (włoskiego producenta filmowego), który obiecał wyłożyć fundusze na kolejne dzieło twórcy Paisy, pod warunkiem, że będzie ono gotowe na weneckie Biennale. Rossellini wziął na warsztat powieść Indro Montanellego, opartą na wspomnieniach dziennikarza z czasów II wojny światowej. Powrócił tym samym do problematyki, jaką po zakończeniu światowego konfliktu podjął w słynnej trylogii wojennej, a która przyniosła mu międzynarodowe uznanie oraz sławę orędownika neorealizmu.

Spojrzenie z perspektywy lat na włoski ruch oporu oraz postawę mieszkańców Półwyspu Apenińskiego wobec wojny było jednak diametralnie inne od tego zawartego w Rzymie, mieście otwartym. Generał Della Rovere okazał się głosem polemicznym wobec utrwalonego tam wizerunku resistenzy i dzielnych Włochów, a zarazem jednym z pierwszych filmów odkrywających niejako na nowo - po dekadzie milczenia lat 50. - temat niedawnej historii Italii; zawarta w nim doza ironii i predylekcja do rewizji narodowych mitów stanowi niejako zwiastun tendencji, która wybrzmi pełnym głosem dopiero pod koniec lat 60., wraz z wystąpieniami młodego pokolenia, odważnie pytającego o przeszłość swoich rodziców i kraju ${ }^{42}$.

${ }^{40}$ Por. Paul Ginsborg, Storia d'Italia dal dopoguerra ad oggi, Torino 1989, s. 441.

${ }^{41}$ Jak podaje Peter Bondanella, Generał Della Rovere zarobił 650 milionów lirów (więcej niż kinowy przebój Podróż do Włoch Rosselliniego), a kosztował 300 tysięcy dolarów. Peter Bondanella, The Films of Roberto Rossellini, Cambridge 1993, s. 112. O ekspresowym tempie produkcji filmu wspomina w jednym z wywiadów Renzo Rossellini, drugi reżyser, który przyznaje, że film powstawał de facto "na cztery ręce” (jego i ojca). Zob. materiały dołączone do zrekonstruowanej na DVD kopii filmu (Criterion Collection). W świetle sukcesu filmu zaskakujący jest brak jego analizy zarówno w piśmiennictwie polskim, anglojęzycznym, jak i włoskim; uwagi na jego temat pojawiają się zazwyczaj na marginesie głównych rozważań autorów.

${ }^{42}$ Ciekawostką jest fakt, że na festiwalu w Wenecji w 1959 roku wraz z filmem Rosselliniego nagrodzono Złotym Lwem film Wielka Wojna (reż. M. Monicelli) traktujący o tytu- 


\section{Odcienie szarości}

Akcja filmu rozgrywa się w 1944 roku, już po zawieszeniu broni i oficjalnym przejściu włoskiego narodu na stronę aliantów. W Generale Della Rovere kilkakrotnie wspominana jest data 8 września 1943, która - jak twierdzi Sara Pesce - uzyskała w kolektywnej pamięci Włoch status swoistego początku: stała się „momentem przebudzenia Włochów z głębokiego snu i podjęcia właściwej walki" ${ }^{43}$. Pod tym względem film Rosselliniego wpisuje się w swoistą tendencję włoskiego kina - wiele fabuł rozpoczyna się bowiem od tego historycznego wydarzenia bądź akcentuje je $\mathrm{w}$ toku narracji. Jedynie produkcje zrealizowane od razu po wojnie, jak choćby Rzym, miasto otwarte, przemilczają niechlubną woltę i "rozbrat” włoskiego społeczeństwa, uwypuklając jedność narodu wobec niemieckiego okupanta. W Generale Della Rovere fabularny punkt wyjścia umożliwia zatem Rosselliniemu refleksję nad ruchem oporu, gdy Włosi i Niemcy stoją już po przeciwnych stronach barykady; w tym kontekście dość znamienne są także miejsca akcji - Genua to bowiem miasto z antyfaszystowskimi tradycjami, zaś w Mediolanie formowane były jedne z pierwszych oddziałów włoskiej dywersji.

Choć akcja filmu rozgrywa się w czasie wojny (a dokładniej w jej ostatniej fazie), właściwym tematem dzieła nie są wydarzenia historyczne ${ }^{44}$. W centrum uwagi pozostaje Vittorio Emanuele Bardone (pseudonim pułkownik Grimaldi), który podczas okupacji żyje z niegodnego procederu: jest oszustem żerującym na ludzkim nieszczęściu. Tym, których bliscy znaleźli się w rękach Gestapo, Bardone (podając się za osobę mającą odpowiednie wpływy i kontakty), obiecuje w zamian za określoną sumę pieniędzy wyjednać zwolnienie lub złagodzenie losu aresztowanego. Bohater zostaje zdemaskowany. Niemcy dają mu szansę uniknięcia procesu i kary za cenę współpracy z Gestapo, na co Vittorio - człowiek o kryminalnej przeszłości - przystaje, chcąc ratować skórę. Pod nazwiskiem Della Rovere

łowej I wojnie światowej. Oba filmy łączyło przedstawienie tragedii wojennych w sposób daleki od dotychczasowego, akcentującego dzielność Włochów; bliźniacza jest także ich intencja ukazania straszliwego chaosu wojny jako czynnika polaryzacji i nieoczekiwanego przewartościowania postaw.

43 Sara Pesce, op. cit., s. 45.

44 Jak wspomniałam, film jest inspirowany nowelą Indro Montanellego. Dziennikarz opisuje w niej losy spotkanego w niemieckim więzieniu Giovanniego Bertoni (w książce nazwisko zostało zmienione na Bertone), który został przez Niemców rozstrzelany w 1944 jako generał. Trudno jednak orzec, czy faktyczny Bertoni (podobnie jak literacki Bertone i filmowy Bardone) rzeczywiście szpiegował w więzieniu na rzecz Niemców. Ten splot fikcji i faktu próbuje rozwikłać Tag Gallagher. Zob. Tag Gallagher, The Adventures of Roberto Rossellini: His Life and Film, New York 1998. 
(włoskiego generała, łącznika aliantów, zabitego w niemieckiej obławie, o czym wiedzą wyłącznie gestapowcy), bohater zostaje zamknięty w celi więźniów politycznych. Jego zadaniem jest zdobyć zaufanie współwięźniów i zidentyfikować znajdującego się wśród nich przywódcę mediolańskiego ruchu oporu - Fabrizia. Dzięki aktorskim zdolnościom mistyfikacja udaje się, ale stopniowo sens gry dla Bardone zaczyna się zmieniać. Protagonista identyfikuje się z obozem walczących. Ostatecznie, nie chcąc czy nie umiejąc już zdradzić, idzie dobrowolnie na śmierć jako włoski generał.

Vittorio Bardone ( $w$ tej roli Vittorio De Sica) przypomina zatem człowieka-kameleona, oportunistycznie zmieniającego barwy i poglądy (w jednej z pierwszych scen na odchodnym pozdrawia Niemca nazistowskim gestem, zapowiadającym niejako późniejszą współpracę bohatera z Gestapo). Jawi się jako chciwy, bezwzględny oszust, który bez skrupułów wyłudza pieniądze od rodaków zatroskanych o losy swoich uwięzionych krewnych (żywnościowe paczki dla więźniów Grimaldi spożywa sam, zaś otrzymane pieniądze natychmiast przegrywa w ruletkę i karty). Dość rozbudowana sekwencja ukazująca próbę sprzedaży przez protagonistę fałszywego pierścionka (Vittorio reklamuje jego wartość mówiąc, że należał do Żydówki) Włochom, ale i Niemcowi, u którego Bardone zaciągnął dług, czyni zeń mistrza włoskiej l'arte d'arrangairsi - sztuki kombinowania; cwaniaka umiejętnie lawirującego w trudnych, naznaczonych cierpieniem i bieda, czasach.

Bardone, zdemaskowany i przyparty do muru przez pułkownika Müllera, nie traci rezonu - świetny retorycznie oraz obeznany w prawnych zawiłościach głośno kalkuluje, czy przyjęcie oferty Gestapo będzie dlań korzystne. Obietnica wyjazdu do Szwajcarii i zawrotnej sumy miliona lirów w zamian za przyjęcie roli generała Della Rovere oraz ujawnienie za pomocą tego "kostiumu” tożsamości partyzanckiego przywódcy, wydaje się transakcją opłacalną. Przede wszystkim dlatego, że Vittorio pragmatycznie przewiduje koniec wojny i powszechną po nim amnestię (która de facto miała w Italii miejsce ${ }^{45}$ ). Bardone jest zresztą aktorem w każdym calu. Człowiekiem, który nieustannie gra - wobec wyzyskiwanych rodaków (w ich oczach jest obrońcą Włochów), wobec wykorzystywanych ekonomicznie kochanek (pozostając dla nich romantycznym mężczyzną) oraz wobec Niemców (nakładając maskę zwolennika nazistów). Wszedłszy w rolę generała, staje się zaś bohaterem resistenzy, a przy okazji mężem kochającej żony i ojcem dla dwójki zapatrzonych w "dzielnego tatę" synów.

45 Amnestię ogłoszono we Włoszech w 1946 roku, kiedy ministrem sprawiedliwości był Palmiro Togliatti. Oznaczała ona de facto blokadę niewystarczającego procesu rozliczeń z faszystowską przeszłością Italii. Próby jej rozliczenia powróciły dopiero w latach 60. 
Pozwoliłam sobie na tak dokładną charakterystykę głównej postaci przede wszystkim dlatego, aby unaocznić jej odmienność od protagonistów wielu powojennych filmów, traktujących o II wojnie światowej i włoskim ruchu oporu. Bardone $\mathrm{w}$ żadnym razie nie jest bowiem herosem, od początku walczącym z przekonania o wolność swojego kraju, ale bohaterem pokroju Piszczyka. Podobnie jak protagoniście Zezowatego szczęścia, Bardonemu nieobca jest postawa konformistyczna (Piszczyk ani razu nie działa z pobudek patriotycznych), ale można dojrzeć w nim także człowieka rozpaczliwie szukającego akceptacji, pragnącego uznania w oczach innych. Wcielenie się w postać legendarnego generała to dla Vittoria szansa na spełnienie swych marzeń - jako Della Rovere jest wielki w oczach współwięźniów (w niewoli współtowarzysze okazują mu szacunek, pomagając w codziennych czynnościach), ale i w swoich własnych. Tak samo jak Piszczyk, Bardone (alias Grimaldi alias Giovanni Della Rovere) wydaje się przy tym „autentyczny” w każdej sytuacji, nawet wówczas, kiedy posługuje się maska; łatwość, z jaką to czyni, stanowi wyróżnik jego osobowości. Jak słusznie twierdzi Adriano Aprà,

postać oszusta-aktora, udającego generała związanego z włoskim ruchem oporu mogła zaistnieć dopiero po 15 latach od zakończenia wojny; w okresie powojennym podobny bohater byłby nie do pomyślenia - potrzebna była bowiem jednoznaczna heroizacja resistenzy ${ }^{46}$.

W Generale Della Rovere Rossellini wprowadza także korektę do wizerunku Niemców. O ile w powojennych filmach włoskich wydają się oni "czystym złem" (Rzym, miasto otwarte), o tyle w analizowanym dziele jawią się jako postaci mniej jednoznaczne. Co prawda dalej uosabiają porządek, doskonałą organizację i precyzję - niemiecka sekretarka natychmiast wyszukuje w zgromadzonych aktach dane uwięzionych Włochów, a planując egzekucję dziesięciu Włochów, Müller każe przygotować zawczasu „awaryjną" listę dziesięciu innych skazańców ${ }^{47}$. To jednak właśnie jego

${ }^{46}$ Adriano Aprà; zob. materiały dołączone do zrekonstruowanej na DVD kopii filmu (Criterion Collection).

${ }^{47}$ Niemiecka precyzja podkreślona zostaje także w ostatniej scenie. Porucznik zwraca się bowiem do pułkownika Müllera, zwracając uwagę, że popełnili błąd - zabito (łącznie z generałem) jedenastu ludzi, a nie umówioną dziesiątkę. Müller odpowiada wtedy po włosku: to jest mój błąd poruczniku, mój błąd, by później powtórzyć tę samą frazę po niemiecku. Referuję tak detalicznie ów epizod, ponieważ wypowiedź Müllera była niekiedy interpretowana - jako przyznanie się Niemców do zbrodni wojennych przed Włochami (zob. Marcia Landy, Italian Film, Cambridge 2000, s. 95). Można by jednak zapytać, dlaczego Müller wyznaje najpierw swą winę po włosku? Może to zatem zawoalowane przyzna- 
zachowanie czyni portret Niemców bardziej złożonym. Elegancki i władający kilkoma językami pułkownik jest zdeklarowanym przeciwnikiem tortur i przemocy, optując za strategią "miękkiej perswazji”. Kiedy dostaje rozkaz wykonania egzekucji, początkowo sprzeciwia się swojemu zwierzchnikowi, argumentując, że represje przyniosą skutek odwrotny do zamierzonego (choć można przypuszczać, że mówi to nie z dobroci, lecz wrodzonego pragmatyzmu); podczas przesłuchań włoskich partyzantów wielokrotnie zaś powtarza: nie chce torturować! Nie zmuszajcie mnie do tego. Za okazana przez Bardone pomoc w naprawie samochodu, pułkownik odwdzięcza się, ułaskawiając na prośbę Vittoria jednego z włoskich więźniów. Müller, podobnie jak Bardone, okazuje się również świetnym aktorem (cecha ta łączy niejako obie postaci). W rozmowie ze zrozpaczoną panią Della Rovere, Niemiec nie ujawnia faktycznej śmierci jej męża, ale umiejętnie odwodzi od zamiaru widzenia się z więźniem (mówię jak przyjaciel - dajmy mu myśleć, że jest pani wraz z dziećmi bezpieczna; proszę napisać raczej list; daje stowo, że zostanie on dostarczony) i wyraża ubolewanie, że nie może spełnić kobiecej prośby (mam wielki szacunek dla generała oraz sympatię; $\dot{z} a \nmid u j e, \dot{z} e$ ta wojna ustawiła nas teraz po przeciwnych stronach). W Generale Della Rovere świat przedstawiony nie jest już miejscem ścierania się dobra i zła, i nie jest, jak w Rzymie, mieście otwartym, nakreślony gruba, zdecydowaną kreska, ale zarysowany delikatniejszą linia, o konturach bardziej rozmazanych, gdzie czarno-biała barwa ustępuje miejsca odcieniom szarości.

Zdaniem Adriano Apry, postać Bardone, sprytnego człowieka o kilku twarzach, uosabia postawę wielu Włochów w czasie II wojny światowej ${ }^{48}$. Opinia ta jest niewątpliwie słuszna, choć zarazem wydaje mi się interpretacją niewystarczającą. Nie chodzi bowiem tylko o zachowania - zaryzykowałabym stwierdzenie, że zmieniającą się pod wpływem okoliczności postawę i perypetie Bardone można także odczytać w planie politycznym jako „historię w pigułce” wojennych losów włoskiego społeczeństwa. Czytając film w taki sposób, początkowe "kombinowanie” bohatera - próba

nie się do błędu włoskiego narodu? Wszak zabicie przez Edmunda swojego ojca w filmie Niemcy, rok zerowy było niekiedy odczytywane jako wypowiedź o Italii - metaforyczne zabicie Mussoliniego: „ojca wszystkich Włochów i ojczyzny” (zob. Anna Maria Torriglia, Broken Time, Fragmented Space. A cultural map for Postwar Italy, Toronto 2002, s. 38). W moim przekonaniu, scenę tę można także potraktować jako odautorski komentarz Rosselliniego. Jeśli przyjmiemy, że Niemiec jest tu swego rodzaju reżyserem, a Bardone aktorem, który nie sprawdził się w przewidzianej dla niego roli i pozostał w heroicznej pozie do końca, epizod ten można byłoby interpretować jako swoiste wyznanie Rosselliniego-Autora, że współtworzony przez niego mit resistenzy przerósł jego oczekiwania; okazał się z perspektywy czasu zgubny dla Włochów, którzy nie rozliczyli się należycie z wojenną przeszłością.

${ }^{48}$ Adriano Aprà, Il dopoguerra di Rossellini, Roma 1995. 
mediacji z Niemcami w sprawie cierpiących cywilów oraz przymykanie oczu na nazistowskie zbrodnie w imię obrony własnych interesów i materialnych korzyści - byłyby odpowiednikiem sytuacji Italii w pierwszej fazie zbrojnego konfliktu. W istocie, Mussolini w 1939 roku próbował negocjacji, a neutralność Włoch trwała formalnie rzecz biorąc do 1940 roku. Kolaboracja Bardone z Niemcami odpowiadałaby faktycznemu zaangażowaniu włoskiego społeczeństwa w wojnę po stronie Hitlera, zaś światopoglądowa przemiana Vittoria i bohaterska śmierć korespondowałaby z niespodziewaną zmianą frontu przez Włochy w ostatniej fazie konfliktu i próbą stworzenia heroicznej historii ${ }^{49}$.

Za taką metaforyczną interpretacją przemawiają "mówiące” nazwiska bohaterów, które czynią ich swoistymi modelami, ilustrującymi pewien typ zachowań jednostki wobec historii. I tak, używany przez Bardone pseudonim Grimaldi nasuwa asocjacje ze słówkiem grimaldello, które oznacza wytrych. Mistrz l'arte d'arrangiarsi rzeczywiście potrafi wkraść się w łaski niemal każdego, zręcznie dobierając klucz do jego serca ${ }^{50}$. Prawdziwe nazwisko bohatera, Bardone bierze zaś swe źródło od włoskiego bardo - wieszcza, patriotycznego poety. Końcówka „one” we włoskim sygnalizuje zgrubienie - nazwisko oszusta, który staje się narodowym bohaterem, można by więc przetłumaczyć jako „poeton”. Wyczuwalnej ironii zawartej w tym przydomku można doszukać się także w przyjęciu przez - zmieniającego jak chorągiewka poglądy - bohatera, tożsamości generała Bracciaforte Della Rovere; a zatem, tłumacząc dosłownie, "generała dęba” (rovere) o mocnych ramionach (bracciaforte), symbolu stabilności, niezłomności i trwałości. Nazwisko Della Rovere niesie zarazem ze sobą konotacje historyczne - Della Rovere to bowiem włoska rodzina z tradycjami, sięgającymi XV wieku ${ }^{51}$ - podobnie jak „królewskie” imiona Bardone: Vittorio Emanuele. Te znaczenia nie zmieniająjednak podstawowej konotacji: Della Rovere jest symbolem siły i stałości (nawiązanie do starodawnego klanu jedynie potęguje te przymioty, sprawiając, że "dąb" wydaje się jeszcze bardziej „zakorzeniony” we włoskiej tradycji), zaś Bardone-Grimaldi to synonim konformisty. Przywołane imiona bohatera można interpretować także jako ironiczny komentarz do postawy króla Vittorio Emanuela III,

${ }^{49}$ Motyw niespodziewanej ideologicznej konwersji bohaterów na „właściwą stronę” $\mathrm{w}$ finale filmu pojawia się zresztą w wielu włoskich realizacjach lat 60. o II wojnie światowej. Zob. m.in. Wszyscy do domu (reż. L. Comencini, 1960) oraz Federale (reż. L. Salce, 1961).

${ }^{50}$ Nie bez znaczenia jest też fakt, iż Vittorio De Sica, nazywany w tamtych latach gigione (dosł. zarozumialec, pyszałek), uznawany był za swoisty symbol Italii. Mianem gigione określa się we Włoszech także aktora grającego przesadnie, z emfazą.

${ }^{51}$ Jednym z najbardziej znanych ówcześnie członków klanu był kardynał Giuliano Della Rovere, który został papieżem (1503-1513), przyjmując imię Juliusz II. 
który, odpowiedzialny za dopuszczenie Mussoliniego do władzy w latach 20. XX wieku, w czasie wojny kilkakrotnie zmieniał front, dbając przede wszystkim o własne interesy. Ten kontekst ponownie uprawnia do rozciągnięcia postawy Bardone na całe Włochy - król jest wszak reprezentantem całego narodu.

\section{De Sica}

W roli Vittoria Bardone wystąpił Vittorio De Sica - poza granicami Włoch identyfikowany raczej jako autor arcydzieł neorealizmu (Dzieci ulicy [Sciuscià, 1946], Złodzieje rowerów [Ladri di biciclette, 1948], Cud w Mediolanie [Miracolo a Milano, 1951], Umberto D. [1952]), w ojczyźnie znany natomiast przede wszystkim jako wyśmienity aktor, głównie komediowy. Powierzenie De Sice pierwszoplanowej roli można byłoby zatem uznać za chwyt czysto komercyjny (przyciągający publiczność) lub tłumaczyć względami osobistymi - Rosselliniego łączyła z twórcą Złodziei rowerów wieloletnia przyjaźń; współpraca przy filmie wydawała się zatem jej „naturalną” konsekwencją. Decyzja wyboru pierwszoplanowego aktora okaże się jednak bardziej znacząca, jeśli dysponujemy kilkoma informacjami z biografii De Siki.

Twórca Umberto $D$. prywatnie był nałogowym hazardzistą. Jak podaje Peter Bondanella, wiele filmów De Siki (głównie tych „post-neorealistycznych") powstało po to, by pokryć długi artysty ${ }^{52}$. Można by powiedzieć, że czyniąc Bardone hazardzista, który jest jednocześnie doskonałym aktorem, Rossellini powraca zatem niejako do... neorealistycznych zasad doboru aktorów. Osobowość Vittoria De Siki pasuje bowiem do odtwarzanej roli w Generale Della Rovere, tak samo jak np. doświadczenia Lamberta Maggiorani, odgrywającego pierwszoplanową rolę w Złodziejach rowerów, korespondowały z losem filmowego Antonia Ricci. O tym, że skojarzenie Bardone z De Siką jest prawomocne, świadczy nie tylko fakt, iż w literackim pierwowzorze wątek hazardu jest całkowicie nieobecny. „Legitymizują" je także inne rozsiane dyskretnie w filmie informacje, odwołujące się bezpośrednio do życiorysu aktora. I tak, znaczący w tym kontekście jest dialog Bardone z Müllerem w jednej z pierwszych sekwencji filmu. Na pytanie Niemca, skąd pochodzi, filmowy Vittorio odpowiada, że jest neapolitańczykiem, po czym precyzuje, że jego rodzinne miasto to Sora (położone między Rzymem a Neapolem), co pokrywa się z rzeczywistym

\footnotetext{
52 Peter Bondanella, op. cit., s. 119.
} 
miejscem urodzenia De Siki ${ }^{53}$. Dodatkowego sensu nabiera również rozmowa Bardone przez telefon z jednym ze swoich klientów, który pragnie zasięgnąć informacji o aresztowanym imieniem Vittorio. Dialog przebiega następująco:

- Czy to Vittorio? - pyta zatroskany głos w słuchawce.

- Nie, to znaczy tak, też Vittorio - odpowiada Vittorio Bardone (Vittorio De Sica).

- Zwycięstwo dla Vittorio (w oryginale: Vittoria per Vittorio) - dodaje po chwili, bawiąc się słowem.

Przywołana rozmowa, funkcjonująca jako swoisty autonomiczny gag w strukturze filmu, ma oczywiście swoje uzasadnienie dramaturgiczne (Vittorio Bardone dzwoni w sprawie innego Vittoria), ale jeśli weźmiemy pod uwagę imię De Siki, ujawnia ona de facto swe „drugie dno". Podobieństwo niektórych elementów persony artystycznej De Siki do życiorysu Bardone może być oczywiście interpretowane jako nawiązanie Rosselliniego do neorealizmu czy też raczej gra z jego konwencją ${ }^{54}$. Przede wszystkim zabieg ten sprawia jednak, że już na poziomie obsady dzieła ewokowana jest niejednoznaczność świata przedstawionego, która współgra z podejmowanymi przez film problemami: prawdy i ułudy.

Wybór De Siki na odtwórcę roli legendarnego generała resistenzy jest istotny dla wymowy filmu również z uwagi na samą karierę aktora. Obsadzenie jednego z najsławniejszych aktorów komediowych faszystowskiego okresu lat 30. w roli heroicznej postaci, podaje niejako w watpliwość prawdziwość ostatecznej przemiany bohatera; każe zapytać, czy nie jest ona kolejnym udanym występem; czy należy traktować ją zatem z przymrużeniem oka, czy też serio. W samej dramaturgii filmu Rossellini nie daje na to pytanie jednoznacznej odpowiedzi. Oczywiście, jasne jest, że początkowo Bardone gra przed politycznymi więźniami, wypełniając „reżyserskie wskazówki” Müllera. Ilustruje to doskonale scena bombowego nalotu, gdy Vittorio, przezwyciężając strach i tchórzostwo, już jako generał uspokaja przerażonych współwięźniów słowami: spokój, trochę samokontroli; zachowujcie się jak mężczyźni; pokażcie tym świniom, że nie boicie się

${ }^{53}$ Scena ta może być zarazem nawiązaniem do nowelowego filmu Złoto Neapolu (reż. V. De Sica, 1954), w którym De Sica wciela się w hazardzistę. Film ten był odczytywany jako hołd reżysera złożony miastu, gdzie spędził swoje dzieciństwo. Zob. Vittorio De Sica: Contemporary perspectives, red. Stephen Snyder, Howard Curle, Toronto 2000, s. 12.

54 Tropów neorealistycznych upatrywano także w częściowo improwizowanych dialogach filmu i zniszczonych wojną filmowych krajobrazach. Zob. Marcia Landy, op. cit., s. 97. 
śmierci; to oni powinni się bać; każda bomba zbliża je do ich końca, a nas do wolności. Odważna przemowa odnosi skutek - we współtowarzyszy niedoli, którzy wierza, że słyszą prawdziwego bohatera, „lidera” resistenzy, wstępuje otucha. O tym, że był to jedynie doskonały występ Bardone, świadczy jednak jego zachowanie po spektaklu. Kamera ukazuje mężczyznę, gdy w zaciszu swojej celi, zdjąwszy bohaterską maskę, panicznie się boi i pogrąża w modlitwie ${ }^{55}$. Ostateczna, moralna przemiana bohatera nie jest jednak tak klarowna. Można oczywiście przyjąć, że nastąpiła ona po torturach, które miały uwiarygodnić bohaterstwo generała w oczach współwięźniów, pod wpływem obcowania z nimi bądź pełnego miłości listu od żony prawdziwego generała. Za taką interpretacją przemawia m.in. scena odczytywania korespondencji - skatowany Bardone, słuchając słów pani Rovere oraz widząc jej zdjęcie z synkami, zaczyna płakać. Można zatem przyjąć, że podobnie jak powracający do walczącej Warszawy Dzidziuś Górkiewicz, Bardone poddaje się ogólnej atmosferze bohaterszczyzny, która - jak się okazuje - udziela się nawet jednostkom niemającym owej „kultury bohaterskiej” ${ }^{\prime \prime}$.

Możliwa jest jednak i druga interpretacja, wedle której mistrz l'arte d'arrangiarsi po prostu pozostaje wierny swej sztuce do końca - finalne poświęcenie byłoby wtedy nie tyle jego „autentycznym bohaterstwem”, co ostatnim występem, grą, dzięki której Bardone przeżywa moment chwały $^{57}$. Ostatnie, pełne patosu gesty: liścik do żony (Ostatnie moje my-

${ }^{55}$ Nalot bombowy stanowi w filmie niejako „dosłowną" karę z nieba, jaka spotyka Bardone po jego pierwszym donosie na partyzantów złożonym Müllerowi. W przywołanym epizodzie Rossellini po raz pierwszy w karierze stosuje zoom. Ten swoisty "przeszkadzacz" dodatkowo podkreśla kreacyjność występu Bardone.

56 Por. wypowiedź Munka: „Chodziło nam o pokazanie, jak ogólna atmosfera bohaterszczyzny wpływa nawet na jednostki, które nie mają owej «kultury bohaterskiej» i czyni z nich bohaterów". Andrzej Munk, O sobie. Z wywiadu udzielonego Stanisławowi Janickiemu, [w:] Andrzej Munk, red. Andrzej Jackiewicz, Warszawa 1964, s. 90.

57 Alicja Helman dostrzega w tej scenie "tragiczną wzniosłość i żałosne komedianctwo". Zob. Alicja Helman, Roberto Rossellini: neorealizm bez granic, [w:] Autorzy kina europejskiego IV, Kraków 2008, s. 171. W postawie Bardone można doszukać się pirandellowskiego umorismo, a sam bohater przypomina nieco postać z dramatu Pirandella - Henryk IV, który początkowo świadomie przyjmuje tożsamość tytułowego króla, by w finale odkryć, że jest uwięziony w tej tożsamości na zawsze. Umorismo to wyczuwanie tragizmu płynącego ze sprzeczności między zewnętrznym obrazem a jej wewnętrznym, ukrytym sensem. Dla zilustrowania pojęcia umorismo Pirandello posługuje się przykładem starej kobiety, przesadnie wymalowanej i ubranej niestosownie do swojego wieku, której widok wywołuje śmiech. Ale komizm tej postaci jest wrażeniem powierzchownym. Umorismo każe zajrzeć za tę komiczną fasadę i pozwala zrozumieć sytuację kobiety, która rozpaczliwie czepia się pozorów młodości, by zachować miłość młodszego od siebie męża. 
śli krą̇yły wokót Ciebie. Niech żyja Włochy!) oraz przemowa przed egzekucją (w tych ostatecznych momentach pomyślmy o naszych rodzinach, o naszym państwie; o naszym królu; niech żyje Italia) byłyby więc świadomym wyborem doskonałego aktora, który przez swą śmierć ostatecznie podtrzymuje wykreowany mit lidera resistenzy, generała zawsze podążającego najtrudniejsza ścieżka. W planie metaforycznym (jeśli przyjmiemy, że perypetie Bardone uosabiają losy włoskiego społeczeństwa) finalne wcielenie Vittoria i jego zgon można byłoby zaś odczytać jako swoistą społeczną katharsis.

Za taką "aktorską" interpretacją transformacji wewnętrznej bohatera przemawia m.in. sceniczna aranżacja egzekucji - rozstrzelanie więźniów ma miejsce nie w plenerze, jak wydaje się w pierwszej chwili, ale na tle namalowanego miasta - odbywa się zatem niejako $\mathrm{w}$ teatralnej dekoracji, którą trudno wyjaśnić fabularnie (np. chęcią wykorzystania przez nazistów takiej aranżacji do materiałów propagandowych). To właśnie brak fabularnego uzasadnienia dla "sztuczności przestrzeni” każe interpretować ją w kategoriach szczególnej intencji Rosselliniego. Odmowę ujawnienia przez Vittoria tożsamości Fabrizia trudno przy tym tłumaczyć chęcią jego ocalenia - Bardone doskonale zdaje sobie bowiem sprawę, że lider mediolańskiej resistenzy jest w grupie, która będzie najprawdopodobniej rozstrzelana niebawem.

Na obecny w Generale Della Rovere trop „udawanego" bohaterstwa oraz odczytywanie egzekucji Vittoria w kategoriach występu i triumfu mitu naprowadzają także informacje pozatekstowe, ponownie związane z karierą zawodową samego De Siki. Otóż gwiazdor włoskiego kina, począwszy od swego debiutu w latach 30., często wcielał się w postacie, które podszywają się pod inne osoby. W filmie Mężczyźni, co za łajdacy! (reż. L. Comencini, 1932) De Sica gra Bruna, biednego szofera udającego bogacza, zaś w Dam milion (reż. M. Camerini, 1935) wciela się w rolę milionera Golda, udającego biedaka i obiecującego dać tytułowy milion lirów osobie, która spontanicznie i bezinteresownie okaże mu dobroć. Wreszcie w Signor Max (reż. M. Camerini, 1937) De Sica gra biednego sprzedawcę gazet, podszywającego się pod bogatego bon vivanta. Powierzając główną rolę w Generale Della Rovere aktorowi, który w swym zawodowym emploi często eksploatował temat faktycznej tożsamości oraz prawdy i fałszu, Rossellini już na wstępie podsuwa zatem sugestię, że „patriotyczne” wcielenie Bardone jest jedynie kolejnym, doskonale odegranym występem. Innymi słowy, poprzez obsadzenie De Siki w tytułowej roli filmu Rossellini uwydatnia kreacyjność zaprezentowanej, bohaterskiej historii, biorąc przedstawione wydarzenia w dystansujący cudzysłów. 


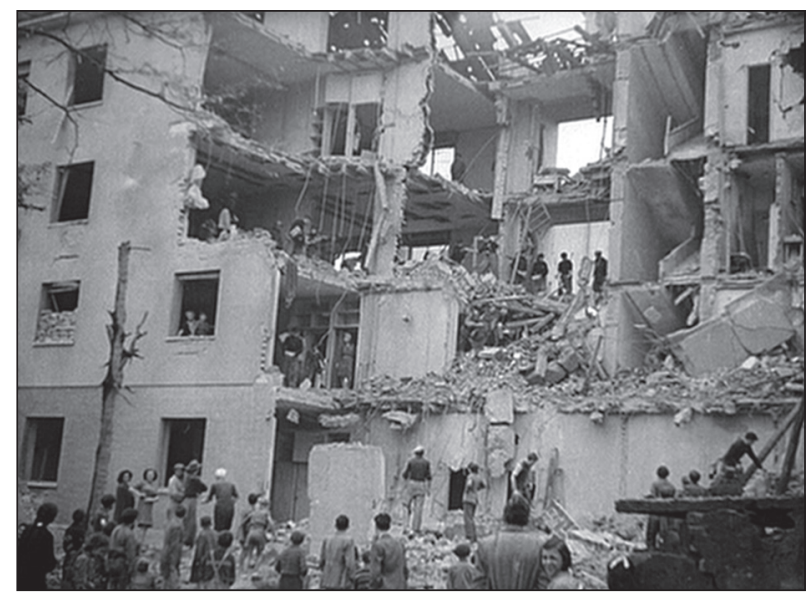

Fot. 3. Generat Della Rovere (reż. Roberto Rossellini, 1959) Wojenne zniszczenia

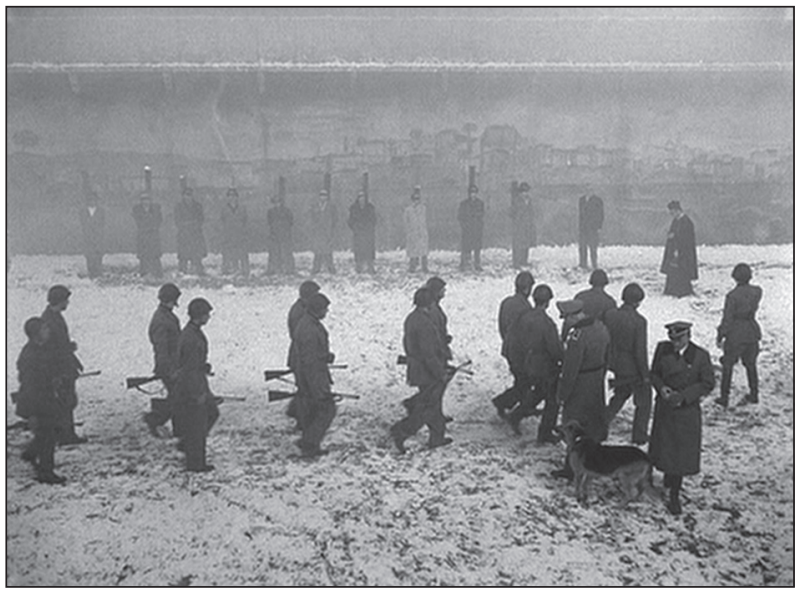

Fot. 4. Generat Della Rovere (reż. Roberto Rossellini, 1959) Finałowa egzekucja - ostatni występ generała

\section{Ruch oporu i faszyści}

W Generale Della Rovere tytułowy bohater nie jest oczywiście jedynym reprezentantem resistenzy. Temat ruchu oporu pozostaje wątkiem wiodącym filmu, choć brak w nim scen bezpośredniej walki. Jedyna zaprezentowana w dziele Rosselliniego akcja zbrojna pojawia się w migawce ukazującej zabicie rzeczywistego generała przez Niemców. Wrażenie okupowania 
cierpiącego kraju, obecne w wielu włoskich filmach o II wojnie światowej, budowane jest zresztą umiejętnie od samego początku dzieła. W jednej z pierwszych sekwencji widzimy np. cywilów (same kobiety i dzieci) zbierających się przy lokalnej studzience w poszukiwaniu wody, cieszących się, że jest pochmurno, bo wtedy trudniej bombardować; kilkakrotnie w toku narracji eksponowane są również wojenne zniszczenia - spalone kadłuby statków w genueńskim porcie, zgliszcza domów i ruiny innych budowli.

Wiktymizacja Włochów osiągana jest także za pomocą scen ukazujących ofiary niemieckich ataków. W sekwencjach tych widać głównie opłakiwane, zabite (niejednokrotnie nagie) dzieci, co potęguje wrażenie niewinności i bezbronności ludu stojącego w opozycji do dobrze uzbrojonego, niemieckiego wojska (właściwie nie mamy ukazanych ofiar po stronie okupantów; w walce są oni zresztą prezentowani bezosobowo, poprzez obraz maszyn lub sam dźwięk - odgłos bombardowania i alarmujących syren). Okrucieństwo Niemców podkreśla także sekwencja tortur złapanych partyzantów, choć, podobnie jak w Rzymie, mieście otwartym, widzimy nie tyle sam akt zadawania katuszy, ile skutki znęcania się nad przeciwnikami nazizmu. W Generale Della Rovere ofiarą brutalnego przesłuchania pada oddany sprawie Bianchelli (który w wyniku odniesionych obrażeń umiera na oczach przerażonego Bardone, wyznając, że nic oprawcom nie zdradzi ${ }^{58}$ ), ale i sam Vittorio (poddany torturom, aby uwiarygodnić jego bohaterstwo w oczach współwięźniów).

Obecność ruchu oporu w filmie Rosselliniego jest eksponowana od samego początku filmu, poprzez plakaty oraz napisy na murach miasta. $\mathrm{W}$ jednej $\mathrm{z}$ pierwszych sekwencji kamera ukazuje m.in. dekret, wedle którego każdy, kto zostanie złapany w posiadaniu broni bez zezwolenia, będzie zastrzelony na miejscu, oraz wypisane kredą na ceglanej ścianie hasło partyzantów - Zwyciężymy! Pół żartem, pół serio można powiedzieć, że podczas wspominanej już pierwszej rozmowy Bardone z Müllerem (w której Vittorio zdradza, że pochodzi z Sory) liczba włoskich partyzantów przypadających na kilometr kwadratowy Italii gwałtownie wzrasta - resistenza okazuje się siłą ogólnonarodową. Müller łapie bowiem gumę na minie podłożonej właśnie przez partyzanckie oddziały, a w toku krótkiej pogawędki wspomina bohaterską obronę Neapolu (szkoda było nam wyjeżdżać, ale neapolitańczycy zaczęli nas wystrzeliwać jak kaczki), opór Rzymu (Rzymianie też nas nie lubia) oraz Mediolanu (Ludzie tam uparci, mnóstwo rebeliantów).

58 Scena zgonu przypomina nieco śmierć skatowanego Manfrediego w Rzymie, mieście otwartym - Vittorio w Generale Della Rovere przeklina Niemców podobnie jak Don Pietro w I części wojennej trylogii Rosselliniego. 
Wrażenie wszechobecności resistenzy potęgują także rzesze uwięzionych przez Gestapo Włochów (o losy których martwią się dalsi i bliżsi krewni) oraz wypełniony po brzegi politycznymi więźniami zakład karny. Napisy w celi, gdzie zostaje umieszczony Bardone już jako generał Della Rovere, autorstwa poprzednich lokatorów (dla waszego syna Mario skończyło się życie [...] przeklęty wróg mnie zabije; kto czyta te słowa proszony jest o poinformowanie mojej rodziny, że zostałem rozstrzelany), są nie tylko świadectwem cierpienia i poświęcenia mieszkańców Włoch. Wypisane hasła sugerują także mnogość członków ruchu oporu, a zarazem ciągłość ich działalności. Jedna z sekwencji ukazuje ich konspiracyjne spotkanie, podczas którego planują wyzwolenie Fabrizo; z krótkiej wymiany zdań wynika, że siatka resistenzy jest niezwykle gęsta. Podczas tajnej narady pada jeszcze jedno istotne stwierdzenie. Gdy jeden z uczestników posiedzenia narzeka na prężną działalność szpiegów niemieckich we włoskich szeregach, jego kolega nie bez słuszności ripostuje: nie dziwi mnie to, kilka miesięcy temu [Niemcy] byli naszymi sojusznikami. Inny partyzant natychmiast go wtedy poprawia, mówiąc: nie naszymi, tylko Mussoliniego. W ten sposób odpowiedzialność za współpracę z nazistami przypisana jest Mussoliniemu, który - jak słusznie zauważa Pierre Sorlin - w wielu filmach włoskich funkcjonuje jako figura szaleńca, uosobienie "choroby", obcej włoskiemu społeczeństwu. Usprawiedliwiający Włochów ton posiada także opinia, która pada podczas pierwszej, przywoływanej już rozmowy między Vittoriem a Müllerem. Niemiec stwierdza bowiem: wy, Włosi nie lubicie zbyt tej wojny, na co Vittorio odpowiada w liczbie mnogiej: generalnie, nie lubimy wojny.

W Generale Della Rovere zastanawiający jest niemal całkowity brak włoskich faszystów. Pojawiają się oni wyłącznie w dwóch kilkunastosekundowych ujęciach na początku filmu, niejako na marginesie $(\mathrm{H})$ istorii. Takie rozłożenie proporcji - włoscy partyzanci nawet liczebnie dominują na ekranie nad zwolennikami Mussoliniego - koresponduje oczywiście z mitem bohaterskiej walki Włoch, który powstał w Italii w okresie powojennym. W scenie otwierającej film włoscy żołnierze śpiewają że... włoskie kobiety ich nie chca, bo nosza czarne koszule. W kolejnym ujęciu kamera ukazuje dekret informujący, że dla dezerterów wojennych oraz uchylających się od służby wojskowej przewidziana jest kara śmierci. Sekwencja ta sugeruje zatem, że akces do faszyzmu ma charakter przymusowy; nie wynika z przekonań, lecz z obawy przed represjami. Za ilustrację światopoglądowej konwersji wielu Włochów (a tym samym wymazywania faszystowskiej przeszłości) można natomiast uznać krótki, ale znaczący 
epizod w siedzibie Gestapo. Mam tu na myśli sekwencję, w której matka i córka uwięzionego Włocha proszą o jego uwolnienie, powołując się na udział zakładnika w walkach w Albanii i Afryce, za co mężczyzna został zresztą odznaczony medalem. Jest zatem jasne, że więzień był zdeklarowanym faszystą i sumiennym żołnierzem Mussoliniego, pozostającym sojusznikiem Hitlera. Niemiecka sekretarka sprawdza jednak dokładnie dane Włocha i okazuje się, że obecnie to... rebeliant walczący przeciw Trzeciej Rzeszy.

Biorąc pod uwagę wyraźne akcentowanie w filmie roli resistenzy, przy jednoczesnym wyciszaniu faszystowskiej przeszłości Italii, Generał Della Rovere może wydać się dziełem, które wpisuje się $\mathrm{w}$ - zapoczątkowaną przez Rzym, miasto otwarte - tendencję do heroizacji włoskiego ruchu oporu. To zresztą dlatego krytyka, narzekając nieco na techniczne mankamenty filmu (o czym za chwilę), pisała, iż Rossellini powraca tą realizacją do swoich korzeni ${ }^{59}$. Faktycznie jednak uważniejsza lektura filmu ujawnia dystans reżysera do bohaterskiej wizji wojennej historii Włoch.

\section{Etyka estetyki?}

Zdjęcia do Generała Della Rovere wykonane zostały w studio. Decyzja ta wynikała po części ze względów technicznych - wyznaczonego przez producenta terminu ukończenia filmu oraz faktu, że w Genui w momencie realizacji dzieła trudno było o plenery ewokujące atmosferę wojny (miasto po wojnie odbudowano). Wyczuwalna teatralność filmowej przestrzeni zarazem była jednak wyborem artystycznym, podkreślającym, jak słusznie zauważa Adriano Aprà, dystans Rosselliniego do podejmowanego tematu. Sztuczność scenerii widoczna w przywoływanej już końcowej sekwencji dzieła - finalnej egzekucji "nieautentycznego" generała wraz ze współwięźniami, w iście teatralnej dekoracji - jest także wyraźnie wyczuwalna m.in. w sekwencjach więziennych (nienaturalność przestrzeni uwypuklona zostaje tu przez symetryczną kompozycję kadrów). Warto przy tym zaznaczyć, że w toku narracji otwarte przestrzenie miasta ustępują tym zamkniętym: m.in. wnętrzom zakładu karnego oraz celi. Architektura przestrzeni potęguje więc niejako wrażenie zamknięcia bohatera w pułapce przyjętej przez niego roli.

Fikcjonalny wymiar prezentowanej przez Rosselliniego historycznej wizji jest podkreślany nie tylko poprzez „teatralną" organizację filmowej przestrzeni, ale także przez fakt łączenia, w wyraźnie dostrzegalny

${ }^{59}$ Podaję za: Peter Bondanella, op. cit., s. 117. 
dla widza sposób, zdjęć dokumentalnych z inscenizacją. Rossellini, podejmując problem prawdy oraz fałszu na poziomie samej konstrukcji dzieła, tka narrację w taki sposób, aby wszelkie "szwy" były widoczne. I tak np. footage ukazujący wojenne zniszczenia i cywilów, którzy wśród ruin próbują ratować przypadkowe ofiary niemieckiego bombardowania, przechodzi w inscenizację, w jaką wkracza Bardone (przywołany epizod ma charakter frazy ujęcia-przeciwujęcia: Grimaldi wchodzi w tłum stojących gapiów, którzy nieruchomo przyglądają się akcji ratunkowej; taka kompozycja sceny dodatkowo uwypukla kontrast między poprzednim, dokumentalnym i dynamicznym materiałem). Podobny zabieg Rossellini stosuje jeszcze dwukrotnie: gdy Bardone jedzie z Müllerem samochodem po zawarciu "aktorskiego kontraktu” (za szybami pojazdu, za pomocą tzw. insetu, widać wtedy archiwalne zdjęcia ukazujące skutki wojennej pożogi) oraz w scenie prezentacji jednego $\mathrm{z}$ włoskich konspiratorów - członek resistenzy jest początkowo ukazany na tle ruchliwej ulicy (wykorzystano tu technikę tylnej projekcji), a w kolejnym ujęciu wchodzi w miejski (zainscenizowany) zaułek, gdzie ma miejsce spotkanie grupy włoskiego ruchu oporu. Celowo pozwoliłam sobie na tak dokładne opisanie obu momentów łączenia ujęć przynależnych do dwóch rodzajów filmowych - rejestracji dokumentalnej i kina fikcji. Widoczne „realizatorskie szwy", które przez krytykę były zazwyczaj traktowane jako reżyserska niedbałość i omyłka, pojawiają się bowiem $\mathrm{w}$ istocie $\mathrm{w}$ tych fragmentach dzieła, które dotyczą resistenzy. Gdy za oknami samochodu migają dokumentalne obrazy miasta, Bardone zapoznaje się bowiem z życiorysem generała Della Rovere; uczy się swojej nowej, bohaterskiej biografii. Te „stylistyczne potknięcia” są w moim przekonaniu intencjonalne, a przynajmniej: dobrze współgrają z dyskursem filmu. Rossellini obnaża w ten sposób "konstrukcyjny” wymiar mitu resistenzy.

Spiżowy monolit zaprezentowanej w filmie bohaterskiej historii, rozbijany przez „estetyczną niedbałość”, kruszy się także pod wpływem pojawienia się w filmie samego Rosselliniego. Obecność sławnego reżysera w jednej ze scen rozgrywających się w siedzibie Gestapo, która narusza wrażenie realności świata przedstawionego, odczytywana była rozmaicie; trudno ją bowiem postrzegać jako swoisty odautorski podpis à la Alfred Hitchcock. Podkreślano zatem przede wszystkim osobisty stosunek reżysera do filmu, wskazując, iż Rossellini odwołuje się w ten sposób do własnych, „wojennych” doświadczeń (w pojawiającej się w tej samej scenie niemieckiej sekretarce dopatrywano się nawet uderzającego podobieństwa do narzeczonej Rosselliniego z lat 1942-1947, niejakiej Roswithy 
Schmidt ${ }^{60}$ ). Ta interpretacja nie wyklucza jednak odczytania obecności reżysera w filmie jako swoistego zanurzenia się Rosselliniego w kreowanej przez siebie "historycznej fikcji”. Pojawiając się w dziele eksponującym włoski ruch oporu, reżyser zdaje się sugerować, że jest niejako współodpowiedzialny za stworzenie takiego właśnie, bohaterskiego obrazu historii (głównie za sprawą wojennej trylogii).

Fakt, że prawdziwy generał Della Rovere niemal w ogóle się w filmie nie pojawia, a inni partyzanci są postaciami drugoplanowymi, z którymi trudno się identyfikować, sugeruje, że postawy oporu należały do myślenia życzeniowego, a przynajmniej: stanowiły społeczny margines; bliższe rzeczywistości było postępowanie wykorzystujące sztukę kombinowania i lawirowania między prawdą a oszustwem. Taką hipotezę potwierdza rozmowa więźniów przed finalną egzekucją. Jeden ze skazańców powtarza, że znalazł się w celi niesłusznie - nic bowiem nie zrobił. Współtowarzysz niedoli odpowiada wtedy:

W tym właśnie tkwi problem - nic nie zrobiłeś. Świat jest w stanie wojny od kilku lat, sa miliony zabitych, setki miast zrujnowanych, a ty nic nie zrobiłeś. Inny więzień zaś dodaje: trzeba było coś zrobić, wziać jedna lub druga stronę. Chciałeś być z dala od konfliktu, troszczyć się o swój interes. Tak naprawdę mówiłeś mi, że nieźle zarabiałeś, gdy inni umierali. A ty co zrobiłeś? - broni się kolejny mistrz włoskiej l'arte d'arrangairsi. W odpowiedzi słyszy: Niewiele, ale wypetniłem swój obowiązek. Bo na tym to polega, aby wykonywać swój obowiązek, nie bacząc na okoliczności. Jeśli wszyscy by tak robili, być może nie byłoby nas tu teraz.

Zawarta w Generale Della Rovere rewizja spetryfikowanych postaw - przede wszystkim narodowego bohaterstwa - czyni film Rosselliniego pokrewnym Eroice. Podobnie jak Munk, twórca Rzymu, miasta otwartego wydobywa tu kompensacyjny i afirmatywny aspekt mitu; jego zdolność budowania społecznej tożsamości, która pozwala przetrwać w momentach kryzysów. Tak samo jak legenda o ucieczce porucznika Zawistowskiego jest w stanie skonsolidować społeczność obozową w niemieckim oflagu, podtrzymany mit generała Della Rovere ocala honor żołnierzy i włoskiego narodu (mit, zachowując pamięć o zakodowanych w nim wartościach, chroni bowiem wspólnotę przed duchową degradacją). Jednocześnie, analogicznie do Eroiki, w filmie Rosselliniego zostaje wydobyty na powierzchnię także „życzeniowy”, raczej negatywny aspekt mitu. Mit Zawistowskiego i generała spełnia przecież także funkcję swoistej protezy - usprawiedliwia zbiorową niemoc jednostkowym wyjątkiem. W analizowanym dziele twórca Rzymu, miasta otwartego podważa zatem

${ }^{60}$ Podaję za: ibidem, s. 118. 
pielęgnowaną w Italii legendę ogólnonarodowej resistenzy. Jego „bohaterska symfonia" celowo pobrzmiewa fałszywymi nutami - warsztatowe dysonanse podkreślają sceptyczny wydźwięk filmu. Zmiana tonacji dzieła - z początkowo satyrycznej scherzo all' italiana na finalne ostinato lugubre ${ }^{61}$ - może być odczytana jako ironiczny komentarz Rosselliniego do procesu konstruowania martyrologicznej, wojennej historii Włoch. Ten „demaskatorski" walor filmu, dostrzegł w momencie jego realizacji Pier Paolo Pasolini. Nazwał on Generała Della Rovere bardzo ważną realizacją włoskiego kina, która udowadnia, że istnieje we Włoszech kultura zdolna do „ukazania prawdziwej twarzy Italii, 15 lat po wojnie ${ }^{\prime 62}$. Podobne doń filmowe wypowiedzi wybrzmią jednak mocnym akordem dopiero pod koniec dekady.

${ }^{61}$ Scherzo all'italiana to konwencja żartobliwa, z przymrużeniem oka (scherzo to po włosku żart, kawał); ostinato lugubre - to zaś dosłownie „uporczywie, nieustannie żałobny". Obie konwencje są także terminami muzycznymi, odnoszącymi się do kompozycji melodycznych; w takim znaczeniu wykorzystał je Munk w Eroice.

${ }^{62}$ Pier Paolo Pasolini, L'anno del Generale Della Rovere, „Il reporter”, 5.01.1960. 


\section{Rozdział V}

\section{Lata 1969-1978: kontestacja i rozliczenia}

Na przełomie lat 60. i 70. kino autorskie było często postrzegane jako medium publicznej debaty, w której reżyser wypowiada się nie tylko jako artysta, ale także jako obywatel. Już w połowie złotej dekady włoskiego kina pojawiają się debiuty młodego pokolenia filmowców, które uznawane są za początek włoskiego kina kontestacji (Przed rewolucja [Prima della rivoluzione, 1964] Bernardo Bertolucciego oraz Pięści w kieszeni [Pugni in tasca, 1965] Marco Bellocchia). Fenomen ten - bogaty zarówno pod względem ilościowym, jak i tematycznym - został szczegółowo omówiony w innym miejscu ${ }^{1}$; tu przypomnę jedynie, że prócz młodego pokolenia reżyserów - którzy, podobnie jak ich rówieśnicy w innych krajach europejskich, ujawniali w swych filmach dysfunkcje ówczesnego systemu społecznego (obok wspomnianego Bertolucciego i Bellocchia można wymienić jeszcze braci Tavianich oraz Marco Ferreriego) - krytycznie o włoskim społeczeństwie wypowiadali się także starsi, m.in. Pier Paolo Pasolini, uznawany za prawodawcę kontestacyjnego ruchu. Jak celnie zauważa Jerzy Kossak, głównym ideowym motywem całej twórczości artysty była „walka ze współczesnym mieszczaninem, z mieszczańskością w sferze postaw moralnych, w stosunkach międzyludzkich i religii"². Podobną opinię wyraża Umberto Eco: „Dla Pasoliniego walka była powołaniem [...]. Pasolini był pełen pasji i zuchwałej odwagi [...] szukał ataku i prowokował go, gdy pogłębiła się gnuśna obojętność społeczeństwa" ${ }^{3}$. Swoistą areną dla skandalizujących i zaangażowanych filmów niemalże z całego świata był Festiwal Nowego Kina w Pesaro (organizowany od 1965 roku), który pod koniec dekady stał się jedną z ważniejszych imprez filmowych w Europie.

\footnotetext{
${ }^{1}$ Zob. Konrad Klejsa, Filmowe oblicza kontestacji, Warszawa 2008 (szczególnie rozdział VII).

2 Jerzy Kossak, Kino Pasoliniego, Warszawa 1976, s. 28.

${ }^{3}$ Umberto Eco, Moje spory z Pasolinim. Cyt. za: Pasolini: tak pięknie jest śnić, red. Andrzej Pitrus, Kraków 2002, s. 65.
} 
Młode pokolenie pytało o faszystowską przeszłość i żądało rozliczenia $\mathrm{z}$ trudnym dziedzictwem historycznym ${ }^{4}$. Ruch oporu postrzegany przez skrajną lewicę jako fenomen, którego znaczenie zostało zaprzepaszczone przez polityczne elity Włoch - $\mathrm{w}$ ",dekadzie ołowiu” zyskuje także nowe znaczenia: powraca jako element bieżących debat politycznych oraz symbol oporu wobec systemu. Symptomatyczna pod tym względem jest mocno zideologizowana wypowiedź reżysera Giorgio Trentina: „Zrozumiałem, że w tym konkretnym momencie historycznym konieczna była druga resistenza; [...] nie uczestnicząc w pierwszej, chciałem partycypować w drugiej, która była ruchem oporu przeciwko reżimowi konsolidującemu się we Włoszech" ${ }^{5}$. Wojenna przeszłość, w tym włoski ruch oporu, odczytywana była przez pokolenie kontestatorów przez pryzmat marksizmu (i jego rozmaitych odmian). Dominują upolitycznione biografie herosów resistenzy, jak np. Corbari (1970), ale i filmy na kanwie literatury - Masakra w Rzymie (Rappresaglia, 1973), Agnieszka idzie na śmierć (Agnese va a morire, 1976).

Warto zwrócić uwagę, że - z małymi wyjątkami - filmy o resistenzy powstałe $\mathrm{w}$ tej dekadzie były najczęściej klasyczne pod względem formalnym. Eksperymentowanie z językiem filmu we Włoszech nie było tak powszechne jak na przykład we Francji, choć pojawili się twórcy przeczący tej zasadzie. Dobrym przykładem pozostaje tu twórczość Bernardo Bertolucciego - nowatorska formalnie Strategia pająka (1970) wyróżnia się na tle innych produkcji o ruchu oporu powstałych w latach 70. i jej będzie poświęcona osobna analiza.

W latach 70. krytycy filmowi niezwykle surowo oceniali kondycję X Muzy na Półwyspie Apenińskim. Lino Micciché, we wstępie do największej monografii poświęconej kinu tej dekady, pracy o znamiennym tytule Czekajac na Godota..., stwierdza, iż „pod koniec '68 odpływ zamienił morze «włoskiego kina» w swego rodzaju [...] bagnisty teren, gdzie ocię-

${ }^{4} \mathrm{O}$ ponownym zainteresowaniu niedawną przeszłością świadczą zrealizowane w latach 60. i 70. dokumenty, m.in. Do broni, jesteśmy faszystami (All'armi siam fascisti, 1962) sygnowany przez Lino De Fra i Lino Micciché. Także w telewizji historia powróciła do łask. Ermanno Olmi i Corrado Stajano realizują w 1971 roku W imieniu ludu włoskiego (In nome del popolo italiano - trzecią część historycznego cyklu Nascita della repubblica), a w 1972 powstaje cykl Korzenie wolności (Le radici della libertà - cztery fikcjonalne odcinki o historycznych postaciach związanych z antyfaszyzmem). Georgio Trentin zrealizował zaś m.in. Pewna prywatna sprawe (Una questione privata, 1966) na podstawie powieści Beppe Fenoglia z 1965 roku o tym samym co film tytule. Powieść ta ukazała się w języku polskim w 1979 roku.

${ }^{5}$ Cyt. za: Memoria, mito, storia. La parola ai registi, 37 interviste, red. Alessandro Amaducci, Torino 1994, s. 292. 
żali sternicy siedzący w gnijącej łodzi i odurzeni zapachem błota oczekują zresztą bez większego przekonania, [...] że jakiś prąd poruszy wody już zamulone i cuchnące. Czekają czekają [...], a niedługo włoskiemu kinu będzie można zaśpiewać requiem" ${ }^{\prime 6}$.

Faktem jest, iż w „dekadzie ołowiu” odchodzą wielcy włoskiego kina: Vittorio De Sica, Pietro Germi, Roberto Rossellini i Luchino Visconti; w 1975 roku zostaje zamordowany Pier Paolo Pasolini. W zgodnej opinii badaczy, wydarzenia bieżące oraz polityczno-społeczne napięcia niejako in status nascendi komentowało najczęściej - w trybie fikcjonalnym - kino popularne ${ }^{7}$. Jednak to właśnie Autorzy (niektórzy u schyłku życia) kształtowali estymę włoskiego kina i bronili jego miejsca w światowej czołówce; w "dekadzie ołowiu” powstaje m.in. niemiecka trylogia Viscontiego (Zmierzch bogów [Caduta degli dei, 1969], Śmierć w Wenecji [Morte a Venezia, 1971], Ludwig [1972]), Fellini realizuje Rzym (Roma, 1972) i nagrodzony Oscarem Amarcord (1973), Antonioni kręci w USA Zabriskie Point (1970) oraz Zawód reporter (Professione: reporter, 1975), a Pasolini skandalizujące dzieła, tzw. „Trylogię życia” (1971-1974) i Salò, czyli 120 dni Sodomy (Salò o le 120 giornate di Sodoma, 1975).

Symptomatyczne, że w przywołanych filmach, ale także w twórczości innych reżyserów włoskiego kina tamtych latt ${ }^{8}$, można doszukać się motywu śmierci lub/i zdiagnozowanego przez krytykę przeświadczenia o zbliżającej się katastrofie. Trylogia Viscontiego, wpisując się w poetykę dekadencji obecną $\mathrm{w}$ wielu filmach Mistrza, koresponduje niejako z obecnymi w dziełach Felliniego motywami przemijania (Amarcord w dialekcie romańskim oznacza zwrot: „przypominam sobie”) i agonii (Casanova [Il Casanova di Federico Fellini, 1976], nazywany przez Felliniego „filmem - pogrzebem"). W wizji eksplodującego świata burżuazji zawartej w Zabriskie Point (myślę tu o filmowanej w zwolnionym tempie ostatniej scenie, w której Daria wysadza w wyobraźni willę swego pracodawcy), można zaś dopatrzeć się podobnych intuicji, co w Salò... Jak pisał Bolesław Michałek, film Pasoliniego "to obraz potworny, trudny do zniesienia, sprawiający fizyczny ból [...]. Jest w tym coś z końca świata, końca pewnej

\footnotetext{
6 Por. Lino Micciché, Cinema italiano degli anni '70, Venezia 1989, s. 18.

7 Zob. Christian Uva, Schermi di piombo. Il terrorismo nel cinema italiano, Rubbettino 2007, s. 23.

${ }^{8}$ Myślę tu przede wszystkim o Marco Ferrerim. Przykładowo w jego filmie Nasienie mężczyzny (Seme dell'uomo, 1969) mamy scenę finalnego wybuchu podobnego do tego w Zabriskie Point. Więcej o twórczości Marco Ferreriego i jej apokaliptycznych wątkach zob. Anna Miller, Marco Ferreri: kultura w stanie rozkładu, [w:] Autorzy kina europejskiego VI, red. Alicja Helman, Andrzej Pitrus, Warszawa 2011.
} 
cywilizacji"9; apokaliptyczny wymiar filmu Antonioniego podkreśla natomiast zamykający całość napis End zamiast zwyczajowego The End.

Kryzys włoskiej kinematografii znajduje swoje odbicie $\mathrm{w}$ polityce kulturalnej Italii. Jak wskazuje Micciché, trudności przeżywał cały Zarząd Kinematografii (tzw. Ente Gestione Cinema) - państwowy koncern, prowadzący przemysłową działalność filmową za pośrednictwem trzech przedsiębiorstw: Italnoleggio (rozpowszechnianie filmów), Istituto Luce (produkcja filmów) i Cinecittà (laboratoria, hale zdjęciowe itp.). Dość powiedzieć, że o ile w 1974 roku wyprodukowano we Włoszech 224 filmy, o tyle w 1977 już tylko 150 . Z drugiej strony, telewizja ${ }^{10}$ zaczyna produkować „ambitne” dzieła nagradzane na festiwalach filmowych (m.in. uhonorowane Złotymi Palmami na kolejnych canneńskich festiwalach filmy We władzy ojca [Padre padrone, 1977] braci Tavianich i Drzewo na saboty [1978] Olmiego), a do kin cały czas chodzą rzesze Włochów (w 1975 roku sprzedano 530 milionów biletów - najwięcej w Europie Zachodniej) ${ }^{11}$. Bujnie rozwija się kino popularne - prócz komedii dominują kryminały (giallo, poliziesco), w których także dostrzec można odblaski społecznych niepokojów tamtej dekady. W swoim artykule Badania audytorium filmowego we Włoszech, sporządzonym na podstawie danych Instytutu Badań Statystycznych i Analiz Opinii Publicznej DOXA, autorka podaje, iż widzowie preferują najczęściej „filmy zaangażowane, o zawartości polityczno-społecznej $(22 \%)$, na drugim miejscu komedie (21\%), następnie filmy policyjne $18 \% " 12$.

Jeśli uznać te dane za wiarygodne, można z dużym prawdopodobieństwem sądzić, że najchętniej oglądane były te o anni di piombo - współczesnych problemach kraju. Jak zauważa Lino Micciché,

kino włoskie było zawsze (przynajmniej od czasów neorealizmu) niezmiernie wyczulone na dynamikę społeczną [obecnie zaś - przyp. A. M.-K.] społeczeństwo włoskie

9 Bolesław Michałek, Filmy, które widzieliśmy: erotyzm i śmierć, „Kino” 1976, nr 3.

${ }^{10}$ O rozwoju telewizji najlepiej świadczą festiwale twórczości telewizyjnej: Prix Italia (corocznie organizowany w innej miejscowości) oraz Telewizyjne Konfrontacje w Chianciano.

${ }^{11} \mathrm{~W}$ latach 70. nagrodami uhonorowano także innych włoskich filmowców, między innymi Elio Petri za film Klasa robotnicza idzie do raju (La classe operaia va in paradiso, 1971) oraz Francesco Rosi za Sprawę Mattei (Il caso Mattei, 1972) otrzymują ex aequo Złotą Palmę w Cannes w 1972 roku. Nagrodzeni zostają też Nino Rota (1974; Oscar za muzykę do Ojca chrzestnego II [The Godfather, Part Two]) i Vittorio Storaro (1979, Oscar za zdjęcia do Czasu Apokalipsy [Apocalypse Now]).

12 Zainteresowanie dla filmów zaangażowanych i policyjnych jest większe wśród ludzi młodych i wśród osób należących do klas wyższej i średniej. Zob. Jadwiga Korycka, Badania audytorium filmowego we Włoszech, „Kino” 1978, nr 7, s. 29. 
przeżywa sprzeczne procesy ewolucji i regresu: z jednej strony rozszerza się sprzeciw, dojrzewa świadoma potrzeba zmian, rośnie opozycja przeciwko status quo [...]. $\mathrm{Z}$ drugiej strony rozprzestrzenia się gwałt, postępuje rozkład państwa, wzrasta niekontrolowany niepokój ${ }^{13}$.

Właściwy „złotej dekadzie” kina włoskiego optymizm ustąpił zwątpieniu; symptomatyczna pod tym względem jest choćby wypowiedź Ettore Scoli: „Włochy dzisiejsze są zdewastowane w każdym sensie - ekonomicznie, politycznie, moralnie, są krajem pomieszanych idei" ${ }^{14}$.

Jak nie bez racji przypomina historyk Anna Bravo, „rozróżnienie na resistenze zorganizowaną oraz cywilny, obywatelski ruch oporu, który bezpośrednio nie walczył [...] wiąże się często z podziałem «płci». [...] W szeregach «biernego oporu» znajdowały się głównie kobiety dające partyzantom jeść, lub ukrywające ich w swoich domach, ryzykując przy tym własnym życiem" ${ }^{15}$. Ciekawym przykładem fikcjonalnego filmu podejmującym ten temat jest Agnieszka idzie na śmierć (Agnese va a morire, reż. G. Montaldo, 1977). W realizacji Montaldo - będącej adaptacją powojennego bestsellera Renaty Viganò o tym samym co film tytule ${ }^{16}-$ pobrzmiewają bowiem wyraźnie echa ówczesnych politycznych debat i społecznych napięć, m.in. tych związanych z coraz silniejszym we Włoszech ruchem feministycznym.

Akcja filmu toczy się po zawieszeniu broni, między 8 września 1943 roku a zimą 1944/1945. Tytułowa bohaterka, chłopka w średnim wieku, po śmierci związanego z ruchem oporu męża (Pality) zaczyna

${ }^{13}$ Lino Micciché, Kino włoskie - w oczekiwaniu na Godota, tłum. Wanda Wertenstein, „Kino" 1976, nr 2, s. 26.

14 Fragment wywiadu dla Jeana A. Gili, „Ekran” 1976, nr 46. Przedruk w: „Filmowy Serwis Prasowy" 1976, nr 18, s. 26.

15 Anna Bravo, Anna Bruzzone, In guerra senz'armi. Storie di donne 1940-'45, RomaBari 1995.

${ }^{16}$ Renata Viganò, współautorka scenariusza, zawarła w swojej powieści elementy autobiograficzne - uczestniczyła bowiem sama w partyzanckiej walce. Książka stała się ogromnym sukcesem wydawniczym; zdobyła Premio Viareggio i została przetłumaczona na wiele języków. W Polsce ukazała się w 1955 roku w nakładzie 100 tysięcy egzemplarzy (pewnie z uwagi na swą polityczną wymowę). W filmie występują m.in. Michele Placido i ulubiony aktor Pasoliniego, Ninetto Davoli; w rolę Agnieszki wcieliła się natomiast „aktorka Bergmana", Ingrid Thulin. 
działać w konspiracji i współpracować z partyzantką jako łączniczka. Kobieta, początkowo całkowicie obojętna sprawom publicznym (sprawom $m e ̨ z ̇ c z y z n)$, przechodzi ewolucję i staje się świadoma celów walki.

Teraz ona wiedziała, rozumiała to wszystko. Bogaci chcą być coraz bogatsi, a biedni niech będą coraz biedniejsi, ciemni i sponiewierani. Bogaci zarabiają na wojnie, a biedni tracą na niej życie [...]. Ale przecież byli tacy, którzy protestowali: partia, towarzysze, wszyscy ci mężczyźni i kobiety, którzy nie bali się niczego. Mówili, że tak dalej trwać nie może, że świat trzeba zmienić, że przyszedł już czas, żeby skończyć $\mathrm{z}$ tą wojna, że chleba musi być dosyć dla wszystkich i to nie tylko chleba, ale i innych rzeczy: rozrywek, radości, odpoczynku ${ }^{17}$.

Polityczne dojrzewanie bohaterki wraz z wyraźnie zaznaczonym w literackim pierwowzorze schematem prezentacji postaci - podziałem na dobrych, biednych chłopów oraz złych Niemców, wspomaganych przez bogatych Włochów - przypomina poetykę socrealistyczną i wpisuje się $\mathrm{W}$ zimnowojenną retorykę ${ }^{18}$. W filmie manichejski świat dobra i zła nie jest już tak wyraźny. Poprzez postać dzielnej Agnieszki - niewykształconej praczki, która przystaje do partyzantów, czynnie wspomagając ich oddział - podkreślona zostaje rzecz jasna rola proletariatu. Montaldo przełamuje jednak szablon "szlachetnych wieśniaków”, wprowadzając postaci chłopów nie tylko obojętnych na sprawy kraju, ale też wrogo do partyzantów nastawionych (w konsekwencji donosu najbliższej sąsiadki mąż Agnieszki zostaje aresztowany przez Niemców). Komentarzem do ambiwalentnej postawy wielu Włochów w czasie II wojny światowej są w filmie słowa Waltera (pomagającego partyzantom, a więc także „nieszablonowego", mieszczanina):

Dziś są ludzie, którzy szpieguja ot, tak, ze strachu lub gniewu... Sa pierwsi do ucieczki, jeśli ustysza samolot lub strzaty, ale wystarczy, że zobacza partyzanta. Wtedy sa gotowi go zadenuncjować [...]. I to nie dlatego, że kochaja Niemców, ale dlatego, że nie moga znieść takich jak wy. Nie moga znieść was, bioracych na siebie uciążliwy obowiązek myślenia i działania, za tych, którzy nawet nie rusza palcem, by coś zmienić [...].

Bardziej dosadnie tę postawę podsumowuje Agnieszka: rebelianci umieraja za imbecylów.

${ }^{17}$ Renata Viganò, Agnieszka idzie na śmierć, tłum. Barbara Sieroszewska, Warszawa 1955, s. 167.

${ }_{18}$ W powieści alianci są równie źli, jak Niemcy: nie spieszą się z wyzwoleniem Włoch i bombardują domy dla zabawy. Dobrzy są tylko Rosjanie; Związek Radziecki jest mityczną krainą, gdzie dobro już się dokonało, zaś partyzanci (z komunistycznych oddziałów) są bez wyjątku szlachetni, odpowiedzialni i bohaterscy. 
W realizacji Montaldo w centrum uwagi pozostają partyzanci, którzy pojawiają się $\mathrm{w}$ większości scen. Co istotne, w omawianym filmie podkreślona jest nie tyle ich przynależność polityczna (choć wiemy, że Palita sympatyzował z komunistami), ile osamotnienie w walce. O trudnej sytuacji partyzantów mówi na ekranie bohaterka: Alianci nas opuścili. Chłopcy marzna, nie maja co jeść, a ja jestem odpowiedzialna za aprowizację. Agnieszka Pality odpowiedzialna! Podobnie jak Paisà Rosselliniego, film kończy się w czasie srogiej zimy 1944 roku, kiedy w wyniku obwieszczenia Harolda Alexandra włoskie oddziały, zdezorientowane rozkazem "oczekiwania", pozostawione zostają same sobie. Skojarzenie z Paisa nie jest tu przypadkowe - Agnieszka idzie na śmierć zawiera bowiem bardzo podobną do tej z dzieła Rosselliniego scenę niemieckiego nalotu i ataku na partyzanckie łódki. Nawiązanie do neorealistycznego filmu dostrzegano także w epizodzie z udziałem Anglików, którzy - podobnie jak w czwartej noweli Paisy (o czym była już mowa) - nie pomagają Włochom w walce.

Agnieszka, jak już zostało powiedziane, nie przystępuje do partyzantów ze względu na polityczne przekonania (ja wiem tylko, że Niemcy go [Palite] zabrali), ale z woli „serca” - z uwagi na pamięć męża oraz dlatego że chce „sprawiedliwości”. Ta (pozornie) apolityczna motywacja wydaje się o tyle istotna, iż identyfikuje przynależność do włoskiego ruchu oporu z czymś instynktownym, „naturalnym”. Można odnieść wrażenie, że reżyser wskazuje w ten sposób na z gruntu "dobrą" i „nieskażoną faszyzmem" naturę Włochów.

W realizacji Montaldo pojawia się "gorący" w latach 70. temat rozwodów oraz równouprawnienia kobiet. Agnieszka, która jest niewątpliwie postacią pierwszoplanową wyzwoleńczej walki (przenosi m.in. ważne informacje oraz broń), nie przypadła jednak do gustu środowiskom feministycznym. Jest bowiem cały czas podległa mężczyznom: wykonuje ich rozkazy (m.in. transportuje paczki, ponieważ - jak twierdzą partyzanci - kobiecie łatwiej przejść wśród Niemców) oraz powierzone jej domowe prace (troszczy się o aprowizację, przygotowywanie posiłków i sprzątanie). Choć w dywersyjnych akcjach kobieta udowadnia swoją odwagę i charakter (w finale filmu za swą działalność ginie z rąk Niemca), partyzanci nazywają ją Agnieszka di Palita lub Mamma Agnieszka. Postrzegają ją zatem bądź przez pryzmat męża (jako wdowę po Palicie), bądź przypisują Agnieszce społecznie ustanowione role: matki lub żony.

Scenarzysta filmu, Nicola Badalucco, mówił:

Książka Viganò może wydać się przedawniona i w pewnych aspektach niewątpliwie taka jest; jednakże zawiera elementy, które mogą zostać odczytane w kluczu 
feministycznym. Patrząc z tej perspektywy, w filmie specjalnie zaakcentowaliśmy negatywne aspekty relacji Agnieszki z mężem, który trzyma ją z dala od swojej działalności politycznej i kompletnie przyćmiewa bohaterkę, zmuszając do bycia podległą mężowi. Ten sam stosunek podległości charakteryzuje relację Agnieszki z partyzanckim komendantem traktującym kobietę w sposób bardzo instrumentalny ${ }^{19}$.

Rzeczywiście: komendant, będący dla Agnieszki swego rodzaju „światopoglądowym przewodnikiem”, decyduje się zabrać ją ze sobą jako „pomoc domową", choć to przecież kobieta, która dowiodła swej odwagi - zabiła Niemca (dokonując tym samym "politycznego" wyboru ${ }^{20}$ ).

Ze słów scenarzysty wynika zatem, że jedną z intencji twórców była krytyka ówczesnych, stereotypowo pojmowanych ról przypisanych płciom. Agnieszka akceptuje jednak swoją rolę (Palita wie o tylu sprawach, o których ja nie mam pojęcia - mówi z dumą kobieta, a na ironiczne pytanie komendanta, który pyta chłopkę ze zdziwieniem, dlaczego tak światły mąż nie nauczył jej czytać ani pisać, Agnieszka reaguje obroną zmarłego, kłamiąc: To ja tego nie chciałam!). Film Montaldo pozostaje jednak przede wszystkim ciekawą wypowiedzią o włoskim ruchu oporu. Losy Agnieszki unaoczniają bowiem nie tylko transformację „oporu biernego" w resistenze „aktywną" - zbrojną, ale uwypuklają również rolę kobiet w walce o wolność.

Kobietą zaangażowaną we włoski ruch oporu, która pozostaje w centrum reżyserskiej uwagi, jest także Libera - tytułowa bohaterka filmu Libera, moja miłość (Libera, amore mio, reż. M. Bolognini, 1973). Pod względem ewokowania historii realizacja Bologniniego należy jednak do innej kategorii niż dzieło Montanda - filmów fikcjonalnych, których akcja rozgrywa się wyłącznie w przeszłości (w stosunku do ich powstania), ale które zawierają $\mathrm{w}$ swej strukturze materiał archiwalny. W Liberze odnajdziemy więc m.in. footage ukazujący rozbicie postumentu Mussoliniego (symboliczny koniec jego władzy), migawki z egzekucji dyktatora oraz dokumentalne zdjęcia prezentujące wojenne zniszczenia.

Przez prymat losów tytułowej bohaterki ukazane zostaje kilkanaście lat historii Włoch - lata 30., wojna oraz sytuacja Italii w kilka dni po wyzwoleniu, przy czym akcent pada w filmie na ostatnie dwa lata zbrojnego konfliktu (ten okres wojny, w którym Włochy walczą po stronie Hitlera, jest w filmie kompletnie pominięty!). Podobnie jak Agnieszka, Libera walczy wraz z oddziałem partyzantów przeciw niemieckiemu okupantowi

${ }^{19}$ Cyt. za: Giuliano Montaldo e L'Agnese va a morire, red. Laura Bonaparte, Milano 1976, s. $24-25$.

${ }^{20}$ Agnieszka zabija Niemca, ponieważ ten uśmierca jej kota - ulubieńca męża. 
i faszystom, transportując broń oraz dbając o aprowizację $e^{21}$. Pod względem osobowości różni się jednak diametralnie od żony Pality. Libera (grana przez Claudię Cardinale) jest bowiem kobietą świadomą politycznie, odważną w głoszeniu swoich poglądów (krytykuje podręczniki wychwalające Duce i poświęcone mu propagandowe filmy) oraz w pełni niezależną (nie słucha męża, który namawia ją by przez wzgląd na niego i dzieci zaniechała otwartego manifestowania swoich racji). Za swoje przekonania płaci - podobnie jak Agnieszka - najwyższą cenę (torturowana i więziona umiera $\mathrm{z}$ rąk faszysty). W filmie podkreślone jest raczej zaangażowanie Libery w sprawy kraju i czynną walkę z wrogiem (bohaterka uczestniczy m.in. w akcji wysadzania "strategicznego" mostu); sprawy domu schodzą tu na daleki plan, za co protagonistka jest w filmie krytykowana (m.in. przez swoją szwagierkę-tradycjonalistkę), ale co przysporzyło jej sympatię środowisk feminizujących, które okrzyknęły „odważną kobietę-partyzanta" - feministką ante litteram².

Włosi w Liberze... pokazani są bądź jako dzielni bojownicy, bądź niewinne ofiary wojny. Ich cierpienie oraz poświęcenie wyeksponowane zostaje w długich sekwencjach egzekucji (partyzantów oraz cywilów), tortur oraz $\mathrm{w}$ rozbudowanych scenach prezentujących zwłoki cywilnej ludności. Wrogiem w filmie Bologniniego są zaś zarówno okrutni Niemcy, jak i „bracia” faszyści (to oni m.in. wtrącają Liberę do więzienia, z którego zostaje uwolniona przez syna-partyzanta). Wątek ten - wewnętrznych podziałów politycznych - jest istotny o tyle, że przyczynił się do interpretowania filmu (wstrzymanego na dwa lata przez cenzurę) przez pryzmat współczesności. Szczególnie kontrowersyjnym fragmentem realizacji (zarówno dla prawej strony włoskiej areny politycznej, jak i dla lewicy parlamentarnej) okazało się zakończenie. W finale, już w wolnych Włoszech, Libera spotyka bowiem faszystowskiego komisarza, który przez lata ją prześladował, a teraz jest kierownikiem urzędu zajmującego się nieruchomościami. Gdy bohaterka idzie do siedziby Komitetu Wyzwolenia Narodowego ze skargą, domagając się usunięcia faszysty, szef CLN próbuje ją przekonać, by zrezygnowała z interwencji, gdyż nie można

${ }^{21}$ Historia tytułowej bohaterki, wedle wspomnień Bologniniego, inspirowana była losami matki jednego ze scenarzystów filmu - Luciano Vincenzoniego. Wypowiedź zawata w: Memoria, mito, storia. La parola ai registi, 37 interviste, s. 25.

${ }^{22}$ Co ciekawe, ciało „wyzwolonej Libery” jest w filmie fetyszyzowane zgodnie z voyerystyczną konwencją kina klasycznego (bohaterka pomimo upływu lat i dramatycznych perypetii w ogóle się nie starzeje; od pierwszej do ostatniej sceny wygląda młodzieńczo i ponętnie). Jeśli film Bologniniego ma być dyskursem „poważnym”, traktującym o odważnej bohaterce ruchu oporu, dlaczego pokazuje się uda Cardinale? Dla paru dolarów więcej? - pytał zasadnie Tullio Kezich. Por. Tullio Kezich, Il Millefilm, Milano 1980, s. 315. 
zlikwidować i zwolnić połowy (związanych z faszyzmem) włoskich urzędników. Na nic zdają się upomnienia, że urzędnik ma na swoim koncie przestępstwa kryminalne. Libera słyszy w odpowiedzi, że powinna wrócić do swoich „kobiecych” zadań, z dala od polityki:

Towarzyszko Zanoni. Libero, w demokracji, teraz, gdy burza już minęła, każdy musi na nowo odnaleźć się w swojej roli. Ktoś pracuje na wsi, ktoś pracuje w fabryce i w administracji, ktoś zajmuje się polityką... Miejscem kobiety takiej jak ty, która walczyła i cierpiała, jest dom. Zaskoczona Libera odpowiada: Chcesz powiedzieć, że przez dwadzieścia lat byłam szalona? Wojna nauczyła mnie wielu rzeczy, ale także bezlitośnie mnie wyczerpała... Teraz wy mnie ostabiacie. Tworzycie Italię z faszystami!

Wymowa tej sceny jest jasna: zwolennicy Mussoliniego przetrwali - w nowej, powojennej rzeczywistości nadal piastują urzędy. Film oskarża zatem włoski rząd, ale także opozycyjną partię komunistyczną za to, że nie przeprowadziła po wojnie gruntownej defaszyzacji, szczególnie w elitach władzy. „Ganiąc partie, że przegapiły okazję, by oczyścić życie polityczne z faszyzmu, film powtarza dzisiejszą debatę między ultralewicą a włoską partią komunistyczna, oskarżaną o ugodowość wobec mieszczańskiego systemu" - pisał na łamach "Corriere della Sera" Giovanni Graziani, dodając jednak, że realizacja Bologniniego „nie przeprowadza analizy historycznej" ${ }^{23}$ i nie mówi o przyczynach takiego stanu rzeczy. Wedle Grazianiego bardziej zasadna jest zatem wyzierająca z finału filmu krytyka władzy, która zapomniała o walczących za ojczyznę kobietach.

\begin{abstract}
Zmuszona przez Komitet Wyzwolenia Narodowego, aby wykonywać znowu domowe prace i wrócić do roli kury domowej, Libera jest symboliczną ofiarą polityki, która nie wykorzystała impulsu chwili. Dopiero dzięki ruchowi feministycznemu kobieta potwierdza swoje pragnienie uczestnictwa w życiu publicznym kraju ${ }^{24}$.
\end{abstract}

Libera, która dla kraju poświęciła całe swoje życie, w finale nie tylko zostaje niedoceniona, ale ponosi śmierć z rąk grasującego w okolicy zwolennika Mussoliniego. Jej ciało, niezauważone przez ostrzeliwujących snajpera partyzantów, stanowi swoistą ilustrację miejsca kobiety - na marginesie historii. Strzały faszysty, który niewidoczny dla oka włoskich obywateli sieje zamęt, także odczytywano jako komentarz do teraźniej-

${ }^{23}$ Giovanni Graziani, Libera, amore mio, „Corriere della Sera”, 22.03.1975. Przedruk w: Gianfranco Casadio, La Guerra al cinema. I film di Guerra nel cinema italiano, t. II, Ravenna 1998, s. 129.

${ }^{24}$ Ibidem. Imię Libera znaczy w języku włoskim dosł. „,wolna”. 
szości. Symptomatyczna pod tym względem jest recenzja opublikowana w "Cineforum". Bruno Damiani interpretował w nim finał filmu jako

jasny osąd ostatnich kryminalnych i krwawych wydarzeń, które obecnie mają miejsce we Włoszech (bomby faszystowskie w pociągach i na placach). Czego nie potrafił zdusić faszyzm w czarnej koszuli, zdołała więc zabić nowa demokracja, która może obarczyć winą za zbrodnię fanatycznych snajperów, ale która w istocie sama jest odpowiedzialna, politycznie i moralnie, za dramatyczne fakty współczesności²5.

Gorzką refleksję o włoskiej demokracji zawiera także fikcjonalny film Byliśmy tacy zakochani (reż. E. Scola, 1974). Na przykładzie losów trzech przyjaciół związanych w czasie wojny z ruchem oporu - proletariusza-socjalisty Antonia, pryncypialnego inteligenta-komunisty Nicoli i liberała Gianniego, który dorobił się majątku, zaprzedając swe młodzieńcze ideały - Scola przedstawia panoramę politycznych i obyczajowych przeobrażeń we Włoszech w powojennym trzydziestoleciu. Film przyjmuje formułę wspomnień samych protagonistów i opatrzony jest ciekawą, współczesną ramą narracyjną. W pierwszej sekwencji Gianni wykonuje skok do basenu. Gdy bohater odbija się od trampoliny, jego sylwetka zostaje zamrożona na stopklatce. Narrator zwraca się do widza: Gianni dokończy swój skok, który zaczą 30 lat temu i zanurkuje w finale filmu ${ }^{26}$.

Retrospekcja cofa narrację do czasów wojny. W czarno-białych kadrach widzimy trzech przyjaciół, którzy podczas srogiej zimy, w partyzanckiej akcji detonują z powodzeniem ładunek wybuchowy. Kolejna sekwencja zbudowana jest ze zdjęć archiwalnych - ukazują one Włochów w „wolnej Italii" wiwatujących na powitanie Amerykanów - i płynnie przechodzi $\mathrm{w}$ inscenizację. Reprezentacja ruchu oporu w filmie Scoli ogranicza się zatem do jednego, kilkuminutowego epizodu stanowiącego prolog filmu. Jest to jednak epizod fundamentalny dla całej fabuły. W realizacji Scoli nadany jest mu sens swoistego idealistycznego początku, także w wymiarze symbolicznym; to okres heroizmu, przyjacielskiej solidarności oraz

25 Bruno Damiani, Libera, amore mio, „Cineforum”, 15.08.1975. Przedruk w: Giuseppe Ghigi, La memoria inquieta. Cinema e resistenza, Venezia 2009, s. 198.

${ }^{26}$ Prezentowana historia trzech przyjaciół jest ciekawie znaczona aluzjami do kolei losu kinematografii narodowej. Odnajdziemy tu odwołanie do Złodziei rowerów, jesteśmy na planie Słodkiego życia. W filmie pojawiają się także we własnej osobie gwiazdy włoskiego kina - Fellini, Mastroianni, De Sica, Anita Ekberg, a także telewizyjny showman Mike Bongiorno. Fim zawiera dedykację dla zmarłego w trakcie realizacji filmu De Siki. Sam tytuł pochodzi zaś z piosenki śpiewanej przez De Sikę - Come pioveva. Rozbudowany wątek filmu sugeruje, że kino włoskie zawsze towarzyszyło procesom transformacji włoskiego społeczeństwa, reprezentowało je i uczestniczyło w nich. 
nadziei na zrealizowanie marzeń, które w toku narracji - w latach 60. i 70. (dekadach ukazanych już na taśmie barwnej) - są nieustannie negowane ${ }^{27}$.

Przesłanie filmu jest jednak gorzkie - chcieliśmy zmienić świat, a to on zmienit nas - mówi w finale jeden z przyjaciół. Sekwencja przy ognisku, przy którym po latach spotykają się dawni towarzysze broni, w kraju rozdartym sprzecznościami i bliskim chaosu nawiązuje do „odległej, partyzanckiej przeszłości”. Zgromadzeni przy ognisku Włosi śpiewają bowiem (nietłumaczona, niestety w angielskiej wersji DVD) pieśń:

\begin{abstract}
maszerowaliśmy z dusza na ramieniu [...], byliśmy wszyscy gotowi na śmierć, ale o śmierci nigdy nie mówiliśmy. Mówiliśmy o przysztości. Jeśli przeznaczenie nas oddala, wspomnienie tamtych dni zawsze nas jednoczy. Nie pamiętam nawet twego imienia - znam tylko twoje wojenne imię.
\end{abstract}

W zakończeniu filmu ponownie podkreślona zostaje więc wartość resistenzy. Wydaje się ona zamierzchłą przeszłością marzeń, które pozostały niespełnione i okazały się złudzeniami; nic więc dziwnego, że początkowo film miał nosić tytuł: Jesteśmy tacy rozczarowani ${ }^{28}$.

\title{
Rekonstrukcje
}

Oddzielną grupę filmów stanowią te, które fabularyzują faktyczne wydarzenia lub losy postaci historycznych. Przykładem takiej produkcji (tj. niezawierającej w swej strukturze materiałów archiwalnych) jest Corbari (reż. V. Orsini, 1970). Tytuł filmu przywołuje nazwisko legendar-

27 Trudno nie oprzeć się wrażeniu, że perypetie trzech mężczyzn reprezentujących różne polityczne poglądy, postawy i profesje (karierowicz Gianni jest wziętym adwokatem; intelektualista Nicola, pretendujący do funkcji "społecznego trybuna", pracuje jako nauczyciel, zaś Antonio to lekarz) tworzą metaforyczny obraz Włoch. Efekt ten jest potęgowany przez miejsce zamieszkania bohaterów, przypisanych do trzech różnych części Italii: Gianni rozpoczyna karierę na północy Włoch, Nicola pracuje na południu, a Antonio w Rzymie, gdzie wszyscy trzej po latach się spotykają. Jeśliby przyjąć taką metaforyczną optykę, można by zaryzykować twierdzenie, że Luciana - kobieta, która romansuje po kolei z wszystkimi przyjaciółmi, by w finale powrócić do zakochanego w niej przez wszystkie lata Antonia - jest uosobieniem Italii (na taki trop wskazuje Pasquale Iaccio; zob. Pasquale Iaccio, Non ti piace la fine del XX secolo? La storia nei film di Scola, [w:] Treviso-Cinecittà. L'avventuroso viaggio di Ettore Scola, red. Vito Zaggario, Venezia 2002, s. 134). Uwiedziona przez Gianniego i Nicolę, którzy rozczarowują ją zostaje z proletariuszem-socjalistą. Antonio nigdy jej nie zdradził; i choć nie zrobił kariery, nie może poszczycić się sławą lub majątkiem, to właśnie on wydaje się "wygrany” - odnalazł bowiem rodzinne szczęście i pozostał najbliższy swoim ideałom.

${ }^{28}$ Aldo Tassone, Parla il cinema italiano II, Milano 1980, s. 322. 
nego bohatera włoskiego ruchu oporu - Silvio Corbariego, który działając w 1944 roku wraz ze swoją bandą (tzw. banda di Corbari liczyła około trzydziestu osób), wyzwolił Tregnano, miasteczko na północy Włoch, i stworzył tam autonomiczną republikę, tzw. „wolną strefę Corbariego” (przetrwała ona kilkanaście dni). Film Orsiniego rekonstruuje spektakularne akcje rebelianta, który nie uznawał żadnej zwierzchniej władzy oraz działał bez rozkazów oficjalnego „sztabu” resistenzy. Przedstawione zostają m.in. brawurowe akcje zdetonowania ładunku wybuchowego, w wyniku którego ginie kilkunastu Niemców, oraz zabicia faszystowskiego dygnitarza, Gustavo Marabiniego (postać autentyczna). 18 sierpnia 1944 roku - wraz z przyjaciółmi (Adriano Casadeim i Arturo Spazzolim) oraz swoją miłościa, Iris Versari, Corbari został zaskoczony przez faszystów. Dziewczyna popełniła samobójstwo, natomiast Silvio wraz z kolegami został aresztowany, a następnie powieszony publicznie na placu w Frioli. Film także w tym względzie jest wierny faktom: ekranowa partnerka rebelianta (w filmie nosi imię Ines) popełnia samobójstwo, w finale zaś oglądamy szubienicę z pozostawionymi „ku przestrodze” zwłokami partyzantów.

Film utrzymany jest w konwencji przygodowej, która wydobywa $z$ tej historii brawurę bandy Corbariego, jej niezależność oraz dramatyczne poświęcenie. Silvio przypomina Robin Hooda - zabierającego bogatym i rozdającego biednym (Corbari faktycznie $w$ utworzonej przez siebie „wolnej strefie" rozdał chłopom ziemię oraz "anulował” ich długi wobec włoskich banków i właścicieli ziemskich). Film był odczytywany również przez pryzmat współczesności, m.in. z uwagi na wyraźny wątek klasowy - w dialogach wielokrotnie pojawia się teza, że faszyzm chroni własność bogatych, zaś członkowie bandy to bądź robotnicy, bądź świadomi politycznie studenci. Resistenza identyfikowana jest więc z walką klas, a wrogami włoskiej partyzantki są przede wszystkim faszyści oraz sympatyzujący z nimi przedstawiciele burżuazji: przemysłowcy i magnaci prasowi. Niemcy pełnią rolę drugoplanową.

Ruch oporu to zatem w filmie Orsiniego raczej proletariacka rewolucja niż drugie risorgimento, ponieważ - jak słusznie zauważa Ghigi - „ekranowy Corbari jest synem politycznej dekady buntu i ołowiu" ${ }^{29}$. O tym, że omawiany film był odczytywany przez pryzmat anni di piombo, świadczą nie tylko ówczesne recenzje filmowe (Lino Micciché pisał, że "Corbari to rekonstrukcja przeszłości, a zarazem jasna metafora teraźniejszości”), ale także reakcja widzów na poszczególne sceny. Jak relacjonuje Giovanni De Luna, ogromny aplauz wzbudziła np. sekwencja, w której właściciel fabryki, inżynier Riccardi, zostaje powieszony głową w dół na bramie

${ }^{29}$ Giuseppe Ghigi, op. cit., s. 172. 
fabryki (koło trupa widnieje karteczka z napisem: ha vissuto sfruttando gli operai poi è venuto Corbari ${ }^{30}$ ), zaś ekranową zemstę na wydawcy poczytnego dziennika, który przeinaczał fakty, interpretowano jako komentarz do świeżej jeszcze sprawy Pinellego i zamachu na Piazza Fontana w 1969 roku $^{31}$.

Nieprzypadkowo także głównym wrogiem w filmie Orsiniego pozostają faszyści. Taki zabieg oddaje ducha epoki w tym sensie, iż ukazuje bratobójczą walkę - eksponuje zatem inaczej niż np. filmy zrealizowane od razu po wojnie, podział włoskiego społeczeństwa na zwolenników Mussoliniego oraz jego przeciwników. Jednocześnie odzwierciedla społeczne napięcia lat 70. w tym wymiarze, iż w dekadzie ołowiu (o czym będzie jeszcze mowa) ugrupowania skrajnej lewicy nazywały te ultraprawicowe właśnie faszystowskimi (które zresztą jawnie czerpały z tej tradycji). Resistenza w latach 70. w sloganach środowiska lewackiego uzyskuje zatem nowe znaczenia - staje się oporem przeciw neofaszystowskiemu, czarnemu terroryzmowi.

W Corbarim faszyści przedstawieni są jako okrutnicy, czerpiący satysfakcję z zadawanych partyzantom tortur. Znamienne pod tym względem są dwie sekwencje: w pierwszej czarne koszule urządzają osobliwą "zabawę" (każą nagiemu partyzantowi uciekać w szczerym polu, po czym puszczają za nim psy szkolone w zabijaniu ludzi); w drugiej zaś przedstawiono rozstrzeliwanie członków bandy Corbariego, złapanych w czasie nalotu na „wolną strefę" w Tregnano. Sekwencja egzekucji jest niezwykle rozbudowana. W akompaniamencie muzyki ilustracyjnej oglądamy partyzantów, którzy po kolei ukazywani są na tle muru - swoistej „ściany śmierci". Niektórzy z nich płacza, inni patrzą z niedowierzaniem lub strachem na oprawców. Następnie widać naprzemiennie twarze członków bandy i faszystów oraz ich oczy w dużym zbliżeniu, tak jakbyśmy mieli do czynienia $\mathrm{z}$ „nierównym” pojedynkiem (ten fragment sekwencji zmontowany jest w szybszym tempie). Muzyce ilustracyjnej zaczyna towarzyszyć odgłos przyspieszonego bicia serca. Oglądamy usta faszysty wypowiadające niesłyszalny dla widza rozkaz, partyzanta na tle ściany, wreszcie lufę pistoletu w momencie strzału i ponownie twarz oprawcy. Podobny „rytm” pojawia się jeszcze kilkakrotnie, choć kamera zatrzymuje się za każdym razem na ofierze - jeden z partyzantów modli się; inny pa-

${ }^{30}$ Dosł.: „żył wykorzystując robotników, później przyszedł Corbari”. W oryginale słowa tworzą swoisty rymowany epigram.

${ }^{31}$ O sprawie Pinellego piszę więcej w artykule "Przypadkowa śmierć anarchisty”. Tzw. sprawa Pinellego i jej fabularyzacja w włoskich tekstach kultury, [w:] Historia w kulturze wspótczesnej, red. Piotr Witek, Mariusz Mazur, Ewa Solska, Lublin 2011. 
trzy w niebo, jakby w poszukiwaniu boskiej opatrzności; dwóch kolejnych pada na kolana. Takie pozy przydają omawianej sekwencji dodatkowego sensu. Partyzanci wydają się tu męczennikami, zaś cała masakra zyskuje znaczenie bardziej abstrakcyjne - wydaje się starciem dobra ze złem.

Nieposłuszeństwo wobec władz resistenzy, spontaniczność organizacji, a także reprezentowany przez Corbariego antykapitalizm czynią $\mathrm{z}$ bohatera figurę idealnego rebelianta przełomu lat 60. i 70. Jak słusznie zauważa Ghigi,

Corbari uosabia młodzieńczą niecierpliwość i nietolerancję młodych Włochów wobec tych partii na początku lat 70., które chciały w przyszłości przygotować historyczny kompromis i które wybrały drogę żmudnych mediacji z obowiązującym systemem. Szczególnie krytykowani są komuniści - wedle kontestatorów zaprzepaścili oni bowiem rozpoczęty po wojnie proces rewolucyjnej zmiany społeczeństwa ${ }^{32}$.

W filmie Orsiniego głosem włoskiej partii komunistycznej pozostaje Ulianow (zwierzchnik komunistycznego oddziału partyzantów). Kluczowa dla wymowy filmu długa (i bardzo teatralna) dysputa między reprezentantem „rewolucyjnej cierpliwości” a kierującym się „sercem i instynktem" Corbarim była nie bez racji odczytywana jako komentarz do wydarzeń współczesnych. Sandro Zambetti na łamach „Cineforum” pisał:

w słowach Ulianowa, komendanta resistenzy można dopatrzeć się tych samych argumentów (odpowiedzialność zarządzania dużym liczebnie ruchem, a w konsekwencji konieczność rozwagi - niemożność ryzykowania losem wielu ludzi wobec celów jeszcze niedojrzałych), jakie zostały ostatnio użyte przez Pietro Ingaro, by usprawiedliwić postawę włoskiej partii komunistycznej wobec polityki wewnętrznej; stanowisko przeciwne do tego reprezentowanego przez lewicę pozaparlamentarna które jest bliższe Corbariemu nadającemu resistenzy impuls zdecydowanie bardziej rewolucyjny ${ }^{33}$.

W filmie Orsiniego Corbari jest rzecznikiem ultralewicy, wedle której „rewolucyjna siła resistenzy została uśpiona, zahamowana instytucjonalnie, a podjęta próba kompromisu była de facto przyzwoleniem na rządy chadecji". Film zdaje się sympatyzować z Silvio (z uwagi na jego brawurę i slogany ekranowy Corbari przy pomina nieco Salvatore z Mafia nie przebacza [reż. P. i V. Taviani i V. Orsini, 1962]). Nie dziwi więc fakt, że realizacja

${ }^{32}$ Giuseppe Ghigi, op. cit., s. 168.

33 Sandro Zambetti, Corbari, „Cineforum” 1970, nr 97-98. Pietro Ingaro - włoski polityk i dziennikarz związany z włoską partią komunistyczną. 
została skrytykowana przez włoską partię komunistyczną (Antonello Trombadori atakował film twierdząc, że kompletnie zmienił on sens i oblicze resistenzy). Jest $\mathrm{w}$ tym sporo racji - trudno bowiem przypuszczać, że Corbari-postać historyczna miał polityczne poglądy właściwe lewackim radykałom, które zostały mu przez Orsiniego przypisane.

Interesującym wątkiem filmu jest ,transcendentny" porządek w kreacji bohatera. Jeden z członków bandy zwraca się do Corbariego słowami: Nie wierze w cuda, ale tobie udało się jednego dokonać. Swe rewolucyjne hasła o rozdaniu ziemi chłopom i pomyśle na funkcjonowanie „wolnej strefy Corbariego" bohater głosi w kościele (ubrany w ciemną bluzę z kapturem przypomina raczej mnicha niż partyzanta). Wszystkim akcjom Corbariego towarzyszy zaś dźwięk kościelnych dzwonów - wybrzmiewają one za każdym razem, gdy mężczyzna „wymierza sprawiedliwość” oraz przy egzekucji na końcu filmu. W finale bohater umiera, zyskując przez to status „męczennika za sprawę" (choć jednocześnie jawi się ona jako niemożliwa do spełnienia). To istotne „sprofilowanie" Corbariego wydaje się charakterystyczne dla całej dekady. Podobny zabieg, w tym samym roku co Orsini, zastosował choćby Richard Fleischer, realizując Che! (1970); nieco wcześniej Pier Paolo Pasolini odwrócił kierunek skojarzeń w Ewangelii według Mateusza (ll vangelo secondo Matteo, 1964), w której Chrystus przedstawiony jest jako rewolucjonista.

Corbari - w tej roli Giuliano Gemma ${ }^{34}$, z szerokim uśmiechem i twarzą studenta, który wydaje się wzięty wprost z manifestacji w Mediolanie - dobrze uosabia sny pokolenia identyfikującego się z Marksem, Mao i Marcusem. Z uwagi na dramaturgiczne niedostatki filmu Corbari nie został jednak polityczną ikoną, choć teoretycznie - jak słusznie zauważa Ghigi - postać ta miała wszystkie atuty, by stać się „,kinowym, włoskim Che Guevarą lat 70." ${ }^{35}$

W tej samej grupie filmów co Corbari sytuuje się Masakra w Rzymie (Rappresaglia, reż. G. Cosmatos, 1973) ${ }^{36}$. Film fabularyzuje tragiczne wydarzenia z marca 1944 roku. W wyniku partyzanckiej akcji dywersyjnej na Via Rasella w Rzymie zginęło wtedy trzydziestu dwóch Niemców; w od-

${ }^{34}$ Giuliano Gemma to aktor grający popularnego w latach 60. Ringo - bohatera spaghetti-westernów. Fakt, że ten sam aktor zagrał Corbariego jest kolejnym elementem mitologizującym postać.

35 Giuseppe Ghigi, op. cit., s. 174.

${ }^{36}$ Film został zrealizowany z rozmachem i był dużym międzynarodowym przedsięwzięciem (w koprodukcji włosko-francuskiej wyreżyserowanej przez włosko-greckiego reżysera na podstawie powieści Amerykanina Roberta Katza zagrały gwiazdy brytyjskiego i włoskiego kina - m.in. Richard Burton i Marcello Mastroianni). 
wecie naziści z rozkazu Hitlera następnego dnia (24 marca 1944 roku) zabili 330 Włochów (za śmierć jednego Niemca miało zapłacić życiem dziesięciu Włochów ${ }^{37}$ ). Wydarzenie to, nazywane masakrą w Jaskiniach Ardeatyńskich (wł. Fosse Ardeatine - od miejsca rzezi), pozostaje jedną $\mathrm{z}$ najokrutniejszych zbrodni wojennych wobec włoskiej ludności. Masakra ta, upamiętniona poprzez mauzoleum w miejscu zbrodni i pamiątkowe tablice, została także utrwalona $\mathrm{w}$ licznych publikacjach ${ }^{38}$, teatrze (sztuka Carlo Bernariego Roma 335) oraz muzyce (Amerykanin William Schuman skomponował w 1968 roku symfonię nr 9, zatytułowaną Le fosse ardeatine).

Również w tym filmie powstaje wrażenie resistenzy jako ruchu ogólnonarodowego. Taki efekt wytwarzany jest już od pierwszej sekwencji. Podczas napisów początkowych widzimy bowiem włoskich konspiratorów (wszyscy w beretach z antenką), którzy ukradkiem, z różnych miejsc Rzymu, obserwują przemarsz Niemców na Via Rasella (kamera w finale tego swoistego prologu ukazuje tabliczkę z nazwą ulicy). Porozumiewawcze gesty, spoglądanie na zegarki oraz ich synchronizacja w rytm niemieckich równych kroków i głosu niemieckiego dowódcy wyznaczającego tempo pochodu - ein, zwei, ein, zwei... wytwarza wrażenie, że w Italii (a przynajmniej w stolicy kraju) działa rozbudowana, sprawnie działająca siatka włoskiego ruchu oporu. $W$ istocie, w ciągu pierwszych trzech minut filmu oglądamy Włochów bądź bezpośrednio $\mathrm{w}$ resistenzę zaangażowanych, bądź manifestujących swą niechęć do Niemców. Prócz sześciu włoskich partyzantów bacznie śledzących nazistowski przemarsz, widzimy m.in. reakcję Włocha, który na dźwięk niemieckich kroków przeklina, zostaje jednak porozumiewawczo uciszony przez golącego go fryzjera. Wszyscy Włosi pojawiający się w filmowym prologu są zatem jawnie nieprzychylni nazistowskiej władzy. Statystyka ta w toku narracji pozostaje niemal niezmienna - Włosi są w filmie Cosmatosa generalnie "dobrzy" (wyjątkiem jest tu jedyny w filmie faszysta Caruso - szef włoskiej policji [postać historyczna]), zaś Niemcy bez wyjątku okrutni.

Niechęć włoskiego społeczeństwa do niemieckiego okupanta podkreślona zostaje także w sekwencji „masowego” słuchania Radia Londyn. Kiedy z odbiornika padają słowa otuchy: nie załamujcie się drodzy włoscy przyjaciele. Pomóżcie sobie, żeby alianci mogli wam pomóc, oglądamy wnętrza

${ }^{37}$ W szpitalu w rzeczywistości (i w filmie) zmarł jeszcze jeden Niemiec, stąd doliczono kolejną dziesiątkę skazańców. Wedle niektórych źródeł zginęło jednak 335 Włochów.

38 Zob. np. Sergio Piccioni, Roma 1944: le Fosse Ardeatine, Firenze 1968; Lorenzo Baratter, Le Dolomiti del Terzo Reich, Milano 2005; Alessandro Portelli, L'ordine è già stato eseguito. Roma, le Fosse Ardeatine, la memoria, Roma 1999. 
czterech różnych mieszkań, w których Włosi, nadstawiają ucha, by zdobyć najświeższe informacje $z$ frontu (komunikat funkcjonuje więc jako mostek dźwiękowy spajający cztery odrębne przestrzenie). Jak podsumowuje jeden z Niemców: gdy Stevens jest w eterze, wszystkie odbiorniki sa właczone.

Partyzanci pojawiają się w filmie jeszcze kilkakrotnie - ukazani są m.in. podczas przygotowań do akcji i rzecz jasna w trakcie jej realizacji. Sekwencja konstruowania ładunku wybuchowego oraz detalicznego planowania zamachu jest o tyle ciekawa, że jej akompaniament stanowi aria śpiewana przez niemieckiego żołnierza, który relaksuje się wraz z kolegami w towarzystwie kobiet przy dźwiękach muzyki klasycznej. W istocie, sceny prezentujące odpoczynek nazistów przeplatane są tymi ukazującymi przygotowania partyzantów oraz migawkami tortur Włochów (w sekundowych ujęciach widać fragmenty zakrwawionych, wykrzywionych w bólu twarzy). Śpiewana przez Niemca aria staje się zatem swoistym spoiwem trzech linii narracyjnych: sprawców, ofiar i rebeliantów.

Niemcy w Masakrze w Rzymie sportretowani zostają dość sztampowo - jako trybiki okrutnej „nazistowskiej machiny”. Znamienna pod tym względem jest przywoływana już (a pojawiająca się $\mathrm{w}$ filmie jeszcze dwukrotnie) scena przemarszu Niemców przez Via Rasella. Maszerujący piątkami żołnierze kadrowani są bądź w planie dalekim - aby wyeksponować geometryczną kompozycję „pochodu” (idący tworzą bowiem razem idealny prostokąt), bądź na zbliżeniach. Tyle, że widzimy w nich albo fragmenty ciała (szereg dłoni machających w takt kroków), albo munduru (wyglansowane buty lub lśniące hełmy). Akcentowany jest zatem kolektyw, a nie jednostka - nawet w zbliżeniach w obrębie jednego kadru ukazana jest zbiorowość (dłonie, buty, hełmy), a nie detal (np. twarz jednego z żołnierzy). W efekcie powstaje wrażenie, że włoską ulicę przemierza „ludzki czołg” na lśniących, tworzonych przez wypucowane buty gąsienicach, któremu nie przeszkadza rzucona pod nogi dziecięca piłka.

Jedynym Niemcem o pogłębionym portrecie psychologicznym jest w filmie Herbert Kappler - pułkownik gestapo (postać historyczna), który na zlecenie Alberta Kesserlinga tworzy w pośpiechu listę skazańców. To Kappler - wraz z przeciwstawionym mu światopoglądowo włoskim księdzem, a zarazem konserwatorem zabytków, Antonellim - staje się w zasadzie protagonistą drugiej połowy filmu. Zarówno pułkownik, jak i kapłan, to esteci, ceniący kulturę wysoką i to na tym obszarze możliwe jest między nimi porozumienie. Jak mówi Antonelli: jedynie sztuka pozwala komunikować się narodom i pokoleniom. W pięknie trwa nadzieja na zbawienie świata. Piękno, prawda i dobro to trójca, która jest starsza od Kościoła. Na quasi-filozoficznych dysputach o etruskich wazach i obrazach Masaccia 
dialog włosko-niemiecki jednak się kończy. Kappler posłuszny rozkazom zwierzchników sporządza listę skazańców przy udziale faszysty Caruso, choć w filmie zdarzają się momenty, kiedy nad ślepym posłuszeństwem wydają się zwyciężać ludzkie odruchy. Kappler targuje się np. ze swoim zwierzchnikiem o liczbę skazańców (pragnąc maksymalnie ją zredukować) oraz chce uchronić od zagłady ludność cywilną (proponuje poświęcić wyłącznie tych uprzednio skazanych na śmierć). Można odnieść nawet wrażenie, że Kappler jest przeciwny planowanej akcji; za taką hipotezą przemawia m.in. scena obmywania dłoni po wykonanym spisie (jeśli to oficjalny rozkaz, oddam ludzi do waszej dyspozycji, ale sam nie zamierzam brać udziału w operacji - mówi zwierzchnikowi); zaś na argumentację Antonellego, by zatrzymać zbrodniczy plan odpowiada: za późno, ojcze, machina poszła w ruch. Jestem człowiekiem, sam nic nie zmienie. Niech zadecyduje koło fortuny. Ostatecznie jednak posłuszny pisemnemu rozkazowi daje przykład innym i zabija (w finale jego ofiara jest Antonelli) ${ }^{39}$.

W filmie Cosmatosa okrutną rzeź, która utrwala wizerunek Włochów jako niewinne ofiary, poprzedza rozbudowana sekwencja konstruowania listy śmierci. Widzimy zatem Kapplera, który w mundurze, wśród zebranych pieczołowicie akt, wypisuje na papierze wiecznym piórem nazwiska skazańców. Detal ręki, kaligrafującej wyuczonym pismem poszczególne litery oraz skupionych oczu Niemca, podkreśla nieludzkość „matematycznego zadania", które przez Kapplera właśnie w takich czysto buchalteryjnych kategoriach jest rozpatrywane: Niemiec kilkakrotnie dodaje nazwiska (poszczególne ludzkie istnienia) na papierze, tak jakby były to zwykłe liczby. Ujęcia prezentujące Kapplera przy pracy zestawione zostają na zasadzie montażu równoległego z tymi ukazującymi Caruso, który również pomaga nazistom, wypisując na maszynie swoje "typy". W ten sposób podkreślona zostaje współodpowiedzialność faszystów za tytułową masakrę (choć, jak wspomniałam, Caruso jest jedynym zwolennikiem Mussoliniego w całym filmie).

Swoistą inżynierię śmierci unaocznia scena informacyjnego zebrania przed "operacją". Kappler, który na wstępie anuluje ewentualny temat moralnych rozterek - nie ma mowy o poczuciu winy; jako żotnierze wykonujemy tylko rozkazy - przechodzi do detalicznego omówienia operacji:

${ }^{39}$ Postać Antonellego to postać fikcyjna, choć niekiedy dopatrywano się w nim odwołania do Don Pietro Papagallo - postaci historycznej (księdza, który zginął w Fosse Ardeatine i został odznaczony pośmiertnie medalem wojskowym; od 2000 roku Don Pietro Papagallo stał się męczennikiem Kościoła XX wieku). Postać Antonellego niweluje niejako negatywny obraz instytucji Kościoła jako biernego wobec zbrodni. Film, podobnie jak książka, nie waha się bowiem zadać pytania: dlaczego Pius XII nie interweniował, jeśli rzeczywiście był poinformowany o planowanej zbrodni? 
opisuje dokładną topografię miejsca kaźni (eksploatowane jaskinie z wapienia, które po zakończeniu operacji zostanq zamknięte), a następnie podaje w prostych, jednoznacznych słowach sposób wykonania samego zadania. Wszystko zostało zaplanowane w najdrobniejszych szczegółach, tak aby operacja była maksymalnie efektywna przy możliwe najmniejszym nakładzie czasu i wysiłku: Mamy trzy godziny na zgrupowanie ludzi, godzine na transport, minute na każda egzekucję. Powinniśmy skończyć o zachodzie słońca, jeśli wszystko pójdzie według planu. Ta racjonalizacja zbrodni jest porażająca (szczególnie przy świadomości, że prezentowane wydarzenia zostały poparte studiami archiwalnych dokumentów).

Pięcioosobowe plutony będa rozstrzeliwać po pięciu skazanych. Każdy z nas zabije po czterech, pięciu ludzi; ściany tuneli sa z wapienia, po zamknięciu stana się naturalnym grobowcem - informuje beznamiętnie pułkownik. Następnie tłumaczy procedurę postępowania. Podaje instrukcję traktowania ofiary, demonstrując poszczególne etapy uśmiercania na "modelu” (Niemcu), by "na sucho” przećwiczyć i rozwiać wszelkie wątpliwości: skazany uklęknie, głowa lekko do przodu, lufa przy karku (nie musi dotykać). Kula przejdzie przez ośrodek mózgu. Zbrodnia zostaje zatem zredukowana do technicznych wskazówek, przypominających instrukcję segregowania śmieci. Skojarzenie z odpadami jest tu o tyle silne, że Niemiec wspomina o utylizacji (wapień przyspieszy rozkład zwłok) i problemach spedycyjnych (zamówiłem 40 ciężarówek). Tym bardziej strasznie brzmią w tym kontekście słowa o szybkiej i bezbolesnej (chciałoby się dopowiedzieć „,humanitarnej”!) śmierci. Najważniejsze dla Niemców wydają się więc pisemne zgody oraz kwity - sens całej operacji gubi się między lakonicznymi słowami, stemplami i podpisami.

Sama egzekucja w grotach także przypomina śmiercionośną „manufakturę". Dowiezieni ciężarówkami Włosi zostają najpierw „odhaczeni” na liście, a następnie małymi grupami - niczym owieczki prowadzone na rzeź - idą do miejsca kaźni (ostatnią drogę więźniów oglądamy niekiedy $\mathrm{z}$ ich perspektywy, z punktu widzenia ofiar, przez co wzmocniona zostaje identyfikacja widzów z nimi). Masakra ukazana jest w bliskich planach: zbliżenie na wiązane ręce, odchylanie głowy, strzał w potylicę i następny, następny... Migawki ukazujące rurę wydechową z ulatniającym się gazem oraz ogrodzenie z drutem kolczastym obarczają rzymską masakrę dodatkowym bagażem skojarzeń (krematoriów i obozów koncentracyjnych), wpisując ją tym samym w kontekst innych nazistowskich zbrodni. Gdy na ekranie pada ostatni strzał, pojawia się wykaz ofiar opatrzony komentarzem, informującym o losie sprawców. Dowiadujemy się m.in., że Pietro Caruso został rozstrzelany, feldmarszałek Albert Kesserling, który był sądzony w Wielkiej Brytanii w 1946 roku i skazany na śmierć, ostatecznie 
wyszedł na wolność w 1952 (wyroku nie wykonano), zaś pułkownik Kappler - sadzony w 1948 roku w Rzymie, uznany za winnego i skazany, odbywa kare we włoskim więzieniu ${ }^{40}$.

Film spotkał się z przychylnymi ocenami krytyki. Tullio Kezich pisał, że realizacja Cosmatosa to doskonale udokumentowany "proces przeciw inżynierom śmierci" ${ }^{\prime 1}$. Lino Micciché, dostrzegając zalety produkcji, zwracał natomiast uwagę, że zamach na Via Rasella wydaje się w realizacji Cosmatosa akcją jednostkową - partyzanci znienacka znikają w połowie filmu ${ }^{42}$. Niezależnie od tych ocen i opinii, Masakra w Rzymie jest bezsprzecznym świadectwem ponownego zainteresowania włoskiego kina tematem II wojny światowej i jej „,zapomnianych”, dramatycznych epizodów.

Przykładem filmu fabularyzującego wydarzenia historyczne, który zawiera w swej strukturze materiały archiwalne, jest Mussolini, ostatni akt (Mussolini, ultimo atto, reż C. Lizzani, 1974) ${ }^{43}$. Jak wskazuje sam tytuł - realizacja, będąca efektem skrupulatnych studiów i archiwalnej kwerendy - ukazuje ostatnie dni Duce: jego nieudaną ucieczkę do Szwajcarii, pojmanie przez włoski ruch oporu i wreszcie śmierć (wraz z kochanką Clarettą Petacci). Resistenza w filmie Lizzaniego nie jest zatem wiodącym tematem filmu (w centrum narracji pozostaje osamotniony i przeczuwający klęskę Mussolini), ale stanowi istotny jego wątek.

Film wzbudził duże zainteresowanie krytyki. Giovanni Graziani na łamach „Corriere della Sera” napisał:

Realizacja Lizzaniego traktuje o istotnym momencie włoskiego życia politycznego, w którym ukazane zostają ostatnie spazmy faszystowskiej dyktatury [...]. Temat

${ }^{40}$ Historia dopisała inny epilog niż ten zawarty w filmie w momencie jego realizacji. Kappler uciekł bowiem z więzienia w 1976 roku i zmarł rok później w swoim domu w RFN. Kesserling wrócił zaś do Niemiec, gdzie został powitany jak bohater. Będąc już w ojczyźnie Kesserling zadeklarował, że nie żałuje czasu spędzonego podczas niemieckiej kampanii we Włoszech i powiedział, że Włosi powinni mu wystawić pomnik w ramach wdzięczności. Słowa te wywołały rzecz jasna oburzenie w Italii. Piero Calamandrei (pisarz, poeta i polityk włoski) w odpowiedzi na nie napisał wiersz, który został wyryty pierwszy raz na tablicy w Cuneo (obecnie podobne tablice znajdują się i w innych miejscowościach). Tekst wiersza dostępny jest m.in. na stronie www.pensieriparole.it/poesie/poesie-d-autore/poesia-19437. Chyba najsłynniejsza jest ostatnia zwrotka poematu, w której Calamandrei obiecuje, że jeżeli Kesserling wróci do Włoch znajdzie żywych i zmarłych zgromadzonych wokół pomnika, który nazywa się „,ora e sempre resistenza” (teraz i zawsze resistenza).

${ }^{41}$ Tullio Kezich, „Panorama”, 1.11.1973. Przedruk w: Gianfranco Casadio, op. cit., s. 223.

${ }^{42}$ Lino Micciché, Cinema italiano degli anni '70, s. 172.

${ }^{43}$ Materiały archiwalne ukazują głównie lata masowego poparcia dla Mussoliniego, a zostają wprowadzone $\mathrm{w}$ formule wspomnień Duce, który wraca pamięcią do dni swojej chwały. W filmie występują m.in. Rod Steiger (w roli Duce), Franco Nero, Henry Fonda oraz Lisa Gastoni. 
- choć minęło niemal trzydzieści lat od zaprezentowanych faktów - jest cały czas dla wielu gorący, ponieważ właśnie w przeszłości splatają się więzy krępujące nas do dziś. [...] Obecność w filmie wielu postaci historycznych, które jeszcze żyja, podnosi jego temperaturę $e^{44}$.

Rzeczywiście, w momencie projekcji żyli zarówno Pier Luigi Bellini delle Stelle - dowódca partyzanckiego oddziału, który zdemaskował Mussoliniego, usiłującego przedrzeć się za granicę w przebraniu niemieckiego żołnierza, jak i Walter Audisio - wykonawca wyroku na Duce.

Ruch oporu pojawia się pierwszy raz na ekranie w udanej skądinąd sekwencji rozpoznania Mussoliniego. Wcześniej resistenza wspominana jest $\mathrm{w}$ dialogach: w okolicznych górach jest mnóstwo partyzantów; jak zaatakuja, nie będziemy mieć szans; partyzantów jest petno - szepczą między sobą faszyści, którzy przeczuwają koniec swojej władzy. W efekcie powstaje wrażenie, że resistenza to ruch liczebnie mocny i politycznie znaczący. Tezę tę podtrzymuje i potwierdza sekwencja przejazdu Niemców przez partyzancki patrol (naziści, którzy witają go białymi flagami, uzyskują zgodę na opuszczenie Włoch bez walki). W akompaniamencie muzyki ilustracyjnej oglądamy - z punktu widzenia jadących (w eskorcie partyzantów), pokonanych Niemców - „krajobraz po bitwie”. Niewiele ma on jednak wspólnego z dramatycznym obrazem powojennych zniszczeń eksponowanych $\mathrm{w}$ wielu filmach neorealistycznych. Widać raczej radość i dumę partyzantów, którzy ze sobą współpracują. Można by zatem powiedzieć, że w planie symbolicznym sekwencja ukazuje postawę „Nowych Włoch”, zdeterminowanych, by odbudować kraj.

Sposób przedstawienia oddziału, który zdemaskował Mussoliniego (52. Brygada Garibaldczyków), akcentuje znaczenie komunistycznej partyzantki. Unaocznia to doskonale ujęcie, w którym na pierwszym planie garibaldczycy zatykają flagę komunistyczna, zaś w tle inna grupka niesie flagę włoską. Hierarchia planów jest tu znacząca - akcent pada na opcję polityczną, a nie „narodową" jedność.

Partyzanci - komuniści, którzy pragną zlikwidować Mussoliniego - przeciwstawieni zostają w filmie Lizzaniego Amerykanom, którzy negocjują z faszystami i chcą ocalić Mussoliniego, by zaskarbić sobie proamerykańskie wpływy we Włoszech. W tej polaryzacji poglądów można doszukać się oczywiście wymowy politycznej (nie bez znaczenia pozostaje tu fakt, że Lizzani był członkiem włoskiej partii komunistycznej). W finale filmu pojawia się napis - słowa deklaracji podpisanej przez reprezentantów różnych partii ${ }^{45}$ :

${ }^{44}$ Giovanni Grazziani „Corriere della Sera”, 5.04.1974.

45 Pojawiają się nazwiska m.in. Luigi Longo, Ferruccio Parri, Augusto De Gasperi i Sandro Pertini. 
Komitet Wyzwolenia Narodowego deklaruje, że zabicie Mussoliniego i jego wspótpracowników zlecone przez CLN to konieczna konkluzja historycznej fazy, która pozostawia nasz kraj okryty zniszczeniami materialnymi i moralnymi. To zakończenie walki powstańczej, która oznacza dla ojczyzny obietnice odrodzenia.

Filmu nie ominęła krytyka. Wytykano mu m.in. wolne tempo oraz fabularne niespójności. Rzeczywiście, przestrzeń diegetyczna budowana jest nieudolnie, czasem trudno rozeznać się w mnogości postaci. Roberto Alemanno na łamach "Cinema Nuovo" pisał:

Zrodzony z antyfaszystowskich intencji, Mussolini, ostatni akt w praktyce okazał się przykładem rozbieżności między zamysłem reżysera a efektem końcowym [...]. Film miał być "obiektywną" relacją z ostatnich dni Mussoliniego i Pettaci, ale zawiódł zarówno w planie „dokumentalnym”, jak i w planie ideologii, ponieważ zaprezentowana agonia dyktatora kompletnie nie tłumaczy istoty dyktatury ${ }^{46}$.

Leo Pestelli w „La Stampie” wskazywał zaś nie bez racji, że

człowiek, który ukazany jest w ostatniej fazie życia i który nie może uciec od przeznaczenia zawsze wzbudza litość. Oglądając film współczujemy Mussoliniemu, co przydaje wymowie realizacji nieco politycznej ambiwalencji [...]. Czy reżyser nie powinien zająć bardziej jednoznacznej pozycji wobec przedstawionych wydarzeń? - pytał krytyk ${ }^{47}$

Do tej samej pod względem ewokowania historii grupy filmów co Mussolini, ostatni akt należy Rok pierwszy (Anno uno, reż. R. Rossellini, 1974). Wprawdzie nie traktuje on o resistenzy sensu stricto - realizacja jest biografią jednego z najważniejszych powojennych włoskich polityków, Alcide De Gasperiego - ale zdecydowałam się film ten przywołać, ponieważ zawiera istotny wątek debat Komitetu Wyzwolenia Narodowego oraz ilustruje dynamikę politycznych napięć, które pojawiły się wśród partyzanckich frakcji w schyłkowej fazie wojny. I tak, prócz stosunków $\mathrm{z}$ aliantami w debatach władz włoskiego ruchu oporu podkreślona zostaje konieczność unii sił antyfaszystowskich - zarówno na polu politycznym, jak i wojskowym. De Gasperi w filmie Rosselliniego jawi się jako osobowość nastawiona na dialog ${ }^{48}$, potrafiąca zjednoczyć „ideologicznych oponentów", by osiągnąć wspólny cel - wyzwolenie kraju.

\footnotetext{
46 Roberto Alemanno, Mussolini, ultimo atto, "Cinema nuovo" 1974, nr 231. Przedruk w: Gianfranco Casadio, op. cit., t. I, s. 125.

47 Leo Pestelli, „La Stampa” 1974, nr 228. Przedruk w: Gianfranco Casadio, op. cit., t. I, s. 126 .

${ }^{48}$ De Gasperi mówi w filmie cały czas o dialogu, ale forma zaprzecza tu niejako treści jego postulatów. Film zawiera bowiem niemal wyłącznie monologi De Gasperiego.
} 
Rok pierwszy prezentuje działalność chadeka od 1944 roku do lat 50. na tle historycznych faktów; zaznaczone zostają m.in. zwycięskie dla chadecji wybory z 1948 roku, zamach na Togliattiego oraz przystąpienie Włoch do NATO. Sposób prezentacji biografii bohatera ma charakter bez mała hagiograficzny. W swych płomiennych przemowach, które stanowią dramaturgiczną dominantę filmu, De Gasperi wydaje się nie tylko ojcem zjednoczonej Europy, ale wręcz prorokiem, a w każdym razie - kimś „widzącym więcej” niż współcześni mu politycy (członkowie partii socjalistycznej i partii komunistycznej - które po wojnie stanowiły silniejsze stronnictwa niż rodząca się partia katolicka - są u Rosselliniego aktorami drugiego planu).

$\mathrm{Z}$ uwagi na spiżowy wizerunek bohatera film był atakowany przez krytykę. Tullio Kezich na łamach "Corriere della Sera" zdefiniował realizację Rosselliniego jako „chadecki film propagandowy, całkowicie sfinansowany z pieniędzy publicznych Italoleggio, zawiadywanych przez prawicowego producenta Edilio Rusconi" ${ }^{\prime 9}$. Rossellini na zarzuty odpowiedział dwoma listami (opublikowanymi w "Paese Sera” i "Quoitidiano dei lavoratori”). Tłumaczył w nich koncept „kina dydaktycznego", zdolnego do kreowania świadomości oraz podkreślał jego rolę wobec włoskiego społeczeństwa chorego na „etykę sukcesu”, które zapomniało o „etyce współpracy". Reżyser podkreślał:

W Roku pierwszym jest wyraźnie powiedziane, że początek odbudowywania kraju był możliwy przy współpracy wszystkich partii politycznych: chadeków, komunistów, socjalistów, akcjonistów, liberałów etc. [...] Historia tamtych lat pokazuje, że nasze dzisiejsze obawy mogą być pokłosiem historycznego kompromisu, który wtedy ostatecznie nie doszedł do skutku ${ }^{50}$.

Ruch oporu u Rosselliniego funkcjonuje zatem jako fundament włoskiej demokracji.

Choć Rok pierwszy pozostaje ważnym filmem z uwagi na temat, pod względem formuły narracyjnej, bliskiej konwencji "gadających głów", sprawia wrażenie wprawki realizacyjnej. Lino Micciché pisał:

Błąd Rosselliniego bierze się wprawdzie ze szlachetnych intencji pedagogiczno-dydaktycznych, ale tym niemniej jest ewidentny. Twórca Rzymu, miasta otwartego postanowił bowiem w swej obecnej działalności filmowo-telewizyjnej osiodłać groźnego tygrysa środków masowego przekazu, redukując medium hot, jakim jest kino, do

${ }^{49}$ Cyt. za: Giuseppe Ghigi, op. cit., s. 207.

${ }^{50}$ Roberto Rossellini, Rossellini e Anno uno, „Passe Sera”, 27.11.1974. 
medium cool, jakim jest telewizja. Rossellini przyjmuje wobec rzeczywistości [...] jednakową postawę dystansu: strzępy historii i życia, aforyzmy i legendy, zdarzenia historyczne i mityczne, są opowiadane z taką samą bezosobową neutralnością [...]. Nie sprawdziło się to w stosunku do De Gasperiego i sprawiło, że Rok pierwszy, być może wbrew woli Autora, stał się czymś w rodzaju podręcznika wzorowego chrześcijańskiego demokraty ${ }^{51}$.

Wątek resistenzy pojawia się także w zrealizowanym przez Bernardo Bertolucciego Wieku XX (Novecento, 1976) - historycznym fresku, którego akcja obejmuje 45 lat tytułowego stulecia. Losy Włoch przedstawione są tu przez pryzmat Olma (z rodziny chłopskiej) i Alfreda Berlinghierego (dziedzica fortuny najbogatszego w okolicy obszarnika), którzy przyszli na świat w tym samym dniu 1900 roku. W kontekście tematu niniejszej pracy najbardziej interesująca pozostaje rama narracyjna filmu - film Wiek XX rozpoczyna się bowiem i kończy w dniu wyzwolenia Włoch: 25 kwietnia 1945 roku $^{52}$. W pierwszej sekwencji filmu oglądamy młodego partyzanta, który idąc przez pola ze strzelba, śpiewa: Za te wszystkie wychudłe twarze, za wszystkie ofiary niepomszczone zrewanżujemy się na barykadach/ołów za ołów! Na surowych szczytach gór staliśmy się wilkami/nasze zawołanie to wolność lub śmierćlna nizine schodzimy z karabinem maszynowym, by walczyć! Chłopakowi pieśń grzęźnie w gardle, gdy spostrzega faszystę mierzącego doń z karabinu. Faszysta strzela. Młody partyzant z niedowierzaniem patrzy na swój zakrwawiony brzuch i szepcze: Ale wojna się skończyła... dlaczego? Dlaczego?

W finale filmu resistenza skojarzona jest ze sprawą parcelacji majątków ziemskich. Pada pytanie: czy to prawda, że od dziś, w wolnych Włoszech ziemie panów zostana rozdane tym, którzy na nich pracowali, zaś Alfredo, znienawidzony "padrone”, staje przed sądem ludowym. Ostatecznie Berlinghieri nie zostaje ukarany - potraktowano go bowiem jako żywy przykład hańby ziemiaństwa i wyzysku klasowego. Po procesie chłopi rozpoczynają wśród czerwonych sztandarów huczne obchody „wolności”,

${ }^{51}$ Lino Micciché, Cinema italiano degli anni '70, s. 246.

52 Dla ścisłości należy przypomnieć, że film zawiera także krótki, współczesny epilog ukazujący staruszków Olma i Alfredo, którzy nadal biją się jak za dawnych lat. Alegoria jest jasna - walka klas trwa. „Morał” ten powtarza ostatnia, także alegoryczna sekwencja filmu. Alfredo kładzie się w poprzek torów. Z oddali nadjeżdża pociąg. Wydaje się, że lokomotywa rozjedzie „klasę panów”. Jednak ostatnie ujęcie pokazuje, że Alfredo położył się wzdłuż, wewnątrz "toru” - pociąg przejechał, a on pozostał nietknięty. 
wpadając w „rewolucyjną ekstazę". Nie trwa ona jednak długo - zostaje zatrzymana przez przybycie Komitetu Wyzwolenia Narodowego, który każe chłopom oddać broń. Za namową Olma chłopi posłusznie słuchają rozkazu. Film zawiera zatem sugestię, że w istocie Pan żyje - jak mruczy z satysfakcją Alfredo, a resistenza wygasła, nie przynosząc radykalnych zmian.

$\mathrm{W}$ jednej z ostatnich sekwencji filmu Bertolucci umieszcza scenę, w której młoda chłopka, na wozie ze stogiem siana, w pozie nasuwającej skojarzenie z Marianną na barykadach, informuje podniosłym głosem będących w dole chłopów, że widzi czarne koszule, które uciekają przed chłopem z kijem. Horyzont jest jednak pusty; staruszka wypowiada wtedy znamienne słowa: błogosławiona młodzież, która widzi tego, czego nie ma. Czyżby Bertolucci sugerował tym samym, że Włochy cały czas nie rozliczyły się z faszyzmem?

\section{Strategia pająka: narracja pamięci}

Film Bernardo Bertolucciego Strategia pajaka (Strategia del ragno, 1970), inspirowany opowiadaniem Jorge Luisa Borgesa Temat zdrajcy i bohatera, jest świadectwem wnikliwej lektury pierwowzoru, stanowiąc jednocześnie autorską wypowiedź reżysera o powojennej rzeczywistości Włoch. Dla Bertolucciego film ten był kolejnym spotkaniem z literaturą - po Konformiście (Conformista, 1970), zrealizowanym na podstawie tekstu Moravii, Partnerze (Sosia, 1968), inspirowanym opowiadaniem Dostojewskiego, oraz debiutanckiej fabule Przed rewolucja (Prima della rivoluzione, 1964), dla której punktem wyjścia była powieść Stendhala. Podobnie jak wcześniejsze Powiększenie (Blow up, 1966) Antonioniego (inspirowane opowiadaniem Julio Cortàzara Babie lato), Strategia pająka dyskontowała ówczesną popularność prozy iberoamerykańskiej, a jednocześnie przyczyniła się do upowszechnienia utworu niezbyt znanego, uchodzącego za drugorzędny w dorobku cenionego pisarza.

\section{Interteksty}

Film Bertolucciego opowiada zaczerpniętą z opowiadania Borgesa historię dwóch mężczyzn: narodowego bohatera oraz jego potomka, który odkrywa, że „męczennik ojczyzny” był w rzeczywistości zdrajcą. W obu narracjach wiarołomca (Fergus Kilpatrick w opowiadaniu, Athos Magnani w filmie) przyznaje się do winy i przekonuje swych towarzy- 
szy, by nie ujawniali jej publicznie. Wyrok wykonany na nim w teatrze przechodzi do legendy jako zabójstwo bohaterskiego spiskowca-patrioty. Dowiedziawszy się po latach prawdy o tym zdarzeniu, potomek bohatera postanawia również zachować swoje odkrycie w tajemnicy i podtrzymać oficjalną wersję historii pro publico bono.

U Borgesa „wewnętrzna” opowieść rozgrywa się w Irlandii; w Strategii pajaka miejsce akcji zostało przeniesione w okolice Padu, do miejscowości Tara. Nazwa ta niesie ze sobą wielorakie konotacje, będąc zarazem świetnym przykładem swoistej polifonii, jaką odznaczają się również inne elementy struktury filmu. Po pierwsze, "Tara” jest nawiązaniem do tekstu Borgesa (oznacza miejsce ważne dla irlandzkiej kultury narodowej - wzgórze w hrabstwie Meath, dawną siedzibę królów oraz ośrodek ruchu religijnego). Po drugie, może stanowić aluzję do Przeminęło z wiatrem - a tym samym przywołuje „utracony świat młodości”. Trzecie znaczenie, prowadzące do tytułu filmu poprzez pokrewieństwo z wyrazem "tarantula", jest zapewne czytelne dla użytkowników wielu języków. Czwarte wymaga już znajomości włoskiego: "tara” oznacza w nim potocznie wadę genetyczna, która przenoszona jest z pokolenia na pokolenie. Właśnie owa swoiście pojmowana skaza - w tym wypadku przybierająca postać "piętna historii" - jest jednym z tematów filmu.

Bertolucci przenosi miejsce akcji na południe Europy, korzystając z możliwości zawartych w samym pierwowzorze, który nieustannie podkreśla własną szkicowość. Narrator wprowadza w intrygę w taki oto sposób: „Akcja przebiega w jakimś uciśnionym, lecz nieposkromionym kraju: w Polsce, Irlandii, Republice Weneckiej, w którymś z państw bałkańskich czy Ameryki Południowej... Powiedzmy (dla wygody narracji), Irlandia. Powiedzmy, rok $1824^{\prime \prime 53}$. Fragment ten ma, rzecz jasna, charakter samozwrotny (czytelnikowi ujawnia się proces formowania narracji), ale pełni zarazem inną rolę. Akcentowana u Borgesa "prowizoryczność" realiów, w jakich rozgrywa się akcja sprawia, że tym ważniejszy i bardziej wyrazisty, niejako zuniwersalizowany, staje się tytułowy temat zdrajcy i bohatera. Opowiadanie jest więc de facto przypowieścia, natomiast Bertolucci ukonkretnia dyskurs, zawężając jego sensy do kontekstu włoskiego.

Spostrzeżenie to trzeba uzupełnić uwaga, że „zitalianizowanie” miejsca akcji może być różnie odczytane - inaczej przez widzów, których wiedza o kulturze włoskiej jest skromna, inaczej przez rodowitych Włochów;

${ }^{53}$ Jorge Luis Borges, Temat zdrajcy i bohatera, [w:] idem, Fikcje, tłum. Kazimierz Piekarec, Andrzej Sobol-Jurczykowski, Kalina Wojciechowska, Stanisław Zembrzuski, Warszawa 1972, s. 106. 
odmiennie przez odbiorców dysponujących wiedzą o okolicznościach realizacji filmu i tych, którzy nie są $\mathrm{w}$ stanie tego kontekstu uwzględnić. W filmie jest wyraźnie powiedziane, że Tara położona jest niedaleko Pavii, w regionie Emilia-Romania. Tymczasem zdjęcia powstały w miejscowości Sabionetta - renesansowym miasteczku w Lombardii, a w realizacji Bertolucciego wystąpili naturszczycy, posługujący się dialektem tego regionu. Wprawdzie niezbyt różni się on od tego używanego w Emilii-Romanii, ale dla wielu Włochów, którzy tradycyjnie przykładają ogromną wagę do miejsca urodzenia, może być to odmiana rozpoznawalna. Mamy tu do czynienia z wydawałoby się sprzecznymi decyzjami Bertolucciego: poprzez obsadę podkreśla on "prawdziwość" i „naturalność" scenerii, a jednocześnie dostarcza dyskretnych sygnałów, pozwalających ujawnić jej umowność i fikcjonalność ${ }^{54}$. Już na tym poziomie filmu uwidacznia się więc niejednoznaczność świata przedstawionego, która współgra z podejmowanymi w dziele problemami: wierności i zdrady, prawdy i ułudy. Miasteczko jest zatem „,konkretne”, ale jednocześnie nosi znamiona konstruktu parabolicznego, co zostaje podkreślone przez topografię przestrzeni (izolacja od „reszty świata” - znamienna jest w tym kontekście scena, w której podróżny pyta, jak dotrzeć do Mediolanu, po czym okrąża rynek i odjeżdża droga, jaką wcześniej przybył) oraz epizodyczne wydarzenia (brak gazet, których "nie dowieziono"; głos na dworcu informujący: "czasami zapominaja że istniejemy" ${ }^{55}$ ).

W opowiadaniu Borgesa "aspekty zagadki posiadają charakter cykliczny: zdają się powtarzać lub zestawiać fakty pochodzące z odległych krajów, z odległych epok" ${ }^{\prime \prime 6}$. U Bertolucciego historyczny dystans przedstawianych wydarzeń zostaje zredukowany do, mniej więcej, trzydziestu lat. W opowiadaniu Borgesa bohaterem zainteresowanym losami przywódcy spiskowców jest prawnuk Ryan, zaś źródłem jego wiedzy są dokumenty pisane (protagonista pracuje nad biografią pradziadka). W Strategii pająka to syn Athosa Magnani (noszący to samo co on imię i nazwisko) pragnie rozwiązać zagadkę tajemniczego zabójstwa ojca, a informacje na temat minionych wydarzeń czerpie od ich żyjących świadków - przede wszystkim z opowieści trzech weteranów ruchu oporu: Costy, Gaibazziego i Razoriego oraz z rozmów z kochanką zabitego, Draifą.

54 Angela Dalle Vacche, Antifascism after May 1968, [w:] eadem, The Body in the Mirror: Shapes of History in Italian Cinema, Princeton 1992, s. 223. Autorka sugeruje, że chodzi tu także o swoistą grę z konwencją neorealizmu.

${ }^{55}$ Cytaty z filmu podaję zgodnie z listą dialogową.

${ }^{56}$ Jorge Luis Borges, op. cit., s. 107. 
Powyższe uwagi nie oznaczaja, iż "czas historyczny” Strategii pajaka całkowicie wypiera "czas mityczny”, ewokowany przez Temat zdrajcy $i$ bohatera. U Bertolucciego, jak pisze Yosefa Loschitzky, "tak jak syn jest sobowtórem ojca, tak zabójstwo ojca jest powtórzeniem morderstwa Cezara" ${ }^{57}$. Zachowane zostają zatem dwie właściwości prozy Borgesa: zasada cykliczności (teraźniejszość jako emanacja mitu) oraz koncepcja historii jako labiryntu (w którym czas może biec do przodu, ale i cofać się).

Film Bertolucciego zbudowany jest z dwóch przeplatających się linii akcji: współczesnej (działania Athosa-syna i jego próby rozwiązania zagadki) oraz historycznej (losy Athosa-ojca i przebieg samej zbrodni). Struktura ta zaczerpnięta jest $\mathrm{z}$ Tematu zdrajcy... - z tą różnica, iż Borges więcej miejsca poświęca wydarzeniom z przeszłości. U Borgesa mamy bowiem de facto dwa śledztwa: pierwsze (we współczesnej linii narracyjnej) prowadzi Ryan, drugie zaś (w czasach Kilpatricka) niejaki James Nolan, który ma wskazać zdrajce w gronie swych towarzyszy (analogicznej postaci nie ma w Strategii pajaka). Ani w opowiadaniu, ani w filmie nie zostaje wyjaśnione, dlaczego Fergus/Athos wystąpił przeciw swym przyjaciołom. Tym samym Bertolucci zdaje się zachowywać charakter literackiego pierwowzoru - zasygnalizowana w Strategii pająka jałowość dążenia do absolutnego poznania motywów ludzkich działań stanowi stały wątek twórczości Borgesa.

Ani w opowiadaniu, ani w filmie narracja nie służy zresztą kreowaniu „wiarygodnych sylwetek bohaterów”. Są oni raczej swego rodzaju modelami, ilustrującymi pewien typ zachowań jednostki wobec historii, czy też figurami rozrzuconymi po planszy zapełnionej materialnymi i symbolicznymi artefaktami czasów minionych. Ważną właściwość opowiadania Borgesa stanowi niezwykłe nasycenie tekstu nazwiskami historyków i pisarzy oraz tytułami ich dzieł. W filmie owa Borgesowska biblioteka nie jest tak spektakularna - choć również obecna: cytowane są dramaty Szekspira (Makbet, Otello i Juliusz Cezar), opery Verdiego (Bal maskowy, Ernani oraz Rigoletto), a także wiersz Giacomo Leopardiego (Il sabato del villaggio) oraz Giovanniego Pascoli (La cavalla storna).

W filmie odniesienia do innych tekstów kultury mają nieco inny charakter niż $\mathrm{w}$ opowiadaniu. U Borgesa na plan pierwszy wysuwa się mnogość przytaczanych dzieł, bujność ewokowanych przez nie znaczeń, którymi "oblepione” zostają działania bohaterów. Te ostatnie są jedynie mimowolną repetycją tego, co zostało kiedyś opisane, opowiedziane i zinterpretowane. Jak zostało już wspomniane, koncept ów jest obecny również u Bertolucciego, choć jednocześnie intertekstualność wydaje się

57 Yosefa Loshitzky, The Radical Faces of Godard and Bertolucci, Michigan 1995, s. 56. 
tu silniej „zlokalizowana”. Na przykład, przywołany Juliusz Cezar wskazuje w filmie na sensy „włoskie” - o tyle, że właśnie na odwołaniach do starożytnego Rzymu opierał się podtrzymywany przez faszystów mit latinità (kultury łacińskiej) ${ }^{58}$.

Szczególną rolę w dyskursie filmu pełnią przywołania oper. U Bertolucciego planowane jest zabójstwo Duce, w Rigoletto zamordowany ma być książę Mantui (a motyw zabójstwa pojawia się także w Balu maskowym $)^{59}$. Fakt, że zbrodnia ma być dokonana właśnie przy dźwiękach muzyki Verdiego jest szczególnie istotny - jego opery są dla mieszkańców Italii symbolem spektaklu wyzwoleńczego, zaś samo nazwisko kompozytora stanowi synonim niepodległego państwa ${ }^{60}$.

Przytaczane przez Bertolucciego teksty kultury są silniej niż u Borgesa zespolone $\mathrm{z}$ dramaturgią filmu - można powiedzieć: faktycznie "grają". Dobrą tego ilustracją jest ujęcie prezentujące grupę mężczyzn na tle przyczepy; na ścieżce dźwiękowej słychać jedynie: przekleństwo! Słowo to nabiera sensu dopiero wówczas, gdy dowiadujemy się o planowanym zamachu i sposobie jego realizacji - „przekleństwo!” to tekst z Rigoletta, sygnalizujący moment, w którym podczas spektaklu Verdiego ma zginąć początkowo Mussolini, a ostatecznie, po swej zdradzie, Athos Magnani. Tajemnicza przyczepa - miejsce zebrań spiskowców, które w klasycznej narracji byłoby zapewne przedstawione $\mathrm{w}$ dłuższym ujęciu lokalizującym - w omawianej scenie ma charakter ledwie migawki. Wykorzystanie utworu Verdiego jako „okoliczności zbrodni” wskazuje natomiast na aluzyjny charakter przywołanego fragmentu.

\section{Narracja}

Strategia narracyjna, w której na pierwszy plan wysuwa się temat śledztwa, ewokuje strukturę opowieści kryminalnej. To, co dzieje się „teraz", ma posłużyć do naświetlenia tego, co zdarzyło się „wtedy”. W Stra-

58 Zob. Eugenio Bolongaro, Why Truth Matters: Ideology and Ethics in Bertolucci's The Spider's Stratagem, "Italian Culture” 2005, nr 23, s. 80. Autor ten doszukuje się intertekstów filmu Bertolucciego w sposób cokolwiek ryzykowny, odwołując się na przykład do biografii cytowanych w filmie poetów (przypomina, że Leopardi miał trudne relacje z ojcem, a Pascoli stracił go, mając dwanaście lat), które jakoby miałyby mieć związek z tematem filmu.

${ }^{59} \mathrm{O}$ inspiracjach operowych w Strategii pajaka zob. Deborah Crisp, Roger Hillman, Verdi and Schoenberg in Bertolucci's "The Spider's Stratagem", "Music and Letters" 2001, nr 2.

${ }^{60}$ Po premierze Balu maskowego na murach włoskich miast zwolennicy niepodległości Włoch malowali napis VIVA V.E.R.D.I.! - akronim hasła politycznego „Viva Vittorio Emanuele Re d'Italia"' (Niech żyje Wiktor Emanuel, król Włoch). 
tegii pająka jest ona jednak realizowana w sposób utrudniający, jeśli nie uniemożliwiający, precyzyjne przypisanie wielu spośród prezentowanych zdarzeń do „współczesnej” lub „historycznej” linii akcji.

Ów efekt konfuzji wywoływany jest już na poziomie wyglądu świata przedstawionego. W obie role - syna i ojca - wciela się ten sam aktor, Giulio Brogi, a jedynymi atrybutami różniącymi obu bohaterów są szczegóły ubioru: czerwona chusta i kurtka safari wskazuje ojca, marynarka zaś została przypisana synowi. Podobieństwo obu postaci służy przy tym nie tylko dezorientacji widza, ale pełni także ważną rolę w dyskursie problemowym filmu ${ }^{61}$. Athos-senior w pewnym sensie „zachowuje młodość", co można interpretować jako metaforyczne podkreślenie żywotności jego heroicznej legendy. Mit ten jak gdyby przyćmiewa głównego - młodego bohatera, co ukazane jest zresztą nader dosadnie. Na przykład na początku filmu, podczas wędrówki Athosa-juniora do hotelu, ustawienie kamery powoduje nakładanie się obrazu bohatera na oglądane przez niego popiersie ojca; gdy protagonista mija pomnik, ruch kamery sprawia, że rzeźba zasłania idącego.

Utożsamianie losów obu postaci dobrze ilustrują dwie inne sekwencje: spektaklu Rigoletto (ukazanego w filmie jako rekonstrukcja prawdziwego zamachu) oraz ucieczki Athosa-ojca?/syna? przez las (sekwencja ta zbudowana jest na zasadzie montażu symultanicznego, sugerującego różne przestrzenie czasowe; dzięki serii match-cuts syn i ojciec zostają niejako zespoleni w jedną postać). Scen, których nie możemy jednoznacznie przyporządkować do konkretnej linii narracyjnej, jest zresztą w Strategii... więcej. Przykładowo, gdy towarzysze Athosa formują kondukt żałobny, dwaj niosą na tacy głowę martwego lwa. Ten zaskakujący obraz nie posiada żadnej ramy wyjaśniającej; możemy jedynie domniemywać, że rekwizyt ten w metaforyczny sposób odnosi się do Athosa-seniora ${ }^{62}$. Wygląd

${ }^{61}$ Krytyka filmowa stawiała Bertolucciemu zarzuty związane między innymi z owym „przymusowym podobieństwem” ojca i syna. Aleksander Jackiewicz pisał na przykład: "Zeszły się w duszy Athosa-syna pokolenia zmarłych i żywych, ojcowie i dzieci. W tym nagromadzeniu jednak jest banał. $W$ tym łączeniu się wszystkiego ze wszystkim film Bertolucciego traci. Jak tracą uczucia już nazbyt nie kontrolowane, prawdy już nazbyt dialektycznie potraktowane, życie myśli nazbyt pomnożone - wobec śladu autentycznej filozofii. Borges w Temacie zdrajcy i bohatera wziął na siebie rolę filozofa. Bertolucci - naiwnego, cóż że dobrego artysty". Aleksander Jackiewicz, Temat zdrajcy i bohatera u Borgesa i w filmie Bertolucciego, „Kino" 1973, nr 1, s. 58-59.

${ }^{62}$ Martwy lew - Athos jest dla potomnych symbolem ofiary, dzięki której pamięć o narodowym bohaterze jest wciąż żywa. Obrazy lwa i Athosa zestawione są także w retrospekcji, z której dowiadujemy się, że zwierzę uciekło z niemieckiego cyrku (wyrwało się z faszystowskiego systemu?), ostatecznie zostało jednak osaczone (zdradza antyfaszystowskie ideały?) i zabite. 
przyjaciół ojca w przywołanej scenie oraz w całym dziele nie stanowi tutaj żadnej wskazówki; zarówno w części współczesnej, jak i w przeszłości są oni bowiem "tacy sami" - tacy, jakimi ich widzi syn bohatera-zdrajcy.

Skomplikowana konstrukcja narracyjna filmu zawiera liczne retrospekcje. Znaczna ich część pojawia się niejako „znienacka” (bez konwencjonalnej zapowiedzi w rodzaju przenikania, najazdu na twarz bohatera etc.) lub nie kończy się powrotem do wyjściowej sceny. Tym samym widz musi dokonać niemałego wysiłku, by ułożyć przedstawione wydarzenia w logiczną całość. Dobrym przykładem takiego chwytu jest choćby wspomnienie Gaibazziego o zabawie, którą faszyści przerwali odegraniem własnego hymnu - Giovinezzy. Athos-senior wykorzystuje tę melodię do tańca, prowokując przedstawicieli czarnych koszul ${ }^{63}$. Sekwencję z przeszłości kończy obraz prezentujący roześmianą kobietę, która cieszy się z wiadomości, że sam Duce zamierza przyjechać do Tary na otwarcie teatru; kolejne ujęcie przedstawia natomiast teraźniejszość - drugiego przyjaciela Athosa-seniora (Razoriego), rozpoczynającego spotkanie z synem spiskowca westchnieniem: Twój ojciec... Twój ojciec. Widz musi więc zrekonstruować część „niepokazanych” działań ze współczesnej linii opowiadania.

Przykładów łamania klasycznych reguł narracji odnajdziemy w Strategii pająka więcej. Dobrze ilustruje je choćby rozmowa Athosa-juniora z Gaibazzim w pomieszczeniu, gdzie dojrzewają szynki. Scena ta została rozbita na kilka ujęć przedzielonych ściemnieniami, które nie mają uzasadnienia "sytuacyjnego", gdyż nie oznaczają upływu czasu. Kierują one uwagę widza na ten właśnie problem. Nie są zatem „pustym” ozdobnikiem, lecz stanowią estetyczny naddatek, który - owszem - udziwnia narracje, ale czyni to w zgodzie z jej dyskursywnym celem, jakim jest podkreślenie „dziwności” czasu.

Wiele scen Strategii... zrealizowanych jest tak, iż trudno orzec, z czyjej perspektywy prowadzona jest narracja (a zatem czy zachowuje ona swój „bezosobowy” status, czy też ulega subiektywizacji). Za przykład może posłużyć scena, w której syn przygląda się popiersiu ojca. Jest ono

${ }^{63}$ Scena ta jest dwuznaczna: $\mathrm{z}$ jednej strony, wydaje się formą otwarcie demonstrowanego buntu Athosa-seniora wobec faszyzmu, z drugiej zaś (retrospektywnie to znaczy, gdy już wiemy o zdradzie bohatera) może być rozumiana jako „taniec na faszystowską nutę", a zatem podporządkowanie się faszystowskiej symbolice (zob. Claudia Tonetti, Bernardo Bertolucci: the Cinema of Ambiguity, New York 1995, s. 91). Scenę tę można także odczytywać przez pryzmat Tematu zdrajcy i bohatera - Borges cytuje bowiem wiersz Yeatsa Rok tysiąc dziewięćset dziewiętnasty, w którym pojawiają się tancerze („I tak Platoński Rok/ Powraca w stary krąg/Wirując w nowym - słusznym czy też nie;/Ludzie są tancerzami i stosują krok/Do dźwięku, jaki daje barbarzyński gong" - fragment wiersza w tłum. Ludmiły Marjańskiej, cyt. za: Jorge Luis Borges, op. cit., s. 106). 
umieszczone na postumencie, górującym nad placem miasteczka (u Borgesa brak informacji o jakiejkolwiek „konfrontacji” Ryana z pomnikiem pradziadka). Z pozoru scena ta zbudowana jest klasycznie - obraz pokazuje naprzemiennie młodego Athosa oraz oglądaną z jego perspektywy statuę. Tyle, że $w$ kolejnych ujęciach popiersie zmienia barwę: nie ma już jednolitego koloru kamienia, zaś wyżłobienia wyobrażające oczy zostają pokryte białą farbą (dodatkowo na szyi Athosa-seniora pojawia się czerwona chusta). Zmiany te można przypisać wyobraźni młodego bohatera - byłby to zatem typowy mindscreen. Dezorientujący jest natomiast ruch kamery: Athos krąży wokół pomnika, ale rzeźbę widzimy ciągle z tej samej perspektywy (zmienia się wyłącznie tło). Co więcej, gdy Athos-junior przystaje, pomnik kontynuuje ruch okrężny, w kierunku przeciwnym do tego, który młodzieniec obrał wcześniej. Komu przypisać tę ostatnią perspektywę widzenia? Mamy tu do czynienia ze swoistym „ożywieniem” posągu, dzięki czemu scena zdaje się spotkaniem dwóch żyjących bohaterów, którzy krążą wokół siebie niczym przeciwnicy na ringu, obrzucając się wrogimi spojrzeniami ${ }^{64}$.

Poczynione wcześniej uwagi dowodza, iż Strategia pająka posługuje się narracją nieklasyczna, która rozbija spójność diegezy (na poziomie poszczególnych scen) oraz utrudnia rekonstrukcję związków przyczynowo-skutkowych (w całościowo pojmowanej strukturze filmu). Wniosek ten trudno byłoby jednak uznać za oryginalny (tym bardziej, że już Bordwell uznał film Bertolucciego za emblematyczny przykład nietypowej organizacji formalnej); należy go zatem uzupełnić odpowiedzią na pytanie, czemu w zasadzie owa „nieklasycznośćc służy.

Strategię pająka nazwałabym podróżą przez meandry pa$\mathrm{m}$ i ę c i. Jej charakter ujawnia się już w pierwszej scenie. Kiedy Athos Magnani przybywa do Tary, kamera w kilkusekundowym („przytrzymanym”) ujęciu ukazuje tył głowy bohatera - jakby chciała doń „wejść", a następnie prezentuje tabliczkę z nazwą ulicy i wykonuje jazdę od prawej do lewej, zmuszając widza do odczytania od końca napisu Via Athos Magnani. Bertolucci proponuje w ten sposób odwrócenie kierunku wędrówki-zwróconej nie ku nieznanej przyszłości, ale ku początkowi. Jej celem jest czas miniony - tam kryje się prawda o tym, co zostało wyparte, zapomniane, zmanipulowane. Znaczenia, jakie nadamy Strategii..., zależą zatem w dużej mierze od tego, w jakich kategoriach rozpatrywać będziemy ową „podróż

${ }^{64}$ David Bordwell przywołuje tę scenę w swym artykule poświęconym filmowi Bertolucciemu; robi to także Andrzej Michalski, który w swojej analizie Strategii pająka szczegółowo odnosi się do tekstu Bordwella. Zob.: David Bordwell, Temporal Stratagems and Spoils, [w:] idem, Narration in the Fiction Film, Madison 1985, s. 89; Andrzej Michalski, Świat w teatrze Bernarda Bertolucciego, „Kwartalnik Filmowy” 2000, nr 31-32, s. 277. 
przez meandry pamięci”. W wariancie "psychologicznym” na plan pierwszy wysuną się te elementy filmu, które wydają się zaczerpnięte $\mathrm{z}$ freudowskiego leksykonu, a istotnym kontekstem będzie relacja autortekst (a zatem także biografia Bertolucciego i jego wypowiedzi dotyczące filmu). Z kolei posłużenie się kluczem „społecznym” będzie wymagało zgody na wspomnianą wcześniej parabolizację Tary jako Włoch; w tej optyce najważniejszą rolę będzie odgrywać relacja historia-pamięć. Pierwsza perspektywa jest całkowicie obca duchowi opowiadania Borgesa; interpretacja „historyczna” (rozumiana, oczywiście, nie w kontekście włoskim, ale jako ogólna zasada ludzkich dziejów) wydaje mu się bliższa.

\section{Psychoanaliza}

Do odczytań psychoanalitycznych dzieła zachęcał sam Bertolucci, który przed realizacją Strategii pająka rozpoczął terapię i otwarcie przyznawał, że film był jej swoistym przedłużeniem ${ }^{65}$. Centrum tego rodzaju interpretacji stanowiłaby relacja ojciec-syn, analizowana przez pryzmat biografii reżysera (zbezczeszczenie grobu rodziciela przez Athosa-juniora traktowano zatem jako artystyczne przepracowanie relacji twórcy z oj$\left(\mathrm{cem}^{66}\right)$. Wypowiedzi reżysera trzeba jednak rozumieć tak, jak na to zasługują - nie jako "deszyfratory” wskazujące na jedyne możliwe odczytanie, ale jako informację o procesie powstawania filmu (ale przecież także - echo ówczesnej mody na psychoanalizę).

Psychoanalityczne interpretacje Strategii pająka wspiera oniryczna estetyka obrazu. Efekt jego „nierzeczywistości” wywoływany jest przez jaskrawa, "tropikalną" kolorystykę filmu o intensywności płócien Ligabue'a - włoskiego malarza prymitywisty, którego obrazy otwierają dzieło Bertolucciego. Rozrzutna, agresywna, „nieprawdziwa” uroda ogrodu, wnętrza domu o ognistej czerwieni - swoiste, ",nadmierne” piękno otoczenia odrealnia świat Tary. Jego surrealistyczny charakter podkreślają także niektóre kadry, przypominające do złudzenia obrazy Magritte'a ${ }^{67}$.

${ }^{65}$ Elias Chaluja, Sebastian Schadhauser, Gianna Mingrone, A Conversation with Bertolucci, [w:] Bernardo Bertolucci. Interviews, red. Fabien Gerard, Thomas Jefferson Kline, Bruce Sklarew, Mississippi 2000, s. 55-56.

${ }^{66}$ Zarówno w wypowiedziach samego Bertolucciego, jak i w wielu - psychoanalitycznie ukierunkowanych - publikacjach krytycznych o jego twórczości, często podejmowanym wątkiem była relacja pomiędzy reżyserem a jego ojcem - znanym wówczas poetą. Dla porządku należy także przypomnieć, iż pojawiające się w Strategii pająka motywy: ojca, sobowtóra i podróży powtarzają się we wcześniejszych i późniejszych filmach Bertolucciego.

${ }^{67} \mathrm{~W}$ filmie możemy doszukać się kadrów skomponowanych na wzór Eloge de la dialectique, Golkondy, L'Homme au journal czy cyklu obrazów Imperium światła. Bertolucci 
Widz zostaje zatem wprowadzony w świat będący syntezą prawdy i fałszu, faktów i złudzeń. Jeśli przyjąć tę optykę, przestaje dziwić zmieniający się, za każdym razem gdy ukazuje go kamera, portret Athosa-seniora na ścianie. Podczas pierwszej rozmowy młodego detektywa z Draifa, podobizna bohatera pojawia się w różnych uczesaniach, co można interpretować jako wizualizację jego odmiennych wizerunków wyłaniających się z opowieści mieszkańców miasteczka. Nie zaskakuje także niespodziewana przemiana dnia $\mathrm{w}$ noc $\mathrm{w}$ tej właśnie scenie (pora dnia sygnalizowana jest otwartymi drzwiami do ogrodu na początku i końcu epizodu). Na ważną rolę różnicy jasność/ciemność wskazują również dwie inne sceny. W pierwszej Athos-junior, w tajemniczy sposób zamknięty w stodole, zapala zapałkę, która na chwilę oświetla wnętrze. W drugiej Athos-senior głośnym kukuryku powoduje przebudzenie miasteczka (to już świt, udowodnie wam to), po chwili z okolicznych gospodarstw dobywa się pianie kogutów (epizod ten jest też okazją do prezentacji bohatera jako aktora i manipulatora, zapowiadając niejako polityczną intrygę utkaną przy jego współudziale).

Niejednoznaczność świata przedstawionego podkreślana jest także przez kategorialne właściwości protagonistów. Nie chodzi przy tym wyłącznie o ojca i syna, ale także o wątki poboczne: postać służącego, który okazuje się dziewczynką czy epizod z królikiem o trudnej do rozpoznania płci. Swoistym „centrum wieloznaczności” w filmie Bertolucciego jest Draifa. Jej zachowanie - bohaterka na przemian odpycha i wabi Athosa-juniora (jestem zajęta, nie możesz już nigdy odejść) - można oczywiście wyjaśnić w kategoriach psychologicznych (schizofrenia) lub potraktować jako przykład posłużenia się przez Bertolucciego konwencją femme fatale; wydaje się jednak, że postać ta pełni funkcję istotniejszą (w opowiadaniu nie pojawia się ani ona, ani żaden jej odpowiednik). Obecność Draify dopełnia bowiem edypalny schemat dramaturgiczny Strategii... - przy czym pełni ona podwójną rolę: matki, ale i Sfinksa („zagadka” dotyczy losu ojca) ${ }^{68}$.

deklarował: „Kupiłem album Magritte'a i długo studiowałem go wraz z Vittorio [Storaro - przyp. A. M.-K.]. Byłem zainteresowany nocnym światłem, pełnym niebieskich refleksów; światłem tych nocy, w których możesz zobaczyć wszystko; wszystkie niebieskie sekwencje Strategii pająka były kręcone między dniem a nocą - o zmierzchu". Cyt. za: Thomas Jefferson Kline, Bertolucci's Dream Loom: Psychoanalytic Study of Cinema, Amherst 1987, s. 69.

${ }^{68}$ Dalle Vacche zwraca uwagę, że biologiczna matka Athosa nie posiada imienia i jest „milcząca”, gdyż uosobiona jedynie przez obraz, który bohater znajduje w stodole. Jest to jednak sugestia ocierająca się o błąd rzeczowy, ponieważ w filmie nie zostaje powiedziane, że obraz ten przedstawia matkę bohatera. Podobieństwo do Zwiastowania Antonella Da Messiny wskazywałoby raczej na „ukryta, ale obecną” tradycję katolicką. Angela Dalle Vacche, op. cit., s. 243-245. 
Wedle Jeffersona Kline'a, Draifa przypomina pajęczycę, która łapie Athosa-juniora $\mathrm{w}$ sieć identyfikacji z ojcem (postać wykrzykuje m.in.: patrz, jak bardzo go przypominasz; jesteś wskrzeszonym Athosem! $)^{69}$. Za swoistą wizualizację procesu zniewalania bohatera uznawana jest scena, w której Draifa owija Athosa bandażem, tworzącym swego rodzaju owadzi kokon. Argumentem potwierdzającym „pajęczą" naturę Draify ma być także jej willa w ogrodzie przypominającym gniazdo (choć bardziej przekonująca wydaje się opinia Torlasco o „willi optycznych złudzeń”, w której wiszące na ścianach obrazy oraz aranżacja wnętrza skutecznie utrudniają rozróżnienie pomiędzy "tym, co na zewnątrz" i „tym, co w środku"70). Dodatkowym kontekstem dla niejednoznacznego zachowania bohaterki jest jej imię, odsyłające, jak sama mówi, do Dreyfusa - przywołanie tej postaci ewokuje tematy przewijające się przez cały film: domniemanej zdrady, fałszywego oskarżenia, politycznej intrygi, a najogólniej rzecz ujmując - historii ${ }^{71}$.

\section{Historia}

Strategia pająka, niezależnie od „psychologizujących” interpretacji, stanowi także wypowiedź na temat niechlubnej faszystowskiej przeszłości Włoch; podejmuje tym samym problem pamięci społecznej. Film Bertolucciego był swoistym remedium na historyczną amnezję. Polegała ona z jednej strony na wymazaniu z powojennego dyskursu publicznego faktycznej skali poparcia włoskiego społeczeństwa dla Mussoliniego, z drugiej zaś - na nadmiernym eksponowaniu roli antyfaszystowskiej partyzantki. Dla odradzającej się Italii taka interpretacja najnowszej przeszłości miała rozstrzygające znaczenie. Stosunek Włochów do wojny, o czym była już mowa, określiło wszechobecne oddzielenie faszystowskich zbrodni od działań i aspiracji narodu włoskiego.

Aby unaocznić zasygnalizowane $\mathrm{w}$ filmie taktyki kształtowania nowych ram pamięci, posłużę się typologia, która została zastosowana przez niemiecką badaczkę kultury - Aleidę Assman. Wyróżnia ona pięć strategii

${ }^{69}$ Ibidem, s. 74. Bohaterka nazywana jest także mityczną Ariadną oraz Arachne (zmienioną w pająka przez Atenę).

${ }^{70}$ Domietta Torlasco, The Time of the Crime: Phenomenology, Psychoanalysis, Italian Film, Stanford 2008, s. 93.

${ }^{71}$ O tym, jak ważny w Strategii pająka jest motyw zwielokrotnienia (na przykład ojca i syna), świadczy zabawna hipoteza przedstawiona przez dziennikarza, który w rozmowie z Bertoluccim zapytał, czy słowo „Draifa” nie pochodzi aby od niemieckiego „dreifach” („potrójny”). Bertolucci replikował: „to interpretacja prowadzona w dobrym kierunku, ale idąca zdecydowanie zbyt daleko" (Elias Chaluja, Sebastian Schadhauser, Gianna Mingrone, op. cit., s. 54). 
wypierania ze świadomości: przeinaczanie, wyłączanie, milczenie, eksternalizację oraz kompensację ${ }^{72}$. W filmie Bertolucciego wskazać można przykłady każdej z nich - przy czym najlepiej zilustrowana jest pierwsza taktyka, a zatem celowa zmiana dokonywana w historycznej narracji.

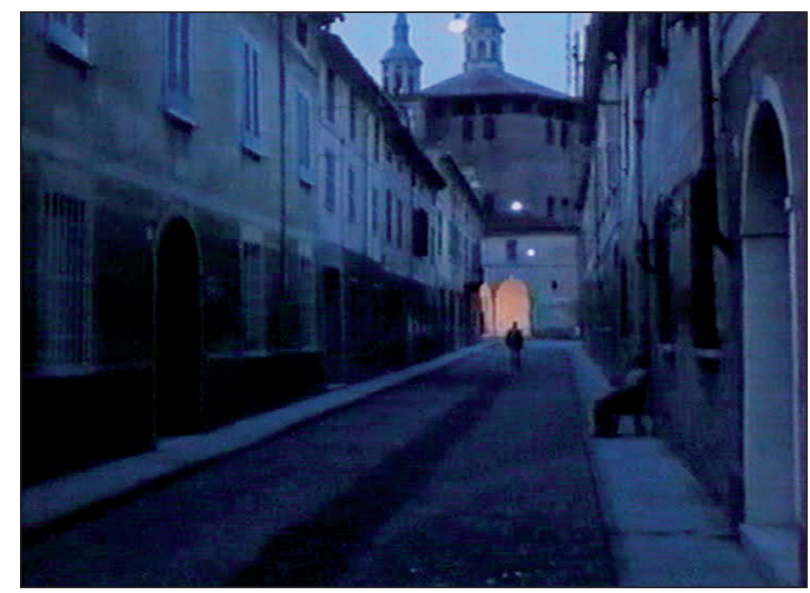

Fot. 5. Strategia pająka (reż. Bernardo Bertolucci, 1970)

Nierzeczywiste miasto

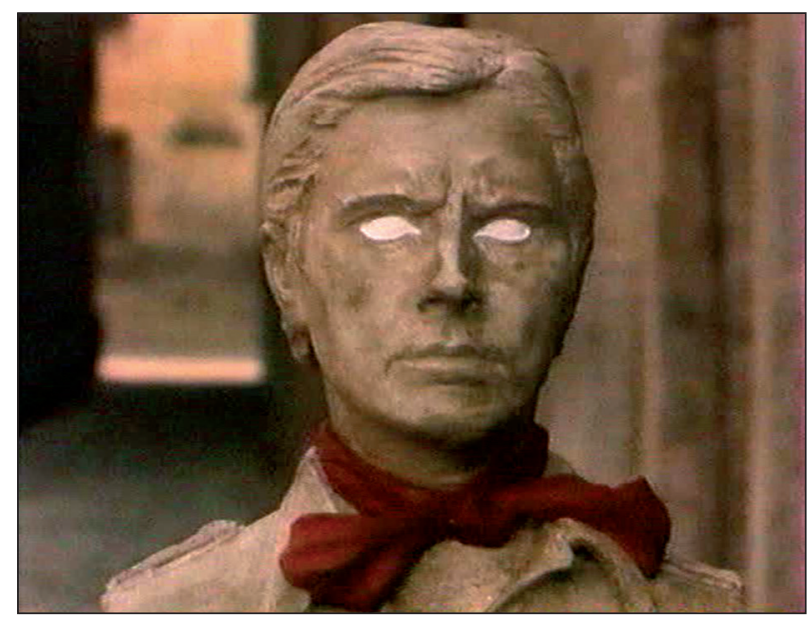

Fot. 6. Strategia pajaka (reż. Bernardo Bertolucci, 1970) Pomnik pamięci Athosa-ojca

72 Aleida Assmann, Pięć strategii wypierania ze świadomości, tłum. Artur Pełka, [w:] Pamieć zbiorowa i kulturowa. Współczesna perspektywa niemiecka, red. Magdalena Saryusz-Wolska, Kraków 2010. Wprawdzie wspomniana klasyfikacja odnosi się głównie do kontekstu niemieckiego, ale wydaje się adekwatna także wobec realiów włoskich. 
Kolejna strategia - wyłączanie - polega na niedostrzeganiu niewygodnych faktów, co skutkuje brakiem jakichkolwiek, związanych z nimi wspomnień. By wydarzenie mogło odcisnąć w pamięci swój ślad, musi bowiem najpierw zostać dostrzeżone. W Strategii pająka owo wyłączenie stało się udziałem mieszkańców Tary (a zatem - w planie metaforycznym - całego włoskiego społeczeństwa), którzy pamiętają jedynie heroiczne czyny Athosa. W licznych filmowych retrospekcjach nie ma jakiegokolwiek śladu wojennych ofiar ani faszystowskich zbrodni (włoscy obywatele brali $\mathrm{w}$ nich przecież niejednokrotnie czynny udział), a jedynym poszkodowanym wydaje się reprezentant ruchu oporu, Magnani-senior.

Strategia milczenia (rozumiana jako milczenie sprawców, a więc pomijanie pewnych wydarzeń, nie zaś jako milczenie ofiar) realizowana jest głównie przez towarzyszy lokalnego bohatera. Nie ujawniają oni bowiem współmieszkańcom faktycznego przebiegu zdarzeń i podtrzymują chlubną legendę Athosa (to również, rzecz jasna, można uznać za odniesienie do powojennej polityki Włoch). Film wydaje się przy tym zawierać ostrzeżenie przed zagrożeniem potencjalnym nawrotem faszystowskiej ideologii, której proces defaszyzacji nie zdołał skutecznie wyplenić. Przypuszczenie to uzasadnia wspomniany już niezmienny, zastygły obraz miasteczka oraz rola, jaką pełni w nim ,jedyny faszysta w Tarze" - Becaccia (jest on kimś w rodzaju burmistrza, w każdym razie cieszy się ogólnym posłuchem).

Czwarta taktyka wskazana przez Assman - eksternalizacja - oznacza proces oddalenia od siebie winy i przypisania jej innym. To strategia poszukiwania kozła ofiarnego, która ze współwinnego czyni niewinną ofiarę - nieświadome narzędzie zbrodni, wykonujące tylko rozkazy. U Bertolucciego uosobieniem wszelkiego zła są abstrakcyjny (nieobecny na ekranie) Duce oraz Becaccia, oskarżony między innymi o zbeszczeszczanie grobu Athosa-seniora (czego faktycznie dokonał syn zmarłego). Reszta mieszkańców z faszyzmem nie miała, jak się wydaje, nic wspólnego. Planowanie zabójstwa Duce przy dźwiękach Rigoletta uwypukla zatem rzekomą „ogólnonarodową” walkę ze znienawidzonym najeźdźcą. A muzyczny „akompaniament" zbrodni przydaje bohaterskiej ofierze dodatkowego dramatyzmu - tym bardziej porusza serca i wyobraźnię mieszkańców Tary.

Ostatnia wyróżniona przez Assman kategoria - kompensacja - uobecniona jest w filmie przez zamiłowanie mieszkańców Tary do praktyk upamiętniających. Przede wszystkim zalicza się do nich wystawienie w rocznicę zamachu Rigoletta (w przedstawieniu bierze udział całe miasto), ale także rozmaite elementy architektoniczne: ulica imienia Athosa, tablica ku czci bohatera oraz pomnik (całowany przez staruszka w jednej 
z końcowych scen filmu). O tym, że miasto „należy” do Athosa Magnani, dowiadujemy się zresztą na samym początku Strategii pająka. W scenie pokazującej przejście młodego bohatera z dworca do hotelu kamera wyprzedza lub zostawia $\mathrm{z}$ tyłu protagonistę, pokazując - niejako $\mathrm{w}$ zamian, zamiast kluczowej dramaturgicznie postaci - wszechobecne napisy upamiętniające sławnego antyfaszystę (kim jest idący, dowiadujemy się dopiero po dziesięciu minutach filmu, gdy młody Athos przedstawia się właścicielowi pensjonatu). Wyobrażenie, że to „bogowie są żywi i kierują światem", sugeruje także zmiana barwy popiersia, niejako ożywiająca pomnik, w przywoływanej już scenie konfrontacji syna ze statuą ojca (epizod ten może być nawiązaniem, jak wskazuje Robert P. Kolker, do Pogardy [Le mépris, 1963] Godarda, gdzie w „wewnętrznym” filmie Fritza Langa prezentowane są na przemian białe i kolorowe głowy greckich bogów ${ }^{73}$ ).

Podobnie jak w opowiadaniu Borgesa, w filmie Bertolucciego, wykonanie wyroku na zdrajcy miało rozegrać się „,w okolicznościach szczególnie dramatycznych, które by oddziałały silnie na ludową wyobraźnię ${ }^{\prime 74}$. Athos Magnani (którego nazwisko może, notabene, odsyłać do słynnego włoskiego scenografa - Girolama Magnaniego, współpracownika Giuseppe Verdiego!) zostaje zabity w teatrze; jak jednak podkreśla pisarz, a za nim reżyser (w Strategii pająka słyszymy dokładny cytat z opowiadania): „za teatr posłużyło mu (bohaterowi - zdrajcy [przyp. - A. M.-K.]) całe miasto, i były całe rzesze aktorów i dramat ukoronowany jego śmiercią wypełnił wiele dni i wiele nocy ${ }^{\prime \prime 75}$. Borges odwołuje się tu do koncepcji świata jako teatru, znanej z dramatów Calderona i Szekspira ${ }^{76}$. Bertolucci nadaje jej wymiar dodatkowy, rzec by można - polityczny. Egzekucja w Strategii pajaka ma charakter aktu subwersywnego - powtarza faszystowską praktykę działania politycznego jako spektaklu, ale i „wywraca” ją. Spektakl został wszak „ustawiony” tak, by gawiedź sądziła, iż wykonawcami egzekucji byli faszyści - podczas gdy zamordowany zostaje ich agent ${ }^{77}$.

${ }^{73}$ Robert P. Kolker, Bernardo Bertolucci, Oxford 1985, s. 113; wspomina o tym także cytowany już Michalski.

${ }^{74}$ Jorge Luis Borges, op. cit., s. 109.

${ }^{75}$ Ibidem, s. 108.

76 Zdaniem Michalskiego, konwencji teatralnej w filmie Bertolucciego można doszukiwać się w specyficznym wykorzystaniu dalszego planu - mianowicie w umieszczaniu w jednym obrazie, jak na scenie, dwóch różnych akcji z dwóch obszarów czasowych (takie rozwiązanie jest oczywiście skrajnie odmienne od Bazinowskiej „głębi ostrości”). Por. Andrzej Michalski, op. cit., s. 288.

77 Loshitzky idzie w tej interpretacji dalej. Twierdzi mianowicie, że Bertolucci pokazuje faszyzm jako spektakl, a tym samym powiela model, który tak zaciekle krytykował podówczas - w duchu 1968 roku - Jean-Luc Godard. Zob. Yosefa Loshitzky, op. cit., s. 58. 
Przywołane powyżej cytaty możemy odnieść do interesującego mnie problemu - poświadczają one, że w narracji historycznej ważniejszy od prawdy jest sposób przedstawienia wydarzeń. Jeśli mieszkańców Tary uznamy za metonimię (synekdochę) włoskiego społeczeństwa, wówczas owe "wiele dni i wiele nocy" po zamachu możemy interpretować dwojako. Jako dwa ostatnie lata wojny od 1943 do wyzwolenia (pamięć o bohaterze wpływałaby wtedy na aktywność wyzwoleńczych ruchów antyfaszystowskich), ale także jako rzeczywistość Włoch powojennych, a w szczególności rozpolitykowanych lat 60. (kiedy to młode pokolenie zaczęło odważnie stawiać pytania o historię).

Maj 1968 jest niewątpliwie ważnym kontekstem filmu Bertolucciego - istotnym tym bardziej, iż poszerza horyzont interpretacji konfliktu generacyjnego. Nie chodzi bowiem wyłącznie o problem „zbrodni faszystowskich i pamięci o ruchu oporu", ale także o - wówczas bardzo żywe - powojenne konflikty polityczne. O tym, do jakiego stopnia decydowały one o charakterze ówczesnych włoskich debat, także tych dotyczących kina, zaświadcza następująca wypowiedź Bertolucciego: „W Strategii pajakka związek między Athosem-synem i Athosem-ojcem jest podobny do tego, jaki istniał - tak sobie wyobrażałem - między Berlinguerem i Togliattim: syn odkrywający zdradę ojca bohatera jest Berlinguerem, który ujawnia stalinizm Togliattiego" ${ }^{\prime 78}$. Z dzisiejszej perspektywy odczytanie Strategii... jako komentarza do utarczek pomiędzy przywódcami partii komunistycznej jest chyba już tylko ciekawostką - ale też jedynym sensownym wytłumaczeniem motywu, który z zadziwiającą konsekwencją umyka interpretatorom filmu. Chodzi o postać marynarza, pojawiającego się na początku i w zakończeniu filmu; jego obecność podkreśla klamrę narracyjna, choć nie jest w żaden sposób motywowana fabularnie. Trop intertekstualny pozwala domniemywać, że ów marynarz to Wakulińczuk z Pancernika Potiomkina [Bronienosiec Potiomkin, 1925] (co jest prawdopodobne nie tylko z uwagi na ówczesne afiliacje polityczne Bertolucciego, ale także z uwagi na swoistą „wędrówkę” Wakulińczuka przez zaangażowane politycznie kino przełomu lat 60. i 70., na przykład u Godarda czy Makavejeva). Aluzja ta nie byłaby oczywiście przejawem „pustej” kinofilii

78 Strategia nonkonformisty wedtug Bertolucciego (fragmenty wywiadu, który przeprowadził z Bernardem Bertoluccim Enzo Ungari), [w:] Bernardo Bertolucci w opinii krytyki zagranicznej, opr. Tadeusz Miczka, Warszawa 1993, s. 210-211. Przypomnijmy: Palmiro Togliatti to współzałożyciel Włoskiej Partii Komunistycznej i jej lider (po uwięzieniu przez faszystów Antonia Gramsciego). Enrico Berlinguer, następca Togliattiego, dążył do zawarcia z chrześcijańsko-demokratycznym stronnictwem historycznego kompromisu, odczytanego przez radykalne ugrupowania jako zdrada „interesów proletariatu”. 
- ewokuje bowiem całkiem udatnie pojęcie „komunizm”, a tym samym wprowadza perspektywę, którą sam reżyser zwerbalizował w cytowanej wypowiedzi.

O konieczności rozrachunku z przeszłością traktuje najwymowniej zakończenie filmu; nie znajduje ono swojego odpowiednika w literackim pierwowzorze. Finałowa sekwencja (poprzedza ją scena, w której Athos-junior wygłasza mowę podtrzymującą fałszywy mit bohaterstwa ojca) rozgrywa się na dworcu, przez co tworzy ona swoistą klamrę narracyjną z początkiem filmu. Athos czeka na pociąg. Spóźnia się on dwadzieścia minut, później dalszy kwadrans... Po torach przejeżdża drezyna. Bohater czeka - a przyglądając się szynom odkrywa, że zarosły one trawą (w kilku ujęciach widzimy coraz bujniejszą roślinność, która ostatecznie wypełnia cały obraz). Szyny są więc od lat nieużywane; Athos orientuje się, że oczekiwany pociąg nie nadjedzie. Seria obrazów prezentujących zieloną gęstwinę porastającą tory ma charakter wizualnej metafory. Za jej pomocą Bertolucci zdaje się sugerować, że bez rozliczenia się z przeszłością nie nastąpi „ciąg dalszy"79. Innymi słowy, polityka polegająca na konstruowaniu nowych ram pamięci i narzucaniu kolejnym pokoleniom oficjalnej, wyuczonej oraz celebrowanej wersji wydarzeń domaga się zmiany.

Zakończenie filmu może zostać także odczytane jako sugestia, że niezależnie od tego, jak bardzo oddalone w czasie wydają się wydarzenia minione, historia odnosi się do teraźniejszości: bieżących potrzeb i aspiracji. Mitologia antyfaszystowskiego ruchu oporu została ukazana jako „wygodna iluzja”, wytworzona przez pokolenie wypierające faktyczną skalę poparcia dla Mussoliniego. Jak słusznie zauważa Eugenio Bolongaro, w iluzji tej kryje się poważne niebezpieczeństwo: „redukując historię, innych i siebie samego jedynie do roli narzędzi ideologii, Athos-senior broni reguł ją podtrzymujących, uniemożliwiając faktyczne z nią zerwanie $^{\prime \prime 0}$. Decyzja o podtrzymaniu bohaterskiego mitu podjęta przez młodego bohatera powiela ten schemat - młody Athos pozostanie „spadkobiercą" kłamstwa. Konsekwencje takiej postawy zostały zilustrowane poprzez przywołany obraz „zachwaszczonych" szyn - jest on zachętą do rozrachunku z dziedzictwem przeszłości, a jednocześnie przestrogą przed wybiórczym jej „porządkowaniem”.

79 Ten „opóźniony pociąg” był odczytywany również jako dodatkowy, ironiczny żart z faszystowskiej propagandy - a konkretnie z wypowiedzi Mussoliniego, w których chwalił się on, iż za jego rządów pociągi są wreszcie punktualne (zob. Mabel Berezie, Making the Fascist Self: the Political Culture of Interwar Italy, Ithaca 1997, s. 66; podaję za: Deborah Crisp, Roger Hillman, op. cit., s. 266).

${ }^{80}$ Eugenio Bolongaro, op. cit., s. 90. 
W Borgesowskim opowiadaniu i w inspirowanym nim filmie Bertolucciego przedmiotem refleksji pozostaje "tajemnicza forma czasu", w której to nie przeszłość określa teraźniejszość, lecz ta ostatnia definiuje zdarzenia minione. W Temacie zdrajcy $i$ bohatera jest ona przede wszystkim uniwersalną zasadą wiecznego powrotu. W Strategii pająka została zaś potraktowana jako obszar najpełniej wyrażający doświadczenie niejednoznaczności. Świadomy jej interpretator - schwytany w sieć iluzji, którą tak precyzyjnie tka Bertolucci - zmuszony jest powtórzyć za Borgesem: „brakuje tu jeszcze szczegółów, potrzebne są poprawki i dociągnięcia; pewne miejsca tej historii nie zostały mi jeszcze objawione" ${ }^{\prime \prime 1}$.

${ }^{81}$ Jorge Luis Borges, op. cit., s. 106. 


\section{Rozdział VI}

\section{Lata 1979-1994: baśniowe formuły}

Kino włoskie lat 80. i 90. jest zjawiskiem pełnym sprzeczności i paradoksów. Jak twierdzi Tadeusz Miczka (pisząc o pierwszej z wymienionych dekad), ,z mozaiki tematów, hybrydycznych konwencji gatunkowych i ideologii mieniących się różnymi barwami [...] nie wyłania się całościowy obraz jakiegoś kierunku lub nurtu, formacji pokoleniowej lub artystycznej, jakiegoś ruchu odnowy czy stylu" ${ }^{\prime 1}$. Eklektyzm tematyczno-stylistyczny rodzimej produkcji potwierdza także opinia Gianfranco Bettetiniego, który sytuację włoskiego kina określał słówkiem „marmelada”2.

„Wydaje się, że kino włoskie, rozdrobnione w archipelagu reżyserów, odzwierciedla społeczne rozprężenie i rozpad międzyludzkich więzi; straciło czucie, jest niemal martwe" ${ }^{3}$ - stwierdza Gian Piero Brunetta, diagnozując w ten sposób kondycję X muzy na Półwyspie Apenińskim lat 80. Na ekranach włoskich kin tego okresu dominują „intrygi all'americana: historie miłosne i przygodowe z wyraźnie zaznaczonym wątkiem rywalizacji" ${ }^{4}$. Resistenza przestaje być tematem chętnie podejmowanym przez reżyserów. Jedynie twórcy starszego pokolenia, jak np. Valentino Orsini i bracia Taviani podtrzymują pamięć o ruchu oporu, realizując m.in. Ludzie czy nie (Uomini e no, 1980) oraz Noc świętego Wawrzyńca (Notte di San Lorenzo, 1982).

Lata 90. przyniosły zaś wedle Gianniego Ghigiego „kino bez bohaterów, którzy rozczarowani teraźniejszością wypatrują przyszłości" ${ }^{5}$.

1 Tadeusz Miczka, W Cinecittà $i$ okolicach. Historia kina włoskiego od połowy lat pięćdziesiatych do końca lat osiemdziesiatych XX wieku, Kraków 1993, s. 387.

2 Por. Gianfranco Bettetini, La conversazione audiovisiva. Problemi dell'enunciazione filmica e televisiva, Milano 1984.

${ }^{3}$ Gian P. Brunetta, Il cinema italiano contemporaneo da La dolce vita a Centochiodi, Bari 2007, s. 550.

${ }^{4}$ Gianfranco Casadio, La Guerra al cinema. I film di Guerra nel cinema italiano, t. II, Ravenna 1998, s. 217.

${ }^{5}$ Giuseppe Ghigi, La memoria inquieta. Cinema e resistenza, Venezia 2009, s. 217. Przełom lat 80. i 90. to także okres próby nawiązania do tradycji i dziedzictwa włoskiego kina, 
Reżyserzy debiutujący w tej dekadzie (m.in. Daniele Luchetti, Francesca Archibugi czy Silvio Solidni) to - jak stwierdza Lino Micciché - „spadkobiercy niczego" ${ }^{\prime 6}$. Miażdżąca opinia krytyki o ówczesnej kondycji włoskiego kina jest zaskakująco zgodna. Morando Morandini na łamach "Cinemazero” pisał o „niedokrwistości myśli, formy, technik artystycznych i pomysłów twórczych" oraz wyrażał przekonanie, że „kino włoskie już nie istnieje, robi się tylko filmy"7.

W omawianym okresie najwięcej filmów (spośród garstki, które $\mathrm{w}$ tym czasie opowiadały o włoskim ruchu oporu) podejmuje temat resistenzy $\mathrm{w}$ trybie fikcjonalnym. Większość tych realizacji nie zawiera w swej strukturze materiałów archiwalnych. Interesującym przykładem takiej realizacji jest film Ludzie czy nie (Uomini e no, reż. V. Orsini, 1980), na podstawie powieści Elio Vittoriniego o tym samym tytule. Akcja rozgrywa się w 1944 roku w Mediolanie. W centrum uwagi pozostają dowódca partyzantów o pseudonimie $\mathrm{N}^{8}$ - intelektualista pełen wątpliwości, jak powinien postępować - oraz Berta, jego dawna miłość, która ostatecznie decyduje się wrócić do ukochanego. Wojenne zmagania i partyzancka walka przedstawione zostają $\mathrm{w}$ filmie przez pryzmat skomplikowanej historii miłosnej (Berta jest już mężatką i początkowo wydaje się, że połączenie kochanków będzie niemożliwe).

W Ludziach czy nie mamy zatem charakterystyczny dla lat 80 . zwrot w stronę prywatności. O tym aspekcie filmu mówi reżyser w następujący sposób: „rzeczywistość N2 to jego prywatność i indywidualizm typowy dla intelektualisty, który ma większe predyspozycje, by «rozmyślać» i «patrzeć», a nie «działać». [...] Bohater cały czas oscyluje między obserwowaniem a działaniem" ${ }^{\prime 9}$. Ten konflikt oraz konstrukcja bohatera, który nie-

czego świadectwem są filmy nostalgiczne, m.in. Rodzina (reż. E. Scola, 1987) i obsypane deszczem nagród Kino Paradiso (reż. G. Tornatore, 1988).

${ }^{6}$ Lino Micciché, Filmologia e filologia: studi sul cinema italiano, Venezia 2002, s. 52.

7 Mirando Morandini, "Cinemazero” 1991, nr 1 i 2. Cyt. za: Tadeusz Miczka, Kino włoskie, Gdańsk 2009, s. 597.

${ }^{8}$ Pseudonim bohatera N2 może odnosić się do topografii Mediolanu (Naviglio 2 - kanał nr 2) lub być skrótem od „niente nome” - bez imienia.

${ }^{9}$ Cyt. za: Memoria, mito, storia. La parola ai registi, 37 interviste, red. Alessandro Amaducci, Torino 1994, s. 239. Orsini przyznaje przy tym: „Pierwszy raz stworzyłem postać, której nie lubię, w której się nie odnajduję" - ibidem. 
ustannie cierpi i podejmuje decyzje z poczuciem klęski w punkcie wyjścia (kto cię prosit, byś nosit krzyż za wszystkich. Nikt nie ma takiego prawa - mówi jedna z „towarzyszek broni”), był odczytywany jako komentarz do współczesności. Jak pisze Ghigi: „To film powstały po zabójstwie Moro - ukazujący pokolenie zrezygnowane i wycieńczone polityką"10. ${ }^{10} 2$ bardzo różni się przecież od Corbariego (bohatera filmu zrealizowanego dekadę wcześniej, omawianego w poprzednim rozdziale). Ten ostatni, o czym była już mowa, nieustannie walczy, chcąc zmienić świat; N2 nie ma już tego zapału. O ile Corbariego można więc nazwać synem 1968 roku, o tyle N2 to bohater czasów po kontestacji.

Przywołana opinia Ghigiego wskazuje, że na narrację o resistenzy nałożony jest dyskurs współczesny. Nie oznacza to jednak, że film ogranicza się wyłącznie do tego wymiaru. Podobnie jak literacki oryginał, realizacja Orsiniego zawiera bowiem refleksję nie tylko o włoskiej partyzantce, ale staje się „poematem o wolności”, podejmuje zasygnalizowany w tytule temat „bycia człowiekiem”. Ten szerszy zakres rozważań dobrze ilustruje zawarty w powieści, a obecny w filmie w niemal niezmienionej wersji dialog między bohaterami:

- Pracujemy po to, aby ludzie byli szczęśliwi. Jaki sens miałaby nasza praca, gdyby jej celem nie było uszczęśliwianie ludzi. Po to właśnie pracujemy. Czy nie po to?

- Po to - odparł Enne 2.

- Czyż nie po to? - powtórzyła Selva. [...] Na Boga! - dodała - Ludzie powinni być szczęśliwi. Jaki sens miałaby nasza praca, gdyby ludzie nie mogli być szczęśliwi?

- Czy nasze tajne gazetki miatyby sens? Czy nasza konspiracja miałaby sens?

- Nie sadzę.

- A nasi rozstrzelani - czyż to miałoby sens? Nie miałoby sensu.

- Nie, nie miałoby sensu.

- Czy cokolwiek na świecie miałoby sens? Czyż miałyby sens bomby, które fabrykujemy?

- Nic nie miatoby sensu ${ }^{11}$.

Temat ruchu oporu to zatem zarówno dla Vittoriniego, jak i Orsiniego, kwestia moralna. Ukazując krwawe represje, jakich doświadczają partyzanci ze strony faszystów i niemieckich okupantów, reżyser sugeruje, że ci pierwsi są tytułowymi „ludźmi” tylko z nazwy; w istocie mają niewiele wspólnego z człowieczeństwem (o czym świadczy na przykład

${ }^{10}$ Giuseppe Ghigi, op. cit., s. 204.

11 Elio Vittorini, Ludzie czy nie, tłum. Halina Ochęduszko, Warszawa 1958, s. 15-16. Joanna Ugniewska słusznie zauważa, że maniera powtarzania słów i zwrotów nieco odrealnia narrację. Zob. Historia literatury włoskiej, red. Joanna Ugniewska, Warszawa 2001, szczególnie s. 222-226. 
epizod, w którym jeden z niemieckich oficerów każe swoim psom rozszarpać wziętego do niewoli partyzanta). Z przywołanej wymiany zdań wyziera jednak wiara $\mathrm{w}$ nowy porządek, który wyłonić się ma $\mathrm{z}$ bezmiaru wojennych zbrodni i cierpień. Podobną wymowę ma finał filmu. Wprawdzie N2 umiera w udanej skądinąd akcji, która ma na celu zabicie dowódcy faszystów Cane Nero, ale ostatnia sekwencja ukazuje akces do partyzanckiej formacji młodzieńca, który - inaczej niż protagonista filmu - z zapałem pragnie dalej walczyć z najeźdźcą.

\section{Z perspektywy czasu}

Fikcjonalnym filmem podejmującym temat resistenzy, który nie zawiera w swej strukturze materiałów archiwalnych, jest także Sprawa Martella (Il caso Martello, reż. G. Chiesa, 1991). Sytuuje się on jednak w innej kategorii niż filmy dotychczas omówione, ponieważ ruch oporu jest w nim ukazany z perspektywy współczesnej - epizody prezentujące wojenne perypetie włoskich partyzantów pojawiają się na ekranie retrospektywnie, $\mathrm{w}$ formule wspomnień bohaterów.

Sprawa Martella zawiera tezę o zapominaniu historii przez młode pokolenie. Reżyser filmu, Guido Chiesa, deklarował:

Fenomen resistenzy wydał mi się użyteczny, by opowiedzieć o współczesności - Włochach Craxiego, yuppies i telewizji Berlusconiego [...]. Chciałem pokazać, jak Italia lat 80. i początku kolejnej dekady wymazuje własną przeszłość, tracąc w konsekwencji tożsamość ${ }^{12}$.

Teraźniejszość w filmie reprezentowana jest przez trzydziestoletniego Cesare Verra - yuppie lat 80., dla którego główny i jedyny cel stanowi kariera; przeszłość uosabia zaś obecny w tytule filmu Antonio Martello, były partyzant, który wycofał się z życia w 1950 roku po stracie żony. Spółka ubezpieczeniowa, gdzie pracuje Cesare, powinna wypłacić mężczyźnie odszkodowanie, ale niemal czterdzieści lat po incydencie sprawa cały czas jest otwarta. Ambitnemu Verrze zostaje powierzone rozwikłanie tej zagadki.

W dramaturgicznym pomyśle - owianej tajemnicą „sprawy sprzed lat" - można doszukać się komentarza do wydarzeń politycznych na początku lat 90. (skandal Tangentopoli, w który zamieszani byli niemal

${ }^{12}$ Tra emozione e ragione. Il cinema di Guido Chiesa, red. Domenico De Gaetano, Torino 2000, s. 29. 
wszyscy aktorzy włoskiej sceny politycznej). Dla tematu niniejszej pracy kluczowa jest jednak rozmowa między Cesarem i Antoniem, który tak wspomina resistenze oraz powojenne czasy:

w czasie wojny i zaraz po jej zakończeniu mieliśmy broń $i$ kobiety, ludzie darzyli nas szacunkiem. Stara władza bała się nas. Później musieliśmy odtożyć broń, kobiety powychodzity za mą̇̇, stara władza wróciła. Wszystko tak jak przedtem. Musiałem pracować w fabryce w Turynie, ale oczywiście to nie było to, o co walczyłem. [...] Gdy pieniadze sie skończyty, w nocy zdarzało się nam żebrać od bogatych... Od tych, którzy byli wcześniej faszystami... Później sptacaliśmy im dtugi.

Taki opis powojennych losów członków resistenzy wzbudził sprzeciw szczególnie środowisk kombatanckich. Byli członkowie włoskiego ruchu oporu po przedpremierowym pokazie filmu z oburzeniem komentowali, że „na jednego, który zachowywał się tak, jak zostało to pokazane w filmie, dziewięćdziesięciu dziewięciu postępowało inaczej" ${ }^{13}$. Chiesa ripostował, że „należy akceptować historię i nie wstydzić się jej” ${ }^{14}$.

Podobny, kontrowersyjny koncept zawiera film Gangsterzy (Gangsters, reż. M. Giulielmi, 1993). Wprawdzie nie opowiada on o włoskim ruchu oporu sensu stricto - prezentuje bowiem losy byłych partyzantów, którzy po wojnie nie akceptują ogłoszonej przez Togliattiego amnestii i nie wierząc w instytucje wymiaru sprawiedliwości, wymierzają ją na własną rękę (wojenne losy protagonistów nie zostają pokazane na ekranie). Zdecydowałam się jednak film ten przywołać, ponieważ członkowie włoskiej resistenzy zostają $\mathrm{w}$ nim przedstawieni, co sugeruje już tytuł realizacji, jako wyjęci spod prawa "gangsterzy". O kontrowersjach, jakie wzbudził film Giulielmiego, świadczy najlepiej odmowa pokazania go na festiwalu w Wenecji - decyzja ta była komentowana w ostrych słowach m.in. przez producenta Gangsterów, Gianni Minerviniego: „To czysta złośliwość. Polityczna cenzura starego partyjniaka, który nie potrafi zaakceptować prawdziwej, niewygodnej i trudnej prawdy historycznej”"15. Film wywołał debatę dotyczącą domniemanej przestępczej działalności partyzantów-komunistów po zakończeniu zbrojnego konfliktu (faktem jest, że na północy kraju w latach powojennych grasowały ich bandy) ${ }^{16}$. Jak zauważa

${ }^{13}$ Podaję za Memoria, mito, storia. La parola ai registi, 37 interviste, s. 61.

${ }^{14}$ Ibidem.

15 Gianni Minervini, Venezia esclude il mio film perché da fastidio a Pontecorvo, „La Reppublica", 1.08.1992. Producent odnosi się tu do osoby Gillo Pontecorvo; ostatecznie film pokazano poza programem.

${ }^{16}$ Więcej o tym fenomenie zob. Giovanni Fantozzi, Vittime dell'odio: l'ordine pubblico a Modena dopo la liberazione (1945-1946), Bologna 1990. 
Giulielmi: „dla włoskiej partii komunistycznej ci mężczyźni byli szalonymi prowokatorami, dla historii - postaciami dwuznacznymi, do zapomnienia, zaś dla ówczesnej prasy - zwykłymi gangsterami"17. Powstaje pytanie, czy redukowanie obrazu włoskiej resistenzy do grupy rzezimieszków nie jest nadużyciem. Reżyser, broniąc się przed zarzutami manipulacji pamięcią historyczna, zapewniał: „nie zrobiłem filmu pod dyktando politycznej partii [...] nie chcieliśmy tu wyrażać żadnych sądów"18.

$\mathrm{Na}$ początku lat 90. we włoskiej telewizji zaprezentowana zostaje także seria filmów dokumentalnych w cyklu Combat film. Wprawdzie - jak zastrzegałam na początku pracy - realizacje dokumentalne o resistenzy domagałyby się oddzielnego opracowania, ale ponieważ cykl ten wydaje mi się istotny dla unaocznienia przemian w sposobie reprezentacji włoskiego ruchu oporu zdecydowałam się choćby słowem wspomnieć o pierwszym z odcinków serii, wyświetlonym w telewizji 5 kwietnia 1994 roku (a zatem krótko po zwycięstwie wyborczym Berlusconiego) ${ }^{19}$.

Odcinek ten rozpoczynał się szokującym obrazem: na ekranie pojawiły się bowiem zmasakrowane ciała Mussoliniego i Claretty Pettaci na Piazzale Loreto, dla których kontrapunkt stanowiły usatysfakcjonowane twarze zgromadzonych wokół zwłok Włochów. Następnie sekwencje ukazywały kolejno: ofiary masakry Fosse Ardeatine; egzekucję faszystowskich szpiegów, wygłodzoną ludność Lukki; erupcję Wezuwiusza i wreszcie wigilię $\mathrm{u}$ sierot $\mathrm{w}$ Montecatini ${ }^{20}$. Pozwoliłam sobie na opisanie kolejności poszczególnych sekwencji dlatego, by podkreślić iż de facto mamy tu do czynienia z odrębnymi obrazami przemocy i cierpienia, ułożonymi niechronologicznie (np. śmierć Mussoliniego, pokazana w pierwszym ujęciu, nastąpiła w rzeczywistości później niż rzeź w Jaskiniach Ardeatyńskich). Otwierająca film scena jest o tyle ciekawa, iż - wyrwana z historycznego kontekstu - może wywołać współczucie

17 Wywiad z Massimo Guglielmi zamieszczony w „Corriere della Sera”, 15.09.1992, dostępny na stronie: http://archiviostorico.corriere.it/1992/settembre/15/regista_chiamarono_gangsters_co_0_92091518188.shtml.

${ }^{18}$ Ibidem.

19 Seria wykorzystywała materiały archiwalne nakręcone w czasie wojny przez Amerykanów i przechowywane w Narodowym Archiwum w Waszyngtonie. W założeniu pomysłodawców (Roberta Olla i Leonardo Valente) wszystkie odcinki miały pozostać bez słownego komentarza. Dodatkiem miała być jedynie muzyka skomponowana przez Ezio Rinaldiego. Jak podaje Cooke, do studia przed projekcją zaproszono gości. Jednym z nich był Gianfranco Fini, którego ostatecznie zastąpił inny były żołnierz Republiki Salò, Giano Accame. Zob. Philip Cooke, The Legacy of the Italian Resistance, New York 2011, s. 164.

${ }^{20}$ Więcej o całym cyklu zob. Simona Monticelli, National Identity and Representation of Italy at War: The Case of Cobat Film, „Modern Italy” 2000, nr 5. 
dla zabitych. Układ i treść przywołanych sekwencji skłania zaś do następującego wniosku: Italia podczas wojny doznała przemocy - był to czas, w którym cierpiał cały naród. Co istotne (i zaskakujące), żadne z pokazanych okrucieństw nie zostało wykonane przez żołnierzy Republiki Salò. Niemal ośmiominutowa scena erupcji Wezuwiusza (metafora wojennego kataklizmu?) może natomiast sugerować, że przemoc i zniszczenie, jakie spustoszyły kraj, były tyleż „przypadkowe”, co naturalne. W takich również kategoriach należy rozpatrywać wojenną przeszłość, ciesząc się, że powrócił spokój.

\section{Noc świętego Wawrzyńca: cienie (zapomnianych) przodków}

Obsypany nagrodami (m.in. Nagrodą Jury w Cannes oraz pięcioma nagrodami Davida di Donatello) film braci Tavianich Noc świętego Wawrzyńca to dzieło bardzo osobiste. Taviani powracają w nim bowiem do wojennej tragedii z lat dziecinnych, której doświadczyli w rodzinnej miejscowości - San Miniato. W lipcu 1944 roku Niemcy zgromadzili tam lokalną ludność w katedrze, przekonując, że w ten sposób mieszkańcy unikną niebezpieczeństwa - wysadzenia w powietrze zaminowanych wcześniej domów. Katedrę wraz ze zgromadzonymi wiernymi spotkał jednak ten sam los, co pozostałe budynki - większość mieszkańców poniosła śmierć. Przeżyli ci, którzy nie posłuchali rozkazu okupanta; wśród nich Taviani, którzy - jak deklarowali w jednym z wywiadów - „ukrywali się z grupą ludzi przed Niemcami i faszystami, próbując odnaleźć Amerykanów"21. Ta wojenna masakra stała się tematem filmowego debiutu braci: San Miniato, lipiec 1944 (San Miniato, luglio 1944) - dziesięciominutowego dokumentu, zrealizowanego w 1954 roku przy współpracy z Cesare Zavattinim. Noc świętego Wawrzyńca jest zatem swoistym artystycznym powrotem do traumatycznego doświadczenia, w całkowicie nowej, tym razem niedokumentalnej formie ${ }^{22}$.

${ }^{21}$ Wypowiedź zamieszczona w Paolo e Vittorio Taviani: Poetry of the Italian Landscape, red. Riccardo Ferucci, Patrizia Turini, Roma 1995, s. 66. Miasteczko w filmie nosi nazwę San Martino, a nie San Miniato.

22 Jedyna kopia dokumentu została wyprodukowana przez Comune di San Miniato e la Provincia di Pisa. Jak wspominają bracia: „Film został zablokowany z uwagi na naruszanie porządku publicznego: mówił o faszystach, Niemcach i - wedle cenzury - mógł wywołać zamieszanie w salach! [...] Po pokazie na festiwalu został więc odłożony na półkę, a ostatecznie zaginął podczas wielkiej powodzi we Florencji w 1960 roku". Zob. Memoria, mito, storia. La parola ai registi, 37 interviste, s. 274. 


\section{Z dziecięcej pespektywy - w kręgu baśni}

Oniryczno-baśniową tonację, w jakiej utrzymany jest cały film, sugeruje już prolog dzieła. Podczas napisów początkowych kamera ukazuje bowiem wnętrze sypialni z otwartym na oścież oknem, przez które widać granatowe, rozgwieżdżone niebo. W nocnej ciszy kobiecy (ponadkadrowy) głos mówi szeptem:

To Noc świętego Wawrzyńca, kochanie; noc spadajacych gwiazd. Tu w Toskanii mówimy, że każda spadajaca gwiazda spetnia życzenie. Zaczekaj, nie śpij - Wiesz, co życzę sobie dziś? Żeby znaleźć stowa, by móc Ci opowiedzieć o innej Nocy świętego Wawrzyńca wiele lat temu.

Ten sam głos (w funkcji narracyjnej klamry) powraca w finale filmu:

Tak kończy się moja historia, kochanie. Nie wiem, czy wszystko miało miejsce dokładnie tak, jak opowiedziałam... Miałam wtedy tylko sześć lat, ale to prawdziwa historia...

Narratorem przedstawianych wydarzeń jest Cecylia; to ona z perspektywy czasu opowiada o masakrze w rodzinnym miasteczku, której była świadkiem. Dziecięca perspektywa oglądu świata uzasadnia nadane mu zgoła nadprzyrodzone właściwości. Nie dziwi więc na przykład sekwencja, w której na obserwowanym przez dziewczynkę obrazie, przedstawiającym piekielne męki oraz archanioła $z$ mieczem, jego ostrze zaczyna lśnić prawdziwym blaskiem, a z samotnej gruszy (w scenie otwierającej film) pod wpływem nagłego gwałtownego wiatru „znikąd” spadają wszystkie owoce. Wojenna tragedia zostaje sprowadzona do ekscytującej przygody: w oczekiwaniu na wybuchy dziewczynka prosi Boga (jej słowa zostają wprowadzone za pomocą voice-over): wysadź już domy w powietrze, czekam od godziny. Nigdy nie bawiłam się tak dobrze.

Perspektywa dziecka niesie zarazem ze sobą istotne konsekwencje dla wymowy filmu. Przefiltrowanie wydarzeń z czasów II wojny światowej przez pryzmat świadomości sześcioletniej dziewczynki prowadzi w istocie do wizji, jeśli nie zgoła „apolitycznej” (dziewczynka wieść o wyzwoleniu przez Amerykanów przyjmuje dość obojętnie, bardziej ciesząc się z otrzymanych kolczyków od jednej z kobiet), to na pewno odkonkretnionej. Wszystko, co oglądamy, okazuje się więc w istocie świadectwem ówczesnej świadomości bohaterki i jej sposobu pojmowania świata, zdominowanego przez opowieści, jakie przyswajają dzieci i jakie opowiadają pociechom ich krewni. Dlatego też uczestnicy bratobójczej bitwy - starcia partyzantów z faszystami - w oczach dziew- 
czynki zamieniają się w trojańskich wojowników rodem z homeryckiego eposu, który cytowany jest w jednej z pierwszych sekwencji filmu przez dziadka Cecylii. A dziecięca wyliczanka, zasłyszana od mamy, posiada moc swoistego zaklęcia - egzorcyzmu chroniącego bohaterkę przed jednym z agresorów. Czyżby Taviani sugerowali w ten sposób, że w Italii lat 80. II wojna światowa jest dla Włochów historią równie odległą, co starożytne mity i ludowe klechdy opowiadane na dobranoc i tylko $\mathrm{w}$ takiej formule może być zrozumiana? A może wręcz przeciwnie - polor legendy nadany wydarzeniom z czasów II wojny ma wskazywać na trwałość tego konfliktu w zbiorowej pamięci i jej istotność dla włoskiego dziedzictwa kulturowego ${ }^{23}$ ?

W filmie pojawiają się jednak epizody, których dziewczynka nie mogła być świadkiem (nie mogła np. uczestniczyć w miłosnej nocy Galvano i Concetty). Gdybyśmy chcieli więc uzasadnić ich obecność w opowieści kobiety, dojdziemy do wniosku, że historia opowiadana przez Cecylię jest $\mathrm{w}$ istocie wspomnieniem utkanym z doświadczeń i wrażeń całej lokalnej społeczności miasteczka. Innymi słowy, Cecylia za pomocą swojej indywidualnej pamięci wyraża tu pamięć zbiorowości. Potwierdzeniem tej hipotezy są zawarte w narracji słyszalne dla widza myśli współtowarzyszy podróży oraz wizualizacje ich wspomnień. Gdy uciekinierzy w ciemności czekają nieopodal miasteczka na zapowiedziane przez Niemców wybuchy, jedna z dziewcząt - Rosanna wyobraża sobie swój pusty dom (kamera z ręki ukazuje korytarz oraz pokoje, w których widzimy kolejno: tańczącą małą Rosannę, nastolatkę uczącą się w ulubionym „żółtym” salonie i wreszcie obraz niedawny - dziewczynę o obecnym wyglądzie - która przegląda się w lustrze).

Bohaterem filmu pozostaje zbiorowość - grupa mieszkańców San Martino, która pod dowództwem Galvano Galvaniego (służącego lokalnego prawnika) wyrusza na poszukiwanie amerykańskich wyzwolicieli. Kiedy rozlegają się wybuchy, widzimy zbliżenia na uszy poszczególnych uczestników wyprawy - staruszka, Cecylii i bogatej kobiety (o jej zamożności świadczą noszone przez nią kolczyki). Sekwencja ta podkreśla niejako zbiorowy charakter wojennej tragedii - katastrofa (utrata domu) dotyka wszystkich Włochów, bez względu na wiek i płeć, a zarazem

${ }^{23}$ Warto $\mathrm{w}$ tym miejscu przypomnieć, że perspektywa dziecka była często wykorzystywana przez włoskich artystów od razu po wojnie, zarówno w powieściach (Ścieżka pajęczych gniazd [1947] Italo Calvino lub Dom na wzgórzu [La casa in collina, 1949] Cesare Pavese), jak i w filmach (m.in. trzeci film w trylogii wojennej Rosselliniego - Niemcy, rok zerowy [Germania anno zero, reż. R. Rossellini, 1948]). 
podkreśla polifoniczność kolektywnego bohatera; sugeruje różnorodność wojennych przeżyć - jasne jest bowiem, że dźwięk wybuchu inaczej odbierany jest przez małą dziewczynkę a inaczej przez sędziwego mężczyznę. Ulotna materia wspomnień Cecylii ulega więc w jej opowieści daleko idącym przekształceniom pod wpływem opowieści innych uczestników dramatycznego epizodu. Historia przekazywana z ust do ust przesycona jest elementami lokalnego folkloru (na co zwracają już uwagę słowa prologu - my w Toskanii wierzymy), ale i wiary w kosmologiczny ład oraz interwencję czynników boskich i nadprzyrodzonych w bieg dziejów; wiary w łączność między światem doczesnym a transcendentnym (święty Wawrzyniec w sierpniową noc spełnia ludzkie pragnienia). Taviani deklarowali w jednym z wywiadów „Noc Św. Wawrzyńca to nie Wojna peloponeska Tukidydesa. Nam bliższy jest Herodot" ${ }^{24}$.

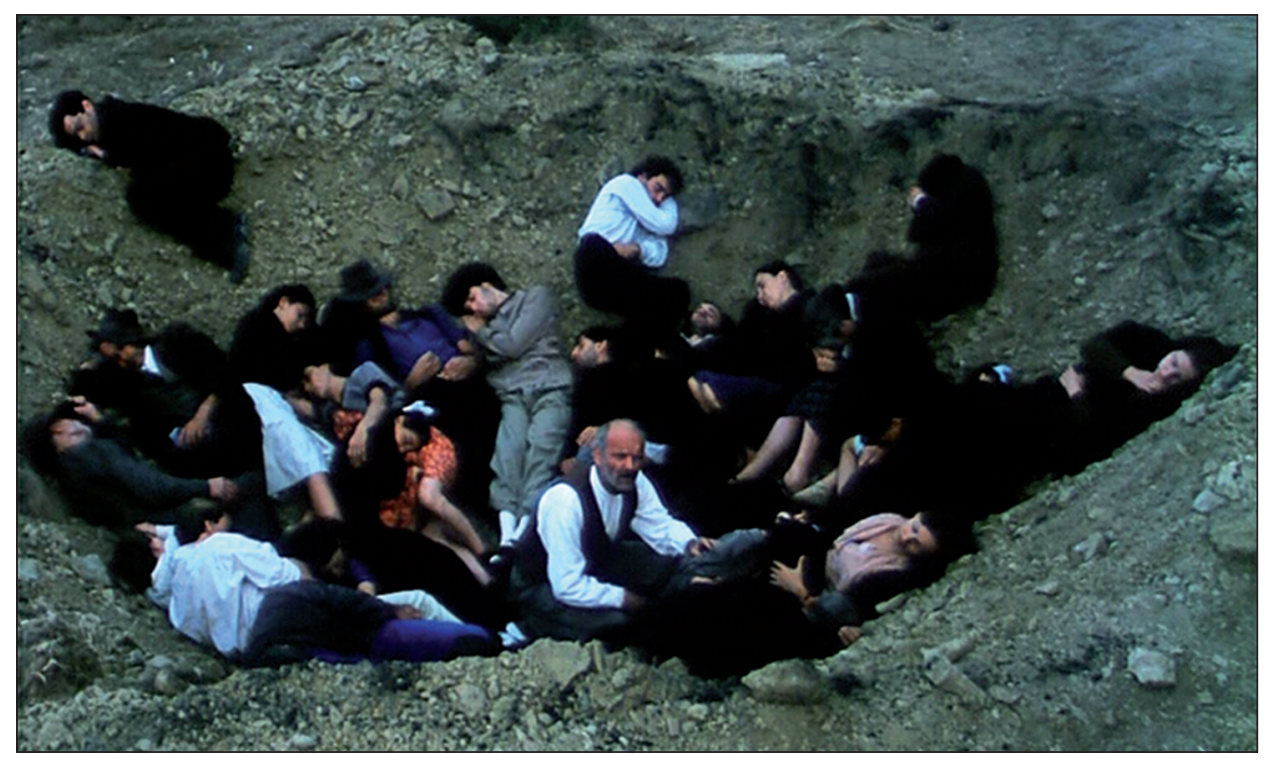

Fot. 7. Noc świętego Wawrzyńca (reż. Paolo i Vittorio Taviani, 1982)

Galvano ze swoimi owieczkami

${ }^{24}$ Bracia Taviani: wspomnienia o letniej nocy (wywiad), „Film” 1983, nr 9, s. 18-19. Tukidydes pierwszy potraktował historię jako naukę, która powinna dostarczyć obiektywnych wiadomości o przeszłości. Dążenie do ujmowania opisywanych wypadków w ich związku przyczynowym oraz krytyczny stosunek do wykorzystywanych źródeł zbliżają dzieło Tukidydesa do dzieł historiografii nowożytnej. Herodot łączył zaś zapis faktograficzny z domniemaniami oraz z baśnią. 


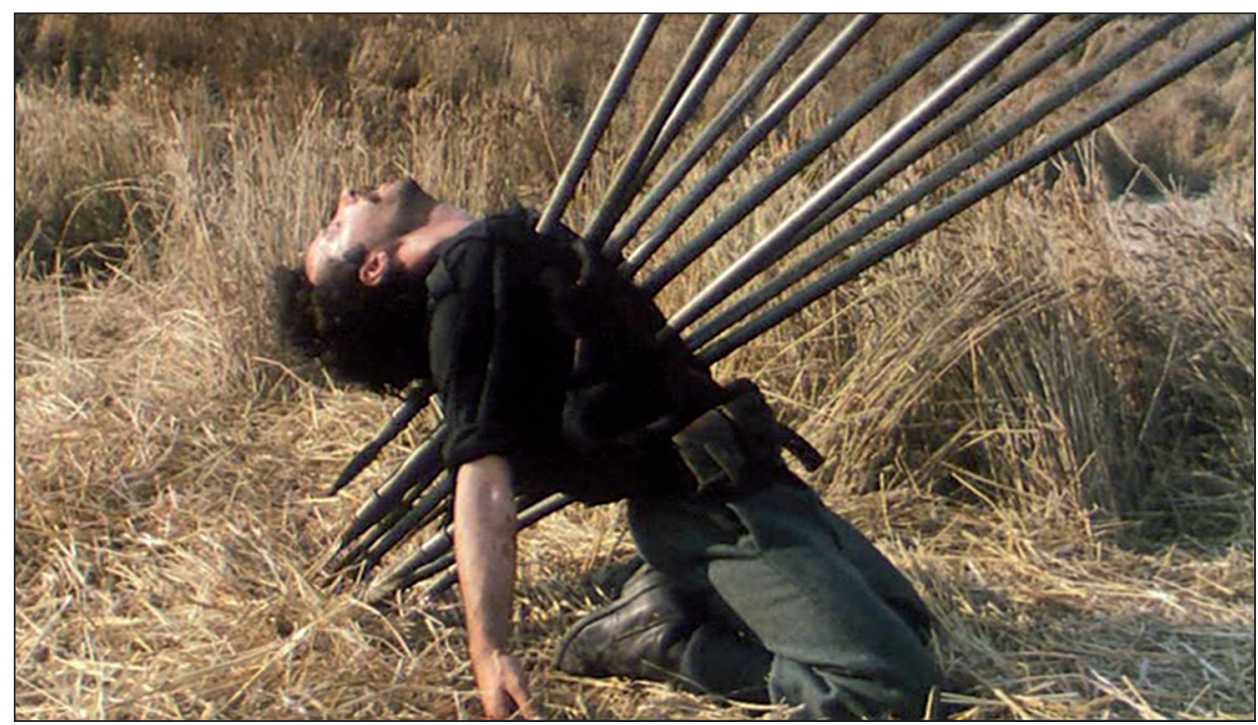

Fot. 8. Noc świętego Wawrzyńca (reż. Paolo i Vittorio Taviani, 1982) Homeryckie starcie na polu pszenicy

\section{Oblicza wroga}

Wedle Pierre'a Sorlina Noc świętego Wawrzyńca to kronika wojny domowej. Rzeczywiście w dziele Tavianich - inaczej niż na przykład w filmach zrealizowanych od razu po wojnie - akcent pada na „wewnętrzny” podział Włochów: konflikt między zwolennikami Mussoliniego a antyfaszystami. Niemcy są tu $\mathrm{w}$ zasadzie nieobecni; pojawiają się zaledwie w kilku epizodach - w roli oprawców, gdy zabijają biegnącą na spotkanie amerykańsko-sycylijskiego batalionu Sycylijkę oraz w scenie żałobnego konduktu. Powolny - obserwowany przez grupę Włochów - pochód niemieckich żołnierzy, maszerujących w rytm wagnerowskiej arii, zdaje się ukazywać "ludzką twarz wroga" - po policzkach śpiewającego Niemca płyną łzy. Rzeczywistymi oprawcami pozostają w filmie faszyści - rodacy, którzy bestialsko traktują znanych im lub wręcz spokrewnionych z nimi politycznych adwersarzy. Fakt, że czarnymi charakterami filmu są w istocie "czarne (sic!) koszule” unaocznia dobrze scena "nieusprawiedliwionego" okrucieństwa: faszyści (ojciec i syn) z lubością roztrzaskują głowę niedołężnego staruszka o drzewo.

Prawdziwym bratobójczym pojedynkiem okazuje się jednak bitwa na polu pszenicy (stanowiąca punkt kulminacyjny filmu). Zwolennicy Mussoliniego napadają partyzantów, do których dołącza grupa Galvano 
(o ruchu oporu za chwilę) podczas żniw. Złowrogą zapowiedzią jest tu zauważony przez pracujących na polu partyzantów faszystowski samochód, który wśród kłosów pszenicy wygląda jak drapieżnik, czający się do śmiercionośnego skoku. Rozpoczyna się walka na śmierć i życie, tym tragiczniejsza, że po obu stronach barykady są niejednokrotnie rodziny lub przyjaciele. Wśród okrzyków przerażenia i jęków, w bitewnym amoku siostra walcząca po stronie partyzantów, spotyka nagle swojego brata - faszystę. Czy mama wie, że jesteś z nimi? - pyta zaskoczona. We Florencji... - zaczyna chłopak, ale nie kończy wyjaśnień; zostaje bowiem zabity przez innego z wojowników. Epizod podkreślający okrucieństwo wojny stanowi także scena pojedynku między dwoma przyjaciółmi. Jest ona o tyle ciekawa, że początkowo widz może przypuszczać, iż oto wśród wojennej pożogi przeważy emocjonalna międzyludzka więź; mężczyźni pokazani są bowiem we wzajemnym uścisku i nawzajem przekonują się, by jeden stał się zakładnikiem drugiego. Wreszcie wydają się przyjacielsko obejmować. Dopiero po chwili okazuje się, że jeden z mężczyzn wbił (początkowo niewidoczny dla widza) nóż w brzuch dawnego kolegi. Podobne znaczenie, które można by zawrzeć w stwierdzeniu: „wojna jest szaleństwem", ma scena opatrywania rannych. Oto w jednym kadrze widzimy dwa obozy - faszystów i partyzantów, którzy próbują ocucić swoich towarzyszy. Jeden z Włochów, słysząc, że obok mają wodę, prosi o trochę płynu dla rannego. Bukłak wędruje $z$ rąk do rąk, ale w momencie jego przekazywania podający orientują się, że należą do dwóch różnych obozów. Przez ułamek sekundy zastygają w pierwszym odruchu pomocy; ludzki impuls serdeczności po chwili wahania zostaje jednak zastąpiony śmiercionośnym strzałem.

Faszyści nie znają litości - zabijają z zimną krwią nawet bezbronnych i niedołężnych. Poruszającą sceną jest ta, w której dziadek Cecylii, chcąc ochronić wnuczkę przed wrogiem niczym prawdziwy Achilles (pseudonim wybrany przez niego przekornie jako partyzanckie imię) rzuca widłami (nasuwającymi asocjacje z włócznią) w jednego z faszystów. Mityczną konotację podsuwa także ścieżka dźwiękowa sekwencji. Naturalnym dźwiękom świata przedstawionego (odgłosom deptanego zboża i wojennym okrzykom) zaczyna bowiem w przywołanym epizodzie towarzyszyć muzyka ilustracyjna - osobliwy marsz skomponowany na trąbki i trąby zapowiada niejako "ostateczne starcie”. „Włócznia” sędziwego Achilla, który niewiele ma wspólnego ze sprawnością fizyczną swego literackiego pierwowzoru, chybia jednak celu, a faszysta z zimną krwią zabija staruszka na oczach dziecka. To właśnie wtedy dziewczynka nadaje wal- 
czącym postać mitycznych wojowników, którzy ostatecznie uśmiercają złego faszystę ${ }^{25}$. Partyzanci także posługują się przemocą. Jeden z członków ruchu oporu zabija piętnastoletniego faszystę (który na czworakach dosłownie skamle o litość), nie zważając na wiek i prośby chłopaka oraz jego ojca, oferującego swoje życie w zamian za ocalenie nastolatka.

Skojarzenie bratobójczej bitwy z mityczną rozgrywką rodem z Iliady Homera jest dramaturgicznie uzasadnione punktem widzenia dziewczynki wzrosłej w kulturze starożytnych mitów i posiada istotne znaczenie dla wymowy filmu. Nasycenie całej narracji odniesieniami do starożytnego eposu (prócz wspomnianego epizodu na polu bitwy i wojennego pseudonimu staruszka [Achilles] wypada wymienić także dość długi fragment Iliady, który jest cytowany przez dziadka Cecylii po ślubie ciężarnej dziewczyny z partyzantem ${ }^{26}$ ) powoduje mitologizację okresu II wojny światowej. W ten sposób zyskuje ona status historiozoficzny. Taviani wydobywają więc niejako afirmatywny aspekt mitu; jego zdolność budowania społecznej tożsamości, która pozwala przetrwać w momentach kryzysów, zachowując pamięć o zakodowanych w nim wartościach; mit chroni bowiem wspólnotę przed duchowym regresem.

Mitologizacja prezentowanej przeszłości osiągana jest także przez styl filmu. Prócz kadrów stylizowanych na renesansowe dzieła (Paolo Ucella i Filippo Lippiego) zwracają uwagę te oparte na geometrycznej kompozycji (głównie w scenach zbiorowych). Toskański krajobraz - równin i dolin, skąpanych w promieniach słońca, oliwnych gajów i zielonych lasów - dopełniany jest elementami „mistycznej” ikonografii: złotych łanów pszenicy, przesuwających się po niebie chmur oraz wody w postaci rzek i deszczu. Jak przyznawali w jednym z wywiadów Taviani: „tworzymy filmy bajkowe. Fellini kreuje rzeczywistość w teatrze, my tworzymy teatr z rzeczywistości" ${ }^{27}$.

${ }^{25}$ Faszysta przebity włóczniami zastyga w teatralnej pozie przypominającej postaci z renesansowych obrazów Paolo Ucello. Na to nawiązanie wskazuje Riccardo Ferucci, zob. Paolo e Vittorio Taviani: Poetry of the Italian Landscape, s. 17.

${ }^{26}$ Dziadek Cecylii cytuje fragment ukazujący pożegnanie Hektora z żoną Andromachą i synkiem przed wojną trojańską. W cytowanym tekście można doszukać się luźnej paraleli między losami postaci z eposu a parą nowożeńców, których także rozdziela tragiczna śmierć jednego z małżonków w czasie wojny.

${ }^{27}$ Bracia Taviani: wspomnienia o letniej nocy (wywiad), s. 19. W Nocy świętego Wawrzyńca zastosowano także roletki. Takie przejścia montażowe podkreślają "mitologizujący" ton dzieła. Roletki - popularne w klasycznym kinie - w latach 70. i 80. pojawiały się w wielu filmach wywołujących efekt nostalgii za "starymi, dobrymi czasami" (Żadło [The Sting], reż. G. Hill, 1973; Gwiezdne wojny [Star Wars], reż. G. Lucas, 1977). 


\section{Biblijna przypowieść}

Prócz starożytnej mitologii, drugim źródłem inspiracji dla Tavianich jest Biblia. Zaryzykuję twierdzenie, że historia wojennych perypetii Cecylii w filmie Tavianich, zyskuje cechy biblijnej przypowieści, w której faszyzm i nazizm skojarzone zostają ze złem, zaś ruchowi oporu przypisane zostaja przymioty dobra i moralnego odrodzenia, podobnie jak Amerykanom (o których za chwilę) konotującym wyzwolenie i „boskie błogosławieństwo" ${ }^{28}$.

Ucieczka grupy mieszkańców z San Martino w filmie wydaje się przyrównana do biblijnego exodusu. Wyrwanie się z niewoli faszyzmu (opuszczenie miasteczka) byłoby $w$ tej optyce wyjściem $\mathrm{z}$ niewoli egipskiej, zaś podróż do terytoriów wyzwolonych przez Amerykanów stanowiłaby pielgrzymkę do ziemi obiecanej. To naddane znaczenie osiągane jest m.in. przez biblijną ikonografię - uciekinierzy, którym przewodzi Galvano, przypominają owce potrzebujące nieustannej opieki swojego pasterza. Ciekawa w tym kontekście jest sekwencja ucieczki z miasteczka pod osłoną nocy. Mieszkańcy przyodziani są w czarne chusty bądź koszule; gdy wstaje słońce, $\mathrm{z}$ radością je zrzucają. Wykorzystanie takich kostiumów ma rzecz jasna swoje uzasadnienie dramaturgiczne - czarne ubrania dobrze maskują uciekinierów w ciemności. Trudno jednak nie dopatrzeć się w niej sensu metaforycznego: odrzucenia faszyzmu, którego symbolem są właśnie camicie nere.

Tropem potwierdzającym przyjętą hipotezę o nadawaniu prezentowanej historii z II wojny światowej znaczeń biblijnych jest także epizod "cudownego" posiłku na polu arbuzów. Soczyste owoce, które zgłodniali podróżni zachłannie spożywają nasuwają bowiem skojarzenia z boską „manną z nieba”. Wątków chrześcijańskich dopatrzeć się można wreszcie w dość długiej scenie zbiorowej kąpieli w rzece, będącej dla podróżnych swoistym chrztem - obmyciem z „grzechów przeszłości”. O tym, że podróży Włochów nadawane są sensy biblijnego oczyszczenia i odrodzenia, świadczy również rozbudowana sekwencja zmiany imion, po dołączeniu przez grupę Galvano do partyzantów. Dramaturgicznie jest to uzasad-

${ }^{28}$ Taviani w jednym z wywiadów deklarowali: „my dwaj urodziliśmy się w miasteczku San Miniato, które było faszystowskie, w Toskanii, która była faszystowska i we Włoszech, które były faszystowskie. Tak, istniały formy oporu, ale rzeczywistością dla nas w szkole był faszyzm: rzeczywistością która wydawała się nie do zniszczenia. Widzieliśmy jednak na własne oczy, jak ta negatywna rzeczywistość zmienia się w swoje przeciwieństwo; jak dobro zwycięża nad złem" - zob. Memoria, mito, storia. La parola ai registi, 37 interviste, s. 282. 
nione „zmyleniem wroga” w czasie potencjalnej bitwy. Wydaje się jednak, że epizod ten, stanowiący swego rodzaju kolejny "chrzest", ma na celu przede wszystkim podkreślenie przyjęcia przez Włochów nowej „nieskażonej" tożsamości - przeistoczenia się w bojowników ruchu oporu.

Resistenza w filmie Tavianich skojarzona zostaje więc z nowym życiem, odrodzeniem. Jej znaczenie dla historii Italii oraz kulturowej pamięci Włoch podkreślają dodatkowo imiona partyzantów. „Dante” przywodzi bowiem na myśl arcydzieło włoskiej literatury - Boska komedię; jej autor jest zaś uznawany za prekursora włoskiego odrodzenia (sic!) i kodyfikatora włoskiego języka; pseudonim „Requiem” przyjęty przez innego mężczyznę odsyła natomiast do Giuseppe Verdiego. Nawiązanie to jest o tyle znaczące, o ile wpisuje ono włoski ruch oporu w tradycję ruchów wyzwoleńczych risorgimento, które doprowadziły do zjednoczenia Włoch i powstania „nowego państwa" ${ }^{29}$. Fakt nieustannego wikłania, czy może raczej zakorzeniania ekranowej historii w układzie odniesień do innych reprezentacji - literackich eposów czy renesansowych obrazów - podkreśla zresztą ważność całej narracji o II wojnie dla dziedzictwa kulturowego Włoch.

Warto przy tym zaznaczyć, że obraz ruchu oporu jest u Tavianich dość nietypowy na tle innych jego filmowych reprezentacji. Partyzanci w Nocy świętego Wawrzyńca pojawiają się bowiem po raz pierwszy nie w zbrojnej akcji lub podczas jej planowania, lecz zostają ukazani w czasie pracy na polu - przy żniwach. Scena zbioru plonów, unaoczniająca walkę o przetrwanie, podkreśla zarazem pragnienie nie tyle zniszczenia przeciwnika, co ocalenia pokarmu i ziemi, a zatem sugeruje, że działania resistenzy ukierunkowane są na łączenie, a nie destrukcję. Przez lwią część historii oglądamy natomiast zbuntowanych przeciw nazistom mieszkańców San Martino. Ich nieposłuszeństwo wynika jednak (przynajmniej na początku) bardziej z intuicji niż z politycznej świadomości. Z tego powodu Pierre Sorlin nazywa grupę Galvano „resistenzą nie-polityczną” (choć równie istotną), polegającą na aktywnym przeciwstawieniu się okupantowi, która dopiero z upływem czasu decyduje się na uczestnictwo $\mathrm{w}$ przedsięwzięciach militarnych ${ }^{30}$. Biblijne odniesienia są chyba najpełniej widoczne w scenie bratobójczej walki między partyzantami a faszystami na polu pszenicy. Starcie dobra ze złem przypomina tu raczej apokaliptyczną wizję awizowaną

${ }^{29}$ Jak już była mowa w rozdziale o Strategii pająka, zwolennicy niepodległości i zjednoczenia Włoch na murach miast malowali napis VIVA V.E.R.D.I.! - akronim hasła politycznego „Viva Vittorio Emanuele Re d'Italia” (Niech żyje Wiktor Emanuel, król Włoch).

${ }^{30}$ Pierre Sorlin, The Night of the Shooting Stars. Fascism, Resistance and the Liberation of Italy, [w:] Revisioning History. Film and the Construction of a New Past, red. Robert A. Rosenstone, Princeton 1995, s. 78. 
$\mathrm{w}$ jednej $\mathrm{z}$ pierwszych sekwencji filmu przez księdza podczas mszy (kapłan wspomina o Dies Irae - Dniu Gniewu; wzmianka ta zostaje wzmocniona wspominaną już wizją Cecylii, która na obrazie przedstawiającym sąd ostateczny dostrzega "prawdziwy” błysk miecza Michała Archanioła - pogromcy szatana). Zabijający z zimną krwią faszyści przypominają demony. Szatańskie konotacje wytwarza szczególnie scena prezentująca pełzającego po zbożu (ubranego na czarno) rannego faszystę. Mężczyzna czołga się do grupki sparaliżowanych strachem „dobrych", powtarzając w amoku Mussolini, Mussolini. Nazwisko Duce wymawia jednak bardzo specyficznie - wydłużając za każdym razem zgłoskę „s"; powstaje zatem wrażenie, iż z ust mężczyzny wydobywa się syk węża. Kolejna scena wydaje się ilustracją diabelskiej przebiegłości - widzimy bowiem pięknego chłopca, z malutkim czarnym znamieniem na policzku, który wyłania się ze zboża i odpowiada na nawoływanie partyzanta. Gdy ten ostatni wynurza się z łanów pszenicy, by ostrzec dziecko, zostaje zabity przez ukrytego nieopodal faszystę. Okazuje się, że chłopiec jest zwolennikiem Mussoliniego - podstępnie zdjął czarną koszulę, by zmylić wroga.

Sceneria, w której rozgrywa się bitwa, także odsyła do chrześcijańskiej wiary. Uprawa pola, ziarno i żniwa - to przecież symbole często wykorzystywane w biblijnych przypowieściach. I tak, epizod bratobójczej walki nasuwa skojarzenia z przypowieścią o wyplenianiu chwastów zawartą w Ewangelii św. Mateusza ${ }^{31}$. Znaczące w kontekście biblijnych tropów wydaje się także zakończenie pielgrzymki Toskańczyków. Cecylia wraz z mieszkańcami San Martino w finale opowieści dociera bowiem do „anielskiego” miasteczka (Sant'Angelo), gdzie dociera wieść o wyzwoleniu regionu przez Amerykanów. Nadchodzi zatem ostateczne wyzwolenie - partyzanci radują się i cieszą skąpani w słońcu oraz strugach deszczu. To niepopularne zjawisko atmosferyczne nadaje „politycznej” wiadomości ponownie wymiar cudowności, ingerencji boskiej opatrzności; jak gdyby Włosi po złożeniu (krwawej - starotestamentowej) ofiary i wewnętrznej przemianie (odrzuceniu faszyzmu) zaczynali nowe życie - zawarli „nowe przymierze". Oczyszczający charakter sekwencji jest potęgowany przez padający - obmywający (z grzechów przeszłości) - deszcz.

${ }^{31}$ W Ewangelii św. Mateusza, Jezus przedkłada uczniom przypowieść o Królestwie Niebieskim podobnym do człowieka, który posiał dobre nasienie na swej roli. Przyszedł jednak nieprzyjaciel i zasiał w pszenicy chwast. Gdy słudzy gospodarza pytali, czy mają chwast wyrwać, gospodarz im odpowiedział: Pozwólcie obojgu [pszenicy i chwastom - przyp. A. M.-K.] róść aż do żniwa; a w czasie żniwa powiem żeńcom: Zbierzcie najpierw chwast i powią̇cie go w snopki na spalenie; pszenice zaś zwieźcie do mego spichlerza - por. Biblia Tysiaclecia, Poznań 2012, Mt 13, 24-30. 
W filmie Tavianich brak politycznej debaty czy przedstawienia racji faszystów bądź partyzantów. Jak już zostało powiedziane, taka „apolityczna" wizja wydarzeń i stronnictw konfliktu wynika po części z dziecięcej świadomości, przez której pryzmat przefiltrowana została cała narracja. Teoretycznie można byłoby sobie jednak wyobrazić, że Cecylia wspomina ówczesne argumenty uczestników osobliwej podróży bądź że jest świadkiem światopoglądowej tyrady zwolenników faszyzmu. Tego wątku jednak w Nocy świętego Wawrzyńca brak. Wydaje mi się to znaczące, ponieważ $w$ ten sposób podkreślona zostaje irracjonalność politycznego wyboru Włochów. W konsekwencji, odpowiedzialność za złe czyny faszystów w filmie Tavianich oraz bierne im posłuszeństwo wydaje się raczej wynikiem bądź przypadku, bądź swego rodzaju opętania przez „złego ducha". Za taką hipotezą przemawia choćby epizod spotkania Galvano z faszystowskim żołnierzem na początku filmu. Przeczuwając podstęp Niemców, staruszek podpytuje młodzieńca (w którym rozpoznaje syna swego dobrego przyjaciela), czy warto iść do katedry. Chłopak, początkowo głośno wyśmiewa Galvano, niejako na pokaz, tak by usłyszeli go stojący nieopodal koledzy, po czym tonem konfidencjonalnym odpowiada mężczyźnie słowami, które zdradzają zagubienie żołnierza - w tych czasach trudno przewidzieć, co jest dobre, a co złe.

Rozdarcie Włochów między faszyzmem a resistenza oraz społeczna dezorientacja, akcentowane są od początku filmu. Proces ten doskonale ilustruje scena podziału społeczności miasteczka na grupę, która decyduje się uciec z Galvano i tę, która poddaje się rozkazowi Niemców i gromadzi się w katedrze. Co istotne, oba obozy tworzą się pod wpływem chwili, intuicyjnie; $w$ ostatnim momencie dwie kobiety zmieniają jeszcze zdanie i przebiegają na stronę tych, którzy postanawiają wykonać rozkaz okupanta. Taviani nie wyjaśniają także, dlaczego ludzie słuchają charyzmatycznego Galvano. Epizod ten w planie metaforycznym można odczytać jako komentarz do postawy włoskiego społeczeństwa w czasie wojny. Eksponując „rozbrat” Włoch, Taviani jednocześnie usprawiedliwiają niejako bierność włoskiego społeczeństwa wobec faszyzmu; tłumaczą bowiem polityczne wybory ludzkim strachem i intuicją, a nie świadomymi decyzjami.

„Politycznie niewinni”, a ulegli niemieckiemu rozkazowi, płacą zresztą w filmie ogromną cenę - ponoszą śmierć. Sekwencja ta jest o tyle znacząca i poruszająca, że w sposób najbardziej intensywny unaocznia okrucieństwo wojny, która dotyka zgromadzonych w kościele bezbronnych 
starców, kobiety i dzieci. Konotacje chrześcijańskie są tu bardzo wyraźne, z uwagi na fakt, że cała tragedia rozgrywa się w kościele w trakcie mszy, podczas sakramentu Eucharystii (bardzo rozbudowana jest sekwencja poświęcenia zwykłego chleba, by "opłatka” starczyło dla wszystkich oraz rozdawania go wiernym). Mieszkańcy San Martino zostają zatem ukazani jako ofiary - ich wiktymizacja jest podkreślona w filmie za pomocą długiej sekwencji wynoszenia zmarłych (głównie kobiet, w tym ciężarnej dziewczyny i dzieci) oraz opatrywania ran. Wojennej masakrze zostają tym samym nadane sensy ewangeliczne - swoistej pokuty i odkupienia win ${ }^{32}$. Sakramentu Eucharystii możemy dopatrzeć się również w sekwencji dzielenia chleba przez Galvano, który przed długą drogą posila się nim wraz $\mathrm{z}$ innymi uciekinierami.

\section{American dream}

Amerykanie są $\mathrm{w}$ filmie Tavianich symbolem wolności i obietnicą szczęścia. O tym, jak ogromne nadzieje włoska ludność wiąże z amerykańskim wojskiem, zaświadcza scena muzycznego żartu, który mieszkańcom przygotowuje cyniczny prawnik. Przypomnijmy - sekwencja rozpoczyna się dochodzącą z oddali muzyką amerykańskiej pieśni wojskowej. Plotka, że oto nadciągają Amerykanie, roznosi się błyskawicznie. Mieszkańcy San Martino niezależnie od wieku i płci wybiegają na powitanie „aniołów wolności" i uporczywie wpatrują się w horyzont. Młodsi wspinają się na drzewa, by pierwsi dojrzeć upragnione postaci. Jeden z mężczyzn zastyga $\mathrm{w}$ powitalnym geście $\mathrm{z}$ kapeluszem $\mathrm{w}$ ręku. Kolejne ujęcie zdradza, że dźwięki marszu dochodzą z gramofonowej płyty z premedytacją włączonej przez prawnika. Pragnienie zobaczenia Amerykanów przez grupę wyczekujących Włochów jest jednak na tyle silne, że jeden z młodzieńców oczami wyobraźni dostrzega przybyszów, szepcząc z satysfakcją - widze ich!, a kobiety zaczynają wymachiwać chustami na powitanie.

Pozwoliłam sobie na tak dokładny opis sceny pierwszego „pseudo-spotkania" z Amerykanami, gdyż awizuje ona tryb, w jakim będą się oni pojawiać w całym filmie. Żołnierze US Army zjawiają się w Nocy świętego Wawrzyńca jeszcze dwukrotnie - w przedśmiertnej wizji postrzelonej przez Niemców Sycylijki, oraz realnie - w trakcie porannej toalety; ten jeden raz „,w rzeczywistości” i „na żywo” są jednak widziani wyłącznie przez Cecylię

${ }^{32}$ Męczeński wymiar historii podkreśla także sam tytuł filmu - święty Wawrzyniec był bowiem męczennikiem, który skonał w ogromnych boleściach. Jego święto przypada 10 sierpnia. Wtedy to obserwowane jest astronomiczne zjawisko spadających meteorów (Perseidów) - gwiazd nazywanych jego łzami. 
i jej koleżankę. Istnieją zatem głównie w sferze wyobraźni włoskiej społeczności. Zaryzykuję więc twierdzenie, że Amerykanie w filmie Tavianich kojarzeni są z „dobrymi duchami”, aniołami zwiastującymi pokój i szczęście.

Za taką hipotezą przemawia choćby sekwencja rozmowy rannej Sycylijki z amerykańskimi żołnierzami, którzy okazują się iluzją amerykańskim snem dziewczyny i spełnieniem jej marzeń o raju (jeden z wojskowych wydaje się dalekim krewnym dziewczyny mieszkającym w Brooklynie, a drugi oczarowuje ją zabawką - zamkniętą w szklanej kuli miniaturką Statuy Wolności). Gdy Mara zamyka oczy i umiera (obraz na chwilę traci ostrość), mężczyźni „przeistaczają się” w Niemców - rzeczywistych morderców kobiety. Anielskie konotacje wytwarza także fakt, że dziewczynki spotykają dwójkę Amerykanów na rozstaju dróg przy krzyżu (gdy wracają na miejsce „objawienia” wraz z całą grupą podróżujących, pod krzyżem odnajdują wyłącznie paczkę cameli). Wreszcie finalna wiadomość o wyzwoleniu regionu przez amerykańskie wojsko wydaje się cudem z uwagi na nagłość wiadomości, ale i towarzyszące jej niespotykane zjawisko atmosferyczne (deszcz w promieniach słońca, o którym była już mowa). Poprzez taki tryb prezentacji Amerykanów w filmie Tavianich podkreślona zostaje fascynacja Włochów Stanami Zjednoczonymi, charakteryzująca Italię w przeszłości ${ }^{33}$. Oniryczno-fantastyczny tryb egzystencji Amerykanów w filmie Tavianich zdaje się zarazem sugerować iluzoryczność amerykańskiej pomocy Włochom w czasie II wojny światowej. W istocie Amerykanie w Nocy świętego Wawrzyńca są niemal nieobecni. Gdy się pojawiaja, zamiast realnej pomocy oferują czekoladowy batonik i... nadmuchaną prezerwatywę jako balonik-trofeum. Co prawda w finale filmu, o czym była już mowa, dowiadujemy się, że to Amerykanie wyzwolili Toskanię, ale to wydarzenie zostaje niejako dodane na zasadzie deus ex machina.

33 O amerykańskim micie i jego funkcjonowaniu we Włoszech nieco ironicznie piszą m.in. Umberto Eco i Andrea De Carlo. Zob. np. Umberto Eco, Mit amerykański trzech pokoleń nastawionych antyamerykańsko, tłum. Joanna Ugniewska, [w:] idem, O literaturze, Warszawa 2003 oraz Andrea De Carlo, Śmietankowy pociag, tłum. Halina Bernhardt-Kralowa, Warszawa 2007. Fascynacja Ameryką jest podkreślona w filmie Tavianich także za pomocą epizodów. Gdy Galvano wraz z grupą odnajduje przy wypalonym ognisku camele, z namaszczeniem zaciąga się jednym z nich, potwierdzając "markowy” smak. Scena ta poprzez swoją ikonografię - spaloną słońcem równinę, ognisko, kapelusz Galvano, wydaje się „wyjęta” z westernu. Włosi pełniliby tu rolę Indian, którzy z ciekawością odkrywają zwyczaje białych. Skojarzenie to wytwarzają także niektóre pseudonimy przyjmowane przez "nowych partyzantów” (lew, orangutan, orzeł) oraz fakt życia w głuszy, blisko natury. Partyzanci stają się niejako na nowo „dzicy”, w pozytywnym sensie tego słowa. 
W obecnym w Nocy świętego Wawrzyńca wątku amerykańskim możemy dopatrzeć się polemiki Tavianich z Rossellinim, a dokładniej z wizerunkiem Amerykanów w Paisie, która była dla obu braci dziełem niezwykle istotnym ${ }^{34}$. O ile bowiem Rossellini podkreślał możliwość nawiązania dialogu między obiema kulturami, ukazywał np. współdziałanie oddziału aliantów i włoskich partyzantów (w finalnym tragicznym epizodzie w dolinie Padu), Taviani wskazują na pozorność tego porozumienia. Przyjazna konwersacja z Amerykanami odbywa się w wyobraźni umierającej Mary, ta prawdziwa (uczestniczy w niej Cecylia) ogranicza się wyłącznie do wymiany dziwnych gestów i min. Sekwencja wizji Sycylijki jest chyba najwyraźniejszym nawiązaniem do Paisy, a dokładniej do pierwszego, "sycylijskiego" epizodu, w którym młoda Włoszka zawiązuje bliższą znajomość z jednym z amerykańskich żołnierzy. W obu filmach dziewczyny umierają. O ile jednak u Rosselliniego dziewczyna umiera (zabita przez Niemców), gdyż chce ostrzec i ocalić amerykańskich przyjaciół, o tyle Mara ginie na próżno.

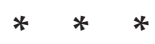

Cecylia kończy swą opowieść w radosnym momencie wyzwolenia i nadziei. Jak mówi w epilogu filmu: czasem nawet prawdziwe historie moga skończyć się dobrze. Współczesna rama narracyjna powoduje jednak pewien dysonans w tej optymistycznej baśni o zwycięstwie miłości i wolności. Kamera ukazuje bowiem dorosłą już Cecylię i jej słuchacza, którym okazuje się nie ukochany mężczyzna, jak można by przypuszczać, ale śpiące dziecko ${ }^{35}$. Znaczący wydaje się także fakt, że gdy Cecylia kończy

${ }^{34} \mathrm{~W}$ wywiadzie z Jeanem Gili Taviani przyznaja, że to pod wpływem obejrzanej w dzieciństwie Paisy zadecydowali o wyborze kariery filmowców (Jean Gili, Le cinéma italien, Paris 1996, s. 332). Swój stosunek do neorealizmu Taviani z perspektywy czasu porównywali do miłości i nienawiści, która jakoby przypomina stosunek ojca do syna: „Zrodzeni z kochanego i podziwianego ojca protestowaliśmy potem przeciwko niemu z okrutną niewdzięcznością dzieci [...]. Protest pozostaje jednak zawsze swoistą formą więzi. Nasze zajęcie się kinem wiązało się z miłością w szczególności do neorealizmu. Potem nastąpił protest, dzisiaj - dystans. [...] Rossellini z ostatniego epizodu Paisy jest dla nas nadal wzorcem świadomym i nieświadomym". Paolo i Vittorio Taviani. Próba bliższego poznania (wywiad), „Film” 1987, nr 18, s. 14.

${ }^{35} \mathrm{~W}$ swej interpretacji, którą oceniam jako oryginalną, ale dość ryzykowna, Milicent Marcus zwraca uwagę, że Cecylia nie ma w zasadzie kontaktu z płcią przeciwną - w grupie uciekinierów brak rówieśników, dziewczynka nie ma ojca; jedynym bliskim jej mężczyzną jest dziadek (którego żona zmarła - mamy zatem kolejną „niepełną rodzinę”). Wedle Marcus trop ten wskazuje na brak możliwości harmonijnego rozwoju Cecylii, która 
swoją baśń, dziecko śpi - nie słyszało więc całej historii matki pomimo tego, że kobieta prosiła: zaczekaj, nie śpij! Możemy zatem przypuszczać, że narracja o II wojnie światowej (być może zbyt trudna dla maleństwa) znużyła je na tyle, że zasnęło. Scena ta w planie metaforycznym sugeruje zatem, że nowe pokolenie Włochów nie jest zainteresowane nie tak odległą przecież przeszłością; uśpione, nie rozumie wagi II wojny światowej. Ostatnia scena filmu ukazuje Cecylię, która nachylając się nad śniącym dzieckiem, zaczyna szeptem powtarzać dziecięcą wyliczankę - „zaklęcie”, które niegdyś ochroniło ją przed śmiercią z rąk faszysty. Głos kobiety nie cichnie po ściemnieniu ekranu. Cecylia powtarza zaklęcie, a film kończy się, urywając wyliczankę w pół zadania. Story is not over - zdają się mówić Taviani. Należy przypominać historię i opowiadać o II wojnie światowej, by nie dopuścić do kolejnej hekatomby.

Można to oczywiście czynić w rozmaity sposób. Oniryczna poetyka przyjęta przez Tavianich, tkanie ekranowej historii z dyskursów należących do różnych porządków (faktu i baśni), wreszcie nadawanie epizodowi z II wojny światowej cech mitologicznego eposu bądź charakteru biblijnego, przez które zostaje podkreślona ważność narracji, zapewnia filmowi Tavianich świeżość spojrzenia. Twórcy niejako uaktualniają pamięć o skomplikowanych losach Włoch w czasie II wojny poprzez wpisanie tego doświadczenia w zupełnie nowe dla tego tematu formy reprezentacji. Zabieg ten ma moc ocalająca, przywołuje bowiem obrazy z przeszłości, które łatwo mogłyby ulec standaryzacji, a tym samym zapomnieniu. Trwałość narracji, jak twierdzi Paul Ricoeur, zależy bowiem od dwóch czynników: innowacji i utrwalenia; to zmienność stosunków między tymi biegunami decyduje o żywotności narracyjnej tradycji ${ }^{36}$.

symbolizuje w filmie nowe pokolenie (problem ten dotyczy także jej potomstwa). Zob. Milicent Marcus, Italian Film in the Light of Neorealism, Princeton 1986, s. 375.

Pierre Sorlin z kolei argumentuje, popierając tezę o niemożliwości prawdziwej „odnowy społecznej" we Włoszech, że jedyną sceną miłości, jakiej jesteśmy świadkiem, to bliskość Galvano i Concetty, a zatem osób w podeszłym wieku, niezdolnych już do posiadania potomstwa. Pierre Sorlin, op. cit., s. 86. Scena ta ma jednak, jak sądzę, przede wszystkim charakter pozytywny - Concetta i Galvano pomimo „społecznych przeszkód”: różnic klasowych, materialnego statusu i mimo wieku, spełniają swoje marzenie. Miłość przezwycięża tu wszelkie bariery. Riccardo Ferucci zwraca uwagę, że „dziwna pogoda" po miłosnej nocy staruszków związana jest z toskańskim przysłowiem: "Quando piove e c'e il sole e i vecchi fanno l'amore” - „Kiedy pada deszcz i świeci słońce, starzy się kochają". Zob. Paolo e Vittorio Taviani: Poetry of the Italian Landscape, s. 17.

${ }^{36}$ Paul Ricoeur, Pamięć, historia, zapomnienie, tłum. Janusz Margański, Kraków 2006. 



\section{Rozdział VII}

\section{Lata 1995-2012: historyczne rewizje}

W latach 90. temat włoskiego ruchu oporu powraca na ekrany, ale nowa władza - na czele z Silvio Berlusconim, który zawiązuje koalicje z partiami postfaszystowskimi (m.in. z Sojuszem Narodowym) - próbuje postponować znaczenie włoskiego ruchu oporu. Symptomatyczna pod tym względem jest choćby wypowiedź Gianfranco Finiego. Polityk ten, rozpoczynający swą działalność w ramach postfaszystowskiego Włoskiego Ruchu Socjalnego (MSI) na początku lat 90. powiedział, że Italia prędzej czy później będzie się wstydzić, iż prezydentem Republiki Włoskiej był Sandro Pertini, „wspólnik tych morderców - partyzantów”"1.

Proces umniejszania roli włoskiego ruchu oporu widoczny był także w telewizji, zmonopolizowanej de facto przez "medialnego magnata" - Berlusconiego. Akcentowanie bratobójczej walki w latach 1943-1945, przy jednoczesnym wyjaśnianiu motywacji obu stron konfliktu (również faszystów), było bardzo wyraźne w trzyodcinkowym, sygnowanym przez Francescę Bozzano, programie Guerra civile (Wojna domowa), wyemitowanym po raz pierwszy na antenie w czerwcu 1999 roku. Dokumentalne wstawki przeplatane są tu wspomnieniami zarówno partyzantów, jak i „chłopców z Salò”. Ci ostatni zostają zdefiniowani jako osoby kierujące się ideatami honoru oraz wierności danemu słowu. Słyszymy m.in.:

Jest tu ten, kto znalazł sie w wojsku i nie ma sity uciec, bo jest szantażowany represjami wobec rodziny, i ten, kto stuży Mussoliniemu z przyzwyczajenia lub powołania. [...] Nie wszyscy sa faszystami. Niektórzy myśla po prostu, że na wojnie nie zmienia się frontu (sic!) ${ }^{2}$.

${ }^{1}$ Wspomina o tym także Giuseppe Ghigi. Zob. Giuseppe Ghigi, La memoria inquieta. Cinema e resistenza, Venezia 2009, s. 244.

${ }^{2}$ Równocześnie powstają jednak filmy dokumentalne reżyserów związanych z lewicą m.in. Mimmo Caloprestiego 1943: wybór (1943: la scelta, 1993) oraz Chleb, pokój, wolność 1943/1945 (Pane, pace, libertà 1943/1945, 1994) na temat udziału robotników w walce z nazistami i faszystami. Inne filmy dokumentalne o resistenzy powstałe w latach 90 . to m.in.: Wspomnienia o resistenzy (Memorie della resistenza, reż. Enrico Cerasuolo, 1993), Kobiety w cieniu 
Pierwsza dekada XXI wieku przyniosła ponowne zainteresowanie II wojną światową. Malena (reż. G. Tornatore, 2000), Rozdarte niebo (Cielo cade, reż. A. Frazzi, 2000), Nieuczciwa konkurencja (Concorrenza Sleale, reż. E. Scola, 2001), Baaria (reż. G. Tornatore, 2009) - to tylko kilka tytułów podejmujących $\mathrm{w}$ rozmaity sposób problem faszyzmu, wojny i ruchu oporu. We współczesnym kinie włoskim temat resistenzy przyjmuje najczęściej formułę indywidualnych doświadczeń bohaterów lub ich osobistych wspomnień, jak np. w Partyzancie Johnnym (Partigiano Johnny, reż. G. Chiesa, 2000) i Czerwonych ziemiach (Terre rosse, reż. D. Della, 2008) ${ }^{3}$. Paradoksalnie przez tę prywatną perspektywę oglądu wydarzeń (czy raczej wglądu w przeszłość), która niejednokrotnie pomija historyczny kontekst, włoska resistenza sytuuje się niejako „poza historią” i zyskuje wartość bardziej uniwersalną.

Przykładem fikcjonalnego filmu, który nie zawiera w swej strukturze materiałów archiwalnych, są Mali mistrzowie (Piccoli maestri, reż. D. Luchetti, 1998). Realizacja Luchettiego, inspirowana jest powieścią - wydanym pośmiertnie dziełem Luigiego Meneghello (włoskiego partyzanta) o tym samym co film tytule. Fabuła opowiada o grupie przyjaciół - studentów, którzy po 8 września 1943 roku decydują się przyłączyć do resistenzy i czynnie działać na rzecz wyzwolenia kraju.

Wojenne losy kolegów z uniwersytetu prezentowane są z przymrużeniem oka $\mathrm{w}$ konwencji filmu przygodowego. $\mathrm{W}$ istocie, roześmiani bohaterowie - którzy w uczelnianych marynarkach jadą w góry, a podczas odpoczynku na polanie żartuja ,przy okazji” snując wojenne plany

(Donne nell'ombra, reż. Marco Melega 1995) oraz Kroniki filmowe partyzantów (Cinecronache partigane, 1996) w reżyserii Daniele Gaglianone. Z okazji jubileuszowych 50. obchodów upamiętniających resistenze w Turynie odbyły się także przeglądy kinowe pod tytułem „Il sole sorge ancora” i „Europa ritrovata” (w dniach 26.10-7.11.1994 i 22.04-8.05.1995) z inicjatywy regionu Piemonte. W przeglądzie czynnie uczestniczyło Archivio Nazionale Cinematografico della Resistenza wraz z jego dyrektorem (i jednym z założycieli) Paolo Gobettim. Ukazała się także publikacja debat i seminariów związanych z przeglądami kinowymi pod tytułem Gli atti delle rassegne e seminari "Il sole sorge ancora" ed "Europa ritrova$t a^{\prime \prime}$, red. Paola Olivetti, Torino 1995.

${ }^{3}$ Film Czerwone ziemie, zrealizowany na podstawie wspomnień włoskiego partyzanta, Flavio Pizzato, jest o tyle interesujący, że zagrali w nim niemal sami amatorzy, a całkowity budżet filmu wyniósł zaledwie 20000 euro. Więcej o sukcesie filmu zob. na stronie www.terrerosse.org/. 
- przypominają raczej niedojrzałych wyrostków o wybujałej wyobraźni niż partyzantów bohatersko walczących o wolność Italii. Przy pierwszym spotkaniu z Niemcami (pojawiają się oni dopiero po 42 minutach czasu ekranowego) młodzieńcy bądź zastygają w niemym przerażeniu (i giną), bądź zaskoczeni uciekają w las niczym spłoszona zwierzyna. $Z$ broni, jaką scenę wcześniej mężczyźni dokładnie oglądaja, niemal żaden z nich nie korzysta (a jeśli nawet to robi, strzały trafiają w powietrze).

Kierowana przez Gigiego (najbardziej zindywidualizowaną postać filmu) dywersyjna działalność studentów, przyjmuje formułę wesołych przygód Robin Hooda. Emblematyczna pod tym względem jest akcja wykradzenia ze spichlerza należącego do Niemców zapasu włoskiego parmezanu (!). Podekscytowani koledzy zostawiają nawet na miejscu swego czynu swoisty "znak Zorro" - karteczkę z podpisem grupy. Ich „heroizm” nie zostaje jednak doceniony przez okoliczną ludność. Ku zdumieniu partyzantów, wieśniacy odmawiają bowiem przyjęcia darów w obawie przed niemieckimi represjami.

Taka prezentacja włoskiego ruchu oporu, tworzonego w dużej mierze - jak wynika z filmu Luchettiego - przez osoby niedojrzałe, traktujące wojnę jako pasmo przygód rodem $\mathrm{z}$ awanturniczej powieści, zaś Niemców i faszystów postrzegające jako ciamajdowatego wroga, któremu łatwo można zrobić psikusa, korespondowała z wyrażanym głośno zamiarem reżysera. Luchetti wielokrotnie bowiem powtarzał: „W Małych mistrzach pragnąłem zaprezentować wizję młodzieńczej niewinności" ${ }^{\prime 4}$ w innym miejscu deklarował natomiast: „Nie chciałbym, żeby mój film definiowano wyłącznie jako film o resistenzy. Myślę o czymś więcej... O filmie o dojrzewaniu, w stylu Tomka Sawyera" ${ }^{5}$.

Opowiedziana zgodnie $\mathrm{z}$ tymi zamierzeniami historia o resistenzy przydaje jej charakteru niezobowiązującej zabawy, działalności nie całkiem na serio lub swoistego spektaklu czy popisu. Dobrą ilustracją tej hipotezy jest sekwencja porwania wiekowego doktora, zdeklarowanego faszysty, oraz przejazd jego - wziętą w posiadanie przez partyzantów - limuzyną przez główny plac miasteczka. Podekscytowani młodzieńcy, czując na sobie spojrzenia wyglądających z balkonów dziewcząt, dumnie się pręża, wymachują bronią i wznoszą (wbrew wcześniejszym przyrzeczeniom) podniosłe okrzyki: Precz z faszyzmem! Niech żyje Italia! ${ }^{6}$. Niestety,

${ }^{4}$ Cyt. za: Giuseppe Ghigi, op. cit., s. 240.

${ }^{5}$ Cyt. za: Gianfranco Casadio, La Guerra al cinema. I film di Guerra nel cinema italiano, t. II, Ravenna 1998, s. 237.

${ }^{6}$ Bohaterowie umawiają się, że ten $\mathrm{z}$ nich, kto będzie nazbyt pompatyczny, musi odbyć karę pięciu dni o chlebie i wodzie. 
zwycięska parada zostaje przerwana przez awarię samochodu. Dzielni partyzanci nie wychodzą jednak z roli i popychając wespół zepsuty pojazd, posyłają wiwatującym na ich cześć kobietom uwodzicielskie uśmiechy (skojarzenie $\mathrm{z}$ teatrem nasuwa $\mathrm{w}$ przywołanej sekwencji organizacja przestrzeni - kobiety stoją bowiem na balkonie niczym w loży, zaś plac, na który patrza, przypomina scenę) $)^{7}$.

Komizm tego epizodu jest tu oczywiście sprawą drugorzędną. Najistotniejsza wydaje się bowiem teatralizacja resistenzy - przedstawienie działalności ruchu oporu jako swoistego występu. W przywołanej sekwencji Włosi nie tyle „są”, co „grają” rolę narodowych bohaterów. Czyżby Luchetti komentował w ten sposób faktyczny przebieg wojennych losów Italii? Za taką hipotezą przemawiać może wyraźnie zaznaczony w filmie wątek konwersji włoskiego społeczeństwa - ze zwolenników Mussoliniego na sprzymierzeńców ruchu oporu. Byłem faszysta, teraz jestem partyzantem - wyznaje Gigi swojemu nauczycielowi należącemu do oddziału. Początkowo wszyscy byliśmy faszystami, a obecnie tworzymy ruch oporu - odpowiada profesor, choć w przemowie do swoich podopiecznych oddziela zwolenników Mussoliniego od „włoskiego społeczeństwa”. Nauczyciel mówi bowiem:

\begin{abstract}
Od dwudziestu lat faszyści nauczyli nas myśleć niewłaściwie. Jesteśmy przyzwyczajeni, by mówić zawsze "tak" [...] teraz, kiedy musimy myśleć samodzielnie, nie potrafimy. Sa faszyści i naziści, którzy okupuja nasz kraj i jesteśmy my... w górach. Musimy stawiać opór: słowami, inteligencja, ale także zbrojnie. Nawet ten, kto nie umie strzelać, musi się nauczyć, dla naszej wolności, wolności naszych dzieci i kraju. [...] Musimy wyzwolić Italię. Jeśli zdołamy sformować prowizoryczny rząd przed pojawieniem się aliantów, wygraliśmy wojne, ponieważ teraz prawdziwa Italia jesteśmy my.
\end{abstract}

Choć partyzanci buńczucznie twierdzą, że będą bezwzględnie zabijać wroga, okazuje się, że w rzeczywistości nie są w stanie nacisnąć cyngla pistoletu. Opory przed wykonaniem wyroków (które za każdym razem poprzedzone są długimi dyskusjami grupy oraz procesem), dobrze unaocznia epizod z Niemcem, wojennym szpiegiem. Decyzja jest zgodna - wróg zostaje skazany na śmierć. Ostatecznie Niemiec zostaje zabity przez wskazanego przez siebie partyzanta. Sama egzekucja nie zostaje jednak pokazana - w jej trakcie towarzyszymy Gigiemu biegnącemu przez pola, jakby uciekającemu od odpowiedzialności lub przytłoczonemu ciężarem wspólnego postanowienia; w momencie wystrzału chłopak zatyka uszy.

${ }^{7}$ Znamienne, że wszyscy świadkowie opisanego zajścia na placu popierają partyzantów. O „ogólnonarodowym” dla nich poparciu świadczy także końcowa, rozbudowana sekwencja radości Włochów po wyzwoleniu. 
Przywołany epizod z bezbronnym Niemcem, który łamiącym się głosem prosi, by „,kat” celował w samo serce, jest wart komentarza także z uwagi na recenzje, jakie pojawiły się po projekcji filmu, pióra krytyków sympatyzujących z prawą stroną areny politycznej. „Wreszcie film, który oddaje nieco sprawiedliwości, ukazując robotę partyzantów jako zwykłe, okrutne zabójstwo" - pisano na łamach prasy ${ }^{8}$. Powoływano się przy tym na obecną w realizacji Luchettiego drastyczną scenę skalpowania faszystów oraz niemieckich jeńców przez komunistyczny oddział partyzantów. W filmie Luchettiego próbowano zatem dopatrzeć się negatywnej oceny resistenzy. Przywołane opinie według mnie mają jednak charakter wyłącznie prowokatorski. Luchetti równoważy bowiem domniemane okrucieństwo partyzantów bestialstwem wroga. Film zawiera m.in. rozbudowaną sekwencję przyglądania się zwłokom poległych partigiani, wśród których bohater rozpoznaje przyjaciół; jest również sekwencja ukazująca ciała partyzantów powieszonych przez Niemców na pokaz - ku przestrodze włoskiej ludności, a także wzruszająca scena pogrzebu dziesięcioletniego bojownika ruchu oporu. Kiedy na czołgach do miasta wjeżdżają alianci, Padwa jest już wyzwolona. Luchetti ostatecznie podtrzymuje zatem bohaterski mit resistenzy, która zjednoczyła naród i przyniosła zwycięstwo.

\section{Z perspektywy czasu}

Fikcjonalnymi filmami podejmującymi temat resistenzy, które nie zawierają w swej strukturze materiałów archiwalnych, są także Nasze lata (Nostri anni, reż. D. Gaglianone, 2000) oraz Krew zwyciężonych (Il sangue dei vinti, reż. M. Soavi, 2008). Sytuują się one jednak w innej kategorii niż dotychczas omówione, ponieważ ruch oporu jest w nich ukazany z perspektywy współczesnej - epizody prezentujące wojenne perypetie włoskich partyzantów pojawiają się na ekranie retrospektywnie, w formule wspomnień bohaterów. W Naszych latach protagonistami są dwaj staruszkowie, Natalino i Alberto, byli partyzanci, którzy - nieco zgorzkniali i rozczarowani powojenną rzeczywistością - żyją przeszłościa, przypominając sobie dawne czasy. O rozwianych złudzeniach mówią wprost:

Po zakończeniu wojny - opowiada Natalino - prawie wszyscy skazani w sadowych procesach jako wojenni zbrodniarze wyszli na wolność. Kaci, kryminaliści... wszyscy! Za to mnie w latach 50. wytoczono proces, ponieważ były faszysta oskarżył mnie, że podczas wojny okradtem go [...]. To nie żart.

${ }^{8}$ Zob. np. Maurizio Cabona, Piccoli maestri, „Il Giornale”, 8.09.1998. Recenzja dostępna na stronie: www.iann.it/film/Critiche.asp?IdFilm=1335 (dostęp: 10.08.2013). 
Przyjęta przez reżysera formuła opowiadania, redukująca narrację o resistenzy wyłącznie do osobistych wspomnień staruszków, zdaje się korespondować z gorzką opinią jednego z mężczyzn, który stwierdza: Duch resistenzy? Dziś ta historia mało kogo interesuje. Nic nie zostało. Pamiatkowe tablice, wyschte wience, piękne mowy... Nikogo to już nie obchodzi. Nie ulega jednak wątpliwości, że sam film (fakt jego powstania) przywraca temat ruchu oporu do sfery publicznej, przypominając, że w przeszłości, jak mówi Gaglianone, „istniały osoby, które potrafiły powiedzieć «nie»" ${ }^{9}$.

Krew zwyciężonych to luźna adaptacja książki Giampaolo Pansy o tym samym tytule, co film ${ }^{10}$. Główny bohater, policjant Franco Dogiliani (Michele Placido) po latach wraca do sprawy zabójstwa włoskiej prostytutki, którą zajmował się pod koniec wojny. Wraz z powtórnie podjętym śledztwem powracają obrazy z przeszłości i rodzinna historia - siostra Lucia, która opowiedziała się po stronie Republiki Salò oraz brat Ettore, walczący w oddziałach komunistycznej partyzantki. Film wzbudził kontrowersje, ponieważ w filmie Soaviego to głównie partyzanci komuniści bezwzględnie mordują „politycznych przeciwników”; akces Lucii do faszystów jest zaś podyktowany śmiercią jej męża z rąk... aliantów (ginie on w trakcie amerykańskich nalotów na Rzym). Alianckie bombardowania są w filmie pokazane jak te niemieckie - wydaje się, że Amerykanie nie tyle „wyzwalają", ale zostaje im przypisana rola okupanta. W porównaniu z bezwzględnymi partyzantami, należąca do faszystów Lucia - która ciągle mówi o „honorze ojczyzny” oraz ratuje z niewoli niemieckiej Żyda - sprawia wrażenie prawdziwie dobrej i ludzkiej. Ten gest nie tylko zjednuje jej (a przez to i czarnym koszulom) sympatię, ale powoduje również, że - jak słusznie zauważa Lichtner - koniec końców to Niemcy okazują się w filmie najgorsi ${ }^{11}$.

${ }^{9}$ Wypowiedź cyt. za: Giuseppe Ghigi, op. cit., s. 258.

${ }^{10}$ Krew zwyciężonych (2003) stała się najbardziej komentowana, a przez to popularną książką o resistenzy ostatnich lat. Jak podaje Cooke, długo znajdowała się w pierwszej dziesiątce najlepiej sprzedających się książek wraz z Harrym Potterem i Kodem Leonarda Da Vinci. Zob. Philip Cooke, The Legacy of the Italian Resistance, New York 2011, s. 179. Kilka lat później, niejako w odpowiedzi na książkę Pansy, ukazała się publikacja historyka Massimo Storchi Krew zwycięzców (Il sangue dei vincitori: Saggio sui Rimini fascisti e i processi del dopoguerra 1945-1946, Reggio Emilia 2008), która ukazywała ogrom przemocy faszystowskiej. Lewakom, którzy wedle Pansy zawłaszczyli pamięć o włoskim ruchu oporu, pisarz poświęcił książki: Wielkie kłamstwo (La grande bugia, Milan 2006) i Żandarmi pamięci (Gendarmi della memoria, Milan 2007), zaś o powojennej przemocy komunistów traktuje jego ostatnie dzieło: Zwyciężeni nie zapominaja (I Vinti non dimenticano, Milan 2010).

${ }^{11}$ Giacomo Lichtner, Fascism in Italian Cinema since 1945, New York 2013, s. 36. Film został odrzucony przez festiwal w Wenecji, ale pokazany na festiwalu w Rzymie (Festa del cinema di Roma), gdzie wzbudził duże emocje. O dyskusjach towarzyszących projekcji 
Wedle Ghigiego, prezentując partyzantów jako okrutnych zbrodniarzy - komunistów, których głównym celem jest wcielenie w życie rewolucyjnych idei, a nie oswobodzenie Włoch z niemieckiej okupacji - film odzwierciedla politykę historyczną współczesnej Italii postponującą resistenzę. Atakowany za deprecjonowanie włoskiego ruchu oporu reżyser deklarował: „umieszczając w centrum filmu ludzkie wartości, chcę nim pogodzić zwaśnione strony” i dodawał: „wiem, o czym opowiadam - moja matka była żydówka, a mój ojciec dołączył do Salò" ${ }^{\prime 2}$. W koncyliacyjnym tonie wypowiadał się również producent filmu Aleksandro Fracassi - „zależało nam, by nie otwierać starych ran, ale by pójść krok dalej" ${ }^{13}$. W filmie pada zdanie, że wszyscy (Włosi) sa przegrani. Oglądając Krew zwyciężonych trudno jednak nie odnieść wrażenia, że choć i chłopcy z Salò, i partyzanci (którzy w filmie są wyłącznie komunistami) zbłądzili w wojennym szaleństwie, to ci ostatni zawinili ciężej.

\section{Materiały archiwalne}

Przykładem fikcjonalnego filmu, którego akcja rozgrywa się wyłącznie w przeszłości w stosunku do czasu jego powstania, ale który zawiera w swej strukturze dokumentalny footage, jest Partyzant Johnny (Partigiano Johnny, reż. G. Chiesa, 2000) ${ }^{14}$. Historia tytułowego bohatera zafascynowanego literaturą angielską, który po 8 września 1943 roku ucieka z wojska, wraca do domu do rodzinnej Alby, a następnie przyłącza się do włoskiego ruchu oporu, jest adaptacją powieści Beppe Fenoglia o tym samym tytule, co film ${ }^{15}$.

świadczy choćby recenzja - Claudia Morgoglione, Tutti gli orrori dei partigiani nel film più discusso del Festiwal, „La Repubblica”, 26.10.2008.

12 Giuseppe Ghigi, op. cit., s. 300.

${ }^{13}$ Il sangue dei vinti: pressbook, red. Alessandro Fracassi, 2008. Pressbook dostępny pod adresem: www.fctp.it/media//pdf/ilsanguedei\%20vinti.pdf (dostęp: 10.08.2012).

${ }^{14}$ Archiwalne materiały stanowią w filmie swoisty prolog - ukazują lądowanie aliantów na Sycylii, spotkanie Mussoliniego z Hitlerem oraz niemieckie wojsko. Guido Chiesa - autor omawianego wcześniej filmu Sprawa Martello - w latach 80. wyjechał do USA; pracował m.in. z Jimem Jarmuschem i Nicolasem Roegiem.

${ }^{15}$ Dla Chiesy Partyzant Johnny był projektem wyczekiwanym. Reżyser pierwszy raz przeczytał powieść Fenoglia, będąc jeszcze studentem i napisał - ostatecznie nieprzeniesiony na ekran - scenariusz La guerra di Johnny (Wojna Johnny'ego, inspirowany także debiutem literackim pisarza: opowiadaniami Dwadzieścia trzy dni miasta Alby [1952]). Kiedy Chiesa zaprezentował w latach 80. swój scenariusz Instytutowi Luce, usłyszał jakoby: „Mamy po dziurki w nosie tych partyzantów" (wypowiedź reżysera umieszczona w: Memoria, mito, storia. La parola ai registi, 37 interviste, red. Alessandro Amaducci, Torino 1994, s. 57). 
Stosunek filmu do literackiego oryginału jest bardzo złożony. Dość powiedzieć, że wydana po śmierci Fenoglia (w 1968 roku) powieść nie została przez pisarza ukończona; istniało także kilka jej wersji. Nie zamierzam w tym miejscu podejmować wątku adaptacji, który zasługiwałby na obszerne, osobne omówienie. Nie sposób nie poświęcić jednak powieści oraz jej autorowi, który jest ceniony we Włoszech, ale pozostaje mało znany w Polsce, choćby kilku słów - całkowite pominięcie literackiego kontekstu byłoby bowiem w przypadku Partyzanta Johnny'ego znaczącym uchybieniem.

Publikacja Partyzanta Johnny'ego stała się wydarzeniem literackim, sam zaś utwór okrzyknięty został „współczesną Odyseja” i zyskał status jednej z ulubionych lektur pokolenia '68. Pisarz zaskakiwał nie tylko nowatorskim stylem - lapidarnym, pozbawionym patosu, wykorzystującym neologizmy oraz anglicyzmy - ale także ujęciem tematu partyzanckiej walki. Przyjęty przez Fenoglia punkt widzenia daleki był bowiem od obowiązującej po wojnie heroizacji. W Partyzancie Johnnym uderza uparte powracanie do wątku przemocy jako stałego elementu wszelkich relacji międzyludzkich oraz wszechobecność śmierci - pozbawionej godności, przypadkowej i banalnej. O tym, że głosy polemiczne wobec powieści nie cichną do dziś, świadczy najlepiej opublikowana na łamach „La Stampy” w 2007 roku wypowiedź Giorgio Bocca (dziennikarza, pisarza oraz partyzanta): „Fenoglio nic nie zrozumiał z ruchu oporu [...]. Jego resistenza jest fałszywa. To teatr zbrodni, biedaków i drani"16. Opinia ta doczekała się szybkiej riposty - na łamach "Corriere della Sera" Lorenzo Mondo, uznany badacz twórczości Fenoglia, napisał:

Tylko mordercy, dranie i biedacy? Czy Bocca nie dostrzega, że u Fenoglia są także figury o wysokim morale, tacy jak Johnny? [...] Fenoglio dokonał cudu, pisząc epopeję $\mathrm{z}$ literackim talentem, który przekracza utarte schematy narracyjne ${ }^{17}$.

W 1998 roku Chiesa zrealizował dokument telewizyjny o życiu Fenoglia: Una questione privata. Vita di Beppe Fenoglio. Wreszcie dwa lata później przeniósł na ekran Partyzanta Johnny'ego, powieść - wedle słów reżysera - będącą fascynującą odyseją z której chciał wydobyć "prywatną sprawę" bohatera: jego codzienny wysiłek stawania się człowiekiem w tragicznej sytuacji wojny i upadku faszyzmu. Cyt. w: Tra emozione e ragione. Il cinema di Guido Chiesa, red. Domenico De Gaetano, Torino 2000, s. 121. W wypowiedzi reżysera zawarta jest gra słów. Pewna prywatna sprawa to bowiem inna powieść Fenoglia (jedyna tłumaczona na język polski), która doczekała się kilku ekranizacji. Była przenoszona na ekran m.in. przez Giorgio Trentina (1966), Alessandro Cane (1982) i Alberto Negrina (1991). Polski przekład powieści, autorstwa K. i E. Kabatców, pochodzi z 1979 roku.

${ }^{16}$ Giorgio Bocca, Com'ê falsa la resistenza di Fenoglio, "La Stampa”, 31.03.2007.

17 Zob. artykuł Fenoglio un partigiano sotto accusa, "Corriere della Sera", 1.04.2007. 
Pozwoliłam sobie na tak dokładne zrelacjonowanie reperkusji, jakie spowodowała publikacja Partyzanta Johnny'ego po to, aby uzmysłowić, jak dużym wyzwaniem było reżyserskie przedsięwzięcie Chiesy. O wysokiej pozycji dzieła Fenoglia we włoskiej kulturze świadczą najlepiej słowa Marii Corti (innej uznanej badaczki Fenoglia), która na łamach „Espresso” ostrzegała:

Jestem bardzo zadowolona, że ma powstać film Partyzant Johnny, ale pod jednym warunkiem - że tak jak powieść będzie to dzieło epickie [...]. Trzeba potrafić nadać mu ton nie neorealistyczny, właściwy wielu filmom o II wojnie światowej, ale raczej Wojny i pokoju. Reżyser musi zdawać sobie sprawę, że stawić czoła Partyzantowi Johnny'emu to tak jakby mieć do czynienia z Iliadą ${ }^{18}$.

Chiesa wydobywa z powieści refleksję natury egzystencjalnej- poczucie nicości, pustki i samotności tytułowego protagonisty, która nie zwalnia go jednak od moralnych wyborów oraz poświęcenia. To Johnny pozostaje w centrum uwagi kamery - kadrowany jest zazwyczaj sam, gdy czyta książkę lub w zadumie pali papierosa, patrząc na otaczający go krajobraz. Wydarzenia ukazane $\mathrm{w}$ filmie przefiltrowane są niejako przez psychikę mężczyzny - z perspektywy Johnny'ego oglądamy wojenne starcia z wrogiem, wraz z nim uczestniczymy w potyczkach oraz zasadzkach i wymykamy się obławom. Występujące $\mathrm{w}$ filmie częste ujęcia subiektywne, z POV bohatera, ale i te kręcone kamerą z ręki, wreszcie wykorzystanie głosu ponadkadrowego (voice-over), dzięki któremu poznajemy myśli bohatera - wszystkie te zabiegi podkreślają subiektywny, introspekcyjny charakter przedstawionej rzeczywistości.

Co istotne, w filmie Chiesy akcentowana jest nie tyle bohaterska walka głównego bohatera, ile tragizm i absurd wojny. Motyw śmierci obecny jest już od początku filmu - w jednej z pierwszych sekwencji widzimy młodego więźnia, który idąc w szeregu innych, decyduje się na ucieczkę. Pada strzał; bezimienny chłopak zostaje zabity. Jego ciało leży na ulicy, pozostawione jak wyrzucony od niechcenia śmieć. Kamera zatrzymuje się przez chwilę na miejscu zbrodni, aby pokazać, że życie toczy się dalej, tak jakby nic nie zaszło. Wojenne sceny utrzymane są w zimnej tonacji - niektóre krajobrazy wydają się wręcz pozbawione kolorów, co dodatkowo wzmacnia wrażenie nienaturalności walki, ale i wyalienowanie samego bohatera ${ }^{19}$.

18 Zob. Maria Corti, Partigiano Johnny, „L' Espresso”, 23.05.1999.

19 Trudno oprzeć się przy tym wrażeniu, że Chiesa inspirował się nieco Cienka czerwona linia (reż. T. Malick, 1998) w reprezentacji zbrojnego konfliktu. Podobnie jak w dziele 
W Partyzancie Johnnym wyraźnie zostaje zaznaczony podział partyzanckich frakcji. Protagonista początkowo dołącza do komunistycznego oddziału, a następnie do tzw. azzurri (błękitnych): ugrupowania zrzeszającego osoby o niekomunistycznych poglądach (oddziały są w filmie łatwo rozpoznawalne po kolorach chustek noszonych na szyi). Bohater nie może sobie jednak znaleźć miejsca ani u jednych, ani u drugich. U „czerwonych", którzy traktują wykształconego studenta z rezerwą, razi go nieustanne akcentowanie polityki, u „niebieskich” zaś zniechęca go sztywna hierarchia oddziału (przypomina on strukturę znienawidzonego wojska) i konieczność jej przestrzegania. Mimo tych różnic film zawiera jednak sugestię jedności narodu - przed walką o Albę kamera ukazuje z ptasiej perspektywy ulicę, po której płynie niebiesko-czerwony nurt ruchu oporu, szykującego się do ostatecznego szturmu.

Podobnie jak w Małych mistrzach, u Chiesy podkreślona jest infantylność oraz niefrasobliwość młodych partyzantów. Gdy bohater podejmuje decyzję, by „pójść w góry” z innymi i żegna się z kierującymi $\mathrm{w}$ miasteczku ruchem oporu akademickimi nauczycielami, koledzy Johnny'ego buńczucznie deklaruja że będą bezlitośnie zabijać wroga. Jeden z profesorów pyta wtedy, czy będą równie zdecydowani, gdy uświadomią sobie, że za jednego zabitego Niemca straci życie 10 niewinnych cywilów. Pyta także, co zrobia, gdy ich rodzice okażą się uwikłani w faszystowski system, czy też zabiją ich bez mrugnięcia okiem? Bagatelizując ten dylemat, młodzieńcy ripostuja, że takie przypadki to ekstremalne sytuacje. Wtedy nauczyciel stwierdza: wojna to wyłacznie ekstremalne sytuacje.

Wojna partyzancka stanowi więc w filmie Chiesy, podobnie jak w powieści Fenoglia, moment prawdy, ujawnienia się dramatyzmu ludzkiego losu oraz starcia moralnych racji. Ekranowy partyzant Johnny pozostaje wierny swoim przekonaniom nawet za cenę całkowitego osamotnienia. $\mathrm{W}$ tej nonkonformistycznej postawie protagonisty reżyser upatrywał współczesny „morał” filmu:

\footnotetext{
Malicka, okrutny świat wojny zostaje bowiem w Partyzancie Johnnym zestawiony - na zasadzie krzyczącego kontrastu - z obrazem, waloryzowanej dodatnio, harmonijnej natury, która jawi się jako swoisty eden, „,raj utracony”. Dobrą ilustracją tej hipotezy jest sekwencja prezentująca nagiego bohatera, który z dala od wojennej walki z radością kąpie się w rzece, a następnie, siedząc na gałęzi niczym Tarzan, długo przygląda się swoim dłoniom. Skojarzenia z dziełem Malicka nasuwają także obrazy przyrody, rozsądzające niejako historię militarnej, dziejowej misji Włocha. I tak, w wirze wojennej pożogi Johnny przygląda się m.in. ślimakowi, który z trudem pnie się po źdźble trawy.
} 
Dziś myślę, że przykłady indywidualne, rozumiane jako wybór sposobu życia, który zależy od człowieka, a nie od Boga, są istotne. Johnny, ze wszystkimi swoimi ograniczeniami daje przykład: jego osobisty wybór [...] w tym konkretnym momencie wydaje mi się bardzo ważny. W propagowaniu tej postawy widzę aktualność filmu - deklarował w jednym z wywiadów ${ }^{20}$.

Film nominowany do Złotego Lwa na festiwalu w Wenecji w 2000 roku, przez krytykę został uznany jako „odważny i ważny, pomimo narracyjnych ułomności i stylistycznych uchybień"21.

\section{Rekonstrukcje}

Oddzielną grupę filmów stanowią te, które fabularyzują faktyczne wydarzenia. Przykładem takiego utworu, niezawierającego w swej strukturze materiałów archiwalnych, jest Porzus (reż. Renzo Martinelli, 199722. Film rekonstruuje tragiczne wydarzenia z lutego 1945, kiedy to partyzancka formacja Osoppo, pod dowództwem Francesco De Gregoriego (pseudonim Bolla) ${ }^{23}$, zrzeszająca - jak informuje napis na początku filmu - „wszystkie niekomunistyczne siły” włoskiego ruchu oporu, została zmasakrowana przez komunistyczny oddział resistenzy (pod dowództwem Mario Toffanina). Brygada Osoppo odmówiła bowiem poddania się rozkazom komunistycznej partyzantki walczącej w regionie Friuli w porozumieniu z IX korpusem Jugosłowiańskiej Ludowej Armii Wyzwolenia Josipa Tity. W wyniku tej bratobójczej rzezi zginęło siedemnastu Włochów, w tym młodszy brat Pier Paolo Pasoliniego - Guido, który w listach tak opisywał atmosferę dni przed masakrą:

Włoski oficer polityczny Vanni zażądał od naszego dowódcy, by na rozkaz marszałka Tity nasza brygada opuściła ten teren, bo jest ona strefą słoweńskich wpływów. [...] Byłbym zapomniał: oficerowie garibaldczyków mówią że Friuli będzie republiką sowiecką i przyczółkiem, z którego ruszy bolszewizacja całej Italiii ${ }^{24}$.

${ }^{20}$ Wypowiedź cyt. w: Tra emozione e ragione. Il cinema di Guido Chiesa, s. 40.

${ }^{21}$ Zob. Roberto Nepoti, Partigiano Johnny, „La Reppublica”, 18.11.2000.

${ }^{22} \mathrm{~W}$ tym samym roku co film ukazała się publikacja o tym wydarzeniu: Sergio Gervasutti, Il giorno nero di Porzus, Venice 1997. Warto może wspomnieć, iż tenże Renzo Martnelli zrealizował w 2012 roku film Bitwa pod Wiedniem.

${ }^{23}$ Brygady Osoppo, do których trafił osiemnastoletni Guido Pasolini, zawiązały się z inicjatywy katolickich duchownych i świeckich w Udine w grudniu 1943. Nazwa „Osoppo" pochodzi od miejscowości, której mieszkańcy podczas powstania w 1848 roku stawiali czoła austro-węgierskiej armii marszałka Radetzky'ego.

${ }^{24}$ Cyt. za: Lettere di condannati a morte della Resistenza italiana, red. Piero Malvezzi, Giovanni Pirelli, Torino 1952, s. 221. O tym, że tragedia Porzus była wykorzystywana do 
Do dziś nie wiadomo do końca, kto wydał rozkaz rzezi. W dokumentach brygady Osoppo istnieje notatka ze spotkania 1 stycznia 1945 roku między komendantem II Brygady Osoppo Romano Zofio a oficerem politycznym słoweńskiego batalionu Rezianska, który miał wyjaśnić:

wasza obecność na tym terytorium przeszkadza naszej propagandzie. Nie wykluczamy, że pewnego dnia otrzymamy rozkaz rozbrojenia was. Z pewnością Brytyjczycy nie pomogą wam. Wielka Brytania będzie jutro naszym wrogiem ${ }^{25}$.

Można się jedynie domyślać, że z praktycznych względów morderczą misję w Porzus powierzono włoskim towarzyszom. Faktem jest, że w terenie włoscy komuniści oskarżali brygady Osoppo o zdradę, czyli współpracę z Niemcami i faszystami Republiki Salò ${ }^{26}$.

Film Martinellego rekonstruuje te napięcia dość skrupulatnie. Pokazuje kolejne etapy bratobójczej masakry - aresztowanie zastraszonych partyzantów, farsę sądu ludowego i systematyczne wyroki śmierci wykonywane w pobliskim lesie ( $w$ istocie cała tragedia rozegrała się między 8 a 18 lutego 1945 roku) oraz desperacką ucieczkę kapitana, jedynego z brygady Osoppo, któremu pomimo odniesionych ran udało się uratować. Cały epizod przedstawiony jest w formule wspomnień: ocalonego Storno oraz żyjącego w Słowenii, wiekowego przywódcy komunistów,

politycznych przepychanek także w przeszłości świadczy m.in. epizod z 1961 roku, kiedy w liście wysłanym do „Vie Nuove” czytelnik prosił Pier Paolo Pasoliniego, by wyraził swoje zdanie na temat plakatu neofaszystowskiej partii MSI (Włoskiego Ruchu Socjalnego), nawiązującego do śmierci Guido Pasoliniego, zabitego przez partyzantów Geko. Wypowiedź twórcy Mammy Romy, należącego wtedy do włoskiej partii komunistycznej, stanowi nie tyle odpowiedź na postawiony problem, ile swoiste wyznanie (w którym, co znamienne, nie ma złego słowa o PCI): „Guido umarł [...] choć mógł uratować się tamtego dnia; umarł, ponieważ biegł na pomoc swojemu komendantowi i towarzyszom. Wierzę, że nie ma żadnego komunisty, który mógłby potępić postępowanie partyzanta Guido Pasoliniego. Jestem z niego dumny i wspomnienie o nim, o jego pasji, obliguje mnie, by podążać droga, jaką podążam. [...] Śmierć Guida w takich okolicznościach [...] utwierdza mnie jedynie w przekonaniu, że nic nie jest proste, nic nie zdarza się bez komplikacji i cierpienia. [...] Tym, co się liczy przede wszystkim, jest jasność krytyki niszczącej konwencje i docierającej do sedna spraw, do środka ich sekretnej i nieredukowalnej prawdy". Pier Paolo Pasolini, In risposta, „Vie Nuove” 1961, nr 28. Przedruk w Giuseppe Ghigi, op. cit., s. 232. List Pasoliniego został także przedrukowany po premierze filmu w "Corriere della Sera", 8.08.1997.

${ }^{25} \mathrm{Na}$ temat tragedii Porzus zob. ciekawy artykuł Piotra Kowalczuka Z krwia rodaków na rękach, „Uważam Rze. Historia”, 13.06.2012.

${ }^{26}$ Zarzuty o kolaborację uwiarygodnić miała intryga z niejaką Eldą Turchetti. W 1944 roku została ona oskarżona o szpiegostwo na rzecz Niemców, a w trakcie masakry przebywała z partyzantami Osoppo. 
Geko, którego Strono po latach odnajduje, by wymierzyć na własną rękę sprawiedliwośćc ${ }^{27}$.

Porzus stał się wydarzeniem politycznym. Środowiska lewicowe, które nie chciały plamić mitu włoskiego ruchu oporu bratobójczą rzezia, oskarżyły reżysera o rewizjonizm, a nawet faszystowskie sympatie i oprotestowały pokaz filmu na festiwalu w Wenecji (ostatecznie film został pokazany poza konkursem). Dla prawicy Porzus był oczywiście tematem bardzo ważnym, wykorzystywanym w debatach o zbrodniach komunizmu i potwierdzającym „brudną twarz resistenzy” (znany rysownik, Giorgio Forattini w swojej rubryce Mascalzonate w czasopiśmie „Panorama” stworzył na tę okazję obrazek, na którym resistenza jest pokazana jako śmierć z sierpem i młotem).

Martinelli na zarzuty krytyki odpowiadał: „Nie opowiedziałem prawdy o Porzusie. Tak, przeprowadziłem kwerendę: przeczytałem mnóstwo dokumentów, rozmawiałem ze świadkami. Ale jestem reżyserem - nie muszę opowiadać prawdy. To inni są zobowiązani, by udowadniać i wyjaśniać. Moim zadaniem jest opowiadanie w zajmujący sposób historii”. Reżyser deklarował przy tym: „,nie chciałbym, aby film stał się pretekstem do walki dla tych, którzy pragną zdyskredytować resistenzę, z tymi, którzy zamierzają jej bronić za wszelką cenę"28.

Niezależnie od tych wypowiedzi sam film rzeczywiście może wydać się dyskusyjny. Martinelli szkicuje w nim bowiem manichejski świat: dobrych (bez wyjątku) partyzantów Osoppo i złych komunistów - zwolenników Tity. Głównymi reprezentantami tej dychotomii są Storno oraz Geko. Pierwszy potępia przemoc i dąży do dialogu, odmawiając jednak sojuszu z brygadą Tity, drugi zaś to opętany chęcią zemsty fanatyk, który jest gotowy poświęcić ludzkie życia dla sprawy rewolucji (kto jest przeciwko komunizmowi, ten jest przeciw nam - powtarza, po latach zaś tak przedstawia bilans tragedii: gdybym mógł cofnać czas, zrobiłbym to samo ${ }^{29}$ ). Mamy więc

${ }^{27}$ W filmie Martinellego zostały zmienione imiona i nazwiska protagonistów. Mario Toffanin to w filmie Carlo Tofani - "Geko", zaś "Storno" wzorowany jest na postaci Aldo Bricco. Wypada przy okazji przypomnieć, że wydarzenia przedstawione w Porzus zostały pierwszy raz ukazane w krótkometrażowym, amatorskim filmie I due volti (1983) zrealizowanym przez amatora Enrico Mengotti; nakręcił on także dokument Porzus: due volti della resistenza na podstawie świadectw i wspomnień partyzantów, którzy brali udział w całym wydarzeniu.

${ }^{28}$ Wywiad z reżyserem: Porzus? Non cerco la verità: il regista non è un giudice, "La Repubblica", 25.08.1997.

${ }^{29}$ Jedynym wyłamującym się z szablonu "złych” komunistów jest jeden z towarzyszy Geko, który mówi: ja was nie rozumiem! jestem komunista, ale nie myśle jak Ty; nie chce twojego komunizmu.

Przy okazji warto wspomnieć, że w 2005 roku telewizja RAI wyprodukowała dwuodcinkowy film Serce w studni (Il cuore nel pozzo, reż. Alberto Negrin), by upamiętnić włoskie 
resistenzę dobrą i złą. Uogólnienie to w realizacji Martinellego nie dotyczy jednak (i tu kryje się poważna słabość filmu) wyłącznie tragedii Porzus (w tym konkretnym przypadku taki obraz jest bowiem uzasadniony), ale rozszerza się na walkę partyzancką tout court, co łatwo uznać za nadużycie.

W Porzus na pierwszym planie pozostaje zatem problem bratobójczej walki wewnątrz resistenzy: prowadzimy podwójna wojnę: przeciw Niemcom i faszystom oraz przeciw komunistom, takim jak Geko - mówi jeden z partyzantów Osoppo. Sportretowani dość sztampowo Niemcy (kojarzeni z maszynami, kadrowani w zimnej tonacji barw) stanowią jednak wyłącznie tło: pojawiają się zaledwie kilkakrotnie - najdłużej podczas przeprowadzania „pokazowej” egzekucji.

Porzus, zrealizowany przy wsparciu Departamentu Sztuk Widowiskowych Ministerstwa Dziedzictwa Kulturowego, budził także inne zastrzeżenia. Krytykowano również osobliwy styl filmu. Tullio Kezich na łamach „Corriere della Sera” pisał:

Zachłyśnięty stylem reklam Martinelli naszpikował film efektami specjalnymi w złym guście - fajerwerkami, fleszami, zoomami i osobliwą ścieżką dźwiękową. Wenecja właśnie skończyła celebrowanie twórczości Rosselliniego, to zaś jest anty-Rossellini: wyobrażacie sobie Paisę w akompaniamencie trio Schuberta? ${ }^{30}$.

Nagromadzenie efektów specjalnych utrudnia podążanie za skomplikowaną intrygą; niektóre z nich, np. morphing, pochodzą z estetyki reklam telewizyjnych. Krytyka utyskiwała także na nadmiar muzyki ilustracyjnej oraz nadużywanie w filmie zwolnionego tempa ruchu ${ }^{31}$. Zwracano również uwagę na nadekspresyjną grę wiekowych protagonistów (Gabriele Ferzetti i Gastone Moschin), wychwytując przy okazji detale, które mogą umknąć polskiemu widzowi, nieznającemu niuansów języka włoskiego ${ }^{32}$.

ofiary w Jugosławii. Więcej o tej politycznej produkcji zob. Giacomo Lichtner, op. cit., s. 35. Sam reżyser Alberto Negrin nakręcił wcześniej dla RAI film Perlasca - włoski bohater (Perlasca: un eroe italiano, 2002). Tytułowym protagonistą był tu, jak zauważa Lichtner - „idealny bohater Włoch Berlusconiego": konserwatysta z klasy średniej, po wojnie blisko związany z neofaszystowskim Włoskim Ruchem Socjalnym, a w jej czasie faszystowski weteran walk w Etiopii i Hiszpanii, ale zarazem człowiek o dobrym sercu (Perlasca ratuje m.in. Żydów).

30 Tullio Kezich, Porzus, „Corriere della Sera”, 19.03.1997.

${ }^{31}$ Irene Bignardi, Porzus, „La Repubblica”, 1.09.1997.

32 Podkreślano na przykład, że Moschin w roli starego Geka wielokrotnie wykrzykuje: Ma va in mona, by przypomnieć, że dowódca komunistycznego oddziału pochodził z Padwy, choć owo wykrzyknienie używane jest w całym regionie Veneto; tymczasem młody Geko (Lorenzo Crespi) mówi z akcentem południowym. Te detale, jak podaje Ghigi, utrudniały ponoć włoskiej publiczności identyfikację postaci (za młodu i tej współczesnej). Giuseppe Ghigi, op. cit., s. 228. 
Autentyczne losy sprawców masakry mogłyby stać się kanwą odrębnego filmu. Rodziny ofiar już pod koniec czerwca 1945 roku oskarżyły garibaldczyków o zbrodnię. Proces rozpoczął jednak się dopiero w 1950 roku, kiedy główni sprawcy, dzięki pomocy towarzyszy, już przebywali za granicą ${ }^{33}$. Włoski sąd $\mathrm{w}$ trzech instancjach skazał zaocznie Toffanina i jego dwóch zastępców na dożywocie. Inni towarzysze, choć także skazani, dzięki nakładającym się na siebie amnestiom, często nie spędzili za kratkami ani jednego dnia.

Innym filmem opartym na faktach jest Salvo D'Acquisto (reż. A. Sironi, $2003)^{34}$. Tytułowym bohaterem jest włoski karabinier, który po powrocie z Libii i ukończeniu szkoły oficerskiej został przydzielony do komisariatu policji w miasteczku Torrimpietra. 22 września 1943 roku podczas przeszukiwania porzuconych koszar dwóch niemieckich żołnierzy zginęło na skutek wybuchu granatu, a dwóch innych zostało rannych. Dowódca niemieckiej dywizji za ten „zamach" (który najprawdopodobniej był nieszczęśliwym wypadkiem, a nie zaplanowaną akcja; taka sugestia pojawia się również w filmie) obwinił mieszkańców miasteczka i zwrócił się do lokalnej policji (w tym Salvo) o pomoc w znalezieniu sprawców. Ponieważ akcja szukania winnych nie przyniosła rezultatów, następnego dnia niemieccy żołnierze aresztowali 22 losowo wybrane osoby (zgodnie z „przelicznikiem” - 10 Włochów za jednego Niemca). Widząc co się święci, Salvo D’Acquisto, wedle świadków (którzy dzięki niemu przeżyli) w ostatniej chwili przed egzekucją wziął na siebie odpowiedzialność za zorganizowanie domniemanego zamachu na Niemców. Rozstrzelany w wieku zaledwie 22 lat został pośmiertnie odznaczony Medalem Waleczności Wojskowej za odwagę, a w 2007 roku otrzymał status „sługi bożego”. Film został dobrze przyjęty przez krytykę i cieszył się popularnością wśród widzów ${ }^{35}$.

${ }^{33}$ Toffanin schronił się najpierw w Jugosławii, gdzie otrzymał najwyższe odznaczenia państwowe, a w 1949 roku wyjechał do Czechosłowacji. Ostatecznie wrócił do słoweńskiej Sesany, gdzie zmarł w 1999 roku. Toffanin wielokrotnie udzielał wywiadów we włoskiej prasie, w których podawał sprzeczne ze sobą wersje wydarzeń. Raz twierdził, że wykonywał rozkazy, innym razem chełpił się, że cała akcja była jego prywatną inicjatywą.

34 Pierwotnie film był dwuodcinkową miniserią telewizyjną wyświetloną pierwszy raz w 2003 roku. Później realizację przekształcono w jedną spójną całość. Dla porządku należy przypomnieć, że pierwszym filmem o losach Salvo D'Acqusto nakręcono w 1974 roku (Salvo D'Acquisto, reż. Romolo Guerrieri).

${ }^{35}$ Giuseppe Ghigi, op. cit., s. 232. 
Fabuła, którą można zaliczyć do kategorii fabularyzacji autentycznych wydarzeń, jest także Dzika krew (Sangue pazzo, reż. M. Giordana, 2008) ${ }^{36}$. Realizacja Giordany prezentuje losy Oswalda Valentiego i Luisy Feridy, gwiazd ekranowych z czasów kina faszystowskiego, które występowały w filmach zrealizowanych w Republice Socjalnej Salò, a w ostatnich dniach wojny zginęły z rąk partyzantów. Osią fabuły pozostaje burzliwy romans aktorów; wątek włoskiego ruchu oporu jest w filmie drugoplanowy, choć istotny oraz stale obecny - historię miłosnej relacji oglądamy bowiem we wspomnieniach Lucii i Oswalda, którzy złapani i aresztowani przez partyzantów podróżują z nimi na specjalnie zorganizowany „proces".

Przedstawiciele ruchu oporu są w filmie Giordany przedstawieni dwuznacznie. Wprawdzie wspierający faszystowską dyktaturę swym talentem i urokiem aktorzy mają być „sprawiedliwie sądzeni”, ale obiecana rozprawa to wynik starań znajomego Luisy z lat 30. (obecnie partyzanta) - bez niego artyści zostaliby rozstrzelani „od ręki” ${ }^{37}$; sam proces okazuje się zaś kolejnym spektaklem, w którym finał (w postaci wyroku) jest znany od początku. Na napastliwe pytania partyzanta: czy Valenti był faszysta czy nie?, świadek oskarżenia odpowiada: nie byt faszysta; to Sandokan; Pirat $z$ Malezji. Zastraszony przez przesłuchującego mężczyzna pyta wreszcie Valentiego: co mam powiedzieć? Mów im, co chca styszeć - odpowiada aktor.

Finał filmu, w którym para filmowych gwiazd zostaje przez partyzantów zabita strzałem w plecy pod osłoną mroku, wzmacnia wrażenie, że Valenti i Luisa są w gruncie rzeczy niewinnymi ofiarami, zaś partigiani występują w roli bezwzględnych katów (ich okrucieństwo podkreśla fakt, że Luisa jest $w$ zaawansowanej ciąży). I choć film zawiera sceny ukazujące znajomości aktorów z osobistościami reżimu (Lucia i Osvaldo bawią m.in. u Pietro Kocha - znanego z okrucieństwa dowódcy tajnej policji, o którym była już mowa), wina zdaje się być „poza nimi”. Pobyt podyktowany jest bowiem nałogiem - Valenti i Lucia są kokainistami. Lucia pada przy tym ofiarą perwersji Kocha, który każe jej kochać się w erotycznym trójkącie - ze swoją przyjaciółka, która stylizuje się na aktorkę.

Film zawiera archiwalne zdjęcia: w kinie bohaterowie oglądają propagandowe kroniki Mussoliniego, gdzie Duce jest prezentowany jako mąż

36 Tadeusz Miczka w swej książce dość zaskakująco tłumaczy tytuł filmu jako Rozwodniona krew. Zob. Tadeusz Miczka, Kino włoskie, Gdańsk 2009, s. 631. Jest to o tyle zaskakujące, że w Polsce film wydano na DVD pod tytułem Dzika krew.

${ }_{37}$ W partyzancie, przyjacielu Lucii (postaci fikcyjnej), który jest także reżyserem-arystokratą i homoseksualistą, dopatrywano się aluzji do Luchina Viscontiego. 
opatrznościowy Włoch, choć za kulisami jeden z faszystowskich notabli mówi, że Mussolini to zakładnik Hitlera. Wątek kina, za sprawą profesji bohaterów, jest w Dzikiej krwi stale obecny. Jesteśmy na przykład świadkami przemowy faszystowskiego dygnitarza, który stwierdza, że Cinecittà odrodzi się nad zatoka bez Rosselliniego. Dzika krew jest więc także refleksją nad rolą artysty (i kina) w służbie politycznego reżimu (w tym sensie film Giordany przypomina nieco Mefista [reż. István Szabó, 1981]). Jesteś artysta, co z nimi robisz - wykrzykuje do Valentiego jedna z więźniarek $\mathrm{w}$ piwnicy tortur, która znajduje się w siedzibie Kocha. To ty jesteś bohaterem - mówi kolega-faszysta, gdy Valenti rozdaje ludziom autografy. Ostatnimi rolami Lucii i Oswalda okazuje się zatem gra w sztuce chylącej się ku upadkowi ideologii.

\section{Człowiek, który nadejdzie: historia, która powraca}

Wielokrotnie nagradzany film Giorgio Dirittiego, Człowiek, który nadejdzie (L'uomo, che verrà, 2009), stanowi swoiste świadectwo „nieprzemijalności" tematu resistenzy w kinie włoskim ${ }^{38}$. Film traktuje o jednej z największych wojennych rzezi przeprowadzonych na terenie Włoch przez Niemców (tzw. strage di Marzabotto). Między 29 września a 5 października 1944 roku oddziały 16. Dywizji Grenadierów Pancernych SS pod dowództwem Waltera Redera wymordowały ludność gminy Marzabotto oraz okolic masywu Monte Sole (części apenińskich wzgórz należących do prowincji bolońskiej). Wśród ok. 770 ofiar znalazły się głównie dzieci, kobiety i starcy. Akt terroru miał być odpowiedzią na akcje działającego w regionie partyzanckiego oddziału Stella Rossa (Czerwonej Gwiazdy) oraz pomoc, którą członkowie ruchu oporu otrzymywali od miejscowej ludności.

Film dedykowany jest rodzinom ponad 700 osób zabitych $i$ milionom cywilów wciagniętych w wojne - a tym samym stanowi swoisty pomnik pamięci. Choć w pierwszoplanowych bohaterach (o nich za chwilę) trudno dopatrzeć się inspiracji postaciami historycznymi, należy zaznaczyć, że w filmie takowe się pojawiają. Do zaprezentowanych w realizacji Dirittiego bohaterów rzeczywistych (występujących pod „historycznymi”

${ }^{38}$ Film otrzymał trzynaście nominacji do nagrody Davida Donatello (zdobył ostatecznie cztery statuetki) oraz złotego Marc' Aurelio (nagrodę publiczności dla najlepszego filmu). Uroczystość przyznawania najważniejszej włoskiej nagrody filmowej w 2010 roku została zdominowana przez filmy historyczne. Prócz Człowieka, który nadejdzie, filmem, który otrzymał najwięcej statuetek, był Zwycięzca (2009) Marca Bellocchia, traktujący o Mussolinim. 
nazwiskami) można zaliczyć dwóch zaangażowanych we włoski ruch oporu księży - Giovanniego Fornasini i Ubaldo Marchioniego oraz dowódcę Czerwonej Gwiazdy, partyzanta Mario Musolesiego, znanego jako Lupo (wilk). Wszyscy oni ponieśli śmierć z rąk nazistów. O tym, jak ważne dla Włochów są to postaci, świadczą nie tylko poświęcone im tablice w samym Marzabotto. W 1998 roku rozpoczął się proces kanonizacji obu kleryków nazywanych martini di Monte Sole („męczennicy z Monte Sole”), zaś partyzant Lupo został odznaczony Medaglia d'oro al valor militare (złotym medalem wojskowym) ${ }^{39}$.

\section{Z perspektywy dziecka}

"Sercem filmu jest rodzina" - deklarował w jednym z wywiadów Diritti; w innym miejscu zaś twierdził, że protagonistą Człowieka, który nadejdzie jest lokalna społecznośćc ${ }^{40}$. Rzeczywiście, film ukazuje wojenne perypetie Martiny (ośmioletniej dziewczynki, będącej swoistym przewodnikiem po świecie przedstawionym) oraz jej rodziny; wydarzenia te są zaś częścią losów społeczności Marzabotto.

W pierwszej części filmu (do ataku Niemców) na pierwszym planie pozostaje codzienne życie wsi. Akcja rozwija się w rytmie wschodów i zachodów słońca, pracy i odpoczynku, dnia i nocy oraz kolejnych pór roku (film rozpoczyna się w grudniu 1943 roku, kończy zaś dziewięć miesięcy później). Widzimy zatem trud wieśniaków przy uprawie pola oraz sianokosach, wspólne gawędy prowadzone przy stole lub domowych pra-

${ }^{39}$ Informację podaję za: Paolo Pezzino, Il massacro. Guerra ai civili a Monte Sole, Bologna 2009. W 1951 roku Walter Reder został skazany na dożywocie; w 1985 roku wyszedł jednak na wolność. W 2006 roku rozpoczął się proces przeciw siedemnastu członkom Dywizji Grenadierów Pancernych SS. Rok później dziesięciu z nich skazano na dożywocie. Na temat masakry w Marzabotto powstały także filmy dokumentalne: Kłamstwo Marzabotto ( $L a$ menzogna di Marzabotto, reż. C. Di Carlo, 1961) oraz Stan wyjątkowy. Proces w sprawie Monte Sole 62 lata później (Lo Stato di eccezione. Processo per Monte Sole 62 anni dopo, reż. G. Maccioni, 2008). Reżyser pierwszego z nich wspominał: „Pod koniec 1960 roku w Niemczech ukazała się publikacja Die Luge von Marzabotto (Kłamstwo Marzabotto) i we Włoszech wybuchł skandal. Wtedy zainteresowałem się tą historią i nakręciłem o sprawie film dokumentalny. Realizacja była na czasie - temat zajmował pierwsze strony gazet, ale szybko została zakazana dla dzieci do 18 roku życia i nie weszła do kin. Film zaczął jednak cyrkulować w alternatywnym obiegu i przez to stał się bardzo popularny". Zob. Memoria, mito, storia. La parola ai registi, 37 interviste, s. 100. Przy okazji można nadmienić, że przywódca partyzantów - Lupo - jest także jednym z bohaterów Paisy (w epizodzie florenckim próbuje się do niego dostać łączniczka).

${ }^{40}$ www.lastampa.it/redazione/cmsSezioni/cinemaroma/200910articoli (dostęp: 10.08.2013). 
cach - wyplataniu wiklinowych koszyków, zarabianiu ciasta na chleb czy przygotowaniach do świniobicia. Film ukazuje bogactwo życia wiejskiej kultury, która jest oparta na tradycji (gdy zjawiają się zbłąkany wędrowiec oraz rodzina z Bolonii, którzy chcą zapłacić za gościnę, wieśniacy nie biorą pieniędzy; nie tego mnie nauczono - powie ojciec dziewczynki). Choć wojna wkrada się powoli, lecz nieubłaganie w życie mieszkańców (w domu Martiny pojawia się niespodziewanie ranny partyzant, który opowiada o ostatnich krwawych akcjach włoskiego oporu, później zaś domostwo nachodzą Niemcy), życie toczy się swoim rytmem. Dominuje spokój; wieś wydaje się ostoją bezpieczeństwa (co potwierdza przyjazd do Marzabotto uciekinierów z Bolonii). Długie ujęcia prezentujące niekiedy same krajobrazy: zielone pola i lasy oraz skąpane w słońcu pagórki, a także plany dalekie, w których niewielkie sylwetki ludzkie są jednym z elementów obrazu (zostają niejako „wpisane” w naturę), wytwarzają wrażenie harmonijnej koegzystencji chłopów z przyrodą.

Taki obraz „wsi spokojnej, wsi wesołej”, przypominający nieco ten z filmu Olmiego Drzewo na saboty (L'albero degli zoccoli, 1977), zostaje niejako usprawiedliwiony perspektywą dziecka, z której oglądamy świat przedstawiony. $W$ centrum narracji pozostaje bowiem, o czym była już mowa, ośmioletnia Martina. To z jej punktu widzenia (w filmie bardzo często wykorzystywane są ujęcia z POV) ${ }^{41}$ oglądamy większość wydarzeń - tych radosnych (narodziny wyczekiwanego braciszka) oraz tych tragicznych, związanych z niezrozumiałą dla dziewczynki wojną (opatrywanie rannego partyzanta, śmierć matki). I choć w filmie są epizody, w których dziewczynka nie uczestniczyła (nie mogła być np. obecna wśród stłoczonych w kościele mieszkańców, którzy zostają rozstrzelani, ani poznać losu swojego ogłuszonego granatem ojca, ginącego ostatecznie z rąk Niemców), to pojawia się ona niemal w każdej sekwencji. O tym, że to dziecięcy ogląd świata dominuje $\mathrm{w}$ tej historii świadczy także nietypowa rama kompozycyjna filmu. Początek filmu stanowi długie ujęcie (kamera z ręki eksploruje pusty dom, ukazując korytarz i sypialnię spowite w bladym niebiesko-zimnym świetle wczesnego poranka), które okazuje się punktem widzenia Martiny. Scena ta powraca w zakończeniu filmu. Finałowa sekwencja ukazuje zaś dziewczynkę, która z braciszkiem siedzi przed opuszczonym domem. Przyjęta w filmie dziecięca perspektywa oglądu świata, na poziomie fabularnym „usprawiedliwia” niejako niezwykłość świata przedstawionego, w myśl zasady, iż dziecko widzi inaczej - jest

${ }^{41}$ Wiele ujęć skonstruowanych jest tak, że wydaje się, iż to POV Martiny, po czym dziewczynka zjawia się w kadrze. 
wrażliwsze. Nie dziwi więc na przykład scena, w której dziewczynka przygląda się z uwagą żabie lub ta, w której obserwuje z zachwytem przelatujące za oknem ptaki.

Perspektywa dziecka niesie zarazem ze sobą istotne konsekwencje dla wymowy filmu. Przefiltrowanie wydarzeń z czasów II wojny światowej przez pryzmat świadomości ośmioletniej dziewczynki prowadzi w istocie do wizji „apolitycznej” (w rozumieniu: doświadczenia „naiwnego", potencjalnie apelującego do emocji widzów o różnych sympatiach politycznych, także tych mających ograniczoną wiedzę historyczną). W wywiadzie Diritti mówił, że przyjęty tryb narracji (punkt widzenia niewinnego dziecka) umożliwia "dogłębniejszą krytykę wojny" ${ }^{42}$. Owszem, ale dziecięca perspektywa oglądu umożliwia zarazem - o czym Diritti nie wspomina - swoistą eksternalizację winy, zrzucenie odpowiedzialności za zbrojny konflikt i przedstawienie Włochów w roli jego ofiar. W oczach Martiny wojna jest czymś niepojętym, swoistą „zarazą", która przyszła znikąd i która trwa z nieznanych powodów. Potwierdzeniem tej hipotezy są zawarte w narracji (za pomocą dźwięku ponadkadrowego) myśli dziewczynki:

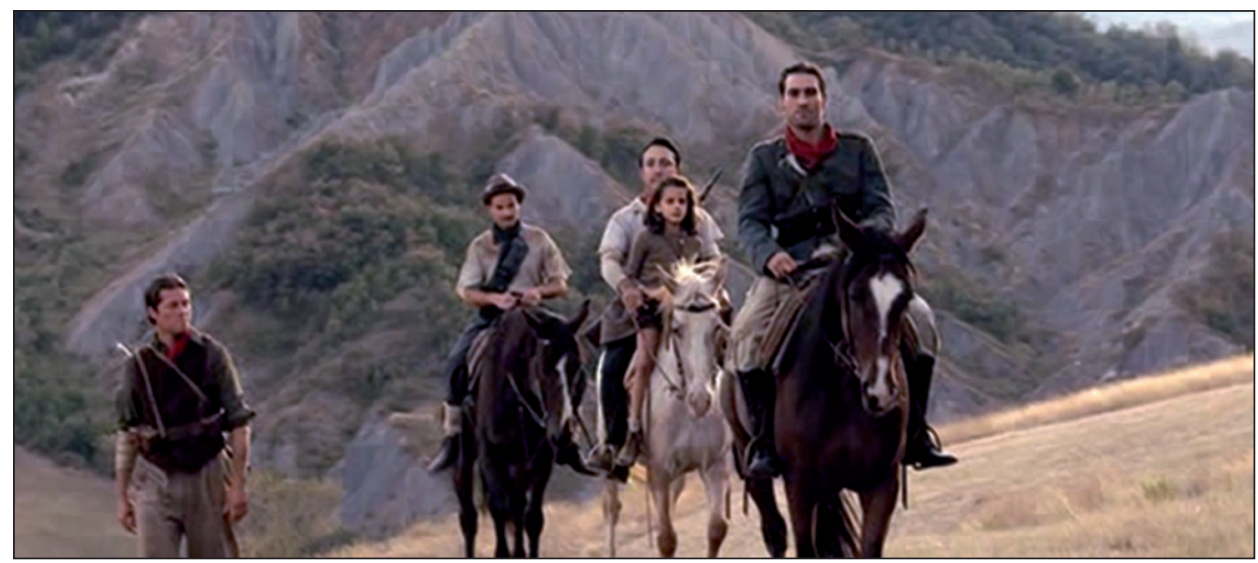

Fot. 9. Człowiek, który nadejdzie (reż. Giorgio Diritti, 2009)

Partyzanci w westernowej scenerii

${ }^{42}$ Informacje dostępne na stronie: www.uomocheverra.com/uomocheverra_pressbookITA.pdf (dostęp: 10.08.2013). Nie bez znaczenia jest fakt, że dziewczynka jest niemową (przestała mówić po śmierci swojego nowo narodzonego braciszka). 


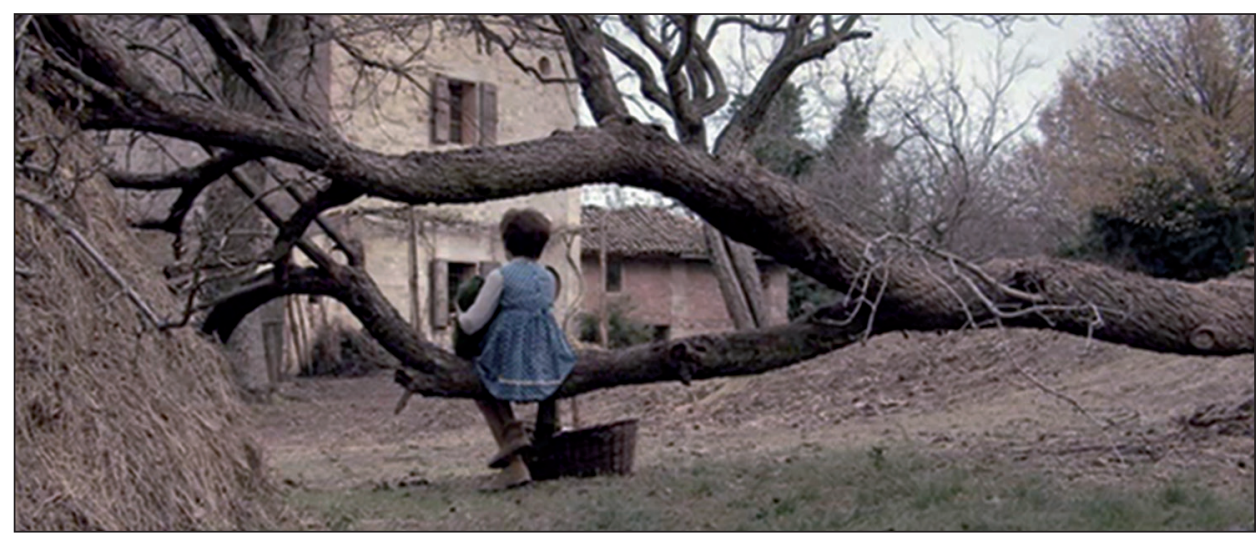

Fot. 10. Człowiek, który nadejdzie (reż. Giorgio Diritti, 2009)

Krajobraz po hekatombie - Martina z braciszkiem

Czasami przychodza do nas Niemcy, żeby coś kupić. Nie umieja mówić. Nie wiem, dlaczego tu sa. Dlaczego nie zostali w domu razem ze swoimi dziećmi. Niemcy maja broń i strzelaja do wroga, ale nie wiem, kim on jest. Styszałam, że walcza z aliantami, ale nigdy ich nie widziałam. W wojnie biora też udziat partyzanci, którzy chca wyrzucić stąd Niemców. Oni także maja broń. [...] Przychodza tu też faszyści. Używaja naszego języka, ale krzycza i mówia, że partyzanci to bandyci, którzy zastuguja na śmierć. Każdy chce kogoś zabić, ale nie rozumiem dlaczego.

Wyrażoną przez Martinę dezorientację wobec nowych okoliczności można by w zasadzie przypisać całej społeczności Marzabotto. Ojciec dziewczynki, gdy przychodzi mu oddawać Niemcom swoje plony, pyta retorycznie ziemskiego rządcy: Dlaczego [Niemcy] nie siedza w domu i nie zajma się swoimi rodzinami? A gdy padrone próbuje ripostować, że Historia petna jest wojen, wieśniak odpowiada: Historia? Kogo obchodzi historia. Nagle najważniejsi staja się ci, co zabijaja i grabia biedaków. Społeczność wiejska wydaje się więc niewinną ofiarą wojny, która kompletnie ich nie dotyczy.

\section{Włosi}

Nietrudno zauważyć, że w filmie Dirittiego niemal wszyscy bohaterowie włoskiego pochodzenia są zaangażowani w ruch oporu. Albo należą (lub przyłączają się) do partyzanckiej grupy Stella Rossa, albo sprzyjają jej członkom, oferując schronienie i pożywienie oraz pomagając przy przekazywaniu informacji. Wedle Martiny wszyscy kochaja dowódce partyzantów Lupo i mówia, że trzeba mu pomagać. Czyni tak zarówno jej wujek Dino, jak 
i ojciec (stanowiący autorytet dla dziewczynki), choć ten ostatni nie może się do nich przyłaczyć, ponieważ ma ziemię. Z relacji dziewczynki wynika więc jasno, że cała społeczność Marzabotto sercem jest za partyzantami, choć niektórzy nie decydują się na walkę zbrojną.

Resistenza w filmie Dirittiego nie ogranicza się więc do tej „czynnej”, polegającej na dywersyjnych akcjach (której reprezentantem jest Lupo wraz ze swoją brygadą), ale ma także swoje drugie oblicze - oporu biernego. Ważne w tym kontekście wydają się słowa ojca Martiny, który namawiany do wstąpienia w szeregi partyzantów stwierdza: jak założymy mundury i zaczniemy strzelać, będziemy tacy sami jak oni. Pojawia się więc sugestia, że mieszkańcy Marazabotto nie chcą rozlewu krwi. Wprawdzie Martina jest świadkiem zabójstwa Niemca przez członków Czerwonej Gwiazdy, ale konieczność stosowania przemocy wobec wroga przez partyzantów zostaje niejako usprawiedliwiona. Ci, którzy decydują się na walkę, czynią to bowiem wyłącznie dla obrony swoich rodzin, co potwierdza przemowa jednego z partyzantów do nowych rekrutów:

Nie nabijacie sobie głowy polityka. Dlaczego tu jesteś? Ja ci podam powód. Ponieważ panosza się tu faszyści i Niemcy. W domu twoim, twoich dziadków i całej twojej rodziny. Pamiętajcie o tym. I kiedy zobaczycie Niemca, nie uciekajcie, ale stawcie mu czoła ${ }^{43}$.

Grupa Lupo przypomina więc obrońców sprawiedliwości „wyjętych spod prawa" i ukrywających się w lesie niczym banda Robin Hooda. Można także dopatrzeć się w nich indiańskich wojowników. Konotacje westernowe podkreśla sekwencja prezentacji partyzantów: gdy w tle słyszymy ponadkadrowy głos Martiny - Wielu [partyzantów - przyp. A. M.-K.] mówi w naszym języku i wyglada tak jak my. Ich dowódca nazywa się Lupo. Wszyscy sie go boja, ale go kochaja - widzimy step, po którym na koniach podążają członkowie Czerwonej Gwiazdy. Niektórzy mają na głowie kowbojskie kapelusze i chusty zawiązane pod szyją, inni czarne, lśniące włosy nasuwające skojarzenia z Indianami (pseudonim „wilk” należący do przywódcy oddziału tylko wzmacnia to wrażenie).

Mieszkańcy Marzabotto zostają ukazani jako ofiary - co jest podkreślane w filmie wielokrotnie poprzez rozbudowane sceny opatrywania ran

${ }^{43}$ Wątek rodziny jest podkreślony w całym filmie; pojawia się on w przywoływanych już wypowiedziach Martiny (Dlaczego Niemcy nie zostali ze swoimi dziećmi?) i jej ojca (dlaczego [Niemcy] nie siedza w domu i nie zajma się swoimi rodzinami?), ale także w wątku oczekiwania na upragnione dziecko (nowego braciszka Martiny), które - jak mówi ojciec dziewczynki - jest całym światem. U Dirittiego familia stanowi więc fundament życia, plasuje się na szczycie w hierarchii wartości wieśniaków. 
członków Czerwonej Gwiazdy oraz sekwencji czuwania przy zmarłym partyzancie. Najbardziej poruszająca jest jednak sekwencja przemocy wobec dzieci i kobiet zaganianych przez Niemców do kościoła i pod ściany cmentarnej kaplicy w celu dokonania egzekucji (ujęcia kręcone są kamerą z ręki, co potęguje wrażenie chaosu panującego wśród Włochów). Sekwencja rozstrzeliwania skonstruowana jest w taki sposób, że akcentuje cierpienie i rozpacz zabijanych, tym bardziej, że jest nakręcona w zwolnionym tempie. Rozpoczyna ją kilka ujęć w kompletnej ciszy, które ukazują w zbliżeniu twarze starców, kobiet i dzieci skamieniałych ze strachu przed tym, co nastąpi. W momencie strzałów, w ścieżce dźwiękowej słychać muzykę ilustracyjną - kościelnego chóru. W kolejnym ujęciu widzimy dziurawione kulami drzwi kaplicy. Kamera (za pomocą jazdy w górę) ukazuje kolejno krzyż i wreszcie niebo, jakby symulując własnym ruchem drogę dusz zmarłych unoszących się ponad ziemię. Kolejne ujęcie ukazuje zgromadzonych $\mathrm{w}$ kościele, do którego zostaje wrzucony granat. Wybuch przysłania cały obraz. Prezentację Włochów jako ofiar podkreśla także długa scena, w której kamera eksploruje ciała zabitych.

W Człowieku, który nadejdzie, jedynym „negatywnym” Włochem, stojącym po stronie okupanta, jest w zasadzie syn handlarza winem, który przybywa na wieś z Bolonii (gdzie jest niebezpiecznie) i okazuje się szpiegiem. W jednej z ostatnich sekwencji filmu ojciec Martiny widzi go, gdy $\mathrm{w}$ niemieckim hełmie zabija $\mathrm{z}$ uśmiechem na ustach przerażonych mieszkańców miasteczka. Postać zdrajcy, burząca manichejski podział na dobrych Włochów i złych Niemców, jest jednak od początku waloryzowana negatywnie. Po pierwsze, to przybysz z zewnątrz ( $\mathrm{z}$ miasta, które wydaje się dla wiejskiej społeczności odległą galaktyką); po drugie, mężczyzna zostaje wprowadzony do historii za pośrednictwem handlarza win, który jest postacią ambiwalentną - $\mathrm{w}$ filmie zasugerowane zostają jego skłonności pedofilskie. Co znamienne, w Człowieku, który nadejdzie ani razu nie pojawiają się inni włoscy faszyści. Wspomina o nich wyłącznie Martina (Przychodza tu też faszyści. Używaja naszego języka, ale krzycza i mówia, że partyzanci to bandyci, którzy zasługuja na śmierć), ale ich nieobecność w świecie przedstawionym wymazuje ich istnienie z pamięci.

\section{Niemcy}

W filmie Dirittiego czarnymi charakterami pozostają Niemcy. To oni uosabiają wszelkie zło, które spada na wioskę i okolice niczym plaga (nie wiem, dlaczego tu sq - stwierdza Martina). Okrucieństwo gestapowców podkreślane jest w kilku scenach: w opisywanej już sekwencji mordu 
bezbronnych starców, dzieci i kobiet, ale także w scenach rozstrzelania matki Martiny (kilka godzin po porodzie długo oczekiwanego dziecka) oraz ojca dziewczynki (ginie on od "dla zasady"; znalazł się bowiem w złym miejscu i czasie - na leśnej ścieżce, naprzeciwko dwóch niemieckich żołnierzy). Demoniczne rysy nadaje Niemcom dodatkowo fakt, że atakują oni i zabijają nie tylko uzbrojonych partyzantów, ale właśnie osoby bezbronne - zniedołężniałe i słabe. Żołnierze z pedantyczną precyzją podpalają domy wieśniaków, przeszukują gospodarstwa w poszukiwaniu ukrywających się dzieci oraz zabierają zapasy żywności i trzodę.

„Dobrym Niemcem” wydaje się przez chwilę oficer, który spośród dogorywających Włochów „wyłuskuje” młodą dziewczynę i zaczyna opatrywać jej rany; każe roztoczyć nad nią opiekę, z uwagi na podobieństwo kobiety do swojej żony (o czym wspomina kompanowi z dywizji). Pomijając osobliwą motywację Niemca, okazuje się, że to co można byłoby wziąć za przebłysk ludzkiej wrażliwości, okazuje się w istocie pragmatyczną kalkulacją. Włoszka została uratowana w określonym celu - by zaspokoić seksualne potrzeby Niemca. O przedmiotowym traktowaniu ludzi i bezduszności oficera świadczy także fakt, że włoskie dziecko, które straciło na własnych oczach matkę, zaczyna płakać, akurat kiedy on opatrywał swą "oblubienicę”, Niemiec zabija je z zimną krwią, by mu nie przeszkadzało. Gdy wraca do rannej, ta w desperacji zabija go pogrzebaczem, a sama ginie od kuli wystrzelonej przez innego nazistę.

Film zawiera jedną tylko sekwencję, która wydaje się przełamywać stereotyp złego Niemca - myślę tu o przymusowym wspólnym posiłku żołnierzy i włoskiej rodziny, w kompletnej ciszy, kiedy to jeden z Niemców kroi chleb i podaje kromki włoskim dzieciom. Scena „porozumienia bez słów" jest jednak krótka. Gdy wojsko zjawia się w filmie kolejny raz, następuje masakra ludności. Obcość między Włochami a Niemcami wzmacniana jest dodatkowo poprzez zmianę tonacji kadrów (ilekroć w scenie pojawia się okupant, dominują w niej barwy zimne - odcienie niebieskiego i szarości) oraz przez powziętą przez Dirittiego decyzję, by niemieccy bohaterowie filmu mówili po niemiecku, a włoscy - po włosku; język niemiecki nie jest przy tym w filmie w ogóle tłumaczony.

\section{Biblia}

Historia wojennych perypetii rodziny Martiny i mieszkańców Marzabotto w filmie Dirittiego zyskuja - podobnie jak inne analizowane wcześniej filmy - cechy biblijnej przypowieści, w której nazizm skojarzony zostaje ze złem, zaś ruchowi oporu przypisane zostają przymioty dobra, 
podobnie jak Amerykanom konotującym wyzwolenie i „boskie błogosławieństwo" (żołnierze US Army pojawiają się tylko raz - dziewczynka obserwuje przez okno spadochroniarzy, którzy wydają się aniołami „spadającymi z nieba" $\left.{ }^{44}\right)$.

Biblijne odniesienia są chyba najpełniej widoczne w epizodzie walki między partyzantami a Niemcami w pobliżu kościoła, w którym zgromadzili się mieszkańcy przekonani, że tam "nie dosięgną ich armaty". Sekwencja starcia z okupantem przeplatana jest ujęciami rozmodlonych starców, kobiet i dzieci. Początkowo scenom bitwy towarzyszy tylko muzyka ilustracyjna ",anielskiego chóru”, zaś w scenach ukazujących Włochów w katedrze słychać dodatkowo modlitwę wiernych. W pewnym momencie odmawiana przez mieszkańców Marzabotto modlitwa Zdrowaś Mario zostaje nałożona na sceny walki partyzantów z Niemcami. Powstaje zatem wrażenie, jakby ścierały się rzeczywiście siły dobra ze złem.

Chrześcijańskich odniesień możemy dopatrzeć się także we wspominanej już scenie masowej egzekucji. Są one wyraźne nie tylko z uwagi na fakt, że cała tragedia rozgrywa się w kościele i przed cmentarną kaplica, ale też dlatego że utrzymana w slow motion egzekucja poprzedzona jest nabożeństwem. W czasie jego trwania ginie ksiądz trzymający w ręce kielich z Najświętszym Sakramentem (w filmie kilkakrotnie zresztą jesteśmy świadkami Eucharystii; mała Martina przystępuje także w toku narracji do pierwszej Komunii Świętej). Konotacje biblijne - skojarzenie wiejskiej społeczności i ruchu oporu z owieczkami - jest zresztą w filmie wyrażone explicite. Niemiecki oficer, przekazując księdzu ciało jednego z zabitych partyzantów, mówi: Ksiądz jako pasterz źle wychowuje swoje owce.

Wątek wojennego zagrożenia i śmierci równoważony jest $w$ filmie przez ten związany z nowym życiem - długo oczekiwanym braciszkiem Martiny, który szczęśliwie przychodzi na świat. Przed porodem matka Martiny modli się bowiem przy kapliczce, na której umieszczony jest obraz ciężarnej Madonny; podczas porodu jedna z kobiet błogosławi brzuch kobiety (w przytrzymanym ujęciu widać położony na nim krzyż). Co istotne, film rozpoczyna się w grudniu 1943 roku w wigilię Bożego Narodzenia; w jednej z pierwszych scen Martina kładzie w żłóbku figurkę małego Jezusa. Trudno zatem oprzeć się wrażeniu, że oto tytułowemu Człowiekowi, który nadejdzie nadane zostają w filmie cechy swoistego „odkupiciela”, zbawcy "grzechów przeszłości”.

${ }^{44} \mathrm{~W}$ jednej ze scen dziewczynka maluje spadochron na kartce papieru i pisze - będzie ich wielu. Komunikat ten brzmi jak swoiste proroctwo, zapowiedź wyzwolenia. 
Hipotezę tę potwierdzają losy dziecka po cudownym uratowaniu go przez Martinę. Dziewczynka kieruje bowiem swe kroki do domu księdza. To tam rodzina kapłana roztacza nad obojgiem rodzeństwa opiekę - dziewczynka zostaje nakarmiona i umyta; wreszcie może poczuć się bezpiecznie. Scena kąpieli Martiny w wielkiej balii nasuwa skojarzenia z chrztem, tym bardziej, że znajduje się ona w bliskim sąsiedztwie prawdziwego chrztu - jej braciszka. Dziewczynka zostaje w ten sposób „matką chrzestną" (choć w istocie matkuje braciszkowi od rozstrzelania mamy obojga dzieci). Co ciekawe, gdy kapłan udziela sakramentu, zmywającego grzechy przeszłości i zapowiadającego nowe życie, wypowiada Credo, Wierze w Boga. Gdy wspomina Mękę Pańską (mówi: umęczon pod Ponckim Piłatem, ukrzyżowan, umart i pogrzebion), spogląda na nadzorującego uroczystość Niemca (jest on widoczny w przeciwujęciu). Powstaje zatem skojarzenie Niemca z biblijnymi oprawcami; w ten sposób całej historii ponownie zostają nadane sensy Ewangelii, tym bardziej, że na słowa zmartwychwstat kamera „wraca” do dziewczynki i nowo narodzonego. Sens Ewangelii w swej istocie nakierowany jest na przyszłość - film Dirittiego to zatem zapowiedź "lepszego jutra” (o czym zdaje się także świadczyć tytuł). Ostatnie ujęcie ukazuje rodzeństwo, które w słoneczny dzień siedzi na powalonym dębie przed rodzinnym domem. Dziewczynka kołysze braciszka do snu, nucąc cicho piosenkę. W finale filmu po raz pierwszy słyszymy więc głos Martiny - jakby traumatyczne wydarzenie z przeszłości zostało „przepracowane”. Rozpoczyna się nowe życie... 


\section{Zakończenie}

Analiza przedstawionych w poprzednich rozdziałach przykładów, ilustrujących strategie reprezentacji resistenzy we włoskim kinie powojennym (a odnoszących się do propozycji terminologicznej ujętej przeze mnie w formie tabeli w rozdziale drugim), pozwala na sformułowanie kilku wniosków.

W reprezentacjach włoskiego ruchu oporu dominują filmy fikcjonalne, które nie zawierają w swej strukturze materiałów archiwalnych. Te ostatnie były włączane do narracji pure fiction stosunkowo często w latach 19601968. Rekonstrukcje faktycznych wydarzeń lub losów postaci historycznych związanych z resistenza były relatywnie częste w latach 1969-1978. W czasie dekady „ołowiu” zrealizowano m.in. filmy o Corbarim (Corbari), De Gasperim (Rok pierwszy) i Mussolinim (Mussolini, ostatni akt) oraz film fabularyzujący tragiczne wydarzenia w Jaskiniach Ardeatyńskich (Masakra w Rzymie). Na podstawie zebranego materiału można także stwierdzić, że o ile w okresie 1969-1978 w "filmach-rekonstrukcjach" wykorzystywano dość chętnie footage, o tyle w latach 1979-1994 i współcześnie twórcy unikają wprowadzania materiałów archiwalnych (nie znajdziemy ich ani w Porzus, ani w Nocy świętego Wawrzyńca, ani w Człowieku, który nadejdzie). Sama formuła rekonstrukcji w ostatnich latach wydaje się wracać do łask (Porzus; Salvo D'Acquisto; Dzika krew; Człowiek, który nadejdzie).

Nie udało się natomiast znaleźć takich fabuł o resistenzy, których narracje fabularyzowałyby fakty, a jednocześnie zawierałyby footage oraz współczesną ramę narracyjną. Nie znaczy to jednak, że nie można sobie takich filmów wyobrazić; niewykluczone zreszta, że egzemplifikacje takie rzeczywiście istnieja, a tylko autorce niniejszej pracy nie udało się wpaść na ich trop.

Szczególnie w latach 1969-1978 powstają także filmy traktujące o współczesności w kostiumie historycznym i odczytywane przez pryzmat wydarzeń bieżących. W tej grupie sytuują się istotne dla tematu mojej pracy filmy o włoskim ruchu oporu, m.in. Corbari oraz Libera, moja miłość. Można zatem powiedzieć, że historia „dekady ołowiu” ewokowana jest także przy pomocy swoistej „mowy ezopowej”. Uważam, że filmy te można rozpatrywać przez pryzmat anni di piombo - z zastrzeżeniem, że interpretacja taka nieuchronnie wkracza w obszar swobodnej "gry skojarzeń". Gdy zaś mowa o historycznej recepcji tych filmów (w czasie ich 
kinowej dystrybucji), tylko w niektórych przypadkach dysponuję materiałem dowodowym (wypowiedzi twórców, głosy krytyki) na poparcie hipotezy, iż taki sposób interpretacji był bądź celowo obierany przez twórców, bądź/oraz odczytywany przez ówczesną krytykę.

Jak już zostało powiedziane, ruch oporu był postrzegany w powojennej Italii jako fenomen symbolizujący odrodzenie włoskiego społeczeństwa. Reżyserzy (oraz pisarze) poczuwali się do obowiązku oddziaływania poprzez sztukę na życie społeczne kraju. Pod hasłem „etyki estetyki” kryła się wizja artysty przekształcającego rzeczywistość; kino stało się zaś medium obywatelskiego zaangażowania (cinema dell'impegno). W zrealizowanych po wojnie filmach resistenza ukazywana jest jako ruch ogólnonarodowy - na ekranach włoskich kin przeciw niemieckiemu okupantowi walczy całe społeczeństwo niezależnie od wieku, płci i społecznego statusu. Podkreślana jest przy tym spontaniczność włoskiego ruchu oporu; jawi się on jako reakcja "oddolnych sił”, a nie działanie zorganizowanych ugrupowań politycznych. Sposób prezentacji postaci, ukonstytuowany niejako przez Rzym, miasto otwarte, jest w tych narracjach niemal identyczny: Włosi występują w roli dzielnych bohaterów i/lub niewinnych ofiar niemieckiej agresji; wrogiem pozostają zaś Niemcy uosabiający okrucieństwo i abstrakcyjną siłę zła. W filmach zrealizowanych zaraz po wojnie oraz w latach 50. afirmowana jest zatem narodowa jedność, pomimo różnic $w$ wojennych doświadczeniach poszczególnych regionów (emblematycznym przykładem jest tu Paisà $)^{1}$.

Oznacza to również, że w zrealizowanych zaraz po wojnie filmach o ruchu oporu faszyści są niemal nieobecni. Jak celnie podsumowuje Giuseppe Ghigi, ów brak zwolenników Mussoliniego był „wyrazem chęci wymazania odpowiedzialności historycznej; jakby wszystkie wojenne zbrodnie, które miały miejsce, były całkowicie obce włoskiemu, dobremu charakterowi. Chodziło o pokazanie, że wrogiem jest «germański barbarzyńca», zaś przyczynę wszystkich bolączek, leczonych przez resistenzę, stanowił nazizm"². Jeśli już w tych fabułach pojawiają się faszyści, po-

${ }^{1}$ Częstym motywem filmów o włoskim ruchu oporu zrealizowanych w latach 19451968 jest także podróż przez kraj (Paisà; Federale; Wszyscy do domu). W filmach tych zdewastowany krajobraz staje się niejako „dodatkowym” bohaterem - symbolizuje narodową traumę.

${ }^{2}$ Giuseppe Ghigi, La memoria inquieta. Cinema e resistenza, Venezia 2009, s. 29. 
kazani są oni jako grupa nieposiadająca politycznej świadomości. Indro Montanelli, komentując pół żartem wizerunek nieco gapowatego, faszystowskiego wojska, obecny w filmach lat 1945-1969, odnotowuje: „Nikt nie uwierzyłby w powagę plutonu egzekucyjnego Włochów, gdyby za jego plecami nie pojawiła się twarz oficera SS kontrolującego, czy w lufach są rzeczywiście naboje" ${ }^{3}$.

$\mathrm{O}$ ile $\mathrm{w}$ pierwszych włoskich filmach powojennych dominował bohater zbiorowy, o tyle na początku lat 60 . zaczynają pojawiać się portrety silnie zindywidualizowane (lata 50., o czym była już mowa, są okresem wyciszenia tematu resistenzy w publicznym dyskursie). To czas osobistych wyborów (Generat Della Rovere, Terrorysta, Dzień lwów) i antybohaterów (można do nich zaliczyć m.in. Arcovazziego z filmu Federale, Innocenziego z Wszyscy do domu i Bertone z Generata Della Rovere). Filmy te piętnują konformizm wielu mieszkańców Italii i ich mistrzostwo w l'arte d'arrangiarsi (sztuce kombinowania). Ta ostatnia wydaje się częścią „kodu genetycznego" ekranowych Włochów i potwierdza prymat sfery prywatnej nad publiczną oraz sprytu nad poczuciem obywatelstwa. Jak słusznie stwierdza Gianni Rondolino, w filmach tych dominuje jednak humor i dążenie do pojednania ${ }^{4}$. Powstałe na początku lat 60. utwory traktujące o resistenzy wydają się bowiem usprawiedliwiać Włochów. Wojna jest przez protagonistów niechciana - mundur chcieliby jak najszybciej zrzucić i wrócić do rodziny. Nie na próżno tłem akcji bywa właśnie wrzesień 1943 roku (w wielu filmach datą graniczną jest 8 września 1943 roku) - okres obalenia reżimu Mussoliniego, układu z aliantami i akcji represyjnej podjętej przez Niemców wobec niedawnego sojusznika. Koncentrując się na tych właśnie wydarzeniach, dramaturgia filmu może oprzeć się bowiem na motywie zniewolenia, ucieczki, a przede wszystkim walki z okupantem. Filmowe opowiadanie oferuje w ten sposób "skutki bez przyczyn" i bez prawdziwie krytycznej autorefleksji, która musiałaby wybiec daleko wcześniej poza rok 1943. Lino Micciché nie bez racji zauważył:

Jest dośćjasne, że nurt satyryczno-farsowy na temat resistenzy i faszyzmu pełni funkcje eskapistyczne [...]. Sukces kasowy niektórych z tych filmów pokazuje, że publiczność chciała się śmiać, ale nie z samego faszyzmu, lecz z udramatyzowanej reprezentacji

${ }^{3}$ Wypowiedź umieszczona w: Joachim Staron, Fosse Ardeatine e Marzabotto. Storia e memoria di due stragi tedesche, Bologna 2007, s. 21.

${ }^{4}$ Por. Gianni Rondolino, L'antifascismo nel cinema italiano, "Il nuovo spettatore cinematografico" 1963, nr 4, s. 36-37. Zresztą w wielu filmach początku lat 60. można dostrzec ewolucję bohatera - z postaci negatywnej na pozytywna; od indyferentyzmu politycznego do odważnych wyborów w imię dobra ogółu (i kraju). 
własnej ambiwalentnej postawy wobec faszyzmu/antyfaszyzmu/resistenzy, a więc $\mathrm{z}$ tej narodowej cechy drobnomieszczańskiej mentalności, która - w piętnaście lat po upadku dyktatury i czterdzieści lat od jej początku - jest świadectwem jej nieusuwalnych korzeni ${ }^{5}$.

W latach 1969-1978 - okresie kontestacji, w którym młode pokolenie pytało o przeszłość ojców i żądało rozliczenia z dziedzictwem faszyzmu - filmy o włoskim ruchu oporu ukazują wojnę jako wydarzenie polaryzujące społeczeństwo. Wrogami partyzantów są tu nie tyle Niemcy, co przede wszystkim faszyści. Ten wątek oddaje ducha epoki w tym sensie, iż ukazuje bratobójczą walkę - eksponuje zatem (inaczej niż filmy zrealizowane od razu po wojnie) podział włoskiego społeczeństwa na zwolenników Mussoliniego oraz jego adwersarzy (co można odczytywać w kategoriach „odkłamywania historii”). Jednocześnie odzwierciedla społeczne napięcia lat 70. w tym wymiarze, iż w owej dekadzie ugrupowania prawicowe były określane przez skrajną lewicę właśnie jako faszystowskie. Jak wspominałam, w latach 70. w sloganach środowiska lewackiego resistenza uzyskuje nowe znaczenie - staje się oporem przeciw neofaszystowskiemu, „czarnemu" terroryzmowi. W „dekadzie ołowiu" na narracje o resistenzy nakładany jest więc dyskurs o anni di piombo. Podejmując temat ruchu oporu, kino włoskie lat 70. traktowało go zatem bądź jako wartość uniwersalną (swoisty impuls wolności), bądź (i to znacznie częściej) nadawało mu aktualne znaczenia polityczne ${ }^{6}$.

Współczesnego wymiaru filmów o włoskim ruchu oporu z lat 70. można dopatrzeć się także w zawartym w nich wizerunku kobiet, który koresponduje z rozwijającym się wtedy w Italii ruchem feministycznym ${ }^{7}$. Przestają być one bowiem milczącymi obserwatorkami lub symbolem politycznego

${ }^{5}$ Lino Micciché, Il cinema, la storia, la storia del cinema, Venezia 1996, s. 34.

${ }^{6}$ Sytuację tę celnie podsumował Pier Paolo Pasolini w pisanych w latach 70. Pismach korsarskich. Pasolini zauważył w nich, że - cytuję fragment w przekładzie Anny Mętrak - „termin «ojciec» semantycznie zaczął się zmieniać wraz z Freudem i psychoanaliza, dlatego dziedzictwo ojca nie jest już koniecznie faktem pozytywnym, a wręcz dozwolona jest jego całkowicie negatywna interpretacja. W istocie ojcowie wydają się wszyscy panami z burżuazji, obnoszącymi czcigodne brody i łysiny [...] siedzącymi godnie na złoconych krzesłach; są oni słowem ojcami przywileju i władzy, a [...] «nowa władza» (która w istocie jest młodymi ojcami) nie chce, żeby plątali jej się pod nogami tacy ojcowie". Pier Paolo Pasolini, Po ludobójstwie. Eseje o języku, polityce i kinie, tłum. Anna Mętrak, Izabela Napiórkowska, Mateusz Salwa, Warszawa 2012.

${ }^{7} \mathrm{~W}$ latach 70. pojawiają się liczne publikacje o zaangażowaniu kobiet w ruch oporu: La resistenza taciuta. Dodici vite di partigiane piemontesi, red. Anna Bruzzone, Rachele Farina, Torino 1976 oraz Bianca Guidetti Serra, Compagne, Torino 1978. 
indyferentyzmu. Wręcz przeciwnie - walczą ramię $\mathrm{w}$ ramię u boku mężczyzn (Agnieszka idzie na śmierć); są również świadome politycznie oraz wyemancypowane (tytułowa bohaterka filmu Libera, moja miłość).

O ile lata 80. to dekada nikłego zainteresowania ruchem oporu, o tyle $\mathrm{w}$ latach 90. temat ten wraca na ekrany kin w nieco innej formule. Rola resistenzy jest wtedy umniejszana. Partyzanci stają się "gangsterami"; podkreślany jest także wątek bratobójczej walki, aby ukazać ambiwalencję bycia sprawcą i ofiara jednocześnie. Ten wizerunek włoskiego ruchu oporu koresponduje z przemianami politycznymi we Włoszech. Nowa władza na czele z Silvio Berlusconim, który współpracuje z partiami postfaszystowskimi, próbuje bowiem legitymizować zawarty sojusz i postponować włoski ruch oporu, kojarzony w dużej mierze z włoską partią komunistyczną.

Choć trudno mówić o nowych sposobach reprezentacji ruchu oporu we współczesnym kinie, jedną z tendencji jest na pewno subiektywizacja narracji. Począwszy od lat 80., w filmach o resistenzy świat przedstawiony jest często przefiltrowany przez pryzmat dziecięcej świadomości; niektóre $\mathrm{z}$ nich są przy tym utrzymane w poetyce onirycznej. Ilustracją tej tendencji są m.in. Noc świętego Wawrzyńca i Człowiek, który nadejdzie9.

Trajektorię obecności tematu ruchu oporu we włoskim kinie (a zarazem w publicznym dyskursie) można by zatem ująć w formie sinusoidy, w której odcinkami „ujemnymi” (wychylonymi w dół), oznaczającymi wyciszenie tej problematyki, byłyby dekady lat 50. i 80. Generalnie jednak włoskie filmy o ruchu oporu ukazują wojnę jako swoistą plagę, karę nałożoną przez zewnętrzne siły. Akcent pada tu przede wszystkim na absurdalność wojny. Christopher Wagstaff słusznie zauważa, że kino włoskie wyróżnia się na tle europejskim tendencją do reprezentowania wojny (często za pośrednictwem gatunku komediowego lub melodramatycznego) jako fenomenu pozbawionego sensu - niechcianego i niepochwalanego ${ }^{10}$. W filmach o resistenzy podkreślany jest przy tym tragiczny wymiar ludzkiego poświęcenia, a nie finałowe zwycięstwo nad okupantem.

${ }^{8}$ Za taki symbol może być uznana choćby Cesira z Matki i córki. Podczas wojny koncentruje się ona bowiem wyłącznie na problemach prywatnych: uniknięciu bombardowań, znalezieniu czegoś do jedzenia, obronie córki. Jeśli nie przyjda bombardować, nie będzie tak źle - powtarza wielokrotnie $\mathrm{w}$ filmie.

${ }_{9}$ Inne współczesne filmy o II wojnie światowej, realizujące ten tryb narracji, to Czerwony goździk (Uova di garofano rosso, reż. S. Agosti, 1991) oraz Życie jest piękne (La vita è bella, reż. R. Benigni, 1997).

${ }^{10}$ Christopher Wagstaff, Il cinema europeo e la resistenza, [w:] L'immagine della Resistenza in Europa: 1945-1960. Letteratura, cinema, arti figurative, ed. Pierre Sorlin et al., Bologna 1996, s. 47. 
Istotną cechą wielu filmów o włoskim ruchu oporu jest także nadanie mu znaczeń odwołujących się do chrześcijaństwa. Wątek ten silnie obecny $\mathrm{w}$ utworach powstałych zaraz po wojnie (Rzym, miasto otwarte; Stońce wschodzi) pojawia się niezależnie od czasu realizacji filmów w każdym $\mathrm{z}$ wyróżnionych okresów - również w latach 70. (Corbari), 80. (Noc świętego Wawrzyńca) oraz współcześnie (Człowiek, który nadejdzie). Transpozycja chrześcijańskich wyobrażeń na działalność partyzantów oraz ukazywanie losów Włoch przez pryzmat niezawinionego cierpienia powoduje, że resistenzy zostaje nadana waga ewangeliczna. Narracje o włoskim ruchu oporu okazują się historiami o ofierze i pokucie; same w sobie zyskują zatem „odkupicielski” charakter.

Wydaje się, że w obliczu malejącej z przyczyn naturalnych liczby świadków i uczestników resistenzy kino coraz częściej będzie się odwoływało do świadectw już zapisanych bądź zarejestrowanych. W warstwie wizualnej materiały archiwalne będą zaś poddawane coraz większym przetworzeniom. Dla młodego pokolenia ruch oporu jest fenomenem historycznym. Pamięć o nim jest utrwalona przede wszystkim w instytucjach i tekstach kultury, a wyrażana zostaje poprzez różnorodne praktyki komemoracyjne, kształtujące wyobrażenia o przeszłości (zwłaszcza instytucje muzealne oraz wystawy) ${ }^{11}$. Pomostem porozumienia między młodym pokoleniem a „artefaktami przeszłości” stają się najczęściej emocje i empatia, w mniejszym zaś stopniu "podręcznikowe” narracje, których głównym zadaniem jest prezentacja faktów historycznych; można zatem przypuszczać, że świadectwa już zarejestrowane i archiwalne materiały będą podlegały coraz silniejszym przetworzeniom, a dawne wydarzenia historyczne - coraz silniejszej mitologizacji.

O tym, że cały czas temat resistenzy jest atrakcyjny dla twórców i publiczności, świadczy jego stała obecność we włoskim kinie, w tym projekty najnowsze - choćby telewizyjna wersja Generała Della Rovere, wyemitowana we włoskiej telewizji jesienią 2011. W tym samym roku włoska grupa rockowa Gang wydała album pod tytułem La Rossa primavera, w całości

${ }^{11} \mathrm{~W}$ ciągu ostatnich 12 lat powstały aż cztery nowe muzea poświęcone włoskiemu ruchowi oporu - w 2000 roku Museo audiovisivo della resistenza (Spezia); w 2002 roku Museo della resistenza (Ancona); w 2003 roku Museo diffuso della resistenza, della deportazione, della guerra, dei diritti e della libertà (Turyn) oraz w 2009 roku Museo della resistenza piacentina (Morfasso). 
poświęcony partyzanckim piosenkom; ukazały się także komiksy o włoskim ruchu oporu, m.in. Per la libertà. La Resistenza nel fumetto. Ostatnio wydano nawet ilustrowaną książkę dla dzieci przybliżającą im dziedzictwo ruchu oporu - Fulmine, un cane coraggioso, która opowiada o losach włoskich partyzantów z perspektywy tytułowego $\mathrm{psa}^{12}$.

Resistenza pozostanie zatem istotnym elementem postpamięci Włoch - przestrzenią działania śladu, który w dużej mierze decyduje o konstytucji tożsamości (tak jednostki, jak i grupy). Warto jednak przy tym pamiętać słuszną uwagę Gustawa Herlinga-Grudzińskiego, że

Włosi, co często się powtarza, są ludźmi bardzo szczególnymi, odpornymi na fanatyzm, skłonnymi w gruncie rzeczy traktować politykę i historię cum grano salis [...]. Jestem przekonany - podobnie jak jeden z moich przyjaciół, dziennikarz z „Corriere della Sera" - że gdyby cała Europa została nagle ogarnięta totalitarnym szaleństwem, to pozostawałby tylko jeden kraj, gdzie można by się schronić. Tym krajem byłyby Włochy ${ }^{13}$.

12 Anna Sarfatti, Michele Sarfatti, Fulmine, un cane coraggioso. La Resistenza raccontata ai bambini, Milan 2011.

${ }^{13}$ Gustaw Herling-Grudziński, Pod światło, Kraków 1998, s. 22. 



\section{Bibliografia}

Alemanno Roberto, Mussolini, ultimo atto "Cinema nuovo" 1974, nr 231; przedruk w: Gianfranco Casadio, La Guerra al cinema. I film di Guerra nel cinema italiano, t. I, Ravenna 1998.

Alvaro Corrado, L'Italia rinunzia?, Palermo 1986 (pierwszy raz opublikowane w 1944).

Andrzej Munk, red. Andrzej Jackiewicz, Warszawa 1964.

Angelino Eduardo, L'inverno dei Mongoli, Turin 1995.

Aprà Adriano, Il dopoguerra di Rossellini, Roma 1995.

Armes Roy, Patterns of Realism. A Study of Italian Neo-Realist Cinema, New Jersey 1971.

Assmann Aleida, Pięć strategii wypierania ze świadomości, tłum. Artur Pełka, [w:] Pamięć zbiorowa i kulturowa. Wspótczesna perspektywa niemiecka, red. Magdalena Saryusz-Wolska, Kraków 2010.

Atlante storico della Resistenza italiana, red. Luca Baldissara, Milan 2000.

Atti del Convegno di studi sulla resistenza nel cinema italiano del dopoguerra 24-27.04.1970, red. Camillo Bassotto, Venezia 1970.

Autorzy kina europejskiego IV, red. Alicja Helman, Andrzej Pitrus, Kraków 2008.

Autorzy kina europejskiego V, red. Alicja Helman, Andrzej Pitrus, Kraków 2009.

Autorzy kina europejskiego VI, red. Alicja Helman, Andrzej Pitrus, Warszawa 2011.

Baratter Lorenzo, Le Dolomiti del Terzo Reich, Milano 2005.

Bazin André, An Aesthetic of Realism: Neorealism. Cinematic Realism and the Italian School of Liberation, [w:] idem, What is cinema: Volume II, Berkeley 2004.

Bernardo Bertolucci w opinii krytyki zagranicznej, oprac. Tadeusz Miczka, Warszawa 1993.

Bernardo Bertolucci. Interviews, red. Fabien Gerard, Thomas Jefferson Kline, Bruce Sklarew, Mississippi 2000.

Bettetini Gianfranco, La conversazione audiovisiva. Problemi dell'enunciazione filmica e televisiva, Milano 1984.

Bignardi Irene, Porzus, „La Repubblica”, 1.09.1997.

Bocca Giorgio, Com'è falsa la resistenza di Fenoglio, „La Stampa”, 31.03.2007.

Bolongaro Eugenio, Why Truth Matters: Ideology and Ethics in Bertolucci's „The Spider's Stratagem", „Italian Culture” 2005, nr 23.

Bondanella Peter, Italian Cinema: From Neorealism to the Present, New York 2004.

Bondanella Peter, The Films of Roberto Rossellini, Cambridge 1993.

Bongioanni Marco, I film della resistenza, Torino 1965.

Bonino Bruno, Il cinema racconta la Resistenza, Torino 1979.

Bordwell David, Narration in the Fiction Film, Madison 1985.

Bordwell David, Thompson Kristin, Film Art: an Introduction, New York 1990.

Borges Jorge Luis, Temat zdrajcy i bohatera, [w:] idem, Fikcje, tłum. Kazimierz Piekarec, Andrzej Sobol-Jurczykowski, Kalina Wojciechowska, Stanisław Zembrzuski, Warszawa 1972.

Bracia Taviani: wspomnienia o letniej nocy (wywiad), „Film” 1983, nr 9.

Bravo Anna, Bruzzone Anna, In guerra senz'armi. Storie di donne 1940-'45, Roma-Bari 1995. 
Brunetta Gian Piero, Cent'Anni di cinema italiano, Roma-Bari 1995.

Brunetta Gian Piero, Il cinema come storia, [w:] La storia al Cinema. Ricostruzione del passato/ interpretazione del presente, red. Gianfranco Gori, Roma 1994.

Brunetta Gian Piero, Il cinema italiano contemporaneo da La dolce vita a Centochiodi, Bari 2007.

Brunetta Gian Piero, Il cinema neorealista italiano da "Roma città aperta" a "I soliti ignoti", Roma-Bari 2009.

Brunetta Gian Piero, Storia del cinema italiano, Laterza 2001.

Bruni David, Roberto Rossellini, Roma città aperta, Torino 2006.

Burgoyne Robert, The Hollywood Historical Film, Malden 2008.

Calvino Italo, Il sentiero dei nidi di ragno, Milano 1993.

Calvino Italo, Ścieżka pajęczych gniazd, tłum. Władysław Minkiewicz, Warszawa 1957.

Carlo Lizzani, Cinema, storia e storia del cinema, red. Gualtiero De Santi, Bernardo Valli, Napoli 2007.

Casadio Gianfranco, La Guerra al cinema. I film di Guerra nel cinema italiano, t. I-II, Ravenna 1998.

Cecchini Lucio, Per la libertà d'Italia, per L'Italia delle Libertà. Profilo storico dell'Associazione Nazionale Partigiani d'Italia, Roma 1996.

Celli Carlo, Cottino-Jones Marga, A New Guide to Italian Cinema, Palgrave 2007.

Cervi Alcide, Moich siedmiu synów, tłum. Maria Baranowicz, Warszawa 1963.

Chaluja Elias, Schadhauser Sebastian, Mingrone Gianna, A Conversation with Bertolucci, [w:] Bernardo Bertolucci. Interviews, red. Fabien Gerard, Thomas Jefferson Kline, Bruce Sklarew, Mississippi 2000.

Chapman James, Film historyczny - kino narodowe, „Kwartalnik Filmowy” 2005, nr 52.

Chiarini Luigi, Cinema senza realtà, „Il Contemporaneo” 1955, nr 37.

Cinema and Nation, red. Mette Hjort, Scott Mackenzie, London 2000.

Cinema, storia, resistenza, 1944-1985, red. Gian Piero Brunetta, Pierre Sorlin, Paolo Gobetti, Milano 1987.

Collin Richard, The De Lorenzo Gambit: the Italian Coup Manqué, Beverly Hills-London 1976.

Cooke Philip, The Italian State and the Resistance Legacy in the 1950s and 1960s, [w:] Culture, Censorship and the State in Twentieth-Century Italy, red. Guido Bonsaver, Robert S. C. Gordon, Oxford 2005.

Cooke Philip, The Legacy of the Italian Resistance, New York 2011.

Convegno di studi: La Resistenza nel cinema italiano del dopoguerra (La Biennale di Venezia, XXXI Mostra Internazionale d'Arte Cinematografica), red. Nedo Ivaldi, Venezia 1970.

Crisp Deborah, Hillman Roger, Verdi and Schoenberg in Bertolucci's "The Spider's Stratagem", "Music and Letters" 2001, nr 2 (82).

Culture, Censorship and the State in Twentieth-Century Italy, red. Guido Bonsaver, Robert S. C. Gordon, Oxford 2005.

Custen George, Bio/pics: How Hollywood Constructed Public History, New Yersey 1992.

Dalle Vacche Angela, The Body in the Mirror: Shapes of History in Italian Cinema, Princeton 1992.

Davies Natalie Zemon, Slaves on Screen: Film and Historical Vision, Cambridge 2000.

De Bosio Gianfranco, Il cinema della resistenza come dialettica aperta, „Filmcritica” 1966, nr 163.

De Carlo Andrea, Śmietankowy pociag, tłum. Halina Bernhardt-Kralowa, Warszawa 2007.

De Luna Giovanni, Fascismo/Antifascismo: le idee, le identità, Firenze 1995.

Dibattito su Rossellini, red. Gianni Menon, Roma 1972.

Dissolving Views: Key Writings of British Cinema, red. Andrew Higson, London 1996. 
Dizionario della Resistenza, vol. 1-2, red. Enzo Colotti, Renato Sandri, Frediano Sessi, Turin 2000-2001.

Eco Umberto, Mit amerykański trzech pokoleń nastawionych antyamerykańsko, [w:] idem, O literaturze, Warszawa 2003.

Eco Umberto, Sześć przechadzek po świecie fikcji, Kraków 1995.

Eco Umberto, Wieczny faszyzm, [w:] Pięć pism moralnych, tłum. Ireneusz Kania, Kraków 2007.

Edensor Tim, Tożsamość narodowa, kultura popularna i życie codzienne, tłum. Agata Sadza, Kraków 2004.

Ellwood David, Il cinema e la proiezione del modello Americano, [w:] Hollywood in Europa, red. Gian Piero Brunetta, Dawid Ellwood, Firenze 1991.

Encyklopedia kina, red. Tadeusz Lubelski, Kraków 2010.

Europejskie manifesty kina, red. Andrzej Gwóźdź, Warszawa 2002.

Faldini Franca, Fofi Goffredo, Il cinema italiano d'oggi, 1970-1984 raccontato dai suoi protagonisti, Milano 1984.

Faldini Franca, Fofi Goffredo, L' avventurosa storia del cinema italiano 1939-1959, Milano 1979.

Fantozzi Giovanni, Vittime dell'odio: l'ordine pubblico a Modena dopo la liberazione (1945-1946), Bologna 1990.

Fantuzzi Virgilio, Riflessi sull'iconografia religiosa nel film "Roma, città aperta" di Roberto Rossellini, „La Civiltà Cattolica” 1995, nr 3489.

Farell James T., Literature and Morality, New York 1946.

Felice Carlo, Avanti a lui tremava tutta Roma, „Film” 1946, nr 32; przedruk w: Ghigi Giuseppe, La memoria inquieta. Cinema e resistenza, Venezia 2009.

Fenoglio Beppe, Pewna prywatna sprawa, tłum. Krystyna i Eugeniusz Kabatcowie, Warszawa 1979.

Ferrero Adelio, Tiro al piccione, "Cinema Nuovo" 1962, nr 155; przedruk w: Casadio Gianfranco, La Guerra al cinema. I film di Guerra nel cinema italiano, t. II, Ravenna 1998.

Ferro Marc, Film. Kontranaliza społeczeństwa?, [w:] Film i historia, red. Iwona Kurz, Warszawa 2008.

Ferro Marc, Historycy i kino, „Kino” 1989, nr 10.

Ferro Marc, Kino i historia, tłum. Tomasz Falkowski, Warszawa 2011.

Film as History/History as Film, red. Patrick Vonderau, Florence-Berlin 1999.

Film i historia, red. Iwona Kurz, Warszawa 2008.

Fink Guido, Być czy istnieć; film włoski - czas i historia, "Cultures” 1974, nr 1; przedruk w: „Film na Świecie” 1980, nr 4.

Fink Guido, Essere o essere stati: il film italiano, il tempo, la storia, [w:] La storia al cinema. Ricostruzione del passato/interpretazione del presente, red. Gianfranco Gori, Roma 1994.

Forgacs David, Space, Rethoric and divided city in "Roma, città aperta", [w:] Roberto Rossellini's "Rome, Open City", red. Sidney Gottlieb, Cambridge 2004.

Franceschini Alberto, Mara, Renato e io. Storia dei fondatori delle BR, Milano 1988.

Franzinelli Mimmo, La resistenza e le provocazioni del sessantotto, „L'impegno” 2001, nr 2.

Franzinelli Mimmo, Le stragi nascoste. L'armadio della vergogna: impunità e rimozione dei crimini di guerra nazifascisti 1943-2001, Milano 2003.

Gallagher Tag, The Adventures of Roberto Rossellini: His Life and Film, New York 1998.

Galmozzi Luciano, Monumenti alla libertà. Antifascismo Resistenza e pace nei monumenti Italiani dal 1945 al 1985, Milan 1986.

Garbicz Adam, Kino wehikuł magiczny. Podróż czwarta 1967-1973, Kraków 2000. 
Garlicki Andrzej, Film wobec świadomości historycznej, „Kino” 1975, nr 10.

Genova in celluloide. Luoghi, protagonisti, storie, red. Claudio Bertieri, Marco Salotti, Genova 1983.

Gervasutti Sergio, Il giorno nero di Porzus, Venezia 1997.

Ghigi Giuseppe, La memoria inquieta. Cinema e resistenza, Venezia 2009.

Gili Jean, Le cinéma italien, Paris 1996.

Ginsborg Paul, A History of Contemporary Italy: Society and Politics, 1943-1980, Harmondsworth 1990.

Ginsborg Paul, Italy and its Discontents: Family, Civil Society, State 1980-2001, London 2001.

Ginsborg Paul, Storia d'Italia dal dopoguerra ad oggi, Torino 1990.

Giuliano Montaldo e L'Agnese va a morire, red. Laura Bonaparte, Milano 1976.

Giustolisi Franco, L'Armadio della vergogna, Roma 2004.

Gli atti delle rassegne e seminari "Il sole sorge ancora" ed "Europa ritrovata", red. Paola Olivetti, Torino 1995.

Grafton Anthony, The footnote: a curious history, Cambridge 1999.

Grimaldi Ugoberto, Marina Saba, Cultura a passo romano, Milan 1983.

Grindon Leger, Shadows on the Past: Studies in the Historical Fiction Film, Philadelphia 1994.

Guidetti Serra Bianca, Compagne, Torino 1978.

Helman Alicja, Roberto Rossellini: neorealizm bez granic, [w:] Autorzy kina europejskiego IV, red. Alicja Helman, Andrzej Pitrus, Kraków 2008.

Helman Alicja, Urok zmierzchu. Filmy Luchina Viscontiego, Gdańsk 2001.

Hendrykowski Marek, Film jako źródło historyczne, Poznań 2000.

Herling-Grudziński Gustaw, Pod światło, Kraków 1998.

Higson Andrew, The Heritage Film and British Cinema, [w:] Dissolving Views: Key Writings of British Cinema, red. Andrew Higson, London 1996.

Historia literatury włoskiej, red. Joanna Ugniewska, Warszawa 2001.

Historia w kulturze wspótczesnej, red. Piotr Witek, Mariusz Mazur, Ewa Solska, Lublin 2011.

Hollywood in Europa, red. Gian Piero Brunetta, Dawid Ellwood, Firenze 1991.

Ignazi Piero, Il polo escluso. Profilo storico del Movimento Sociale Italiano, Bologna 1989.

Il cinema di Bertolucci, red. Antonio Marali, Cesena 1991.

Il cinema italiano degli anni 50., red. Giorgio Tinazzi, Venezia 1979.

Il libro degli anni di piombo. Storia e memoria del terrorismo italiano, red. Marc Lazar, Marie-Anne Matard-Bonucci, Milano 2010.

Italian Fascism. History, Memory and Representations, red. Robert Bosworth, Patrizia Dogliani, London 1999.

Jackiewicz Aleksander, Temat zdrajcy $i$ bohatera u Borgesa $i$ w filmie Bertolucciego, „Kino” 1973, nr 1.

Jackson Martin A., Historyk i kino, „Film na Świecie” 1980, nr 4.

Kezich Tullio, Il Millefilm, Milano 1980.

Kezich Tullio, Porzus, „Corriere della Sera”, 19.03.1997.

Klejsa Konrad, Filmowe oblicza kontestacji, Warszawa 2008.

Kline Thomas Jefferson, Bertolucci's Dream Loom: Psychoanalytic Study of Cinema, Amherst 1987.

Kłys Tomasz, Film fikcji i jego dominanty, Warszawa 1999.

Kolker Robert P., Bernardo Bertolucci, Oxford 1985.

Koniczek Ryszard, Nasz film historyczny, „Kino” 1975, nr 6.

Korycka Jadwiga, Badania audytorium filmowego we Włoszech, „Kino” 1978, nr 7.

Kossak Jerzy, Kino Pasoliniego, Warszawa 1976. 
Kowalczuk Piotr, Z krwią rodaków na rękach, „Uważam Rze. Historia”, 13.06.2012.

Kracauer Siegfried, Theory of Film. The Redemptions of Physical Reality, Princeton 1997.

Kula Witold, Rozważania o historii, Warszawa 1958.

L' avventurosa storia del cinema italiano raccontata dai suoi protagonisti. 1960-1969, red. Franca Faldini, Goffredo Fofi, Milano 1981.

L'immagine della Resistenza in Europa: 1945-1960. Letteratura, cinema, arti figurative, red. Pierre Sorlin, Luisa Cigognetti, Lorenza Servetti, Bologna 1996.

La resistenza nel cinema italiano 1945-1995, red. Mauro Manciotti, Aldo Viganò, Genova 1995.

La resistenza taciuta. Dodici vite di partigiane piemontesi, red. Anna Bruzzone, Rachele Farina, Torino 1976.

La storia al Cinema. Ricostruzione del passato/interpretazione del presente, red. Gianfranco Gori, Roma 1994.

La storia sullo schermo, il Novecento, red. Pasquale Iaccio, Coscenza 2004.

Lagny Michèle, Film history: or history expropriated, „Film History” 1994, nr 6.

Lanaro Silvio, Storia dell'Italia repubblicana: dalla fine della guerra agli anni novanta, Venezia 1992.

Landy Marcia, Italian Film, Cambridge 2000.

Le Goff Jacques, Historia i pamięć, tłum. Anna Gronowska, Joanna Stryjczyk, Warszawa 2007.

Leprohon Pierre, Le cinéma italien, Paris 1967.

Lettere di condannati a morte della Resistenza italiana, red. Piero Malvezzi, Giovanni Pirelli, Torino 1952.

Lichtner Giacomo, Fascism in Italian Cinema since 1945, New York 2013.

Longo Luigi, Sulla via dell'insurezione nazionale, Roma 1954.

Lopez Daniel, Films by Genre: 777 Categories, Styles, Trends and Movements Defined, with a Filmography for each, North Carolina 1993.

Loshitzky Yosefa, The Radical Faces of Godard and Bertolucci, Michigan 1995.

Luzzatto Sergio, La crisi dell'antifascismo, Turin 2004.

Łepkowski Tadeusz, Kilka uwag o filmowej historii. Wokót prawdy, fatszów i przemilczeń, „Kino" 1981, nr 09.

Majewski Tomasz, Zobaczyć Gorgonę. Siegfried Kracauer i teoria filmu po Zagładzie, „Kwartalnik Filmowy" 2009, nr 67-68.

Marcus Milicent, Italian Film in the Light of Neorealism, Princeton 1986.

Mario Serandrei. Giorni di gloria, red. Laura Gaiardoni, Roma 1998.

Marszałek Rafał, Film i historia (I), „Kino” 1981, nr 1-2.

Marszałek Rafał, Filmowa pop-historia, Kraków 1984.

Marszałek Rafał, Kino rzeczy znalezionych, Gdańsk 2006.

Marszałek Rafał, Krajobraz przed bitwa. Aktualności historii, „Kino” 2006, nr 2.

Marszałek Rafał, Polska wojna w obcym filmie, Wrocław 1976.

Maurizio Cabona, Piccoli maestri, „Il Giornale”, 8.09.1998.

Medici Antonio, Gli anni della censura, [w:] Carlo Lizzani, Cinema, storia e storia del cinema, red. Gualtiero De Santi, Bernardo Valli, Napoli 2007.

Memoria, mito, storia. La parola ai registi, 37 interviste, red. Alessandro Amaducci, Torino 1994.

Meyer Schapiro, A Note on "The Open City", „New International” 1946; przedruk w: James T. Farell, Literature and Morality, New York 1946.

Micciché Lino, Film i historia, „Kino” 1981, nr 7.

Micciché Lino, Filmologia e filologia: studi sul cinema italiano, Venezia 2002. 
Micciché Lino, Il cinema, la storia, la storia del cinema, Venezia 1996.

Micciché Lino, Il cinema italiano degli anni '60, Venezia 1975.

Micciché Lino, Il cinema italiano degli anni'70, Venezia 1980.

Micciché Lino, Kino włoskie - w oczekiwaniu na Godota, tłum. Wanda Wertenstein, „Kino” 1976, nr 2.

Michalczyk John, The Italian political filmmakers, Rutherford 1986.

Michalski Andrzej, Świat w teatrze Bernarda Bertolucciego, „Kwartalnik Filmowy” 2000, nr 31-32.

Michałek Bolesław, Jednostka i mechanizmy historii, „Kino” 1973, nr 10.

Miczka Tadeusz, $10000 \mathrm{~km}$ od Hollywood. Historia kina włoskiego od 1896 roku do połowy lat 50. XX wieku, Kraków 1992.

Miczka Tadeusz, Kino włoskie, Gdańsk 2009.

Miczka Tadeusz, W Cinecittà i okolicach. Historia kina włoskiego od połowy lat pięćdziesiatych do końca lat osiemdziesiatych XX wieku, Kraków 1993.

Mida Massimo, Per un film sui partigiani, „Charlie Chaplin” 1944; przedruk w: Giuseppe Ghigi, La memoria inquieta. Cinema e resistenza, Venezia 2009.

Miller Anna, Fabularyzacje zabójstwa Aldo Moro w filmie włoskim, [w:] Przeszłość we wspótczesnej narracji kulturowej, red. Andrzej Plichta, Kraków 2012.

Miller Anna, Marco Ferreri: kultura w stanie rozkładu, [w:] Autorzy kina europejskiego VI, red. Alicja Helman, Andrzej Pitrus, Warszawa 2011.

Miller Anna, „Przypadkowa śmierć anarchisty”. Tzw. sprawa Pinellego i jej fabularyzacja w włoskich tekstach kultury, [w:] Historia w kulturze wspótczesnej, red. Piotr Witek, Mariusz Mazur, Ewa Solska, Lublin 2011.

Miller-Klejsa Anna, Noc Świętego Wawrzyńca. Cienie (zapomnianych) przodków, „Kwartalnik Filmowy" 2013, nr 81.

Minervini Gianni, Venezia esclude il mio film perché da fastidio a Pontecorvo, „La Reppublica”, 1.08.1992.

Miti e storia dell'Italia unita, red. Giovanni Sabbatucci, Giovanni Belardelli, Luciano Cafagna, Bologna 1999.

Monticelli Simona, National Identity and Representation of Italy at War: The Case of Cobat Film, „Modern Italy" 2000, nr 5.

Moretti Mario, Brigate Rosse. Una storia italiano, Milano 2007.

Morgoglione Claudia, Tutti gli orrori dei partigiani nel film più discusso del Festiwal, „La Repubblica", 26.10.2008.

Morley David, Robins Kevin, Spaces od Identity: Global Media, Electronic Landscapes and Cultural Boundaries, London 1995.

Moro Agnese, Un uomo così, Milan 2003.

Nanni Loy un regista fattapposta, red. Antioco Floris, Paola Ugo, Cagliari 1996.

Non solo Scipione: il cinema di Carmine Gallone, red. Pasquale Iaccio, Roberto Calabretto, Napoli 2003.

Noto Paolo i Pitassio Francesco, Il cinema neorealista, Firenze 2010.

Od Manzoniego do Maraini. Ekranizacje literatury włoskiej, red. Artur Gałkowski, Anna Miller-Klejsa, Łódź 2012.

O’Leary Alan, Tragedia all'italiana. Cinema e terrorismo tra Moro e Memoria, Tissi 2007.

Ozimska Joanna, Ulica ubogich kochanków: literacki świat via del Corno na cenzurowanym, [w:] Od Manzoniego do Maraini. Ekranizacje literatury włoskiej, red. Artur Gałkowski, Anna Miller-Klejsa, Łódź 2012. 
Palmieri Eugenio, Un giorno nella vita, „Film”, 1.06.1946, przedruk w: Ghigi Giuseppe, La memoria inquieta. Cinema e resistenza, Venezia 2009.

Pamięć, etyka, historia, red. Ewa Domańska, Poznań 2002.

Pamięć zbiorowa i kulturowa. Współczesna perspektywa niemiecka, red. Magdalena Saryusz-Wolska, Kraków 2010.

Pansa Giampaolo, Il sangue dei vinti, Milan 2003.

Pansa Giampaolo, Gendarmi della memoria, Milan 2007.

Pansa Giampaolo, I Vinti non dimenticano, Milan 2010.

Pansa Giampaolo, La grande bugia, Milan 2006.

Pansa Giampaolo, Ma l'amore no, Milan 1994.

Paolo e Vittorio Taviani: poetry of the Italian landscape, red. Riccardo Ferucci, Patrizia Turini, Roma 1995.

Paolo i Vittorio Taviani. Próba bliższego poznania (wywiad), „Film” 1987, nr 18.

Pasolini Pier Paolo, L'anno del „Generale Della Rovere”, „Il reporter”, 5.01.1960.

Pasolini Pier Paolo, Po ludobójstwie. Eseje o języku, polityce i kinie, tłum. Anna Mętrak, Izabela Napiórkowska, Mateusz Salwa, Warszawa 2012.

Pasolini: tak pięknie jest śnić, red. Andrzej Pitrus, Kraków 2002.

Past Imperfect: History According to the Movies, red. Mark Carnes, New York 1996.

Pavone Claudio, Guerra civile. Saggio storico sulla moralità nella Resistenza, Roma 1995.

Pecchioli Ugo, Perché si è riaperto il dibattito su fascismo e antifascismo, „Rinascita” 1985, nr 8-9.

Pescatore Guglielmo, La voce e il corpo. L'opera lirica al cinema, Udine 2001.

Pesce Sara, Memoria e immaginario. La seconda guerra mondiale nel cinema italiano, Genova 2008.

Petricelli Assunta, Da „Achtung! Banditi!" a „Maria José": La Resistenza nei film di Lizzani, [w:] La storia sullo schermo, il Novecento, red. Pasquale Iaccio, Coscenza 2004.

Petter Guido, Ci chiamavano banditi, Firenze 1995.

Pezzino Paolo, Il massacro. Guerra ai civili a Monte Sole, Bologna 2009.

Piccioni Sergio, Roma 1944: le Fosse Ardeatine, Firenze 1968.

Płażewski Jerzy, Historia filmu 1985-2005, Warszawa 2007.

Płażewski Jerzy, Na ekranie - historia, „Kino” 1978, nr 4.

Pomian Krzysztof, Historia. Nauka wobec pamięci, Lublin 2006.

Portelli Alessandro, L'ordine è già stato eseguito. Roma, le Fosse Ardeatine, la memoria, Roma 1999.

Przeszłość we współczesnej narracji kulturowej, red. Andrzej Plichta, Kraków 2012.

Przylipiak Mirosław, „Narracja”, [w:] Stownik pojęć filmowych, t. 5, red. Alicja Helman, Kraków 1993.

Quaglietti Lorenzo, Storia economico politica del cinema italiano 1945-1980, Roma 1980.

Reich Wilhelm, The Mass Psychology of Fascism, New York 1970.

Revisioning History. Film and the Construction of a New Past, red. Robert A. Rosenstone, Princeton 1995.

Revisioning Italy: National Identity and Global Culture, red. Beverly Allen, Paolo Russo, Mineapolis 1997.

Ricoeur Paul, Czas i opowieść, t. 3: Czas opowiadany, tłum. Urszula Zbrzeźniak, Kraków 2008.

Ricoeur Paul, Pamięć, historia, zapomnienie, tłum. Janusz Margański, Kraków 2006.

Roberto Rossellini's „Rome, Open City”, red. Sidney Gottlieb, Cambridge 2004.

Rondolino Gianni, L'antifascismo nel cinema italiano, "Il nuovo spettatore cinematografico" 1963, nr 4.

Rondolino Gianni, Rossellini, Torino 1989. 
Rosenstone Robert A., Historia w obrazach/historia w słowach: rozważania nad możliwościa przedstawienia historii na taśmie filmowej, [w:] Film i historia, red. Iwona Kurz, Warszawa 2008.

Rosenstone Robert A., The Historical Film: Looking at the Past in a Postliterate Age, [w:] The Historical Film: History and Memory in Media, red. Marcia Landy, New Brunswick, New Jersey 2001.

Rosenstone Robert A., Visions of the Past: The Challenge of Film to Our Idea of History, Cambridge 1995.

Rosner Katarzyna, Narracja, tożsamość i czas, Kraków 2006.

Salvatorelli Luigi, Pensiero e azione nel Risorgimento, Turin 1943.

Sassoon Donald, The Strategy of the Italian Communist Party: From the Resistance to the Historic Compromise, London 1981.

Schwarz Vanessa R., Film and History, [w:] The Sage Handbook of Film Studies, red. James Donald, Michael Renov, Los Angeles 2008.

Secchia Pietro, I comunisti e l'insurrezione: 1943-1945, Roma 1954.

Silj Alessandro, Malpaese. Criminalità, corruzione e politica nell'Italia della prima Repubblica 1943-1994, Roma 1994.

Sitney P. Adams, Vital Crises in Italian Cinema, Austin 1995.

Skotarczak Dorota, Media audiowizualne w warsztacie historyka, Poznań 2008.

Skotarczak Dorota, Obraz społeczeństwa PRL w komedii filmowej, Poznań 2004.

Słownik pojęć filmowych, t. 5, red. Alicja Helman, Kraków 1993.

Sobchack Vivian, "Surge and Splendor". A Phenomenology of the Hollywood Historical Epic, „Representations” 1990, nr 29.

Sobolewski Tadeusz, Obsesja historii. Prawda i pojednanie, „Kino” 2007, nr 6.

Sommier Isabelle, La storia infinita: implicazioni e limiti delle interpretazioni degli anni di piombo, [w:] Il libro degli anni di piombo. Storia e memoria del terrorismo italiano, red. Marc Lazar, Marie-Anne Matard-Bonucci, Milano 2010.

Sontag Susan, O fotografii, tłum. Sławomir Magala, Kraków 2009.

Sorlin Pierre, Cinema e identità europea. Percorsi nel secondo novecento, Firenze 2001.

Sorlin Pierre, Di qua e di là delle Alpi: come è stata rappresentata la Resistenza, [w:] Cinema, storia, resistenza, 1944-1985, red. Gian Piero Brunetta, Pierre Sorlin, Paolo Gobetti, Milano 1987.

Sorlin Pierre, Klio na ekranie albo historyk w mroku, „Film na Świecie” 1980, nr 4.

Sorlin Pierre, The Film in History. Restaging the Past, Oxford 1980.

Sorlin Pierre, The Night of the Shooting Stars. Fascism, Resistance and the Liberation of Italy, [w:] Revisioning History. Film and the Construction of a New Past, red. Robert A. Rosenstone, Princeton 1995.

Staron Joachim, Fosse Ardeatine e Marzabotto. Storia e memoria di due stragi tedesche, Bologna 2007.

Storchi Massimo, Il sangue dei vincitori: Saggio sui Rimini fascisti e i processi del dopoguerra 1945-1946, Reggio Emilia 2008.

Strategia nonkonformisty według Bertolucciego (fragmenty wywiadu, który Enzo Ungari przeprowadził z Bernardem Bertoluccim), [w:] Bernardo Bertolucci w opinii krytyki zagranicznej, oprac. Tadeusz Miczka, Warszawa 1993.

Szacka Barbara, Czas przeszły, pamięć, mit, Warszawa 2006-2007.

Tassone Aldo, Parla il cinema italiano II, Milano 1980.

The Future of Literary Theory, red. Ralph Cohen, New York-London 1989.

The Historical Film: History and Memory in Media, red. Marcia Landy, New Brunswick, New Jersey 2001. 
The Sage Handbook of Film Studies, red. James Donald, Michael Renov, Los Angeles 2008.

Tonetti Claudia, Bernardo Bertolucci: the Cinema of Ambiguity, New York 1995.

Toplin Robert, History by Hollywood. The use and abuse of the American Past, Urbana 1996.

Torlasco Domietta, The Time Of The Crime: Phenomenology, Psychoanalysis, Italian Film, Stanford 2008.

Torriglia Anna Maria, Broken Time, Fragmented Space. A cultural map for Postwar Italy, Toronto 2002.

Tra emozione e ragione. Il cinema di Guido Chiesa, red. Domenico De Gaetano, Torino 2000.

Uva Christian, Schermi di piombo. Il terrorismo nel cinema italiano, Rubbettino 2007.

Viganò Renata, Agnieszka idzie na śmierć, przeł. B. Sieroszewska, Warszawa 1955.

Villa Federica, A writer cannot believe two stories at once: Modes of adaptation in "La lunga notte del '43" (Florestano Vancini, 1960), [w:] Watching Pages, Reading Pictures, red. Daniela De Pau, Georgina Torcello, Cambridge 2008.

Vittorio De Sica: Contemporary perspectives, red. Stephen Snyder, Howard Curle, Toronto 2000.

Vonderau Patrick, Historiography and Film: A Dangerous Liasion?, [w:] Film as History/History as Film, red. Patrick Vonderau, Florence-Berlin 1999.

Wagner Ryszard, Film fabularny jako źródło historyczne, „Kultura i Społeczeństwo” 1974, nr 2, t. XVIII.

Wagstaff Christopher, Il cinema europeo e la resistenza, [w:] L'immagine della Resistenza in Europa: 1945-1960. Letteratura, cinema, arti figurative, red. Pierre Sorlin, Luisa Cigognetti, Lorenza Servetti, Bologna 1996.

Wagstaff Christopher, Italian neorealist cinema: an aestethic approach, Toronto 2007.

Watching Pages, Reading Pictures, red. Daniela De Pau, Georgina Torcello, Cambridge 2008.

White Hayden, Figuring the Nature of the Times Deceased: Literary Theory and Historical Writing, [w:] The future of Literary Theory, red. Ralph Cohen, New York-London 1989.

White Hayden, Historiografia $i$ historiofotia, [w:] Film i historia, red. Iwona Kurz, Warszawa 2008.

White Hayden, Metahistory. The Historical Imagination in Nineteenth-Century Europe, Baltimore-London 1973.

White Hayden, Poetyka pisarstwa historycznego, red. Ewa Domańska, Marek Wilczyński, Kraków 2000.

Witek Piotr, Kultura - film - historia. Metodologiczne problemy doświadczenia audiowizualnego, Lublin 2005.

Wyke Maria, Projecting the Past: Ancient Rome, Cinema and History, London 1997.

Zalewski Andrzej, Meandry czasu teraźniejszego, „Kwartalnik Filmowy” 2001, nr 34.

Zambetti Sandro, Corbari, „Cineforum” 1970, nr 97-98.

Zampa Luigi, Il successo, Roma 1957.

Zavattini Cesare, Neorealizm według mnie, tłum. Krystyna Wojtynek-Musik, [w:] Europejskie manifesty kina, red. Andrzej Gwóźdź, Warszawa 2002.

Zwierzchowski Piotr, Pisanie historii, konstruowanie pamięci, [w:] Historia w kulturze wspótczesnej, red. Piotr Witek, Mariusz Mazur, Ewa Solska, Lublin 2011. 



\section{Metryki analizowanych filmów}

\section{Człowiek, który nadejdzie (L'uomo, che verrà)}

reż. Giorgio Diritti

scen. Giorgio Diritti, Tania Pedroni

zdj. Roberto Cimatti

muz. Marco Biscarini, Daniele Furlati

wyk. Maya Sansa (Lena), Alba Rohrwacher (Beniamina), Claudio Casadio (Armando),

Greta Zuccheri Montanari (Martina), Maria Grazia Naldi (Vittoria)

Włochy 2009

\section{Generat Della Rovere (Generale Della Rovere)}

reż. Roberto Rossellini

scen. Indro Montanelli, Roberto Rossellini, Sergio Amidei, Diego Fabbri

zdj. Carlo Carlini

muz. Renzo Rossellini

wyk. Vittorio De Sica (Vittorio Emanuele Bardone/Grimaldi), Hannes Messemer (pułkownik Müller), Vittorio Caprioli (Aristide Banchelli), Giovanna Ralli (Valeria), Sandra Milo (Olga)

Włochy 1959

\section{Noc świętego Wawrzyńca (Notte di San Lorenzo)}

reż. Paolo i Vittorio Taviani

scen. Paolo i Vittorio Taviani, Tonino Guerra

zdj. Franco Di Giacomo

muz. Nicola Piovani

wyk. Omero Antonutti (Galvano), Margarita Lozano (Concetta), Claudio Bigagli (Corrado), Miriam Guidelli (Belindia), Massimo Bonetti (Nicola), Enrica Maria Modugno (Mara), Sabina Vannucchi (Rosanna), Micol Guidelli (Cecilia)

Włochy 1982

\section{Rzym, miasto otwarte (Roma, città aperta)}

reż. Roberto Rossellini

scen. Roberto Rossellini, Sergio Amidei, Federico Fellini 
zdj. Ubaldo Arata

muz. Renzo Rossellini

wyk. Anna Magnani (Pina), Aldo Fabrizi (Don Pietro), Marcello Pagliero (Luigi Ferraris, alias inżynier Giorgio Manfredi), Maria Michi (Marina Mari)

Włochy 1945

\section{Strategia pająka (Strategia del ragno)}

reż. Bernardo Bertolucci

scen. na motywach opowiadania Jorgego Luisa Borgesa Temat zdrajcy i bohatera: Bernardo Bertolucci, Edoardo De Gregorio

zdj. Vittorio Storaro

muz. fragmenty muzyki Giuseppe Verdiego

wyk. Giulio Brogi (Athos Magnani, ojciec i syn), Alida Valli (Draifa), Tino Scotti (Costa), Pippo Campanini (Gaibazzi), Franco Giovanelli (Rasori)

Włochy 1970 


\section{Indeks filmów}

1860 (reż. A. Blasetti, 1934) 61

1943: wybór (1943: la scelta, reż. M. Calopresti, 1993) 217

Achtung! Banditi! (reż. C. Lizzani, 1951) 81, 88, 90

Agnieszka idzie na śmierć (Agnese va a morire, reż. G. Montaldo, 1977) 84, 154, 157, 159, 247

Akcja pod Arsenałem (reż. J. Łomnicki, 1978) 34

Aleksander Newski (Александр Невский, reż. S. Eisenstein, 1938) 59

Aldo mówi $26 \times 1$ (Aldo dice 26x1, reż. F. Cerchio, 1945) 88

Allonsanfan (reż. P. i V. Taviani, 1974) 61

Amarcord (reż. F. Fellini, 1973) 155

Baaria (reż. G. Tornatore, 2009) 218

Bitwa o Algier (Battaglia di Algeri, reż. G. Pontecorvo, 1965) 34

Bohaterski atak (Carica Eroica, reż. F. De Robertis, 1952) 83

Byliśmy tacy zakochani (C'eravamo tanti amati, reż. E. Scola, 1974) 163

Cabiria (reż. G. Pastrone, 1914) 113

Casanova Federico Felliniego (Casanova di Federico Fellini, reż. F. Fellini, 1976) 155

Che! (reż. R. Fleischer, 1970) 168

Chleb, pokój, wolność 1943/1945 (Pane, pace, libertà 1943/1945, reż. M. Calopresti, 1994) 217

Cienka czerwona linia (The Thin Red Line, reż. T. Malick, 1998) 225

Corbari (reż. V. Orsini, 1970) 154, 164, 166, 168, 243, 248

Cud w Mediolanie (Miracolo a Milano, reż. V. De Sica, 1951) 142

Czapajew (Чanaes, reż. S. i G. Wasiljew, 1934) 44

Czarci Żleb (reż. T. Kański, A. Vergano, 1949) 84

Czas Apokalipsy (Apocalipse now, reż. F. Coppola, 1979) 156

Czerwone ziemie (Terre rosse, reż. D. Dellai, 2008) 218

Czerwony goździk (Uova di garofano rosso, reż. S. Agosti, 1991) 247

Człowiek, który nadejdzie (L'uomo, che verrà, reż. G. Diritti, 2009) 5, 13, 233, 234, 236, 237, 239, 241, 243, 247, 248, 261

Człowiek z marmuru (reż. A. Wajda, 1976) 71, 73

Cztery dni Neapolu (Quattro giornate di Napoli, reż. N. Loy, 1962) 131-133

Dam milion (Darò un millione, reż. M. Camerini, 1935) 145

Danton (reż. A. Wajda, 1982) 59

Django (reż. S. Corbucci, 1966) 113

Dtuga noc 1943 (Lunga notte del 1943, reż. F. Vancini, 1960) 114, 125, 127

Do broni, jesteśmy faszystami (All'armi siam fascisti, reż. L. De Fra, L. Micciché, 1962) 154

Drzewo na saboty (L'albero degli zoccoli, reż. E. Olmi, 1977) 156, 235

Dzieci ulicy (Sciuscià, reż. V. De Sica, 1946) 142 
Dzień lwów (Un giorno da leoni, reż. N. Loy, 1961) 115, 118, 121, 245

Dziękuje, ciociu (Grazie, zia, reż. S. Samperi, 1968) 134

Dzika krew (Sangue pazzo, reż. M. Giordana, 2008) 232, 233, 243

Ewangelia wedtug Mateusza (ll vangelo secondo Matteo, reż. P. P. Pasolini, 1964) 168

Eroica (reż. A. Munk, 1957) 151, 152

Federale (reż. L. Salce, 1961) 115, 118, 120, 121, 141, 244, 245

Fiołki we włosach (Violette nei capelli, reż. C. Bragaglia, 1941) 127

Forrest Gump (reż. R. Zemeckis, 1994) 74

Gandhi (reż. R. Attenborough, 1982) 49

Gangsterzy (Gangsters, reż. M. Giulielmi, 1993) 199

Garbus (Il Gobbo, reż. C. Lizzani, 1960) 124

Gdzie indziej jestem (I'm not there, reż. T. Haynes, 2007) 68

Generat Della Rovere (Generale Della Rovere, reż. R. Rossellini, 1959) 5, 12, 118, 128, 136, 137,

$139,140,142,145-149,151,152,245,261,277$

Generat Della Rovere (reż. C. Carlei, 2011) 248

Gorzki ryż (Riso amaro, reż. G. De Santis, 1949) 84, 88, 97

Gwiezdne wojny (Star Wars, reż. G. Lucas, 1977) 207

Henryk V (Henry V, reż. L. Olivier, 1944) 60

Hiroszima moja miłość (Hiroshima mon amour, reż. A. Resnais, 1959) 56

Hitler: film z Niemiec (Hitler - ein Film aus Deutschland, reż. H. Syberberg, 1977) 56

Jak zostać królem (King's Speech, reż. T. Hopper, 2010) 73

Jeden dzień z życia (Un giorno nella vita, reż. A. Blasetti, 1946) 87

JFK (reż. O. Stone, 1991) 34, 73

Joanna D'Arc (reż. L. Besson, 1999) 72

Kapò (reż. G. Pontecorvo, 1960) 84, 114

Katyń (reż. A. Wajda, 2007) 65

Kino Paradiso (Nuovo cinema Paradiso, reż. G. Tornatore, 1989) 196

Klasa robotnicza idzie do raju (La classe operaia va in paradiso, reż. E. Petri, 1971) 156

Kłamstwo Marzabotto (La menzogna di Marzabotto, reż. C. Di Carlo, 1961) 234

Kobiety w cieniu (Donne nell'ombra, reż. Marco Melega, 1995) 217

Konformista (Conformista, reż. B. Bertolucci, 1970) 178

Kopia mistrza (Copying Beethoven, reż. A. Holland, 2006) 65

Korzenie wolności (Le radici della libertà, reż. E. Olmi, C. Stajano, 1972) 154

Krew zwyciężonych (Il sangue dei vinti, reż. M. Soavi, 2008) 221-223

Kroniki filmowe partyzantów (Cinecronache partigane, reż. D. Gaglianone, 1996) 218

Królowa Margot (La Reine Margot, reż. Jeana Dreville, 1953) 42

Królowa Margot (La Reine Margot, reż. Partice Chereau, 1993) 42

Krzyżacy (reż. A. Ford, 1960) 70

La strada (reż. F. Fellini, 1954) 80

Libera, moja miłość (Libera, amore mio, reż. M. Bolognini, 1973) 84, 160, 161, 243, 247

Ludwig (reż. L. Visconti, 1972) 155

Ludzie czy nie (Uomini e no, reż. V. Orsini, 1980) 195, 196 
Mafia nie przebacza (Uomo da bruciare, reż. P. i V. Taviani, V. Orsini, 1962) 167

Malena (reż. G. Tornatore, 2000) 218

Mali mistrzowie (Piccoli maestri, reż. D. Luchetti, 1998) 218, 219, 226

Masakra w Rzymie (Rappresaglia, reż. G. Cosmatos, 1973) 154, 168, 170, 173, 243

Matka i córka (Ciociara, reż. V. De Sica, 1960) 114, 247

Matka Królów (reż. J. Zaorski, 1982) 65

Mefisto (reż. I. Szabó, 1981) 233

Mężczyźni, co za łajdacy! (Gli uomini, che mascalzoni!, reż. L. Comencini, 1932) 145

Mroczny przedmiot pożądania (Cet obscur objet du désir, reż. L. Buñuel, 1977) 68

Mussolini, ostatni akt (Mussolini, ultimo atto, reż. C. Lizzani, 1974) 173, 175

Napoleon (reż. A. Gance, 1927) 34

Nasienie mężczyzny (Seme dell'uomo, reż. M. Ferreri, 1969) 155

Niebezpieczne zwiazki (Liaisons dangereuses, reż. S. Frears, 1988) 64

Niemcy, rok zerowy (Germania anno zero, reż. R. Rossellini, 1948) 140, 203

Nietolerancja (Intolerance, reż. D. W. Griffith, 1916) 42

Nieuczciwa konkurencja (Concorenza Sleale, reż. E. Scola, 2001) 218

Noc nad Rzymem (Era Notte a Roma, reż. R. Rossellini, 1960) 114, 128, 129

Noc świętego Wawrzyńca (Notte di San Lorenzo, reż. P. i V. Taviani, 1982) 5, 13, 14, 72, 195, 201, 204, 205, 207, 209, 211-214, 243, 247, 248, 261

Obywatel Kane (Citizen Kane, reż. O. Welles, 1941) 67

Ojciec chrzestny II (The Godfather II, reż. F. Coppola, 1974) 156

Okno na podwórze (Rear Window, reż. A. Hitchcock, 1954) 126

Opuszczeni (Sbandati, reż. F. Maselli, 1955) 90

O sole mio (reż. G. Gentilomo, 1946) 132

Paisà (reż. R. Rossellini, 1946) 93-96, 136, 159, 214, 230, 234, 244

Palace niebo (Il cielo brucia, reż. G. Masini, 1957) 83

Pancernik Potiomkin (Броненосеи Потёмкин, reż. S. Eisenstein, 1925) 192

Pan Wotodyjowski (reż. J. Hoffman, 1968) 70

Partner (Sosia, reż. B. Bertolucci, 1968) 178

Partyzant Johnny (Partigiano Johnny, reż. G. Chiesa, 2000) 218, 223-226

Perlasca - włoski bohater (Perlasca - un eroe italiano, reż. A. Negrin, 2002) 230

Pewna prywatna sprawa (Una questione privata, reż. G. Trentin, 1966) 154, 224

Pięści w kieszeni (Pugni in tasca, reż. M. Bellocchio, 1965) 153

Pistolet dla Ringa (Pistola per Ringo, reż. D. Tessari, 1965) 113

Plan gwiazd (Pian delle stelle, reż. G. Ferroni, 1946) 87

Podróż do Indii (A Passage to India, reż. D. Lean, 1984) 33

Podróż do Nowej Ziemi (The New World, reż. T. Malick, 2005) 34

Podróż do Włoch (Viaggio in Italia, reż. R. Rossellini, 1954) 100, 136

Pogarda (Mépris, reż. J.-L. Godard, 1963) 191

Porzus (reż. R. Martinelli, 1997) 227, 229, 230, 243

Potop (reż. J. Hoffman, 1974) 34

Potwory (Mostri, reż. D. Risi, 1963) 114

Powiększenie (Blow up, reż. M. Antonioni, 1966) 178 
Prywatne życie Henryka VIII (The private Life of Henry VIII, reż. A. Korda, 1933) 60

Przed nim drżał cały Rzym (Avanti a lui tremava tutta Roma, reż. C. Gallone, 1946) 85-87

Przed rewolucja (Prima della rivoluzione, reż. B. Bertolucci, 1964) 153, 178

Przejście nad Renem (Passage du Rhin, reż. A. Cayatte, 1960) 114

Przeminęło z wiatrem (Gone With the Wind, reż. V. Fleming, 1939) 64, 179

Przestuchanie (reż. R. Bugajski, 1982) 65

Quo vadis (reż. E. Guazzoni, 1913) 34

Rocco i jego bracia (Rocco e i suoi fratelli, reż. L. Visconti, 1960) 113, 114

Rodzina (Familia, reż. E. Scola, 1986) 196

Rok pierwszy (Anno uno, reż. R. Rossellini, 1974) 175-177, 243

Rozdarte niebo (Cielo cade, reż. A. Frazzi, 2000) 218

Różyczka (reż. J. Kidawa-Błoński, 2010) 66, 67

Rycerze Okragłego Stotu (Knights of the Round Table, reż. R. Thorpe, 1953) 33

Ryczace lata (Anni Ruggenti, reż. L. Zampa, 1963) 91

Rzemiosto wojenne (Mestiere delle armi, reż. E. Olmi, 2001) 34

Rzym (Roma, reż. F. Fellini, 1972) 155

Rzym, miasto otwarte (Roma, città aperta, reż. R. Rossellini, 1945) 5, 12, 27, 37, 71, 85, 88, 96, 97, 99-103, 105, 106, 108-111, 115, 136, 137, 139, 140, 147, 149, 151, 176, 244, 248, 261

Salò, czyli 120 dni Sodomy (Salò o le 120 giornate di Sodoma, reż. P. P. Pasolini, 1975) 155

Salvo D'Acquisto (reż. R. Guerrieri, 1974) 231

Salvo D'Acquisto (reż. A. Sironi, 2003) 231, 243

San Miniato, lipiec 1944 (San Miniato, luglio 1944, reż. P. i V. Taviani, 1954) 201

Scypion afrykański (Scipione l'africano, reż. C. Gallone, 1937) 61, 87

Serce w studni (Il cuore nel pozzo, reż. A. Negrin, 2005) 229

Siedmiu braci Cervi (Sette fratelli Cervi, reż. G. Puccini, 1968) 134, 135

Signor Max (reż. M. Camerini, 1937) 145

Słodkie życie (Dolce vita, reż. F. Fellini, 1960) 113, 163

Słońce wschodzi (Sole sorge ancora, reż. A. Vergano, 1946) 83, 85, 88, 248

Spartakus (reż. S. Kubrick, 1960) 34, 72

Sprawa Martello (Il caso Martello, reż. G. Chiesa, 1991) 198, 223

Sprawa Mattei (Il caso Mattei, reż. F. Rosi, 1972) 156

Stan wyjatkowy. Proces w sprawie Monte Sole 62 lata później (Lo Stato di eccezione. Processo per

Monte Sole 62 anni dopo, reż. G. Maccioni, 2008) 234

Stara gwardia (Vecchia guardia, reż. A. Blasetti, 1934) 87

Strajk (Cmaчka, reż. S. Eisenstein, 1924) 68

Strategia pająka (Strategia del ragno, reż. B. Bertolucci, 1970) 5, 12, 154, 178-192, 194, 209, 262

Strzat do gołębia (Tiro al piccione, reż. G. Montaldo, 1961) 130, 131

Szarża lekkiej brygady (The charge of the Light Brigade, reż. T. Richardson, 1968) 58

Szcześlizwy los (La buona fortuna, reż. F. Cerchio, 1944) 88

Sztuka kombinowania (L'arte d'arrangairsi, reż. L. Zampa, 1954) 91

Śmierć prezydenta (reż. J. Kawalerowicz, 1977) 65

Śmierć w Wenecji (Morte a Venezia, reż. L. Visconti, 1971) 155

Święty Michał miał koguta (San Michele aveva un gallo, reż. P. i V. Taviani, 1972) 61 
Titanic (reż. J. Cameron, 1997) 34

Totò i Karolina (Totò e Carolina, reż. M. Monicelli, 1955) 80

Towarzysze broni (Grande Illusion, reż. J. Renoir, 1937) 45

Triumf woli (Triumph des Willens, reż. L. Riefenstah, 1934) 38

Trudne lata (Anni difficili, reż. L. Zampa, 1948) 91

Trudne życie (Una vita difficile, reż. D. Risi, 1961) 117

Trzej muszkieterowie (Three Musketeers, reż. S. Herek, 1993) 64

Ulica ubogich kochanków (Cronache di poveri amanti, reż. C. Lizzani, 1954) 80, 81

Umberto D. (reż. V. De Sica, 1950) 80, 142

We władzy ojca (Padre, padrone, reż. P. i V. Taviani, 1977) 156

Wedtug prawa (По закону, reż. L. Kuleszow, 1926) 44

Wiek XX (Novecento, reż. B. Bertolucci, 1976) 177

Wielka Wojna (Grande guerra, reż. M. Monicelli, 1959) 136

W imieniu ludu włoskiego (In nome del popolo italiano, reż. E. Olmi, C. Stajano, 1971) 154

Wojna i pokój (Война u мuиp, reż. S. Bondarczuk, 1967) 225

World Trade Center (reż. O. Stone, 2006) 34

Wspomnienia o resistenzy (Memorie della resistenza, reż. E. Cerasuolo, 1993) 217

Wszyscy do domu (Tutti a casa, reż. L. Comencini, 1960) 115, 118, 141, 244, 245

Zabójstwo Matteotiego (Delitto Matteotti, reż. F. Vancini, 1973) 61

Zabriskie Point (reż. M. Antonioni, 1970) 155

Zakazane piosenki (reż. L. Buczkowski, 1947) 37, 103

Zamachowiec (Terrorista, reż. G. De Bosio, 1963) 122, 124, 125

Zawód reporter (Professione: reporter, reż. M. Antonioni, 1975) 155

Zelig (reż. W. Allen, 1983) 74

Zezowate szczęście (reż. A. Munk, 1960) 139

Ziemia obiecana (reż. A. Wajda, 1974) 67

Złodzieje rowerów (Ladri di biciclette, reż. V. De Sica, 1948) 88, 142, 163

Złoto Neapolu (L'oro di Napoli, reż. V. De Sica, 1954) 143

Zmierzch Bogów (Caduta degli dei, reż. L. Visconti, 1969) 155

Zwycięzca (Vincere, reż. M. Bellocchio, 2009) 65, 69, 233

Żądto (The Sting, reż. G. Hill, 1973) 207

Żelazna dama (The Iron Lady, reż. P. Lloyd, 2011) 73

Życie jest piękne (La vita è bella, reż. R. Benigni, 1997) 247

Życie na podstuchu (Das Leben der Anderen, reż. F. Donnersmarck, 2006) 75

Żyć w pokoju (Vivere in pace, reż. L. Zampa, 1947) 91

Żyd Süss (Jud Süß, reż. V. Harlan, 1940) 60

Żywe torpedy (Siluri umani, reż. A. Leonviola, 1954) 83 



\section{Indeks osób}

Agosti Silvano 247, 263

Albano Giuseppe 124

Alemanno Roberto 175, 251

Alexander Harold 90, 96, 159

Alfieri Dino 18

Allen Woody 74, 267

Alvaro Corrado 109, 251

Amaducci Alessandro 116, 154, 196, 223, 255

Amendola Giorgio 83

Andreotti Giulio 24, 80

Angelino Eduardo 27, 251

Antioco Floris 133, 256

Antonioni Michelangelo 79, 83, 88, 113, 155, 156, 178, 265, 267

Aprà Adriano 102, 111, 139, 140, 149, 251

Archibugi Francesca 196

Aristarco Guido 77, 81, 84

Armes Roy 83, 98, 251

Assmann Aleida 188-190, 251

Astaire Fred 116

Attenborough Richard 49, 264

Audisio Walter 174

Badoglio Pietro 15, 131

Baldissara Luca 29, 251

Baranowicz Maria 134, 252

Baratter Lorenzo 169, 251

Barbaro Umberto 77, 99

Bassotto Camillo 84, 251

Bazin André 97, 251

Bellini delle Stelle Pier Luigi 174

Bellocchio Marco 65, 153, 233, 265, 267

Benigni Roberto 247, 267

Berlinguer Enrico 192

Berlusconi Silvio 11, 26, 27, 29, 30, 198, 200, 217, 230, 247

Bernari Carlo 169

Bernhardt-Kralowa Halina 213, 252

Bertieri Claudio 254
Bertolucci Bernardo 12, 153, 154, 177-194, 251, 252, 254-256, 258, 259, 262, 264267,277

Bertoni Giovanni 137

Besson Luc 72, 264

Bettetini Gianfranco 195, 251

Beverly Allen 257

Bianca Guidetti Serra 246, 254

Bignardi Irene 230, 251

Blasetti Alessandro 61, 87, 118, 263, 264, 266

Bocca Giorgio 25, 224, 251

Bolongaro Eugenio 182, 193, 251

Bolognini Mauro 84, 160-162, 264

Bonaparte Laura 160, 254

Bondanella Peter 104, 111, 113, 136, 142, 149,251

Bondarczuk Siergiej 267

Bongioanni Marco 123, 124, 251

Bongiorno Mike 163

Bonino Bruno 135, 251

Bonsaver Guido 19, 252

Bordwell David 68, 185, 251

Borges Jorge Luis 178-186, 191, 194, 251, 254,262

Bosworth Robert 13, 17, 18, 77, 254

Bottai Giuseppe 18

Bozzano Francesca 217

Bragaglia Carlo 127, 264

Brancati Vitaliano 91

Bravo Anna 157, 251

Brook Peter 69

Brunetta Gian Piero 58, 78, 79, 82, 96, 99, 195, 252-254, 258

Bruni David 99, 110, 111, 252

Bruzzone Anna 157, 246, 251, 255

Buczkowski Leonard 103, 267

Bugajski Ryszard 65, 266

Buñuel Luis 68, 265

Burgoyne Robert 34, 252

Burton Richard 168 
Cabona Maurizio 221, 255

Calabretto Roberto 86, 256

Calamandrei Piero 173

Calderon de la Barca Pedro 191

Calopresti Mimmo 217, 263

Calvino Italo 78, 79, 203, 252

Camerini Mario 145, 263, 266

Cameron James 34, 266

Cardinale Claudia 161

Carlei Carlo 264

Carnes Mark 38, 257

Caruso Pietro 99, 100, 169, 171, 172

Casadio Gianfranco 117, 124, 131, 162, $173,175,195,219,251-253$

Cayatte André 114, 266

Cecchi d'Amico Suso 93

Cecchini Lucio 20, 252

Cegani Elisa 87

Celli Carlo 113, 252

Cerasuolo Enrico 217, 267

Cerchio Fernando 88, 263, 266

Cervi Alcide 134, 252

Cezar Juliusz 181, 182

Chaluja Elias 186, 188, 252

Chapman James 33, 252

Chereau Partice 42, 264

Chiarini Luigi 82, 90, 252

Chiesa Guido 198, 199, 218, 223-225, 227, $259,265,266$

Cocteau Jean 81

Cohen Ralph 48, 258, 259

Collin Richard 252

Colotti Enzo 29, 253

Comencini Luigi 115-118, 141, 145, 265, 267

Cooke Philip 13, 19-21, 24, 26, 27, 200, 222, 252

Coppola Francis Ford 263, 265

Corbari Silvio 165-168, 197, 243

Corbucci Sergio 113, 263

Cortàzar Julio 178

Corti Maria 225

Cosmatos George 168, 169, 171, 173, 265

Cottino-Jones Marga 113, 252

Crespi Lorenzo 230

Crisp Deborah 182, 193, 252

Croce Benedetto 16, 19

Croce Lidia 19

Curle Howard 143, 259

Custen George 34, 252
D'Acquisto Salvo 231

Dalle Vacche Angela 180, 187, 252

Dalser Ida 66

Damiani Bruno 113, 163

Darowska Zofia 66

Davies Natalie Zemon 33, 252

Davoli Ninetto 157

De Bosio Gianfranco 83, 122, 124, 125, 252, 267

De Carlo Andrea 213, 252

De Fra Lino 154, 263

De Gaetano Domenico 198, 224, 259

De Gasperi Alcide 81, 174-177, 243

De Gregori Francesco 227

De Laurentiis Dino 113

De Luna Giovanni 27, 165, 252

De Pau Daniela 126, 259

De Pirro Nicola 81

De Robertis Francesco 83, 263

De Santi Gualtiero 80, 117, 252, 255

De Santis Giuseppe 78, 84, 88, 97, 264

De Sica Vittorio 79, 80, 88, 114, 138, 141$143,145,155,163,259,261,263,265$, 267

De Tommasi Gianni 81

Di Carlo Carlo 234, 264

Di Venanzo Gianni 88

Diritti Giorgio 13, 233, 234, 236-240, 242, $261,263,277$

Dogliani Patrizia 13, 17, 254

Dolman Eugen 99

Domańska Ewa 47, 62, 257, 259

Donald James 39, 258, 259

Donnersmarck Florian 75, 267

Dostojewski Fiodor 178

Dreville Jean 42, 264

Dumas Alexander 64

Eco Umberto 29, 39, 153, 213, 253

Edensor Tim 61, 253

Eisenstein Siergiej 59, 68, 263, 265, 266

Ekberg Anita 163

Ellwood David 79, 253, 254

Emanuel I Wiktor 15

Faldini Franca 85, 93, 116, 253, 255

Falkowski Tomasz 42, 253

Fantozzi Giovanni 199, 253 
Fantuzzi Virgilio 108, 253

Farassino Alberto 86

Farell James T. 108, 253, 255

Farina Rachele 246, 255

Felice Carlo 86, 253

Fellini Federico 80, 83, 88, 113, 155, 163, 207, 261, 263, 264, 266

Fenoglio Beppe 154, 223-226, 253

Ferida Luisa 232

Ferucci Riccardo 201, 207, 215, 257

Ferreri Marco 153, 155, 256, 265

Ferrero Adelio 120, 124, 130, 131, 253

Ferro Luigi 87

Ferro Marc 10, 41-45, 59, 60, 68, 253

Ferroni Giorgio 87, 265

Finetti Ugo 28

Fini Gianfranco 26, 27, 200, 217

Fink Guido 61, 100, 253

Fleischer Richard 168, 263

Fleming Victor 64, 266

Foffi Goffredo 85, 93

Fonda Henry 173

Fontana Sandro 166

Ford Aleksander 70, 264

Forgacs David 98, 110-112, 253

Fornasini Giovanni 234

Franceschini Alberto 23, 253

Franzinelli Mimmo 24, 29, 253

Frazzi Andrea 218, 266

Frears Stephen 64, 265

Frischenschlager Friedhelm 25

Fulchignoni Enrico 116, 117

Gaglianone Daniele 218, 221, 222, 264

Gaiardoni Laura 78, 255

Gallagher Tag 137, 253

Gallone Carmine 61, 85-88, 256, 266

Galmozzi Luciano 21, 253

Gałkowski Artur 7, 81, 256

Gance Abel 34, 265

Garbicz Adam 253

Garibaldi Giuseppe 17

Garlicki Andrzej 39, 62, 63, 254

Gassman Vittorio 118

Gastoni Lisa 134, 173

Gemma Giuliano 168

Gentilomo Giacomo 132, 265

Gerard Fabien 186, 251, 252
Geremek Bronisław 36

Germi Pietro 155

Gervasutti Sergio 227, 254

Ghigi Giuseppe 13, 19, 24, 26, 78, 82-84, $86,87,89,124,127,163,165,167,168$, $176,195,197,217,219,222,223,228$, 230, 231, 244, 253, 254, 256, 257

Gili Jean 157, 214, 254

Ginsborg Paul 22, 136, 254

Giordana Marco Tullio 232, 233, 264

Giulielmi Massimo 199, 200, 264

Giustolisi Franco 29, 254

Godard Jean-Luc 181, 191, 192, 255, 265

Godlewski Zbigniew 132

Gordon Robert S. C. 19, 252

Gori Gianfranco 13, 58, 100, 227, 252, 253, 255

Grafton Anthony 42, 254

Grazzini Gianni 132

Griffith David Wark 42, 265

Grifone Pietro 83

Grimaldi Ugoberto 17, 25, 137-139, 141, 150, 254, 261

Gronowska Anna 59, 255

Grosso Giuseppe 114

Guazzoni Enrico 34, 266

Guerrieri Romolo 231, 266

Gullace Maria Teresa 98

Guttuso Renato 17

Gwóźdź Andrzej 97, 253, 259

Harlan Veit 60, 267

Haynes Todd 68, 264

Hearst William Randolph 67

Helman Alicja 72, 96, 99, 105, 144, 155, 251, 254, 256-258

Hendrykowski Marek 10, 32, 38, 39, 41, 58, $69,75,254$

Henryk V 60, 264

Henryk VIII 60, 265

Herek Stephen 64, 267

Herling-Grudziński Gustaw 19, 249, 254

Higson Andrew 33, 252, 254

Hill George 207, 267

Hillman Roger 182, 193, 252

Hitchcock Alfred 126, 150, 265

Hitler Adolf 29, 56, 82, 141, 149, 160, 169, $223,233,264$ 
Hjort Mette 60, 252

Hoffman Jerzy 34, 70, 265

Holland Agnieszka 65, 264

Hopper Tom 73, 264

Iaccio Pasquale 81, 86, 164, 255-257

Ignazi Piero 254

Ingaro Pietro 167

Jackiewicz Aleksander 144, 183, 251, 254

Jackson Martin A. 47, 58, 59, 254

Jarmusch Jim 223

Jasienica Paweł 66

Jerzy VI 73

Kabatc Eugeniusz 224, 253

Kabatc Krystyna 224, 253

Kania Ireneusz 29, 253

Kański Tadeusz 84, 263

Kappler Herbert 24, 99, 170, 171, 173

Katz Robert 168

Kawalerowicz Jerzy 65, 266

Kennedy John F. 74

Kesserling Albert 86, 170, 172, 173,

Kezich Tullio 161, 173, 176, 230, 254

Kidawa-Błoński Jan 66, 266

Klejsa Konrad 13, 134, 153, 254

Kline Thomas Jefferson 186-188, 251, 252, 254

Kłys Tomasz 7, 46, 67, 68, 254

Koch Pietro 100, 232, 233

Kolker Robert 191, 254

Koniczek Ryszard 36, 254

Korda Alexander 60, 265

Korycka Jadwiga 156, 254

Kossak Jerzy 153, 254

Kowalczuk Piotr 228, 255

Kracauer Siegfried 105, 255

Kubrick Stanley 34, 59, 72, 266

Kula Witold 47, 48, 255

Kuleszow Lew 44, 267

Kurz Iwona 10, 43, 253, 258, 259

Lagny Michèle 42, 255

Lanaro Silvio 255

Landy Marcia 52, 139, 143, 255, 258

Lattauda Alberto 79

Lazar Marc 23, 254, 258
Le Goff Jacques 59, 62, 63, 255

Lean David 33, 265

Leger Grindon 35, 254

Leone Sergio 113

Leonviola Antonio 83, 267

Leopardi Giacomo 181, 182

Leprohon Pierre 80, 255

Levi Carlo 19

Lichtner Giacomo 29, 83, 91, 222, 230, 255

Litka Piotr 34

Lizzani Carlo 80, 84, 85, 88, 99, 117, 252, 255

Lloyd Phyllid 73, 267

Longo Luigi 17, 19, 24, 28, 174, 255

Lopez Daniel 35, 255

Loshitzky Yosefa 181, 191, 255

Lotti Marcella 87

Loy Nanni 115, 121, 131, 133, 134, 256, 263

Lubelski Tadeusz 34, 253

Lucas George 207, 264

Luchetti Daniele 196, 218-221, 265

Ludwik XIII 64

Luzzatto Sergio 255

Łepkowski Tadeusz 40, 255

Łomnicki Jerzy 34, 263

Maccioni Germano 234, 266

Mackenzie Scott 60, 252

Magala Sławomir 9, 258

Magnani Girolamo 191

Majewski Tomasz 105, 255

Malick Terence 34, 225, 226

Malvezzi Piero 20, 227, 255

Manciotti Mauro 94, 131, 255

Marabini Gustavo 165

Marali Antonio 254

Marchioni Ubaldo 234

Marconi Guglielmo 19

Marcus Milicent 96, 99, 100, 103, 108, 214, 215,255

Marcuse Herbert 168

Margański Janusz 215, 257

Marks Karol 168

Marszałek Rafał 38, 40, 58, 61, 69, 255

Martinelli Renzo 227-230, 265

Maselli Francesco 90, 91, 265

Mastroianni Marcello 163, 168

Matard-Bonucci Marie-Anne 23, 254, 258 
Mattei Enrico 28, 156, 266

Matuszewski Bolesław 32

Mazur Mariusz 11, 39, 166, 254, 256, 259

Medici Antonio 80, 81, 255

Melega Marco 218, 264

Méliès Georges 32

Meluschi Antonio 18

Meneghetti Egidio 124, 125

Menon Gianni 102, 252

Mercandino Idelmo 124

Mętrak Anna 246, 257

Micciché Lino 55, 58, 121, 154-157, 165, 173, 176, 177, 196, 245, 246, 255, 256, 263

Michalczyk John 256

Michalski Andrzej 185, 191, 256

Michałek Bolesław 35, 41, 155, 156, 256

Miczka Tadeusz 13, 79, 80, 192, 195, 196, $232,251,256,258$

Mida Massimo 78, 256

Miller-Klejsa Anna 14, 81, 155, 256, 279

Minervini Gianni 199, 256

Mingrone Gianna 186, 188, 252

Monicelli Mario 80, 136, 266, 267

Montaldo Giuliano 84, 130, 131, 157-160, 254, 263, 266

Monti Mario 30

Monticelli Simona 200, 256

Morandini Morando 196

Moravia Alberto 19, 178

Moretti Mario 23, 256

Morgoglione Claudia 223, 256

Moris Ergas 136

Morley David 61, 256

Moro Agnese 256

Moro Aldo 11, 21, 24, 197, 256

Morosini Giuseppe 99, 100

Munk Andrzej 144, 151, 152, 251, 264, 267

Musolesi Mario 234

Mussolini Benito 15-18, 22, 24, 26, 28, 29, $41,65,69,87,97,104,119,120,122$, 127, 129-131, 135, 140-142, 148, 149, 160, 162, 166, 171, 173-175, 182, 188, 193, 200, 205, 210, 217, 220, 223, 232, 233, 243-246, 251, 265

Mussolini Rachele 18

Mussolini Vittorio 18

Napiórkowska Izabela 246, 257

Narutowicz Gabriel 65

Nazzari Amedeo 87
Nedo Ivaldi 99, 252

Negarville Celeste 98

Negrin Alberto 224, 229, 230, 265, 266

Nero Franco 173

Niewiadomski Eligiusz 65

Nixon Richard 74

Noto Paolo 83, 256

O'Connor John E. 47

O'Leary Alan 125, 256

Olivetti Paola 12, 218, 254

Olivier Lawrence 60, 264

Olla Robert 200

Olmi Ermanno 34, 154, 156, 235, 263, 264, 266, 267

Orsini Valentino 164-168, 195-197, 263265

Ozimska Joanna 81, 256

Pajetta Giancarlo 17

Palmieri Eugenio 87, 257

Pansa Giampaolo 27, 222, 257

Paola Ugo 133, 256

Papagallo Pietro 99, 171

Parri Feruccio 24, 98, 114, 174

Pascoli Giovanni 181, 182

Pasolini Guido 227, 228

Pasolini Pier Paolo 152, 153, 155, 157, 168, 227, 228, 246, 254, 257, 264, 266

Pastrone Giovanni 263

Pavone Claudio 26, 257

Pecchioli Ugo 25, 257

Pełka Artur 189, 251

Pertini Sandro 20, 24, 174, 217

Pescatore Guglielmo 86, 257

Pesce Sara 13, 21, 96, 111, 112, 114, 118, $120,135,137,257$

Pestelli Leo 119, 132, 175

Petacci Claretta 173

Petri Elio 156, 264

Petricelli Assunta 81, 257

Petter Guido 27, 257

Pezzino Paolo 234, 257

Piccioni Sergio 169, 257

Piekarec Kazimierz 179, 251

Pighin Otello 124

Pinelli Giuseppe 11, 166, 256

Pirelli Giovanni 20, 227, 255 
Pitassio Francesco 83, 256

Pitrus Andrzej 153, 155, 251, 254, 256, 257

Pius XII 171

Pizzoni Alfredo 28

Plichta Andrzej 11, 256, 257

Płażewski Jerzy 40, 257

Pomian Krzysztof 62, 257

Pontecorvo Gillo 34, 84, 114, 199, 256, 263,264

Ponti Carlo 80, 93

Portelli Alessandro 169, 257

Pratolini Vasco 80

Priebke Erich 28

Przybyszewska Stanisława 59

Przylipiak Mirosław 72, 257

Puccini Giacomo 86

Puccini Gianni 78, 134-136, 266

Quaglietti Lorenzo 81, 257

Reder Walter 24, 25, 233, 234

Reich Wilhelm 257

Renoir Jean 45, 267

Renov Michael 39, 258, 259

Renzi Renzo 81

Resnais Alain 56, 264

Richardson Tony 58, 266

Ricoeur Paul 46, 50, 215, 257

Riefenstahl Leni 38

Rinaldi Ezio 200

Risi Dino 114, 117, 265, 267

Robins Kevin 61, 256

Roeg Nicolas 223

Rogers Ginger 116

Rondolino Gianni 84, 245, 257

Rosenstone Robert A. 10, 46, 50-57, 59, $128,209,257,258$

Rosi Francesco 156, 266

Rosner Katarzyna 64, 258

Rossellini Renzo 136, 261, 262

Rossellini Roberto 12, 27, 37, 71, 85, 88, 93$108,110-112,114,128,129,136,137$, $139,140,142-147,149-152,155,159$, 175-177, 203, 214, 230, 233, 251-254, $257,261,264-266$

Rusconi Edilio 176

Russo Paolo 257

Saba Marina 17, 254

Sabbatucci Giovanni 256

Sadza Agata 61, 253
Salce Luciano 115, 118, 120, 121, 141, 264

Salvatorelli Luigi 16, 258

Salwa Mateusz 246, 257

Samperi Salvatore 134, 264

Saryusz-Wolska Magdalena 189, 251, 257

Sassoon Donald 16, 258

Scalfaro Oscar 27

Scarpato Federico 100

Scelba Mario 18

Schadhauser Sebastian 186, 188, 252

Schapiro Meyer 107, 108, 255

Schuman William 169

Schwarz Vanessa R. 39, 258

Scola Ettore 157, 163, 164, 196, 218, 263, 265,266

Secchia Pietro 19, 258

Sidney Gottlieb 98, 253, 257

Sieroszewska Barbara 158, 259

Silj Alessandro 258

Sironi Alberto 231, 266

Sitney P. Adams 95, 105, 258

Sklarew Bruce 186, 251, 252

Skorzenny Otto 15

Skotarczak Dorota 10, 39, 55, 258

Snyder Stephen 143, 259

Soavi Michele 221, 222, 264

Sobchack Vivian 57, 258

Sobolewski Tadeusz 75, 258

Sobol-Jurczykowski Andrzej 179, 251

Solidni Silvio 196

Solska Ewa 11, 39, 166, 254, 256, 259

Sommier Isabelle 258

Sontag Susan 9, 258

Sordi Alberto 115, 117, 118

Sorlin Pierre 13, 33, 58, 82, 97, 103, 106$108,128,148,205,209,215,247,252$, $255,258,259$

Sossoli Dina 87

Spinazzola Vittorio 117

Stajano Corrado 154, 264, 267

Staron Joachim 245, 258

Steiger Rod 173

Stendhal Marie-Henri 178

Stone Olivier 34, 73, 79, 264, 267

Storaro Vittorio 156, 187, 262

Storchi Massimo 222, 258

Stryjczyk Joanna 59, 255

Syberberg Hans 56, 264 
Szabó István 233, 265

Szacka Barbara 62, 258

Szekspir William 41, 181, 191

Tambroni Fernando 11, 20, 114

Tassone Aldo 164, 258

Taviani Paolo 13, 61, 72, 153, 156, 167, 195, 201, 203-205, 207-209, 211-215, 251, $257,261,263,265-267,277$

Taviani Vittorio 13, 61, 72, 153, 156, 167, 195, 201, 203-205, 207-209, 211-215, $251,257,261,263,265-267,277$

Teresio Olivelli 17

Tessari Duccio 113, 265

Thatcher Margaret 73

Thompson Kristin 68, 251

Thorpe Richard 33, 266

Thulin Ingrid 157

Tinazzi Giorgio 82, 254

Tito Gobbi 132

Tito Josip 227, 229

Toffanin Mario 227, 229, 231

Tognazzi Ugo 115, 118

Tonetti Claudia 184, 259

Toplin Robert 60, 259

Torcello Georgina 126, 259

Torlasco Domietta 188, 259

Tornatore Guiseppe 196, 218, 263-265

Torriglia Anna Maria 140, 259

Tremaglia Mirko 28

Trentin Giorgio 154, 224, 265

Trombadori Antonello 168

Trombadori Francesco 17

Turini Patrizia 201, 257

Ugniewska Joanna 197, 213, 254

Umiński Władysław 32

Uva Christian 125, 155, 259

Valente Leonardo 200

Valenti Oswaldo 232, 233

Valli Bernardo 80, 117, 252, 255
Vancini Florestano 61, 114, 125-127, 259, 263, 267

Varalli Claudio 22

Verdi Giuseppe 181, 182, 191, 209, 252, 262

Vergano Aldo 83-85, 88, 263, 266

Versari Iris 165

Viganò Aldo 94, 131, 255

Viganò Renata 18, 157-159, 259

Villa Federica 126, 259

Vincenzoni Luciano 161

Violante Luciano 28

Visconti Luchino 83, 88, 113, 114, 155, 232, 254, 264, 266, 267

Vittorini Elio 17, 196, 197

Volonté Gian Maria 123, 125, 132, 134

Vonderau Patrick 57, 76, 253, 259

Wagner Ryszard 35-37, 39, 71, 259

Wagstaff Christopher 97, 111, 247, 259

Wajda Andrzej 38, 59, 65, 67, 71, 263, 264, 267

Wasiljew Siergiej 44, 263

Wasiljew Georgij 44, 263

Welles Orson 39, 67, 265

White Hayden 10, 46-52, 54, 57, 59, 259

Wilczyński Marek 47, 259

Witek Piotr 10, 11, 39, 166, 254, 256, 259

Wojciechowska Kalina 179, 251

Wojtyła Karol 73

Wołoszański Bogusław 65

Wyke Maria 59, 259

Zalewski Andrzej 70, 71, 259

Zambetti Sandro 167, 259

Zampa Luigi 79, 82, 91-93, 259, 265-267

Zaorski Janusz 65, 265

Zavattini Cesare 79, 97, 201, 259

Zbrzeźniak Urszula 50, 257

Zembrzuski Stanisław 179, 251

Zemeckis Robert 74, 264

Zibecchi Giannino 22

Zwierzchowski Piotr 7, 65, 259 



\title{
Resistance in the Italian feature film
}

\author{
(Summary)
}

The dissertation is concerned with an analysis of certain strategies in Italian cinema, which involved discussing the myth of resistance (19431945). A vast body of movies dedicated to this subject constitute - together with festive anniversaries, monuments and museums - a cultural memory of modern Italian state.

The basic method of research is textual analysis; critical reception as well as social and cultural context have been also included, since the movies themselves are dependent upon political agendas.

In the second chapter, complex relations between film and history are being discussed. The following chapters are focused on major movies dealing with Italian resistance: Rossellini's Rome, Open City and General Della Rovere, Bertolucci's Spider's Strategem, Tavianis' The Night of the Shooting Stars and Diritti's The Man who will come. 



\section{Od Redakcji}

Dr Anna Miller-Klejsa - adiunkt w Zakładzie Italianistyki na Wydziale Filologicznym Uniwersytetu Łódzkiego. Absolwentka filmoznawstwa oraz italianistyki; odbyła staże dydaktyczne w Università degli Studi della Tuscia $w$ Viterbo oraz Università degli Studi di Milano. W kręgu jej zainteresowań znajduje się kultura wizualna Italii, w szczególności włoskie kino po 1945 roku. Publikowała w tomach zbiorowych, „Kwartalniku Filmowym” i „Studiach Filmoznawczych". W ramach Narodowego Programu Rozwoju Humanistyki realizuje projekt badawczy „Italianistyka dla filmoznawstwa, filmoznawstwo dla italianistyki. Paradygmat audiowizualny w badaniach polsko-włoskiego transferu kulturowego"; otrzymała także grant Narodowego Centrum Nauki „Anni di piombo we włoskim filmie fabularnym". 